
ALBERT R. MANN

\section{LIBRARY}

AT

CCRNELL UNIVERIITY 


\section{Cornell University Library}

The original of this book is in the Cornell University Library.

There are no known copyright restrictions in the United States on the use of the text. 




\section{Production Note}

Cornell University Library produced this volume to replace the irreparably deteriorated original. It was scanned at 600 dots per inch resolution and compressed prior to storage using CCITT/ITU Group 4 compression. The digital data were used to create Cornell's replacement volume on paper that meets the ANSI Standard Z39.48-1992. The production of this volume was supported by the United States Department of Education, Higher Education Act, Title II-C.

Scanned as part of the A. R. Mann Library project to preserve and enhance access to the Core Historical Literature of the Agricultural Sciences. Titles included in this collection are listed in the volumes published by the Cornell University Press in the series The Literature of the Agricultural Sciences, 1991-1996, Wallace C. Olsen, series editor. 



\section{WEST AFRICAN FORESTS AND FORESTRY}




\section{Z A N Z I B A R :}

\section{THE ISLAND METROPOLIS \\ OF EASTERN AFRICA}

BX

Major FRANCIS B. PEARCE, C.M.G.

(British Resident in Zanzibar)

With a Map and 32 pages of lllustrations

(SECOND IMPRESSION)

Super Royal \&vo, cloth. 30s. net.

This important work deals with the past and present history of Zanzibar. From the earliest times this island, owing to its commanding position off the coast of Africa, controlled the great trade-routes which traversed the Continent from the Indian to the Atlantic Oceans, and it has remained to the present day the Metropolis of the East African Region. It has known many over-lords, and the author, who is His Majesty's Representative in Zanzibar, traces the story of this romantic island-kingdom down the centuries. The close association of this African island with ancient and mediæval Arabia is demonstrated, and the advent of the old Persian colonists to its shores explained. Coming to later times, such names as Vasco da Gama and Sir James Lancaster, that famous Elizabethan sea-captain, are met with ; until, leaving beaten tracks, the author introduces the reader to the hoary kingdom of Oman, whence came those princes of the Arabian desert who subdued to their sway the rich spice-island of Zanzibar and the adjacent territories of Central Africa. Modern Zanzibar is fully dealt with, and the enlightened Prince who occupies the throne of Zanzibar to-day is introduced to the reader in a personal interview. The latter portion of the work is devoted to descriptions of the ruined Arab and Persian stone-built towns-the very names of which are now forgotten-which, until cleared by the author, lay mouldering in the forests of Zanzibar and Pemba. The text is elucidated by a series of beautiful photographs and by specially prepared maps.

This volume must be regarded as the standard work on the Sultanate of Zanzibar.

T. FISHER UNWIN LTD., LONDON 



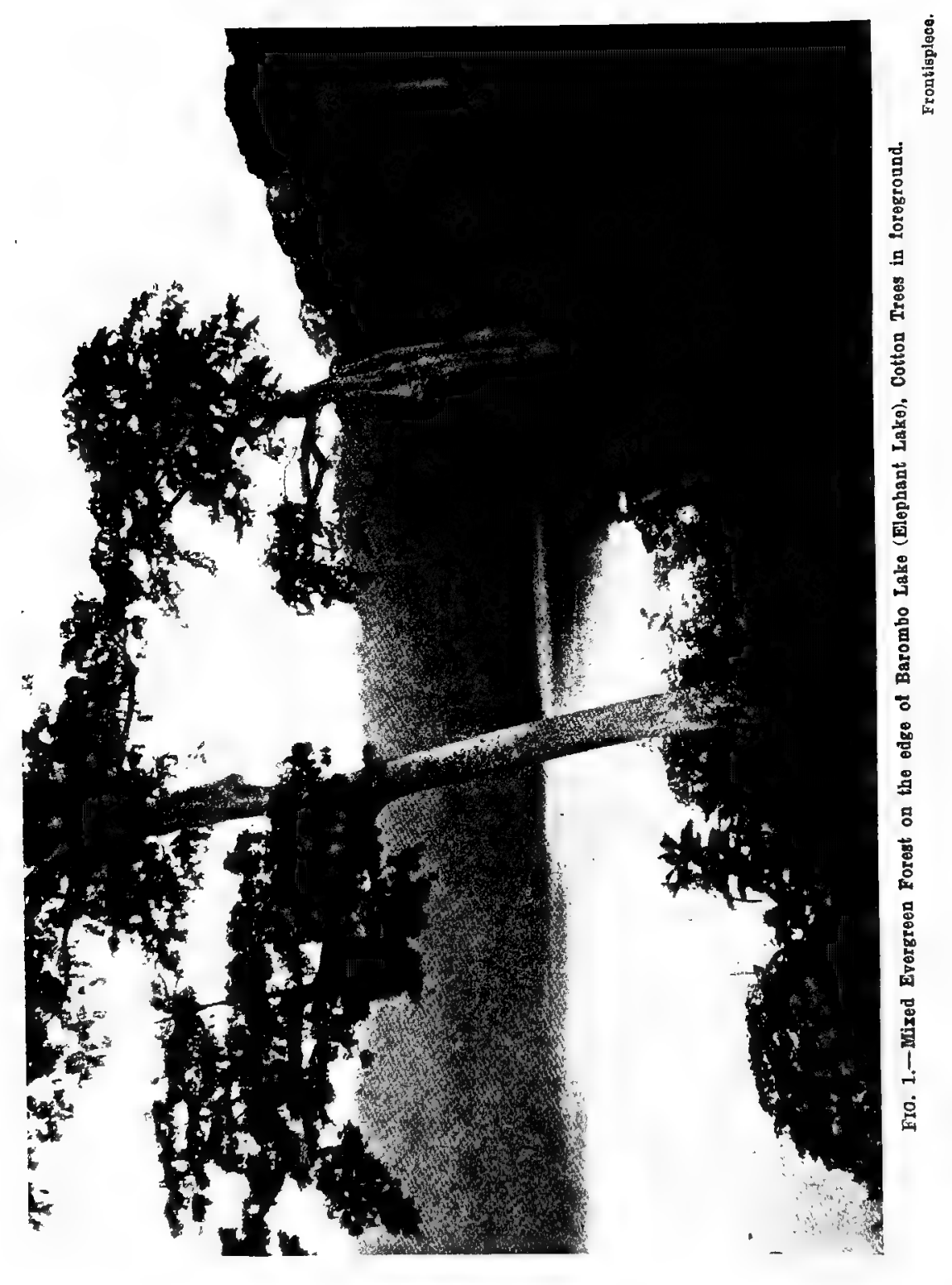




\title{
WEST AFRICAN FORESTS AND FORESTRY
}

\author{
BY \\ A. HAROLD UNWIN \\ D.Oec., M.CAN., S.F.E. \\ Late Senior Conservator of Forests, Nigeria
}

WITH 110 ILLUSTTRATIONS

BY THE AUTHOR

T. FISHER UNWIN LTD

LONDON: ADELPHI TERRACE 
First publishod in 1920

(All rights roserved) 
TO

MY MOTHER 



\section{PREFACE}

WHHE going round inspecting timber areas being worked by European firms in Nigeria, I have often been asked for a book with illustrations showing the different kinds of trees which might be felled, and also giving some account of the trees themselves, as well as the main work of the Forest Department. It is with the idea of trying to supply this want that I have mainly compiled this work, in the hope that, however imperfect it may be, the various timber getters and users in Nigeria may find it useful.

I have not attempted to give accurate descriptions of the trees, as this has already been done by Mr. Foster in his work Notes on Nigerian Trees and Plants, and I would refer readers to that volume, and to the botanical works, such as Useful Plants of Nigeria, issued under the authority of the Director of Kew Gardens, and the Flora of Tropical Africa, by Oliver; but only refer to some specific feature of the trees that are most common or useful, by which they can be recognized by an ordinary observer without botanical knowledge.

I wish to acknowledge with thanks the assistance given to me by the Central and Southern Secretaries for permission to use the annual Forest Report from the year 1906 onwards.

I wish also to express my thanks to the Under-Secretary of State for the Colonies for permission to use my Reports on the Forests of Sierra Leone and the Afforestation of Togo.

To Mr. H. N. Thompson, the Chief Conservator of Forests of Nigeria, I am indebted for much useful information obtained from his Report on the Gold Coast Forests.

To Mr. R. E. Dennett, Deputy Chief Conservator of Forests, who has given me much help and advice in compiling this work, and more especially for reading through the proofs, I tender my grateful thanks. 


\section{WEST AFRICAN FORESTS AND FORESTRY}

Two most valuable chapters on the Forests and botanical features of the Northern Provinces of Nigeria were written by Dr. J. M. Dalziel, to whom I owe grateful thanks for his encouragement in this work.

My greatest thanks are due to Mr. C. E. Lane-Poole, Commissioner of Forests, Victoria, for the use of the list of the Sierra Leone trees.

To M. Chevalier I return grateful thanks for his list of the Ivory Coast trees.

For the constant and unfailing interest and devotion to the work of Miss Christina E. Lacy, acting as amanuensis, I beg to extend my heartfelt thanks.

Further thanks are also due to my wife, who has lent not only practical assistance, but has been the mainspring of inspiration for the completion of this work. 


\section{CONTENTS}

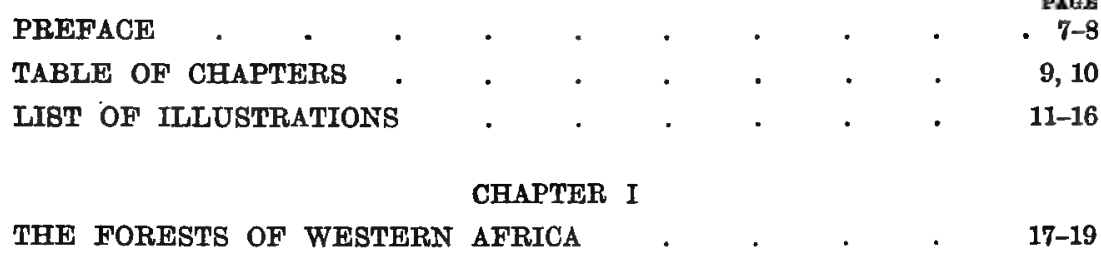

\section{CHAPTER II}

THE GAMBIA .

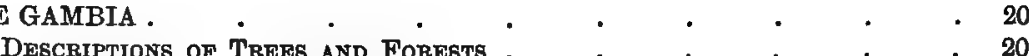
Appendix I. The Forest LaW. (Fres) .

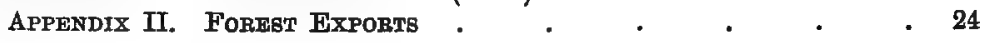

\section{CHAPTER III}

SIERRA LEONE

I. THE Forests..$\quad \cdot \quad \cdot \quad \cdot \quad \cdot \quad \cdot \quad \cdot \quad \cdot 25$

II. Notes on Tmaber Trees. (Export and Locas UsE) : $\quad \cdot \quad \cdot 26$

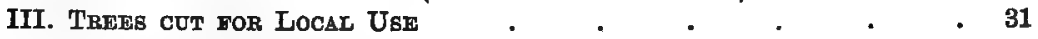

IV. MnNor Foregr Produce $\quad \cdot \quad \cdot \quad \cdot \quad \cdot \quad \cdot \quad \cdot \quad \cdot \quad \cdot 35$

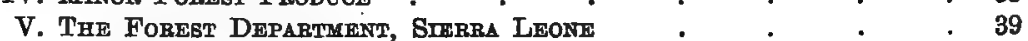

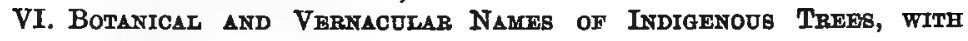

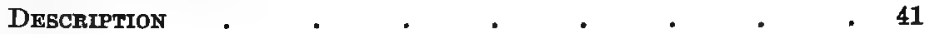

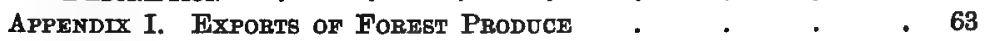
Appendix II. Forest Proddce, 1827-1835 . . . . . 64

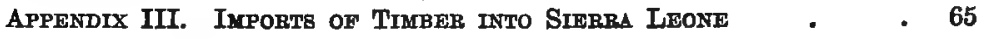

\section{CHAPTER IV}

\section{LIBERIA}

T. THE GOLA FOREBT

ON THE MOBT VALUABLE TREes : $\cdot \cdot \cdot \cdot \cdot 66$

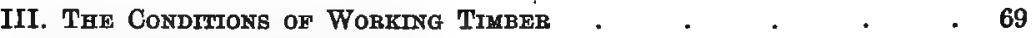

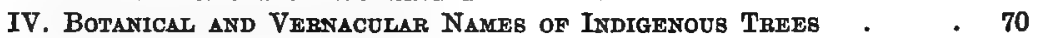
APPENDIX. FOREST EXPORTS . . . . . . 80

\section{CHAPTER V}

THE IVORY COAST

A Note on the Forest and Mahogany Indugtry.$\cdot 81$

Botanical and Verinacular Names of Trees. By Monigiedr august

Chevalier . . . . . . . . . 83

APPENDIX. FOBEST EXPORTS $\quad \cdot \quad$. $\quad . \quad$. $\quad$. $\quad .90$

\section{CHAPTER VI}

THE GOLD COAST

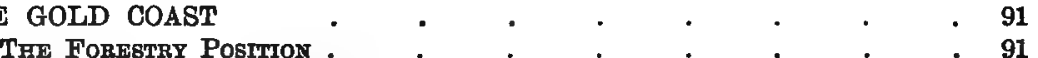

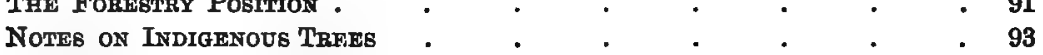

Botantcal and Vhenacolat Names. (From Mr. H. N. Thompgon's

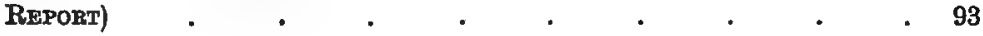

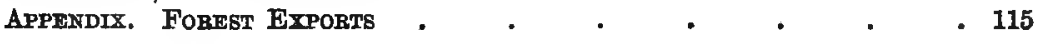




\section{WEST AFRICAN FORESTS AND FORESTRY}

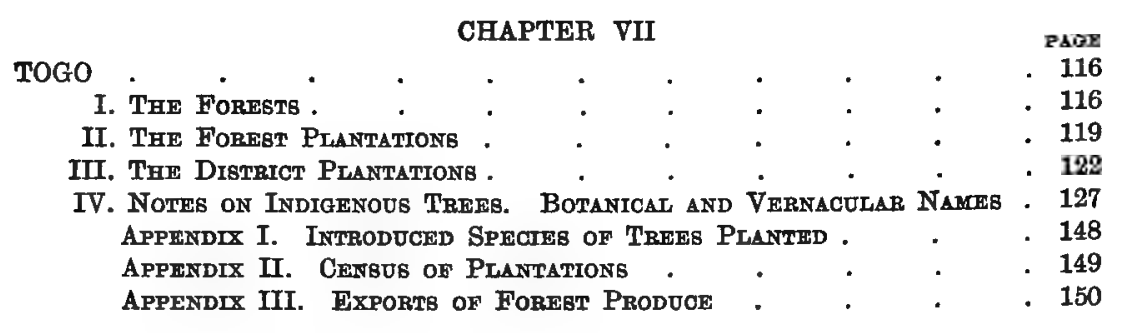

CHAPTER VIU

NIGERIA

I. The Rivers, Ports and Forestr. $\cdot{ }^{\circ} \cdot{ }^{\prime} \cdot 151$

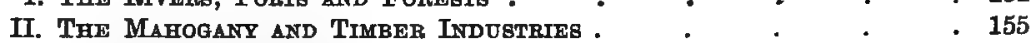

III. The Permaneant Forests or Forest Regerveg $\quad$. . . . 160

IV. AFFORESTATTON IN NIGERTA $. \quad . \quad . \quad . \quad \cdot \quad \cdot 166$

V. The Fortest DepkrTikent . $\quad . \quad . \quad . \quad . \quad . \quad 184$

VI. Review of the Botanical freatures of N. Nigeria. By Dr, J. M. DaLzTEL . $\cdot 188$

Some Trees of Hadgatand. By Dr. J. M. Datziel . . . 205 appendix I. Botantcal and Vermactlar Names of Indigenous

Trees. Northera Provtrces . . . . . . 218

Apptendix II. Exports of Forest Proddce . . . 226

APPENDIX III. ImPORTB OF TIMBER INTO NIGHBIA . . . . 227

appendix IV. The figes and Royalties on Tmber Trems . . 298

CHAPTER IX

THE NIGERIAN TIMBER TREES

CHAPTER $\mathrm{X}$

THE FORESTS AND TIMBER PRODUCTION OF THE BRITISH SPHERE

OF THE CAMEROONS - $\cdot{ }^{\circ} \cdot{ }^{\circ} \cdot{ }^{\circ}$

(Wite $a$ Note on the French and Belgian Congo and Spanish Gutnga)

Notms on Descriptions of Triges. Botanicat and Veranacular Names . 425

Appendix I. EXPORTs of Forest Produce . . . . . 444

Appindix II. Exports of Timber according to Port of ShIPMent 445

Appendix III. Expoets of TtMBer according to Destunation • 446

CHAPTER XI

THE OIL BEANS, SEEDS AND NOTS OF THE FOREST $•$. 447

CHAPTER XII

THE OIL PALM AND PALM KERNEL INDUSTRY • • • 464

CHAPTER XIII

THE FOREST IN RELATION TO AGRICULTURE . . . . . 485

CHAPTER XIV

BIBLIOGRAPHY OF WEST AFRICAN FORESTS . . . . . . 496

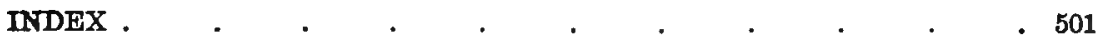




\title{
ILLUSTRATIONS
}

\author{
I.
}

1. Mixed Evergreen Forest on the edge of Barombo Lake (Elephant

Lake). Cotton Trees in foreground . . . . Frontispiece

\section{SIERRA LEONE.}

2. Red Ironwood (Lophira procera), in the Forest, Gumah . . To face page

3. Mature Cola Tree (Cola vera), growing in Fundo village, Protectorate of Sierra Leone . . . . . . . . . . . 16

4. View of Gumah Mountein from the Gumah . . . . . 16

5. African Oak (Oldfieldia Africana), showing bole in middle foreground, near Bureh Town Bridge . • • . . $\quad$. 24

6. African Oak (Oldfieldia Africana), showing scaly bark at base of tree, the late Mr. C. W. Smythe standing beside it . . . . 24

7. Pterocarpus esculentus in flower near Fakar Kole, at the edge of the Peninsular Forest

8. Forest of true Gum Copal (Copaifera salikounda), showing nearly all the trees bare of foliage and dying, due to overtapping, near Susauwuru, Moyamba District

9. True Gum Copel (Copaifera salikounda), showing base of stem with tapping squares, near the bank of the Rokell River, north of Moyamba District

\section{LIBERIA.}

10. Large Brimstone Tree (Sarcocephalus sp.), Goln Forest - . . 66

11. African Satinwood (Afrormosia lasiflora), Gola Forest - • . 66

12. Gola Forest, general view, near Morro River . . . . $\quad .80$

13. Mahogany (Khaya Ivoriensis), the late Mr. C. W. Smythe standing beside it, Gola Forest . . . . . . . . . . 80

14. Young Yawey Cedar (Heritiera ?), Gola Forest . . . . . . $\quad$. 80

IV. TOGO.

15. Teak Plantation of 1908,35 feet high, Sokode, in 1911 . . . 90

16. Teak Plantation of 1907 and 1908 on hill-eide, Atakpame . . . 90

17. One-year-old Oil Palms amongst seven- to ten-year-old trees, 1911 . 116

18. Two-year-old Oil Palm Plantation, Sokode . . . . . 116

19. Three-year-old Oil Palm Plantetion, Sokode . . . . . 116

20. Four-year-old Oil Palm Plantation, Sokode . . . . . . 116

21. Chlorophora excelsa, 1911 . . . . . . . . . . 126

22. Five-year-old Oil Palm Plantation, Sokode - . - . . 126

23. Five-year-old Khaya Senegalensis, 1911 . $\quad$. . . . . . . 126

24. Teak Plantation made in 1907 at Pfandu, in 1911 . $\quad$. $\quad$. $\quad$ - 136

25. Khaya Klaineana, 17 feet in girth, Misahohe Station . • • . 136

26. Corner of a 1907 Teak Plantation, Pfandu, in 1911 . $\quad$. $\quad$. 136 


\section{WEST AFRICAN FORESTS AND FORESTRY}

\section{WESTERN CIRCLE, NIGERIA.}

\section{Ebuttemetia Gardens.}

To face page

27. Large Teak Tree (Tectona grandis), about sixteen years old, Ebuttemetta Gardens . .

28. Large Para (Hevea Braziliensis), Ebuttemetta Gardens, age about aixteen years

\section{WESTERN CIRCLE, NIGERIA.}

\section{Olokemej Arboretum and Ramifat Plantation and Two} Studies of Capgules.

29. The Chief Conservator of Forests' House, with five-year-old Albizzia Lcbbek standing beside it . . . . . . . .

30. Three capsules of Mahogany (Khaya grandis Ivoriensis and Punchii), from banks of Owena River . . . . . . .

31. Capsules of three species of Entandrophragma: E. macrophyllum, the largest ; $E$. utilis, the next in size; and $E$. cylindricum, the smallest

32. Cedrela odorata, seven years old, with Forest Office in background, Olokemeji .

33. Cedrela odorata, Cigar-box Cedar, girth 5 feet, twelve years old, Olokemeji Arboretum . . . . . . . . . . 174

34. Teak (Tectona grandis), ten years old, Olokemeji Arboretum . - 174

35. Teak, six years old, Olokemeji Arboretum . . . . . . $\quad$. $\quad$. 184

36. Khaya Senegalensis, five years old, from seed obtained by $H$. N. Thompson, Esq., in Shaki District . . . . . .

37. Mature Iroko Tree (Chlorophora excelsa), over 12 feet in girth in 1911 , since cut down and used for building the Chief Conservator of Forests' house

\section{NORTHERN PROVINCES, NIGERIA.}

38. Marsh or "fadama" with islets of foliage, Benué overflow near Yola . 196

39. The Lower Niger in flood . . . . . . . 196

40. Fringing Forest on River Benué, in the rainy season . . . . 196

41. A Baobab (Adansonia digitata) $. \quad . \quad . \quad . \quad . \quad . \quad 208$

42. Giginya or "Fan Palm " (Borassus flabellifer, var. Athiopum), with waterlilies (Nymphceacece) : . . . . . . . 208

\section{WESTERN CIRCLE, OLOKEMEJI ARBORETUM.}

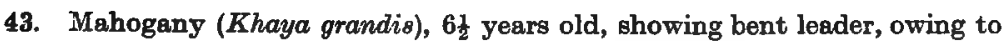
previous one being eaten out by the leading-shoot borer

44. 1909 Mahogany (Khaya grandis and $K$. Punchii) Plantation after six years' growth, near road to Chief Conservator's house, Olokemeji Arboretum .

45. The largest Mahogany (Khaya Punchii), seven years old, Olokemeji Arboretum, in the Forest Reserve . . . . . .

46. Corner of the 1908 Teak Plantation, Olokemeji Arboretum, showing it at the end of the dry season, March 1915, Captain Owens .

47. Cedrela odorata, Cigar-box Cedar, three years old (seen close),

R. E. Dennett, Esq.
48. Corner tree of the 1908 Teak Plantation, with H. N. Thompson, Esq., 1911 .

49. Shea Butter Tree (Butyrospermum Parkii), standing near the Conservator of Forests' house, June 1915, after being protected from fire eight years . 
50. Teak (Tectona grandis), three years old Compartment 2 , Olokemeji Forest Reserve. . . . . . . .

51. Shea Butter Tree (Butyrospermum Parkii) in fruit, April 1911, standing near the Conservator of Forests' house. This tree has been protected from fire for nearly four years.

52. Shea Butter Tree (Butyrospermum Parkii), standing near the Conservator
of Forests' house. The same tree of which the fruit was photographed

52. Shea Butter Tree (Butyrospermum Parkii), standing near the Conservator
of Forests' house. The same tree of which the fruit was photographed April 1911 April 1911

\section{WESTERN CIRCLE, NIGERIA.}

Studies of Trefs, Olokfmejt Reserve.

53. Mature Opepe (Sarcocephalus esculentus), in middle of picture, across Ogun River, Olokemeji Forest Reserve

54. Mature Oganwo (Khaya Punchii), near Dajopa, Olokemeji Reserve, showing base of stem for nearly 12 feet stripped of bark .

55. Large Emido (Mimusops multinervis), 10 feet in girth, Dajopa, Olokemeji Forest Reserve.

56. Large-leaved Mahogany (Khaya grandis), 14 feet in girth, with smaller Iroko (Chlorophora excelsa), standing at the side, Olokemeji Forest Reserve

57. Arere (Triplochiton Nigericum), 120 feet high, thirty years old : .

58. Ebony (Diospyros mespiliformis), 7 feet 6 inches in girth, on Dajopa Road, Olokemeji Reserve . . . . . . . .

59. Large Ayin (Anogeissus leiocarpus), 10 feet in girth, Dajopa, Olokemeji

60. Oil Palm in bearing, two bunches of fruit in view, Olokemeji Forest

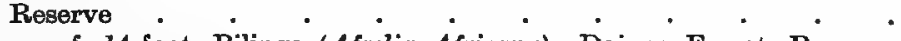

61. Base of 14-foot Bilinga (Afzelia Africana), Dajops Forest Reserve, Olokemeji Reserve . . . . . . . . .

62. Shea Butter (Butyrospermum Parkii), 7 feet in girth, near Oniloku Road, Olokemji Reserve . . . . . . . . .

63. Afara (Terminalia superba), base of mature tree over 12 feet in girth,

64. Afzelia Africana, 14 feet in girth, showing bole and usual fork, Ijaiye Range, Dajopa, Olokemeji Forest Reserve . . . . . 284

\section{WESTERN CTRCLE.}

Forest Trees, Itaro.

65. Khaya Ivoriensis, 14 feet 8 inches in girth, Haro Forest Reserve . .
66. Iroko (Chlorophora excelsa), 8 feet in girth, standing in Maro Forest Reserve after Forest was cleared . . . . . . . . 294

\section{WESTERN CIRCLE,}

Dry Zone Vegetation, Oyo District.

67. Khaya Senegalensis, 1910, on bank of Ogun River, near Iporin, Oyo

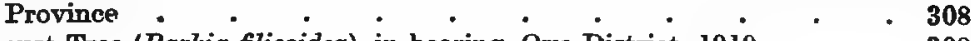

68. Locust Tree (Parkia filicoidea), in bearing, Oyo District, $1910 \quad$. $\quad 308$

\section{WESTERN CIRCLE.}

\section{STudifs of Forest Vhamation, Ado and Mamu Forest.}

69. Mature Iroko (Chlorophora excelsa) and Teak, one year old, Mamu - Forest Reserve, Ibadan Province, 1915 


\section{WEST AFRICAN FORESTS AND FORESTRY}

70. Large full-grown. Iroko Tree (Chlorophora excelsa) standing near Ibadan, Jebu Ode Road, Mamu Forest Reserve, in May 1910. See Fig. 69, which is of the same tree taken five years later . . . . 320

71. Untouched Forest on summit of Ado Rock, Oyo Province, 1910 . $\quad 320$

\section{WESTERN CIRCLE, OSHUN AND MAMU FORESTS.}

72. Forest on banks of Oshun River, looking downstrean, Oshun Forest Reserve . . . . . . . . . . 332

73. Large Arere Tree (Triplochiton Nigericum) already girdled and dead - 332

74. Forest on banks of Oshun River, looking upstream, Oshun Forest Reserve, Jebu Ode District . . . . . . . 332

75. Ride between Compartments $C$ and D, Mamu Forest Reserve, Funtumia seedlings on either side, six to eight years old . . . 332

XIV. WESTERN CIRCLE, NIGERIA, ONDO AND IWOYE FORESTS.

76. Path in Iwoye Forest, Western Circle, showing parts of four mahogany trees in the picture. . . . 342

77. Mature Cocoanut Grove near stream in the middle of Idanre Town, 1910342

XV. CENTRAL CIRCLE, NIGERIA, IFON FOREST.

78. Osse River, looking downstream, edge of the Pool, Ifon District . $\quad 354$

79. Mixed Forest near Osse, looking upstream, Ifon District . . . . 354

\section{CENTRAL CIRCLE, NIGERIA, EBEKWI FOREST.}

80. Heavy Sapeli Mahogany (Entandrophragma utilis) standing near the road between Uyeri and Benin City, Benin Province . . . 364

81. Agba (Benin), (Pterogopodium ?), standing noar Ifon Road, south of Oyeri, Benin Province . . . . . . . . 364

XVII. CENTRAL CIRCLE, NIGERIA.

OgBa Prantamon, Bmints.

82. Benin Satinwood (Afrormosia laxiflora) standing in the Ogba Plantation, Benin District . . . . . . . . .

83. Mixed Mahogany Plantation, Khaya grandis on left, $\boldsymbol{K}$. Punchii in centre, and Entandrophragma in the right foreground, six years old, near Ogba, Benin Province.

84. Ogea, Gum Copal (Daniellia caudata), standing in the Ogba Plantation, Benin Province

XVII. CENTRAL CIRCLE, OBAGIE FOREST, BENIN.

85. Khaya anthoteca, 16 feet in girth, Obagie Forest Reserve, Benin

86. Oken (Cylicodiscus Oabunensis), Africen Greenheart, 24 foet in girth, standing in Obagie Forest Reserve, Besin Province 
XIX. CENTRAL CIRCLE, NIGERIA, KOKO TOWN MAHOGANY.

87. Koko Town, with raft of mahogany logs moored near the bank To face page

88. Mahogany logs floating in the river above Koko Town $\quad \cdot \quad \cdot \quad \cdot \quad 396$

XX. CENTRAL CIRCLE, NIGERIA, OSSE RIVER FOREST.

89. Funtumia Rubber Plantation, both sides of the road, Igwoshudi,

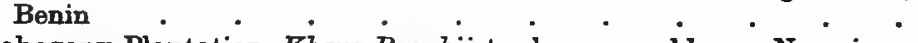

90. Mahogany Plantation, Khaya Punchii, twelve years old, near Noami, on the banks of the Osse River, Benin Province . . . 408

91. Entandrophragma log with three sides already squared and fourth partially cut ready for squaring . . . . . . 408

92. Stump of Khaya Punchii with log at base, left in the Benin Forest . . $\quad 408$

\section{EASTERN CIRCLE, NIGERIA, STUDIES OF TREES.}

\section{Degema Forest Station, including Imo Beidge.}

93. Mimusops Djave, about twelve years old, standing near Prison, Degema Station, Eastern Circle

94. Mature Light African Greenheart, Piptadenia Africana, standing in the middle of Degema Station . . . . . . .

95. Young Oil Bean Tree in bearing, Pentaclethra macrophylla, Degems Station . . . . . . . . . . .

96. Red Oak, Berlinia acuminata, 20 feet in girth, standing near the Sombreiro River, Degema Station . . . . . .

97. Base of Red Oak, Berlinia acuminata, showing smooth bark with comparatively few large scales, Degema Station . . $\cdot$.

98. Iroko, Chlorophora excelsa, nursery bed, with seedlings two years old, at the side of Forest House, Degema . . . . . .

99. The temporary Wooden Bridge over the Imo, on the Eastern Division, Nigerian Railway. Note, only native, locally grown timber used in its construction . - . - * * * : *

100. Medium-sized African Pearwood, Mimusops Djave, standing in the middle of the road outside Degema Station on the road to Illimema, since felled, and logs sold in England.

101. Inoi Tree, Poga oleosa, standing at the edge of the Degeme Station grounds

\section{EASTERN CIRCLE, NIGERIA, CALABAR ARBORETUM AND STATION.}

102. Oil Palm, Elocis Guineensis, eight years old, in bearing, showing nine out of the twenty-one bunches of fruit on the tree -

103. Seven-year-old Oil Palm in bearing, rather over-pruned, showing male inflorescence just below boy's finger and bunch of fruit in the middle

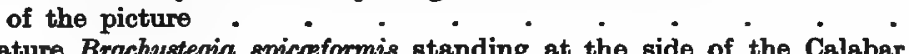

104. Mature Brachystegia apicaeformis standing at the side of the Calabar Road, Calabar, showing the typical shape of the crown and

105. Base of mature Brachystegia spicaformis standing at the side of the Calabar Road, Calabar, showing both the scaly untouched bark and the wounded section covered with nodules. 


\section{WEST AFRICAN FORESTS AND FORESTRY}

XXIII. EASTERN CIRCLE, NIGERIA, CROSS RIVER.

Teak Plantations, Nofh.

106. Regt Houge Touk Planterion pape apart and 4 feet between . . . . . . . . 486

107. View between the lines of one-year-old Teak Plantation at Ndeh, in which trees were planted 4 feet apart . . . . 486

XXIV. FASTERN CIRCLE, NIGERIA, STUDIES OF TREES.

IKRIGON FoBmst.

108. Shinglewood, Terminalia scutifera, 12 foet in girth, standing in the Ikrigon Forest Reserve, Eastern Circle

109. Iroko, Chlorophora excelsa, 15 foet in girth, standing in Ikrigon Forest

Reserve . . . . . . . . . . . 496

110. Mahogany, Khaya Senegalensis (?), standing at the edge of Ikrigon Forest Reserve, showing base of trunk with old bark wounds already healed over 

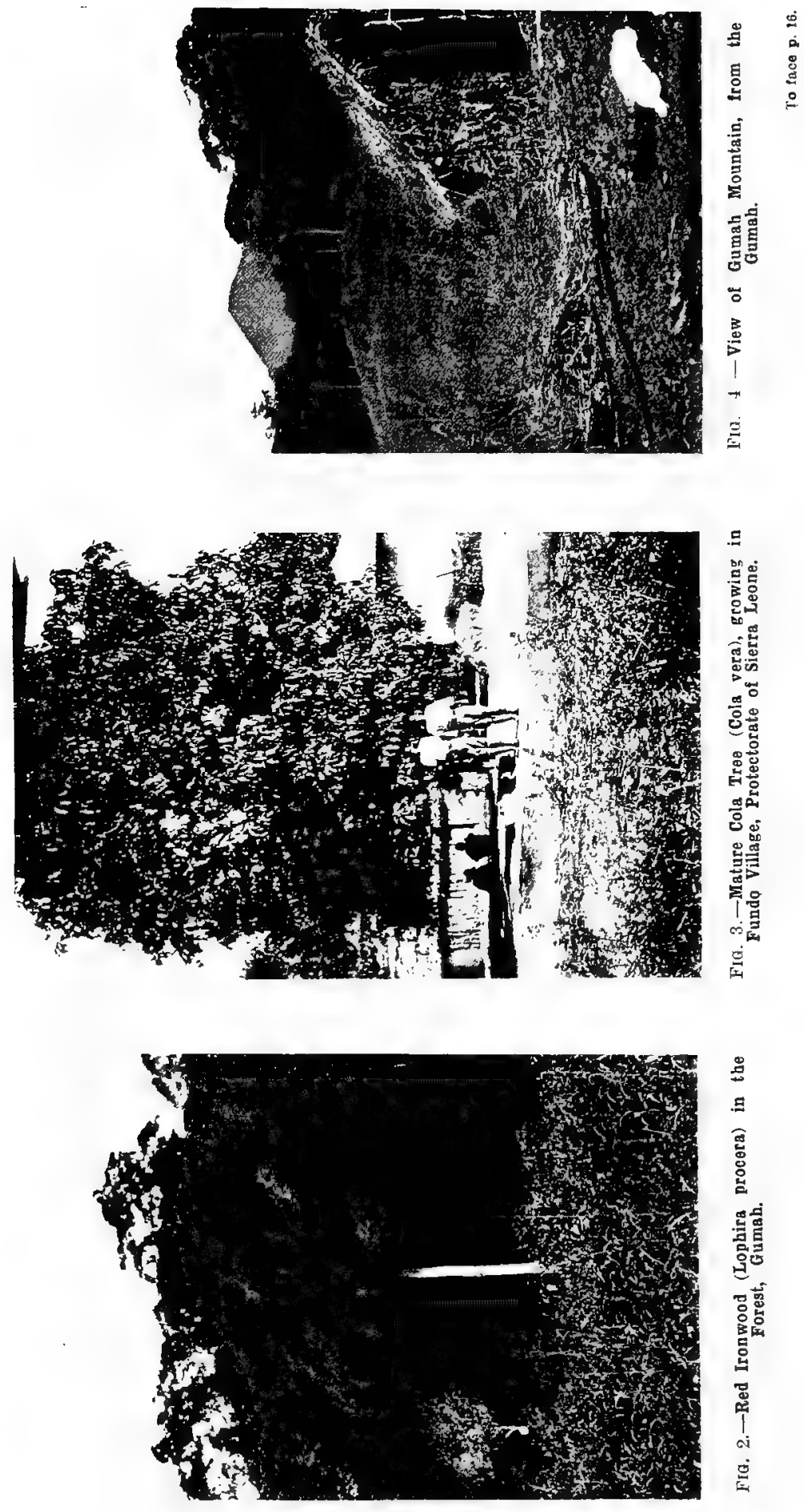



\section{WEST AFRICAN FORESTS AND FORESTRY}

\section{CHAPTER I \\ THE FORESTS OF WESTERN AFRICA}

From a large scale-map of Africa, the various British West Airican Colonies and Protectorates, as well as Liberia, French Ivory Coast, the late German Colonies of Togo and Cameroons, can be seen on the western side of that Continent. In fact, these territories are all within the Tropies, and also between the latitudes of $13^{\circ}$ North in the Gambia to nearly the Equator in the Cameroons, and between longitude of $17^{\circ}$ West to $10^{\circ}$ East. Roughly speaking, Upper Guinea, as this part is usually called, covers an area of 100 to 200 miles wide by a length of over 1,500 miles, as a sylvan belt mainly of one type of vegetation, which botanically, however, only begins to alter as the boundary of the Cameroons is approached in the eastern part of Nigeria. Therefore one finds several trees extending right through this area, and also an almost unbroken forest all the way along the coast line, and roughly 100 to 150 miles inland. The width of the forest varies rather according to the aspect of the coast line, because the prevalent wind being south-west, the greatest rainfall, and thus the heaviest type of forest, occurs when the coast line runs at right angles to the prevailing wind. This occurs, for instance, near Calabar, Nigeria in the Cameroons, part of the Gold Coast near Axim, and Sierra Leone near Freetown. In some instances this effect is accentuated by the proximity of mountains near the coast, as, for instance, north of Calabar and north of Benin. One tree, which might be taken as a type, is the Rhodesian Mahogany, Afzelia Africana, which is found right in this belt of forest on its northern side. As the name implies, it is also found in Rhodesia, near the Victoria Falls. Mahogany, Khaya Senegalensis, is another tree found in the Gambia, also in Nigeria right up to the Cameroon border, over 1,500 miles away.

However, in this huge forest belt there are great variations in the rainfall, from 20 to over 175 inches in the Oban Hills of Nigeria. There are also, naturally, variations in soil and elevation, which make differ- 


\section{WEST AFRICAN FORESTS AND FORESTRY}

ences in the character of the forest. The proximity to the sea causes yet another difference in the type of vegetation, combined as it often is with low elevation.

Broadly speaking, then, one can differentiate several distinct types of forest, though owing to slight changes in a locality the one merges into the other and very sharp boundary lines cannot be drawn.

I. The Mangrove Swamps are usually near the sea coast, though not always at the sea coast; a strip of Evergreen Forest is usually found actually on the sandy dunes of the sea coast. The Mangrove Swamps also extend up the rivers near the coast as a fringe a mile or more wide.

II. The Evergreen Forest is usually found on the sea coast, also extending inland up the rivers, and also on low land up to an elevation of a few hundred feet, as, for instance, the forest on the banks of the Calabar River.

III. The Freshwater Swamp Forests are also found in this type of locality.

IV. The Mixed intermediate Forest is found usually where the rainfall does not exceed 60 inches, or in slightly hilly country, and contains a few deciduous trees. Typical trees of this forest are the Triplochiton Nigericum and Mimusops multinervis. It contains both evergreen and deciduous trees.

V. The Fringing Forest, or "Gallerie" Forest of the Germans, is found at the edge of rivers or lakes, where the rainfall is otherwise too low for the mixed deciduous forests.

VI. The Savannah Forest, sometimes so-called Dry-zone Forest, usually occurs with a rainfall of 30 to 50 inches. The typical tree of this is the Lophira alata.

VII. The Evergreen Forest of the hills, chiefly above an altitude of 2,000 or 3,000 feet. It is especially noticeable on Mount Itakum and the Boji Hills (elevation 5,000 feet).

VIII. The Open Orchard Forest, with shrubby trees of small growth.

These, then, roughly follow the Ecological Divisions according to Warming, which are as follows:

\section{Mangrove Swamp,}

True Savannah,

Treeless Savannah, low and high grass,

Bush Savannah,

Tree Savannah,

Savannah Forest,

Sclerophyllus formations, such as

Bush and Forest,

Bamboo Forest. 
Forests are in addition named after the locality, such as Benin Forests, Oban Forests, Ondo Forests. Again, yet another nomenclature is after the kind of tree represented, such as Evergreen Forest, where all the trees are evergreen all the year round; for instance, Calabar Forests, Ondo, South Benin.

The mixed forests and intermediate forests, where the trees are both evergreen and deciduous, growing side by side, such as Olokemeji Forests, Benin Forests, Obubra Forests, and Bende Forests. Thus summarising the Nigerian Forests, we get the following formations :

1. Nigerian Swamp _. $\quad$.. Evergreen: Mangrove, type tree.

2. Evergreen Forests .. .. Lophira procera, Parinarium.

2a. Freshwater Swamp Forests .. Cynometra mitragyne.

3. Mixed Deciduous, intermediate Triplochiton, Iroko, Chlorophora Forests excelsa.

3a. Fringing Forests $\quad$. . . Mixed, deciduous really.

4. Canopied Deciduous Forests Olokemeji: Berlinia, Afzelia. (sometimes termed dense Savannah Forests)

5. Open Deciduous Forests _. Paradaniella Oliverii, Ugenia Owariensis, Terminalia Togoensis.

6. Tree Savannah Orchard Forest Lophiraalata, Shea butter,Acacia; Iuru, Oyo, Ndeh.

7. Treeless Savannah .. .. Grass, a few stunted bushes of Acacia Isoberlinia, North Ogoja. 


\section{CHAPTER II}

\section{THE GAMBIA}

IN the early part of the nineteenth century a considerable quantity of African Mahogany, obtained from Khaya Senegalensis, a dry-zone mahogany-tree, was shipped to England; in fact, this was the original source of African Mahogany, as also it was the first tree from which it was obtained. Even now this tree is one of the most prevalent in the strip of land on both banks of the Gambia, so far as British territory is concerned.

At the present time no mahogany is being shipped from the Gambia, but recently an Ordinance was passed regulating the cutting of firewood and forest trees.

Forests in the ordinary sense of the word cannot be said to exist in the Gambia, but no doubt a considerable amount of timber could be obtained from the dry-zone country. The total length of the colony is $\mathbf{3 0 0}$ miles, and approximately 5 miles wide, on either side of the Gambia River, which makes it in the aggregate a considerable tract of country, in all 4,500 square miles, of which the colony proper occupies 4 square miles.

So far only Rosewood (Pterocarpus erinaceus), Mahogany (Khaya Senegalensis), and small pieces of Baywood, probably also a mahogany, have been reported from the Gambia. In 1908 a certain amount of wood was cut for the making of charcoal by a man from the Canary Islands. In 1909, 102 tons of charcoal were exported, and in 1910, 176 tons, valued at 1634 . Since then no other returns are available, so apparently this industry has come to an end. There is no Forest Officer in the Gambia, and no proposals for Forest Reserves have been put forward by the Government. Part of the land near the mouth of the Gambia is swampy and covered with the usual Mangrove forests.

In the Bulletin of the Imperial Institute, vol. viii, 1910, p. 244, it is stated that the specimens of rosewood and mahogany forwarded to the Imperial Institute were reported on as follows:

Rosewood (Dalbergia sp.), reddish-yellow with darker lines and red pores, solid and compact, resembling rosewood except in colour. The timber would not pass as rosewood on the market. It has an 
agreeable odour, is hard and heavy, weighing $45 \frac{1}{2} \mathrm{lb}$. per cubic foot. It turned and polished well, sawed very easily, but was difficult to plane; planing left a smooth, bright surface.

Mahogany (Khaya Senegalensis) may be looked upon as inferior baywood, the wood light in colour, of poor figure, hard to plane, but when planed leaves the surface bright and woolly in alternate bands; very cross grained, sawed and turned easily. Weight, $41 \frac{1}{2} \mathrm{lb}$. per cubic foot. Should be very useful locally, but probably not of sufficient value for much export trade.

Even in this comparatively small colony a certain amount of forest land should be pr-eserved, more especially that which is unsuitable for agriculture. In every country there is always some poor or rocky land which is not favourable to the growing of agricultural crops.

The oil palm is another useful tree, which yields the well-known palm oil and kernels; however, here the oil is required locally for alimentary purposes, and therefore only the palm kernels are exported.

The following shows the exports for five years:

$\begin{array}{ccccccccc}\text { Year. } & & & & \text { Tons. } & & \text { E } & \text { o. } & \text { d. } \\ 1910 & . . & . & . . & 467 & \ldots & 5,640 & 0 & 0 \\ 1911 & . . & . . & . & 443 & . . & 4,756 & 0 & 0 \\ 1912 & . & . . & . & 445 & . . & 6,518 & 0 & 0 \\ 1913 & . & . & . . & 545 & . . & 9,026 & 0 & 0 \\ 1914 & . . & . . & . . & 494 \frac{1}{2} & . . & 7,814 & 17 & 11\end{array}$

It will be noticed that the very high prices ruling for part of 1913 and the beginning of 1914 had the effect of causing increased exports to be made.

Here, as in the case of other products, planting could be undertaken with advantage, as the yield of kernels and oil is good; even if the increased amount of oil produced was sold locally, the increased output of kernels would find a market in England, where they are needed.

It is a tree which allows cultivation of field crops to be made between the oil palms for several years before the palms become too big and shut out the light necessary for field crops. In the drier climate of the Gambia a planting distance of probably 16 feet would be sufficient to ensure a good yield, and yet give sufficient distance between the trees to allow room for them even when mature.

If an Agricultural or Forest Department, which at present does not exist in the Gambia, could not supply young seedlings or nuts for planting, one of the trading firms could secure them from one of the other West Coast Protectorates. Of course, in many cases, 


\section{WEST AFRICAN FORESTS AND FORESTRY}

if the natives could be induced to believe that a good price would always be paid for kernels, they would no doubt make small plantations of oil palms themselves, as some fruit always falls to the ground in the picking, is thus not boiled, and so is suitable for furnishing seed for planting. It is, of course, inadvisable to plant boiled nuts, as many do not germinate, owing to the germ having been destroyed by the boiling of the fruit; others do, however, as can be seen in the young oil palms sprouting from heaps of uncracked nuts which the natives leave near the villages. 


\section{APPENDIX I}

\section{FOREST FEES IN GAMBIA}

A New list was published by the Legislative Council in Gambis which fixes the different rates of fees for the right of felling useful timber for export.

The fees are as follows:

Felling of Useful Timber for Export.

For each sort of useful trunk $\quad . . \quad \ldots \quad$.. 10 s. per trunk.

Felling of Useful Timber which is not intended for Export.

For each trunk, Rosewood (Jacaranda, Pali-

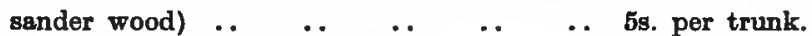

For each trunk, Mahogany $\quad . . \quad$.. $\quad$.. $\quad$ ls. per foot after felling.

For each trunk in Mandingo Falls .. . . 9d. per foot after felling.

For each trunk in Tumbo $\quad . \quad$.. $\quad$.. 8 8d. per foot after felling.

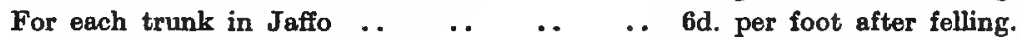

For each trunk, Cotton-tree .. $\quad . . \quad$.. 4 4d. per foot after felling.

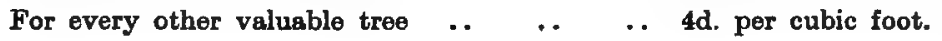




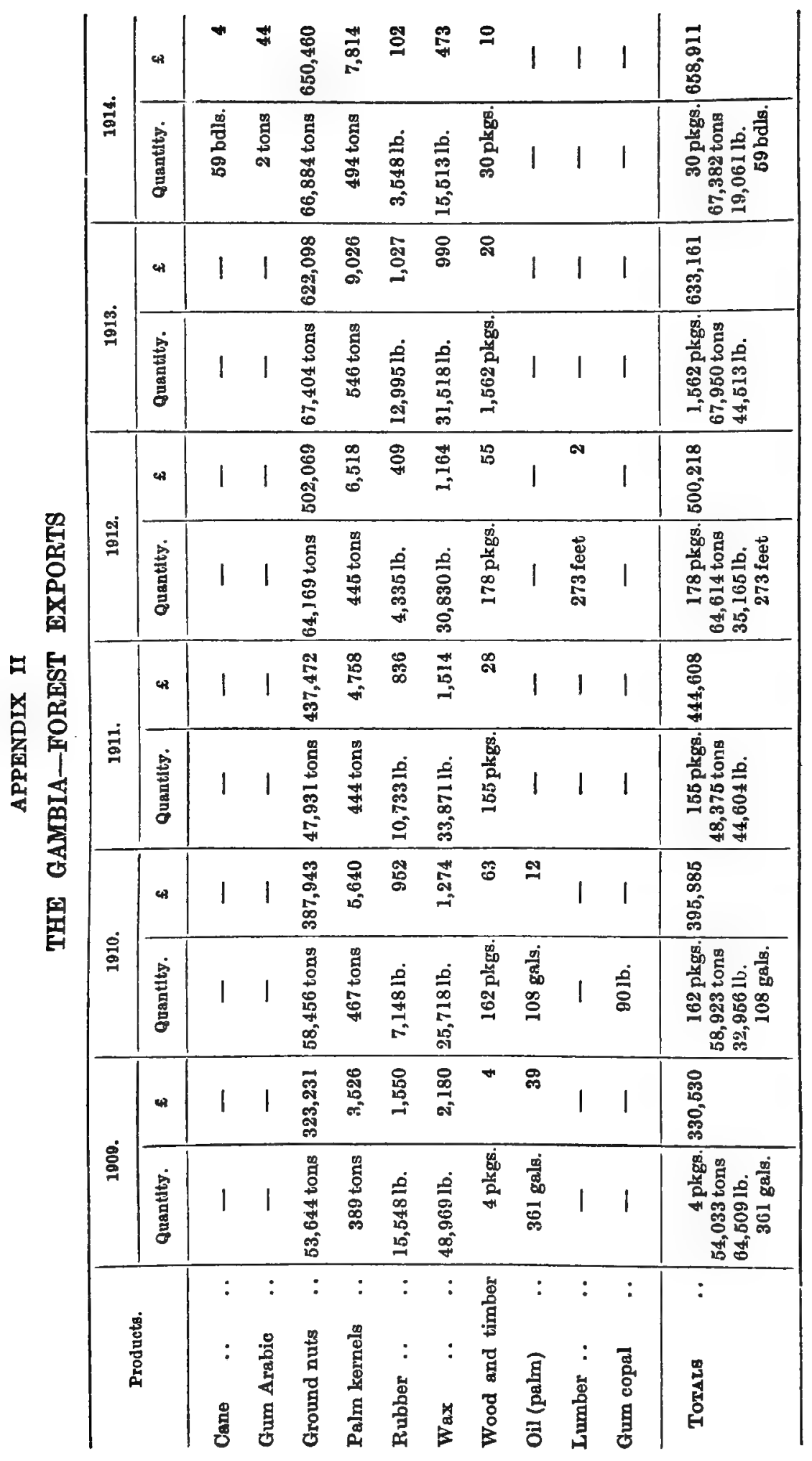




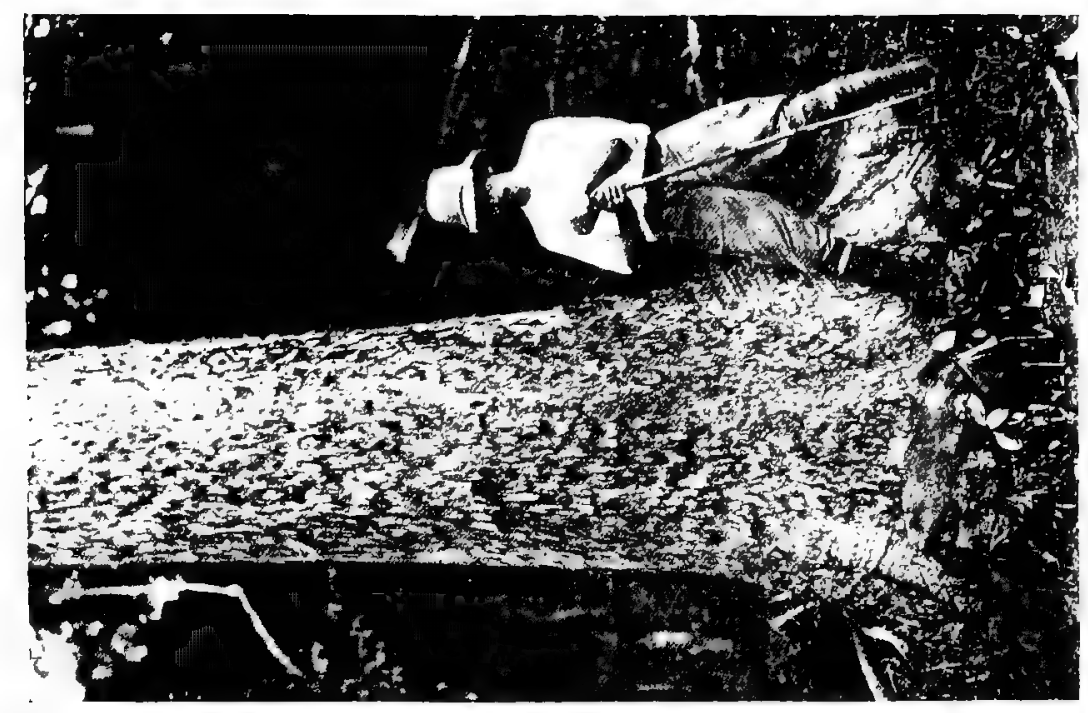

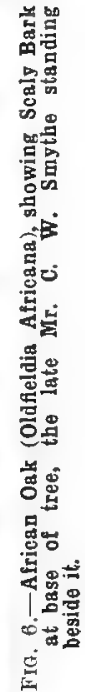

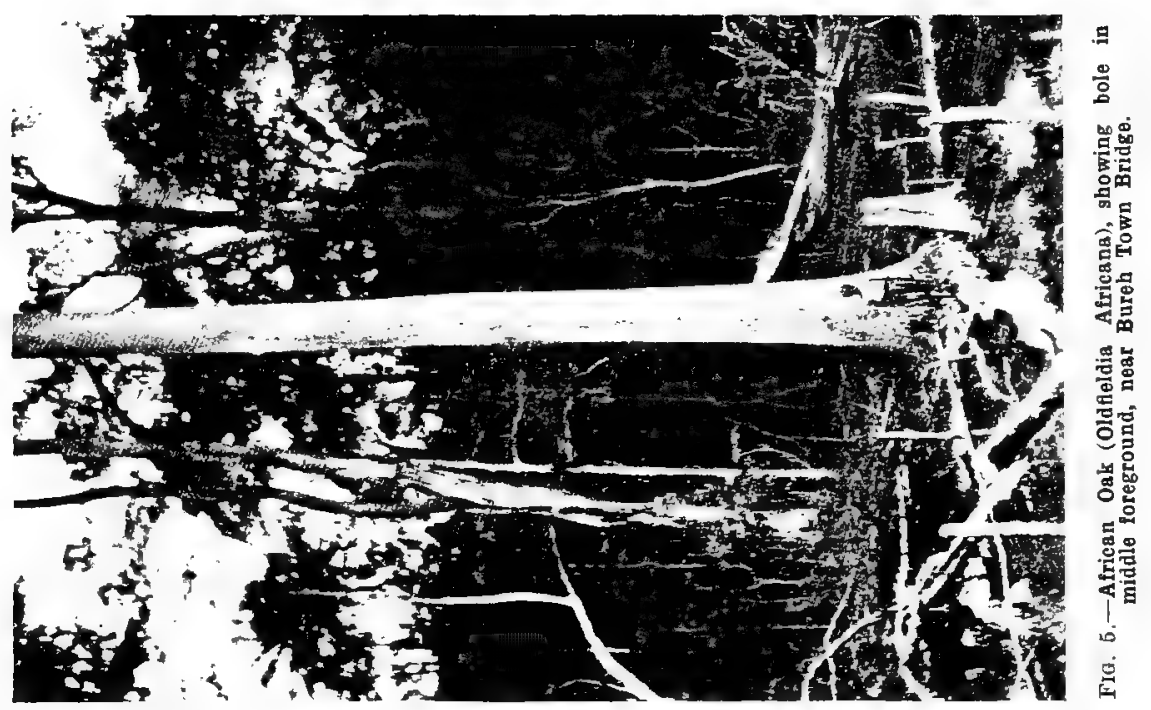





\section{CHAPTER III}

\section{SIERRA LEONE}

\section{The Forests.}

THe Colony and Protectorate of Sierra Leone cover an area of approximately 34,000 square miles, or, to make it more comprehensible, it is almost the same size as Ireland. Probably in the earliest times the whole territory was covered with some kind of arborescent growth, varying from open savannah and deciduous forest to close, impenetrable evergreen rain forest.

Now scarcely 1 per cent. of this forest remains, one of the most important tracts being the Sierra Leone or Peninsular Mountain Forest, situated on the mountain due east of Freetown. The whole of this region was once covered with forest, now reduced to an area of approximately 48 square miles, or 30,000 acres. All this tract down to the 500 -foot control line has been reserved as a permanent forest, so that eventually the whole peninsular forest will have an area of 75 square miles. Illustrations Nos. 2 and 4 show a general view of these forests.

Other important mountain forests are those situated on the Kassewe Hills, Kagnari Mountains, Kambui Hills, Panguma Hills, Nimmini Mountains, Loma Mountains, Bunbola Hills, and Maramper Hills. In addition to these areas, timber trees are felled at Kangahan and Yonni, as well as in the peninsular mountains and Maramper Hills, especially for local use.

Turning now to a consideration of the forests more in detail, one naturally first deals with the most accessible ones, i.e. of the peninsular mountains. From the beautiful harbour of Freetown, Sierra Leone, one sees the edge of these forests between Leicester Peak and Sugar Loaf Mountains. From these two points it skirts the hill station, extending thence roughly parallel to the sea as far as Kent; the lurgest wooded slopes face the ocean, only a narrow strip of forest being found on the landward side of the mountains near Burehtown and John Obey. The forest extends practically from the water's edge on the estuary of the Bureh River right up the mountains to an elevation of 2,000 feet, with a rainfall of upwards of 160 inches per year. Silvan vegetation is very luxuriant, the giant trees standing 


\section{WEST AFRICAN FORESTS AND FORESTRY}

close together, often entwined and joined to each other by various large creepers, the whole forming an almost impenetrable grove, into which only the diffused light of the sun reaches. The undergrowth is not very thick, except where old trees have fallen or where mature trees have been felled; this is partly owing to the dense shade of the tall trees, and therefore the trunks of these trees can be seen. A large Cedar Mahogany 23 feet in circumference was seen. This specimen of a mahogany was one of the largest trees found, and shows to what size the trees attain in this peninsular forest. One of the commonest trees found is the Red Ironwood, or sometimes called in Sierra Leone Ironpost, botanically known as Lophira procera. A picture of a large specimen of one of this species is shown as illustration No. 2. Another very common tree is a species of Mimusops, known as pearwood, or sometimes mahogany, when sold as timber. The African Violetwood, sometimes known as Blackwood, is comparatively common. Rhodesian Mahogany, usually called Kontah, botanically known as Afzelia Africana, is also found. Real African Oak (Ollfieldia Africana) is seen singly scattered throughout forests. A patch of true Gum Copal trees is found, as well as isolated specimens in some parts of the forest. Rock Elm (Chlorophora excelsa) is seen both in the forest and in the clearings made for farms. The Oil Palm (Elaeis guineensis) is sparsely distributed in the forest, but more frequent in the abandoned farms. The above-named trees are representative of some of the very large number of hardwoods and other trees of economic value in the forest. There are, however, also a very large number of softwoods found scattered amongst the other trees in the forest; a beautiful Whitewood (Alstonia Congensis) is, for instance, one of such softwoods. The Cotton Tree (Eriodendron anfractuosum) is probably the one most commonly found. Various Albizzias are also met with in a similar manner.

\section{Notes on TIMber Trees.}

Taking now the different species of timber trees individually, the following are most important :

1. Real African Oak (Oldfieldia Africana), which is termed Tortorza by the Timanis and Paulai by the Mendis. As illustration No. 5 shows, this is a very large and tall tree. It often attains a bole length of 50 feet and a girth of 16 feet. It is found singly, scattered through the forest. The habit of its branches, open crown, and greyish bark make it look not unlike a European oak. In reality the bark is scaly, gradually peeling off in flakes. The tree in illustration No. 6 shows this characteristic peculiarity to advantage, and also shows a medium-sized tree, approximately 10 feet in girth. The tree fruits moderately, and has an indehiscent capsule not unlike 
the shape, size and colour of an oak-apple. The capsule has five faint ribs on its surface, but contains only three seeds. The little seedling, with light grey stem and white lenticels, is easily recognized. It usually has also only three leaflets on its leaves, instead of forming true digitate leaves as a full-grown tree. The sapling once started shows fairly rapid growth, and during the early years stands a good deal of shade. It should therefore be classified as a slight shade-bearer. African Oak is a dark reddish-brown wood, which is very hard and most durable. It has, of course, a much closer grain than ordinary oak. A very smooth surface can be obtained by planing the timber. Locally, small trees are cut for conversion by pit-saw into timber for boat keels. This timber was exported as teak from Sierra Leone 1827 to 1835 for use in the English Navy. It was afterwards lost sight of, though the natives continued to use it locally. During 1908 a few round logs of short length (12-16 feet) of this timber were exported to England and sold in a Liverpool market for 2s. 6 d. per cubic foot (extreme measure).

2. Ironpost, or African Oak, or Red Ironwood (Lophira procera), is the most common tree throughout the peninsula. According to the Conservator of Forests in Sierra Leone, 80 per cent. of the trees of the peninsular forest are Lophira procera. All stages of growth are found, from the smallest seedlings to the largest tree, over 100 feet high and 20 feet in girth. In the forest the tree has an orange-coloured bark, which rapidly turns grey when exposed to the rays of the sun. The bole is not always quite cylindrical, especially near the base, where it often develops rather angular root protuberances. This seems to occur more often on rocky ground, such as that where the tree is found in the peninsula. For a similar reason the bole is not always straight, though in the ordinary way the tree has a comparatively small crown with short branches. Thus, in proportion to the size of the tree, the bole is very long, the twigs are thickish, and the long thin paper-knifelike leaves appear at the ends of them. Seedlings seem to come up wherever suitable conditions of reproduction are found. A clear bole is typical of these trees in the pole stage of growth. Illustration No. 2 shows a large specimen on the edge of the forest, and there are many large trees with the peculiar root protuberances, growing in the forest. The timber is very hard and of a dark red colour, which it retains when dry. The heartwood forms comparatively early in the life of the tree, and although the sapwood is white, it is almost as hard as the heartwood. For this reason comparatively small trees yield timber, and thus can be felled earlier than trees in which the heartwood forms later. Of course, in this connection it should not be forgotten that the market does not desire logs of too small a size, i.e. of 18 inches or under, when squared. Locally this 


\section{WEST AFRICAN FORESTS AND FORESTRY}

is known as Ironpost, and is sold for house-building, and, as its name implies, it is used for the uprights of the house. The Public Works Department have a regular schedule of timbers which are used, and this timber is mentioned amongst them, and is bought from native contractors at $3 \mathrm{~d}$. per superficial foot for boards, and $3 \mathrm{~d}$. to $6 \mathrm{~d}$. per linear foot for beams and posts. This timber has been used as a substitute for real African Oak, when it is sold as African Oak. A regular supply of logs could be obtained from the peninsular forest.

3. Cedar Mahogany (Pseudocedrela sp.; termed Bissimi by the Mendis). This tree, which grows to a very large size, is not very prevalent. The largest tree, some 23 feet in girth, was found above the Gumah. The bole is usually very long and straight, which makes it very cylindrical. This last characteristic of the tree is all the more accentuated by its having no root projections at its base. This species appears to be one of the largest trees in the forest. It is apparently a very fast-growing tree, forming heartwood comparatively early, though the sapwood is rather wide (up to 10 inches in a tree 7 feet in diameter). This timber has not been exported, but wood from similar trees on the coast has been exported and sold in the European market as mahogany (scented). There is no reason to believe, therefore, that the wood from this tree would not fetch a similar price. Owing to this tree being so fullwooded, a larger proportion of the bole can be converted into logs than is the case with other kinds of mahogany trees which have large root flanges.

4. African Walnut (Lovoa Klaineana). This is a medium-sized tree of the Mahogany family, which, owing to the brown colour of the wood, has been termed African Walnut in the timber trade. Although not very prevalent, it yields one of the timbers suitable for export.

5. Satin Mahogany (Guarea sp.) is another medium-sized tree which is prevalent in most parts of the peninsula. The grain of the timber is of course similar to Mahogany, as the tree from which it is obtained belongs to the Mahogany family. The timber when planed has a satiny sheen on it, which may make it valuable in the European market. It has not been cut for local use.

6. African Pearwood (Mimusops sp.) is a large tree with a good bole of fair length. Only a moderate number of this species were found, but there are at least two, if not three, other species of Mimusops which yield a timber which has been sold as mahogany. The grain of the timber of the first-named tree is more open, sometimes figured, and of a lighter reddish colour than the other species. These other trees yield a dark-red timber of close grain, which is much harder than mahogany. These Mimusops are found at a higher altitude than most timber trees. The forest, therefore, above an elevation of 2,000 feet, is much more valuable owing to the presence of this tree. These 
trees attain a girth of 12 feet and a height of upwards of 150 feet. The bark of the trunk of the tree is smoother than that of mahogany.

7. White Mahogany (Canarium Schweinfurthii), also known sometimes as Gaboon Mahogany, is a very tall forest tree which attains a bole length of $\mathbf{7 0}$ feet, with a girth of 10 feet. It is not very plentiful, but is one of the light-coloured species of mahogany. It has a definite shipping value of $2 \mathrm{~s}$. 6d. in the round per cubic foot.

8. African Mammee or Mammy Apple (Ochrocarpus Africanus) is a large tree attaining a girth of 10 feet, with a bole length of 30 feet. It is moderately prevalent. The timber has a pretty grain, and is of a reddish colour, which is similar to mahogany.

9. Dita (Detarium Senegalense) is a large tree with the bole length of 30 feet and a girth of 12 feet. Although it is not a very common tree, it is a useful addition to the number of trees which yield timber similar to mahogany. The fruit is large, has an edible pericarp, and is sold in the market under the name of Dita.

10. Red Cedar (species of Sterculiaceæ) is a large and straightgrowing tree, which reaches a girth of 10 feet. The tree has very characteristic root flanges, which can be seen in illustration No. 10 . The timber has a mahogany-like grain, though of a somewhat more open texture. It is one of the most prevalent trees in the peninsular forest.

11. Kontah, or Mahogany (Afzelia Africana), is a large tree with oval crown and bole length of 30 feet. Only a few specimens were met with in the forest, though the tree often grows up in old clearings. The timber is of a reddish-brown colour, somewhat hard and very durable. It takes the place of an oak timber economically, although it is not really of that type. The grain of the timber has much longer and more open pores than oak, though it could probably be sold as an oak or teak substitute in the European market.

12. Rock Elm, also known as African Oak or Teak, is a common tree attaining large dimensions. Being a very durable wood of moderate hardness, it largely takes the place of European oak in the economy of the country, which, with its yellowish light-brown wood, rapidly becoming a nice old-oak brown colour, makes it a very similar timber, although, as the first name, Rock Elm, indicates, the tree is botanically a member of the Elm family. White ants occasionally attack its sapwood, but make no progress in the heartwood. The wood is not attacked by fungi to any extent. Wherever the rainfall is sufficient, seedlings of this tree come up in the old farms, and when cut down it sprouts again from the stump.

13. East Indian Walnut (Albizzia Lebbek) is a medium-sized tree which grows very quickly. The heartwood, which matures comparatively early, is a light-brown colour, similar to walnut. The 


\section{WEST AFRICAN FORESTS AND FORESTRY}

timber has an open, pretty grain. It is one of the trees which comes up in old farms, provided rainfall is moderate.

14. Satinwood (Zanthoxylum macrophyllum) is a medium-sized tree with a clear bole of 30 feet, combined with a narrow crown and small branches. It is a very common tree in the peninsular forest, and it is also found growing up in the old farms, where the rainfall is adequate ( 60 inches). The wood is the typical light-yellow colour. The grain of the timber is very fine and hard, which makes it less liable to shrink than other more open-grained woods. The heartwood forms early, though where trees grow up very quickly, roughly only half of the diameter width of a tree is made of heartwood. That is to say, in a tree a foot in diameter, approximately 6 inches will be heartwood. In the evergreen forest there is another species of Zanthoxylum which attains a rather larger size than the first named. It is, however, not quite so prevalent as the other species. In common with other species of Zanthoxylum, it bears all round the stem extremely large woody spines. In this species the spiny protuberances are exactly like small round cones of wood, with a diameter 2 inches at the base. Yet a third species of Zanthoxylum Senegalense yields a similar satinwood, almost as close grained, which, however, is found growing as a small tree at the edge of the deciduous forest before the dryzone belt is reached. This tree is characterised by its much smaller leaf, with pinnæ broader in proportion to their length than the former species. In a similar manner the woody protrusions on the stem do not project more than three-quarters of an inch from it, compared to those of the second-named species, which attain a length of 3 inches. The timber of this dry-zone Satinwood is just as valuable as the former species. It is fairly prevalent in the more open forest where it is found. It withstands the annual grass fires to some extent, and seedlings appear in the neighbourhood of mature trees.

15. Violetwood is a medium-sized tree with a smooth bark not unlike beech, and a bole of up to 20 feet in length and 12 feet in girth. It is, however, a little crooked in growth, but this is not an undesirable feature, because the texture of the grain often thus becomes figured. Specimens which were collected showed this growth, and a few species had a very pretty figured grain. It is quite a common tree in the peninsular forest. The fruit of this tree is a pod about a foot long and an inch wide, containing on the average eight oblong flattish beans. The wood is of a greenish-brown colour, and is very hard, heavy and durable, judging by the timber of fallen trees. The timber when planed has a scent of violets, hence the English name which I have given to it. The tree has not been cut for use as an export timber, though it is well worth a trial. It is not used locally, so that all available supplies of timber could be used for export.

16. Pterocarpus erinaceus (African Rosewood) is a small tree of 
the savannah forest, which is found in the Karina district and other parts of the country. It is one of the commonest trees, and occurs in small groups scattered throughout these forests. The timber is a reddish-brown colour and of a similar texture to the ordinary Camwood or Padauk, of which genus it is a member. The wood, however, of this species is much harder than that of the others, and the coloration is often partially streaked, both features being due probably to the much slower growth owing to the annual grass fires. From the neighbouring territory of Senegal the timber has been exported to France as African Rosewood, where it finds a good market; but it is doubtful if it could compete with the Bahia Rosewood in the English market, owing to its less brilliant colour; the timber is, however, worth a trial.

17. Baphia nitida (Camwood) is a small-sized tree, which is commonly found at the edge of villages and in old farms. It is a somewhat slow-growing tree, in which the heartwood forms none too early and in a somewhat irregular manner, occasionally small patches forming comparatively near the bark. The wood is hard, and the heartwood of a deep claret-red colour. The timber is close grained and of fine texture, which planes very smooth after being cut and dried. In recent years much smaller quantities of Camwood have been sent away (see Appendix I) than between the years 1827 and 1835 (see Appendix II), when between 5 and 802 tons were exported. In this connection, too, there can be no doubt that Camwood is obtained from the tree known botanically as Baphia nitida, because this tree is found in Sierra Leone, whereas Barwood, or the so-called Camwood of Nigeria, the produce of Pterocarpus tinctorius or Ostun, which has not yet been reported from the neighbourhood of Sierra Leone, could not have been absolutely killed out between the years 1835 and 1900.

\section{Trees Cut for Local Use.}

1. Morinda citrifolia? (the Brimstone) is the most common tree, from which the largest amount of timber which is used locally is obtained. Growing, as it does, with a girth up to 20 feet and a bole length of 50 feet, the local sawyers can usually make a very large number of 12 -feet planks 1 inch thick out of each tree. The chief use of this timber is for weather-boards, which are sold at 10s. per 100 feet. All the native houses in Freetown are faced with weatherboards of this kind of timber. After being cut down, shoots sprout out from the stump, forming in a few years small trees of useful size, especially in old farms. The name of this tree, Brimstone, denotes the wonderful sulphur-like colour of the wood. The durability of this timber for outside work and its termite-resisting qualities have given it a premier position amongst local timbers. The 


\section{WEST AFRICAN FORESTS AND FORESTRY}

Brimstone has a fruit not unlike coffee, and bears seeds plentifully; it should therefore not be difficult to raise seedlings for making plantations. The trees grown from stool-shoots do not appear to attain nearly such a large size as those grown from seedlings in the forest.

2. Chlorophora excelsa (Rock Elm, African Oak) is a common tree which is cut for local use. The heartwood, which rapidly darkens from a light-yellow brown colour to a dark old-oak brown colour on exposure to air, is very durable for inside or outside work. Though white ants attacks and destroy the sapwood, they make little or no progress in properly seasoned heartwood. Locally it realises $10 \mathrm{~s}$. per 100 feet. It is plentiful, and has a distinct tendency to spread into old farms, where the seedlings have more light to develop than in the forest.

3. Iyawey (Red Cedar, or Isganwe) is also a common tree which is cut for local use. It is a large and straight-growing tree, and attains a girth of about 10 feet. Owing to the wood being comparatively soft, easy to saw and of a nice red colour, it fetches $12 \mathrm{~s}$. per 100 feet, which is more than is obtained for several other local timbers.

4. Oldfieldia Africana (Black Oak, Beechwood) is cut for local use, for sale as planks at $2 \frac{1}{4} \mathrm{~d}$. per foot, and uprights and beams at 3s. per cubic foot. One of the chief uses of this timber is for the keelsons of the locally made sea-going boats. Owing to the diffculty of the local sawyers in handling heavy logs on the raised wooden pit-saw framework on which the logs are sawn, only comparatively small trees are felled, and consequently there is more waste, and undersized trees are prematurely sacrificed owing to the poor methods of the local sawyers. Less timber, especially heartwood, is thus obtained.

5. Parinarium sp. (White Oak) is a moderately common tree. It attains a good height and a girth of 12 feet. It has large root flanges reaching about 10 feet up the bole. Although a somewhat hard wood, it is used locally either as planks and posts or as beams and logs. It is said to be durable, and is worth $2 \mathrm{~s}$. per cubic foot when sawn.

6. Afzelia Africana (Mahogany, Kontah) is a medium-sized tree which is not very prevalent in the forest, but is much more so outside in the open forest country. The timber, which is hard, has an open grain with a good yellow-brown colour, not unlike Iroko. It is very durable, and used as planks and logs. In the plank it is sold at $6 \mathrm{~d}$. per superficial foot, and in the $\log$ at 3s. 6d. per cubic foot. This is considered one of the best local woods, partly owing to its grain being somewhat similar to mahogany. Seedlings appear in old farms where there are but few grasshoppers. Otherwise trees grown in a nursery are attacked by these insects, as well as by rodents of different kinds.

7. Daniellia Ogea (Blue Bessie) is sold as planks at 3d. per super- 
ficial foot. It is closely related to Paradaniella Thurifera; the former tree is more prevalent in the green forest, and the latter in the open deciduous forests, which attains a girth of 10 feet and a bole length of 30 feet, while the first-named species reaches a girth of over 20 feet and a bole length of over 100 feet. It is sold locally chiefiy for house-building.

8. Griffonia palescens Koronko is felled for sale as planks at $2 \frac{1}{2} \mathrm{~d}$. per superficial foot.

9. Coula edulis? (Almond Wood) is a medium-sized tree which is cut into planks 1 to 2 inches thick and up to 12 feet long, and sold at $2 \frac{1}{2} \mathrm{~d}$. per superficial foot.

10. Rhizophora racemosa (Mangrove) grows in pure "stands" in the swamps near the sea coast, chiefly in the estuaries of the rivers. It attains a girth of 4 feet and a height of 80 feet. It is sold as poles 9 to 12 feet in diameter at the rate of $2 \frac{1}{2} \mathrm{~d}$. per cubic foot. Very large areas of mangrove forest occur, so that ample supplies of this kind of timber are assured. Locally it is often used for house-building, and is preferred to many other timbers.

11. Ochrocarpus Africanus (Mammy Apple) is a large tree attaining a girth of 10 feet and a bole length of 30 feet. It is evidently not so prevalent as it used to be, owing to the fact that the best trees have been felled. Seedlings, however, appear very readily from the large fruit when it falls in suitable germinating places in the forest. It is much prized locally on account of its pretty grain and red mahoganylike colour. It is sold as planks, joists or posts at $3 \mathrm{~d}$. or $3 \frac{1}{2} \mathrm{~d}$. per superficial foot.

12. Ansophyllea laurina (Monkey Apple) is a very lofty tree, attaining a girth of 12 feet and a bole length of 40 feet. Although moderately prevalent in the forests, it is very plentiful outside in the deciduous forests. It shoots up very strongly from the stump after an old tree has been cut down. Wood obtained from these stool-shoots is, however, not so good or of such large size as that obtained from seedling trees. The timber is a light-brown colour, but a very pretty grain, full of medullary rays, giving it a sheen not unlike oak. Locally it is sold as joists and posts at the price of 3d. to 6d. per superficial foot.

13. Lophira procera (Red Oak, Kokank, also known as Ironpost) is sold as planks, posts and beams at $3 \frac{1}{2} \mathrm{~d}$. to $6 \mathrm{~d}$. per superficial foot. It is chiefly used for house-building. A full description of this tree is given under the heading of the export timbers, so that nothing more need be added here.

14. Parinarium excelsum (Rough-skinned Plum) is a very common tree, which attains a girth of 12 feet and a bole length of 30 feet. It yields a hard timber with open grain. It is sold locally as planks or logs at $6 \mathrm{~d}$. per cubic foot for building timber. The fruit, which, 


\section{WEST AFRICAN FORESTS AND FORESTRY}

as the name indicates, is like a green plum, is covered with white lenticels, making the surface very rough. The flesh is of a yellowish colour and soft, with a pasty nature. It has a sweet, pleasant taste. The wood, when freshly cut, has a sweet, beeswax-like scent, similar to that of the fruit.

15. Whismore, which is sold as planks at $2 \frac{1}{2} \mathrm{~d}$. per superficial foot, is another very useful timber, not unlike cedar in texture. The tree comes up very readily in old farms, and has very large tri-pinnate leaves. Apparently it grows very fast, though this does not appear to hinder the early formation of heartwood, which is of a very light brown colour, though the sapwood is quite white. It attains a girth of about 9 feet and a bole length of 50 feet. The bark forms very characteristic fissures, dividing it into more or less diamond-shaped pieces, rather reminiscent of the European Elm. Although the tree does not occur in actual groups, more than one will usually be found in the same locality.

16. Uapaca Heudelotti (Sugar Plum, Red Cedar) is a large tree with rather a spread of crown and numerous aerial roots. It attains a girth of 9 feet and a bole length of 20 feet. The timber has a close and fine grain, and is of a reddish colour. Locally it is cut and used for the ribs of sea-going boats. It is apparently quite durable for this purpose. It is very prevalent, and usually grows near waterways.

17. Pycnanthus Kombo (White Cedar) is a very large tree which attains a girth of 12 feet and a bole length of 80 feet. It is very prevalent, and can be recognised by the flat crown and long straight branches coming out at right angles to the stem. When cut it exudes a reddishcoloured mass of semi-liquid nature. The bark reminds one of the Mahoganies, though on the whole it is more fissured. The timber is soft and of a pinkish colour, though it gives more the impression that it is white and tinged with red. It has a very open grain with particularly long pores, reminding one of cedar (Cedrela). It is cut locally for sale as planks.

18. Pterocarpus Erinaceus (African Rosewood) is mentioned amongst the number of possible export timber-bearing trees. It is also used locally in the making of a musical instrument called Balangi, after the timber has lain some months in the ground. In the drier portions of the country it is a useful tree for house-building. It seeds readily, and is usually found in large quantities.

19. Baphia nitida (Camwood) is also one of the export produce bearing trees, but which has been used as a colouring matter for putting on the body from time immemorial. The local people, however, prefer to use cakes of the ground-up produce of the Barwood (Pterocarpus Tinctorius) from Southern Nigeria, which commands a higher price. That this product of Baphia nitida is the true Camwood is practically proved by the fact that this tree was first identified 
from Sierra Leone, whence it is all exported, and also by the fact that Barwood, or the Southern Nigeria Camwood, is not found in Sierra Leone.

Although the above completes the description of the most important local timber trees, there are many others which might be used with satisfaction. One of these trees, known as Yabonji by the Mendis, has a grain, colour and softness similar to white pine, and is sold locally as yellow pine. Erythrophloum Guineense (Sassybark) yields a hard timber suitable for bridge-building, as it is very durable and grows to a large size, though not always with a very long bole. Mountain Mahogany, a species of Lonchocarpus, has a grain similar to pine, with resin-like canals in the wood. It grows to a large size, with a straight bole 50 feet in length and a girth of 10 feet. Combwood (Conapharingia pachysiphon) is a small tree, which yields a yellow wood similar in texture and grain to boxwood, though a little softer. Locally it is used for making native combs. There is also a so-called Leopardwood, termed Koligi by the Mendis, which has a curious striped grain a little reminiscent of a leopard's skin; hence the name. The local inhabitants have various chewsticks, which are obtained from guttiferous trees or Vernonia species. Carapa Gayensis is found and used locally both as a timber and also the seeds for making an oil for the skin. In connection with all this local felling it should be noticed that there is scope for sawn timber of all kinds, more especially when it is taken in conjunction with the fact that over 2,000,000 feet board measure of planks, etc., are imported every year. A small mill placed near Bureh Town would probably be able to supply all wants as far as Freetown and the immediate neighbourhood were concerned, and water power might be available from the Gumah River, which flows down very rapidly to the sea. A mill, on the whole, is more economical in conversion than the local sawyer, as all slabs are left to rot in the forest, but these a mill would consume in power-making, or they would be resawn into smaller boards or shingles. At present there is no sawmill in the whole country, so that there is an open field for this venture, with a forest adjacent to the market and suitable conditions of labour.

\section{Minor Forest Produce.}

No account of the Sierra Leone forest would be complete without a description of the two chief vegetable products of the forest, namely Palm Oil and Kernels and Gum Copal.

Turning first of all to Gum Copal, known botanically as Copaifera Salikounda, which is a true copal gum, not to be confused with the gum from Daniellia Ogea and other allied species, illustrations Nos. 8 and 9 show this tree standing in the open, and also the shape of the 


\section{WEST AFRICAN FORESTRY AND FORESTS}

trunk at nearer inspection. It will be seen that it is rather a tall tree, with open thin crown and straight upward-spreading branches. The bole usually does not exceed $\mathbf{3 0}$ feet in length, and then forks or divides into three main stems. The curious marks on the stem, making the tree look as if it were attacked with some form of canker, are those made by tapping the trees for the gum. At the beginning of the dry season small squares of bark, about an inch across, are removed from the tree, beginning at the ground, upwards to 20 and 30 feet. At the corners of each little square gum gradually exudes during the dry season in the form of an ever-increasing sized globular tear, which hardens on exposure to the air. By the end of the dry season, as in February or March, it has attained a size of half an inch or so, and is then quite hard and white and nearly transparent. Only a few little pieces of bark adhere to its surface, and these are easily removed. Then these tears are collected in a bag, sorted, and then sold to the European firms in Sierra Leone and elsewhere. The average tree yields $1 \mathrm{lb}$. of gum copal per year.

In the peninsular forest a patch of Gum Copal trees is found near Bureh Town. In the Protectorate, irregular belts occur, such as that on the Kassewe Hills and north of Moyamba. On the banks of the Rokell River, too, it occurs in single specimens dotted along the bank. The smooth grey bark of the stem is not unlike Beech, except for the fact that it is pitted by the tapping squares, which occude only very gradually.

The leaves are in pairs, but have such a straight inner edge that they appear like one leaf which has been cut in half down the middle. The main vein of the leaf is at one side of it. In this manner the leaf is unmistakable, though a Cynometra leaf is somewhat similar, and also a Bauhinia; but in the former the vein is more in the centre and the leaves, are quite separate and not close together, and in the latter they are joined at the base. The tree appears to be easily killed by overtapping. Before the formation of the Forest Department, whole forests had been destroyed in this way, one of which I saw north of Moyamba during an inspection of the Gum Copal belt.

The timber of this tree is a red-brown colour, of hard texture, with a pretty grain. It is, of course, of the type of purple-heart. It is very durable and termite-proof, though a borer attacks it slightly. The wood of trees killed by overtapping proves to be quite sound and useful for any purpose where a hard timber is required.

The tree can be grown from the flat, round, paper-like seeds, which are bought at $f 1$ a bushel in Sierra Leone. The tree usually bears well, and the seed is collected off the ground. Young self-sown seedlings are found, which shows that the seeds germinate readily too. It does not stand transplanting very well, but with care soon 
recovers. It grows rapidly, and reaches a tapable size in ten years, approximately. It does not seem very exacting with regard to soil. In the peninsula it grows on rocky soil, and in Moyamba on an alluvial soil.

Recently the exports have decreased, as the following figures show, chiefly owing to the destruction of the trees by overtapping. However, when the forests have recovered, the younger trees have matured, and the trees since planted are in bearing, and an increase may be expected. It is the most valuable, Gum Copal usually being worth 8d. to 1s. 6d. a pound, but if quite clean and white it fetches as much as 2 s. $6 \mathrm{~d}$. a pound. Its chief use is for varnish-making, though the best grades are used for pharmaceutical preparations. It is far easier to tap than rubber, and the cost of preparation is therefore very low, so that it should prove worth cultivating on a large scale. The market for Gum Copal is a comparatively large one, and other sources of supply, such as those of Kauri Gum from New Zealand, are decreasing, or not entirely meeting the demand. It is only a question of time before the whole supply will have to be obtained from cultivated trees.

It stands a certain amount of shade during the first four years, but from the fifth year onwards it is distinctly a light-loving species. On the whole it is almost a gregarious tree, as usually groups of trees are found up to fifty or more, and in a whole forest the prevalent tree will be Gum Copal ; for instance, in the Gum Copal belt near Susuwuru. A planting distance of 6 feet will probably prove advantageous, as the tree has a distinct tendency to branch low down on the stem if not forced to grow up straight by the presence of other trees. Then in the tenth year a judicious thinning out of the weakest trees by tapping to death would give additional space to the others and allow for greater girth increment for the other clean-stemmed trees. An early financial yield would also thus be obtained.

In the economy of the country, more important even than the Gum Copal is the Oil Palm (Elceis Guineensis), which is found in the Forest, scattered in groups and belts amongst farms inland, as at Blama, and near the sea coast, as at Sherbro, and also as isolated individual trees in the drier parts of the Protectorate. Towards the northernmost part of the country it is not seen at all, though climatically there is nothing to stop it growing if planted in suitable localities. It tends to spread with increasing cultivation of the ground, so long as the rainfall is sufficient and the soil moist enough for it. In the forest itself it is very sparsely distributed. Owing to the large population and the comparatively small area on which the Oil Palm is really plentiful, more palm oil is eaten than exported. This is most clearly seen in the quantity of exports of both products, which show a much larger proportion of kernels than oil. 


\section{WEST AFRICAN FORESTS AND FORESTRY}

The fruit usually ripens in January, February, March, or sometimes earlier, and is left for six months. Usually the trees have to some extent been cleared by the natives, then on a certain day the bunches of fruit may be cut. This takes place after the natives have cut the bush down for making the chief's farm. It also ensures, incidentally, that most of the fruit is quite ripe, though this is not the reason why the natives may not begin cutting off the bunches when they like. The bunches of fruit are left in the forest at convenient places at the edge of the path, covered with palm leaves. After a week or so these are taken to the village, and all the drupes cut off with a machete. These are next put in large earthenware pots with a little water, which are then placed over a good fire. In about an hour the fruit is thoroughly steamed. The fruit is then piled into a trough of beaten clay with a palm-nut bottom, or even stones. Water is poured in, and the fruit is pounded with the feet and also with a small pestle. The oil gradually rises in yellow fatty masses on the surface of the water, and is collected with the hand and put into a clean pot. As soon as a pot is filled, it is placed over a good fire to boil. When it has been boiled thoroughly it is strained, the strained oil being that usually eaten or sold to firms for export. The residue of dirt and pieces of fibre is used as an illuminant in the native lamps. The nuts are placed in the sun to dry for two or three months, after which they are cracked with a stone or a piece of iron and the kernels collected in boxes or bags for sale. The fibre in the washing trough is thoroughly squeezed by hand and all oil extracted. The water is let out of the trough gradually, and all oil collected from the sides of it. It is also washed down with water to collect the more adhesive particles. Even so, there is a large percentage of waste. An oil is also made from the kernels by heating them in an iron vessel over a fire. This oil is used for the skin or for wounds.

In the ordinary way oil palms are not planted, though in moving to a new area where farms have not been made before the natives take oil-palm fruit with them, which get scattered as nuts; these germinate and form the nucleus of a group of oil palms in that locality. Considering the large population and its increasing need for the oil, the planting of oil palms appears to be remunerative.

Palm Wine-tree (Raphia vinifera) is used very largely where it is found in the extensive forests near the rivers and sea coast in swampy places. Piassava fibre is obtained from this source, but so far has not been used in Sierra Leone for this purpose, whereas in the neighbouring country some of the best piassava is obtained. The people are, however, otherwise occupied, so that until there is a greater population it is unlikely that this industry will be taken up. The approximate area of wine palms is 3,000 square miles in various parts of the whole country. Some of the best areas are found on the banks 
of the Mano, Morro, Maho and Rokell Rivers. The long fronds of the leaves yield the steering and pushing poles for canoes, also most useful rafters and scantlings for houses. The leaves themselves are made into mats for covering the houses. They are said to last seven years when properly put on. The fruit of the tree is used for stupefying fish, which can then be very easily speared by the natives. The tree is usually set on fire to draw the palm wine, though this more often happens subsequently to the taking of the wine. A tree does not last more than three years with severe tapping, such as it is subject to by the natives.

Borassus flabellifer (Fan Palm, Bottle Palm) is found in the northern, drier part of the Protectorate, but so far is not used to any extent for house-building, for which the timber is most suitable, being very durable, of good length, and can be split. The nuts of the large coconut-like fruit are useful as a substitute for vegetable ivory, though thus far no use has been made of them. The approximate area of distribution of this species of tree is about 4,000 square miles. Quite a trade is done in various kinds of bark, altogether from about fifteen different species of trees, of which most are collected in the Peninsular Forest. Amongst them is found the Sasswood, or that of Erythrophloum Guineense, the notorious native poison, though it is not at all certain that nowadays in Sierra Leone it is used for this purpose.

\section{The Forest Department of Sierra Leone.}

In the course of 1911 a Forest Department was formed by the appointment of a Conservator of Forests; this has been gradually enlarged until there are now three Assistant Conservators of Forests as well. The chief work of the Department so far has been the drafting and passing of a Forestry Ordinance in 1912 and the demarcation of two Forest Reserves. The Peninsular Forest, with its new boundaries, comprises 75 square miles, and the Kassewe Hill. Other areas have been set aside, notably the Kagnari Hills and Kambui Hills as Forest Reserves, and Nimmini and Loma Forests examined previous to demarcation with a view to their reservation. The Gum Forests were closed to tappers with the consent of the chief, so that the trees could recover from previous overtapping. In addition to this work, some rubber planting has been done in the Gumah, and one Assistant spends all his time on this work, nurseries having been formed in different places -Mano, Bo, and Falaba. A large number of botanical specimens of the trees and shrubs have been forwarded to Kew for identification, so that gradually the silvan vegetation is becoming known. No planting of oil palms (Eloeis Guineensis) has been undertaken yet, despite the large export of this product. Rubber planting has not 


\section{WEST AFRICAN FORESTS AND FORESTRY}

been forgotten either. So far very little revenue has been received for timber-felling fees, which means really that in the past the forests have been destroyed, and now only small quantities can be cut. It does indeed make one pause and think what immense forests must have existed in the days of 1827 , when so many loads of timber were exported, as shown in the table on p. 64. If those forests had been preserved then, they would be yielding high returns now, and the Department would be self-supporting, instead of having money invested first in plantations before returns are obtained. However, now that the Department has been formed, a definite Forest Ordinance has been passed, under which Forest Reserves can be made, and the future of the existing forests is thus assured. Sooner or later all of them will yield a monetary return, besides benefiting the country climatically and preserving the soil.

One can really look upon Forestry as a kind of Endowment Assurance, with returns which may begin at once with existing forests, or later with afforestation begun now. The return is always sure, more especially now, with continually rising timber prices. In Sierra Leone, of course, for some years money will have to be put into Forestry work before adequate returns can be made, owing to the reckless mismanagement of the forest in the early part of the nineteenth century. For the purpose of easy reference, a list of some of the most important timber trees is appended, and with both the Mendi and Timani names, when it is possible to give these, and an English equivalent is also given where one uses a name suggestive of the use of the timber.

So far the Department has not leased any areas for the exploitation of timber for export or local use, though there are several areas available, such as the peninsular forest. Even an organization of the sawyers and boat-builders would be a useful work, and machinery for cutting the various woods would lead to greater production and a saving of timber, of which so much is now wasted. Again, the enormous demand for firewood in Freetown, most of which is waterborne, could be more advantageously met with a small sawmill or movable plant in connection with the other wood-using industries already named. The mangrove swamps would provide material ready at hand for conversion. The railway requires firewood at certain points ; there again is scope for improved methods of dealing with it, yielding profit both to the contractor and to the Forest Department. 

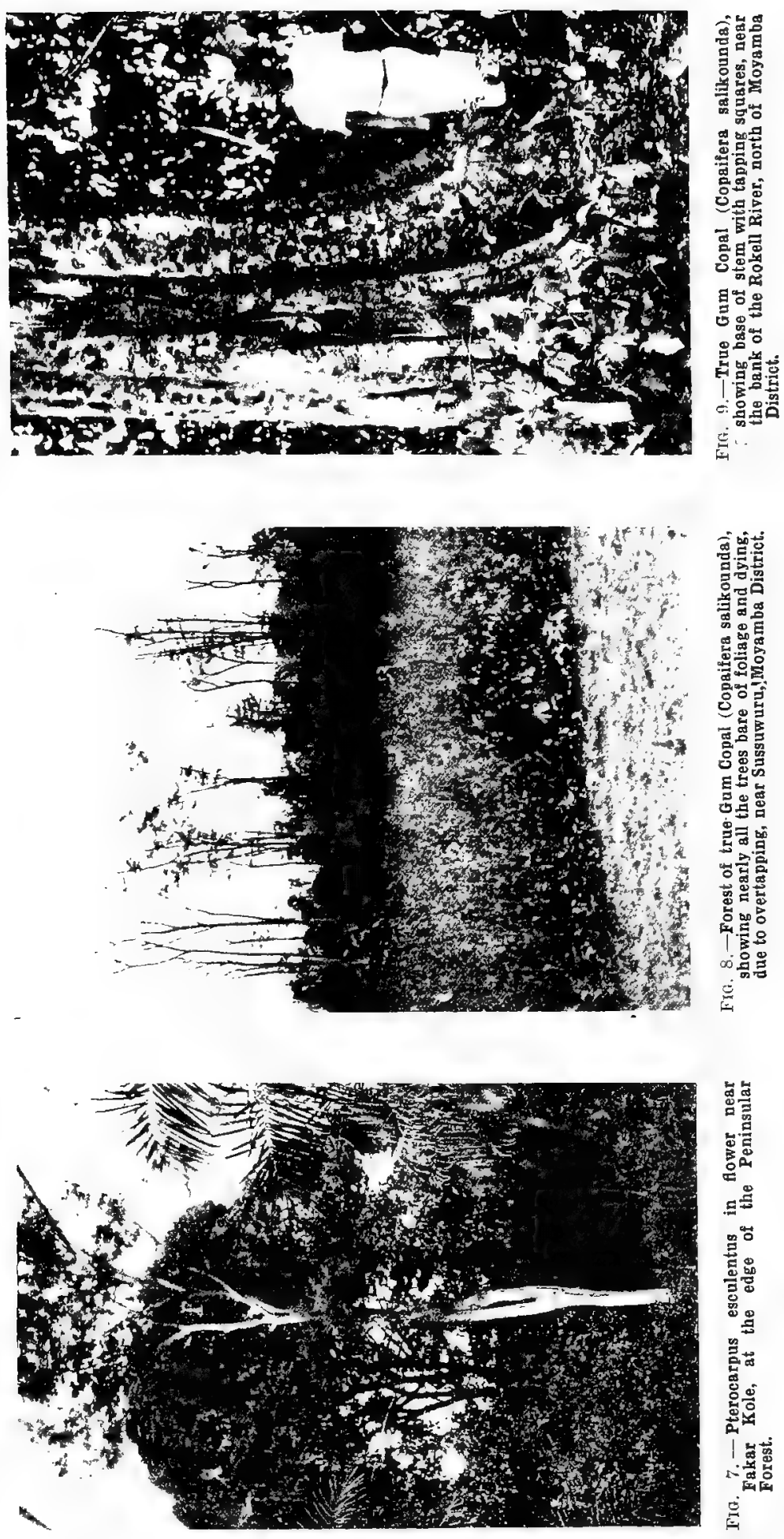



\section{VI.-INDIGENOUS FOREST TREES}

Species marked with an asterisk (*) are Lane Poole' $\mathrm{s}^{\mathbf{1}}$; those marked with an obelisk $(\dagger)$ are the Author's.

\section{Pandanaceæ.}

Pandanus candelabrum. Screw Pine. Bambi (Mendi).

Pandanus sp. near P. candelabrum.* Screw Pine. Pambei (Mendi). It is a tree with wide-spreading prop roots always growing in running fresh water. The leaves are used in basket-making.

\section{Palmæ.}

Eloeis Guineensis.* Oil Palm. Ankump (Timani); Tui, Tauwi, Taupwi (young trees), (Mendi).

The well-known Oil Palm. It is a most useful tree, thriving best near villages, but growing abundantly in the northern part of the forests. The nuts contain a large quantity of oil. They are used also for planting.

Borassus flabellifer.* Fan or Daleb Palm. Tunka (Timani); Hoke (Mendi).

It grows to about $\mathbf{7 0}$ feet in the grass country. Umbrellas are made from the leaves, also baskets. The stems are used for building-posts.

Raphia vinifera.* Wine Palm. Ankent (Timani); Duvui (Mendi).

Sometimes called the Tombo Palm. It is very gregarious, being frequently found forming almost a small forest in swampy ground.

Raphia sp. near $R$. Gaertneri.* Kili (Mendi).

It is a small plant of only 10 feet, growing in the swamps. It does not yield wine. Baskets and mats are made from the leaf stalks and thatch from the leaves.

Calamus sp.* Balui (Mendi).

This is a climbing palm or rattan, growing to the top of the highest trees, having a diameter of 2 inches, armed with strong hooked spines. The stem, when split, is used for tying the rafters of houses; lengths of it are used as clothes-lines. Suspension bridges are even made over the river.

Calamus sp.* Tambelei (Mendi).

This species grows as high as the preceding one, but is only $\frac{1}{2}$ inch in diameter. Besides being used as cordage, it is employed as thatching.

1 Trees, Shrubs, Herbs and Climbers of Sierra Leone. Seo Lane Poole. 


\section{Liliaceæ.}

Draccena Mannii.* Ningei (Mendi).

This tree grows to 30 feet in height, and is called the Asparagus Tree by Europeans, because the flavour of the young leaves is like asparagus. The natives eat them chopped with their rice.

\section{Ulmaceæ.}

Trema affinis.* Gombei (Mendi).

A small tree, from 25 to 30 feet. It springs up in cleared farms; the wood is of little use except as thatching laths. The bark is peeled and eaten for coughs.

Trema Africana.* $\dagger$

A medium-sized tree.

\section{Moraces.}

Ficus Vogelii.* Jol, Lopi (Timani); Gonwi (Mendi).

A much-branched tree, yielding a latex, which coagulated has been sold at from $6 \mathrm{~d}$. to $1 \mathrm{~s}$. a lb. in London as paste rubber.

Ficus sp.* Wild Fig or Sandpaper Tree. Indäihen (Mendi).

This species has rough leaves like sandpaper, hence its name. They are used to clean woodwork.

Ficus platyphytes. Gonwé (Mendi).

Chlorophora excelsa.* Iroko, Teak, African Oak. Tema (Timani); Sime or Semei (Mendi).

It is found particularly near old clearings, but not so frequently in the forest. It is a termite-resisting timber; called Teak, Oroko or African Oak, when exported, it is worth about 1 $\frac{1}{2}$ d. per superficial foot. At one time the latex was used as an adulterant for rubber. It polishes well and makes very handsome furniture. Canoes, pestles, rice-basins, etc., are made from it. Dr. Unwin suggests that Iroko is a corruption for rock elm.

Musanga Smithii.* Corkwood. Ofika (Timani); Govwi (Mendi).

It is a common tree, growing to about 60 feet in old farm lands, and affords a shade for forest species to get a footing. It is remarkable for its wide-spreading prop roots and large palmate leaves.

Myrianthus arboreus.* Fofoi (Mendi).

A small tree.

Myrianthus sp.* Fofoi (Mendi).

A small tree.

Myrianthus serratus.* Fofoi (Mendi).

A small tree with edible fruit. 


\section{Olacaceæ.}

Coula edulis.* Tokei (Mendi).

It is a large tree bearing walnut-like nuts, the kernels of which are good to eat both raw and cooked. Oil is obtained from the kernels, which are valued at $£ 7$ a ton. Olax.*

A small tree.

\section{Loranthaces.}

Loranthus langwensis.* Mistletoe. Gongui (Mendi).

This is the common mistletoe, which may be seen growing on a great number of trees. Specially common on Guava and Kola Trees.

\section{Menispermacez.}

Triclisia macrophylla. Ndawi (Mendi

A climbing shrub.

\section{Anonacex.}

Xylopia ALthiopica.* The Spice Tree. Umberikum (Timani); Kewe or Hewe (Mendi).

Its fruit is much in demand as medicine.

Xylopia sp. Dinklagei.* Mountain Spice. Kapus (Timani); Hui, Hewe (Mendi).

Monodora Myristica.* Calabash Nutmeg or False Nutmeg. Gboite (Mendi).

It is a medium-sized tree, with rose-pink. sweet-smelling flowers. The fruit is the false nutmeg.

Xylopia sp. near $X$. Elliotii.* Yellow Wood. Belvi or Kpaini (Mendi).

This tree grows to a medium height, with thin but very straight stem up to 18 inches in diameter. Its wood has been exported to Europe, where it has taken the place of American whitewood.

Xylopia parviflora.*

A tall tree of 20 feet, growing on the bank of the Moa River. Cleistopholis sp. near C. patens.* Moigbwamy (Mendi).

This tree grows to a height of 80 feet. Strips of the bark are used by the natives for making brow-bands and shoulderstraps when carrying palm hampers.

Hexalobus grandiflorus.* Njahewe (Mendi).

It is a large, wide-crowned tree. with conspicuous white Howers. 


\section{WEST AFRICAN FORESTS AND FORESTRY}

\section{Pachypodanthium Staudtii.*}

A large-boled forest tree, with grey, rough bark, of which the timber is very hard to saw.

Stenanthera hamata.*

A small tree.

Uvaria Afzelii.*

A tree of 15 feet in height, with very heavy-scented flowers. Uvaria $8 p . *$ bark.

A tall, straight tree, with blackish-green longitudinally ribbed

Uvaria macrocarpa.* Finger Root.

This tree is found 15 feet in height. The root is used medicinally by the Creoles, and by them called Finger Root.

\section{Myristicaces.}

Pycnanthus Kombo.* White Cedar. Kuwul (Timani); Boye (Mendi).

It is a very tall tree, attaining a girth of 12 feet, which is cut locally, but not for export, owing to its soft wood and open grain.

\section{Moringacex.}

Moringa pterygosperma.* Horse-radish Tree; or Oil of Ben Tree. The oil in the seeds is 38 per cent., and they are valued at $£ 9$ a ton in London. The oil is suitable for lubricating clocks and watches. The wood is not used.

\section{Rosaceæ.}

Parinarium macrophyllum.* Gingerbread Plum. Ndawei (Mendi).

It is a small tree bearing a fruit the size of a goose's egg. The fruit is the edible ginger-plum.

Parinarium excelsum.* Rough-skinned Plum. Abbis (Timani); Ndanwi Badgi (Mendi).

This tree attains a large size and seeds very readily. It yields a useful hardwood; is felled locally and for building purposes. The grain of the wood is too open to be of much use for export. It is of a reddish-brown colour. The pulp around the seed is eaten.

\section{Leguminosæ.}

Paradaniella thurifera.* Ilorin Balsam Tree. Bessi (Timani); Bessi Kpessei or Gbassei (Mendi).

A quick-growing, soft-wooded tree, pretty evenly distributed through the forest. It attains a girth of 9 feet and a bole length of 30 feet. It is cut locally for house-building and other 
purposes. A fragrant resin is exuded and much used as a scent by the Creoles and natives.

Erythrophloeum Guineense. Sasswood. Kukorn (Timani); Gogwi (Mendi).

A large but not very straight-growing tree, which attains a girth of 9 feet. It has been exported, but the price obtained for it is not available. The wood is hard, but works up well, and has been used by the Public Works Department of Southern Nigeria.

Erythrophloeum sp. near $E$. micranthum.* $\dagger$ Sasswood or Redwater Tree.

The bark contains a virulent poison, which is used as an ordeal. It is a large forest tree, having a green bole. The wood is used to make canoes.

Erythrina Senegalensis.*

A tree 20 feet high, with handsome red flowers. The branches are armed with prickles. The wood is used for fencing.

Erythrina sp.* Malei (Mendi).

This is a large tree, 80 feet in height, with wide-spreading branches. The stem is pale grey and covered with strong prickles. The flowers are pink.

Piptadenia Africana.* K'Kuperb (Timani); Mbeli or Mbelignli (Mendi).

This tree is very plentiful, and attains a large size. The wood is of a brown colour, hard and durable. Strong canoes are made from it.

Cynometra Vogelii.*

A small tree.

Xylia Evansii.* $\dagger$ Bunga (Timani); Tegai (Mendi).

A medium tree.

Griffonia palescens. Koronko (Timani); Koronko (Mendi).

Pentaclethra macrophylla.* Oil Bean Tree. Kekung (Timani); Fai, Fae (Mendi).

The wood is of a brown colour, hard and durable. The natives use the ashes of the burnt pods for making soap. The wood is sold for 1s. 1d. per cubic foot in the English market.

Parkia Africana. Locust Bean. Ebbe (Timani); Gumwi (Mendi).

Parkia filicoidea. Forest Locust. Gimwi (Mendi).

Parkia biglobosa.* Locust Bean.

A wide crowned tree, 50 feet in height, bearing conspicuous red flowers and long pods. The pulp around the seed is edible, but the seed itself is considered a great delicacy ground and mixed in soup.

Parkia sp. Gumni (Mendi).

The tree is much like the $P$. biglobosa, but is found growing 


\section{WEST AFRICAN FORESTS AND FORESTRY}

wild in the forests. It differs in having well-developed buttress roots. The seed is not eaten.

Lonchocarpus. Mountain Mahogany. Ali (Timani); Jumbowill (Mendi), probably Petophorum sp.

A very tall and straight tree, with a bole of 50 feet and a girth of 10 feet. It is found everywhere, especially on the edges of old clearings and in old farms. It has been felled for export, but no data are available as to its worth. The wood resembles pine, being soft and full of resin-like canals.

Lonchocarpus cyanescens. * Big-leaved Indigo. Jalei, Walwei (Mendi).

A valuable dye is obtained from the leaves, which takes the place of indigo and is sold at from $4 \mathrm{~s}$. to $4 \mathrm{~s}$. 6d. a pound in England.

Lonchocarpus sericeus.*

A branched and gnarled tree growing on the sea shore, its roots often being washed by the tide. The timber is closegrained, hard and durable.

Cassia Siberiana.* Bongbo or Bangbwei (Mendi).

A small tree bearing handsome yellow flowers. A decoction is made from the root to ease elephantiasis, also stomach troubles.

Copaifera Guibourtiana.* Sierra Leone Gum Copal. Akak (Timani) ; Kobwi (Mendi).

This tree was found growing on the ridges and low-lying land near York and Bureh Town, also in Ronietta, Karene District, and Kassewe Hills. It is noted for its gum. The dead wood works up very well, having a fine grain and red colour, and should be of value for export. Locally it has only been used for bridge-building. The average price paid by local traders for the gum appears to be 1s. a pound.

Copaifera salikounda.* Buini (Mendi).

A large tree.

Pterocarpus esculentus. Atont (Timani); Batwi (Mendi).

Pterocarpus erinaceus.* Rosewood. Katai (Timani); Bundwi Batwi (Mendi).

This is a small but valuable tree, confined principally to the drier parts of the country, particularly in the Karina forests. The wood finds a good market in France. Locally it is used to make a musical instrument called "Balangi." The seeds are intoxicating when eaten raw.

Macrolobium sp. Jamostima (Mendi).

Macrolobium Palisotii. K'Pal (Timani); Bumbi (Mendi).

Macrolobium sp.?* Limba? African Violet Wood. Tunfall (Timani); Pfandi or Mbombi (Mendi). 
It yields a wood with a pleasant scent, which grows to a stem length of 20 feet and girth of 12 feet. The wood would probably be figured, owing to its peculiar growth, ebony'like, hard, heavy and of a greenish-brown colour. It bears a pod about a foot long and an inch wide. The tree grows in great quantities, but it is not used locally, owing to its hardness. It should be tried in European markets.

\section{Macrolobium elongatum.*}

It is a small shrubby tree.

Macrolobium sp. near M. Heudelotii.* $\dagger$

A medium-sized tree found chiefly near water. The pod is larger than the other Macrolobiums.

Macrolobium Limba.* Mbombi (Mendi).

This tree reaches a height of 40 feet. Its roasted leaves, when ground and mixed with water and ashes, are used for ulcers.

Dialium Guineense.* Black Tumbler or Velvet Tamarind. Mabump (Temni), (Timani); Mamboi (Mendi).

A medium-sized tree bearing edible, velvety seedvessels.

Dialium Senegalense. Black Tumbler. Baut, I (Timani); Burogono Mambui (Mendi).

Afzelia bracteata.* Konta. Konta (Timani); Bendiguri or Kpendeideli (Mendi).

Afzelia Africana.*

These two trees are very much alike as far as timber is concerned. The wood is much used locally, and it may be of value for export, as the texture is similar to mahogany. The $A$. Africana yields a particularly good mahogany substitute under the name of Kontah or Counter wood.

Afzelia $s p$.*

A large-crowned tree.

Berlinia acuminata.* Kpendei (Mendi).

This tree grows to a height of 80 feet, having a very conspicuous flower. It is much used in cabinet-making.

B. Heudelotiana.* Helei (Mendi).

A large tree, 50 feet in height.

B. sp. near B. stipulacece* Tzabembi (Mendi).

A large tree, the seeds of which are made into counters by the Mendis to play Warry.

Brachystegia sp.* Bodgei (Mendi).

It reaches the height of 150 feet, and is one of the largest forest trees, with wide buttress roots.

Cryptosepalum tetraphyllum.* Hellebolei (Mendi).

A large tree. 


\section{WEST AFRICAN FORESTS AND FORESTRY}

Cylicodiscus gabunensis.* African Greenheart. Mbeli-deli (Mendi).

It is very similar to Piptadenia Africana in appearance, and also yields a strong, hard wood.

Dalbergia sp.* Dalbergia Rosewood. Balakenta (Timani); Firbandu Ndambabuli (Mendi).

A small tree.

Baphia polygalacece.* Ndambabuli (Mendi).

A climber, 10 feet in height. The stem used for killing fish.

Baphia nitida.* Camwood Tree. Mat, Kam (Timani); Bendwi or Bunduei (Mendi).

A small tree from which dyewood, a fast red dye, is obtained. The wood is hard and heavy, and is used for rice-mortar pestles and walking-sticks.

Albizzia Brounii.* Albizzia. Bakbwi or Bpakpei (Mendi).

This is a medium-sized tree yielding a reddish wood of moderately fine grain, somewhat resembling mahogany. The heartwood is very pretty. It should be saleable in Liverpool market.

Albizzia fastigata.* Folei-kpakpei, Bakbaboi (Mendi).

This species rarely attains a diameter at the base of more than 18 inches. It nearly always has a rotten heart.

Detarium Senegalense.* Mahogany, Dita. Kita (Timani); Dupwi II, Kolei (Mendi).

It is a very lofty tree, which yields a wood sold as mahogany in the Liverpool market. The grain is not so close as is usual in mahogany, but the colour is good. The fruit is edible and eaten locally. Dita is the name given to it. It is not very common.

Detarium sp.* species.

A large tree of 60 or 70 feet in height, probably a new Millettia cf. drastica.*

A small tree.

Millettia Lane-Poolei.* Togbeli (Mendi).

A small tree or shrub about 15 feet in height, with white, scentless flowers. There are three other varieties, with flowers ranging from white and pink to mauve.

Millettia pallens.*

A medium-sized tree with mauve flowers:

Millettia sp. near M. Sangana.*

A medium-sized tree with erect pods and mauve flowers. Millettia rhodantha.*

A medium-sized tree with yellow, aromatic wood.

Mimosa Dinklagei.* Gumgui (Mendi).

A medium-sized tree, 50 feet in height. 
Newtonia insignis.* roots.

A tree about 80 feet in height, with well developed buttress

Peltophorum.* Njomboguli (Mendi).

A large tree.

Ormosia monophylla.*

\section{Linaces.}

Ochthocosmus Africanum.* Tuanyei (Mendi).

A small, fairly common tree.

\section{Humiriacese.}

Saccoglottis Gabunensis.*

This tree yields a first-class timber. The bark strips off cleanly and is sold in Calabar at 5s. a roll 30 inches long and 18 inches in diameter.

\section{Rutacex.}

Zanthoxylum macrophyllum.* Spiny Satinwood. Witkoran (Timani) ; Pfui II (Mendi).

This tree yields a very pretty yellow wood, with a somewhat open grain.

Zanthoxylum sp. Satinwood. Bek (Timani); Pfui (Mendi).

A medium-sized tree, with most peculiar conically shaped woody protrusions on the bark. It has not been cut locally. Zanthoxylum rubescens.*

An armed tree from 12 to 15 feet high.

\section{Burseraceæ.}

Canarium Schweinfurthii. White Mahogany. Beri (Mendi).

This tree is not very common. A very large tree which has been found 150 feet high, with a bole of 70 feet and a girth of 10 feet. It could be cut locally and would make a valuable addition to local furniture woods. It is, however, hard to saw.

\section{Meliaces.}

Lovoa Klaineana.* $\uparrow$ African Walnut.

It is a medium-sized tree, not very common; the value of the timber varies from $1 \frac{3}{4} d$. to $3 d$. per foot.

Lovoa sp. near L. Klaineana. African Walnut.

A medium-sized tree.

Carapa procera.* Crabwood, Coondi, Kakunt (Timani) ; Kuwi Kowi (Mendi).

It is a medium-sized tree, which is evenly distributed everywhere. It yields a mahogany-like wood, which has been sold in the Liverpool market. 


\section{WEST AFRICAN FORESTS AND FORESTRY}

Carapa Gayensis.

Guarea. Satin Mahogany. Kaffi (Mendi).

A fair-sized tree, having a grain similar to mahogany, but with a satiny sheen which may make it very valuable. It is not cut locally, but might be tried for export.

Guarea sp. near leptotricha.* $\dagger$ Kaffi (Mendi).

A tree.

Pseudocedrela. Cedar Mahogany. Bissimi (Mendi).

This tree grows to a very large size. The timber is similar to that of a tree found in Southern Nigeria, but it appears to be a different species; the sapwood is wider and the heartwood has a better colour. It is fairly common.

Pseudocedrela sp. near $\boldsymbol{P}$. utilis.*

A large tall tree, yielding a handsome wood.

\section{Ekebergia.*}

Medium-sized tree.

\section{Khaya.*}

Dr. A. H. Unwin found a Khaya in a Gola forest which has since been ceded to Liberia. The Khayas yield timber (African Mahogany), gum, tanning-barks and medicaments.

Trichilia Heudelotii.*

Trichilia sp. near T. Prieuriana.*

A medium-sized tree.

Trichilia sp.* Jawei (Mendi).

Turrcea sp.*

A small tree, from 12 to 15 feet.

\section{Polygalacee.}

Carpolobia alba.* Bofelei or Gibofoyoi (Mendi).

It is a small tree called Poor Man's Candle.

Carpolobia lutea.*

A shrub or small tree.

\section{Dichapetalacex.}

Chailletia toxicaria.* Magbevi (Mendi).

A violent poison is made from the kernel, used by the natives to destroy dogs and vermin. They have also used it to poison well-water in hostile villages. The pulp of the fruit is harmless and edible.

\section{Euphorbiaceæ.}

Ricinodendron Heudelotii. Mahogany. Kino (Timani) ; Boi (Mendi).

This tree yields a mahogany valued at 2d, $-3 \frac{1}{2} \mathrm{~d}$. per superficial foot. It is rather an uncommon tree, but as it seeds very 
readily and develops rapidly, more could be planted. A large number are found along the river banks.

Ricinodendron Africanus.* Gbolei (Mendi).

A tree 90 feet high with horse-chestnutlike leaf. The timber is soft, and used for making masks for Bundu devils, also rice spoons and plates. The seeds are rich in oil, but the natives do not extract it; they are, however, used by the native women in the rattle for their Bundu dance.

Uapaca Guineensis.* Sugar Plum, Red Cedar. Kulil (Timani); Kondi (Mendi).

A large spreading tree with aerial roots. It is cut locally and used for the ribs of local boats. The wood is of a reddish colour and fine grain, which might sell as mahogany. Some species yield edible fruits.

Uapaca Heudelotii.*

This is a tree growing up to 60 feet along the bank of the Moo River.

Uapaca Togoensis.*

This tree grows in the riverside forests.

Oldfieldia Africana.* Real African Oak. Tortorza (Timani); Paulai, Pawi Kpaoloe (Mendi).

This tree attains a large size, a height of 120 feet and diameter at the base of $5 \frac{1}{2}$ feet. The bole often reaches 60 feet without a branch, though sometimes the bole is short, owing to its growing in a laterite soil. It is more frequent in the southern than the northern forests. It has not been cut locally, though the natives recognise it as a very hard wood. It has been used for dock gates.

Cyclostemon. Toye (Mendi).

Fluggea microcarpa.* Tigwi (Mendi).

Amanoa bracteata.* Jagbouei (Mendi).

A tree which grows up to 5 feet in diameter, and straight. from the ground to a height of 60 feet. It is then much branched. The timber is not used.

Anthostema Senegalense.* Mamboi (Mendi).

It is a small tree growing on the sea shore. Antidesma lacinatum.

A tree attaining a height of 25 feet.

Bridelia ferruginea.*

It is a small tree of about 20 feet high, very much branched. All through the dry season it drips water at night.

Bridelia micrantha.* Igili (Mendi).

This species also reaches a height of 20 feet. It is used for making charcoal, and a medicine is made from meat stewed in the water in which the roots have been boiled. 


\section{WEST AFRICAN FORESTS AND FORESTRY}

Hasskarlia didymostemon.*

This tree grows to a height of 50 feet, with a diameter at the base of 20 feet. It is one of the diccious trees.

Hymenocardia acida.* Fagbajoi (Mendi).

A small tree, knotted, gnarled and branched, growing both in the open and in the forest.

Hymenocardia Heudelotii.*

A small tree.

Hymenocardia lyrata.* $\dagger$

This species is found in the peninsular forests.

Macaranga Barteri.* Ndeiwei (Mendi).

It is a medium-sized armed tree, reaching about 50 feet, and 18 inches in diameter at the base. A light wood used for firewood.

Macaranga heterophylla.* Fofui (Mendi).

A medium-sized tree.

Macaranga monandra.* Ndeiwei (Mendi).

It is a medium-sized armed tree, up to 50 feet high, and 8 inches at the base, with reddish-brown pubescent branches. It is useless except as firewood.

Masobotrya $s p . *$

A small tree.

Mareya spicata.* Nguangua (Mendi).

A tree reaching 30 feet in height. The leaves have a bitter taste; a decoction of them is used as a poison.

Microdesmis puberula.* Nikli (Mendi).

A small tree, reaching about 15 feet in height. The fruit is edible.

Phyllanthus discoideus.* Tijoi (Mendi).

A common tree, 60 feet in height, with a diameter of 18 inches.

\section{Anacardiaceæ.}

Mangifera Africana.* White Oak or Greenheart. Peri (Timani) ; Bewe-Bauban (Mendi).

A tree growing to 40 feet in height, with root flanges extending 10 feet up the stem; it has a girth of 12 feet. The tree is cut locally. The seeds are edible.

Spondias lutea.* Common Plum or the Hog Plum of the Creoles. Luep (Timani); Bogi or Gbojei (Mendi).

A large tree, with rough, grey bark; it resists the grass fires very well. They yield timber, tanning material, medicaments and edible fruit, from which a spirituous drink is prepared.

Odina $s p . *$

It reaches a height of 30 feet. 
Sorindeia juglandifolia.* Creole Damson. Ni-Kaffei (Mendi).

A tree of $\mathbf{5 0}$ feet in height, having aerial roots. A broken branch or scraped root has a resinous smell.

\section{Icacinaces.}

Leptaulos daphnoides.* Propri (Timani); Bongani (Mendi). A small tree.

\section{Sapindaceæ.}

Bersama Paullinioides.* Nyomdobai (Mendi).

A tree growing to a height of 35 feet. It is regarded as an evil tree, and neither man nor beast touches it. A poison is extracted from the root, with which Mendis poison their enemies.

\section{Lecaniodiscus cupanioides.* $\uparrow$}

A small tree.

Phialodiscus unijugatus.* Yokomi (Mendi).

A tree of 50 feet in height. This tree bears conspicuous red capsules, which contain black seeds having a yellow ovule. The leaves and twigs are macerated in pools in the rivers to kill fish.

Schmidelia Africana.* Komigbulei (Mendi).

A small tree.

\section{Tiliacex.}

Glyphcea Grewioides.* Swamp Rice. Beibolei (Mendi).

A decoction of the leaves is used for curing gonorrhœa.

\section{Bombacacex.}

Adansonia digitata.* Baobab, Cream of Tartar or Monkey Bread. Ungari (Timani); Sackwi Mbauwi (Mendi).

It is a slow-growing tree, but a valuable one, yielding fibre, paper pulp and a native medicine. Sodium chloride, potassium and acid tartrate have been found in the leaves.

Bombax Buonopozense.* Kinguei (Mendi).

A large deciduous tree, often called the Red Cotton Tree on account of its flowers. It yields a fibre called Kapok.

Eriodendron anfractuosum. Cotton Tree. Pullum (Timani); Ungwe (Mendi).

Eriodendron orientale.* Cotton Tree. Nhuei (Mendi).

The Cotton Tree of commerce. The fibre fetches from $2 \mathrm{~d}$. to 4d. a pound in London. It grows readily from seed. The seed is valuable, as it yields an oil, and the ash of the seed contains 28.5 per cent. of phosphoric acid and 24.6 per cent. of potash (the latter makes a valuable manure). The wood is used locally for canoes and platters. 


\section{WEST AFRICAN FORESTS AND FORESTRY}

\section{Sterculiacese.}

Sterculia tragacantha.* African Tragacantha. Kobei (Mendi).

The ashes are used for soap. It yields a gum similar to that of Tragacanth, Astragalus gummifer.

Sterculia cordifolia. Red Oak. K'fut (Timani); Buni (Mendi).

Cola acuminata.* The Kola Tree. Tuloi (Mendi).

This tree yields the Kola nut, a most valuable export. Very little, however, is sent to Europe, but great quantities to French Senegal. It contains great stimulating properties, and enables travellers to march long distances without food. The tree grows wild in certain forests, and begins to yield at six or seven years old. The nut is little thought of by Europeans, owing to its bitter taste. The price varies from $f 10$ to $£ 12$ a measure (160 lb.).

Cola augustifolia.* Denbehawi (Mendi).

A small tree, the leaves of which are used as a stomach medicine. The Munchis use the wood to make their short bows.

Cola leonensis.* $\uparrow$ Booni (Mendi).

A small tree with large leaves.

Cola simiarum.* Baboon Kola. N'goloduloi (Mendi).

A large tree, 60 feet in height. A fine specimen of it grows over the wooden bridge at Kennema.

Heritiera.* Red Cedar or Harmon. Yawi (Mendi).

It yields a very handsome, easily worked wood, useful for any purpose. The fruit is edible.

Leptonychia.* Mbagboldede (Mendi).

It grows only to the size of a shrub or small tree. The leaves are used to cure thorn wounds.

\section{Ochnacex.}

Lophira procera.* African Oak, Red Ironwood, Ironpost. Ringa (Timani); Hendui or Endwi (Mendi).

This tree attains about the same size of the Oldfieldia; there does not seem to be any microscopical difference in the texture or grain of the wood. It is much used by builders, as it is proof against the attacks of termites. This tree also yields oily seeds and medicaments.

Lophira Alata.* Katank (Timani); Endwi (Mendi).

A small tree having seed yielding 43 per cent. oil, valued at $£ 24$ to $£ 25$ a ton.

Gomphia congesta.* Colonguli (Mendi).

A small tree undergrowth.

\section{Ochna sp.*}

A small tree. 


\section{Guttifere.}

Ochrocarpus Africanus.* African Apple or Mammy Apple Tree. Mammee, Bakum (Timani); Kaikumba (Mendi).

A large tree, attaining a girth of 10 feet and a bole of from 20 to 30 feet. It has been cut locally, and is much prized on account of its pretty grain and red colour. It is used for joinery and similar work.

Garcinia Kola.*† Kofé (Mendi).

Garcinia epunctata.*†

A small tree.

Garcinia polyantha.* Bitter Kola. Sagbei (Mendi).

This is a small tree with thick yellow latex; the fruit is edible.

Pentadesma butyracea.* Chewstick. Komdi (Timani); Mdayen (Mendi).

Chewstick. This is a very prevalent tree, though it does not reach very stout dimensions. The roots are used extensively for native chewsticks.

Haronga Madagascariensis.* Mbeli (Mendi).

It is a small tree which grows readily on farm lands. The juice below the bark is orange-red. The wood resembles that of Proteaceous trees and is very beautiful.

Mammea sapota.*

Locally called Mammy Supporter. It is a handsome tree and has an edible fruit.

Visinia leonensis.*

A small tree of 15 feet.

Allanblackia floribunda.*

A medium-sized tree.

\section{Violaces.}

Alsodeia sp.*

A small tree. Some of these yield timber.

Alsodeia sp.*

A medium-sized tree growing near the river.

\section{Flacourtiaceæ.}

Homalium molle.* Niagalei (Mendi).

It is a large tree, very tall and straight.

Homalium sp.* Kologalei (Mendi).

A large straight tree, often confused with $H$. molle.

\section{Rhizophoraceæ.}

Anisophyllea laurina.* Monkey Apple. Kant (Timani); Kanti (Mendi). 


\section{WEST AFRICAN FORESTS AND FORESTRY}

This is a very lofty tree, with a bole of 40 feet and girth of 12 feet. It has not been tried as timber away from the locality, but should be valuable as an export, having a pretty grain, full of medullary rays. The local value is $3 \mathrm{~d}$. to $6 \mathrm{~d}$. per lineal foot. It is fairly common in the forest, but very plentiful outside, as it shoots up from the stump when cut down. Naturally, the wood from such trees is not so good as from seedlings.

Rhizophora racemosa.* Mangrove. Dingi (Mendi).

This is a small tree of the swamps which is found very useful for poles and firewood. It fetches a high price from the bakers- $f l 10 \mathrm{~s}$. to $f 1$ 15s. a cord. The bark contains 18 per cent. of tannin.

\section{Combretacee.}

Anogeissus.* $\dagger$

A chewstick with a black heart. It will kill out Lalong grass. Laguncularia racemosa.*

This is a shrub which grows in the mangrove swamps. It yields a second-rate tannin bark.

Terminalia scutifera. ${ }^{*} \dagger$

A large straight, tall-boled tree, yielding a useful timber to shipwrights.

Terminalia sp.* Bagi (Mendi).

A very large tree, even taller than $T$. superba, and the timber is yellower. The tree is gnarled and much branched near the sea-shore. The wood is much used for canoes. Dye and a yellow wash for sore feet are obtained from the bark. Terminalia superba.* Kojagei (Mendi).

A very large tree of $\mathbf{1 5 0}$ feet or more. The timber is soft and white, used for indoor work, but it is much attacked by borers.

\section{Myrtacese.}

Eugenia calophylloides.*

A small tree.

\section{Melastomaces.}

Memecylon, cf. M. spathulandra.†

It is a small tree growing in the swamps near Bureh town.

\section{Araliaces.}

Cussonia Djalonensis.

A medium-sized to large tree growing in the savannah forests. It has a thick grey, rough bark. 


\section{Sapotacex.}

Mimusops sp. Benin Mahogany. Tuntumi (Timani); Sukai I (Mendi).

It is a kind of mahogany which is very common, and attains a girth of 12 feet, with a smaller bole than the ordinary mahogany. The wood is of a reddish colour and rather hard. This tree is found growing at a higher altitude than most timber trees, which makes the forest situated at 2,000 feet much more valuable.

Mimusops sp. Mahogany substitute. Bobbyboya Water (Timani).

This is a very large tree, with hard red wood sold as mahogany, not very plentiful.

Mimusops. Mahogany substitute. Abugie (Mendi).

Another species of hard mahogany. It is not very plentiful, but worthy of export. It is of large size and good "form figure," somewhat the shape of a cylinder.

Mimusops Djave.* $\dagger$

A large beautiful tree, yielding a valuable sound timber. Mimusops. African Pearwood. Sukai II (Mendi).

A large tree with a good bole. It has been exported and sold in the Hamburg market at 6d. a foot. The wood is of a reddish colour, a little harder than mahogany, and of close grain. It would pay to plant out any seedlings found.

Sideroxylon longistylum. Kafe or Kaffi (Mendi).

Some species yield timber, edible seeds and medicaments. Sideroxylon Alymerii. Teyei (Mendi).

A medium-sized tree bearing a seed rich in oil. The oil of the seed is very like that of the coconut in taste; it is used for frying food or for hair-oil.

Chrysophyllum sp. Tuinynelli (Mendi). fruits.

All the Chrysophyllum species yield timber and edible

Chrysophyllum sp. Star-apple. Terle (Mendi).

Chrysophyllum ellipticus.* Beari (Mendi).

A small species growing on the sea-shore.

Chrysophyllum. African Star-apple. Bungi (Mendi).

Chrysophyllum pruniforme.* Heleilahin (Mendi).

Elephants are fond of the bark.

\section{Ebenacex.}

Diospyros sp.* $\dagger$

A medium-sized ebony.

Maba Mannii.

A tree. 


\section{WEST AFRICAN FORESTS AND FORESTRY}

\section{Loganiaceze.}

Anthocleista nobilis.* Pongoi-hei (Mendi).

This is a larger species than the $A$. parviflora; it is not armed. The root is used as a medicine. The wood is soft and useless.

Anthocleista parviflora.* Pongoi-hini (Mendi).

In English sometimes called Cabbage Palm. This species reaches scarcely over 30 feet in height; it is armed with strong, twin-set spines. The wood is soft and useless.

\section{Apocynacea.}

Funtumia elastica.* African Rubber Tree. Emarr (Timani); Buboi (Mendi).

This tree grows to a height of $\mathbf{5 0}$ feet. It is rare in Sierra Leone, but has been found in Kagnari, Nimmini and Loma Mountains. It yields a good rubber.

Funtumia Africana.* Rubber. Buboi (Mendi).

This species grows to a height of 70 feet. It yields an abundant latex of no commercial value.

Polydoa Elliotii. Boxwood. K'Palen (Timani); Kofee or Kofei (Mendi).

It is a small tree with greenish pimply bark. The wood is very hard, like boxwood, and is used to make hair combs and hoe handles. Medicine is made from the bark.

Alstonia Congensis.* $\dagger$ Kauwi (Mendi).

A large, tall tree with a straight stem, found in the peninsular forests.

Landolphia Owariensis jenje.* Common Rubber Vine. Huwi Djenjei (Mendi).

The export of this rubber was at one time very profitable, but the natives overtapped the tree, and even dug up the roots to extract the rubber. The fruit of this species is edible.

\section{Landolphia Heudelotii.*}

This is a climber 40 feet in height, and one of the most valuable of the Landolphias, found in many parts; but it is the characteristic vegetation of the dry interior of Senegambia and the Upper Niger.

Landolphia leonensis.* Nali (Mendi).

A climber reaching the tops of the highest trees. The fruit is $3 \frac{1}{2}$ inches in diameter. The pulp around the seed is edible. The latex is used as bird-lime, but yields no rubber, and cannot even be used as an adulterant.

Callichilia subsessilis.*

It is a shrub or small tree having a handsome flower. 
Conopharyngia crassa.*

A small tree bearing a double fruit as large as a child's head.

C. longiflora.*

A small tree bearing a conspicuous heavy-scented flower. Holarrhena Africana.* Nukoi (Mendi).

A small or medium-sized tree. Wooden serving spoons for rice are made from the wood. The leaves beaten to a pulp are used for poultices.

Holarrhena ovata.* Bubbuoi (Mendi).

Used as a stirring-stick.

Pleioceras Afzelii.

A small tree.

Pleiocarpa tricarpella.

A small tree.

Rauwolfia vomitoria. Kawogei (Mendi).

A very common small tree, 20 feet high. Swizzle-sticks for mixing drinks are made from it, and the natives use the large branches for mixing indigo dye.

Voacanga Africana.*

A tree 30 feet high bearing very fragrant flowers.

Voacanga obtusa.*

A tall tree.

Voacanga Thonnersii.*

A medium-sized tree of 50 feet in height, with ornamental cream flowers. It has been seen growing in the swamp-land near the 180th milestone on the railway to Kennema.

\section{Asclepiadacez.}

Xysmalobium granitiolum.

A small tree in the river bed.

\section{Borraginaces.}

Cordia $s p$. Kpetellahen (Mendi).

It is a large tree growing on river banks. The bark is edible.

\section{Verbenacex.}

Vitex grandifolia.

Some of this species yield timber, vegetables, edible fruits and medicaments.

Vitex Cienkowskii.* Heinokohun (Mendi).

A tall tree growing at the edge of the forest.

Vitex doniana.* Lubei (Mendi).

A small tree growing in the savannah country in the Koina- 


\section{WEST AFRICAN FORESTS AND FORESTRY}

dugu district. An ink made from the leaves is used by the Mohammedan teachers.

Vitex micrantha.* Fevei (Mendi).

A tree reaching a height of 70 feet and 2 feet 6 inches at the base. The timber is useful for many purposes. The Mohammedan teacher has his school slates made from it.

Vitex oxycuspis.* $\dagger$

A small tree.

Avicennia Africana.*

A small tree growing in the mangrove swamps.

Premna hispida.* Kafei (Mendi).

A small tree. A decoction for ulcerated mouths is made from the leaves.

\section{Bignoniacex.}

Spathodea campanulata* Tulip Tree.

It is a large tree yielding timber, edible seeds and medicaments. It is also used as an ornamental tree.

Newbouldia lavis.* Anyolo (Timani) ; Bogi Ponamagbei (Mendi).

It is a tree reaching a height of 40 feet. Its use is principally medicinal. The root and leaves are used for scrotal elephantiasis, and a decoction from the bark is applied to sore feet. It is much used for quick fences, as it grows readily from stakes.

Kigelia.*

A tree 50 feet in height.

Stereospermum leonense.*

A medium-sized tree bearing pink blossoms.

\section{Rubiacex.}

Morinda sp. ? citrifolia.* Brimstone. Ketum (Timani); Bundwi Bundui (Mendi).

This tree grows to a height of 150 feet, and has been found with a bole of 50 feet, a girth of 16 to 20 feet, and diameter of 5 feet without any branches. The wood is of a bright yellow colour, commonly used for weather-boards. It is sold near Freetown at 10s. per 100 feet. Its English name is given because of the peculiar colour of the wood. Its durability and ant-resisting qualities have given it a high place among the local timbers. It is used for building wooden vessels, mortars, etc. It will shoot up from the stump, so a good deal of small timber is obtained from old farms. Neither its colour nor grain make it of any worth for export. The bark is made into a decoction for malaria, and the natives after marching bathe their feet in the water in which it has been boiled. 
Morinda confusa.* Wawae (Mendi).

It is a climber, the leaves of which are used in medicine. Morinda quadrangularis.* Brimstone Bush. Jashuli (Mendi).

A small tree, 30 feet in height and about $1+1$ feet in diameter at the base. It is only useful as firewood. The leaves are used as medicine in various diseases; supposed to be specially efficacious for malaria.

Pausynistalia Lane-Poolei.* Gibowali (Mendi).

It is a large tree having green-brown deciduous bark, on which marked depressions are left when it comes off. The bole is straight and branchless up to 40 feet. The flowers are light yellow on first coming out, afterwards turning a purple pink.

Pavetta Baconia.*

A shrub or small tree.

Psilanthus ebracteolatus.*

A small tree, 20 feet in height, having white flowers.

Bertiera glabrata.* Kafahinei (Mendi).

A small tree, 25 feet in height. The leaves are made into a medicine to soothe teething babies.

Blighia sapida.* Akee Tree. Islii of the Akus.

It is cultivated for its fruit, which is wholesome and savoury.

Canthium discolor.* Totengei (Mendi).

A shrub to small tree with strong, sharp spines.

Corynanthe paniculata.* Gibowuli (Mendi).

A tree 50 feet high.

Craterispermum laurinum.* Alum Bark. Njelei (Mendi).

A tree 25 feet in height, having a diameter of 1 foot at the base. The bark, when dried and beaten into powder, is used as a remedy for sore feet. The wood splits easily and is used in thatching.

Crossopteryx Kotschyana? or Africana.*

A small tree.

Croton penduliflorus.*

A small tree of 35 feet.

Gaertnera paniculata.*

This is only found as a small tree on the sea-shore, but said to grow big in the forest.

Gardenia sp. near G. physophylla.* Buittigirri (Mendi).

A medium-sized tree growing in swamps.

Heinsia jasminiflora.* Pegblagei (Mendi).

It is a tree of about 20 feet in height; the flowers white and much like jasmin. Scrapings of the bark are used for irritation of the skin at rice-harvest. 


\section{WEST AFRICAN FORESTS AND FORESTRY}

Mitragyne. Mbuandae or M'boy (Mendi).

A large, tall tree, 100 feet high and $4 \frac{1}{2}$ feet in diameter at the base. It is only found in swamp-land. It yields a light, white wood much used in indoor work. The leaves are very large and are used for wrapping kolas; they are sold in Free town at 3d. a bundle.

Morelia Senegalensis.*

This is a small tree half scandent.

Oxyanthus unilocularis.*

A small tree.

Oxyanthus speciosus. Pebulai (Mendi).*

This tree is common near Freetown. The bark is aromatic, and when dried in the sun is used as a scent.

Randia acuminata.*

A small tree with large oval fruit.

Randia genipoeflora.*

A shrub or small tree.

Randia macrantha.*

A small tree common everywhere. It bears handsome white fragrant bell-flowers. The black pulp around the seed is edible.

Randia malleifera.* Pondei (Mendi).

A small tree bearing very fragrant white bell-flowers. The seeds when ground are mixed with water to make a sort of black paint used by the native women.

Randia $s p$. near $R$. macrantha.*

A small tree, 20 feet in height, bearing an oval-shaped fruit. Randia $s p$. near $R$. candata.*

A small tree, 25 feet high, bearing small but conspicuous fan-shaped fragrant flowers.

Vangueria nigrescens.

A small tree.

Sarcocephalus esculentus.* Sierra Leone Peach. Ameliki (Timani); Golli Nyumbuyambei (Mendi).

A very common tree growing to a height of 25 feet. It has conspicuous white heads of flowers and an edible fruit.

\section{Compositz.}

Vernonia conferta. African Cabbage Tree, the Soap Tree. Kupkup (Timani) ; Kongoli (Mendi).

A small tree about 25 feet in height, growing in the rain forest. The burnt ashes are used in soap-making and the sediment, when dried, is used as snuff or Lubi. 


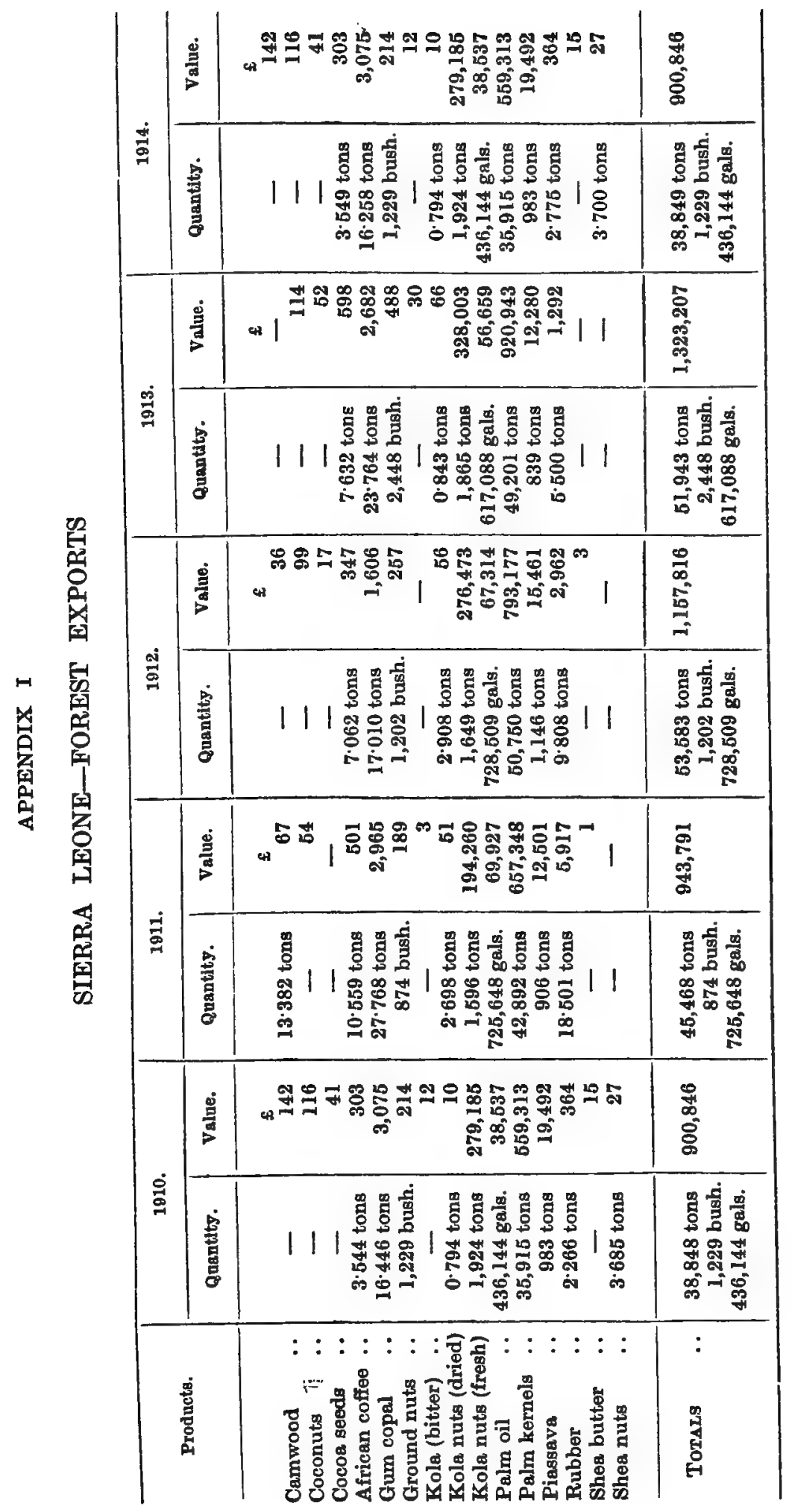




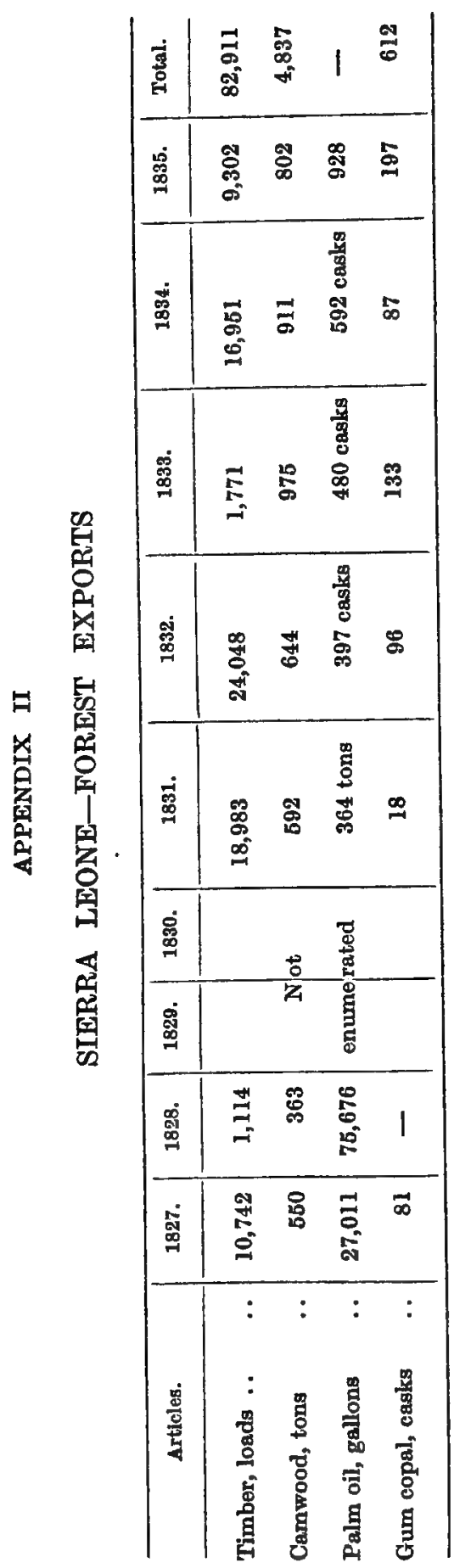


APPENDIX III

COMPARATIVE STATEMENT OF TIMBER IMPORTS INTO SIERRA LEONE, 1902-7 AND 1910-15

\begin{tabular}{|c|c|c|c|c|c|}
\hline Year. & Superflcial feet. & Value. & Year. & Superficial feet. & Value. \\
\hline $1902 \quad \ldots$ & 765,501 & $\stackrel{f}{4,765}$ & $1910 \quad \ldots$ & $1,273,631$ & $\begin{array}{c}\varepsilon \\
9,935\end{array}$ \\
\hline $1903 \ldots$ & $1,705,805$ & 11,066 & $1911 \ldots$ & 965,410 & 8,842 \\
\hline $1904 \quad \ldots$ & $1,642,738$ & 10,097 & $1912 \ldots$ & $2,337,851$ & 21,403 \\
\hline $1905 \quad \ldots$ & $1,768,611$ & 8,886 & $1913 \ldots$ & $2,507,327$ & 22,425 \\
\hline 1906 & $1,188,702$ & 9,827 & $1914 \quad \ldots$ & $2,883,564$ & 26,893 \\
\hline 1907 & $2,351,559$ & 18,856 & $1915 \quad \ldots$ & $2,503,751$ & 26,279 \\
\hline TotaI .. & $9,422,916$ & 63,497 & Total . . & $12,471,534$ & 115,777 \\
\hline
\end{tabular}




\section{CHAPTER IV}

\section{LIBERIA}

\section{The Gola Forest.}

THIs comparatively narrow strip of Africa, extending from Cape Palmas on the east to the Mano River on the west, an area of 40,000 square miles, is a Negro Republic under the nominal protection of the United States. It is bounded on the west by the British Colony and Protectorate of Sierra Leone, and on the north and east by the French possessions of Senegal and the French Ivory Coast.

Some years ago a large rubber company was formed to exploit the wild-growing rubber vines and trees, and until recently fairly large amounts were secured. Apart from rubber, however, there are large forests, one of the best being the Gola Forest, on the western boundary and contiguous to the Sierra Leone Protectorate.

This Gola Forest is formed by the confluence of the Morro and Mano Rivers, being thus triangular in shape and approximately 250 square miles in extent. No natives actually live in it, though there are a few villages at the edge, such as Yandahun and Dambarra. The typical forest is seen in the view of the River Morro near the junction of the Mano. Here herds of elephants roam and make tracks through the dense growth of numerous trees; in fact, the only paths there have been made by the elephant. The Chief of Tunkia always has at least ten youths with him learning the art of elephant-hunting, for which a large fee for tuition is paid. In illustrations Nos. 10 and 12 views of the inner parts of the forest are given.

\section{The Most Valdable Trees.}

The chief species of trees suitable for cutting for export are the following :

1. Mahogany (Khaya ivoriensis), probably, a very well textured wood with some very pretty medullary rays and a thorough sheen on it when planed. Illustration No. 13 shows a specimen of this tree.

2. Satinwood (Afrormosia laxiflora), a large tree with smooth bark, which varies from light green or yellow to an orange-red shade, thus making it very conspicuous in the forest. See illustration No. 11, which shows one of these trees of medium size. 

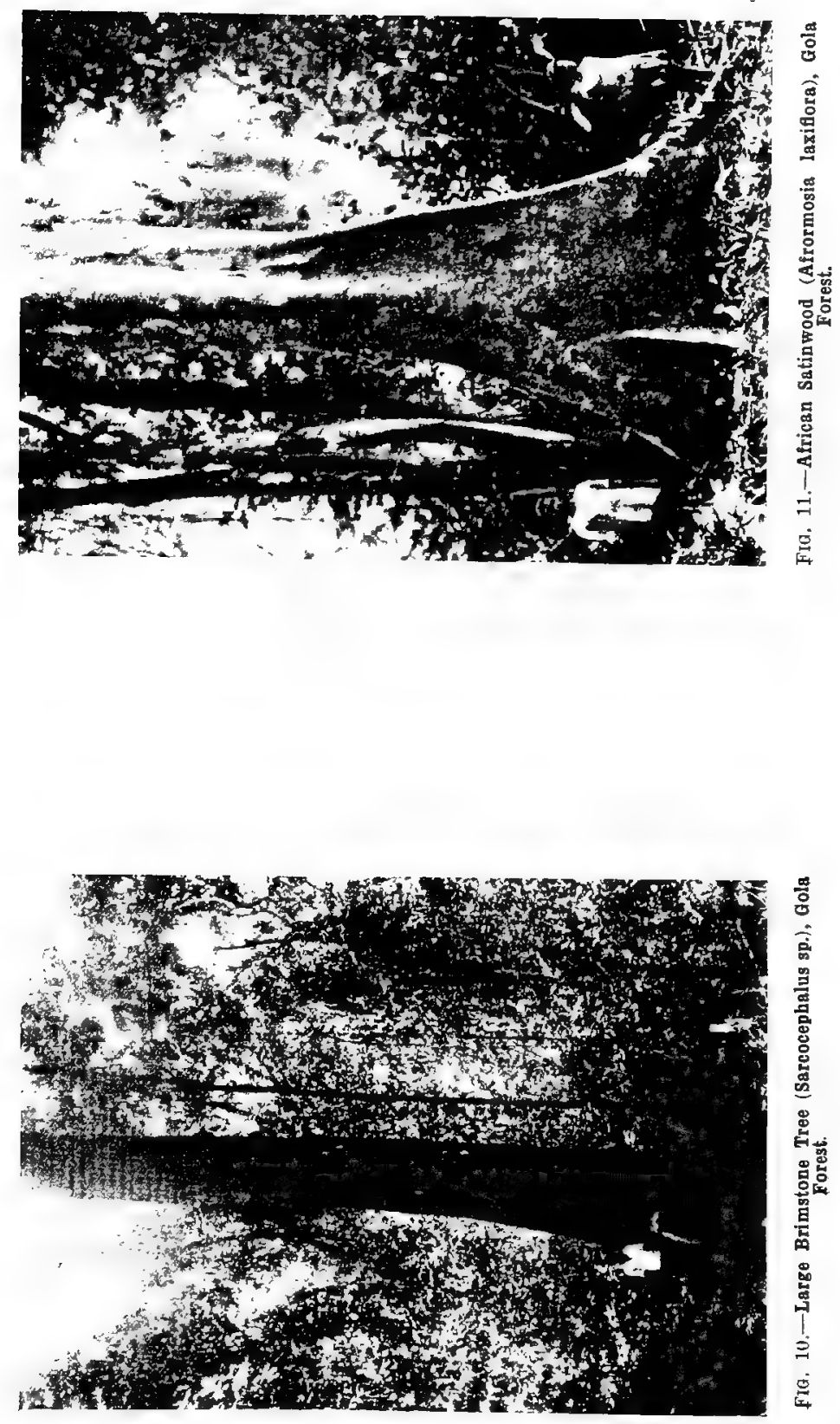

3. The African Oak (Oldfieldia africana), Paulai of the Mendis is more common in the southern than in the northern part of the forest. It attains a large size, but has not yet been exploited either by a European or a native firm. This is one of the most durable of African timbers. As it has already been described in the chapter on the Sierra Leone trees, further notes on this tree are unnecessary here. Illustrations Nos. 5 and 6 show this tree to advantage, especially its straightness of growth.

4. The real Satinwood (Zanthoxylum macrophyllum), not an uncommon tree, of small size. It is most easily recognised by its very long pinnate leaves. One leaf may attain a length of 6 feet. There is another species of Zanthoxylum which also has a similar kind of timber.

5. African Walnut (Lovoa Klaineana). This tree is not very prevalent, but is scattered in small groups throughout the forest.

6. Cedar Mahogany, a species of Guarea which attains a large size. It is none too prevalent, though it is scattered singly throughout the forest.

7. African Pearwood (Mimusops lacera) is a very good reddish timber, often with figure in the grain. Although much harder than mahogany, it has been sold as such.

8. The Iroko (Chlorophora excelsa) is common near the old farms, but is not so prevalent in the forest proper. It has not yet been exploited from here, nor is it cut locally.

9. The Red Ironwood Tree (Lophira procera) is very prevalent, and attains much the same size as elsewhere. It has not yet been exploited.

10. The so-called Mahogany, the timber of a tree, a species of Parinarium, known as Pauwilli of the Mendis. This is one of the most prevalent trees in the forest. It is also somewhat gregarious, as many as forty specimens being sometimes found in one group. The timber of this tree was exported from Southern Nigeria some years ago. It grows to a height of 150 feet, with a clear bole of 60 feet in height, and upwards of 18 feet in girth. Illustration No. 2 shows the trunk especially, and the base of one of these trees. A most typical scene in the northern part of the Gola Forest is shown in illustration No. 12, several of the trees in that picture being Pauwilli.

All the above-mentioned trees have been cut and exported in the log from various parts of Western Africa. There are, however, several other trees which might be cut and used as export timbers, as, for instance :

11. The White Mahogany (Canarium Schweinfurthii), which attains the same size as elsewhere, but is not so commonly found.

12. Rhodesian Mahogany (Afzelia bracteata?), which is fairly common and attains a medium size. 


\section{WEST AFRICAN FORESTS AND FORESTRY}

13. Brachystegia spicaformis, which yields a light-brown hardish timber with very pretty grain. (See illustration No. 104, which shows a very large specimen of this tree in Nigeria.) It is very prevalent, in fact one of the commonest trees in the Gola Forest, so that large quantities of timber could be obtained.

14. Wismah (Sierra Leone name) is also found, and apparently grows up very quickly in old farms.

15. The Red Oak (Berlinia auriculata) is quite prevalent, especially near the banks of streams. It attains a large size, and the timber has been sold as oak in the European market. Here it has not yet been cut.

In addition to the trees which can be felled for conversion into export timbers, there are others which may be cut for sale locally, such as':

16. The Brimstone (Morinda citrifolia?), one of the most suitable trees for the purpose. One of the largest trees was 5 feet in diameter, and had also a clear bole of 50 feet. On the whole it grows to a larger size in the Gola Forest than in Sierra Leone. Illustration No. 10 shows one of these trees from which a timber specimen had been cut.

17. The Hamon, which is apparently a species of Sterculiaceæ, although not of enormous size, has a straight bole, which divides up into four or five very large and thin root flanges. It is one of the most prevalent trees in the forest. Illustration No. 14 shows the peculiar formation of the roots of this tree.

18. Piptadenia africana, a very large tree with small and fine pinnate leaves. It is frequently met with, in fact one of the commonest of the trees in the forest. It yields a hard brown wood which is durable.

19. The so-called Mountain Mahogany, probably a species of Leguminosex. It attains a large size, and yields a timber not unlike that of Red Pine.

Up to the present no local or other sawyers have worked in this forest. Although only a few trees have been mentioned which could be cut for use locally, there are many others out of approximately a hundred different kinds which are found in the forest.

There are other products, such as oil beans, obtained from Pentaclethra macrophylla; a large forest tree; gum copal, obtained from Daniellia Ogea, one of the largest forest trees; palm oil and kernels from the Oil Palm (Eloesis guineensis), which is found in all the clearings. Piassava, obtained from Raphia vinifera, is found on the banks of the two rivers, Morro and Mano. Rubber could be obtained from the African Rubber Tree (Funtumia elastica) and various rubber vines, such as Landolphia Owariensis, and others. Dika nuts could be procured, as the tree which bears them, Irvingia Barteri, is com- 
monly found; also the Tallow Tree (Pentadesma butyracea), which bears a large number of oil-bearing nuts in its large fruit; the Dita (Detarium Senegalensis), which yields a mango-like fruit, eaten locally. Bitter Kola (Garcinia kola) is found, but not often sold in the local market. The rough-skinned Parinarium excelsum yields a fruit which is eaten locally; the African Star-apple (Chrysophyllum Africanum) is found in the forest, and also planted. In other villages the Akee, being obtained from Blighia sapida, is quite common in the forest, though the edible fruit is not used. The Mackay or Sea Bean (Entada scandens) is a huge creeper which grows to $\mathbf{3 5 0}$ feet in length and 3 feet in girth. Near Dambarra, from a stout specimen hung a complete pod containing fourteen beans.

\section{Conditions of Working Timber.}

The Mano or Bewa River forms the natural outlet for the extraction of timber, as the Morro River forms one boundary of the Gola Forest, and this river joins the former rather more than half-way through the forest. The Mano River reaches the sea about 80 miles from the end of the forest; thus logs of timber could be brought down the Mano straight into the sea.

Very good timber of various kinds of mahogany has been shipped from several ports, such as Sassandra and Grand Bassam on the Ivory Coast. Good prices, such as 1s. to 2s. 3d. per superficial foot, have usually been paid for this timber. There is therefore no reason why similar timber from Liberia should not fetch equally good rates, when properly cut, squared, and sold under similar conditions.

Conditions of working are very similar on the West Coast of Africa, but may vary somewhat in detail from place to place. However, if at the outset natives accustomed to working timber in Nigeria or the Ivory Coast were employed, good results would be obtained. Gradually a local native staff would be built up, so that the services of those from another part of the coast could be dispensed with and cheaper working thus assured; because imported labour, whether skilled or otherwise, is usually more expensive than that of the locality. Lower shipping rates should be paid from Liberia than from the Ivory Coast or Gold Coast, owing to the distance being less to the European markets where the timber is sold.

The other forests of Liberia should be thoroughly examined to see what amount of timber is there. It is usual to work several areas in conjunction, as the cost of management per unit of output (the $\log$ ) is thus reduced. 


\section{TREES AND RUBBER VINES}

\section{Palme.}

Elcesis Guineensis. Oil Palm.

The well-known Oil Palm. It does not thrive in the forests among taller trees. It grows best near villages. (Found in Sierra Leone, too.) Quantities of oil obtained from it. The leaves are used for roof coverings.

Raphia vinifera. Wine Palm.

The leaves used in weaving, brushes, mats, etc. Grows in swampy ground.

Borassus flabellifer and $B$. Aithiopium. Fan Palm, Piassave.

Both most useful trees. The leaves for roofs, fibre for ropes. The sap made into a sweet kind of toddy. Wood for house and bridge building. The $B$. Athiopium grows from 60 to 80 feet high, the leaves 5 to 12 feet long.

Ancistrophyllum.

Fibre used for weaving.

\section{Liliacex.}

Dracana surculosa. Dragon's Blood.

A much branched tree, having white flowers and red berries. Found in Sino Kim, Kakatown and Monrovia.

\section{Moracex.}

Chlorophora excelsa. Oroko, Teak, African Oak.

A large, well-known tree, used for many purposes where durability is required. Frequently found; it grows well near old farms. It is also found in Sierra Leone. The wood seems to be proof against termites and fungoid diseases. It is the best wood for railway sleepers.

Musanga Smithii. Corkwood.

The first tree to appear after a farm has been abandoned; its thick leaves, when they fall, form a heavy layer of humus.

Antiaris. Fig species.

Fig-like fruit, used in medicine.

Ficus Vogelii. Rubber.

Grows from 20 to 40 feet, yields so-called Balata, or an inferior rubber. Found on St. Paul's River, Grand Basā. 
Ficus sp. Rubber.

Yields rubber ; branches reddish colour; grows in the Kuru country.

Ficus Whyteii. Rubber.

A large forest tree yielding abundant rubber.

Myrianthus serratus. taste.

A deciduous tree having mulberry-like fruit of pleasant

\section{Olacacez.}

Coula edulis.

Bark and leaves have a resinous sap. The oily seeds of this tree are very pleasant to the taste; it has no connection, however, with the Cola Nut.

\section{Anonacex.}

Xylopia oxypetala. Yellow wood.

A moderate-sized tree with white, scented flowers, growing in the bush of the littoral.

Xylopia Dinklagei.

A small glabrous tree.

Xylopia Ethiopica.

From 30 to 60 feet in height. Fruit aromatic, used as a tonic. Wood elastic, made into masts and oars.

Xylopia humilis.

A small tree with broad top and pendulous branches, growing in the primary forests of the littoral.

Uvaria scabrida.

A moderate-sized tree in the primary forest, found on the banks of the Cestos River.

Uvaria Dinklagei.

Similar to the last; grows in the humid parts of the coast bush.

Uvaria Afzelii.

Similar to the above.

Polyalthia Oliverii.

A small glabrous tree growing in the coast forests.

Popowia Whyteii.

A small tree with glabrous leaves.

Anona muricata. Sour Sop.

A small glabrous tree, the Sour Sop of English colonists. Anona palustris. Alligator Apple.

A tree with soft wood, used as cork. Fruit edible, frequently made into a refreshing drink. It is found in the swamps of Grand Basā. 


\section{WEST AFRICAN FORESTS AND FORESTRY}

Monodora myristica. Calabash Nutmeg.

A small tree having showy flowers and aromatic seed; the much esteemed Calabash Nutmeg of West Africa.

Monodora tenuifolia.

Found in the primary forests of Grand Basā. Very similar to the last; narrower leaved.

\section{Myristicaces.}

Pycnanthus Dinklagei. Muskat Nut.

Tree reaches the height of $30 \mathrm{feet}$, with drooping branches.

It supplies good timber and oily seeds.

Pycnanthus kombo.

The seeds of this variety contain 73 per cent. of fat and burn like a candle.

\section{Rosacez.}

Parinarium macrophyllum. Rough-skinned Plum.

A very common tree, used locally for building purposes ; oak-like texture. Fruit yellow, the size of a goose-egg; sometimes called Gingerbread Plum.

Parinarium excelsum. Wild Plum.

Parinarium sp. Wild Plum.

Also found in Sierra Leone. Used for building locally; grain too open for export. $P$. excelsum and $s p$. very similar.

Chrysobalanus icaco. Cocoa Plum.

Chrysobalanus ellipticus. Cocoa Plum.

A tall shrub or small tree, with greenish-purple edible fruit known as Cocoa Plums. These two are very similar; both found near Grand Basā.

\section{Leguminose.}

Lonchocarpus laxiflora. Mountain Mahogany.

Supplies a good useful wood and dyes. It is also found in Sierra Leone.

Lonchocarpus sericeus.

An ornamental tree with downy twigs, reddish-violet papilionaceous flowers; wood hard and heavy, not very well known. Found in Grand Basā.

Lonchocarpus Barteri.

Similar to $L$. sericeus, but a loftier tree.

Lonchocarpus Zenkeri.

Entada scandens. Mackay or Sea Bean.

The well-known liana, the fibre used in rope and net making. 


\section{LIBERIA}

Dialium Senegalense. Black Tumbler.

A hard wood, useful in the building trade; also grows in Sierra Leone.

Dialium Englerii.

Timber useful for many purposes. A refreshing drink is made from the edible fruit.

Dialium Dinklagei.

A small tree with umbrella-like top.

Albizzia fastigata. Albizzia.

All Albizzias are proof against termites. Wood used where durability is required, and therefore very valuable. The branches are pendulous, flowers white and fragrant. Found in Monrovia and Sino Basin.

Albizzia Brownei. Albizzia.

A hard, useful wood. A large forest tree with cracked greyish bark.

Albizzia sp. Albizzia.

A large tree of good form and hard wood. The tree cylinder shaped, heartwood a bright, pretty colour. Not very plentiful. Quite worthy of export.

Detarium Senegalense. Mahogany, Dita.

A beautifully marked hard wood, with a bole of 30 feet and girth of 12 feet.

Pentaclethra macrophylla. Oil Bean Tree.

Yields oil-bearing seeds or beans, used as an article of food. The ashes after burning the dry pods are useful in soap-making. Parkia filicoidea. Forest Locust or Locust Bean.

A very common tree in Liberia, but wood of little value. The bean is eaten locally.

Erythrina Senegalense.

Deeply cleft bark; wood of little value.

Piptadenia Africana.

It grows everywhere in great quantities in Liberia. The wood is hard and valuable.

Afrormosia laxiflora. Satinwood.

A beautiful clear brown wood, used for building purposes. Baphia nitida. Camwood.

Very valuable as a red dye-wood.

Baphia pubescens. Camwood.

Valuable dye-wood.

Cassia podocarpa.

Grows best on very dry ground; common on native farms, 70 miles up the St. Paul River. Wood extraordinarily hard. Mimosa Dinklagei.

A small tree found in the coast woods of Grand Basā. 


\section{WEST AFRICAN FORESTS AND FORESTRY}

Daniellia Ogea. Benin Gum Copal.

Wood soft. When the tree has attained a large size, it is attacked by the boring beetle; the gum then exudes and falls to the ground, and is so collected. Value, 5d. or $6 \mathrm{~d}$. a pound.

Daniellia sp. Gum Copal sp.

Very similar to the $C$. Ogea.

Didelotia Engleri.

A small tree found in the humid woods of the coast.

Polystemonanthus Dinklagei.

A small tree growing on the banks of St. John's River, Grand Basä.

Xylia Evansii.

Beautiful plumed trees; small heads of flowers. A pretty ornamental tree.

\section{Rutaceæ.}

Zanthoxylon sp. Satinwood.

Fairly hard wood, with rough, knotty bark in the shape of cone-like, woody protrusions.

Zanthoxylon macrophyllum. Spiny Satinwood.

Smaller than the last, but somewhat similar; the wood a very pretty yellow, with open grain.

Citrus aurantium. Common Orange.

A very ornamental tree. Leaves and buds used in perfumery. Fruit edible, valuable for export. Timber useful in many ways.

\section{Simarubacez.}

Irvingia Barteri. Dika Nut or Borbor.

The fruit is edible, seeds oily. Dika butter, dika bread and a kind of chocolate are made from it. The wood is also used.

\section{Burseraces.}

Canarium Schweinfurthii.

Wood useful in commerce. The oily seeds are edible.

\section{Meliaceæ.}

Lovoa Klaineana. African Walnut.

Has a shady crown of branches. A good shade tree.

Carapa procera. Crabwood.

A small tree cut and sold as cedar mahogany for building purposes. 
Carapa Gayensis.

This tree supplies a good timber; the oily seeds are used in medicine.

Pseudocedrela. Cedar Mahogany or African Walnut.

The tree is 65 feet in height, wood used for building purposes and for furniture; not very common. It should be a useful export timber.

Trichilia Heudelotii.

A small tree; wood easy to work; not well known.

Khaya grandis. Benin Mahogany.

A fine tree, sometimes attaining the height of 130 feet, and 14 feet in diameter. The trunk has slight root flanges. The wood of a beautiful surface, a most valuable wood in furniture and carriage making.

Guarea Africana. Satin Mahogany

Grain similar to mahogany and might be sold for it. Should be a useful export wood.

Pyncertia ealcensis.

Not very well known; flowers in long, showy panicles.

\section{Euphorbiacez.}

Ricinodendron Heudelotii. ? Mahogany.

Sold as mahogany. The wood is used locally for boatbuilding. The tree seeds readily, so could easily be planted. Hasskarlia didymostemon.

Attains the height of 40 to 80 feet ; leaves yellowish-green and yellow catkins. Not well known.

Oldfieldia Africana. Real African Oak.

A tall, fine tree, with a bole of 50 feet and girth of 16 feet. Most useful in boat-building, especially for the keels. It seeds very readily. Many years ago it was exported as teak (1827-35), though this afterwards ceased.

\section{Anacardiaces.}

Mangifera. Mango species, Greenheart.

The Mango Tree, very plentiful. It attains a girth of 12 feet. A greyish wood used for building purposes.

Mangifera sp. Bush Pawpaw.

Used in building.

Mangifera sp. Whitewood.

Used in building.

Odina acida.

A small deciduous, glabrous tree; the powdered bark, mixed with other substances, used as a paint for the face. 


\section{WEST AFRICAN FORESTS AND FORESTRY}

Spondias lutea.

A tall, glabrous tree, with yellow, plum-like fruits, which are edible. They are often made into a refreshing drink. The wood bright-coloured and hard; it has the useful quality of growing when put in as fence posts.

\section{Sapindacex.}

Blighia supida. Akee.

A useful shade tree near dwellings, growing to the height of $97 \frac{1}{2}$ feet. Wood light yellow in colour.

Allophyllus Africana.

A small, common tree with hard, blackish fruit, growing along the coast of Grand Basa; wood useful in many ways. Dodonoea viscosa.

A small tree having viscid branchlets saturated with resin, which serve as torches. The wood is used for engraving and in turnery.

\section{Malvacex.}

Gossypium Peruvianum. Kidney-tree Cotton.

These African cotton-plants are still imperfectly known. Probably used locally.

\section{Bombacacex.}

Eriodendron anfractuosum. Cotton Tree.

Grows to the height of 160 feet. Smooth, bright grey bark, having cracked appearance. Wood not of much value in commerce. Handsome, brilliant crimson flowers.

Bombax Buonopozense. Red Cotton Tree.

A large deciduous tree, often attaining 162 feet in height, with tuberculate, prickly bark and scarlet flowers with firm, velvety petals. Wood of little value in commerce.

\section{Sterculiacex.}

Sterculia oblonga. Yellow Wood.

A tree of medium height, the wood soft, and fibre strong and tough. Exudes gum.

Sterculia $s p$.

Fruit edible, the oily seeds used medicinally.

Triplochiton.

Fruit winged, flowers panicled, leaves ragged. 
Cola acuminata. Cola.

Much like the Poplar in appearance. The wood is used in ship-building, house-building and furniture. The oily, edible Cola Nut is in great demand.

Cola digitata.

The oily seeds much used in medicine.

Heritiera utilis.

The timber hard and useful for various purposes, the bark in tanning. Fruit woody.

\section{Dilleniacer.}

Tetracera potatoria. Water Tree.

A small, hairy tree growing on the dry and sunny parts of the coast savannahs. It yields a profuse amount of water from the stems; hence its name.

Tetracera arocarpa.

Very similar to the above. Used as a medicine by the natives.

Tetracera Dinklagei.

Similar to the other Tetracera species.

Tetracera sp. White Cedar.

Reaches a girth of 10 or 12 feet. Wood soft and grain too open for export.

\section{Ochnacex.}

Lophira procera. African Oak or Red Ironwood.

This tree yields oil-bearing seeds. The wood is hard and heavy, of a reddish brown. Sold as African Oak. The wood is also used in charcoal-making.

\section{Guttiferæ.}

Pentadesma. Butter or Tallow Tree.

A tall, slender tree growing by the streams. Wood light in colour, useful in various ways. Also found in Sierra Leone.

Garcinia kola. Bitter Cola.

- A large but slow-growing tree, with a hard, prettily grained wood, rather uncommon.

Garcinia sp. ? Mahogany.

The wood sometimes sold as mahogany.

Garcinia sp. Chew-stick.

The smaller roots are used as chew-sticks, but taking these in the drastic method in which it is done generally means death to the tree. It is found on summits of the mountains. 


\section{WEST AFRICAN FORESTS AND FORESTRY}

\section{Flacourtiaceæ.}

Smeathmannia loevigata.

Smeathmannia sp.

The buds are single, growing in the axils of the leaves. Leaves toothed. There are fifteen species of this tree; not very common. Wood of little value.

\section{Rhizophoracea.}

Rhizophora mangle.

The Mangrove species. It grows in swamps or on the banks of rivers of Liberia. The wood is hard and heavy but easily worked; much used for poles and firewood, the bark in tanning.

Rhizophora racemosa.

The Mangrove species. Very similar to the above.

\section{Myrtacex.}

Psidium guajava. Guava.

A small tree growing near Monrovia. Fruit edible, the well-known Guava of commerce.

\section{Sapotaceæ.}

Mimusops sp. The Bobby Water or Benin Mahogany.

A very common kind of Mahogany, attaining a bole of 50 feet and girth of 12 feet. It will grow at a higher elevation than most forest trees. Wood very useful in the making of furniture.

Mimusops lacera. African Pearwood.

A tall, fine-looking tree, with good bole. It would pay to plant these unsparingly. It grows well near the coast. The hard, red wood is very useful and most valuable in furnituremaking, inlaying, veneering, etc.

Chrysophyllum sp.

A tree of medium height. Fruit edible. The wood not well known in commerce.

Sideroxylon longistylum.

This tree supplies a good timber. The fruit is edible. Omphalocarpum.

A kind of Guttapercha is obtained from this tree. It supplies also a good, useful timber.

\section{Apocynacez.}

Rauwolfia vomitoria. Swizzle-stick.

A good workable timber is obtained from it. Stone fruit. 
Funtumia Africana. False Rubber Tree.

The rubber is useless, being sticky, like birdlime. Height from 15 to 20 feet.

Funtumia sp. Boxwood.

Much the same as above. Found also in Sierra Leone.

Funtumia elastica. True Rubber Tree.

One of the most important rubber-trees of Africa (also Sierra Leone); produces good rubber. Height 100 feet.

Conopharyngia. Rubber.

Another rubber-tree, yielding only small quantities, of little use in commerce.

Landolphia Owariensis. Vine Rubber.

Another of the best rubber-trees; grows in the Sino Basin. Landolphia jenje. Vine or White Ball Rubber.

A very good rubber, even better than L. Owariensis.

\section{Bignoniaces.}

Newbouldia loevis.

A pinnate-leaved tree with dense panicles of pink flowers like the foxglove; the fruit long and slender. The brightcoloured wood is very even in texture, much used in fencemaking.

\section{Rubiaces.}

Sarcocephalus esculentus. Sierra Leone Peach.

Flowers in large heads, white and fragrant. Deep-red fruit, the peach of the country, the size of a man's fist. The wood much used for inlaying.

Morinda sp.? Brimstone.

A tree with bole of 50 feet in height, girth from 16 to 20 feet. The wood is bright yellow in colour, not of much value, but the root-wood is sold in the native markets for yellow dye and the bole wood for weather-boards. It is very hard and resists attacks of insects.

Randia maculata. flowers.

A very pretty ornamental tree, with glossy leaves and white

Coffea Liberica. Liberian Coffee.

A tree about 20 feet in height. Coffee-berries the size of a cherry. 


\begin{tabular}{|c|c|c|c|c|c|c|c|c|c|c|c|c|c|}
\hline \multirow{11}{*}{ 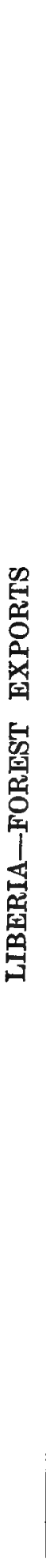 } & a & 11 & 1 & 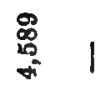 & 1 1 & 1 & 1 & 1 & & 1 & & & 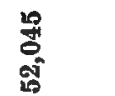 \\
\hline & 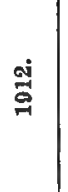 & 11 & 1 & 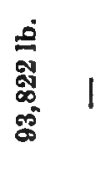 & 1 & 1 & 1 & 1 & 1 & 1 & 1 & & 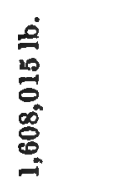 \\
\hline & $\Leftrightarrow$ & 11 & 1 & 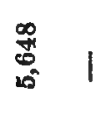 & 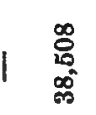 & 1 & 1 & 1 & 1 & 1 & 1 & & 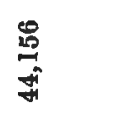 \\
\hline & $\dot{\Xi}$ & 11 & 1 & 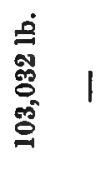 & 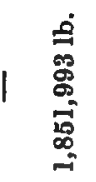 & 1 & 1 & 1 & 1 & 1 & 1 & & 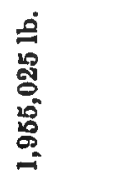 \\
\hline & « & 1 & 1 & 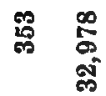 & 量 & 1 & 1 & 总 & 1 & 1 & 1 & & 兽 \\
\hline & 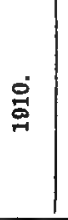 & 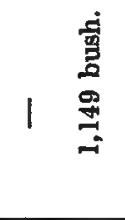 & 1 & 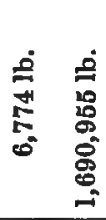 & | & 1 & 1 & 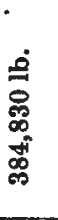 & 1 & 1 & 1 & & 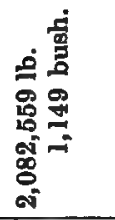 \\
\hline & $*$ & 11 & 1 & 11 & 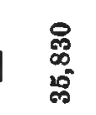 & 1 & 1 & 1 & 1 & 1 & 1 & & 勇 \\
\hline & 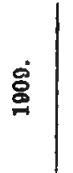 & 11 & 1 & 11 & 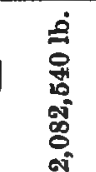 & 1 & 1 & 1 & 1 & 1 & & & 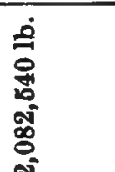 \\
\hline & a & 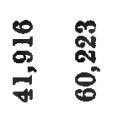 & $\begin{array}{l}\infty \\
\substack{\infty \\
\infty \\
\infty}\end{array}$ & \begin{tabular}{ll}
$\stackrel{8}{*}$ \\
\multirow{\circ}{*}{}
\end{tabular} & 1 & 1 & 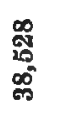 & 1 & ติ & & 1 & & 兽 \\
\hline & 兽 & 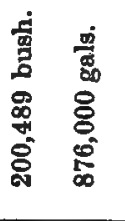 & 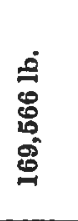 & 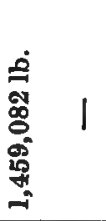 & 1 & 1 & 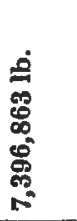 & 1 & 离 & & 1 & & 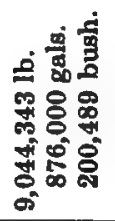 \\
\hline & 童 & 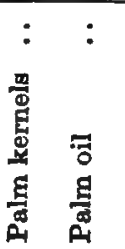 & 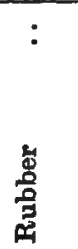 & 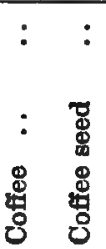 & 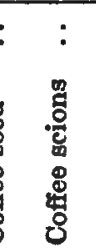 & 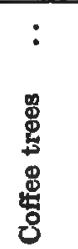 & $:$ & 罗 & $:$ & : & 关 & & $\begin{array}{l}: \\
0 \\
\text { : } \\
\end{array}$ \\
\hline
\end{tabular}



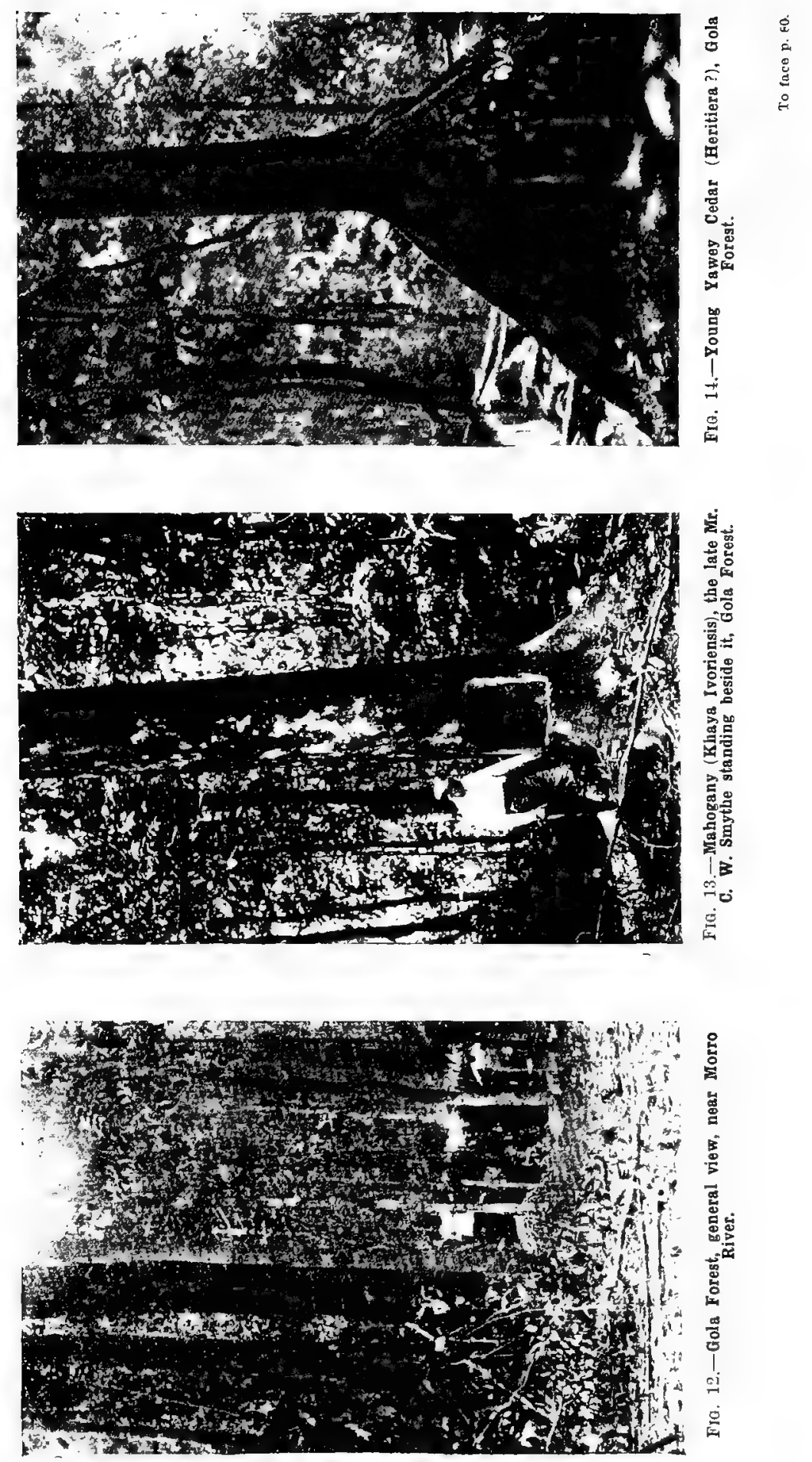



\section{CHAPTER V}

\section{THE IVORY COAST}

Thanks to Monsieur Auguste Chevalier's very varied and extensive travels on the Ivory Coast, we have obtained very graphic descriptions of the belt of forest extending nearly 150 miles inland and parallel to the coast.

In his books Les Végétaux Utiles de l'Afrique Tropicale Française, Fasc. V., Première Etude sur les Bois de la Côte d'Ivoire, and Les Végétaux utiles de l'Afrique tropicale française, Fasc. VII (Première Partie), Documents sur le Palmier à Huile, on the vegetation of this French Colony, not only are there general descriptions of some of the best and most accessible forests, but also there are full descriptions of the individual trees, together with most of their botanical and most valuable vernacular names.

Considering that the area of the Ivory Coast is 130,000 square miles, and the forest belt about 150 miles wide, the mahogany industry should be still further developed than it is at the present time.

So far, on the average, the Ivory Coast has been noted for its figured mahogany, the Ports of Grand Bassam, Assinie (a town and river of Upper Guinea), and La Hou being the most noted, and having given almost their name to different classes of Irory Coast mahogany. For several reasons this type of mahogany has fetched higher prices than that of the average from elsewhere. Sassandra, at the mouth of a similar named river, and also Cavally, on the Cavally, are minor ports for the shipment of mahogany.

First and foremost the wood obtained from what Monsieur Chevalier terms Khaya Ivoriensis is of a much more sheeny nature than that of either Khaya Seneyalensis, Khaya grandis or Khaya Punchii.

In the next place, the method of working is most peculiar. Usually, individual natives cut a: ew trees at a time, standing nearest a waterway or lagoon ; in fact, these were picked trees which the natives thought contained figured wood, and this had the effect of only a one-sided working of the forest, thus leaving many other valuable trees. On the average, the distribution of the numbers and of the various species is about the same as in other parts of West Africa. Apparently many of the ordinary trees have often been left standing, or at any rate most of those which are too inaccessible. A tree standing more than about 
a mile from water is too far for a native working almost single-handed, and only collecting a few labourers for hauling his logs to the waterway.

In recent years, however, British as well as French firms, with a larger amount of capital, have started to work the forests. Regulations have been drawn up by the local Government in a similar manner and of a similar nature to those in force generally on the West Coast of Africa. The Government also has built a railway passing through and near some of the forests north of Grand Bassam. Since its inception, a further impetus has been given to the mahogany trade. However, in the matter of water transport, the rivers of the Ivory Coast, such as the Tano, mostly flowing in British territory, but emptying itself into the sea at Assinie (the port for logs in French territory), the Yar or Abi, the Komoe, the Zini, and Bandana, the Sassandra and Cavally, can none of them be said to be at all good for the floating out of Jogs. La Hou is the port for the Bandana and Zini Rivers, after their junction; Sassandra is the port for the Sassandra and Cavally for the Cavally. At the mouth of each of them there is a shallow bar, and this in turn causes a bad surf, and in other parts the coast lacks harbours, and the formation of it is unsuitable for the shipment of timber. No doubt, as time goes on, an effective means will be invented for dealing with the passage of the logs through the surf, especially at the mouths of rivers. So far, from all accounts, the rivers themselves have not been cleared of snags and rocky obstructions for the transport of the timber. This factor again has reacted on the output, and many of the finest forests remain unworked. Owing to the fact of this accidental policy of only cutting the best mahogany trees, the intensive exploitation of the forests by cutting other species of trees (the timber of which has already found a market in Europe) has been greatly hindered. Among such timbers are the following:
Khaya Ivoriensis,
Chlorophora excelsa,
Lophira alata,
Af selia microcarpa,
Entandrophragma macrophylla,
Canarium Schweinfurthii, or Occidentalis.

On the whole, English firms working on the Ivory Coast have been encouraged and not hindered, but some of the minor regulations appear to be rather irksome and vexatious in their working, and the firms have felt that their tenure of the forest rights was not quite so secure as elsewhere in West Africa.

The export duties placed on mahogany cut on the banks of the Tano in Gold Coast territory are almost of such a nature as to prohibit the profitable working of the Tano forests. 


\section{LIST OF TREES}

\section{Pandanaceæ.}

\section{(Chevalier's.)}

Pandanus candelabrum. Sometimes known as Screw Pine.

A well-branched tree, supported by aerial roots; lcaves spinous and in dense spirals.

\section{Palmz.}

Borassus flabellifer Ronier (Colons); Dendo (Attie); Makube (Fanti); Ekube (Agni).

\section{Liliaceæ.}

Dracana Perrotetti. Nkiebe (Mbonoi); Adjonde (Ebrie).

\section{Ulmacea.}

Celtis integrifolia. Mgua (Abe); Tongo (Bondoukou).

\section{Moraceæ.}

Antiaris toxiaria. Ake (Mbonoi).

Chlorophora excelsa. Corkwood (English); Akede (Abe); Bakana (Fanti) ; Guele (Bondoukou); Elui (Agni) ; Bonzo (Bambara); Agui (Ebrie); Odum (Appollonien).

Ficus Goliath. Abono (Mbonoi).

Ficus Guineensis. Aturn (Mbonoi).

Ficus sp. Mekhi (Attie); Diangue (Agni); Karfa (Bambara).

Pontya excelsa. Metchi (Attie); Triwa (Agni).

Morus mesozygia. Bana (Attie); Cecerui (Agni).

Musanga Smithii. Parasolier (Colons); Loho (Abe); Guima Djuna (Bondoukou); Egui (Agni); Congo-congo (Gabonais).

Myrianthus arboreus. Agnon (Abe); Atolaie (Mbonoi); Agniere (Ebrie).

Myrianthus serratus. Nianga-magui (English); Diancangue (Attie);

Nianga (Agni); Nianga-magui (Indenie).

Treculia africana. Izaqueute Portugais (Colons); Yukugo (Bondoukou).

\section{Olacacex.}

Coula edulis. Atsan (Attie); Bogüe (Agni); Akion (Ebrie).

Ongokea Klaineana. So (Abe).

Strombosia pustulata. Myole Polie (Abe); Patabua (Bondoukon); Fognian (Mbonoi). 


\section{WEST AFRICAN FORESTS AND FORESTRY}

Octolnemataces.

Octoknema affinis. Guangua (Attie).

\section{Anonaces.}

Cleistopholis patens. Kotopuan (Attie); Bofu (Fanti); Eutie (Agni).

Enantia chlorantha. Mbawe (Abe); Esuro (Attie).

Monodora myristica. Mbang (Attie); Efuen (Agni); Hane (Ebrie). Stenanthera Laniate. T'sainf (Attie); Surua (Agni).

Pachypodanthium.

Xylopia athiopica. Ethiopian pepper (Colons); Fonde (Attie); Efomu (Agni); Endiar or N'diar (Wolof).

Xylopia parviflora.

\section{Myristicaceæ.}

Colocaryon oxycarpum. Kinkonawon (Mbonoi).

Pycnanthus Kombo. Walehe (Abe); Hetere (Bondoukou); Etama (Agni); Anaküe (Mbonoi); Edna (Appolonien).

\section{Capparidaceæ.}

Buchholzia macrophylla. Mon (Attie); Akotompo (Fanti); Amizi (Agni); Do (Trepo).

\section{Rosaces.}

Chrysobalanus ellipticus. Hanfuru (Agni).

Parinarium robustum. Aroba (Mbonoi).

Parinarium tenuifolium. Simua (Attie); Gatesima (Mbonoi).

\section{Leguminosz.}

Albizzia fastigiata. San (Attie); Piampian (Fanti); Kuanguan (Agni).

Albizzia ferruginea.

Albizzia gigantea. Turndogo, Bosole (Bondoukou).

Albizzia rhombifolia. Küe (Attie); Pranpran (Fanti); Kure (Agni). Afzelia microcarpa. Asemigniri (Mbonoi).

Aphanocalyx sp. Redwood (Colons); Taceribe (Mbonoi); Arabmetu (Adionkron).

Baphia nitida. Camwood (English); Tte (Attie); Ekuro (Fanti); Exin (Agni) ; Eseme (Mbonoi).

Berlinia acuminata. Beguan (Attie); Gueguirotta baka (Agni).

Cynometra Vogelii. Tiupe (Attie).

Cynometra cryptosepalum. Kiukuesin (Attie); Patapara (Agni).

Daniellia oblonga. Trakuan (Attie); Kuangua (Agni).

Dialium Dinklagei.

Dialium Guineense. Fe (Attie); Warie (Agni). 
Erythrophloeum Ivoriensis. Amerere (Agni).

Erythrophloum Guineense. Erüi (Agni); Teli (Bambara); Aranhe (Mbonoi).

Lonchocarpus sericeus. Acacia de Gabon (Colons); Akuosi, Amba (Fanti) ; Ekopa (Agni).

Macrolobium Palisoti.

Milletia sp. Vandaküe (Attie); Bakahehessi (Agni); Ekimi (Mbonoi).

Parkia Agboensis. Lo (Abe); Dogo (Bondoukou); Asama (Mbonoi). Pentaclethra macrophylla. Owala (Gabonais).

Piptadenia Africana. Bon (Attie) ; Nainvi (Bondoukou) ; Kuangua iniama (Agni).

Piptadenia Chevalieri. Lo (Attie).

Pterocarpus esculentus. Totohote (Attie); Assihaoto (Agni).

Tetrapleura Thonningii.

\section{Pandacex.}

Porphyranthus Zenkeri. Tebo (Attie); Akwankusuma (Fanti); Akuana (Agni).

\section{Linaceæ.}

Phyllocosmus Africanus.

\section{Humiriacex.}

Saccoglottis Gabunensis. Amuan (Attie).

\section{Rutacese.}

Fagara macrophylla. Hanwego (Bondoukou); Kengüe (Mbonoi). Zanthoxylum parvifolium. M'Bon (Attie); Kanton (Fanti); Heudje, Heugué (Agni).

\section{Simarubacex.}

Hannoa Klaineana. Haiefai? (Abe); Neube? (Attie); Hete bake (Mbonoi).

Irvingia. Akwabu (Mbonoi); Lubigniati (Adionkron).

Mannia Africana. Hate (Attie); Sotibia (Fanti); Bomoku (Agni) ; Akodo (Mbonoi).

\section{Burseraceæ.}

Canarium Occidentalis. Okume d'Troire (Colons); Segna (Attie); Krendja Haigue (Agni).

\section{Meliacez.}

Bingeria Africana. Hakue (Attie); Hague (Agni).

Carapa microcarpa. Dona (Abe); Kuli pia (Bondoukou); Kobi (Bambara). 
Carapa velutina. Bibiabe (Attie); Akumasse (Fanti); Sorowa (Agni).

Charia Indiensis. Zacoba (Attie); Zacoba (Agni).

Entandrophragma ferruginea. Locobo (Attie); Tiamatiama (Agni). Entandrophragma macrophylla. Baka-biringui (Abe); Lokoba (Attie); Kaiguigo (Bondoukou); Makua (Mbonoi); Tiamatiama (Appolonien).

Entandrophragma rufa. Cedrat (Colons); Kaiguigo (Bondoukou).

Entandrophragma Septentrionalis. Baka-birin-gui (Abe); Keiwgo (Bondoukou).

Khaya Ivoriensis. Bariba or Biribi (Colons); Ekuie (Abe) ; Lokobua (Attie); Dukuma Dugura (Agni); Humpe (Ebrie) ; Tiamatiama (Appolonien).

Pyncertia Occidentalis. Hainde (Agni); Kassekui (Mbonoi); Dubiri Keguigo (Appolonien).

Trichilia Candollei. Tanna (English); Fe (Attie) ; Tenuba, Tanuba (Agni).

Trichilia cedrata. Ngnanake (Abe); Mbosse (Agni); Anokue (Mbonoi).

Trichilia acutifoliata.

\section{Euphorbiaceæ.}

Macaranga Hendelotii. Abo (Attie); Eson (Fanti); Ekna (Agni). Moesobotrya Stapfiana. Senan (Attie); Emuinguim (Fanti); Asa bogüie (Agni).

Oldfieldia Africana. African Teak (English); Fu (Attie); Etüi (Agni).

Ricinodendron Africanus. Hobo Hapi (Abe).; Isain (Attie); Sosaü (Fanti); Haipi (Bondoukou); Haipi (Agni); Poposi (Mbonoi) ; Poposi (Ebrie); Nbob (Moyen Cavally).

Uapaca Benguelensis. African Oak (English); Chêne d'Afrique (Colons); Rikio (Abe); Niondobi (Bondoukou); Cosomon (Bambara); Sannaba (Mbonoi).

Uapaca Bingervillensis. Rikio (Abe); Na (Attie); Kayo (Bondoukou); Elekhua (Agni); Orobo (Mbonoi).

Alchornea sp. Bonyurome (Mbonoi); Aguaya (Ebrie); Tatairo (Moyen Cavally).

Baccaurea Bonneti. Habizacue (Attie); Kuatiecuale (Agni).

Bridelia speciosa. Chicue (Attie).

Hasskarlia didymostemon. Nguepe (Attie); Echirua (Agni).

\section{Anacardiacex.}

Hamatostaphis Barteri. Vi (Abe); Esanke, Esangue (Attie).

Lannea acidissima. Ngolo ngoloti (Abe); Tchiko (Attie); Kakoro (Fanti); Durgo, Duroko, Duko (Bondoukou); Borepore (Agni). 
Lannea sp. Ebruke (Attie); Bembe (Bambara).

Spondias lutea. Ngua (Abe); Ningo (Bambara); Haperrie (Mbonoi).

\section{Icacinacex.}

Leptaulus daphnoides. Paradedi (Attie); Eborodumuen (Agni)

\section{Sapindacex.}

Blighia sapida. Sago (Bondoukou); Finzan (Bambara).

Deinbollia Indeniensis. Ngua, Abo (Attie); Ekosuba, Zenna, Kerenya (Agni); Kaüsa (Indenie).

Placodiscus pseudostipularis. Para dakue (Attie).

\section{Tiliacex.}

Duboscia macrocarpa. Pianro (Agni).

\section{Bombacacese.}

Bombax Buonopozense.

\section{Sterculiacex.}

Cola cordifolia. Awa (Attie); Amhio (Bondoukou); Dabudabu (Agni); Ntaba (Bambara).

Cola mirabilis. Gnibi (Attie); Kamou aguire (Agni).

Cola proteiformis. Kouanda (Attie); Kokotsi (Fanti); Guiangon (Agni).

Cola vera. Awasse (Abe); Lo (Attie); Buesse (Mbonoi); Hapo (Ebrie); Guere (Neyau); Guresu (Bete); Hure (Plapo); We (Trepo); Halu (Adionkron).

Pterygota cordifolia. Ape (Attie); Sounoum (Fanti); Ware Borf ware (Agni).

Sterculia oblonga. Azodo (Abe).

Sterculia tragacantha. Porepore (Abe); Botapia (Attie); Lomburu (Bondoukou); Kotokie (Indenia).

Triplochiton scleroxylon. Hofa (Abe); Samba, Sankamba (Bondoukou); Batabua (Agni); Wa-wa (Appolonien); Wa-wa (Indenia).

\section{Syctopetalacex.}

Rhaptopetalum Sieghemi. Mosangui (Attie); Djo Arbi (Mbonoi).

\section{Ochnacex.}

Lophira procera. Nokue (Attie); Esore (Agni).

\section{Guttiferze.}

Allanblackia parviflora. Wohotelimon (Abe); Bissaboko (Attie); Akumase (Fanti); Alabenun (Agni) ; Wotobe Ewotebo (Mbonoi). 


\section{WEST AFRICAN FORESTS AND FORESTRY}

Garcinia polyantha. Mamie Kini (Agni).

Ochrocarpus Africanus. African Apricot (Colons); Quelipe Kelipe (Bondoukou).

Pentadesma leucantha. Piche Aboko (Attie); Allahbanunu (Agni) Symphonia globulifera. Arquane (Mbonoi'.

\section{Flacourtiaceæ.}

Homalium Africanum. Akouibia (Fanti); Akoima (Agni).

Scottellia coriacece. Bakaza (Attie); Aburuhi (Fanti).

Scottellia Kamerunensis. Akosica (Abe); Edde (Mbonoi).

\section{Rhizophoracex.}

Rhizophora racemosa. Paletuvier rouge (Colons); Ntagne (Attie); Koghia bera (Fanti); Ende (Agni).

\section{Combretaceæ.}

Anogeissus sp. Kakaleka (Bondoukou); Krekete (Bambara).

Combretum vivoflora. Kati (Abe); Esive (Mbonoi).

Terminalia altissima. Pe (Abe); Fram (Bondoukou); Frake (Agni).

Terminalia Ivoriensis. Satinwood (English); Mboti, Buma (Attie); Tuhidja (Bondoukou); Framine (Agni); Fela (Bambara); Cauri (Mbonoi).

\section{Myrtacex.}

Eugenia syzygium. Amerere (Agni).

\section{Melastomacex.}

Memycylon polyanthemos. Taisin (Attie); Tai (Agni).

\section{Ebenacese.}

Diospyros sanza. Nguobi, Kusibiri (Attie); Sanza, Minika, Asun, Seka (Agni).

\section{Oleacex.}

Linociera Mannii. Akodiombi, Zakuebiembi (Attie); Akokotsua (Fanti); Aqua egbua (Agni); Akoriie (Indenie).

\section{Loganiacex.}

Anthocleista nobilis. Buro-Nuro (Mbonoi).

\section{Apocynaceæ.}

Alstonia Congensis. Kolue (Attie).

Conopharyngia crassa. Choka (Attie); Akotompo Atsim (Fanti); Pakie-pakie, Kuakie-kuakie (Agni); Apukur (Mbonoi). 
Funtumia Africana. Pesin (Attie); Wala (Bondoukou).

Funtumia elastica. Pechi (Attie); Poyndua (Fanti) ; Efurumundu

(Agni); Ofuntum (Appolonien); Twe (Neyau); Uruba su (Bete); Dorose-Populu (Plapo); Bebeti (Moyen Cavally).

Picralima Elliotii. Hainfain (Attie); Kakana (Agni).

Rauncolfia vomitoria. Embi-siembi (Agni); Gonguonkiur (Mbonoi).

\section{Verbenacex.}

Vitex micrantha. Kiangu (Mbonoi).

\section{Bignoniacex.}

Spathodea campanulata. Tulipier de Gabon (Colons); Kokomazur (Mbonoi).

\section{Rubiacez.}

Grumilea vanosa. Tchiat Kottse (Attie); Aburese baka (Agni). Gardenia viscidissima.

Mitragyne macrophylla. Sofo (Attie); Bahia (Agni).

Morinda citrifolia. Alongua (Bondoukou); Sangongo (Bambara). Pseudocinchona Africana. Mbrahu (Abe); Kiumba (Bondoukou). Sarcocephalus esculentus. Tetere (Mbonoi).

Sarcocephalus Pobejuini. Ndebere (Attie); Ekusamba (Fanti); Boisima (Agni); Zeronga (Bambara). 


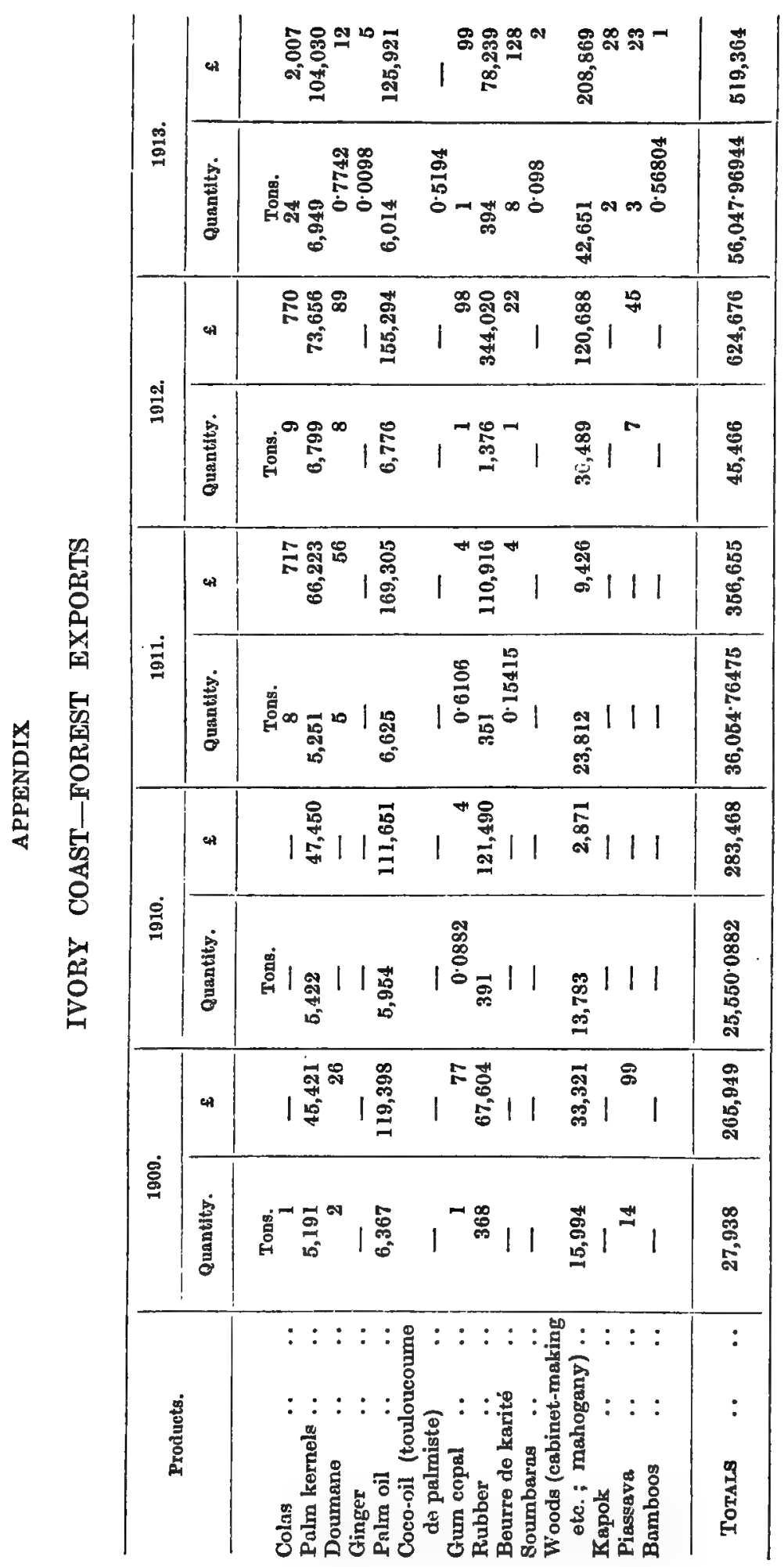




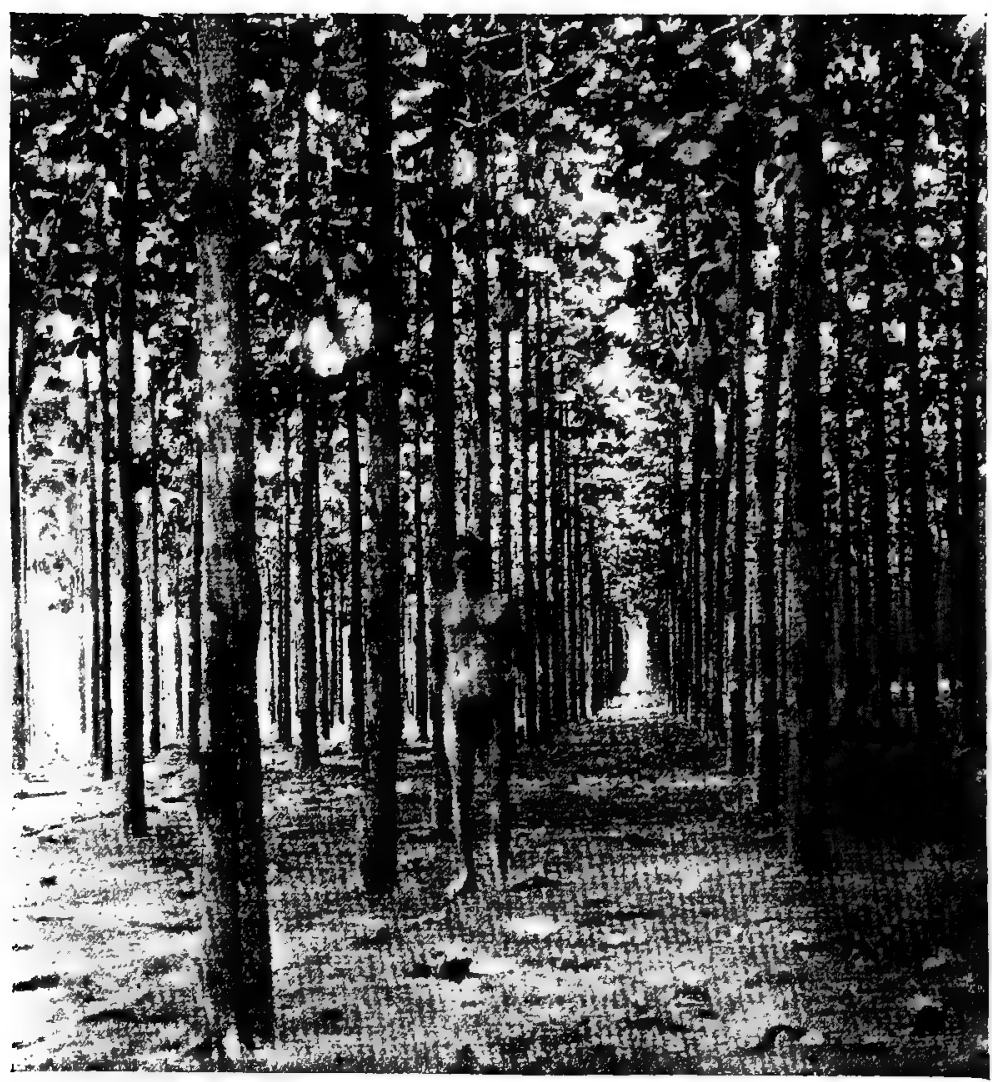

Fia. 15.-Teak Plantation of 1908, 35 feet high, Sokode, in 1911.

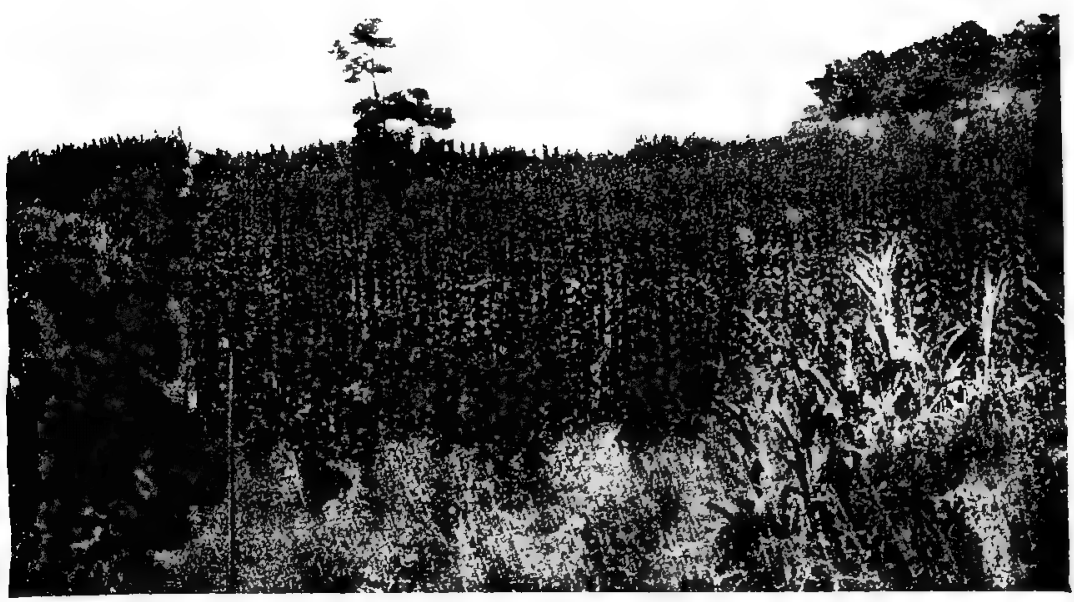

FIG. 16.-Teak Plantation of 1907 and 1908 on Bill-side, Atakpames 



\section{CHAPTER VI}

\section{THE GOLD COAST}

AREA, 80,000 square miles.

During 1909, a most interesting and exhaustive Report on the Forest of the Gold Coast. as well as Ashanti and the Northern Territories, was written by Mr. H. N. Thompson, the Chief Conservator of Forests of Nigeria. As a result of this Report, a Forest Department was formed in 1910. This Forest Department now consists of a Conservator, Deputy, and three Assistant Conservators of Forests. However, legislation for the proper preservation of the forest and creation of Forest Reserves has not been passed, so that the scope of the Forest Department's usefulness has been much curtailed.

It would be quite superfluous here to try and describe the forests in such a masterly fashion as has been done by Mr. Thompson, but anyone who is interested in the Gold Coast Forests should read the Report for themselves. It will suffice to give an outline of the main features of the Forest Administration and a general description of the forests.

With the author's permission I have given a list of the timbertrees, together with the botanical names, so far as they are known.

The people of this very rich country have in a short-sighted way very much hindered real progress in Forestry by refusing to assist in the creation of Forest Reserves. Forest Reserves are, of course, simply forest permanently set aside for the production of timber or other such forest products. The people of the Gold Coast have, apparently, judging by extracts from the local Press, got the idea into their heads that the malking of a Forest Reserve necessarily means the ownership of the land on which the forest stands passing into the possession of the Government. This, of course, is quite a contrary view to the true conception of a Forest Reserve, which is an area set apart by the Supreme Government as a forest for the permanent production of timber, etc., and usually managed by the Forest Department of the country. It may be a State forest, a communal forest, a municipal forest, or even a private forest which is thus placed under Forest Laws as a Forest Reserve. The user (that is, the man who has the right of usufruct in it) is not generally in a position to protect it thoroughly, and to some extent foregoes present temporary profits for future permanent returns. 
The diverse forms of forests named above, under the permanent management of the State, are seen in Switzerland, Germany, France, Russia, Japan, and India, not to mention Nigeria, so that it cannot be called an isolated system.

The cocoa industry has quite overshadowed that of collecting palm fruit, making paim oil, and cracking of palm nuts to obtain the kernels, with the result that these exports are small compared with Sierra Leone even, which is a much smaller colony, with a clinuate less propitious for palm-trees.

The following table shows the exports for the last five years:

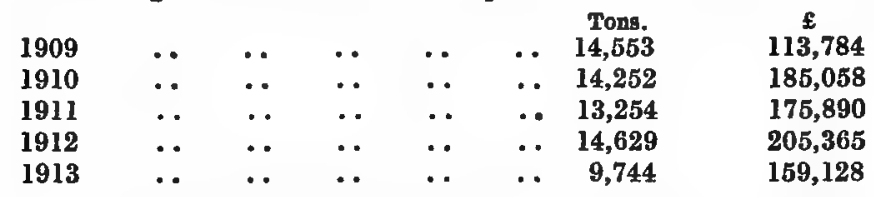

In the year 1913 forest produce, in the shape of logs, etc., to the value of $£ 3,327,743$ was exported. It would be disastrous to the country if a few loud-voiced, narrow-minded people were to prevent proper measures being adopted for the welfare of the country. Considering their previous education and small experience in these wide economic matters, it is only natural that they should take this view, but, on the other hand, that is no reason why the Supreme Government should not do what is necessary for the future permanent benefit of the country. A child is not allowed to play with fire, although it may very much like to see the flames; in the same way the British people, as locally represented by the Gold Coast Government, cannot allow the inhabitants of the district to play fast and loose with their priceless treasures, the African forests, well knowing that the country will be permanently injured thereby. Examples are to be found to-da.y of countries which have allowed their forests to be destroyed. Spain and Portugal are typical of this, and even in Africa one has the spectacle of France putting untold millions into Forestry in Algeria in order to restore the rainfall. Morocco and Mesopotamia are further examples of countries in a similar condition, where the forests have been destroyed. Palestine, with its ancient forests of Lebanon, is the most drastic example of forest destruction, quite apart from Turkish misrule. A similar process has taken place in the Soudan, and this locality is only now being laboriously re-afforested by the Forest Department there. In India, European countries, Canada, Australia, and in the United States it has been proved that it is only by a central Government Agency that the forests will be properly preserved both for this generation and the next; therefore, before it is too late, it behoves the Gold Coast people to recognise their responsibility to future generations and allow the necessary legislation, so that the forests may be preserved and rightly utilised. 


\section{LIST OF INDIGENOUS TREES AND RUBBER VINES}

(From Mr. H. N. Thompson's Report on the Gold Coast Forests.)

\section{Pandanacexe.}

Pandanus s.p. Ntung (Fanti); Ntung (Ashanti); Ndau (Apollonian); Ndau (Aowin); Ekpa (Krepi).

Screw Pine. Often found near villages on the coast and where drier conditions prevail, in sheltered spots. Reaches height of 30 feet. Leaves used in mat-making.

\section{Gramines.}

Bamboo sp.

Some of these attain a great height. Used for many purposes by the natives.

\section{Cyperacex.}

Bulbostylis barbata.

Bulbostylis laniceps.

Quite small trees.

\section{Palmæ.}

Ancistrophyllum sp. Eye (Fanti).

Large kind of rattan. Scandent palm

Borassus flabellifer. Makube (Fanti); Makube (Ashanti); Kube (Akwapim); Malankwi (Apollonian); Ago (Quitta); Ago (Krepi) ; Ago (Accra).

Borassus athiopica.

The wood, exclusive of pith, extremely hard. Fericarp of nut edible. Savannah forests.

Raphia vinifera. Adube and Doka (Fanti); Doka (Ashanti); Tombo (general West Coast); Doka (Apollonian); Doka (Aowin); Alati (Quitta); Alati (Krepi).

Raphia Hookeri.

Wine (from stem) and bamboo palm. Piassava fibre prepared from the rachis and the leaves, poles from bamboo in building; pinnæ for baskets and thatch. Seed beaten to pulp thrown in water to catch fish.

Elais Guineensis. Abe (Fanti); Arere, Abeletia (Apollonian); Beteng (Aowin); Ede (Quitta); Ede (Krepi).

Oil Palm of commerce Derived from this tree, also, the chief supply of palm wine and piassava fibre. The coast natives use the leaf rachis for building and the leaves for thatch. 


\section{WEST AFRICAN FORESTS AND FORESTRY}

Calamus Barteri.

Scandent palm.

Calamus deerratus. (West) Uwatia and Oyea (Ash.) (Ashanti).

The common rattan; marshes.

Cocos nucifera. Kube (Fanti); Kukwi (Ashanti); Ajui (Aowin); Eue (Quitta); Eavune (Krepi); Hukwi (Axim).

Cocoanut, found in the vicinity of villages on the coast, sometimes inland.

Fan Palm or Doum. Ago (general West Coast).

Wood provides beams for building; fruit edible; leaves for thatching; and a strong wine is made from the stem.

Phoenix reclinata, or Wild Date Palm. Euchresia (Fanti) ; Mileishia (Apollonian); Mileishia (Aowin); Aeyedi (Quitta); Iedi (Krepi).

A small date palm; grows on the sea-shore. Fruit edible. The terminal buds are cooked as a vegetable. A wine is made from the stem.

\section{Liliaces.}

Sansevieria.

Small tree, fibre-yielding.

Dracana arborea.

40 feet in height.

Draccena Mannii.

30 fect in height. Yields a light-coloured dye.

Draccena surculosa.

\section{Ulmacese.}

Trema affinis.

A small tree.

Trema Africana.

Small tree of secondary forest.

\section{Moracex.}

Ficus sp. Shedua or Abonsandua (Twi); Mousandua or Okitsiwanfu (Fanti); Shedua (Ashanti); Adowa (Apollonian); Adowa and Dupain (Aowin); Kapro (Grunchi); Aiu (Krepi), Kingkanga (Hausa).

Some Ficus are tapped for rubber, others fruited. This species is a large, smooth-barked tree.

Ficus platyphylla.

Fruit edible, cf. Vogelii, and in great demand.

Ficus Vogelii.

Medium-sized tree. Latex extracted by tapping. A good shade tree. 
Ficus asperifolia. Yankran (Fanti).

Savannah forests. Called Sandpaper Tree, because the rough leaves are used to smooth planks. The ashes are used in making dyes.

Ficus elegans.

Ficus eriobotryoides.

Ficus Ottonicefolia.

Ficus triangularis.

Musanga Smithii. Juma (Wassaw); Ajama (Fanti); Ajama (West), Ojamba (Ashanti); Eguni (Apollonian); Egeun (Aowin); Ajama (Krepi).

The Umbrella or Corkwood Tree ; used as buoys for fishingnets in Apollonia, and roof shingles in Ashanti.

Myrianthus arboreus. Niankuma (Fanti); Niankuma (Ashanti); Niankuma (Apollonian); Niangama (Aowin).

The fruit is eaten by the natives.

Myrianthus serratus.

Small tree with edible fruit.

Antiaris sp. Chenchen (Twi).

A large tree, the timber of which is liable to attacks by white ants; when seasoned, used for planks. The latex is one of the chief rubber adulterants.

Antiaris toxicaria. Ofu, Ohonton (Fanti).

Antiaris Africana.

Chlorophora excelsa. Odoum or Odum (Twi).

Timber very hard and durable ; not easy to export, because it will not float in its green state. A large and valuable timbertree found in the fringing forests, the driest parts.

\section{Urticaces.}

Urera.

A small tree, very common. Fibre very useful.

\section{Olacacese.}

Coula edulis.

Medium-sized tree with edible fruit.

Olax subscorpoidea.

\section{Anonacex.}

Anona Senegalensis.

The wild Custard Apple. Fruit edible.

Anona palustris.

Truit edible. Both these grow in savannah forests. Roots used in making floats. 


\section{WEST AFRICAN FORESTS AND FORESTRY}

Monodora brevipes.

Found in mixed deciduous forests.

Monodora tenuifolia. Dubiddi (Ashanti)

Hexalobus grandiflora.

A large, handsome troe.

Xylopia parviflora.

Xylopia striata.

Xylopias all small trees, except Apthiopica.

Xylopia Asthiopica.

A fairly large tree. Wood resists attacks of white ants. Used for native house-posts.

\section{Myristicaceæ.}

Pycnanthus Kombo. Ote (Twi). Oti or Etsu (Fanti); Oti (Ashanti); Tika (Apollonian); Attenli (Aowin); Oti (Accra).

The timber is useful for domestic purposes, roof shingles, etc. A fatty oil is obtained from the seeds. A medium-sized tree, straight-stemmed; wood not durable.

\section{Lauraces.}

Tylostemon Mannii.

A small tree.

\section{Rosaceæ.}

Parinarium sp. Affram (Twi).

Wood used by natives for building purposes.

Parinarium curatelloefolium.

Very common locally. The fruit edible.

Parinarium robustum.

Very little known about this tree.

Parinarium polyandrum.

In the savannah forests.

Parinarium mobola.

Small tree, but good timber. Fruit edible.

Chrysobalanus ellipticus. Ababele (Apollonian).

Found near fresh-water lagoon. The fruit of a blue colour, small and edible.

\section{Connaraceæ.}

Cnestis ferruginea.

Ageloea obliqua.

\section{Leguminosex.}

Piptadenia sp. Dahumah (Twi); Adadawa (Wassaw).

A large species. 
Piptadenia Africana. Dahomah (Twi); Odahuma (Wassaw).

Feathery foliage. Fruit a pod 1 foot long, 1 inch broad.

A common forest tree; hard timber, good for railway sleepers.

Cylicodiscus Gabomensis? Denya (Twi); Odenya (Wassaw).

Very large tree of the evergreen forests.

Daniellia Ogea. Ahedua (Twi).

Gum Copal.

Pentaclethra macrophylla. Atawah or Althawah (Twi); Ekuana (Fanti).

The Oil-bean Tree. Fruit edible; regetable oils and fats.

Timber hard, suitable for turnery.

Detarium $s p$. Biunwe (Twi).

A gigantic forest tree. Timber good.

Detarium sp. Bowiwunua (Twi).

Much like the first. Timber good.

Detarium Senegalensis. Bowiwasi (Fanti).

Not so large as other species; doubtful if the timber would be durable on exposure to the atmosphere.

Parkia filicoidea.

Fruit edible. The Locust-bean Tree. Savannah forests.

Peltophorum sp. Memchin (Apollonian).

Bauhinia reticulata.

The bast fibres are very long and tough; used as ropes by the natives.

Paradaniella thurifera.

Balsam Copaiba Tree-wood oil. Timber of little value.

Tetrapleura Thonningii Prekese.

Feathery-leaved tree. Four-angled fruit (pod), edible.

Used for medicinal purposes. Wood of medium hardness.

Xylia Evansii. Samanta (Twi); Samantawa (Fanti).

Pithecolobium altissimum. Augwameatee (Aowin).

A medium-sized tree, growing on river banks. A good shade tree.

Afromosia laxiflora. Duakobin or Duabayi (general West Coast).

A large tree. Timber good, reddish colour; has been sold in Liverpool as satinwood. Canoes made from it.

Afzelia Africana. Opapao (Twi); Papao (Ashanti); Opapao (Akwapim).

A first-class, durable tree. Timber very valuable. The dominant tree of the savannah forests. Pod 4 to 7 inches long. Used for railway sleepers, furniture, and building purposes.

Afzelia fastigata . 


\section{WEST AFRICAN FORESTS AND FORESTRY}

Erythrophloum Guineense.

A fine, spreading tree of the savannah forests. Wood hard and durable; used for building. The Sasswood or Ordeal Tree. The bark is poisonous; infusions of it are used by the natives for the ordeal test, especially on the Kroo coast. It regenerates freely from seed. Impervious to attacks of white ants.

Erythrophloeum micranthum. Potedon (Wassaw) ; Potedon (Fanti) ; Potedon (Ashanti); Potedon (Apollonian); Etsa (Krepi).

A reddish-brown coloured poison obtained from it.

Tamarindus Indica.

Wood very ornamental; fruit edible. The tree is found near the large rivers Volta and Affram.

Macrolobium Palisotii.

Macrolobium stipulaceum.

Macrolobium sp. Wulfram (Fanti); Ofarm (Ashanti); Ndukwun (Apollonian); Kotopapa (Krepi).

Common in marshy places.

Macrolobium limba.

Macrolobium reticulatum.

A medium-sized tree.

Cynometra Alzelii.

Cynometra all grow near streams.

Cynometra Mannii.

Cynometra sp.

Fringing forests, close to streams.

Pterocarpus esculentus.

Found in the fringing forests. Small tree, of little use.

Pterocarpus erinaceus.

The Senegal Rosewood Tree. The savannah forests.

Albizzia Brownei.

Fringing forests. Valuable wood, rich brown colour; hard and very durable. Height of tree about 100 to 120 feet, girth of 10 feet.

Albizzia Angolensis.

Albizzia Abruana.

Albizzia fastigata.

Found on disused farms. The timber should be useful for local bridge-making, etc., also furniture. A gum of little value obtained from it.

Acacia Sieberiana.

Acacia catechu.

A common tree, very gregarious, in open grass country. Catechu procured from it. Similar to the species in Burma. The heartwood less well developed than Burmese variety. Sometimes called the Cutch Tree. Gum arabic. 
Baphia nitida.

A small tree, frequently found, except in the driest parts. The Camwood of commerce, though camwood is really the product of Pterocarpus.

Dialium Guineense.

Known as Sierra Leone Tamarind. Very local; fruit edible. Berlinia acuminata.

Medium-sized tree. Gum obtained from it. Ornamental wood; does not work well.

Berlinia Auriculata.

A small tree.

Berlinia Heudelotii.

Medium height. Grows on river banks.

Cassia bicapsularis.

Cassia fistula.

Tree much like a laburnum, of medium size.

Cassia tora.

Cassia alata.

Flowers more brilliant then $C$. fistula. Found near villages.

Cassia lophira.

Cassia Sieberiana.

Cassia Occidentalis.

Milletia Thonningii.

Milletia Zechiana.

Bussea Occidentalis.

A small tree with bright-yellow flowers.

Neutonia insignis.

A tall tree with very smooth bark.

Calpocalyx.

A medium-sized tree of the evergreen forests.

Lonchocarpus sericeus.

Timber not much good; branches for hoe-handles.

Lonchocarpus cyanescens.

The young leaves for making blue dye.

Entada Soudanica.

A small, spiky tree; grows in dry, open country.

Entada Abyssinica.

Grows in savannah forests. Small tree.

Dichrostachys nutans.

Ormosia laxiflora.

A tree of about 30 feet in height, much gnarled and twisted. Copaifera salikounda.

Cylicodiscus Gabunensis. Ajumkobi (Ashanti).

Sold as greenheart in the Liverpool market; 90 or 100 feet in height. Very much like Piptadenia Africana. 


\section{WEST AFRICAN FORESTS AND FORESTRY}

Distemonanthus Benthamiam.

Ecastaphyllum Brownei.

A small white-flowered tree.

Erythrina Senegalensis.

A medium-sized tree, found chiefly in the dry parts. It has very ornamental scarlet flowers.

\section{Linacese.}

Hugonia acuminata.

Hugonia Planchoni.

Hugonia playsepala.

Hugonia octhocosum.

The Hugonia species are all small trees growing on the sea-shore.

\section{Rutacex.}

Zanthoxylum Senegalense. Ainyere (Apollonian).

Timber good quality. Bark used medicinally. A tree of the fringing forests-from a shrub on the sea-shore to a tree of 40 feet in height inland.

\section{Simarubaceæ.}

Hannoa Klaineana. Feutia (Aowin).

A medium-sized tree. Timber soft.

Irvingia sp. Okurii (Ashanti).

Yields a latex copious white when tapped, but turning red on exposure. Used as a rubber adulterant.

Irvingia Barterii.

One of the species that bears the Dika Nut or Wild Mango of commerce. Edible. Vegetable oils and fats. Tree of medium size.

Harrisonia Abyssinia.

A small tree.

\section{Bursuraceæ.}

Boswellia Klaineana.

The Ehye or Incense Tree. Timber good.

Santiriopsis.

Timber good.

\section{Meliacez.}

Khaya anthotheca. Kwabohri (Twi); Akwabohori (Fanti); Kwaboho (Ashanti).

White Mahogany. Medium-sized tree; timber good. 
Khaya grandis. Appapayi or Wausauwah (Twi).

A mahogany growing on the shores of the Sacred Lake. Fringing forests.

Khaya Senegalensis.

This tree attains the height of from 50 to 60 feet and a girth of 6 feet. Grows best in open dry-zone grass country. Not easy to export, as it does not grow near waterways. A gum of little value obtained from it.

Khaya Punchii.

Found in fringing forests, rainy districts and swamps. Timber very useful in furniture-making.

Khaya Ivoriensis.

The principal mahogany-yielding tree (Mr. Thompson).

Khaya caudata.

Khaya sp. (Dubon or Dubini). Dubini (Twi); Dubini (Wassaw);

Odupon or Dubini (Fanti); Odubin (Ashanti); Tiame Tiame (Apollonian); Tiama Tiama (Aowin).

The ordinary mahogany of the moist evergreen forests.

Khaya sp. Krubua (Twi); Okunmankra (Fanti).

Khaya sp. Afana or Apurro (Twi); Appapyayi (Fanti).

Two small unidentified trees from the mixed forests.

Lovoa Klaineana (Pebedum). Akwantanuro (Fanti); Kwantanura (Ashanti).

Shipped sometimes as African Walnut. A good timber-tree, closely resembling the teak in colour and structure. Very ornamental wood.

Pynartia ealcensis. Kokotswi (Twi); Anchi (Fanti).

A good timber-tree, much used locally.

Guarea sp. Bossè (Twi).

A good timber-tree; appearance of cedar, and exported as such. Moist evergreen forests.

Pseudocedrela utilis. Effnobrodidwa (Twi); Effnokonkonti (Ashanti).

Cedar; the largest of the species. A fine timbertree.

Pseudocedrela Kotschyii.

Savannah forests; attains a great height. Timber hard, of reddish colour, gnarled and twisted, so difficult to obtain timber of any size. Used for building by the natives. Roots, bark and leaves used medicinally (rheumatism).

Pseudocedrela sp. Tiama Tiama (Apollonian).

A new species of the cedars.

Pseudocedrela cylindrica. Peukwa (Twi); Punkwa (Wassaw); Tiama Tiama (Apollonian).

This cedar produces excellent timber. 


\section{WEST AFRICAN FORESTS AND FORESTRY}

Carapa Guianensis. Osuabise (Akwapim) ; Asokoru (Apollonian) ; Asoroa (Aowin).

A large tree of the fringing forests, growing on the banks of the streams; sometimes shipped as mahogany. Vegetable oils and fats obtained from it.

Entandrophragma cylindricum.

Entandrophragma ferrugineum.

Entandrophragma macrophylla.

Entandrophragma Septentrionale.

Entandrophragma utilis.

Found near Mansu and Supom. The timber of the Entandrophragma species is exported under the name of cedar. The cylindricum attains a height of 100 feet. Wood gummy, and unsuitable for veneers. Sometimes called " unscented mahogany." The utilis under the name of "sapele scented wood."

Trichilia Heudelottii.

A small tree of little value.

Trichilia rubescens.

Attains a height of 30 feet.

Trichilia Prieuriana.

Medium-sized tree with flaky bark and much-curled branches. Wood of red colour, not unlike cedar, but close-grained and hard, and has a tendency to twist when sawn.

Malphigeaces.

Heteropterys Africana.

Small tree; not very well known.

\section{Euphorbiacez.}

Ricinodendron Africanus. Assomah (Twi); Asoma (Fanti); Owama (Ashanti).

In fringing forests on the banks of streams. Vegetable oils and fats obtained from this tree. The wood is soft, but burns well; used by natives as fuel.

Bridelia micrantha.

Small tree of the dry zone. A deep reddish-brown dye obtained from this tree. It is made a fast colour by the admixture of old iron, such as old kerosene tins, which seems an important part of the fixing.

Macaranga Barterii.

Macaranga heterophylla.

Macaranga monandra.

Macaranga Rowlandii.

These four Macaranga species are all small, little-known trees. The Monandra species is a small cauliflorous tree. 


\section{THE GOLD COAST}

Masobotrya cauliflora.

A small tree; has conspicuous red fruit

Masobotrya sparsiflora.

A small, little-known tree.

Megabaria Trillesii. Chuiansa (Apollonian).

Small tree bearing poisonous fruit.

Microdesmis puberula. Aforwa (Wassaw); Offenma (Ashanti); Chuiansa (Apollonian).

A small tree. Wood very useful in the making of agricultural instruments, also chew-sticks.

Uapaca Heudelottii.

A large tree; very common on river banks.

Hasskarlia didymostemon.

A small tree; wood of little worth.

Hymenocardia acida.

Hymenocardia Chevalieri.

The Hymenocardia are both small trees of the savannah forests.

Excoecaria.

Small tree of the savannah forests.

Phyllanthus reticulatus.

Small tree of the savannah forests.

Bridelia ferruginea.

An antidote against poisons.

Bridelia atroviridis.

Not well known. About 10 feet in height. A small tree of the savannah forests.

Discoglypremna caloneura.

A small tree of the savannah forests.

Elceophorbia drupifera. Kamhan (Fanti); Dudu (Apollonian); Ajurlo (Krepi).

A small tree growing near the sea.

Cleidion Gabunicum.

A small tree. Chew-sticks obtained from it.

Antidesma venosum.

Antidesma laciniatum.

Anidesma anbryanthum.

A white latex obtained from it.

\section{Anacardiacex.}

Spondias lutea. Atwaba (Fanti); Atawa (Ashanti); Twani (Apollonian); Tongoma (Aowin); Akukan (Quitta); Akukan (Krepi).

Found in the fringing forests. A very fine tree. Fruit edible, called Hog-plum-like yellow plums in appearance; a sharp, acid taste, not unpleasant. 


\section{WEST AFRICAN FORESTS AND FORESTRY}

Odina $s p$.

A small, uncommon tree.

Pseudospondias microcarpa.

A fair-sized tree, not unlike the Spondias lutea.

Trichoscypha.

A small tree, little known.

Celastiaces.

Salacia debilis.

A tall shrub, 20 feet in height.

Icacinacex.

Apodytes Beninensis.

A small tree, little known.

\section{Sapindaces.}

Blighia sapida. Takwadua (Twi); Takwadua (Wassaw).

Often planted near villages. A useful shade tree, and part of the fruit edible, called Akee. In the forest a good-sized, straight tree. Timber excellent; hard, good grain, and easily worked.

Paullinia pinnata.

A small tree or shrub.

Phialodiscus unijugata.

Small tree. Wood of little account.

Lecaniodiscus.

Small tree. Wood of little account.

Eriocolum.

A river-side tree.

Aphania.

Small tree, little known.

Deinbollia insignis.

Small tree, little known.

\section{Melianthaceæ.}

Bersama Chippii.

A small ornamental tree with sweet-scented flowers.

\section{Rhamnacez.}

Zizyphus Spina-Christi.

A small tree with edible fruit. Wood very useful in cabinetwork.

Lasiodiscus.

A small, little-known tree.

Zizyphus mucronata.

A small tree of the savennah forests. 
Vitacese.

Leea.

A small tree of the savannah forests. Fruit edible.

\section{Tiliaces.}

Grewia carpinifolia.

Glyphaa Arewioides.

Triumfetta sp.

Three small fibre-yielding trees. The Grewia has brilliant yellow flowers.

\section{Malvaces.}

Hibiscus tiliaceus.

A yellow-flowered tree. Wood durable under water.

Thespesia populuea. Fref (Fanti); Eijan (Apollonian).

A small tree growing on sea-shore.

\section{Bombacaces.}

Bombax Buonopozense. Akata (Twi); Akata (Denkira); Ekuba (Apollonian) ; Eku (Aowin) ; Kafro (Grunchi) ; Agutesi (Krepi) ; Akronkron (Accra).

The Silk Cotton Tree. Red-flowered. A tall tree with horizontal branches with spiny protuberances. Grows in the mixed forests. It yields a kapok (fibre) similar to the Eriodendrons.

Bombax brevicuspe. Kuntunkun (Twi); Kuntunkuni (Denkira).

A new species of cotton-tree. Timber used for canoes, bark for dye, and cotton for native pillows.

Bombax sp. Eku (Twi); Nyi-nu-kobin (general West Coast); Akata (Denkira); Ekuba (Apollonian); Ekui (Aowin); Kafro (Grunchi); Agutesi (Krepi); Akronkron (Accra).

This species is confined to the rain forests of the maritime zone.

Adansonia digitata.

The Baobab Tree. The pulp of the fruit is eaten by the natives; flavour acid. The seeds are washed, pounded and steeped in water for ten days. The North-west Ashanti natives use it to flavour soup. This tree is very rich in wood fibre, which realises from $£ 9$ to $£ 10$ per ton, and is of great commercial value. A gouty-looking tree, and grows in open country, rocky soil.

Eriodendron anfractuosum. Ongina (Twi); Enyena (Wassaw); Onyina or Enyena (Fanti); Enyena (Ashanti); Enyenga (Apollonian) ; Enyo (Aowin) ; Gung (Grunchi) ; Ofwho (Quitta); Ofwho (Krepi).

The white-flowered silk cotton-tree of the fringing forests, 
one of the largest trees of West Africa. The wood is very light, and should be useful in making light wood articles, such as boxes and toys, but there is no market for it at present. The fibre is good, and the wood should also make pulp in papermaking; but there is no market, owing to the expense involved in collecting it.

\section{Sterculiaces.}

Heritiera utilis. Awabima (Twi) ; Pteryyota Wawampe'e (Ashanti); N'yankon, Yankom or Yankun (general West Coast).

Good timber-tree, medium-sized.

Sterculia cordifolia. Wawapupuo (Twi); Duamenyi (Fanti).

Tall tree; height, 60 to 100 feet. The wood of little value, as it is very soft. Found in the fringing and intermediate forests.

Sterculia tomentosa.

Height, 40 to 50 feet. Intermediate and fringing forests. The fruit grows in clusters, kidney shaped, with a dense, reddish tomentum.

Sterculia Barterii.

Flowers when the tree is leafless-appears covered with red flame. The wood is soft and of little value; it should make a good paper-pulp. The inner bark used to make rope.

Sterculia tragacantha.

A medium-sized tree. Wood of little worth.

Triplochiton Johnsonii. Wawa or Wawwaw (Twi); Owawa (Wassaw).

A good timber-tree. Bark used locally for roofing. Strong, works well and has satiny sheen. When used in exposed places it is subject to dry-rot. Tall, straight-growing tree. Should be useful for inside building.

Cola Afzelia.

Fringing forests. Monkey Cola. Fruit bright-red in colour, something like Kola. Tree grows to a height of 40 or 50 feet. Cola laurifolia.

A very small species.

Cola acuminata. Bessi (Ashanti); Esseri (Apollonian); Ewasi (Aowin); Gwe (Grunchi); Evi (Quitta); Guru (Hausa).

The Kola Nut of commerce is obtained from this tree.

Cola caricifolia.

Nansonia altissima.

Timber-tree; useful for domestic purposes.

Cola cordifolia.

Found in the savannah forests.

Cola sublobata. 
Cola vera.

The Hausa, supposed to be the best.

Cola verticulata.

Tree little known and of little value.

\section{Scytopetalacex.}

Scytopetalum Tarquense.

A small tree of the evergreen forests, bearing white flowers.

\section{Ochnacese.}

Lophira procera.

Lophira is also called the Kaku or Red Ironwood Tree; the most durable timber of the West Coast. Very valuable as fuel ; it has highly calorific properties. It grows solely in the maritime zone, in swampy land. It is of great weight, and will not float. Very useful for piles in wharves, etc.

Lophira alata.

A very fine, tall tree, growing from 20 to 50 feet. The bark is dark and rough; timber very hard and durable. The seeds are rich in oils. The tree is sometimes mistaken for the Shea Butter Tree. Common in open grass country.

\section{Guttifers.}

Pentadesma butyracece. Pija (Wassaw); Pija (Fanti); Ehukei (Apollonian); Asuaindokun (Aowin); Bromabina (Axim).

Butter or Tallow Tree. An edible fat is obtained from the seeds. Also used in soap-making. A thick yellow juice exudes from the tree when cut. A fine tree.

Allanblackia floribunda. Suein (Apollonian); Anane (Axim).

Small tree, not well known.

Garcinia Guineensis. Ablari (Fanti).

A purgative is made from a decoction of the leaves.

Haronga Madagascariensis. Ngodua (Fanti); Kursua (Apollonian).

A yellow dye is obtained from the bark. The leaves are used as a medicine for dysentery. There is a red watery exudation from the bark.

Psorospermum.

A large shrub, sometimes may be called a tree, in the savannah forests.

\section{Cochlospermacex.}

Cochlospermum tinctorium.

A large shrub of the savannah forests. The bark is used in rope-making. A yellow dye is obtained from the roots.

Lindackeria dentata.

A medium-sized tree. 


\section{WEST AFRICAN FORESTS AND FORESTRY}

\section{Violacex.}

Alsodeia. Notonima (Ashanti).

A shrubbery tree of little value.

Smeathmannia pubescens.

A shrubby tree with conspicuous white flowers.

\section{Flacourtiacese}

Oncoba echinata.

A small tree with white cauline flowers.

Oncaba Gilgiana.

A large shrub.

Oncoba dentata.

A small tree.

Rawsonia spinosa.

A medium-sized tree.

Smeathmannia pubescens.

A shrubby tree with conspicuous white flowers.

\section{Lecythidacez.}

Napoleona Vogelii.

A small tree, grows by river banks. The wood is easily worked. Fruit edible.

\section{Rhizophoraces.}

Anopyxis ealoenis. Kokoti (Wassaw); Anchi or Kokoti (Fanti); Abari (Apollonian).

Good timber-tree, much used for fuel.

\section{Combretacee.}

Combretum Afzelia.

Found near rivers.

Laguncularia racemosa.

White Mangrove. Grows in swamps.

Anogeissus leiocarpus.

A tall tree, from 30 to $\mathbf{5 0}$ feet in height. The roots are used as chew-sticks. The heartwood very durable, brown or blackishbrown. The grey ash of sap and heart woods used as a mordant. Tannin and gum obtained from this tree.

Combretum Zenkerii.

A large, shrubby tree.

Combretum sp. Esseah or Essia (general West Coast).

The "Stinkwood" Tree.

Terminalia sp. Emril, or Emil or Emiri (general West Coast).

The wood is used locally for shingles. In intermediate forests. Branches in tiers or whorls. A huge tree, bark black. 
Terminalia superba. Offram (Twi); Offram (Fanti).

Found in the fringing forests, of great height and extremely straight. Branches in whorls, barely noticeable in the fullgrown tree. Timber medium strength and hardness, light coloured, with discoloured patches. Works up very well, but of no great value for export.

Terminalia macroptera.

Found in the savannah forests.

Terminalia Togoensis.

A small tree of dry zone, of no particular value.

Pieleopsis.

A large tree. Timber little used.

Strephonema Apoloniensis.

A small tree, species little known.

\section{Myrtaceze.}

Eugenia Guineensis.

A large tree. Work used for many purposes. Fruit edible and medicinal.

Eugenia Owariensis.

Grows in the dry zone. A spreading tree.

Psidium Guajava. Aduaba (Apollonian).

The Guava Tree. Fruit edible.

\section{Sapotacex.}

Omphalocarpum sp. Assoro (Twi); Ketibubaka (Aowin).

A workable wood obtained from it, also guttapercha. The seeds worn as ornaments at their feasts by Apollonians.

Mimusops multinervis.

Grows to the height of 60 or 80 feet, with a corresponding girth. Timber hard and durable, red in colour, with a fine grain. Its weight and hardness are against its ordinary use, but it is a fine wood for sleepers.

Butyrospermum Parkii. N'ku (Fanti); N'ku (Akwapim); Iakuni (Quitta); Salkuni (Krepi).

Shea Butter Tree. One of the most valuable trees, found very frequently. Bark thick, rough, and often gnarled and twisted. Flowers creamy-white, leaves straplike. The fruit is something like a yellow plum, ripe in May. It is very similar in appearance to the Lophira alata, but the Shea butter tree exudes a white latex when cut; the Lophira does not. Timber good, but as the tree is usually only from 20 to 30 feet in height (occasionally 50 feet), it is not large enough for most purposes. The vegetable oil or butter has an agreeable sweetish taste, much used in cooking. 


\section{WEST AFRICAN FORESTS AND FORESTRY}

Mimusops. sp. Opapea (Twi) ; Opepeli (Fanti).

Vegetable oils from all the Mimusops species.

Mimusops Djave. Baku (Twi); Baku (Fanti); Baku (Ashanti); Makure (Apollonian); Makwe (Aowin); Abaku (Accra).

Vegetable oils and fats obtained from $M$. Djave. A very good timber-tree.

Vincentella ampressa.

A new species. A large tree, found growing on the river banks.

Chrysophyllum albidum.

Edible fruit. Not so well known as Chrysophyllum Africanum. Chrysophyllum Africanum.

The Star-apple Tree, often cultivated for its fruit, and also as a shade tree.

\section{Ebenacea.}

Diospyros mespiliformis.

A tree of the fringing forests-the Ebony Tree. Very abundant. Of medium size, 50 to 60 feet in height, 6 to 8 in girth. The heartwood is usually streaked with brown. The larger trees are generally hollow.

Diospyros Mombuttensis.

Diospyros xanthoxplamys.

\section{Oleacex.}

Schrebera Golungensis.

Found in the fringing forests. Very uncommon. A large tree; timber very good.

\section{Loganiacee.}

Strychnos emarginata and others.

Anthocleista sp.

A medium-sized tree, near fresh-water swamps. Large white flowers. - Wood of no special value.

Anthocleista magnifica. Honum (Twi).

A small tree with very large leaves.

Anthocleista nobilis. Otendui (Fanti); Tendeba (Apollonian);

Tendeba (Aowin).

A small tree, of little value.

\section{Apocynaceze.}

Landolphia bracteata.

A vine-like tree. Does not yield rubber.

Landolphia ferruginea.

Like the above. 
Landolphia Owariensis. Pau (Twi) ; Kwantama (Wassaw) ; Opaina (Fanti) ; Jama (Ashanti) ; Kwantama (general West Coast) ; Amale (Apollonian); Faia (Aowin); Danko (Hausa); Jahdanko (Accra).

Two kinds of rubber obtained: "root-rubber," after crushing the bark and stems and washing out the rubber, or "white-ball," by tapping and scoring, and coagulating the latex as it exudes by lime-juice rubbed on the bark. It is valued at 1 s. 9 d. to 2 s. a pound, the root-rubber at 1s. 6 d. a pound.

Landolphia florida.

A quantity of milky juice which becomes a pasty mass, but has no market value.

Landolphia Droogmansiana.

Good rubber obtained when growing in dry ground, worthless when in swampy ground.

Landolphia Senegalensis.

Landolphia Thompsonii.

Widely spread in the fringing forests; does not yield good rubber, only a pasty mass from the latex.

Landolphia scandens.

No yield of rubber.

Landolphia Klainei.

Inferior rubber.

Carpodinus hirsuta. Alibida (Hausa).

Very robust and hairy (hence its name). Found in mixed forest belts. It yields a flake or paste rubber, extracted by tapping and coagulated by boiling.

Clitandra elastica. Beckindanko (Hausa).

Yields a good rubber, sold at 1s. 3d. or 1s. 6d. a pound.

Funtumia elastica. Fruntum(Ashanti) ; Efunmundon (Apollonian) ; Efunmundon (Aowin); Puni (Krepi).

The yield of this rubber-tree is called the Lagos or Silk rubber. Found in the evergreen rain forests. Very little inferior to Para rubber. The amount procured from $F$. elastica is less than Para rubber.

Funtumia Africana.

Spurious rubber-tree; though in appearance very much like $F$. elastica, the leaves are coarser and pods longer. The latex, when coagulated, forms a sticky mass like birdlime, sometimes used for adulterating other latices.

Alstonia Congensis. Niamidua (Twi); Sindra (Ashanti); Nimeribaka (Apollonian).

Wood rather soft; only fit for inside building or toy-making. It grows best in the swamp country. A fairly large tree, slightly 


\section{WEST AFRICAN FORESTS AND FORESTRY}

buttressed with smooth bark. The natives mix the latex with rubber.

Rauwolfia Cumminsii.

Rauwolfia vomitoria.

A small tree, not over 20 feet in height.

Polyadoa umbellata.

Tree of $\mathbf{3 0}$ feet in height, growing in the fringing forests near rivers.

Holarrhena Wulfsbergii.

Grows in the fringing forests. A tree with drooping branches. Flowers white and fragrant. The wood is very soft, of little value.

Voacanga Africana.

A small tree, widely distributed. It has a milky latex, which is used in adulterating rubber.

\section{Asclepiadaces.}

Kanahia consimilis.

A shrubby tree growing near water.

\section{Convolvulaceze.}

Prevostea Africana.

A small tree, little known.

Prevostea Heudelotii.

Small tree; wood of no value.

\section{Borraginacer.}

Cordia Irvingii.

Found in the rain forests of the Okwawu hill system. Timber used locally for shingles. A spreading tree, reaching to about 60 feet in height.

Ehretia cymosa.

A small tree. Wood used for various purposes. Fruit edible and medicinal.

\section{Verbenacez.}

Lantaha camara.

Shrubby tree.

Lippia adoensis.

Shrubby tree.

Vitex megaphylla.

Both Vitex species grow in the savannah forests.

Vitex cuneata. value.

A common tree about 30 feet in height. Of no known 


\section{THE GOLD COAST}

Avicennia Africana.

One of the tallest trees in the mangrove association, yielding a workable wood, medicine and tannin.

Clerodendron splendens.

A shrubby tree.

\section{Bignoniacea.}

Spathodea campanulata. Osisiru (Ashanti).

A medium-sized tree, found in the fringing forests. Provides a useful timber, medicine, and from the seeds an article of food. . Large yellow trumpet-shaped flowers.

Dolichandrone lutea.

A tree of about 30 feet in height.

Kigelia pinnata.

The fruit has a thick rind and is edible. Timber and drugs obtained from it. Sometimes called Sausage Tree, from the sausage-shaped fruits which hang down a long stalk. A small tree.

Newbouldia laevis. Sasanemasa (Ashanti).

An evergreen tree, from 30 to 40 feet in height. Pink trumpet-shaped flowers. The natives use it as a boundary tree.

\section{Acanthaceæ.}

Acantha montana.

A shrubby tree having medicinal properties.

\section{Rubiaceæ.}

Mitragyne macrophylla. Baya (Twi); Yar-yar, or Ya-ya (general West Coast) ; Baya (Aowin):

A large tree growing in the fresh-water swamps. Timber good.

Sarcocephalus esculentus. Kusia (Twi); Ekusawa (Fanti); Kishia (general West Coast); Baya (Aowin).

Good timber, used locally. Wood of a golden yellow colour, very ornamental, hard and durable, easily worked.

Sarcocephalus Russegeri. Osupawa (Fanti).

The Russegeri grows in the savannah forests.

Gardenia tenuifolia.

Fruit edible. A bushy, ornamental tree.

Urophyllum hirtellum.

A shrubby tree. Dyes obtained from it.

Randia genipaflora.

A small tree having fine trumpet-shaped flowers. 


\section{WEST AFRICAN FORESTS AND FORESTRY}

Randia maculata.

A bushy tree, very ornamental when in flower.

Oxyanthus tubiflorus.

A very ornamental shrub or small tree. Timber, dyes and medicine obtained from it.

\section{Compositæ.}

Vernonia conferta.

A large-leaved, small tree. The timber of one variety fairly good.

Flintwood, not identified. Okisibisi (Fanti).

Good timber, used for mine-props. 


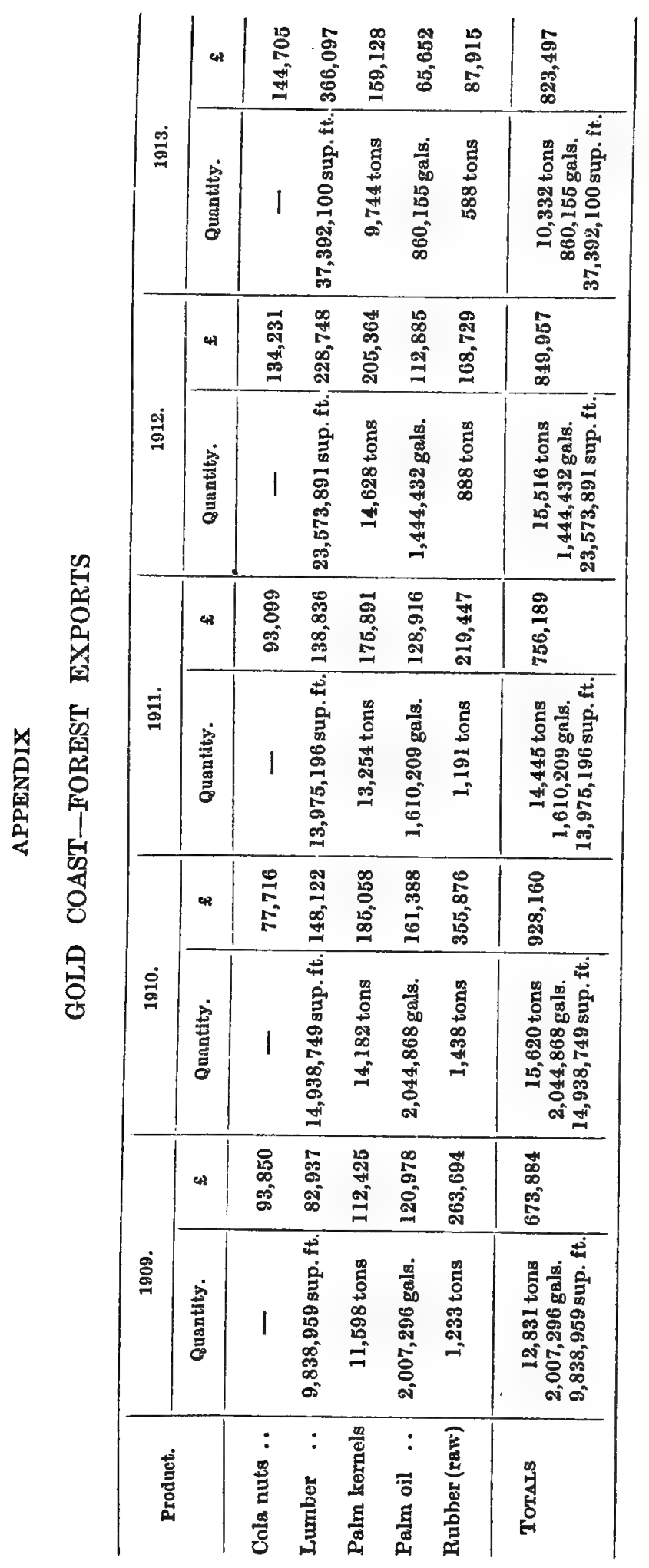




\section{CHAPTER VII}

\section{TOGO}

\section{INTRODUCTION.}

DURING the latter part of 1911 I had the opportunity of visiting Togo. Since August 1914 it has been in the occupation of British and French troops, administered as a co-dominion.

Forest Station work has been the main work of the Forest Department since the inception, both under the District Officer and subsequently under the trained officer. There is only 1 per cent. of forests in the whole country.

Lome, the capital of Togo, formed my starting-point, and there His Excellency the Governor and the Secretary of the Colony advised me as to the best route and supplied me with many interesting details as to the system of taxation, etc.

Taxation.-In Lome every man above sixteen years of age has the choice of paying 6s. per year or working twelve days for the Government. On the coast it is found that the natives prefer to pay the tax, but inland the twelve days' work is usually given. This Government work consists of plantation and road making, bridgebuilding, erecting rest-houses, and many other kinds of public work.

The subject may be divided into three sections:

(1) The Forests between or at the Stations.

(2) The Forest Departmient Plantations.

(3) District Plantations.

\section{The Formsts between or at the Stations.}

Near Lome the ground is very sparsely covered with thorny shrubs and occasional Baobabs, Adansonia digitata, but on nearing the valley of the Schio the soil improves and small plantations of sugar-cane appear. Though no attempt has been made here to develop this industry, the natives of Tagblekovke and other places sell large quantities of the cane. Oil palms are seen on both sides of the line, chiefly, however, on the river banks, owing to the annual grass fires. Scattered silk cotton-trees also occur along the river banks, otherwise only the nonal dry-zone vegetation is found.

The rainfall, however, is quite sufficient for the growth of a deciduous forest. The remains of fringing forests on the banks of the Rivers 
I.

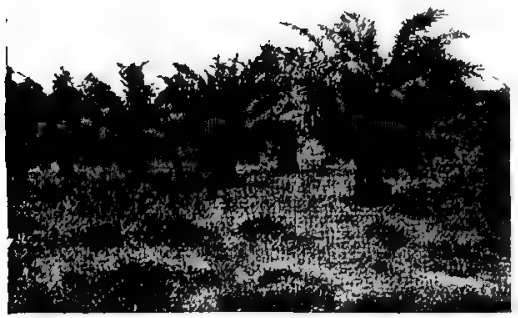

Fia. 17. - One-year-old Oil Palms amongst seven- to ten-year-old Trees, 1911.
II.

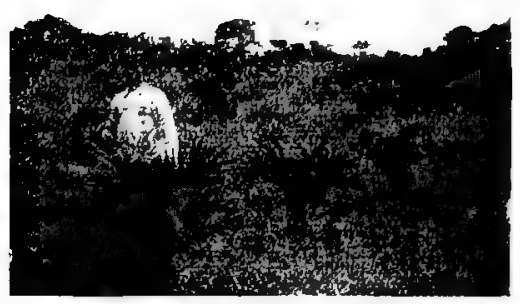

FIG. 1\%. - Two-year-old Oil Palm !Plantation.

III.

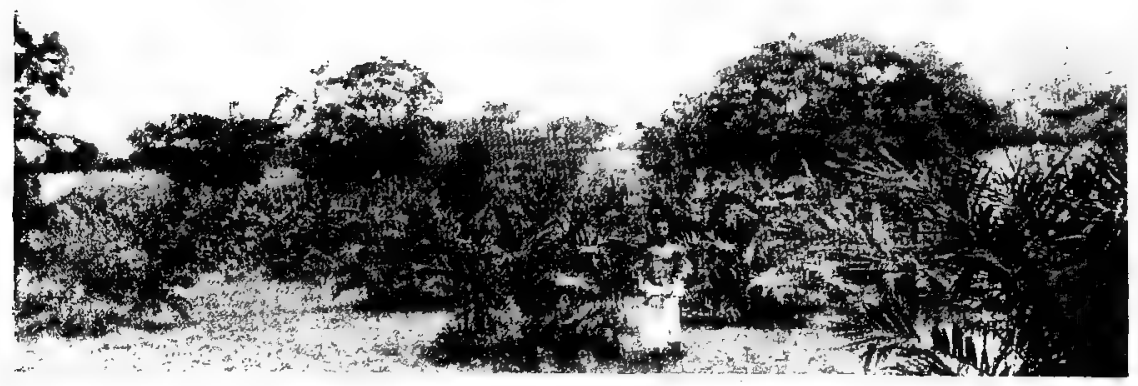

FIG. 19.-Three-year-old Oil Palm Plantation, Sokode,

IV.

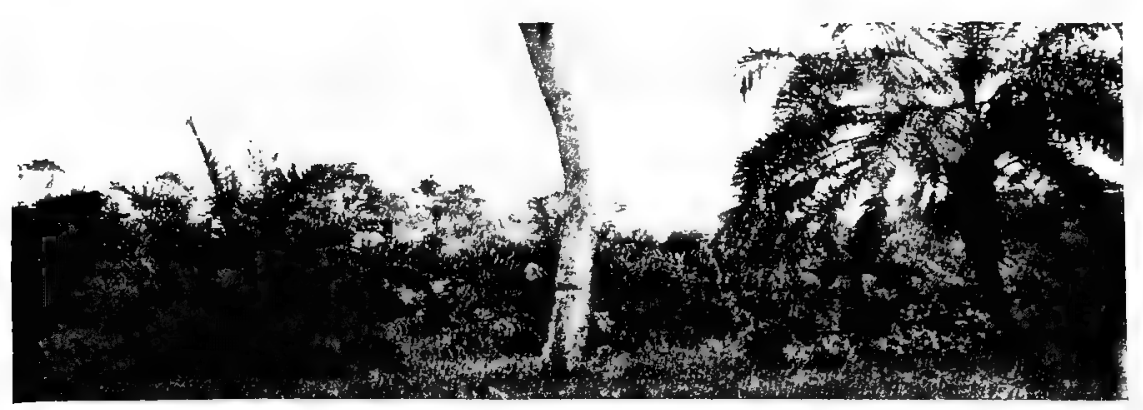

Fug. 20.-Four-gear-old Oil Palm Plantation, Sokode. 

Schio, Lili and Haho consist of Pterocarpus erinaceus, Erythrophbeum Guineense, Terminalia Togoensis and a few speoimens of Afzelia or Cynometra.

Passing on to the Haho-Baloë district, plantations ocour at the junction of these rivers in an open plain of scanty dry-zone forest. A fringing mixed forest of the normal type, varying from 200 to 500 yards in width, was found on the banks of each river, and as it formed a complete fire protection, was left untouched. In the open forest the most common trees are the Pseudocedrelas, Pterocarpus erinaceus, Butyrospermum Parkii and Terminalia.

The rainfall varies at this spot from 28 to 39 inches annually. The higher rainfall is probably the true average, if considered in conjunction with the natural vegetation. A great change in the vegetation was noticeable between Nuatjä and Atakpame; the typical dry-zone trees, such as Pterocarpus erinaceus, Shea Butter, Lophira and others, were soon left behind, and on nearing the hilly country of Atakpame a more flourishing condition was evident. Oil palms were growing in profusion both on the banks of the rivers and also on the sides. Large cotton-trees, Triplochiton Nigericum, Iroko, Chlorophora excelsa, Sterculia cordifolia and other trees of this kind were seen. The rainfall is much higher here, averaging from 58 inches, spread over the months of April, May, June, July, August and September, and a little in October. This rises to 58 inches, falls to 52, 105 miles to the north of Atakpame, in the Sokode District. This is spread over the usual rainy season of West Africa; more rain, however, falls in September than in the northern part of Southern Nigeria during the same month. After leaving the hills of Atakpame behind, we took the road to Sokode, and between the Rivers Tagbadja and Au the following dry-zone trees were most prevalent: Lophira alata, Shea Butter, Terminalia Togoensis and Pterocarpus erinaceus. As we advanced the Shea Butter Tree ceased, but more Terminalia were seen; Pterocarpus in groups and Pseudocedrela Kotschyi became very prevalent. Fringing forests were seen in the level country which followed along the banks of the Ana River.

On the third day's march I found a large specimen of Khaya Senegalensis and several smaller ones at a place just above the eighth parallel of latitude, below which the Khaya Senegalensis is rarely found. Beyond this were Paradaniella thurifera, Borassus flabelliformis, Fan Palm, Afzelia Africana and Shea Butter, and less of the species already mentioned.

These were succeeded by small pure forests of Berlinia Kerstingii, Afzelia, Ormosia laxiflora, Bauhinia reticulata, Erythrina Senegalensis, Parinarium polyandrum and Parkia Africana, syn. filicoidea. Nearing Blita rest-house, bamboos appeared, Agave rigida, and also a Ceararubber plantation. 


\section{WEST AFRICAN FORESTS AND FORESTRY}

It was interesting to find on inquiry that this plantation was the result of $1,000,000$ Ceara seeds distributed to the natives in 1907 . The vegetation on the banks of the rivers and streams consisted mostly of deciduous forest, with typical dry-zone trees at the edges. In addition, Pentadesma Kerstingii and Dalbergia melanoxylon were seen.

The last-named species has, according to German botanists, been confused with Diospyros mespiliformis, so far as the timber is concerned. The last two miles before reaching Sokode were covered with extensive plantations.

Dry-zone Trees.-Between Sokode and Bassari, a distance of 37 miles, are the Malfakassa Mountains, of which the summits are mostly bare, owing to the annual grass fires, but a dense growth of Berlinia Kerstingii, Terminalia and Afzelia Africana grow in the moister valleys.

On the more open ground the usual dry-zone trees were seen, and the Khaya Senegalensis on the banks of each of the four rivers.

The rainfall is the same as that of Sokode, about 52 inches, although the atmosphere is moister, which is partly due to the higher altitude.

The somewhat cooler temperature of the air causes heavy dews, and these also, in their turn, increase the moisture of the air. The differences are thus very marked between Sokode and Bassari as to the atmospheric moisture, and also as to the variation in the growth of the trees at the two stations.

After a short visit of two days I left Bassari for Jendi, 70 miles to the north-west. One range of hills on the way is noticeable for the pure formation of iron ore which "crops out" and causes the tree-growth to be small.

The vegetation becomes very sparse towards the valley of the Oti, 30 miles distant from Bassari, and this is owing to a great change in the climatic conditions as compared with Bassari, as well as the annual grass fires. The sole representatives of the dry-zone vegetation, which, near Bassari, had originally consisted of Khaya Senegalensis, Afzelia and Shea Butter trees, are the Baobabs, Adansonia digitata.

The rainfall is only 43 inches per year. The poor vegetation found near Jendi gradually gives way, between that station and KeteKratschi, to more typical dry-zone trees, such as Shea Butter, Lophira, Afzelia and Berlinia Kerstingii.

Oil palms were found on the third day growing near the banks of the streams, and more Afzelia in the open country. Mimusops multinervis and Diospyros were found near the River Volta, at the edge of a wide belt of evergreen forest.

The dry season is much prolonged in most years. On the average the rainfall is 46.8 inches. At the next station on the tour, Pfandu, 
the rainfall rises to 55 inches per year. Near the summit of the station hill the soil is poor, but excellent on the lower slopes.

The climatic conditions of Pfandu, a substation to Misahöhe, are unfavourable, and labour is less obtainable. The road between these two stations passes through very poor dry-zone forest, but on entering the Misahöhe mountainous region we came upon a fine evergreen forest. The most common trees noticed were Khaya Klainii, Mahogany, Iroko and Terminalia superba, the shingle-wood tree, also Triplochiton, Sterculia cordifolia, Carapa procera, Piptadenia Africana, Pentaclethra macrophylla, Detarium Guineensis, Brachystegia spicaformis, Berlinia acuminata, Afrormosia laxiflora, Satinwood, Alstonia Congensis, Ricinodendron Africanum and Eriodendron Nigericum. The mahoganies of this district were remarkably fine trees, mostly over 10 feet in girth.

A written permit, costing 3s. per tree, has to be obtained for cutting trees, and also permission from the Commissioner, before forest land may be cleared.

The high rainfall of Misahōhe, which is 62 inches per year, produces a very moist atmosphere.

After a visit of three days to the Misahöhe Station, I left for Palime, the terminus of the Lome Railway. On the way down the mountain, the contrast between the eastern and western slopes was very noticeable, a deciduous forest covering the eastern slope and an evergreen forest the western. For the first 10 miles from Palime on the way to Lome, mahoganies, oil palms and other trees abounded, but gradually gave way to the same drier type of forest as that seen on the Nuatjä railway-line.

This condition of vegetation continued until Lome was reached, a distance of 75 miles.

\section{The Forest Department Plantations.}

During 1907 there was a Forestry Conference in Berlin with regard to the afforestation of the Colony of Togo (which is wooded only to the extent of 1 per cent.), with the result that the area of Haho-Baloe was first chosen, and the plantation started at the junction of the rivers.

A fringing mixed forest on each bank of the river was left untouched, as they formed a fire protection for the plantation. Pseudocedrelas, Pterocarpus erinaceus, Butyrospermum Parkii and Terminalia were the most common trees found in the open forest between the rivers.

The altitude of this area above sea-level is about 480 feet. It slopes slightly from north to south and is triangular in shape.

Seedlings were first tried, but did not survive the first season, 
and since that time seeds have been sown, and this proved a great success. Eight species of trees have been used to form these plantations :

(1) Teak, Tectona grandis.

(2) Afzelia Africana, also called Rhodesia Mahogany or Apa.

(3) Sasswood, Erythrophlœum Guineense.

(4) African Mahogany, Khaya Senegalensis.

(5) Khaya Klainii, Mahogany.

(6) Iroko, Chlorophora excelsa.

(7) Kapok, Ceiba pentandra.

(8) Anogeissus Leiocarpus, Chew-stick Tree.

One-sixth of the total area, however, has been planted with teak; in all, 491,300 seedlings. The Erythrophlœum seedlings are most numerous, the wood of this species being hard, durable and termite resisting. It has been used with great success for piles and trestles in bridge-building.

Afzelia and the two mahoganies will be valuable and useful timbers, especially the mahoganies, as they are indigenous to the country, and there is not the element of speculation attending introduced trees.

In addition to the eight chief species named above, a few specimens of Detarium Guineense (the Dita fruit of Sierra Leone) and Cynometra were planted, but their growth is slow. A mixed crop, consisting of Parkia filicoidea, the Locust Tree, Prosopis oblonga, Anogeissus leiocarpus and Detarium Guineense (Senegalense), has also been planted.

The mixture is a good one, but the growth has been slow. The general appearance of the area where teak has been planted, in spite of the fact that the bush was left standing, is that of a teak plantation, for the teak has outgrown all the indigenous trees and formed a complete thicket.

Owing to the lack of drainage in the soil, as well as attacks of the borer, the Khaya Senegalensis has grown slowly. Slow growth is noticed also in the Apa, Afzelia Africana, but that seems to be typical of the tree.

During the first year the cost of planting (including building and labour) worked out at $f 448$. an acre, but by the third year this amount was reduced to $f l$ 28. The valuation of the whole plantation is at least $£ 10,000$.

The second Forest Department's afforestation area is Mo-Kamaa, which is being planted in a similar manner and with similar planting methods to the area situated near the Haho-Balos. Tax labour has been used to a large extent in these plantations. The situation is particularly snitable for planting operations, owing to its being pro- 
tected on two sides by the rivers from the annually recurring fires of this locality. The altitude is about 500 feet above sea-level.

As in the case of Haho, nurseries were made for oil palms only, various species being sown in lines, between which the forest growth was left standing, so as to form shade for the seedlings. Approximately 600,000 seedlings have survived, about 400,000 Khayas and 200,000 teak.

- Dry-zone mahogany, Khaya Senegalensis, and teak have been planted in addition to the oil palm. The Khaya, even up to 12 feet in girth, is found all over the locality, and near the bank of the Kamaa a few oil palms.

The teak has grown much faster than the Khaya, the average height of the former being 6 feet and that of the latter only 2 feet. The teak seedlings are beginning to outstrip the indigenous trees in the locality.

The mixture of these two trees, as far as can be judged, has been a great success. For, by the persistent foliage of the Khaya falling to the ground at a different period to that of the teak, the necessary protection to the soil, when the teak-trees are leafless, is thus given, and the Khaya (Mahogany) benefits by being drawn up by the quickly growing teak, and in both cases there is less tendency to form strong side branches.

With the advent of the proposed railway, the timber in this locality will be of great value; but even without this advantage the present value is at least $£ 1,000$.

The planting scheme contemplated is enormous, and includes an area of 96,000 acres. An actual start has been made with 295 acres.

It is an interesting fact that the mixed plantations in the afforestation areas have nearly all been made by the Forest Department, and the pure plantations by the Commissioners at the District Stations.

Approximately 300 acres are composed of mixed plantations and 256 of pure plantations.

The following mixed plantations are found in the Haho-Baloe afforestation area :

(1) Sasswood and Teak.

(2) Sasswood, Teak and Mahogany, Khaya senegalensis.

(3) Sasswood, Teak and Khaya Klainii.

(4) Sasswood, Afzelia and Cynometra Afzelia.

(5) Sasswood and Afzelia Africana.

(6) Sasswood, Khaya Senegalensis and Afzelia Africana.

(7) Sasswood and Khaya Klainii.

The most profitable mixture of all these is the teak, Khaya Klainii and Sasswood, though all have something in their favour.

These mixed forests need much attention, as one species frequently 
outgrows another, one suppressing the other, and the mixture consequently no longer existing. More European supervision is required to remove suppressed or crooked trees.

\section{District Plantations.}

Avenues of trees suitable for street-planting have been largely made in Lome. The Terminalia catalpa (almond-tree) is one of the most useful trees for this purpose; at least 12 feet of the stems are quite free from branches, and thus the trees cannot harbour many insects.

The coconut, though made use of for this purpose, is not so suitable, as it lacks height-growth; the Dracæna also, which does not improve the roadside, and a species of Ficus, probably platyphylla, which loses its foliage in the dry season, are neither of them a success. Near the Government House a large number of Casuarina equisitifolia have been planted; these have flourished well, as they can stand the ocean wind blowing almost continuously at Lome.

In the Experimental Gardens, which are situated 80 feet above sea-level, there are many interesting varieties.

The soil, a mixture of very poor sand with a great deal of iron, is not favourable to height-growth of the teak (Tectona grandis); the seeds, though in great quantities, are small and ill-developed. The mahogany, too, showed poor height and girth growth, the locality was evidently not suitable for it. Other trees that did not seem to thrive were Cedrela odorata, the Cigar-box Cedar Tree, Pithecolobium dulcis, Funtumia elastica, Bread-fruit, Artocarpus incisa, Ficus Vogelii, Borassus flabellifer, Bixa orellana, Acacia catechu, Casuarina equisitifolia, Manihot Glaziovii and Manihot dichotama; but the oil palms, Elceis Guineensis, and Ficus elastica were doing exceeding well and were of a healthy green colour. Bamboos and the usual tropical fruits had also been planted. The Kapok tree (Ceiba pentandra according to German botanists, and Eriodendron Nigericum according to Kew botanists), which has been planted too far apart, has made very little growth.

Under the guidance of the Director I visited the Agricultural School at Nuatja, 50 miles from Lome. Experimental work of all kinds was carried on here. In the nurseries were to be found Kapok, Ceiba pentandra, cotton and oil palms. In a machinery shed were a cotton gin and press, and husking machines for other seed. Lectures are given early in the year, and as the season advances practical work takes their place.

A great drawback to the extension of the Atakpame District plantations (95 miles from Lome) is the shortness of labour, as the natives pay their tax instead of working. 
The main plantations have been made on the east side of the station, on a slope facing south. Teak has been very largely planted here, no less than 25,400 seedlings since 1901, when the work was started. Others are Treculia Africana, African Bread-fruit, Sasswood, Mimusops multinervis, the hard red wood of the Olokomeji Reserve, Kapok, Ceiba pentandra, and Cashew Nuts. A new Piptadenia, named Kerstingii after Dr. Kersting, was tried, but most of the plants died. An avenue of Eucalyptus citrifolia, with its delicate foliage, has developed well and fully deserves mention.

The teak has grown well everywhere, except in a small swampy area, where the trees look unhealthy. The very large crops of seeds during the last three years have caused the height-growth to fall off in comparison with earlier years.

Most of the trees are planted too far apart, but nevertheless, seeing the whole hillside, east of the station, covered with a teak forest produces a very wonderful effect on the mind.

If the teak alone is taken as a basis of valuation, the total value cannot be less than $£ 2,500$.

The Sokode District plantations have a great advantage over those at Atakpame, as tax labour has been used almost entirely and the population is much larger than elsewhere. As soon as an experiment with regard to agricultural crops, fruit and forest trees proved satisfactory, plantations were at once made.

The orchards, farms and plantations begin on the south-east slope of the hillside, round the station to the south, finishing to the west and north-west of the office building. The plantations occur between the altitude of 1,000 and 1,260 feet. The variations of soil are very remarkable, from poor laterite to rich loam, from sand to swamp; but it is not to be wondered at, when the large area is taken into account.

As at nearly all the other stations, teak has been the most extensively planted tree, some 81,000 seedlings having been set out on an area of 115.9 acres. Oil palms have also been planted in great numbers. These are set some distance apart to get the full benefit of the sun and develop large crowns and stems. Some of the other species planted are: Khaya Senegalensis, Iroko, Funtumia elastica, Ficus elastica, Ceara Rubber, Para, Hevea Braziliensis, Manihot dichotama, Manihot heptaphylla and Manihot Pianhyensis. Three or four species only of the following trees: Albizzia Caesalpinia, including Sappan, Cassia florida, Cedrela odorata, Berlinia Kerstingii, Ceiba pentandra, Detarium Senegalense, Diospyros mespiliformis, Anogeissus leiocarpus, Eucalyptus, Melia azedarach, Morinda citrifolia, Ormosia laxiflora, Parkia Africana, Pentadesma Kerstingii, Poinciana regia, Pseudocedrela Kotschyi, Pterocarpus erinaceus and Aspidosperma Quebracho. 


\section{WEST AFRICAN FORESTS AND FORESTRY}

The mixed plantations are not very plentiful, but teak and oil palms have been planted together, though not systematically, and have proved a very profitable mixture, which is worthy of notice here. In its early years the oil palm is a shade-bearing tree, so that the shade of the teak does not hinder its growth. In the oil-bearing season the teak is leafless, which is beneficial to the formation of fruit in the oil palm. The dense foliage of the oil palm kills the adventitious shoots or side branches of the teak, so rendering pruning unnecessary. In the dry season the soil is protected most thoroughly by the evergreen foliage of the oil palm, and its masses of small roots conserve the moisture of the soil, while the wide-spreading roots of the teak allow the surface water to run away. For instance, teak and Iroko are not so suitable a mixture, as they both cast their leaves at the same time, though when planted together the teak tends to accelerate the height-growth of the Iroko, and also keeps it freer from the attacks of the gall bug.

If space permitted, many more instances of the advantage and disadvantage of these mixtures might be given.

Orchards have been largely planted at Sokode too. Oranges, limes, tangerines and Cola vera have done well, and the Spondias dulcis yields very large fruit. The date palms have not yet fruited. Fibre plants, including sisal hemp, and the Panama palms seem to be growing well; fibre for Panama hats is obtained from this palm.

A substation of Sokode, Bassari, was my next stopping-place. The station is situated on the northern side of the mountain, overlooking the valley of the River Kamaa. The plantations, with the exception of the Ficus elastica, which is 200 feet higher up, are all planted below the station. The approximate altitude is 1,350 feet above sea-level.

The following species have been most extensively planted: Teak, Oil Palms, Afzelia, Khaya Senegalense, Iroko, Ebony, Kapok, Funtumia, Ficus elastica, Manihot heptaphylla, Manihot Pianhyensis, Aspidosperma Quebracho, Casalpinia Sappan and Cassia florida. Large orchards had been made, and these contained tangerines, lemon and many other kinds of tropical fruits; and very fine specimens of Eucalyptus trees showed how suitable this locality was for them.

About 200,000 trees have been planted here within ten years.

Funtumia, when planted with teak, grows well in this area, as the shade of the teak is beneficial to it; but planted alone, the leaves become a poor colour and drop prematurely. The same thing is noticeable when planted with mahogany.

In the case of Ebony, one of the knottiest forestry problems of Europe, viz. that of finding suitable trees for admixture, has been solved. Many of them died when planted pure, but the gaps being filled with teak, the ebony seedlings, put into competition with this 
fast-growing tree, have been "drawn" up quicker than they would have otherwise grown, and have done remarkably well.

The most northerly station that I visited was Jendi, approximately on latitude $9 \cdot 30$, at an altitude of 640 feet above sea-level. The method of planting was slightly different at Jendi, agricultural crops being grown for three years between the rows of forest-tree seeds, only the oil palms and teaks being planted out as one-year seedlings from the nursery.

Besides these two species, Khaya Senegalensis, Afzelia Africana, Date Palms, Ceara Rubber, and Ramboug Rubber have also been planted. Altogether 457,200 seedlings are growing.

As firewood alone is worth $3 \mathrm{~d}$. a bundle, timber of all kinds is very valuable in this locality, the teak plantation alone being worth $\$ 200$.

Kete-Kratschi, the station adjoining Jendi and overlooking the Volto Valley, is a specially interesting one, because it was started by Graf Zech, the late Governor of Togo, who was so desirous of seeing plantations made everywhere. At this station the plantations were first made half a mile away, and these have done better than the later ones planted to the east of the station.

Teak has been largely planted, and considering the poor soil and low rainfall, has done remarkably well. For the first time a parasite in the shape of a species of Loranthus was found growing on the upper branches of two large teak-trees, but no diminution in the growtb of the teak was noticeable. Afzelia, Khaya Klainii and Khaya Senegalensis have been planted in large numbers, and experiments made with Albizzia lebbek, Poinciana regia, Acacia catechn and Ceiba pentandra. A few oil palms and Casuarinas have found a place in the plantations. Eight miles from the Volta Valley is the station of Pfandu, situated on an open, isolated hill with a sheer cliff to the east and sloping gradually away to the north-west and south.

The only variation here in the planting system was that Cassada was largely used as an agricultural crop between the rows of tree seedlings, which were put in the year after the Cassada had been planted. Though the Cassada afforded a shade for the young seedlings, the latter did not seem to show sufficient growth to warrant a further trial of the system. The teak especially thrives here, the tree having reached a height of 36 feet and a girth of 14 inches, and these trees have already been felled for house-building purposes. The plantation is valued at $£ 550$.

Ceara rubber is now being tapped on a large scale. Sasswood, Erythrophloum Guineense, Iroko, Oil Palms, and Funtumia elastica have been planted in large numbers, and a few Afzelias, Diospyros mespiliformis and Kapok trees:

The hill station of Misahöhe overlooks the valley of the Chedscho and Agu, with the highest mountain in Togo opposite. The people 


\section{WEST AFRICAN FORESTS AND FORESTRY}

have means to pay the tax here, so labour is scarce and prisoners are employed in keeping the plantations clean. The altitude of the highest plantation is 1,800 feet above sea-level. Manihot Glaziovii has been planted in greater numbers than any other tree; next comes Teak, then Para Rubber, of which one had been tapped with satisfactory results, Funtumia elastica, Oil Palms, Khaya Klainii, Sasswood and Cola vera. Small plantations of Ficus elastica, Cocoa and Anogeissus leiocarpus have also been made. One curious mixture was seen, Teak and Cola vera; the teak-trees tended to grow much faster, and the Cola benefited by the shade.

The most northerly and the driest stations are Sansane Mangu and Kalangasshi, where I was told 1,037 acres had been planted with Teak, Khaya Senegalensis, Ceara Rubber and Afzelia. It is proposed to form the third afforestation area of 15,000 acres at Kalangasshi.

In smaller quantities are to be found the Locust Bean, Parkia filicoidea, Manihot Glaziovii, Shea Butter, Iroko, Ficus elastica, Oil Palms, Funtumia elastica, Afzelia Africana and Kapok. Some teak and a few other trees had been planted at Bismarckburg, an old substation to Kete-Kratschi, and the same varieties at Ho, a substation to Misahöhe.

I was unable to obtain figures as to the number of trees planted at the above three stations, but teak is reported to be doing well at them all.

In addition to the species of indigenous trees planted, and also introduced, species such as Teak, Tectona grandis, and many others have been planted on a small scale. 

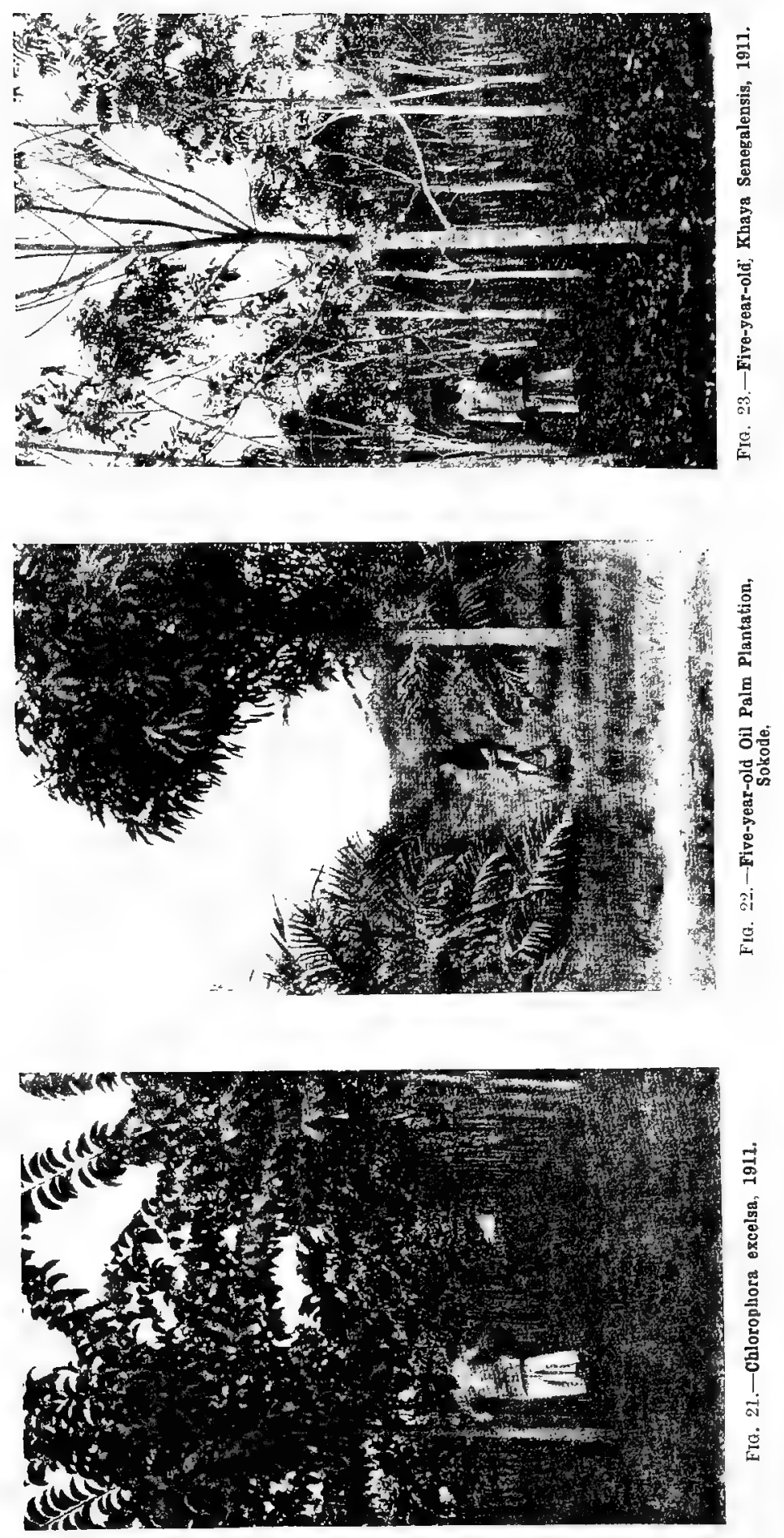



\section{NOTES ON INDIGENOUS TREES}

\section{Pandanacex.}

Pandanus Togoensis. Kpa (Ewe).

$6 \frac{1}{2}$ feet in height.

Pandanus Kerstingii. Abá (Tschandjo).

$32 \frac{1}{2}$ feet in height.

\section{Gramines.}

Oxytenanthera Abyssinia.

Bamboo. $19 \frac{1}{2}$ feet to 26 feet in height.

Andropogon Sorghum. Wo (Ewe).

Used in broom-making and roof-covering.

\section{Palma.}

Raphia vinifera. Ala (Ewe); Táro (Tschandjo); Kpakó (Anago); Ollo (Akposso).

Leaves used for brooms and brushes, mats, baskets, weaving, etc.

Phoenix spinosa or Phanix reclinata.

$32 \frac{1}{2}$ feet high. Leaves, weaving nets, etc.

Eloeis Guineensis.

Oil palm. Covering for roofs from leaves.

Weaving of all kinds, coco fibre, carpets, brushes. Nuts.

Borassus flabelliformis or Hyphane Togoensis, Hyphane coriocea.

Plaiting for hats, nets, etc.

Carludovica palmata.

\section{Flagellariacex.}

Flagellaria indica $L$.

The tough outer stems used as ropes.

\section{Bromeliaces.}

Ananas. Atóto (Ewe).

An attempt has been made to bring the Togo pineapple into the markets, but without success. Fibre much used in weaving, etc.

\section{Liliaces.}

— : Dzogbeblôbe (Ewe).

Sansevieria Guineensis. Baugbaningbamu (Tschandjo).

Long, flat leaves, $4 \frac{7}{8}$ feet long. Fibres useful in commerce. Bowstring hemp. 


\section{WEST AFRICAN FORESTS AND FORESTRY}

Sansevieria cylindrica.

Aloe Barteri.

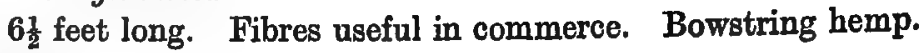

Aloe Buettneri.

Fibre from leaves of both Aloes.

\section{Amaryllidaces.}

Agava Sisalana.

Mauritius hemp.

Both have been introduced into Togo. Fibre used in weaving.

\section{Taccacez.}

Tacca pinnatifida. Dzogbenyabo (Ewe); Ludjŭ (Tschandjo); Bōti (Dyakossi).

Used as a vegetable, having tubers like a potato, about the size of the fist. Leaves much divided. Fibres used in weaving all sorts of articles.

\section{Musacex.}

Wild bananas.

Mohammedan rosaries are made from the seeds.

Musa textilis.

Fibre much used.

\section{Marantacex.}

Aframomum.

Leaves for roofs.

Clinogyne flexuosa. Fita (Haussa); dworom (Asante).

Leaves used in paper-making.

\section{Ulmacex.}

Celtis Prantlii.

Dwarf variety. Bark fibre very much ased.

Celtis integrifolia. Tyentyem (Mangu); Diki (Haussa); Kokojä (Losso) ; Patakli (Atakpame).

130 to $162 \frac{1}{2}$ feet high. Wood not very good.

\section{Moracex.}

Chlorophora excelsa. Logo asagu (Ewe); Ssäre (Tschandjo); Ukloba (Akposso); Odum (Asante); Sserre (Kratschi); Roco (Dahomey).

130 to 195 feet high. From 39 to 65 feet in circumference. One of the highest trees in the Colony. One of the most useful trees of West Africa for building purposes and furniture. 
Musanga Smithii.

65 feet in height. The wood very light, sometimes takes the place of cork. Wood used for cigar boxes, also sometimes in cellulose factories.

Myrianthus arboreus. Avogolo or awogolu (Ewe).

Myrianthus seratus.

Like horse chestnut in appearance; orange flowers. Wood brittle, used for fences.

Antiaris Africana (syn. Antiaris toxicaria). Logo (Ewe); Ssäre (Tschandjo).

Fruit fig-like.

Ficus grandicarpa. Furu (Tschandjo).

Milky juice oozes from bark when cut. 65 feet in height. Bark smooth; regular branching. Figs gathered in March.

Ficus vallis chondee.

Ficus exasperata. Fola (Tschandjo).

Ficus bembicicarpa. Kedā (Tschandjo).

There are about 30 varieties of figs.

Ficus lutea.

Ficus rokko. Kedā (Tschandjo).

Ficus toliifolia. Adyokŭkola (Tschandjo).

Ficus umbrosa. Tisemu (Tschandjo).

Ficus djurensis. Tura (Tschandjo).

Ficus brachypus. Ebö (Ewe); Bauri (Haussa).

Reddish bark. Wood heavy.

Ficus tesselata.

Ficus dusenwides.

Ficus Togoensis.

Ficus sokodensis.

\section{Proteaces.}

Faures speciosa.

Protea Bismarckii. Düdürede (Tschandjo).

Wood yellowish-red in colour, used for furniture. Height $32 \frac{1}{2}$ feet.

\section{Olacaceæ.}

Ximenia Americana.

Yellow heartwood resembles the scented white sandalwood.

\section{Anonaceæ.}

Uvaria chama. Agbana (Ewe); Pereng (Kabure); Liasá (Atakpame) ; Padiivin (Difale).

Small tree with edible fruit. Wood greyish-brown, fairly heavy. 
Cleistopholis patens. Baledia or Welengéle (Tschandjo); Nuso or Aru (Atakpame).

Height $32 \frac{1}{2}$ feet to 65 feet. Wood light-used for barrels and drums - of a grey colour.

Hexalobus morepetalus. Tschabola buanda (Tschandjo); Tumbalaka (Atakpame).

Grows to large tree in Gallery Forests-small in Savannah. No trial of wood made yet.

Xylopia rethiopica. Tso (Ewe); Ssosi (Tschandjo).

Light yellow wood of flexible nature, used for masts of boats.

Xylopia parviflora. Tschabolabunda (Tschandjo).

Root wood takes place of cork.

Xylopia Eminii. Akatapuressosi (Tschandjo).

Fairly large tree, wood reddish, used for furniture.

Anona sp.

Root wood of all the species forms a substitute for cork.

\section{Myristicacex.}

Pycnanthus Kombo. Óbala (Atakpame).

Soft wood. Used in box-making.

\section{Capparidaces.}

Cratava religiosa. Anamolum (Tschandjo); Dengma (Mangu); Tschengunga (Asante). Wood can be turned easily-like boxwood in appearance.

\section{Rosaces.}

Parinarium curatellifolium. Molemóle (Tschandjo); Insofaniwőche (Mangu); Pótepote (Kratschi); Yafo (Kpedyi).

Trees of stunted appearance in Savannah, but growing higher in better soil. Wood is oak-like and very hard-uniform texture. Used for wooden pegs or pins, and other purposes in building, when durability is important.

Parinarium subcordatum. Bende noso (Tschandjo); Insuopangi (Mangu) ; Pekĭre (Losso).

Used for rafters in roofs by the natives of Mangu.

Parinarium polyandrum. Bende noso (Tschandjo).

Parinarium mobola.

Never attains any great height.

Parinarium Kerstingii.

Attains much greater height than the last, a tree worthy of notice.

\section{Leguminoss.}

Abbizzia Brownii. Pangalan (Tschandjo). Kokpara (Atakpame).

Large, handsome forest tree, with greyish-green cracked 
bark. Wood fairly hard. Light sapwood, dark brownish heartwood.

Albizzia Angolensis. Atikuzẽ (Ewe). Kŭpaussŭto (Tschandjo). Height $97 \frac{1}{2}$ feet. Diameter $4 \frac{7}{8}$ feet.

Albizzia fastigata. Asihuë (Atakpame).

The Albizzias are all proof against the termites on account of their hardness. Wood of $A$. fastigata used for the felloes of wheels.

Acacia catechu.

Acacia Arabica. Magarua or Bagarua (Hausa).

About $19 \frac{1}{2}$ feet in height. Characteristic tree of the Steppe north of Oti. . Numerous.

Acacia suma. Gudjápūpŭ or Gudzawuwu (Ewe); Chrinika (Atakpame).

Height $32 \frac{1}{2}$ feet. Yellowish-white wood, heavy and very hard; used for agricultural implements.

Dichrostachys nutans. Ssossōsi (Tschandjo); Beniti (Agome).

Hard wood-dark heartwood, almost black-used for making walking-sticks.

Prosopis oblonga. Akáka (Ewe); Pato (Tschandjo); Pangi (Mangu); Kaki (Atakpame); Kpánenã (Kratschi).

Hard wood-termite-proof. Young branches used for handles of axes and hatchets.

Tetrapleura Thoningii. Prékese (Ewe).

A stately tree, only known in Akposso at present. The wood not yet much used.

Piptadenia Kerstingii. Kapaussuto (Kabure).

Huge tree-stands singly. Blossoms in January, when it is leafless. Fruit appears in April.

Piptadenia Africana. Alagbáta (Atakpame).

Wood doubtless of great value.

Entanda Abyssinia. Ondutu (Tschandjo); Kiria (Hausa); Ketschikantscha (Kratschi).

Tree stunted, leafless in the dry season. Wood spongy, not of much value.

Entanda scandens. Klokpakpa (Ewe).

The well-known Liana, with husks 3 feet long, growing abundantly in the coast provinces. The fibre is much used in the making of nets, ropes, etc.

Parkia Africana. Wo (Ewe); Ssuto (Tschandjo); Dorana (Haussa) Soroño (Asante); Gotschốne (Kratschi).

Height 65 feet. The hard heavy, pale yellowish wood, locustwood of Sierra Leone. In commerce known as Caindah wood.

Parkia filicoidea. Ena (Atakpame).

Grows plentifully on the coast of Atakpame. 
Parkia biglobosa.

Height $97 \frac{1}{2}$ feet. Bark from a clear grey to dark brown, much furrowed.

Erythrophloum Guineense. Tsa (Ewe); Kekëü (Tschandjo).

Wood much valued for its heartwood and because of its rarity. Withstands the attacks of termites, and therefore much used in house and ship building, wheels for gun-carriages, etc. Takes a foremost place in export of wood.

Burkea Africana. Tschísili (Tschandjo); Kiriandutschi (Haussa); Esseresu ophrimú (Asante); Atakpla (Atakpame); Kinkiri (Kratschi).

Height 78 feet. Broad crown. Leaves covered with silky hairs; wood used by the natives for sword handles.

Cynometra megalophylla. Agumü (Tschandjo).

Found in the coast forests.

Cynometra Afzelii.

Cynometra sp.

Detarium microcarpum. Depapātō (Tschandjo); Naparli (Mangu)

Kökpakpa (Kratschi); Záklu (Misahöhe).

A very heavy wood of a brown colour. Used in boat-building.

Detarium Senegalense.

Has a larger fruit than the D. microcarpum. A beautifully marked hard wood. Grows to a great height. Found exclusively on the coast.

Detarium Guineense.

Tamarindus indica. Keditia (Tschandjo); Samia (Haussa); Tamarese (Asante); Kốpu (Kratschi).

Grows near farms and in the prairies. A clear-coloured wood-very heavy to work; will not float in water; used for mill-wheels, powder coal, etc.

Afzelia Africana. Papac (Ewe); Welu (Tschandjo); Apakka (Anago); Ukpami (Akposso); Kao (Haussa) ; Papau (Asante); Kebarre (Kratschi); Kpakpa (Fõ).

Height $48 \%$ feet. A very beautifully marked wood. Proof against attacks of termites; much valued in building and for table-making, also mortars for orushing yams.

Daniellia thurifera. Lipiti or Dsati (Ewe); Tschato (Tschandjo); Orokpo (Anago); Auwolo (Akposso); Masche (Haussa); Saingja (Asante); Kenjang (Kratschi); Sa (Fō).

Height from 65 to $97 \frac{1}{2}$ feet. Common in the prairies. The sapwood is white, and the heartwood reddish and very hard. Barrels are made from it.

Berlinia Heudelotiana. Ademá or Baba (Ewe); Budâ (Tschandjo) ; Kochoá (Kratschi).

Large tree with white showy flowers, growing on banks of 
rivers. Heavy wood of light brown colour. Only of secondary importance.

Berlinia Kerstingii. Tau (Tschandjo).

65 to $97 \frac{1}{2}$ feet high, grows on open prairie. Wood used for rafters in house-building.

Berlinia accuminata.

Berlinia tomentosa.

Bauhinia reticulata. Klo (Ewe); Bākū (Tschandjo); Nyama (Mangu); Okokotaka (Asante); Tamenasi (Atakpame); Aklõ (Anecho).

Fairly heavy wood of dirty brown colour, easily worked. Very plentiful in the prairies.

Dialium Guineense. Zigbli or Toë (Ewe); Madð (Atakpame).

$32 \frac{1}{2}$ to $48 \frac{3}{4}$ feet high, valued as a wood for building, known as Black Tumbler or Velvet Tamarind on the market.

Distemonanthus Benthamianus.

One of the hardest woods of Togo, a gigantic tree.

Cassia Siberiana. Gagamagati (Ewe); Tschamanu (Tschandjo).

Grows best on dry, stony parts of the prairie. Light brown wood, extraordinarily hard, proof against termites. When burnt it causes headache.

Suartzia Madagascariensis. Subando (Tschandjo).

A small tree growing by river banks and on the prairies. Heartwood reddish black.

Cordyla Africana. Kessing (Tschandjo).

Wood used in table-making.

Ormosia laxiflora. Kedeleā or Kodoleā (Tschandjo); Kokoro or Golloklo (Mangu) ; Obri (Asante); Kekpili (Kratschi); Akũgre (Kpedyi).

Beautiful clear brown wood, used by the natives for building. It is termite-proof.

Baphia nitida.

A small slender tree. Tons of the wood are sent yearly to England as red dye-wood.

Milletia atite. Atite (Ewe); Sso abalu (Tschandjo).

Spread through all the colonies. Wood very uniformly marked of clear yellowish-white.

Pterocarpus erinaceus. Doti (Ewe); Tim (Tschandjo); Segbe (Mangu); Keleyu (Kratschi).

Used as a red dye. Height 65 feet. Very heavy wood of reddish-brown colour. Sold as teak-one of the best woods of commerce.

Pterocarpus esculentus. Keruwowo (Tschandjo); Futu (Kirikiri).

Smaller tree than the last, found in prairies. Wood fairly heavy and yellowish-white. 


\section{WEST AFRICAN FORESTS AND FORESTRY}

Lonchocarpus sericeus. Lo (Ewe); Bäbäle (Atakpame); Alobla (Kpedyi).

Found in prairies and terrace woods. Flowers reddishviolet. Wood not well known.

Derris Stuhlmanii. Tschaloware (Tschandjo); Bembu (Mangu).

Height $32 \frac{1}{2}$ feet. Hard, yellowish-white wood.

Andira inermis.

Fairly large mountain tree. The Cabbage Tree of the $\mathrm{W}$.

Indies. Hard, yellowish-white wood. The partridge wood of commerce.

Erythrina Senegalensis. Yrewo (Ewe); Nyimu (Mangu); Baklesu (Atakpame).

Slender tree $32 \frac{1}{2}$ feet in height. Bark deeply cleft, corklike, and thorny. Wood very light and useful in many ways.

Dalbergia melanoxylon. Atiyi (Ewe).

The heartwood is almost hard as iron, proof against attacks of insects. Used for pillars and piles, also in the making of musical instruments.

Brachystegia spicaformis.

Macrolobium stipulaceum.

Pentaclethra macrophylla.

\section{Zygophyllacex.}

Balanites Asgyptiaca. Kunjanapcule (Mangu); Gushiocho (Kratschi).

Height $19 \frac{1}{2}$ to 26 feet. A beautiful golden brown wood, used in the making of ploughs, clubs, sticks.

\section{Rutacese.}

Fagara xanthoxyloides. Eché or Aläfe (Ewe) ; Kelengmâu (Tscandjo); Polu-Dyenye (Mangu); Tigu Schirafinsa (Mangu); Ata (Anago); Uche (Akposso); Che (Fō); Klongbaŭ (Tim).

A fairly large tree of the prairie. In appearance like an apple-tree. Bark rough and knotty.

Limonia Warneckei. Kugónu (Tschandjo); Nguni (Kabure); Tyanka or Hogogo (Atakpame).

Wood light yellow, uniform, hard, and very heavy.

\section{Limonia Preussii.}

\section{Simarubacex.}

Hannoa undulata. Dikbere (Tschandjo); Yayabé (Mangu); Kelantori (Kratschi).

The wood is of a light greyish-white colour, fairly heavy.

\section{Meliaces.}

Khaya Senegalensis. Frimu (Tschandjo).

A large tree sometimes attaining a height of 130 feet and 
over. 137 feet in diameter. Has a beautiful surface; is most useful in commerce for furniture, carriages, cases for microscopes, etc. The fruit is about the size of an apple, with four valves and four rows of flat seeds.

Khaya Klainii.

The seed vessel has five valves, and the fruit is larger than the last. Known as the African or Gambia mahogany of commerce.

Pseudocedrela Kotschyi. Alu (Ewe); Dituturi (Tschandjo); Krŭbete (Asante); Kedemponasi (Kratschi).

65 feet in height. The wood is of a greyish colour, serviceable in building and furniture industry. The natives use it for drums and barrels.

Carapa procera.

Not much known, though used in Senegambia as a building mahogany.

Melia Azedarach.

A small, much cultivated tree; the purplish blue flowers are like the Spanish elder. The sapwood whitish, the heartwood reddish. Easy to work; used in the making of furniture.

Ekebergia Senegalensis. Frimŭabalú (Tschandjo).

A large tree growing in the mountainous districts. Wood light yellow and fairly heavy, and uniform texture.

Trichilia emetica. Adyanyapesō (Tschandjo).

Trichilia Prieuriana. Dilifū (Tschandjo).

These two are small trees, fairly easy to work, of a light yellowish-coloured wood.

\section{Polygalacex.}

Securidaca longepedunculata. Foji (Tschandjo) ; Dyōro (Dyakossi) ;

Ua magungŭna (Haussa); Atakpati (Atakpame).

Small tree. A strong useful fibre obtained from the small branches.

\section{Euphorbiacce.}

Phyllanthus discoideus. Kongkonga (Tschandjo); Dantivi (Atakpame); Kamfuă (Bagu).

A tall primeval forest tree-occasional clumps in the villages. Hard heavy wood of a beautiful red colour.

Hymenocardia acida. Adudze (Ewe); Atidje (Atakpame).

The wood is fairly hard, light brown, with the yearrings clearly marked. Very brittle, so only fit for firewood. 


\section{WEST AFRICAN FORESTS AND FORESTRY}

Hymenocardia ulmoides. Taboia (Atakpame); Bälä (Afem).

Height 130 to $162 \frac{1}{2}$ feet.

Uapaca Togoensis. Egba (Ewe); Kidgeling (Tschandjo); Nagudi (Atakpame).

A prairie tree of medium size. Beautiful brown-coloured wood; used for firewood.

Uapaca Heudelotii. Oli (Atakpame).

Grows in the terraced woods. Useful in building.

Alchornea cordifolia. Tschufốu (Tschandjo); Awowlo (Atakpame).

A small prairie tree. The hollow twigs are used in pipemaking.

Sapium Guineense.

Sapium Kerstingii.

Sapium Mannianum.

These three trees are not of much importance.

Ricinodendron Africanus.

Vegetable oils and fats obtained from this tree. The wood is soft and used for fuel.

\section{Anacardiacez.}

Mangifera Indica.

Mango tree. A greyish wood, useful for building purposes.

Anacardium occidentale. Atisiā (Ewe).

Reddish, fairly hard wood, used in boat-building, also for charcoal.

Spondias lutea. Kinyelu (Tschandjo); Akiko or Agliko (Atakpame) ; Nayile (Konkomba).

Tall, slender tree. The fruit is edible, yellow, and downy. Abundant in the prairies, now introduced in many localities. Bright-coloured wood, fairly hard and heavy.

Pseudospondias microcarpa. Onyangba (Atakpame).

Stately tree, 65 feet in height. Nothing is known of the wood.

Lannea acida. Eknalokpoe (Ewe); Käla (Tschandjo); Tyĕtĕbu (Mangu); Asogedaka (Atakpame).

A common tree in the prairies. The greyish hard wood is used by the natives for arm-rings, chairs, etc.

Lannea Barteri. Tingbatau or Patandeu (Tschandjo); Bēnature (Mangu) ; Akú (Atakpame.)

This tree has a characteristic spiral bark. It grows to a height of 65 feet, with reddish edible fruit.

Hamatostaphis Barteri.

Has a beautiful fruit of a delicious flavour, the blood-plum of Sierra Iseone. The wood has not yet been tried. 


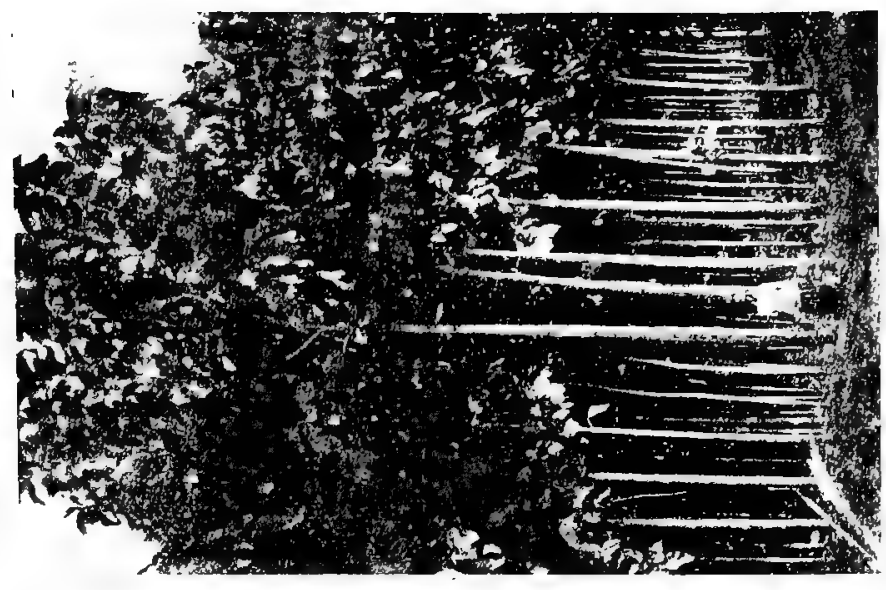

苟

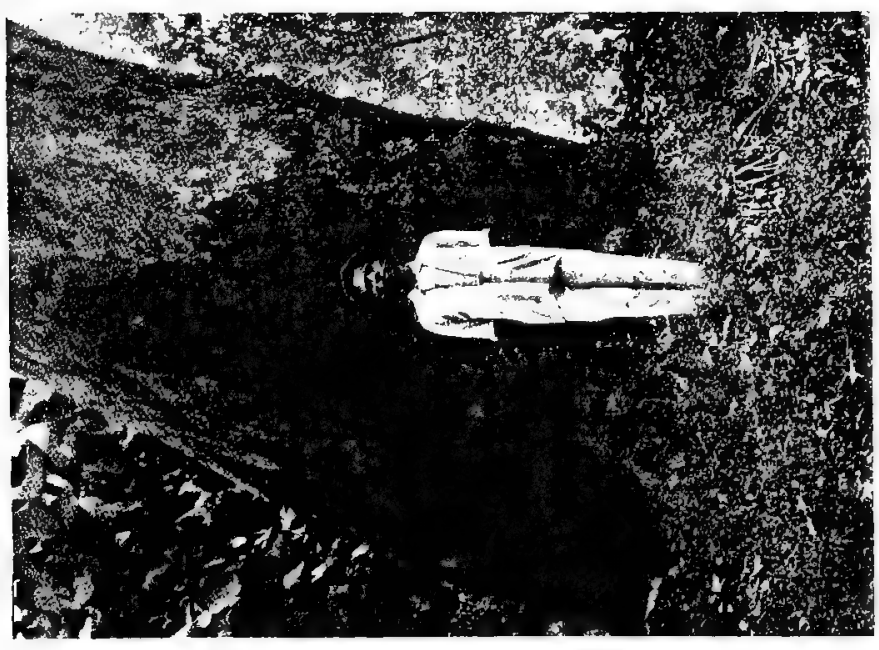

要

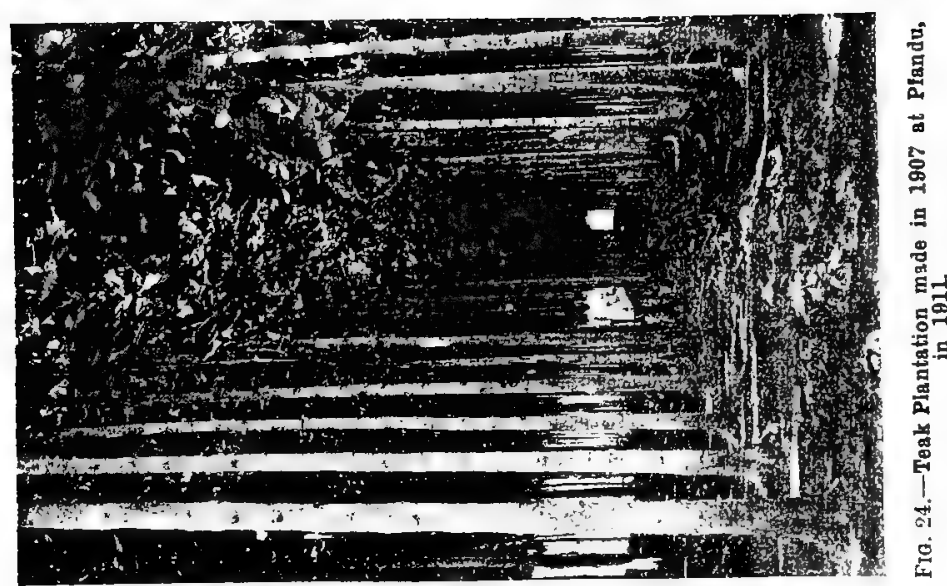



Heeria insignis.

The wood is much valued in the making of specially good furniture.

\section{Sapindaces.}

Blighia sapida. Adza or Adja (Ewe); Peso (Tschandjo); Aki (Asante); Keká (Kratschi).

The wood is light yellow, not of any value. Planted near houses as an orchard tree, and also for its shade. $97 \frac{1}{2}$ feet in height.

Eriocolum Kerstingii. Nimwau Pesō (Tschandjo); Yevo-Gboma (Atakpame).

97 $\frac{1}{2}$ feet in height in the coast forests. A good furniture and building wood.

Talisiopsis oliviformis. Waogbúm (Tschandjo).

Perhaps identical with Zanha golungensis. 65 to $97 \frac{1}{2}$ feet high, with reddish bark. Wood used for furniture and building. The fruit is downy, of an orange colour, and edible.

Allophyllus Africanus. Weti (Atakpame); Kōtīa (Yendi).

A small bushy tree. The wood used for cleaning the teeth. Useful for working in many ways.

\section{Melianthacex.}

Bersama Doeringii.

This tree has aerial roots. The blossoms in long bunches of white flowers.

\section{Rhamnacez.}

Zizyphus Jujuba.

A small shrub-like tree with edible berries. The wood is used in saddle-making and for agricultural implements.

Zizyphus mucronatus. Pangbaīngu (Tschandjo); Sausanyebui (Mangu).

The wood is used in wagon-building.

\section{Tiliacex.}

Grewia gigantiflora. Adzadze (Ewe); Tolábù (Atakpame).

Grewia villosa. Adzadze (Ewe); Yumba (Mangu).

The natives use the wood for handles of spears.

\section{Malvacex.}

Thespesia populuea.

The sap-wood is a bright red, and the hard heartwood a dark red; used for carriage-building and furniture. 


\section{WEST AFRICAN FORESTS AND FORESTRY}

\section{Bombacacere.}

Bombax Buonopozense. Fuló or Folố (Tschandjo); Sanbúgo (Mangu).

Grows on high ground and also by the streams. Height about $162 \frac{1}{2}$ feet. A marvellous sight when covered with its crimson blossoms. The bark is smooth and bright grey, with rough cracked appearance. Of small account in commerce.

Adansonia digitata. Adido (Ewe); Kuka (Haussa); Dádie (Asante) ; Kelle (Kratschi).

Called also bread-fruit tree.

Ceiba pentandra. Wu (Ewe); Komu (Tschandjo); Ogu (Anago); Ju (Akposso); Huti (Fõ).

Wood little used, though it should be valuable in the cellulose factories.

Eriodendron Nigericum.

\section{Sterculiacez.}

Sterculia tragacantha. Akplẽ or Loloẽ (Ewe); Kaderabobo (Tschandjo).

Sterculia tomentosa. Akpoklo or Bofuti (Ewe) ; Modetu (Tschandjo) ; Bolusila (Mangu) ; Oduduku (Atakpame) ; Kelipotu (Kratschi); Apokpo (Anecho).

Sterculia oblonga.

The wood of these three trees is soft and of little value. The fibre strong and tough. Tree medium height.

Cola cordifolia. Uuti (Ewe); Dagbongbore (Tschandjo); Nutssunutssu (Anago); Anwolo (Akposso); Eussú (Misahöhe).

A huge tree of the Gallery Forests, also found singly near villages. The leaves are a foot long. The wood hard and heavy, used in Senegambia for strengthening the coast and for rafters.

Cola acuminata.

The tree resembles the poplar. Proof against the attacks of insects; useful for carriage and furniture-making, and shipbuilding.

Cola laurifolia. Jojau (Kabure).

The wood is very pliable and used in the making of bows (for shooting).

Cola caricifolia. Alensuneku (Atakpame).

Cola astrophora.

Cola supfiana.

Cola Afzelii.

Triplochiton Johnsonii.

Triplochiton Nigericum.

Plerygota Schumanniana.

The wood of these five trees is little known. 
Firmiana Barteri. Tschingbelika (Tschandjo).

From 130 to $162 \frac{1}{2}$ feet high. The regular, pyramidal-shaped trunk ends in plank-like roots. The natives make cups and bowls and floats from the wood. The flowers are a beautiful scarlet, appearing before the leaves.

\section{Ochnaces.}

Ochna Afzelii. Tanam (Tschandjo).

Moderately high tree, with hard, beautifully-marked bright brown wood. Used in turning and table-making.

Lophira alata. Parapára (Tschandjo) ; Akpakpla (Anago) ; Otugba (Akposso); Kekrefunde (Asante); Belengbe (Kratschi) ; Kotublassu (Fõ)

A very common tree of the prairies, so much like the Shea butter as to be frequently mistaken for it. The wood is hard, heavy, and dark, reddish-brown, and sold as African oak.

\section{Cuttiferæ.}

Pentadesma Kerstingii. Budyonū (Tschandjo).

Grows on the wooded banks of streams. A tall, slender tree with lightish brown wood, very similar in texture to that of the Ochnaceæ family. Used by the natives in various ways.

\section{Dipterocarpacex.}

Monotes Kerstingii. Kesáng (Tschandjo).

Height about $48 \frac{3}{4}$ feet. It is found frequently in the prairies. Easily recognized by the likeness of its leaf to a curved hollow of a hand. The wood is only useful for burning.

\section{Flacourtiacez.}

Oncoba spinosa. Kpoe (Ewe); Krutū (Tschandjo); Kongowura (Kotokoli).

A tall, thorny shrub, with white rose-like flowers. The wood is capable of taking a good polish, used in inlaying.

Caloncoba Gilgiana. Efiohlë (Ewe).

A fair-sized tree. The wood is also used for inlaying.

\section{Rhizophoraces.}

Rhizophora mangle. Woto or Atrati (Ewe).

Rhizophora mucronata.

Little is yet known of the mangroves of Togo. The Rhizophora mucronata of East Africa has a reddish brown wood, hard and heavy, but easily worked; used in building.

\section{Combretacex.}

Combretum sokodense. Ssissiku (Tschandjo).

Flourishes in pasture land and by streams. The bark is 


\section{WEST AFRICAN FORESTS AND FORESTRY}

cork-like and deeply corrugated, the wood brownish and very hard. Height, $35 \mathrm{ft}$.

Combretum Kerstingii. Alembole (Tschandjo).

Hard, greyish-brown wood, used for firewood.

Terminalia dictyoneura. Ssua (Tschandjo).

Terminalia macroptera. Ssua dau (Tschandjo).

These two Terminalia both have a beautiful glossy brown wood, useful for many purposes. Both are about $48 \frac{3}{4}$ feet in height.

Terminalia Baumannii. Opäti (Atakpame).

A beautiful prairie tree, the wood not yet tried.

Terminalia superba.

Terminalia Togoensis.

Pteleopsis Kerstingii. Ssissinā (Tschandjo).

A fair-sized tree in the Bassari savannah. The natives say it has neither flowers nor fruit, but this naturally cannot be the case.

Anogeissus leiocarpus. Tsetse or Echéché (Ewe); Kodelia (Tschandjo) ; Anyi (Anago) ; Ogo (Akposso) ; Kánnâ (Asante) ; Kakanla (Kratschi) ; Chlehó (Fõ).

A tree $97 \frac{1}{2}$ feet high, growing on the river banks and on the moist savannahs, very widespread. The fruit is much like that of our alder. The wood very hard, proof against attacks of the termites, with a black heartwood like ebony, and used as such. The most valuable wood of the Colony.

\section{Myrtacer.}

Syzygium Guineense. Tschapēa (Tschandjo).

A fair-sized tree on the shore slopes. A white, easily-worked wood. Used by the natives for making tools, images of their gods, chairs, etc. In some parts for building purposes.

\section{Araliacez.}

Cussonia Barteri. Fegblo (Ewe); Kongolu (Tschandjo); Indoabaka (Mangu); Digo (Anago); Obbǒ (Akposso); Bōnugú (Misahöhe) ; Gotti (Fõ).

A characteristic tree of the Baobab savannahs near Misahöhe. The wood is spongy and cannot be worked, but the ashes are of use in making a blue dye.

\section{Umbelliferæ.}

Peucedanum araliaceum, var. fraxinifolium. Ländo (Tschandjo):

A tree under medium height, of the pasture lands. The bark of the young shoots is used for squirts and syringes The wood is easy to cut. 


\section{Sapotacese.}

Butyrospermum Parkii. Yotsa or Yo (Ewe); Ssomũ (Tschandjo); Káde (Hausa); Krangkú (Asante); Kedempo (Atakpame); Aiomiti (Kirikiri).

The Shea butter tree. Height $48 \frac{3}{4}$ to 65 feet. The tree is so plentiful that it is a rare thing not to find one in any district. The fruit is soft and edible; the wood a beautiful brownish-red of even texture, and capable of taking a good polish. Much used in furniture-making.

Pachystela cinera.

An immense tree growing along the coast. Wood unknown in the market.

Chrysophyllum obovatum. Katumbulia (Tschandjo).

A tree of medium height with edible fruit. Its wood not known in commerce. It should be of use, as are most of those belonging to this family.

Malacantha Warneckeana. Akara (Atakpame); Pusum (Lamatessi).

A large tree found among the mountain streams, and also in the plains of the coast regions. The trunk has on the outside wavy cross-lines that look like a border, and give it a very curious appearance. The hard wood is made into shuttles, shovels, scoops, etc., by the natives.

Mimusops multinervis. Ewelisomū (Tschandjo); Bräkrankū (Asante); Gjira (Kratschi); Ewäti (Anecho).

Mimusops Kerstingii. Ewelisomu (Tschandjo).

The wood of both these two Mimusops is like that of the Butyspermum in colour and structure. Rarely found higher than $32 \frac{1}{2}$ feet.

Mimusops lacera. Wueti (Ewe).

The tallest and most beautiful tree in the immediate neighbourhood of the sea. Its hard red wood is made into walking-sticks, also for inlaying and veneering of furniture and parquets,

\section{Ebenacez.}

Diospyros mespiliformis. Dongke or Jeti (Ewe) ; Tingalō (Tschandjo).

A semi-cultivated tree growing to the height of $81+$ feet. The trunk is often from $3 \frac{1}{4}$ to $4 \frac{1}{16}$ feet in diameter. A widely spreading shady tree. Its height in the prairies is much less. Found very abundantly and takes a high place as in copses and park lands. The fruit is edible, round, and of a bright red colour. The heartwood is hard and durable, and black as ebony. The tree is of great value commercially for many purposes as ebony. 


\section{WEST AFRICAN FORESTS AND FORESTRY}

Diospyros mombuttensis. Liä-nuwasaure (Tschandjo); Etjannaka (Akposso).

A tree growing only from small to moderate size on the hill slopes, with a bright-red fruit-a thorn-bearing tree. The wood is durable and hard, used for shovels, walking-sticks, rafters, etc., and the flexible branches in the making of traps.

Diospyros tricolor.

One of the most frequent trees on the shore and prairies of the coast region, growing only to the height of a man. It has a yellowish-red three-sided fruit; the stem seldom attains more than the thickness of the finger. It is used for walkingsticks. A hard white wood.

Maba .Warneckii.

A fair-sized noticeable tree, rarely found, and little known.

\section{Oleacea.}

Linociera nilotica.

A small, unimportant tree. The wood is light brown, of even texture, and great durability.

\section{Loganiacez.}

Strychnos Buettneri. Kongofura (Tschandjo).

Strychnos laxa. Wagbebě (Ewe); Naprámpŏgo (Dyakossi); Egbo (Atakpame) ; Gõngóvi (Kpedyi) ; Yokharaúgu (Dagomba).

Both these trees have a strong stem of bright-coloured wood, with a fine grain, and should be of value. The fruit of the Buettneri is edible, something like an orange.

Strychnos pubescens. Kongó (Tschandjo).

The natives only use it as firewood.

Anothocleista Kerstingii. Kuwondëü (Tschandjo); Egu (Atakpame).

Height $97 \frac{1}{2}$ feet, growing in the terraced or gallery woods, and also in small groves. The trunk is very straight at first, then widely branched. The trunk of the young trees is marked with leaf-scars; the leaves attain the length of $4 \frac{7}{8}$ feet, and are used by the natives as quivers for their arrows. The white, easily-worked wood is used for many purposes.

\section{Apocynacea.}

Holarrhena Wulfenbergii.

A tall tree of the Agome Mountains and the coast forests of Sokodé-Bassari, also found singly near villages and farms. The white wood is fairly heavy and easily worked, used in carving figures, etc.

Conopharyngia crassa.

A tree of varying height, with drooping branches. Found only in Misahöhe. 
Voacanga Africana. Kongkong (Tschandjo).

A fair-sized, widely-spread tree in copses and by the streams. The wood is like that of the Holarrhena, only of a deeper shade. The round white-coloured fruit, growing two together, look like spots on the dark foliage.

Kickxia Africana (syn. Funtumia elastica).

Reaches the height of 65 feet. Growing in Misahöhe and Kete-Kratschi. The wood is little known. All the trees of this family are distinguished by a rich milky juice in bark, leaves, and fruit.

Alstonia congensis.

\section{Borraginacex.}

Cordia Gharaf.

A fair-sized tree known only in one locality. A hard, durable wood used in building. There is no doubt that there are other species in Togo, and so far as the Cordia has been used, it has proved to be a most useful tree.

Ehretia cymosa. Okoni (Kratschi).

Found in the coast regions, growing to the height of 13 to $16 \frac{1}{4}$ feet. Seldom met with. It has masses of white blossoms ; the fruit is a berry about the size of a pea. The wood has not yet been proved.

\section{Verbenacex.}

Vitex Cienkowskii. Fõ (Ewe) ; Panyero (Tschandjo) ; Orli (Anago) ; Uoli (Akposso); Koto (Dyakossi); Gidjiko (Kratschi) ; Fõjiti (Anecho); Narenga (Dagomba).

A large barkless tree, with spreading crown. Leaf with five divisions in the form of a.hand, the flowers in large clusters of white blossoms. Ink is made from the shiny black, edible fruit and the young leaves. This tree is widely spread over the hill slopes and forest prairies. The wood is moderately hard and useful for inlaying; the natives make ribs of boats from it.

Vitex Camporum. Panyerōbuda (Tschandjo) ; Insuakoto (Mangu); Idjawli (Akposso).

Leaves with three divisions, the underside hairy. Flowers blue, in clusters like the last. The fruit is more like an acorn, and the tree shrub-like. The natives make fishing-tackle from the wood.

Vitex cuneata.

Premna Zenkeri.

A tall tree growing on the mountain slopes of Bassari. 


\section{WEST AFRICAN FORESTS AND FORESTRY}

Leaves simple and broad; the small, white flowers are in panicles a foot long. The wood is entirely like the $V$. Cienkowskii.

Avicennia Africana. Amu-ati (Ewe).

A broad-spreading leafy tree from 39 to $48 \frac{3}{4}$ feet in height, and about 7 inches in diameter; leaves dark green, the underside grey, and tlowers a smudgy white. Its wood is used for boat-building in Gabun, but little known elsewhere. It is closely allied to the Avicennia officinalis of East Africa, which has a beautiful, violet-coloured wood; is very hard and heavy.

\section{Bignoniacex.}

Spathodea campanulata. Adadasé (Ewe); Gbetschigbetschi (Atakpame).

A wonderful leafy tree, $97 \frac{1}{2}$ feet in height, with widespreading crown of foliage, and greyish-green warty trunk. In the flowering time the tree is a mass of crimson flowersa beautiful sight in the coast woods and on the hill slopes. In Europe it goes by the name of tulip-tree. The buds are filled with a sweet, watery fluid, which the children use as squirts. The wood should be of great service, but does not seem to be used.

Newbouldia lavis. Lifui (Ewe); Akinale (Tschandjo); Aboboë (Atakpame).

A medium-sized prairie tree, found plentifully also near the villages, where the small branches are used as material for fences. When the tree is young, it stands very erect, but later the remarkably long branches bend to the ground. The flowers are either rose-coloured, violet, or bright blue. The brightcoloured wood is fairly heavy, uniform in texture, very similar to the V. Cienkowskii.

Markhamia tomentosa. Tschitschine (Atakpame).

Appears to grow only among the mountains. The flowers are yellow, with red stripes; the leaves and husks both yellowish brown. Children use the flower buds as playthings. The wood is like that of the Newbouldia lavis.

Markhamia lutea.

Usually found as a shrub, but occasionally to the height of $19 \frac{1}{2}$ to 26 feet high, with rough or warty, blackish bark, and yellow flowers in great quantities.

Stereospermum Kunthianum. Essobelīa (Tschandjo); Eké-deká (Atakpame).

A small tree seldom found taller than $32 \frac{1}{2}$ feet, a greenishgrey bark, divested of leaves. When in bloom it has much the 
appearance of a peach-tree. The flowers, which appear before the leaves, are pink, edged with white and reddish-brown, with striped and spotted lip. Found frequently in the forest savannahs, and occasionally on the highlands. The brownish dye from the bark is used by the girls for their lips, and chewed as Kola. The wood is much the same as the last three species.

Kigelia Africana. Nyakpekpe (Ewe); Abilū (Tschandjo); Njãkpokpo (Anecho); Njãkpẽ (Anlo).

Found in damp places in the prairies and on the banks of rivers. The well-known liver-sausage tree. The wood is suitable for small buildings.

Kigelia pinnata.

\section{Rubiaceæe.}

Hymenodictyon Kurria.

All belonging to this family have simple leaves in pairs. Found as a shrub and a small tree in the terraced woods and mountains. The solid wood, of a clear mahogany colour, is much used in India for agricultural implements, but little known here in Togo.

Crossopteryx Africana. Tyenyeólo or Pasau (Tschandjo).

Crossopteryx Kotschyana.

Found to the height of $32 \frac{1}{2}$ feet in the prairies of the coast zone and a few scattered inland. According to the opinion of an importer, this wood is one of the best of Togo. It is clear brown, very hard and heavy, and of fine texture. The natives make shuttles and tablets for the Koran from it.

Adina microcephala. Barā (Tschandjo).

A tree of $97 \frac{1}{2}$ feet in height, growing on the river banks of Sokodé-Bassaris. The wood takes a very high place as to value, but it has a peculiar odour and an oily feeling to the touch. The fibres from the twigs are made into tooth-brushes.

Mitragyne macrophylla. Yowi or Togba (Atakpame).

A gigantic tree growing on the swampy banks of streams, with an excellent wood used by the natives for making doors, drums and barrels.

Mitragyne inermis. Intyú (Dyakossi); Shero (Dagomba).

Smaller than the last, found on ground which is occasionally under water. Its yellowish-white wood is used for beams and rafters. It forms also a beautiful, easily-worked furniture wood.

Mitragyne Africana. Séssêu (Atakpame).

A small tree which flourishes in swampy places and parts overflowed by the streams. Its blossoms are used as hay. The particularly valuable wood is proof against attacks of the 


\section{WEST AFRICAN FORESTS AND FORESTRY}

termite, very hard, and much used in building. The wood of all the Mitragyne species are valued in Tropical Africa on account of their durability and being proof against weather and easily worked.

Sarcocephalus sambucinus. Alkukobasa (Ewe); Kedjetjelo (Tschandjo); Nyimo (Atakpame).

A small shrubby tree, with long, tendril-like branches, white fragrant flowers, and strawberry-coloured fruit. The wood is used considerably for mosaic work and inlaying.

Gardenia Thunbergia. Fifei (Ewe); Kau kutoku (Tschandjo); Lángaña (Kratschi); Fifäti (Anecho).

A small tree or shrub with rigid branches, fragrant white flowers, and yellow, spindle-shaped fruit, tasting like a crabapple, scattered in small clumps over the prairie. Spoons and similar articles are made from the white, fairly hard wood.

Gardenia ternifolia. Kau këure (Tschandjo); Nassarli or Nabuli (Dyakossi).

Similar to the preceding tree in appearance, etc., but the fruit is cylindrical in form, like a small cucumber.

Gardenia medicinalis. Kau belia or abalia (Tschandjo).

The same characteristics as the last; the fruit is much smaller, round, and furrowed.

Gardenia assimilis.

Gardenia Abeokutā.

These trees are all found in the higher forests as undergrowth, and are very similar in every respect.

Plectronia vanguerioides. Dädäfunde (Atakpame).

Medium-sized tree. Occasionally found as a shrub in the coast and mountain forests. The wood is only useful as firewood.

Pavetta Baconiana. Genferrebiesó (Mangu).

Pavetta crassipes.

Used as firewood.

Morinda citrifolia. Amakê (Ewo); Ketyĕlenga (Tschandjo); Aké (Atakpame); Maticki (Ho).

A tree $32 \frac{1}{2}$ feet in height, with a broad, shady crown, seems to be bearing blossoms or fruit all the year round. The flowers are in the form of little round bunches; the fruit is greenishyellow, spongy, and growing together in large masses-each fruit about the size of a pear. The white wood is not of much value, but the rootwood is sold in the native markets for making yellow dye. Two species of this tree seem to be known in Togo, one found frequently on the coasts, the best known, and another variety in North Togo, less common and with a much smaller fruit. 


\section{Compositze.}

Vernonia Senegalensis. Avenya (Ewe); Tusima or Tingma (Tschandjo).

The only one of the family which attains a height of $19 \frac{1}{2}$ feet, and stem of 6 or 7 inches in diameter. The leaves are a greyish-green ; the flowers, a yellowish-white, appear in great masses. The wood is fairly heavy, light brown in colour, and very easy to work. Of the many varieties from which the twigs and roots are used for brushes, this one is the most valuable. 


\section{APPENDIX I}

\section{LIST OF INTRODUCED SPECIES PLANTED}

1. Terminalia catalpa.

2. Casuarina equisetifolia.

3. Tectona grandis.

4. Swietenia bijuga.

5. Cedrela odorata.

6. Pithecolobium dulcis.

7. Artocarpus incisa.

8. Cassia florida.

9. Bauhinia Krughii.

10. Eucalyptus marginata.

11. Eucalyptus citriodora.

12. Eucalyptus robusta.

13. Cesalpina arborea.

14. Cæsalpina seppan.

15. Cæsalpina rostrata.

16. Cæsalpina coriaria.

17. Cæsalpina regia.

18. Poinciana regia.
19. Poinciana repanophylle.

20. Melia azedarach.

21. Manihot glaziovii.

22. Manihot dichotama.

23. Manihot pyanhyensis.

24. Manihot heterophylla.

25. Aspidosperma quebracho.

26. Phœnix dactylifera.

27. Cola vera.

28. Ficus elastica.

29. Ficus Sclechteri.

30. Albizzia amara.

31. Albizzia stipulata.

32. Acacia Arabica.

33. Cynometra megalophylle.

34. Detarium Senegalense.

35. Parinarium intermedia. 


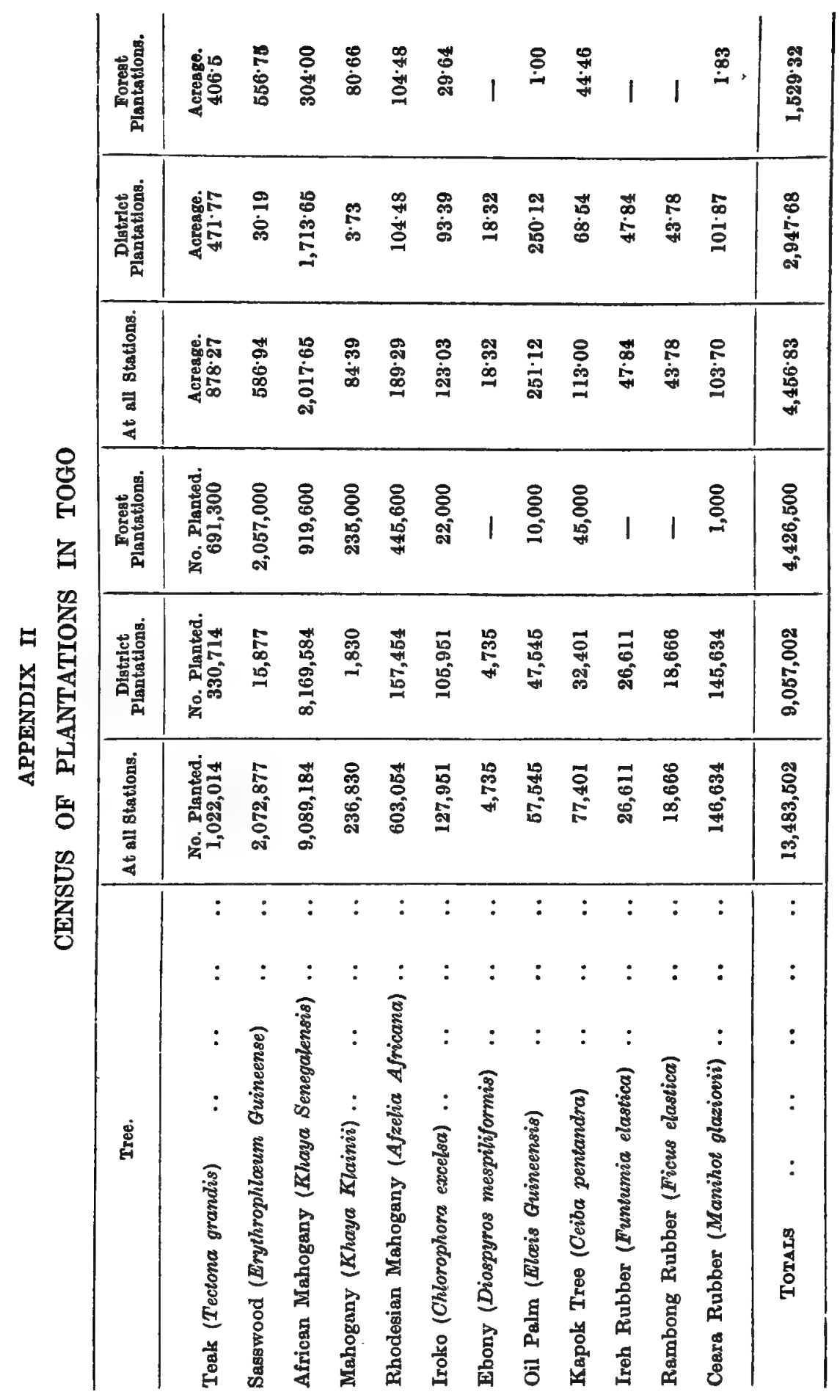




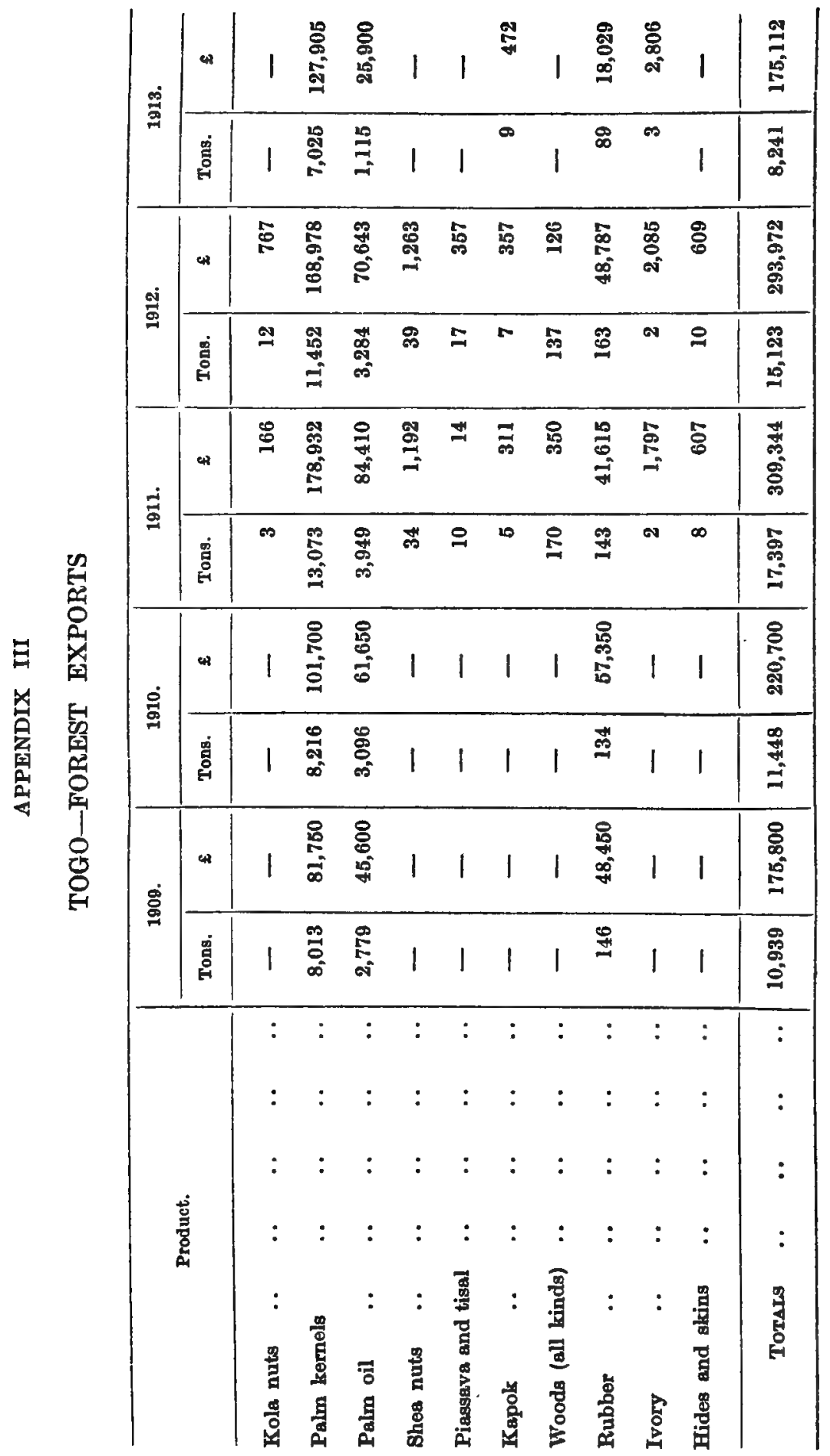



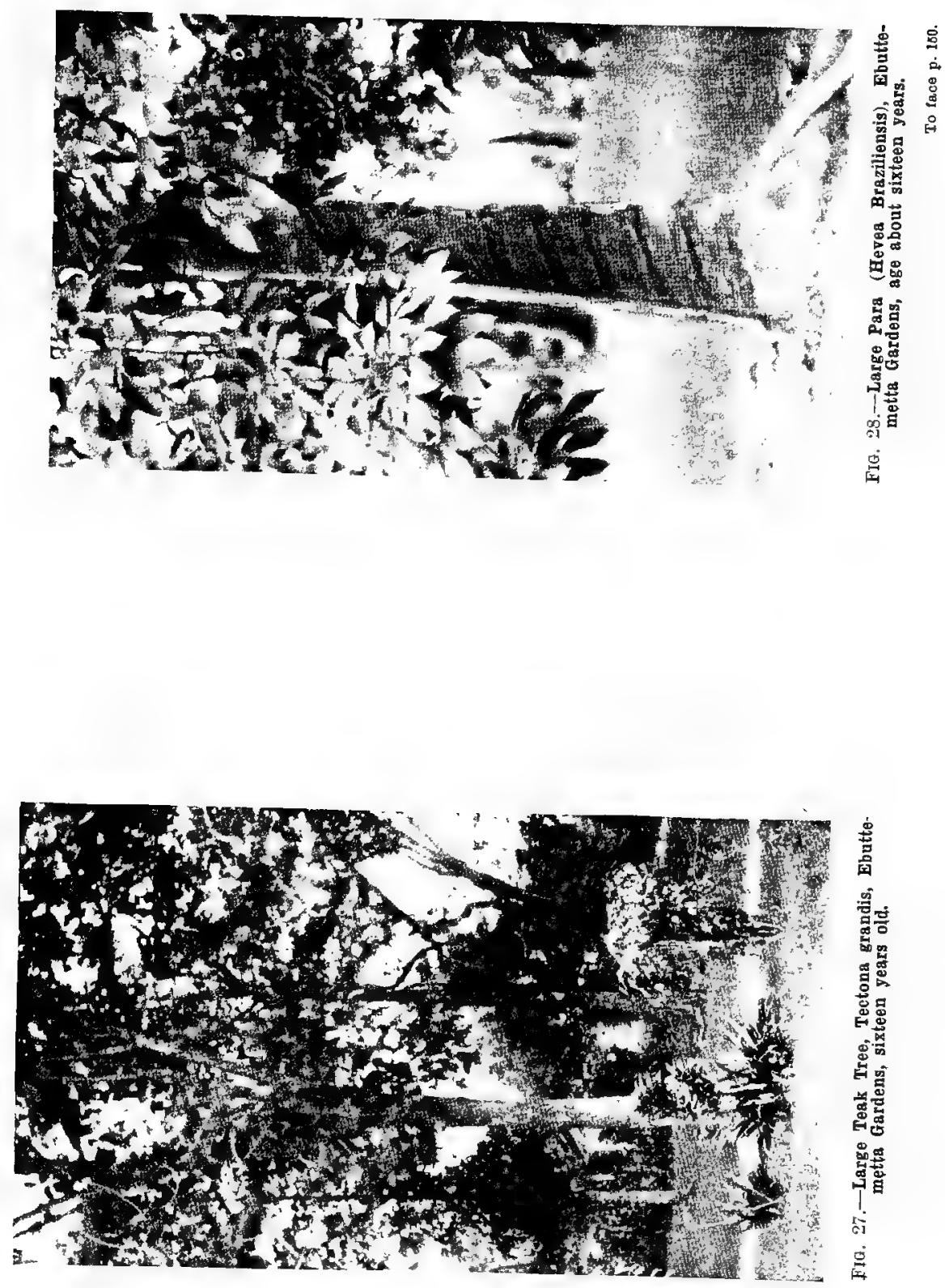



\section{CHAPTER VIII}

\section{NIGERIA}

\section{The Rivers, Ports and Forests of Nigeria.}

Starting from Lagos, the first port of call, the coast is flat, sandy, and low-lying as compared with the typical seaboard of Europe with its cliffs. Long sandy beaches with scattered coconut palms in the background are more prevalent in this part of Nigeria than the watercovered mangrove swamps, showing rather a stunted growth. Westwards from Lagos there are the scattered mangrove formations in the estuary of the Yewa River, near which is the trading station of Badagri. Following the line of the coast, somewhat better mangrove areas are found towards the mouth of the Benin, Escravos and Forcados Rivers. The estuary of the Niger, extending from the last-named river as far as the Sombreiro, shows varied development of the mangrove type of vegetation, as well as the first admixture of other hardwood trees at the edge of the mangrove zone. On the way one passes the Ramos, the Brass, Nun, St. Bartholomew and St. Barbara, each forming outlets for the forests further north. Beyond the Sombreiro the estuaries of the New Calabar, Cawthorne and Bonny Rivers contain further mangrove areas, usually in the form of large islands. Eastwards of the Bonny River the mangrove to some extent gives way to comparatively large areas known as rain forests, owing to the comparatively heavy rainfall in those localities. The Andoni, Opobo, Kwaiebo form the outlets for these forests.

The Cross, Calabar, Kwa and Akwayefe are the most easterly rivers in Nigeria. In the estuary of each, more especially of the Cross River, the finest mangrove forests are to be seen. Next to these in point of height and straightness of bole are the forests on the banks of the St. Barbara and Forcados Rivers.

The Lagos River, with its present bar-draught of 19 feet, is followed eastwards by the port of Forcados, showing 19 feet. As subsidiaries, and northwards from Forcados, are the inland ports of Warri and Koko, both, and especially the latter, being timber-shipping centres. Sapeli, another 40 miles up the Benin River beyond Koko, was and still remains a timber port of some importance, and from it the trade name of one kind of mahogany, namely Sapeli wood, is derived. Brass, considerably further eastward, is practically a seaside port, to which some produce 


\section{WEST AFRICAN FORESTS AND FORESTRY}

of the Niger Delta is brought. Degema, Bugama, Bakana, Okrika and Port Harcourt are inland ports all reached from Bonny, situated at the mouth of the river of the same name. Opobo, on the Imo, is yet another inland port with a 14-foot bar at the river mouth. Eket is the small port for the $\mathrm{K}$ waiebo River, whence small steamers run to Calabar. Oron, on the western side of the estuary, is also a port worthy of mention. Though Calabar is some 15 miles above the junction of the Akwayefe, Kwa and Cross Rivers, it is the chief port of Eastern Nigeria. It is situated on the side of a hill some 200 feet high on the bank of the Calabar River, which is half a mile wide at this point.

Turning now to the next type of forest met with after leaving the mangrove zone, the thick, heavy, evergreen rain forest is seen. On the western side in the province of Abeokuta it has very largely been destroyed, only comparatively small isolated areas remaining. In the Ondo province, however, some of the most extensive and heaviest timber areas of this type are found. A good network of rivers, such as the Ogun, Ona, Oshun, Oni, Shasha and Owenna, when flooded, form the outlets for timber worked in these localities. In the northern part of the Warri province and the southern part of the Benin province large representative areas of the evergreen type are found, though there they tend to mingle with the tall, mixed deciduous forests. To a small extent in the Owerri, but to the largest extent in the Calabar province, the rain forests find their finest development, culminating in the Oban Hills on the eastern side of the latter provinces. The rainfall there is 175 inches per annum.

The Sasswood is one of the first trees to appear when the mangrove swamp gives way to the evergreen forest. Other large trees are the mahoganies, found chiefly on the old banks; red ironwood, with its brilliant red fresh leaves in the late autumn. In fact, these leaves are often taken for flowers, owing to their very bright colour. They gradually, however, assume a dark green colour as the season advances. An unidentified species of gum-copal which grows to colossal dimensions is found scattered rather diffusely and curiously in these areas. Different kinds of ebony, with wood varying from brown to green black, are seen throughout the zone, though, as with other trees, a different species is found in the different provinces; on the whole, the blackest wood is found where the rainfall is heaviest.

The mixed deciduous zone, which consists both of deciduous and evergreen trees, mingles and gradually develops at the northern edge of the evergreen rain forest ; in many cases the one goes over into the other almost imperceptibly, and it is only perhaps after half a day's march that one realizes that one has left the evergreen type behind and reached the forests where half the trees lose their leaves every year. A very large development of these forests is found in the Abeokuta, Oyo, Jebu-ode and Ondo provinces. Very heavy inroads have 
been made in these forests, and it remains to be seen whether sufficient will be preserved to ensure the future fertility of the soil and the requisite rainfall. One of the most prominent species is the cotton-tree, with its great root buttresses and muscle-like protuberances from the stem. The Obechi, or Arere, is another magnificent timber tree, with soft white wood and maple-like leaves, which grows to huge dimensions. The African greenheart, which may grow 12 feet in diameter, is hard enough to break the blade of an axe. The Iroko, taking the place of oak in African economy, is another tree frequently met with, and it extends its area of distribution as the forests are opened up with clearings. East of the Niger this formation is only found to a small extent in the Onitsha province; a little larger in the northern part of the Owerri province, and still largest in the northern part of the Calabar and the southern part of the Ogoja province. In fact, the finest development of the mixed deciduous forests is found in the lastnamed province, just north of the Cross River, where it is really at the edge of the true deciduous forest. In this zone some three kinds of mahogany are found, in some places very diffusely scattered, in others up to a thousand mature trees in eight square miles, or in a third nearly every tree a mahogany on both sides of the road for over half a mile. The four species in this zone vary less from province to province than they do in the case of the evergreen forest zone, though the total number may be greater.

Beginning again on the western side, the open deciduous forest or dry-zone formation shows itself over a very wide extent in Oyo, Northern Jebu-ode, and in the Northern Benin provinces. East of the Niger it is of wide extent in the Northern Onitsha and Northern Ogoja provinces, but it also occurs in the northern part of the Owerri province as an artificial product of man's destruction of the original forest. In some places this formation, owing to the trees being close together, more nearly approaches the deciduous forest. In others, owing to the poor and stunted nature of the arboreal growth, it more nearly approaches the open grass savannah formation. Only north of the Oyo province near Shaki, or north of Ogoja in that province, could it be said that this kind of formation is seen.

One of the most prominent kinds of trees found is the Shea Butter, the nut of which is used in the making of chocolate cream and margarine. This tree, varying in size from a large oak to a short, stunted, gnarled and burnt relic of better forest conditions, is found over very wide areas in the Oyo and northern part of the Abeokuta province. Strangely enough, this tree does not appear in the northern part of the Benin or Onitsha province, and only occurs again in the north-eastern corner of the Ogoja province. The locust-trees, with their open crown and feathery leaves and long pods similar to French beans, are conspicuous all through the zone, and near the villages are specially preserved. 


\section{WEST AFRICAN FORESTS AND FORESTRY}

Mahogany is represented in this zone as another species which does not attain a greater girth than 10 feet and which is often gnarled and crooked owing to the annual grass fires. A medium sized Cedrela, or hard cigar-box wood, is found in isolated patches in the northern part of the Abeokuta and southern part of the Oyo province. The balsam-copaiba-tree is also very common in this zone in the North Benin, Onitsha and Ogoja provinces.

The forests of this zone are perhaps the least valuable from the financial point of view, chiefly owing to their geographical position and defective means of transport, but economically they are of great value to the agricultural community, both for their forest produce as well as their soil-preserving and rainfall-conserving properties. The chief timber areas are situated in the heavy rain forest and mixed deciduous forest areas, though a few have recently been taken up in the mangrove swamps.

As a minor, though important, development to the main forests are the evergreen hill forests, which find wide development in the northern part of the Jebu-ode, Ondo, Benin, Ogoja and Calabar provinces. On the whole, the species do not vary so much as might be expected, and in many cases it simply means a further distribution of certain evergreen trees beyond their zone of natural development, owing to suitable climatic conditions in these hills. For instance, the red ironwood appears next the mangrove swamp on the bank of the St. Barbara River, again in the evergreen forests near Calabar, and reappears in the hill forests of Oban, much further north. Probably the most typical trees of the hill forests are an unidentified species of gum-copal, as well as several species of Guttiferæ.

The fringing forests are found chiefly on the banks of the rivers in an area which is otherwise covered with the open deciduous or dryzone formation. Two leguminous trees are most typical of this zone. Stray deciduous or evergreen trees from the other zones are also seen. Such forest is thick with a fair amount of undergrowth, and the trees form a close canopy. The fringes vary from a few yards to half a mile in width.

A further subsidiary form is found on the summits of the highest mountains, such as the Boji Hills, with their stunted satinwood trees, shrubs and grass. In some places there is yet another minor formation, that of the freshwater swamps. Some typical examples of these are found on the banks of the Calabar, Osse and Owenna Rivers. In most cases only one, or any how only a few species of trees are found, whereas in the major formations several hundred different species appear. The growth in these swamp formations, both mangrove and freshwater, is on the whole not so large as that of the evergreen forest. Again, the evergreen forest does not show such fine development or such height of tree as the mixed deciduous forests, though occasionally the greatest girth of bole is found in the evergreen forests. 


\section{The Mahogany and Trmber Industries.}

According to Nigerian law, timber includes planks sawn for logs and trees hollowed out or shaped for any purpose whatever. The timber-working industry, then, is a wide one, covering really three distinct fields of activity, though one or more may be combined. First, there is the felling of mahogany chiefly, and other furniture-wood trees for export. In the second place, the native, and to a slight extent the European firms, cut timber for local use, mainly in the forest, such as planks, canoes and posts. Thirdly, there is the Government, which under the auspices of the Forestry Department chiefly, and to some extent under the Public Works Department, cuts timber of various kinds, chiefly Iroko, for railway buildings and road bridges.

Turning now first of all to the export industry, which is most important at the present time, though the local demand for timber will soon dwarf that of the former, there is a definite sequence of action necessary in embarking on this form of economic development.

As soon as a firm decides on timber-getting, an application (made out in triplicate) has to be sent in with good maps or plans of the area, which is applied for, to the Conservator of Forests of that circle. It is understood that the area in question has been thoroughly examined by the firm before the application is made. A fee of $\mathfrak{f 3}$ in stamps as well as a banker's guarantee of $\mathfrak{f 4 0 0}$ for each area of 100 square miles is also necessary before the application can be considered. The species of tree to be cut should also be stated, as well as the names of the villages and chiefs occupying or living in or adjacent to the area. Owing to the time taken in making the fullest inquiries into the occupancy and other rights, as well as ascertaining the financial standing of the firm in question, it is usually several months before the applicant hears that the area has been granted.

Before this the applicant should also forward a confidential statement, stating exactly what capital there is available to develop the timber areas. An additional banker's reference to the Crown Agents will save unnecessary delay in the granting of the area.

Before the notification of the grant of the area, the licence is made out in the Conservator's office, for which a $£ 5$ stamp as well as three good maps are necessary. Roughly, an additional $£ 210 \mathrm{~s}$. is required to satisfy the legal fees upon registration, which follows immediately after the execution of the licence by the licensee of the grantees. It should be especially noted that anyone acting on behalf of a firm should be in the possession of a registered power of attorney, enabling him to act in the fullest possible way for the applicant or company acquiring land rights. This power of attorney should be registered beforehand, otherwise another delay will ensue whilst this is being done.

As soon as the area is granted, the applicant should mark all bound- 


\section{WEST AFRICAN FORESTS AND FORESTRY}

aries with the necessary marks, which also appear in the licence. Within six months after the granting of the area, work has to be begun. The first proceeding is to send in a list of trees, numbered serially from one upwards, stating the species, size (girth at 10 feet above ground), where situated, name of nearest village and chief occupying land in the vicinity, together with the amount of fees and royalties payable on the trees. The trees have been marked and numbered previous to the duplicate lists being sent in. It is usual to pay a cheque or bill for the fees and cash for the royalties, then one of the two lists sent in is returned to the sender marked "Permission granted." Felling can now begin. On the whole, the general practice is to cut the trees down in the earlier months of the year and have nearly all completed by March or April. Logging, with a cross-cut saw or axe, and squaring with an axe and adze, follows as soon as the trees are felled, and, as it takes longer, continues afterwards right into May or June. Hauling begins as soon as sufficient logs are ready to be drawn and the hauling roads have been cleared. Usually different gangs haul to those employed on the tree-felling and squaring. Eighty or a hundred boys are lined up and haul on two ropes attached to the end of the log. The $\log$, having been shaped at the end to allow easy hauling over the rollers or ground, is "snaked" along to the nearest waterside, river bank or creek. Here two timber-dogs are driven in the end for attaching the cane or rope to hold several together. In the smaller streams or creeks, single logs, or two joined together, float down to another station, where a bigger raft of 40 to 100 logs is made up. In a good many rivers the rise of the water takes place in July, and it is then that the largest number of logs float out. Another lesser rise for the most part, except in the largest, such as the Cross or Niger Rivers, occurs in October, when all logs possible are got out for that season.

Logs left by this last flood usually have to stay until the following year, when the river will rise again. Sometimes as many as three seasons elapse before it is possible to get out some logs. The higher reaches of the Owenna have an unenviable reputation in this respect. Several short rainy seasons following each other successively cause the same result. The Ijors are the chief "waterboys," who contract to take logs down the creeks at 5s., 10s. or 15s. a log, according to distance and nature of the creek. The Ossiomo has also a bad name, owing to its swift current and the liability of losing the logs.

Most labour is engaged direct, though handed over to a contractor who is paid $1 \frac{1}{2} \mathrm{~d}$. to $1 \frac{3}{4} \mathrm{~d}$. per foot of timber squared or logged brought to the nearest waterside. The labour, however, is paid by the European firm, which is entirely responsible for the payment.

The shipment of the logs is made at Koko, Warri or Forcados from Lagos and at Lagos itself, the first-named port taking the majority. Many firms have a branch store and office at this port, or another firm 
ships logs for others not represented at a fixed charge per log. Export entries showing numbers of logs, size and value are presented to the Customs Department before shipment. Koko, which used to be quite free from the Teredo borer, is now unsafe for logs after a fortnight's floating in the water there.

The shipping companies do not particularly desire logs as freight, owing to their weight and unwieldiness in handling. Space is left between them to some extent in the hold. The hatches have to be especially long to take the biggest logs. From Lagos, Forcados, Calabar, etc., a freight rate varying from $35 \mathrm{~s} ., 40 \mathrm{~s}$., to $45 \mathrm{~s} .{ }^{1}$ per ton for 24, 3 and over 5-ton logs. Kolko, on the other hand, is only 25s., with 10s. extra for primage. This is the same with the other freight rates.

During the voyage the logs gradually dry, and often by the time they are put into the timber yard of the brokers they are split or cracked. Only the best logs, 30 feet long and quite sound at the start, stand all the rough handling they get. Auction sales take place about once a fortnight in the busy season, though sales by private treaty take place occasionally. Logs can sometimes be sold ex quay too, though by far the most of the wood is sold by public auction. The inclusive charge of landing, stacking and selling at the dock is roughly 10 per cent. of the value of the log. In fact, it is quite a considerable item of expense, and often makes the difference between profit and loss on the smaller and lower-grade logs. All logs are sold by the superficial foot, i.e. one foot square, one inch thick "sale measure." Sale measure obtains only in the mahogany trade for square logs, and is roughly 20 per cent. less than the actual cubical contents of the log. Round logs are measured and sold by extreme (full) measure. A wane of six inches or less is left on the squared logs, because it makes them less liable to crack and split at the corners, and also it saves a good deal of timber which would otherwise be wasted.

Liverpool is the best mahogany market, though fair prices are obtainable for good logs in London. Hamburg used to be the market for Gaboon wood, and on the whole new woods were better received than in the English market. As a rule, figured mahogany always commands a good price, whereas plain wood, with the exception of roey or counter-top timber, only fetches a moderate or low price, unless the market is understocked at the time. The best wood is obtained from the Ivory Coast, and the next best is Benin or Lagos wood. Sapeli wood is very heavy, and found a market chiefly in Germany. Cross River wood has yet to be shipped and proved, though samples there looked very good and even showed some figure. So far, only the leased areas have been spoken of. Now we return to the Reserves, where, however, permits to cut trees can only be obtained. Here leases are usually not granted. The rules with regard to replanting do not apply

1 Pre-war rates. 
in the same way, as all planting is in the hands of the Department. On the whole, stricter supervision may be exercised in the Reserves than on leased areas. Although a firm has no lease, the security of tenure for cutting the trees would be at least as good as under a lease. No other firm would be in the same position to fell and extract timber as the first one to whom permission was granted. The Government would not allow any other amounts of trees to be felled that would injure the working of the forest by the first applicant.

Local felling is conducted by one or two firms in their areas, which were in the first instance obtained for export timber. For the most part, however, the natives or native foreigners fell various kinds of trees such as Iroko, Chlorophora excelsa, Owussu, Sarcocephalus esculentus, Ume, Pterocarpus soyauxii and Pterocarpus Osun, Edat, Saccoglottis Gabunensis. Nearly half the permits issued are for Iroko, the main building timber of the Yoruba and Benin and Ibo countries. The Camwoods or Barwoods are felled next to obtain the brilliant red heartwood, chiefly from the roots, but also from the stem. A dyewood which produces a fast colour is obtained by rubbing a small pointed section on a flattish piece of the same wood. A yellow dyewood is obtained from Anyeran Afrormosia laxiflora.

The canoe-making industry absorbs a large number of trees. The native, chiefly Ijor, chooses the tree with great care as to straightness of stem and length of bole. It is felled near a river bank or otherwise reasonably accessible place. First of all two sides are flattened parallel to each other; at the same time the length of the canoe is chosen and the tree bole cut off at the required length. A narrow groove about half the depth of the diameter of the log is now made with small axes and an adzelike instrument. The log is then shaped externally like a canoe, especially both bow and stern. Next, more wood is cut away on the inside and some pieces of wood stuck across to keep the canoe open. A shelter is put over it during a hot day. As soon as the requisite amount has been cut out, dry palm branches are placed all round the canoe outside on the ground; longer cross pieces are fixed over the canoe of the required length for thwarts when the canoe is finished. Long stakes are driven into the ground opposite each of these on each side of the canoe, so that the natives can obtain a strong leverage over the canoe. Fire is now put to the palms, beginning with the bow of the canoe. The heat makes the wood expand and thus opens the canoe; at the same time the natives pull down the stakes at the side of the canoe and press the cross pieces into their places. This extends gradually the whole length of the canoe in the course of the day, which is the most strenuous of all, as upon the energy and care exercised on this day in making the canoe open out evenly in its entire length and the same amount each side depends its future success in the water. It may turn out lopsided. or, as is often 
the case, a hole may appear in the middle of the stern end, owing to the centre of the tree having been rather old and rotten. This can be covered over, and is often above the waterline.

Canoes vary in size from the Oguta canoe, in which the paddler has to keep one foot in the water to balance the canoe, to the twelvepuncheon canoe of the big traders. This last will have a great hollow dug out fully 6 feet deep at the stern end and over 60 feet long.

The sawyers cut the tree all round, fell it, and then cut it into 12-feet length logs, as far as the bole allows. The huge branches are left untouched. A large pit is dug quite close to the logs, and one by one they are placed over and sawn, first two sides and then into three large planks; finally these are cut into 12 -inch planks one inch thick. Most of the work is done within four miles of the railway line or within twenty miles of a large town, such as Jebu-ode, Ife, Ibadan, Abeokuta. Truck loads of this timber may be seen at Ilugun or Ogunshileh, on the Nigerian Railway.

Permits are also issued for the making of smaller articles, such as verandah posts, culled out of a guttiferous tree; sleepers, sawn from Iroko (Chlorophora excelsa); sword-sheaths, made from Ogohen (Musanga Smithii); mortars, cut from Apa (Afzelia Africana); pestles, fashioned out of Eba (Lophira procera).

The dyewood industry in itself is chiefly developed on the banks of the Cross River. The trees are felled in the Oban forests, allowed to lie a year or two, then cut up into long 3- to 4-inch irregular-shaped scantling or poles. These are sold chiefly in the Oban market, after which they are cut into small sections. Women take these up and make lozenge-shaped bricks about a foot long in the greatest length. These are sold at 6 d. each.

Under Government auspices, one of the first enterprises was the sawmill at Etehetem. A very hard redwood, termed Apassa by the Efiks (Mimusops lacera), and also mahogany (Ochrocarpus Africanus) were cut. Owing to the difficulty of expansion and the increasing cost of the logs, the plant is to be moved elsewhere. The railway had a small plant at Han, where timber and sleepers were cut for the Baro Kano line. At Ebuttemetta the railway also have a small mill for cutting chiefly Iroko, Apa, and a little redwood.

Of the various firms, Messrs. McIver had a small mill in Lagos, chiefly for sawing up mahogany logs not worth shipping to England. Later, in 1909, Messrs. Miller Brothers built a mill at Koko town; Agba (Copaifera sp. ?) as well as mahogany logs have been cut; Ebbe and Obiache, and Obechi (Triplochiton Nigericum), the last-named being a good whitewood.

The Anglo-French Company have started a plant near Oron Eastern Circle to cut sleepers out of mangrove wood, Lagenaria and Rhizophora. 
Lastly, the Government have started a new mill at Apapa, near Lagos, for cutting logs obtained near Akilla, on the Oni River, in the Abeokuta province, and the planing, grooving and recutting is done in connection with the Public Works yards and furniture-making establishment in Lagos.

The Akilla work is run entirely by the Forestry Department. Trees are felled, cut into logs and brought to the waterside; then, rafted with others, floated in kerosine tins on lighter wood to Apapa. A regular rate is charged per cubic foot. Work was started in August 1914, and already several thousand logs have been delivered at Apapa.

\section{The Permanent Forests or Forest Rmserves.}

In the main, all Forest Reserves become the permanent forests of a country. So far as Nigeria, for instance, is concerned, certain definite and well-defined portions of the original forests have been set aside, by agreement with the natives, as Forest Reserves. If these areas had not been set aside, they would have been liable to destruction under the form of shifting cultivation which the local people practise. For instance, at Olokemeji there are several thousand acres in the middle of the Reserve which were cleared some years ago and have not jet grown up. This would have been the fate of the rest of the forest if it had not definitely been placed under the care and protection of the Forest Department. The same applies to other areas scattered over the country.

It is somewhat hard to define the meaning of a Reserve. Essentially it is an area permanently set aside for the production of timber or other forest produce. In many cases, however, the trees or the forests have to be preserved in the interests of the climatic conditions of the locality. If it is found that by cutting down a forest the rainfall decreases every year, the springs dry up, and the land becomes covered with grass, where actual grass fires kill all young vegetation and even hinder farming operations, then the forest must be reserved. To take some examples: In the colony of Sierra Leone there is a Peninsular Mountain Forest, a large and valuable Reserve, 80 per cent. of which is covered with red ironwood, Lophira procera. Then in the Protectorate there are the Kambui Hills, Kennema, then Nimmini, and the Loma Mountain Reserve. In the colony and Protectorate of the Gold Coast there is the Dunkwah Reserve. Some of the most improved reserves in the southern province of Nigeria are in the Western Circle. There are Olokemeji, Mamu, Ilaro, Oshun, Owenna and Ondo Reserves. Again, in the Central Circle there are the Okumu, Obagie, Gilli-gilli, the Uhi, and the Ogba Forests.

In the Eastern Circle there are the Oban, Ikrigon and Ajasso Reserves, in all aggregating about 2,000 square miles.

Contrary to the usual idea, we have seen that a Forest Reserve is 
in reality only a permanent forest, which is primarily maintained for the definite production of some forest or other product. It cannot be too much emphasized that it is definitely set aside to be used wisely; and for all the trees taken, suitable replanting operations are undertaken by the Forest Department. The name "Reserve" is in fact rather a misnomer. In the early stages of a forest administration it is convenient to talk about Forest Reserves as distinct from the rest of the country, which is usually covered with forest and termed " unreserved" forest. It may, later on, become agricultural land; it may also be reserved, in which case it becomes a Forest Reserve or one of the permanent forests of the country. The main point to be observed with a Reserve is that it is primarily for use, and not that the timber is to be reserved and not to be utilized by the general public. Even in those cases where the local demands of the people are great and have to be satisfied first, before any outside timber exporter is allowed to work the forest, it is utilized to the greatest extent compatible with its maintaining a yearly permanent output of timber or other forest product. Permanency of output is the watchword, and strict utilization of the increment-bearing capacity of the forest each year. The increment is of course the amount which each tree grows each year. This amount, added together over the whole area, makes up the quantity which may be felled, on the proportional area during the rotation, in any one year. Thus, to give a concrete example : If an area is 100 square miles in extent, and the rotation is 100 years, then one-hundredth of that area, or one square mile, may be cut over in one year; also, if the sum of the growth amounts to 40 cubic feet per acre per year, this means to say that an annual cut of 25,600 cubic feet can be made each year over one square mile of the area, in the case of a clear felling of all the trees, or spread over an area of 10 square miles in the form of a slight thinning of the trees. In the Temperate Zone, on moderate soil, 40 cubic feet of timber per annum is a good yield, so that in the Tropics we may expect a yield of quite double this amount; therefore it will be seen how readily the forest can grow and how much timber can be obtained permanently from the Permanent Forests or Reserves.

Another great advantage of the Permanent Forest or Forest Reserve, compared with the ordinary leased areas, is the fact that the planting is done by the Forest Department and not by the leaseholder. In an ordinary leased area this planting is a considerable source of expenditure and worry to the leaseholder, and even then satisfactory results are hard to be obtained. He is continually being reminded of his planting duties by the Forest Department, and he is continually striving to keep up the proportionate amount of planting, i.e. 24 trees for every tree felled, and this is by no means easy to attain. Although the annual leaseholder working in a Forest Reserve may be under 
greater supervision and more stringent forest regulations than in the ordinary leased areas, on the whole his prospects of getting out greater quantities of timber more expeditiously and cheaply are much greater than in the ordinary areas.

Particularizing some of the great concrete objects for which reserve is made :

Firstly, the permanent supplies of timber of all kinds, with a view to turning out approximately the same quantity year after year in perpetuity-in fact, if anything, gradually increasing the output year after year. This means to say that, although the forest is cut down, it is replaced at the same rate at which it is cut down. Putting it in another way, there must be as many blocks, or portions. or actual "stands" in the forest as represent the number of years which elapse between the time a tree is planted and the time it is cut down. This period is known to foresters as " the rotation," and in northern temperate countries, for Coniferous trees the time is usually reckoned at about 80 years. In the tropics, with mahogany, Iroko and other timbers, it may be only necessary to allow 60 years, or perhaps on very poor ground 100 years. In the case of teak in Burma, a rotation between 80 and 100 years is perhaps about sufficient to enable merchantable timber to be produced. Putting it in another way, in the forest, in order to have the permanent yield, there must be sufficient trees of each girth class, so that when the largest, say those over 12 feet in girth, are cut down, there must be sufficient of those between 10 and 12 feet, which will grow during a 10-year period (in which they are cut) from 10 feet to 12 feet in girth. At the present time it has been found convenient to classify each class as " under 2 feet, 2 to 4 feet, 4 to 6 feet, 6 to 8 feet, 8 to 10 feet, 10 to 12 feet, and over 12 feet." The object of this is to clear away, or have cut, all those trees over 12 feet in girth. This makes room for younger, quicker-growing timber. Although, under the Nigerian Forest Law, the girth of mahogany has been reduced to 11 feet, and in some districts to 10 feet, eventually, as the older and more unremunerative slower-growing trees are cut down, it will be possible to reduce the girth still further. To put this question of the permanent yield in yet another way: All the trees from one year old, or from the smallest size to those over 12 feet in girth, represent what we may call the forest capital. Now, the object of the rotation is only to take the interest on this capital ; that is to say, the amount which grows on all the trees over the whole area for one year. It would, however, not do to clip off little pieces from each tree over the whole area, as they would be quite useless as timber. Therefore this amount is calculated out as so many cubic feet per annum, or so many trees above a girth of 12 feet or 11 feet, or whatever the girth limit may be, and this amount, either in cubic feet or in the number of trees, is allowed to be cut down each year. Then we know 


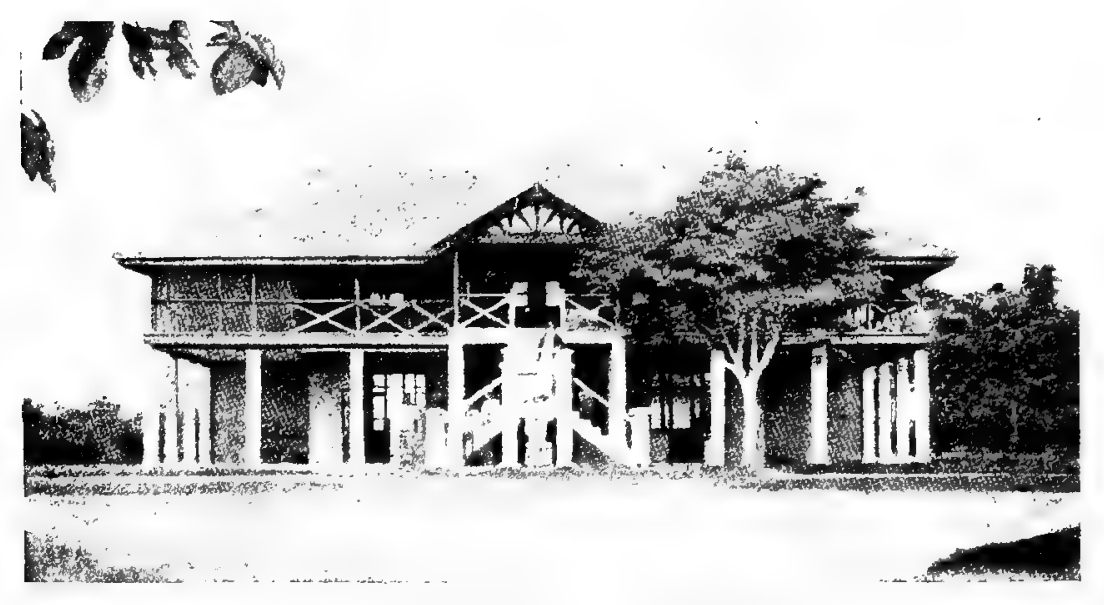

Fjg. 29.-The Chief Conservator of Forests' House, with five-year-old Albizzia Lebbek standing beside it.

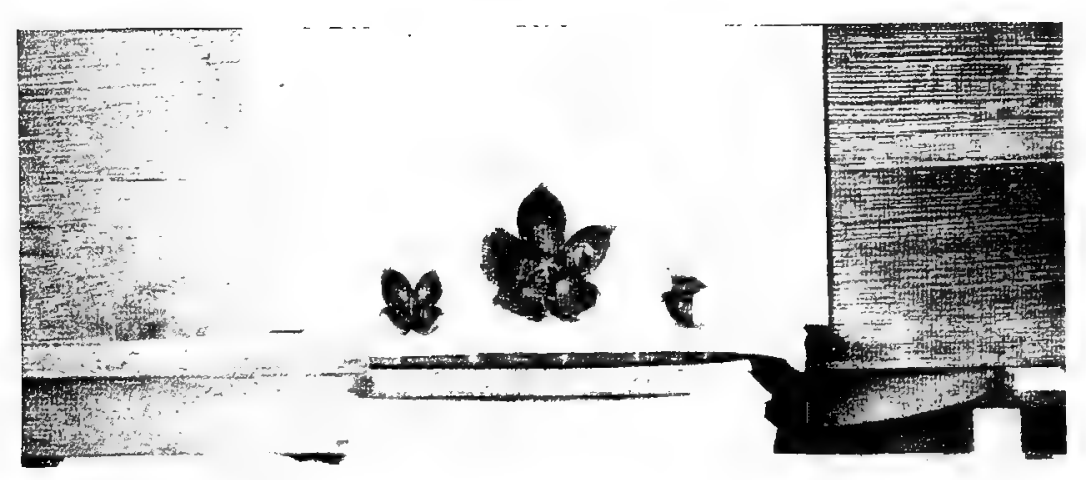

FIG. 30.-Three Capsules of Mahogany (Khaya grandis Ivoriensis and Punchii), from banks of Owena River.

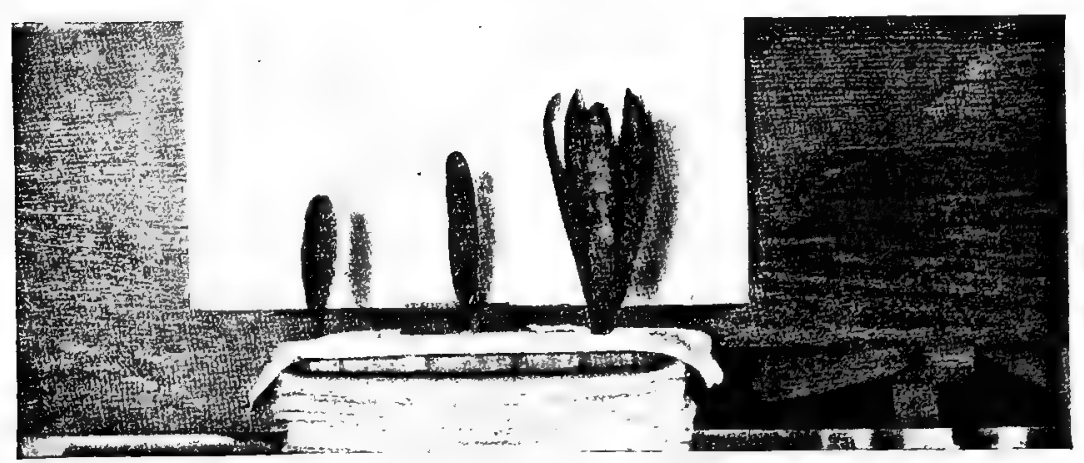

Fra. 31.-Capsules of three Species of Entandrophragma : E. Macrophyllum, the largest; E. ntilis, ' the next in size; and $\mathrm{E}$. cylindricum, the smallest. 

that year after year this amount can be cut down again, and as the soil and other conditions improve and the rate of reproduction is hastened by proper cultural methods in improving the soil, by draining and other methods of amelioration, still larger results may be obtained.

Secondly, the object of these Reserves is to produce firewood, more especially in the neighbourhood of large towns ; in fact, already in several cases, firewood plantations or Reserves have been made, such as those at Ibadan and on the sandy flats near Lagos. In these cases, trees five, seven or ten years old are large enough for that purpose, more especially of the following species, Cassia Siamia, or Albizzia Brownii.

Thirdly, to provide grazing land, more especially in the more northern part of Nigeria, where the object is to divide up the area, so that so many cattle may graze on each area in different years, or for different periods of the year, so as to give the pasture and small trees which may be growing a chance to revive and grow again. By this means the pasture is improved and made of permanent value. It is also possible under this system to undertake permanent improvements in these large pastures by a certain amount of drainage in the lower parts, and fire protection in the upper and higher parts. In this way the cattle obtain a better pasturage and reach maturity all the quicker. In times of bad season, too, some of the closed areas may be opened for pasturage, thus ensuring that the head of cattle may not be allowed to go down owing to death due to drought or lack of pasture. In this way the grazing reserve acts as a kind of insurance against loss of stock in bad seasons of no rainfall.

Fourthly, the production of oil seeds and nuts, such as the Oil Bean, Pentaclethra macrophylla, or the African Wood Oil-nut, Ricinodendron Africanus. It may also be the production of Cola nuts, which thrive in the forests in the shade, or in the partial shade, of other forest trees, and the Cacao Bean, which also, in certain localities, should stand in the partial shade of forest trees, more especially in the dry season.

Fifthly, the production of fibres, such as that from the tree known as Eso, Firmiana Barteri, the bark of which is used for making rope. Then there are the various creepers, such as Kakoba, Entada scandens, which is also used for making rope by the Hausa and Yoruba, more especially fly-switches by the Benin natives. Then there are the canes, such as Egbe, used for roofing amongst the Yorubas and Okakan, Eremospatha sp. (large Benin rattan), and Ikan, Eremospatha macrocarpa (small Benin rattan), also used for making rope, and a kind of string which both the Benin and Jekii natives use for tying lath pieces together in housebuilding and in making coverings for their canoes.

Sixthly, the production of domestic articles, such as sponges, 


\section{WEST AFRICAN FORESTS AND FORESTRY}

Luffa Soudanica, or wrapping-leaves for food, termed Ewayon by the Yorubas, or thatching laths, Ebe by the Benin natives, and the roofing canes termed Itebe by the Yorubas.

Seventhly, the production of medicinal plants, such as those for native Ju-ju ; and some, such as Cassia occidentalis, Cassia fistula, also useful to Europeans.

The main difference between the beautiful, untouched existing forests and a Forest Reserve is chiefly in the matter of management. In the unreserved forests a lease may be granted for five or seven years, and the leaseholder may fell a great number of trees, such as mahogany, Iroko, etc. At the same time there is nothing to hinder the natives or original occupier or user of the land from clearing the greater part of the forest, except the protected trees, and making farms throughout the area ; thus, in fact, gradually hindering, or at least reducing, the possible output of timber from that area. No new seedlings come up in these areas which are farmed, and, in fact, the fires which are made in the course of clearing the land for farming operations kill the young growth of all kinds. In reality, in a Forest Reserve there is more permanency with regard to the output of timber than in the original forest; there is, in fact, absolute permanency. Although no actual lease may be granted for a period of several years in a Forest Reserve, yet, as a matter of fact and usual experience, after a year's working it would be quite unlikely for a Forest Department to stop the timber merchant from working the forest again, or rather from allowing him much the same number of trees as he had in the former year, because not only would the revenue from the forest suffer, but timber experience would have to be gained with another firm, which means a loss of time as well as revenue. Thus, in the ordinary way it is more satisfactory to have the same firm working in that locality year after year, provided they pay an adequate price for all the timber trees which they have. They can then invest the proper amount of capital in plant and hauling appliances, and thus make a greater profit and exploit the forest to better advantage than if a fresh firm came in year after year.

To give a more concrete idea of what these areas mean, we will take it that on the average there are only 50 trees per acre which are of some value or another, either for timber for local use or for export, and taking the average rate of fee at only $4 \mathrm{~s}$. per tree (it should be noted that mahogany and so on are rated at $£ 2168$. per tree), it will be seen that the value of these forests is in all $£ 12,800,000$. This sounds a great deal, but when it is considered what a very large number of trees can now be utilized, either locally, in the form of planks and scantlings, and joists for posts, not to speak of all the various kinds of mahogany, Iroko, walnut, ebony and other substitutes which can be used for export, it will be seen that this value is none too great; in fact, 
to the timber leaseholder they would be worth at least ten times as much. Of course, in this calculation all sizes of trees above a girth of 4 feet are considered, for the sake of making the valuation as complete as possible. Naturally, the smaller girth trees would not immediately be utilized, but when we are totalling up the amount of forest or wood capital involved in the valuation, it is necessary to include them and put a value on them. If the necessity arose, even they could also be utilized and would at least bring in the amount of the lowest valuation per tree.

The Forest Reserves stand also in a special position to the local people, for, after all, these Reserves formed originally part of the forest from which were supplied all the major wants of the native, such as timber, firewood, oil nuts and seeds, fibres, domestic articles and medicinal plants; therefore, whatever the main lines of protection of a good forest, the needs of the people of that locality must have the first consideration. After these wants have been fully supplied, then any surplus in the way of timber or other commercial products can be sold or exported elsewhere. This leads us to consider the fact that a Permanent Forest or Forest Reserve leads to a permanent source of revenue from that particular forest. Owing to the fact that there is the permanent yield of timber established in that area, it means that permanent money is being obtained from those trees and being brought into the Treasury as part of the permanent revenue of the country. If there is any increase, owing to the increased value of the timber trees thus gained-and the more stability there is, the better for the country-better arrangements can be made with regard to the reproduction of the forests. If there is a greater revenue being obtained from the forests, even more money can be justly expended by the Forest Department for the buying of better implements for planting and the Forest Station generally, for the making of permanent improvements in the forests, such as draining, road-making and fire protection. If these forests are not protected and unreserved, then in the course of time they must completely disappear, owing to the fact that man is so constituted that if he sees land, which may or may not be suitable for agriculture, covered with trees, he naturally thinks it would be better to cut these down and see what agricultural crop will grow there, regardless of the fact that there may already exist, or he may have cleared, fifteen times as much land as he requires for farming operations each year.

In addition to all the above, there are the indirect effects of forests, which have been considered in the section dealing with the relation between Agriculture and Forestry. On the whole, it is better for the Central Government or Federal Government to manage the Forest Reserves, as by that means there is greater impartiality in their management and more stability and continuity in the Forest policy adopted 


\section{WEST AFRICAN FORESTS AND FORESTRY}

towards them. In each case, however, it is essential to have either co-opted or elected representatives of the locality, either by the chiefs or by representatives of the people, so that the wishes and needs of the locality may be thoroughly considered.

Lastly, and by no means the least important feature of the Forest Reserve, is the rsthetic view. In the regions of Permanent Forests, healthier localities are afforded for the people, and they are also prettier and more pleasant. This applies not only to temperate-zone forests, but also to tropical forests. It is a well-known fact also that where there are permanent forests the value of the other land in that locality is always rated higher, and is worth more for leasing if adequately covered with a sufficient proportion of forest.

\section{Afforestation in Nigeria.}

The Forest Department, not being content with obtaining a revenue out of the forests from the trees cut down for export or for local use, have spent and are spending several thousands of pounds each year in planting valuable forest trees. Going back historically before the time when the Forest Department had a sub-head in the estimates for "Labour for Plantations" or "Teak Plantations" or "Upkeep and Improvement of Forest Reserves," we had the annual planting of many tens of thousands of mahogany-trees by the timber leaseholder. The whole of this was chiefly done in the Benin district of the Benin province. Although this transplanting of self-sown mahogany-trees into better situations near timber camps, or at the side of falling roads and into the spaces left by the fallen mahogany-trees, was by no means carried out very systematically or under very expert planters, the results are all the more creditable to those who so early started to reproduce the forests. It is most interesting to see in different parts on the banks of the Osse River young thrifty plantations now nearly twenty years old and nearly 30 feet high. In a similar way in the forest there are to be seen large numbers of somewhat smaller sized mahoganies growing singly or in groups, only needing a certain amount of clearing and tending to prevent their being overgrown by other forest trees. Scattered though they are throughout the forest, it is not too much to say that the prospective younger aged forest will be more valuable than that which originally stood in its place.

Easier to find, though in some way less attractive to look at, are the regularly made mahogany plantations of the Forest Department. In addition to isolated specimen trees which are found in the forest Arboretums at Calabar, Degema, Benin City and Olokemeji, several thriving plantations are found near Benin City in the Ogba and Obagie Reserves, in the Ilaro, Mamu and Olokemeji Reserves. In the lastnamed are the most extensive areas of all, and also, despite 
many failures owing to experiments on bad soil and seasons of extreme drought, the growth of the trees gives the greatest promise of mature trees, or at any rate merchantable trees, being grown in a comparatively short period. Plantations have also been made at Awka, Udi, Okwoga and Ida.

Already on the old town site of Ijaiye, mahoganies have been seen over 6 feet in girth which have grown up from self-sown seedlings within a period of about sixty years. The soil in this locality is none too good, and the rainfall on the average certainly does not exceed 50 inches per annum. Near 47 Benin villages small communal plantations of mahogany have been made.

All the mahoganies apparently, especially when grown in "pure" plantations, are attacked by a leading-shoot borer, which so weakens the leading shoot as to make it fall off, and the tree subsequently grows with two leaders. Later on this forms a large fork in the tree, which, when the time comes for felling, is by no means to be despised, forming as it does usually a very good "curl." In other respects it is disadvantageous in reducing the length of the single straight bole. In this manner it has the effect of reducing the number of logs of long length and even shape and large size that can be obtained in one tree. In many cases, a log can be cut above from each limb forming the fork; but of course these are both much smaller than those from the bole, and are usually not nearly so straight, and one or other of the limbs is liable to be broken when the tree is felled. In the original forest only isolated trees are attacked by this leading-shoot borer, whereas in a plantation nearly all the trees suffer by its depredations.

Various species are being tried for admixture with the mahogany in order to hinder the spread of the attacks. At Olokemeji there is a mahogany plantation largely interplanted with two species of Mimusops multinervis and Mimusops Elengi. So far this appears most suitable, as the soil is kept thoroughly covered by the dense shade cast by the Mimusops, and there is a very considerable space between each mahogany-tree. However, the mahogany grows faster than the Mimusops, so that after the first few years it does not have so much effect. Even so, it tends to keep the bole of the mahogany clean and the state of the soil in mechanical and physical condition such as to be most conducive to the growth of mahogany.

A mixture occasionally seen in nature has yet to be copied-that of mahogany and Chewstick (Anogeissus leiocarpus). To some extent it is seen at Olokemeji, where the self-sown seedlings have come up in a mahogany plantation, but of course they were rather too late to effect the result, i.e. protecting the mahogany from the leading-shoot borer. At Ilaro a most typical Mahogany Reserve, an isolated plantation made amongst secondary growth, has more than held its own with little or no tending after the first two years, and yet the trees 


\section{WEST AFRICAN FORESTS AND FORESTRY}

overtop all the surrounding growth. In some cases, both at Olokemeji and Mamu, either self-sown or planted Iroko (Chlorophora excelsa) is found growing amongst the mahogany. Owing to the attacks of the coccus on the Iroko hindering its height growth, it has not had as beneficial an effect as might have been expected. Transplanting self-sown trees from an overshaded locality in the forest, where they usually first appear in a more open locality, has proved on the whole most successful. Again, transplanting self-sown seedlings scarcely one year old from an overshaded locality into one with more light has accelerated the growth of the seedlings, preventing them being killed by the excessive shade, and at much less cost has thus established a small plantation in the Benin forests.

With the collection and planting of the seeds from the teak-trees originally planted about 1889 in the Ebuttemetta garden, a new area opened in the afforestation of Nigeria. Seedlings developed rapidly, and were found to grow at least 10 if not 18 feet in the first year. Although not always keeping up this promise of exceedingly rapid growth, more especially in height, the teak bids fair to become, as in Burma so in Nigeria, the most valuable of all trees. On the whole it has been by far the most extensively planted tree of any in Nigeria, excepting that in the case of mahogany many more have been planted in the Central Circle. Teak plantations are now found as widely apart as on the banks of the Cross River near Ikom, Inkum, Ndeh and Ikrigon amongst the historic stones, and in the Arboretum at Calabar. Near Ndeh, for over a quarter of a mile the river bank is quite enlivened by the large and showy leaves as well as the tall, thin stem of the teak. To a lesser extent, though appearing more picturesque, is the riverside plantation on the opposite bank just below Abragba. In a district with a rainfall of about 60 inches and a deep sand alluvial soil, the teak so far has proved quite at home in the Cross River districts of the Eastern Circle: Even amongst the thickly growing grass at Ikrigon they have survived after coming up from seeds sown at stake, and bid fair to become an established tree of that locality.

Teak has also found a place in the plantation near Mpot and the Oban Reserve. Going over now to the Central Circle, we have Oria, situated near the right bank of the Niger in the Benin province, with its rapidly growing teak plantations. Again choosing a local climate similar to that where teak is found has so far proved it to be a most suitable tree for this locality. Many other trees do not thrive or attain much size near here, so that the teak is all the more valuable for that reason. Near Benin itself, with its heavier rainfall and comparatively approximate to the sea (about 45 miles), it is doubtful if teak will do so well. Even so, growing more slowly, it would prove an additional most valuable tree to those already found growing in the district from which timber has already been obtained. 
Again, in the Western Circle the very largest teak plantations are found: even from the railway carriage window you get an impression of the extent of these just before reaching the Eruwa Road station, and again just after leaving Olokemeji station, between 85 and 90 miles from Lagos respectively. Despite one or two fires, trees at Eruwa Road show quite average growth for the Southern Provinces of Nigeria. In seven years the trees had reached a girth of over 12 inches and a height of over 25 feet. Happily, they were not fruiting so profusely as at Olokemeji. This plantation is all the more interesting in that it was made primarily for the use of the Railway Administration to supply teak timber for sleepers and constructional work.

On closer inspection it will be seen that the Olokemeji plantations nearest the railway comprise six "falls," "stands," or " compartments" of 25 acres each, adjoining each other. Although the trees everywhere have not grown as well as on the better soil, these are far and away the largest plantations of any in Nigeria. Each "stand" is separated from the next by a broad ride and top and bottom by a broad road. Near by these are another two compartments of 25 acres each, though neither of these is entirely filled with teak, as also the first one in the other series. Nearer the bungalows there are the first made plantations of 1908, thriving, yet growing on the poor laterite soil. These stretch away nearly half a mile into the open deciduous forests at the back. What a strange contrast is presented in the dense, close growth of the teak plantation, with its soil covering of decaying and large brown leaves of the teak, compared to the stunted growth of Red Ironwood, small Bauhinia, some Paradaniellas and a few gnarled oak-like Shea Butter Trees! Such teak plantations open up a long vista of future developments in the conversion of the poor dry-zone vegetation into forests of valuable trees, both with and without extensive permanent improvements of the soil and subsoil. Even the large raceme-like clusters of the flowers, almost covering the whole of the teak trees in April and May, are not to be despised for improving the looks of a grassy lawn near a bungalow. A glimpse through the tall Terminalias on both sides of the Ogun, just before the curve is reached at Olokemeji village, reveals yet another teak plantation on the lower slopes of the easternmost of the two hills. Olokemeji means the "man of, or owner of, two hills" (oke means a hill, and meji means two, in Yoruba). Again, still further along in the valley of the stream, near the station, are some other older teak plantations from the years 1910,1911 . Here there is yet a different contrast. The broad, wide masses of the teak plantation are still on one side rather overshadowed towards the hillside by the giants of the mixed deciduous forests, such as the cotton-tree (Eriodendron Orientale) and Sterculia cordifolia and ebony (Diospyros mespiliformis). However, later on the teak, growing on better soil than is found in 
many parts of the Olokemeji Reserve, will no doubt equal it, if not surpass it.

Further to the south, in the Ilaro Reserve, teak has not proved to be so much at home; although growing well the first year or so, the rate of growth since then has been distinctly disappointing. The soil may have been too damp, and the rainfall of the locality may be a little high, and perhaps later on it may be proved that it can be grown on the higher land at a profit.

Further eastward and further northward, in the Mamu Reserve, the teak has grown as well, if not better than up the Cross River. Trees five years old have reached a girth of 24 inches and a height of 35 feet; with its good soil and comparatively high rainfall, probably rather more than 60 inches, Mamu bids fair to be one of the homes of teak in Africa. The older plantations on the river bank, some three miles away from those on the side of the Ibadan-Jebu-ode Road, have done nearly as well as those standing on inferior soil. So far the only damage done to any of the trees anywhere is that caused by a mistletoe-like parasite termed Afoma by the Yorubas, and known botanically as Polystachys odorata. However, only isolated trees having been attacked both at Olokemeji and Mamu, it is not difficult to combat its presence by cutting the trees down and burning the parasite. Still further north, on the bank of the Ogun just above the bridge on the Oyo-Iseyin Road, is yet another teak plantation. This was mainly formed by many of the seedlings in the nursery not being transplanted in time and being allowed to grow up altogether unthinned. Teak, however, forms such very persistent side branches, and has such a tendency to flower and fruit early in its existence, that only helps it to form a clean straight bole and retards the period of flowering by being planted close together. Also, nearly 5 per cent. of all the stems have a tendency to bend over and form stronger side branches than a leader, and have, in fact, rather a more shrub-like habit than that of a tree. Again, quite 1 per cent. grow very slowly right from the beginning and thus sooner or later get suppressed. For these reasons, then, more are required right from the beginning in order to form a full crop of clean-boled timber.

In the Ondo Circle there are some teak at Awshun, where, owing to rather a high rainfall and somewhat low-lying ground, the trees have not grown so very fast after the first year.

In addition to isolated specimens over twelve years old in the Olokemeji Arboretum region, the oldest trees of all are found in the Ebuttemetta gardens near Lagos. These trees are nearly thirty years of age, and show a girth of about 6 feet. By no means growing on good soil, or in a suitable locality either with regard to elevation or the close proximity to the lagoon and the sea, useful for the best growth of teak, they do not at all show the possible limits of growth of this tree. Already 
sample sections have been cut from one or two of these trees and reported on most favourably by the Railway Administration. Similar samples have been sent to the Imperial Institute for exhibition purposes. In a short time the first thinnings of the plantations will take place, and it will be possible to see for what purpose they are most suitable. At any rate, it is a termite-proof wood, and despite the fact that the white ants often attack the growing tree, they usually eat only the outer bark, leaving the tree quite intact and alive:

In all, about 300 acres have been planted with teak, and even at the low valuation of the cost of making them they are worth at least $f 45,000$. In this case a nominal value of only 38 . per cubic foot is assumed. As has proved the case in Burma, probably on the best soils only a period of eighty years will have to elapse before the final filling of the trees is made on the better classes of soil, and one of a hundred on the poorer soils. At approximately regular intervals of every ten years after the first ten or fifteen have elapsed from the date of the making of the plantation, thinnings are made. With each succeeding period the trees cut out are of larger size, and thus of increasing value with each decade. These returns soon more than cover the cost of planting, and assume greater and greater proportion towards the end of the rotation.

Another tree with which a considerable amount of work has been done is the Iroko (Chlorophora excelsa). Here, despite many disappointing results, care and attention show that this tree is capable of reproducing itself in a comparatively short period. Beyond many specimens in the Arboretum at Olokemeji, a whole plantation was made by the Railway between that place and Eruwa Road. Seedlings come up in large numbers from fresh seed sown in a nursery. In fact, sometimes, as at Olokemeji, they have appeared thicker than grass. Subsequently, when transplanted, many thousands died, the roots being apparently unable to quickly adjust themselves to new surroundings and grow again before the leaves have transpired nearly all the moisture from the plant, and thus quite withered and dried it up. However, those which have survived show fair growth, even on poor laterite soil. This soil, of course, is quite unsuited, and certainly one of the poorest mediums in which to plant Iroko.

Natural regeneration or the sowing of seeds at stake seems to be the best method, as we have in nearly all the Reserves large numbers of young Iroko seedlings of all ages and sizes coming up. In that connection one of the most instructive Forest Reserves is that of Ikrigon, where the Iroko (Chlorophora excelsa) is the most prevalent tree. Here, where most of the land has been farmed at one time or another and where the rainfall on the whole is sufficient to induce a good forest growth, the Iroko has tended to increase in numbers all through this part of the country. It may also be said, of course, that 
the natives have directly helped in this process, by leaving some of the less straight and more branched Iroko-trees standing. They have used the best for canoe-making. In this manner seed-bearing trees have been available, and with part of the ground having been cleared for farms, the conditions have been most suitable for the reproduction of the tree. Subsequently the farms have been abandoned and the young trees have grown up amongst the weeds, creepers, and other inferior tree species, such as Albizzia, just according sufficient shade and protection for the young Irokos, and yet not too dense or thick to prevent them from sooner or later emerging and overgrowing the rest of the trees. Although, of course, many trees growing up under these conditions branch somewhat low down, they do not suffer nearly to the same extent, and sometimes not at all, from the attacks of the leaf coccus. This has two effects : not only does it not hinder and retard the sapling's growth, but also all the sooner it reaches the higher zone or greater distance from the ground (as far as its upper foliage is concerned), so that these attacks do not occur. Again, the competition of the various weeds, Albizzias, creepers, etc., has the effect of so stimulating the growth of the young Iroko that in such positions it reaches a much greater height in a quicker time than when planted in pure plantations. From numerous observations it appears that after the first year the height growth may exceed 6 feet in one season. Even later this is kept up, and if the rest of the forest growth remains comparatively thick, no side branches can be formed on the bole of the Iroko, so that clean-stemmed trees are the result. As it gets older the Iroko stands less shade, and thus any small branches which do form are soon killed by the surrounding trees. Thus it is seen how we find these very straight, long-boled Irokos in the forests. Again, too, it is not very expensive, and at least much cheaper, to undertake partial cleaning and pruning amongst the self-sown Irokotrees, especially to eliminate forks low down in the stem. Various experiments undertaken in the Ikrigon, Olokemeji and Mamu Reserves showed how quickly the sapling Irokos respond to this treatment. In some cases, trees only 2 inches in diameter and forked have reached nearly 4 inches in diameter and nearly doubled in height in one year. Another advantageous feature of the Iroko is the rapid, satisfactory, and smooth way in which the occlusion of the wounds made by pruning takes place. Even in the case of a very crooked tree covered with several branches, in fact almost forming a crown, these may be marked but not all cut until the following year. Surfaces of less than 2 inches will be nearly occluded over, and a tendency of the tree towards a crown will be almost obliterated at that point and be forming much higher up the tree.

Apparently, the more northward the tree is found the less liable it is to attack by the leaf coccus. Whilst it is found in the Olokemeji, 
Ilaro and Mamu Reserve, it is less frequent in the Ikrigon Reserve. In the Sokode it was quite unknown. This last-named place is in Togo, and the plantation is situated in a latitude of over $9^{\circ}$ North.

In the Ilaro and to a lesser extent in the Mamu Reserve it has been remarkable how rapidly the Iroko increases in girth when given plenty of space after being freed from the surrounding forest trees. In these trees, when showing a girth of from 4 to 8 feet, the diameter increment is most rapid. In most cases it averages over 6 inches in girth, and in one case at Ilaro it was as much as 11 inches in one year. This rapid growth in girth is all the more valuable as the trees of this size growing in the high forest have usually nearly completed their height growth. Thus the bole is comparatively long and clean, and the extra growth is put on evenly all the way up, tending to make it more cylindrical than before.

With the protection of the forests alone as Forest Reserve both in the evergreen and mixed deciduous forest zone, not only are many Iroko-trees preserved and allowed to grow to their full size, but also large numbers of self-sown seedlings come up in the abandoned ground and augment the value of the forests. This is an additional reason why the farming in a Reserve cannot be continued for any length of time. The old farms become more and more filled up with valuable young Iroko-trees, which would be at any rate damaged, if not killed, by the farming operations.

Even without taking into consideration the number of planted trees, the Forest Department has practically guaranteed certain future quantities of Iroko timber in the number of small trees which have been preserved and the potential value of the little ones grown up since the Reserves were made. Only in one part of the country is this anything like the case, and that is in the Ahoada district, where the natives use the Iroko-tree as a boundary mark between the different village lands and also between many farms. To a minor extent this can be seen in the Onitsha district, where the Iroko-trees have been preserved inside the villages, thus giving them the appearance of being the woods of the country while the rest of the land is bare. It is, however, just the reverse. They form the towns and villages amongst the trees, which are thus preserved from the axe and fire of the local farmer. Despite the fact that a fair number of large oversized Irokos have been cut each year in the Olokemeji Reserve, there are many more of the smaller size now coming on than were in existence when the first fellings took place.

Another tree which has received a considerable amount of attention is the Cigar-box Cedar (Cedrela odorata), and to a lesser extent the Toon (Cedrela Toona). Although both are exotic trees, the former especially shows very quick growth. Despite the unevenness with which it is liable to come up from seed, the rapid growth of the 


\section{WEST AFRICAN FORESTS AND FORESTRY}

tree soon compensates for this disadvantage. In three or four years it may be from 18 to 24 feet high and 8 to 16 inches in girth. Both the largest individual specimens as well as plantations are found in the Olokemeji forest as well.

More in place in the firewood plantations near Lagos and Ibadan is the Casuarina (Casuarina equisetifolia). At Olokemeji this tree has only done comparatively well. Also an exotic, it is most useful for planting near the sea-side on sandy sqil, and in places with a smaller rainfall. It will also stand a comparatively dry atmosphere. The wood of this tree is very hard, almost like Ironwood. It is sometimes known as the Australian Beef Tree. Its numerous small branches on the stem make the wood rather knotty and of less value for general construction work. However, its heating power as a firewood is very great. Amongst all the forest trees it is one which yields the greatest amount of acetic acid, which forms the basis of an explosive.

Another Australian tree which has been used to a lesser extent for Afforestation purposes is the Blue Gum of various kinds. Eucalyptus citriodora and $E$. amygdalina have proved to grow the quickest of any planted in Nigeria. Many others have been tried, but most have not survived. Specimen trees and small groups are seen as far apart as Onitsha, on the banks of the Niger, Ikassa, near the mouth of the Nun branch of the Niger, the Botanical Gardens, Calabar, the Olokemeji Arboretum and Forest Plantations, not to forget the streets of Lagos. In a similar way Casuarinas are seen near Government House at Calabar and in Lagos, besides the forest Arboretums and plantations.

Another exotic from India, Lagostræmia (Lagostramia flos Regina), has grown well both on the banks of the Ogun and on poor laterite soil of the Olokemeji Forest Reserve. For the sake of the flowers alone it is worth planting to ornament a garden or the edge of a plantation. The masses of mauve flowers last a considerable time and blend most beautifully with the foliage and any green grass near by. Although of branching habit when planted 10 feet apart, if planted closer it will grow straighter and with cleaner bole. The timber is hard and very durable. So far this tree has proved a valuable introduction, especially for planting poor soils and river banks liable to inundation.

A later, though an exceedingly good introduction is that of the Satinwood (Swietenia chloroxylon), which gives promise in the Olokemeji Forest Reserve of making a valuable addition to the number of timber trees of indigenous and exotic origin. This tree yields the Ceylon satinwood, which is usually worth at least $£ 12$ per ton. The almost silvery-white tufted formation of the leaves is reminiscent almost of the Eucalyptus, though the leaf is rather smoother 

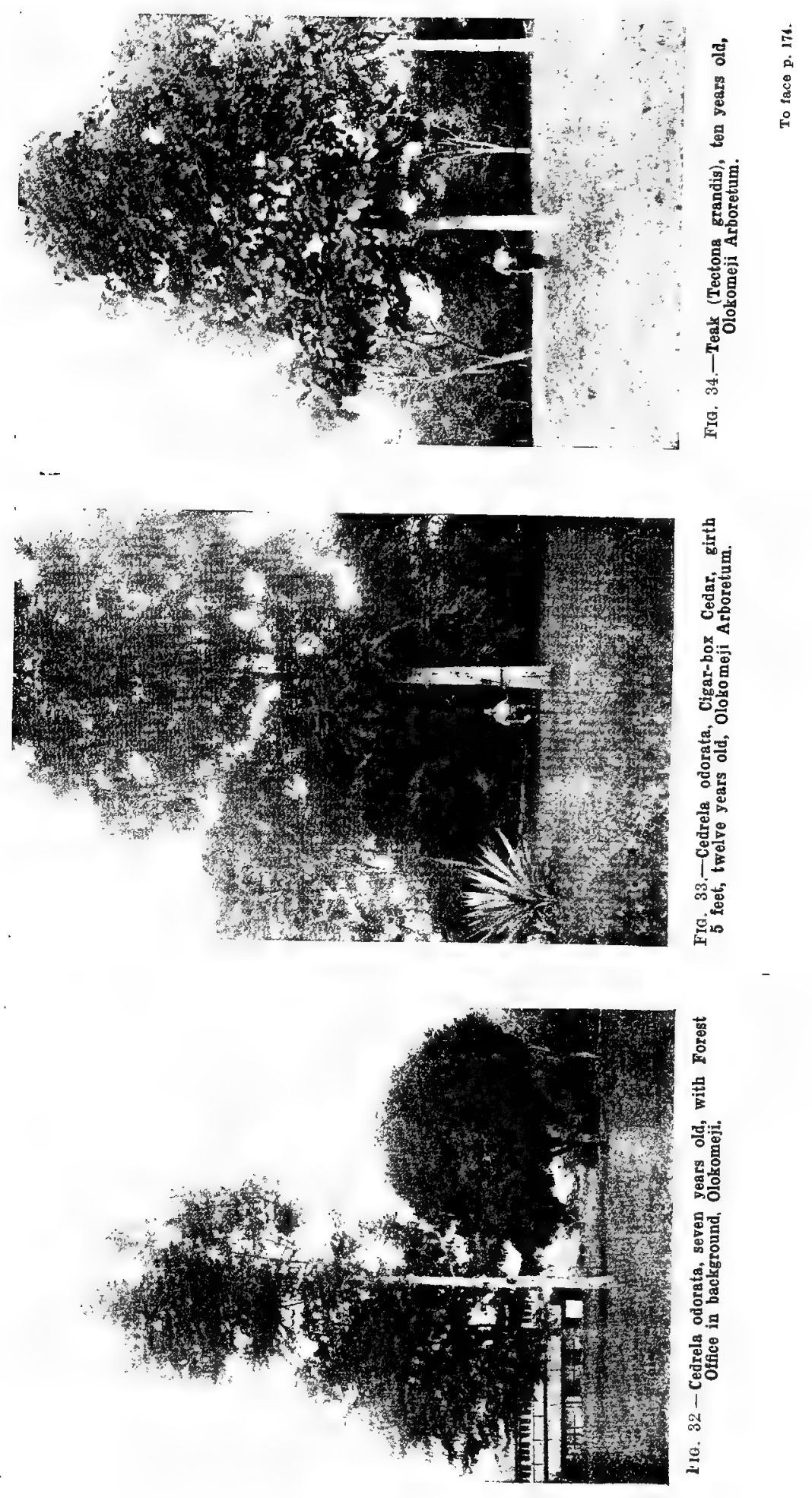

and not quite so narrow in proportion to its length as most of the Eucalyptus family.

Some years ago the seeds of Pinus Mercusii were planted in several places, including those of higher elevation. Although it many cases the seed germinated, the seedlings subsequently died.

Another exotic, the Swamp Cypress or Bald Cypress, or, as it is known in England, the Deciduous Cypress (Taxodium distichum), was tried near Benin City some years ago for swamp "planting. Here, as in the other case, the seeds germinated and the small trees reached the height of about a foot and then subsequently died. The swampy ground where they were planted may, however, have been rather too acid or sour for them. The climate, of course, was no doubt considerably hotter than that of the Southern States of the United States, in which country this tree is indigenous.

The original Spanish Mahogany, or Swietenia mahagoni, was intended for Afforestation purposes with a view to its yielding on the average a more highly valued wood than that of the African Mahogany. However, in Africa generally, and in the Olokemeji Arboretum, it has proved a very slow growth and more liable to attack by the leading-shoot borer than even the indigenous mahogany-tree.

For the comparatively dry laterite soil of the Olokemeji Forest Reserve, Indian Rosewond or Blackwood (Dalbergia latifolia) has proved a valuable introduction. Growing comparatively fast and of somewhat branching habit, it soon covers the ground. It is, of course, better in mixture with others in order to produce clcan stems. Latterly the larger trees have been attacked by a borer and considerable damage has been done. Still, in spite of it the trees have gone on growing, and apparently are capable of outgrowing the damage without an enormous loss of increment. In all, several acres have. been planted with this tree.

Indian Walnut (Albizzia Lebbek) has found a foremost place in the firewood plantation at Ibadan and Ede, as well as in the forest plantations at Olokemeji. Its rapid growth and comparative indifference to soil make it a comparatively valuable tree for Afforestation purposes. Although it is usually only considered suitable for firewood, there is no doubt that its wood can be used as a substitute for walnut, as it is in India. Already, in fact, it is largely a forest escape in Africa, and is found in many of the old farms and cultivated places. Its greyer, almost silvery-grey, foliage easily distinguishes it from that of Albizzia Brownii, which has larger leaves.

A South American exotic, the Lignum Vitæ (Guaiacum officinale), is found in isolated specimens in the Olokemeji Arboretum and forest plantations. With such a very slow-growing tree, which may show half an inch growth in a year, it is difficult to be patient and wait for the many years before it will attain even a size large enough from which 


\section{WEST AFRICAN FORESTS AND FORESTRY}

to cut the smallest bowl for a game of skittles or bowls. Its very yellow small foliage is most distinctive and not unlike box (Buxus sempervirens), but the leaf is flatter and does not curl like box.

One of the most valuable introductions in the forest plantations at Olokemeji and in the firewood plantations at Ibadan is the Siamese Cassia or Bombay Blackwood (Cassia Siamea). Almost indifferent as to soil and not requiring a heavy rainfall, and casting a heavy shade, it soon grows on the laterite, covers the ground, killing weeds, and rapidly attaining the size of a tree. In the plantations at Olokerneji, the trees reached a height of over 20 feet and a girth of about a foot in five years. It is one of the few trees that will thoroughly kill the Econ grass. The masses of yellow flowers which appear in the crown of the tree and also in the leader rather interrupt the height growth, but make a magnificent show at the end of the dry season. It continues to flower and fruit for the larger part of the year. Either as a firewood tree or as a timber tree, it should always be worthy of a place in all Afforestation areas where the rainfall is none too heavy. The hard, almost black wood is of value in India, so that it should prove of value in Nigeria when the trees are large enough for cutting into planks or boards. Amongst the exotic trees which have not yet found a place is the Trinkomali Wood (Berrya Ommomilla) and Indian Rose Chestnut or Ironwood (Mesua ferrua), seedlings which were obtained from seeds of the large trees in the Botanical Gardens at Victoria. If they grow well in Nigeria, the somewhat heavy and flexible Trinkomali Wood or Petwun and the Ironwood should both prove of value for local industrial work.

Although found as specimen trees in the Olokemeji Arboretum, Copaifera officinalis has not been formed in plantations, though small groups of the West African Gum Copal (Copaifera salicilounda) are seen in the Ogba plantation of the Central Circle. Both these trees are doing very well, more especially the latter, which have reached a height of over 12 feet in six years. The former had produced some tears of gum three-quarters of an inch in diameter in the tenth year of its growth. In addition to these two, there is the Cameroon Gum Copal (Copaifera Demeusii), seedlings of which were obtained from the Botanical Gardens at Victoria. Considering that the last-named tree is indigenous in a territory so much closer to Nigeria than either of the first-named Gum Copals, it is highly probable that this one will grow better than either of the others. Up to the present it is not known. however, how the yield of the Gum Copal compares with either of the former. As far as West Africa is concerned, the Sierra Leone Gum Copal has proved to be the most prolific in this respect.

The Indian Almond (Terminalia catappa) is seen more as an avenue tree, mostly in towns such as Lagos, but also in the Mamu Forest Reserve. It is certainly one of the best shade trees for planting at 
the side of roads. Its rather formal habit, with the almost even whorls of branches, fits in with the straightness and even width of a road. By many it is not realized that the nuts can be comparatively easily cracked and the kernel inside is good to eat.

Michelia champaca is another most suitable tree for avenues. The chestnut-like leaf and the large, almost magnolia-like flowers are of a white colour, giving it a "distinguished " appearance such as is necessary for a roadside tree. The flowers, too, are used for making scent.

Both as a shade tree and for its gum the Balsam of Peru (Toluifera Pereirce) is also worthy of a place both in avenues and in plantations. Some seedlings were obtained from the Botanical Gardens at Pretoria, where the tree has grown comparatively well. Not so suitable for plantations apparently at Olokemeji is the Sugar Palm (Arenga saccharifera). However, in isolated places small plantations have been made with the Sago Palm (Corypha elata), such as in the swamp opposite Calabar and the small grove of the Betel Nut Palm (Areca catechu) near Lagos. Both these give promise of being useful acquisitions to the palms of economic use in Africa.

Before leaving the exotic trees, mention must be made of the Thuya (Thuya occidentalis), which were obtained from the Canary Islands by Major Cockburn and planted on the hill at Obubra. Although somewhat slow growing, they have thrived in that climate and do not suffer from disease. This is the only example of a Conifer which has been successfully introduced into Nigeria.

Amongst the other indigenous trees of which plantations have been made there is the Cedar Mahogany (Pseudocedrela Kotschyi), Emi gbegiri, Yoruba, which apparently grows but slowly in Olokemeji. It is much the same with the self-sown seedlings and with root suckers, both of which have proved disappointingly slow in that locality.

Then also at Olokemeji we have the dry-zone Mahogany, Khaya Senegalensis, Oganwo of the Yorubas and Ogwangu of the Benis, growing in a small plantation and raised from seed brought by H. N. Thompson, Esq., from the Shaki district in 1910. So far the growth has been comparatively rapid, though the tree is occasionally attacked by the leading-shoot borer, which makes it fork comparatively low down.

Of the African Walnut and the Long-capsuled Mahogany, Lovoa Klaineana and Entandrophragma Condollei, most isolated specimens and groups appear to have been planted in the leased areas of Benin. In addition to these, some other specimens and small plantations are found in the Calabar, Degama, Benin and Olokemeji Arboretums, as well as in the plantations of the Ogba and Olokemeji. Thus far only the Long-capsuled Mahogany has been planted in these; the difficulty of obtaining seed of the African Walnut has precluded its wider distribu- 


\section{WEST AFRICAN FORESTS AND FORESTRY}

tion in the various plantations. Long-capsuled Mahogany grows very fast, usually with an undivided stem and a big tuft of long pinnate leaves near the top of the tree. Stump shocts form very readily and soon attain a large size, as is noticeable in the specimen in the Benin Arboretum.

The plantations of Ebony (Diospyros mespeliformis), Kanran of the Yorubas, have been made in the Olokemeji Forest Reserve. Although, of course, very slow growing, it demands further attention, as it yields a good black ebony.

Amongst the soft woods there are plantations of Triplochiton Nigericum, Arere of the Yorubas and Obechi of the Benis, in the Olokemeji Forest Reserve. At first growing rather slowly, they bid fair to prove one of the most rapid growing trees. A mixture where teak was introduced to fill up the blanks will be interesting to watch in its future development, as to whether the teak will eventually outgrow the forest maple.

Although the firewood plantations at Ibadan and certain parts of the plantations of Olokemeji have been filled up with West African Walnut (Albizzia Brownii), Ayinre Bonabona of the Yorubas, they will prove probably of greater value for the production of timber than for firewood. However, as a firewood tree it has yielded several cords of wood from one tree after only seven years of growth. So far it has certainly proved to be the tree which produces the greatest amount of firewood in the shortest period of time. It sprouts well from the stump, so that for a time its reproduction is very easy and assured.

The Oil Bean (Pentaclethra macrophylla), Apara of the Yorubas and Opaga of the Benis, is found chiefly reproduced artificially, either by being sown at stake or planted along the sides of the roads in the Owerri and Benin provinces. Considering the hardness of the wood, the tree grows not excessively slowly, though, of course, compared to a softwood it is slow.

Camwood (Pterocarpus Osun), Osun by the Yorubas, Ume by the Benis, has found a place in the Mamu Forest Reserve, its congener Pterocarpus Indicus having been planted in the Olokemeji Forest Reserve. However, as far as the size and habit of growth is concerned, the African Redwood or Barwood appears to be much superior to the Indian Paduak. The latter usually soon develops a triple stem with many small side-branches, whereas the African species always shows an undivided stem. In rate of growth "Osun" seems to be rather slow compared to many other trees. Self-sown seedlings come up readily in suitable localities, such as the Ikrigon Reserve, and on the whole develop more quickly. Anyhow, the continual demand in increasing amounts of this red dye-wood necessitates the careful preservation of the tree in the forest, as well as its continual reproduction by natural regeneration or plantations in the Forest Reserve. 
Amongst the Mamu Forest Plantations there is that of African Oak (Afzelia Africana), Apa (Yoruba), Aligna (Benin), one of the few survivals of the efforts made to reproduce this tree artificially. The many insect and rodent enemies give isolated plantation seedlings very little chance to develop.

Although Shea Butter (Butyrospermum Parkii), Emi Ori or Emigidi (Yoruba), has been tried as a plantation tree, the germination of the nuts is very poor, and the rodents attack them unmercifully. Apparently root-suckers form the chief means of reproduction for this tree. They are very prevalent and very persistent once they have sprouted. The forest fires destroy a great deal of the flower in the early part of the year, preventing formation of the fruit, and thus the means of reproduction by seed is very much reduced. The improvement in trees protected from fire at Olokemeji is most marked.

At Degema there is a plantation of Mimusops Djave (?), or Aganokwi of the Benis, which shows comparatively fast growth ; in eleven years the trees had reached a height of about 25 feet and a girth of 2 feet 6 inches. Although it sprouts well from the stump, it is easier to raise from seed, but the seedlings require great care in transplanting.

At Olokemeji, Shinglewood (Terminalia Superba), Afara, by the Yorubas and Egoyn Nufwa by the Benis, is being tried in a mixed plantation. The growth has been rapid, and would probably surpass that of teak after the first five years.

Over considerable areas of the Olokemeji and the Ibadan plantations the Yoruba Chewstick, or Ayin of the Yorubas (Anogeissus leiocarpus), has been planted. Its growth has been moderately rapid, reaching a height of about 8 feet in four years. In addition to the value of its wood both as a chewstick and from the fact that a mordant for dyes can be made from its ashes, the young plant kills all the Econ grass growing round it with its leaf fall. This makes the tree one of the most advantageous for Afforestation purposes. Its light-green foliage and delicate, graceful build, and slender bole and branches, make it also valuable as an avenue tree in the dryer parts of the country. In its similarity to the European birch it might almost be called the birch of Africa.

With the Dika Nut (Irvingia Barteri), Oro by the Yorubas and Okherli by the Benis, small sample plots have been mado in the Mamu Reserve and isolated specimens planted near the Calabar Arboretum.

Although not for Afforestation purposes but for the production of Palm Wine, Raffia vinifera, Ako by the Yoruba, Augor by the Benis, has been planted and seeds distributed amongst the villagers of the upper parts of the Cross River districts. When these are grown there will not be such a demand for cutting down the oil-palm-tree for making palm wine as there is at the present time. 


\section{WEST AFRICAN FORESTS AND FORESTRY}

Allowing only a value of $3 \mathrm{~d}$. per tree on all the trees planted during the last fifteen years, all the mahoganies and plantations are worth $£ 240,000$.

In two circles and parts of a third a great deal of work of an Afforestation nature was undertaken years before any actual forest plantation could be made. These are the communal rubber plantations of the Ireh Rubber (Funtumia elastica). In the Central Circle, near over 700 villages and towns, plantations varying from a hundred plants to ones covering several acres and containing many thousands, were made, aggregating in all the setting out of over a million trees in a period of about five years. In the Eastern Circle, in over a hundred villages, and in the Ondo and Western Circles over two hundred village plantations were made. Subsequently Para Rubber (Hevea Braziliensis) was added and substituted for the Funtumia wherever the climate was suitable for it. Now the communities concerned have a very valuable asset, which they can tap from year to year and augment at their leisure. Whatever happens to the forest or the immediate neighbourhood of the village, there will at any rate remain the rubber plantation, giving grateful shade to the roadsides and the ground near the villages. In one case a village planted over 1,200 Para rubber-trees, which even as a commercial asset are by no means to be despised.

In addition to these efforts on the part of the natives, acting under the advice and guidance of the Forest Department, there are the numerous rubber plantations in all the Forest Reserves. In the earlier days these were planted with Funtumia, where, for instance, in the Mamu Forest Reserve nearly one square mile of land is planted with this tree.

Then, again, there are the district plantations, more especially in the Eastern Circle, where in many cases Para Rubber was planted instead of Funtumia. These areas are for the most part smaller than those of the Forest Reserve or Communal Plantations They served more as demonstration areas to show how rubber would grow in that locality.

Furthermore, near almost each native court in the Eastern Circle rubber plantations, in many cases of Para and in others of Funtumia, were made.

The general cost of the Communal District and Native Court Plantation was practically limited to the amount involved in payment of the native Forest staff. These men, however, had other duties to perform, and on the average certainly not more than one-third of their time was occupied in the making of these plantations. For the making of the other plantations of the Forest Reserve about $£ 2,500$, or sometimes $£ 3,000$, has been spent annually in making them and in the cost of their upkeep once they have been made. Owing to the long dry season in Nigeria the number of plants failing to survive 
it is somewhat high, and this very considerably increases the cost of the final establishment of the plantation. For some years the cost in many cases amounted to $\mathfrak{f 1 0}$ per acre for the first year and $\mathfrak{f l}$ or $\mathfrak{f 2}$ for subsequent years, for the cost of "beating up" and keeping the plantations clean. With the greater experience gained both in regard to the habits of the different trees and in the methods of reproduction most suitable to various parts of Nigeria, the cost has been somewhat lessened. However, even so, the cost compared to European or English plantations is not abnormally high. In Africa there is no land to buy, and no wire-netting is needed for the plantations, and the land usually planted has not a " letting" or "sporting" value, as it has in England. The buying out or compensating of the native rights of the usufruct of the soil is not so very expensive, especially when it is spread over comparatively large areas, as it usually is in West Africa. Then, again, even with the cost of $£ 10$ per acre, the total value of a crop after fifty or sixty years would certainly not be less than 3s. per cubic foot of the timber, which thus allows ample margin for 5 per cent. compound interest on the original outlay, and a profit besides. In many cases the timber would be worth a great deal more, and also the value of the intermediate thinnings is not inconsiderable. Both these factors have been left out of the account, in order not to in any way exaggerate or make too optinistic estimates of the value of a forest plantation. But beyond the financial side of the value of forest plantations, more especially in a tropical country like Nigeria, is the very valuable indirect effect they have on the whole welfare of the country.

First of all, plantations in forest groves improve and beautify a locality, whether on the level or amongst hills.

In the second place, the forest induces a greater rainfall in itself and its immediate vicinity.

Then the rainfall which actually falls in the forest is partly reevaporated to fall again, thus making extra rainfall, and also the rain which actually reaches the ground in the forest is only gradually absorbed, thus making the flow of springs and rivers regular.

Both on the level and especially on slopes, a covering of trees, such as a forest, hinders the washing away of the surface soil or tilth of the land.

Forest trees only require one-twelth of the mineral matter out of the soil that an agricultural crop does, covering the same area.

In a forest plantation there is always greater humidity in the air, and thus many plants of economic value, such as cocoa, can grow in its vicinity, which would otherwise not be possible to be grown in that locality.

$A$ forest acts as a moderating influence on the temperature of the air, being lower inside the forest than outside, when the sun is very 


\section{WEST AFRICAN FORESTS AND FORESTRY}

hot. Conversely, when it is cold outside in the " harmattan " season it is warmer in the forest.

Nearer the interior of the forest certain better grasses and pasture are found, which are of incalculable value, in a drought, to the cattle in that locality.

During the long period of the rotation, usually at least 60 or 80 years, in most forests there are large accumulations of leaf mould or litter, which on occasion can be used in reasonable quantities for manuring neighbouring agricultural lands. This is of incalculable benefit where the ground outside the forest is comparatively poor and dry.

It has been proved also that in these long forest rotations the mineral rock and subsoil have time to weather, and add further mineral matter to the enrichment of the soil.

The forest, too, provides grateful shelter and sanctuary for game animals and birds of all kinds, thus providing, especially in Africa, the largest source of meat which the native has.

When all these indirect advantages and good effects of the forest are added together and a definite value put on them, and then considered in addition to all the timber and firewood the forest produces, it will be seen how wonderfully and providentially beneficial the forests really are, and also how absolutely essential they are in a country like Africa.

Just as effective, and cheaper, except perhaps as regards time, than the artificially made forest plantation, are the protected forests ; even in the worst case, starting with a poor country growth and small dry-zone shrubs and trees, after ten years there is a compact, close-growth, medium-sized tree with straightened stem and less branching habit, and the ground comparatively free from grass. During a further period this forest can be thinned out by removing the poorer shrubs and trees and allowing seedlings of more valuable species to come up. They will often do this in the shade of poorer and more hardy trees. Still later, as the soil-moisture conditions improve, the humidity increases as well as the rainfall; still other species come in or can be introduced artificially. Eventually, by the end of the first rotation there is probably quite a different forest to that in existence at the time of the annual grass-fires, and one which is more akin to the original forests before the advent of Man with his firestick.

Quite apart from any money which has been spent on direct forest plantations, the indirect effect of the protection afforded to the trees in the various forest reserves is of almost incalculable value. If the figure should be calculated out even at a low rate of only $£ l$ per acre, then the total value is $£ 768,000$ for the Reserves already made. Again, considering this result has only been attained after 


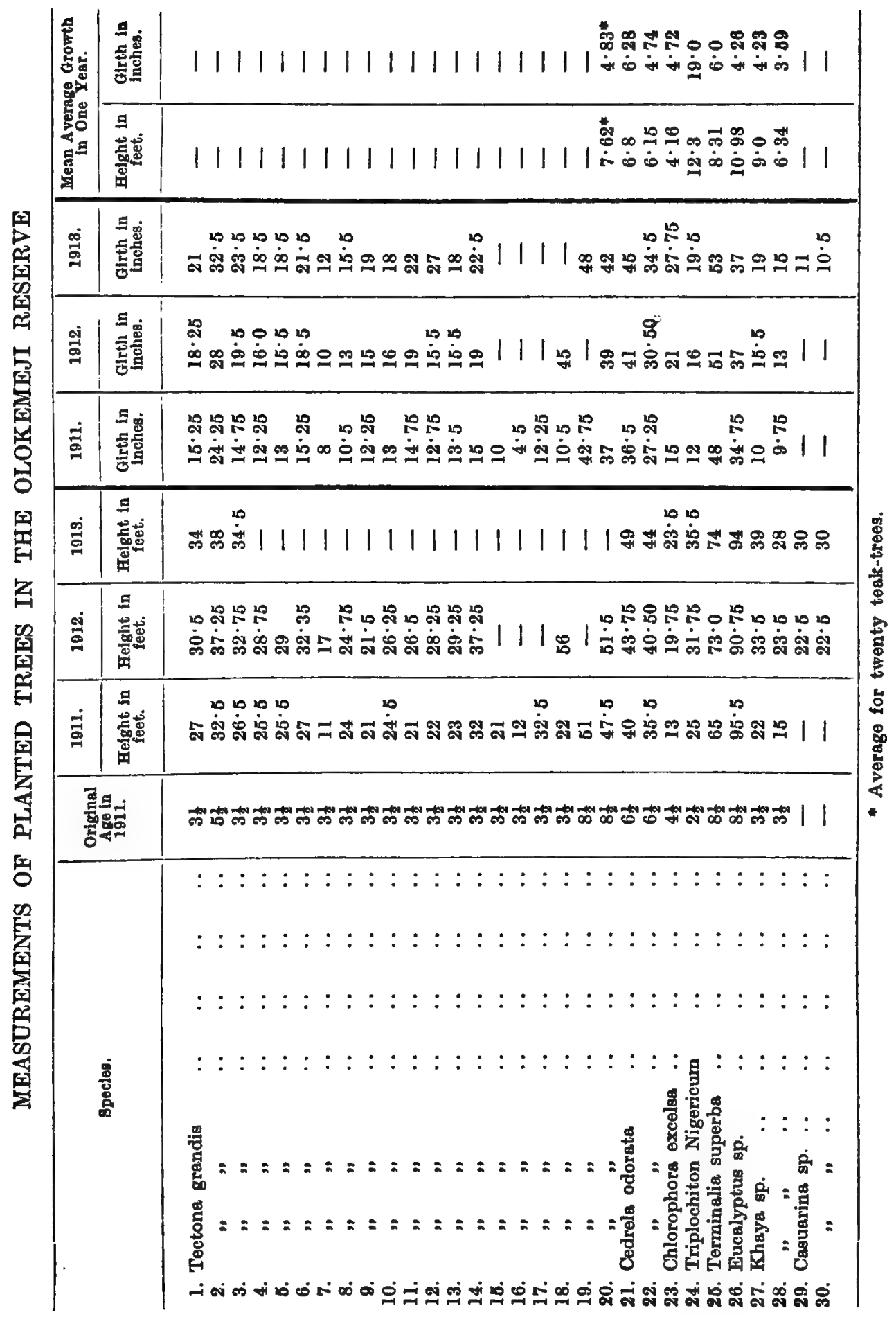




\section{WEST AFRICAN FORESTS AND FORESTRY}

about fifteen years' work, it will only go to show the vast potentialities and resources that may be eventually created, or preserved from destruction, in Nigeria.

\section{The Forest Department.*}

European Forest Officers are of two ranks, the scientifically trained Conservators of Forests and the executively trained Foresters.

The scope of this paper will only cover the former, as very few of the latter are Europeans, and most of them Nigerians.

From Oxford, Cambridge and Edinburgh, graduates in Forestry can usually be procured. The training at these centres covers roughly a year or a year and a half's work on the elementary subjects, such as Botany, Mathematics, Geology, Mensuration, Surveying, and Political Economy. In addition, a year or two years' work on the professional subjects, Silviculture or the growing of Forests, Forest Protection, Forest Utilization, Forest Botany, Forest Entomology, Forest History and Forest Policy is required. At the end of the course, six months' practical work in Scottish or English forests follows, during which period working plans and market conditions are especially studied.

After being accepted for appointment in Nigeria, a further three months' course is taken at the Royal Gardens, Kew ; and six months' practical work on the Continent was (before the war) usually required. At $\mathrm{Kew}$, the object is to acquire a working knowledge of the most important Botanical Orders which contain the African trees. The continental course shows the student forests which have been under a definite scheme of management for over a hundred years. It takes one, in fact, right through the life-history of a tree from a seedling in the nursery-bed to the well-grown financially mature tree, marked ready for the axe, a period of about eighty years.

The initial appointment is for three years on probation, after which it may be confirmed. The initial salary of an Assistant Conservator of Forests is $£ 300$ per annum, rising by increments of $£ 15$ to $£ 400$ per annum. The first appointment dates from the day of sailing, the passage being paid by the Nigerian Government, and salary on half-pay begins from the date of departure until the arrival in Nigeria, when full salary begins to accrue. Intending candidates should bear in mind that an early selection for appointment entitles them to seniority over other candidates who, owing to their being fully qualified, are appointed immediately, and thus reach the Colony before them. Locally, a commuted travelling allowance of $£ 42$ per annum is drawn to compensate for the extra cost entailed in inspecting the forests. A limited number of carriers, or other means of transport,

* Reprinted by kind permission of the Editor of United Empire. 


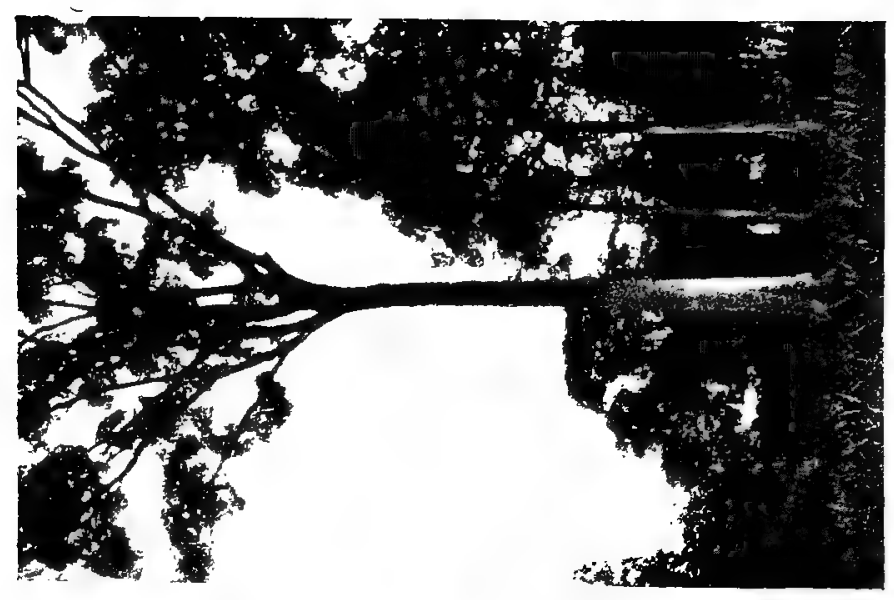

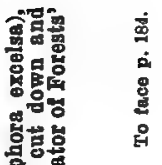
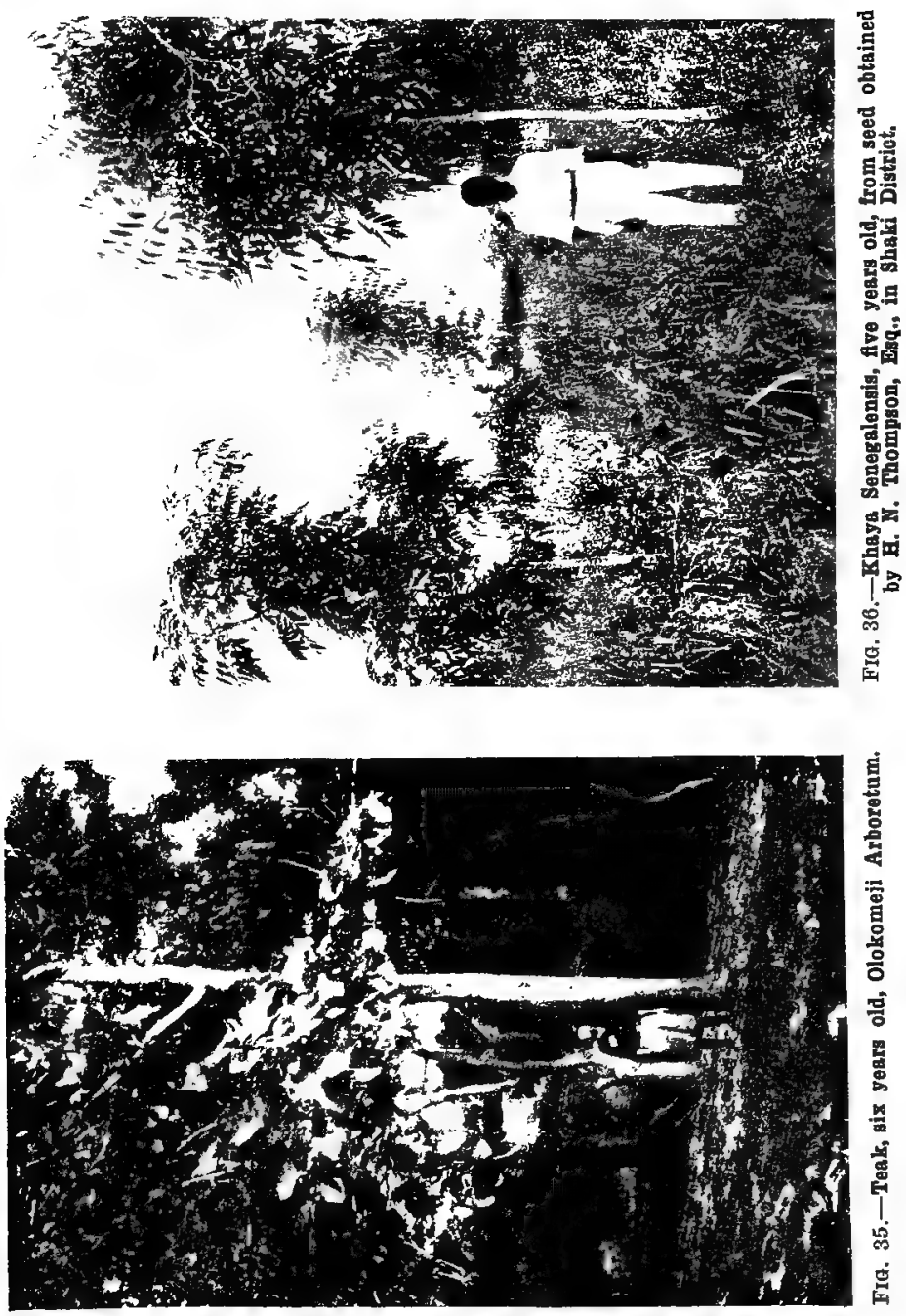

are provided by the Government. For the purpose of more rapidly getting about, a bicycle, motor, or horse may be kept, and an allowance is given for maintenance. The cost of living is high, even when furnished quarters or a bungalow are provided.

Lagos is the first port of call in Nigeria, and there is a railway journey of 123 miles before reaching Ibadan, the temporary headquarters of the Forest Department. Olokomeji, 90 miles from Lagos, is the old headquarters, and from here the forestry work of the Southern Provinces is directed. Zaria, situated some 450 miles from Lagos, is the headquarters of the Forestry Department in the Northern Provinces.

A newly appointed officer would be liable to be sent to either of these last-named places; but owing to the larger number of men being stationed in the Southern Provinces, the majority are sent to that centre. Olokomeji is in the middle of a Forest Reserve 26 square miles in extent, and is also the headquarters both of the Western Circle and of its northern division. In each circle there is a Conservator of Forests in charge, and he has an assistant to manage each division. In the event of a shortage of staff it may happen that a new man is put in charge of a division and thus has an opportunity of learning all about the work much more quickly than would otherwise be the case. In the ordinary way he only corresponds with his Conservator and the timber interests of his division on purely local matters.

Since 1901, a moderately large Arboretum has been planted at Olokomeji, containing quite a number of indigenous trees growing under natural conditions, according to the type of climate found in that locality, and also some exotic trees which grow in similar climates in Asia or South America. In a comparatively short time the new Forest Officer can get a very fair idea of the most important timber trees found locally, as well as elsewhere. In connection with the work of renewing the labels on specimen trees, ocular demonstration of all these trees is obtainable. The local Ranger can usually supply the vernacular names, and here is a wide field for linguistic qualifcations. Yoruba is the local language, Benin is spoken by a large number of people in the Central Circle, and Hausa by nearly all itinerant traders throughout the country. Ibo, another language, is spoken by nearly $3,000,000$ inhabitants, while many of the Cross River people (Eastern Circle) speak Efik; some, however, speak New Calabar or Ibibio, while again, in a large part of the Niger Delta, Brass or Ijor is spoken. Sooner or later the language of the locality should be acquired, and in fact this is prescribed by Government order as a necessary preliminary to the granting of the first increment.

The routine office work includes simple book-keeping, analysis of records, appointments of staff, the engagement of native labour 


\section{WEST AFRICAN FORESTS AND FORESTRY}

and all payments. The executive work outside is carried out by the Forest Guards, Foresters, and Rangers, who require constant supervision. Owing to the distance, only some of them can report at Forest Headquarters each month, and the rest must be seen when the Forest Executive Officer makes his tour of inspection. If possible, travelling should take the place of indoor work for at least ten days a month.

At first sight, on examining the tropical forest, it appears like a very mixed collection of different kinds of trees ; on closer inspection, however, similarities and contrasts are apparent, such as Ebony, Diospyros mespiliformis, with its thin, black scaly bark, and that of the somewhat regularly, deeply fissured bullet-wood tree, Mimusops multinervis, and its white latex, which the former does not exude.

In walking through a forest, it is normally best to make the carriers precede. Owing to their tendency to lag, and their desire to sit down at inconvenient times, it is an advantage to have them in front. Frequently one may have to stop and examine a flower or leaf, and it only adds to the carriers' labour if the whole column has to stop whilst seeds and specimens are being collected. A march of about 15 miles is sufficient, and takes up the better part of the day, if an examination of the forests is being made on the way. In most parts villages are eight to ten miles apart, sometimes nearer; so the carriers can stop and purchase food. In the larger forests, however, a distance of over 20 miles is sometimes covered without sight of a house; in that case the people of the last village are asked to bring food for the carriers, and the carriers themselves are given a day's food as well, which has to be cooked on reaching camp. In some places the chiefs provide food (yams, etc.), which is distributed to the carriers, or in some places 3d. a day per head is allowed them for purchasing food. So long as the carrier gets food and his load is not excessively heavy, he' is quite cheerful and walks well. He will pick his way in mud, over roots, and up the steepest rocks in the hill forests.

Current wages vary from $9 \mathrm{~d}$. to $1 \mathrm{~s}$. a day, the head-man getting from 1s. to 2s. a day. Local felling-permits being issued both by the District and Forest Officers to natives for felling timber for local use, at District Stations a call is paid the District Officer to discuss current forest questions and examine the permit books. At the same time there is an opportunity of seeing what further development of forest work is possible in the district. The local Forest Guards, Foresters, or Forest Rangers report themselves, usually giving a very good account of the local forest conditions. Since the demand for local timber has been growing, a stop may have to be made to supervise the marking or girdling of suitable trees for bridge-building under the auspices of the Public Works Department. On a journey 
through the mahogany forest, the different camps of the timber firms have to be visited. These firms have hundreds of square miles for the purpose of exploiting mahogany and furniture woods. At the same time the checking and inspecting of the stumps of all the trees felled has to be gone through. The young mahogany seedlings are also seen, and from the number of these it is known whether sufficient have been planted to take the place of those cut down. The very rapid growth of these trees can here be studied to advantage; trees now 40 feet high have only been planted a few years. The relative value of the direct planting of seedling trees as compared with the natural regeneration of the forest by self-sown seedlings can be observed with ocular clearness. In one part of the forest one sees natives standing on a platform hacking away with an axe into a huge 50-feet mahogany; in another place a similar tree, fallen, its 90 -feet bole already sawn into three round logs: while in a third locality may be seen a native, axe or adze in hand, squaring mahogany logs with a 4-feet side. Later in the season eighty or more natives are engaged in dragging one of these logs on round billets of wood (for rollers) along a track, roughly cleared to the height of a man, to the nearest natural water-way; still later (that is, in July or August), when the rivers rise, the logs may be seen floating singly down to the rafting-place on the main creek, where rafts are made with logs four or eight abreast, each fastened to the next, from a timber-dog at either end, with cane. From here, riverine natives such as the Ijors take the logs to the nearest river or ocean-going steamer port.

The administrative work of the Department is in the hands of the Senior Conservators of Forests, under whom the Conservators manage their circles. The Chief Conservator of Forests, the head of the Department, initiates and controls the whole policy of the Department, being relieved of all details of administration. In order to ensure continuity of policy and action, a Working-plans Division has been formed. A working plan for the forests is a scheme of management laid down for a number of years; no change can be made in such a plan without special reference both to the head of that division and to the head of the Department. With only one year's service, followed by leave of absence, continuity of action would be broken if it were not for a definitely approved plan.

The Forest Department has supplied the Railway, Marine, and Public Works Department with timber of various kinds. In some cases the timber is obtained by departmental working, and in others is cut by native contractors under the supervision of the Department. In the first instance, the conditions under which timber is to be supplied to other departments are put before the Secretariat, and 


\section{WEST AFRICAN FORESTS AND FORESTRY}

when once the work has been begun, the local Forest Officer deals direct with the department concerned.

Forestry progress in Nigeria has been less tardy than in several other Colonies, though many forests have been destroyed owing to lapse of time before the formation of a department. In 1904 there were eight, and there are now twenty-four administrative appointments. The amalgamation of Northern and Southern Nigeria into one administration should accelerate the development of Forestry. It is as yet only in its initial stages, and scarcely more than a thousand square miles of forests, out of nearly a hundred thousand which exist in some form or another, have been permanently set aside for further timber production. The revenue-earning capacity of the Forest Department has been somewhat diminished by the war; but with recent legislation more local revenue should be obtained, which should more than off-set any loss already sustained. Provided the financial position of Nigeria remains strong, the prospects of the Forest Department are quite bright.

Although Nigeria has by far the largest Forest Department, very similar conditions of service obtain in the other West African Colonies of the Gold Coast and Sierra Leone; but there are no Forest Officers in the Gambia.

\section{A Review of the Botanical Features of Northern Nigeria.}

By Dr. J. M. Dalziel.

The Northern Provinces of Nigeria exhibit in an interesting manner the transition, now familiar in West Africa, of physical characteristics from the tropical forest to the border region "that just divides the desert from the sown."

So far as the progressive stages may be stated in terms of geographical latitude, we may place the northern limit of the forest belt at about $8^{\circ}$ North latitude. A convenient natural boundary in a portion of the area under consideration may be accepted in the lower course of the Benué River from its tributary, the Katsina River, or even as far up as Ibi, to the Niger at Lokoja. On the other hand, the southern limit of the desert is taken at about $17^{\circ}$ North latitude, or higher, and thus falls some three or more degrees beyond the northern boundary.

Between these arbitrary limits lies the greater part of Northern Nigeria and practically the whole of Hausaland, presenting physical features which vary through grassy plains and rolling downs, orchardbush and thin-crowned forest, laterite plateaux and hilly woodlands, to the mountains of the Bauchi Highlands. The vegetative covering over a very large area can be classed as one or other type of savannah, tree and bush savannah, or open orchard and treeless savannah, with intermediate grades. Local topography alters the type here and 
there, galleries of evergreen vegetation occupying the intersecting belts of permanent streams or fringing a marsh, wide meadows bordered by low forest, but occupied entirely by grasses of few species, with scattered islets of foliage, or, again, outcrops of bare laterite and isolated domes and turtle-backs of crystalline rock, "inselbergs" and "kopjes," introducing features of their own.

The Niger Delta displays admirably the high evergreen or moist tropical forest. This probably connects itself through the Kameruns with the great Central African forest of French and Belgian Congo, which is again said to be continuous through the gap between Ruwenzori and Lake Albert with that of British East Africa.

West of the Niger Delta the coast, including Lagos, Dahomey and Togo, is sandy, and bush rather than high forest commences almost on the shore. Ascending the Niger, one finds that the true "rain forest" ends, but not abruptly, in the neighbourhood of Asaba; a gradual transition occurs, first to an intermediate type, partly evergreen with many large trees. but mingled with those that lose their leaves in the months of little rainfall. This change is apparent even on the river-bank, and below Lokoja a more open but still semievergreen forest clothes the valleys, but shows already more of the deciduous element on the hills. Farther north the voyage from the mouth of the Kaduna River to the Zungeru light railway terminus at Barijuko, as often experienced in previous years, reveals again the progressively deciduous character of the foliage, resulting in a still more open forest.

The river-bank, however, possessing permanent moisture and its own local climate, is an inadequate index of the general features over the country at large. To travel by land from Baro to Zungeru, and thence either through Kontagora to Sokoto, or by Zaria to Kano and Gummel, is to have the complete vision of the West African savannah in its various degrees, and, except for local interruptions associated with considerations of altitude or geological outcrop, etc., or with the lines of perennial streams, to have it in its regular sequence.

Leaving out of account for the present the region south of Lokoja and of the south bank of the Benué, which in part represents the "Zone Guinéenne " of Chevalier, we find that the two routes suggested above will take one through country almost entirely of the types included by the same writer within the "Zone Soudanienne," with an approach at places along the Anglo-French boundary to the conditions occurring in his "Zone Sahélienne." It would be difficult and misleading to express these zones definitely in terms of latitude, but one might hazard the statement that the Guinea Zone passes to the Soudan Zone somewhere between $8^{\circ}$ and $10^{\circ}$ North, and the latter extends either to the northern boundary or verges on a drier belt beyond the latitude of $12^{\circ}$ or $13^{\circ}$ North. If a complete botanical 
survey were possible, one could then subdivide each belt into its different areas and provinces, with their special floral characteristics, but at present one must be content to indicate broadly the general composition.

The Soudan Zone, indeed, includes the greater part of Hausaland and is representative of the typical West African savannah and savannah forest. It merges into the drier sandy "steppe " conditions in the north and into the mixed deciduous and semi-evergreen forests farther south. The only giants in height are the silk-cotton-trees (Eriodendron orientale), but baobabs of enormous girth are common, and the largest timber trees are probably the Maje (Paradaniellia Oliveri) and the Kawo (Afzelia Africana), fair specimens of the dryzone mahogany, Madachi (Khaya Senegalensis), occurring also in favourable situations.

Across the central part of Northern Nigeria, let us say from Kontagora and South Sokoto through the whole of Zaria and South Kano to South Bornu (but excluding the Bauchi plateau, of which I cannot speak from personal knowledge), the plants named in the list here given might be regarded as the average association of species, trees, shrubs and herbaceous, the chief Natural Orders being represented as follows:

Anonaceze by the common wild custard apple, Gwandar daji, Anona Senegalensis, a shrub.

CAPPaRIDACE 8 by the Ingidido, Cratceva Adansonii, by shrubs or woody undershrubs of genera Boscia and Marua, some thorny scramblers of the genus Capparis, and the familiar weed Gasaya, Gynandropsis pentaphylla.

Bixinez by the Rawaya, Cochlospermum tinctorium, a shrub. HYPericLne as by the shrub Kaskawami, Psorospermum Senegalense.

OCHNACE $e$ by the Namijin kade, Lophira alata, a tree very typical of the region, two or three species of Gomphia, and a new species of Ochna, a small shrub with crenulate leaves.

MALVACE \& by numerous species of Hibiscus, including the cultivated Rama (chiefly $K$. cannabinus) and Cotton, with the Ramaniya, Urena lobata, and various undershrubs and suffrutescent weeds, mostly of the genus Sida. The Kuka or baobab, Adansonia digitata, and the Rimi or Silk-cotton Tree, Eriodendron orientale, marking the sites of human habitations, past or present, are typical species of this area, as is also the red-flowered Gurjiya, Bombax buonopozense (Bombacaceæ).

Sterculdace 2 by the Kukuki, Sterculia tomentosa, a tree, with which we may place the common undershrub Hankufa, Waltheria Americana.

Turaces by several species of Arewia, the most familiar being the Dargaza, G. mollis, by two or three species of Corchorus, 
edible herbs allied to jute, and by shrubby weeds of the genus Triumfetta.

SIMARUBACE E by Hannoa undulata, a small-sized tree characteristic of the region, and by Irvingia Smithii, a tree more abundant in the South.

Burstraces by two species of frankincense-tree-Boswellia Dalzielii and B. odorata-and by Commiphora Kerstingii, a green-barked tree familiar as an enclosure fence in towns.

Meliace 3 by Khaya Senegalensis, the mahogany of the Soudan Zone, by Trichilia emetica, and by Pseudocedrela Kotschyii; also by the naturalized Kurnan nasara, Melia Azedarach.

Olacace a by the Tsada, Ximenia Americana, a shrub with small yellow, acid plums, and by the evergreen climbing shrub, Opitia celtidifolia.

Cerlastrace typically by the shrub Gymnosporia Senegalensis, and less by two or more species of woody twining Hippocrates.

SAPINDACEA by the woody twiner Paullinia pinnata, the 3-foliate shrub Schmidelia Africana, and the world-wide twining weed Cardiospermum Halicacabum.

ANACARDIACE 2 by the tree Odina Barteri, by other species of Odina of more local distribution, and by two species of Anasphrenium.

ConNaraces by the abundant little shrub Byrsocarpus coccineus.

Proteace a by a single species of Protea, a shrub with large capitate flowers, of local distribution in the Central areas.

Polygamacese by Securidaca longipedunculata and the field weed Polygala arenaria.

LEGUMINOSA by-

Larger trees: the Maji or Kadaura, Paradaniellia Oliveri, and the Kawo, Afzelia Africana.

Medium-sized and smaller trees: Parkia filicoidea, Prosopis oblonga, Pterocarpus erinaceus, Isoberlinia doka, Berlinia acuminata in ravines, Tamarindus Indica; several Acacias, e.g. A. Sieberiana, A. campylacantha, A. Arabica; Albizzia Chevalieri, Entada Sudanica; Afrormosia laxiflora and Burkea Africana.

Small trees and shrubs: Detarium Senegalense, Bauhinia reticulata and $B$. rufescens, Erythrina Senegalensis, Lonchocarpus laxiflorus, Dichrostachys nutans, Mimosa asperata on stream-banks, Cassia Sieberiana, C. Kotschyana and others, along with several shrubby species of Cassia and the dwarf $C$. mimosoides, Swartzia Madagascariensis, Ormocarpum bibracteatum.

To these must be added the Zamarke, Sesbania punctata, and other spp., and a host of herbaceous plants or half woody undershrubs, chiefly belonging to the genera Crotalaria, Indigofera, and Tephrosia, others of Desmodium Eriosema, etc., and twiners of Vigna and Rhynchosia. 


\section{WEST AFRICAN FORESTS AND FORESTRY}

The chief cultivated Leguminosæ of the region are: Indigo, Indigofera arrecta and other spp., Arachis hypogoza, Vigna sineusis in numerous varieties, and Voandzeia subterranea.

ROSACEA mainly by Parinarium curatellaefolium, to which may be added $P$. polyandrum in the South and $P$. macrophyllum in the North.

CombritaCex by several species of Terminalia, of which the commonest are the Baushe (of more than one species) and the Kandari, T. macroptera; more fully by a number of species of Combretum, which are trees often gum-yielding, and very typically by the Marike, Anogeissus leiocarpus.

MYrtace a by Eugenia Owariensis, a tree, and E. coronata, a shrub.

LYThRACE EE by the " henna" shrub, Lawsonia alba, and the weed of damp places, Ammannia Senegalensis.

Araliace $x$ by an interesting species, Cussonia Nigerica, a small tree of peculiar habit.

RUBIACE 2 by Adina microcephala, a fair-sized tree by bush streams; by very numerous small trees and shrubs, e.g. Crossopteryx Kotschyana, Sarcocephalus Russegeri, Pavetta Barteri, Feretia canthioides, the Gardenia erubescens and the Gauden kura, $G$. ternifolia, the Giyaiya, Mitragyne Africana, typical of the islets of foliage clothing the grassy swamps, Moralia Senegalensis on stream-banks, and by more humble but abundant species of Oldenlandia, Spermacoce, Octodon, etc.

SAPOTACE ex by the Shea Butter Tree, Butyrospermum Parkii, probably the most characteristic member of the association.

EBENACEAs by the African Ebony, Diospyros mespiliformis.

Apocynace typically by the arrow-poison woody climber Strophanthus sarmentosus, which is always wild, and $S$. hispidus, which is generally planted near villages-both species called Kwankwanni; also by the more common and inferior rubber vine, Landolphia florida, and shrubs Carissa edulis and Cryptolepis Nigritiana, the woody twiners Tcecazea Barteri and other spp., with numerous others.

AsClipiadaCE Calotropis procera, probably always in association with man, the smaller undershrub Asclepias lineolata, and several suffrutescent herbs with tuberous and sometimes edible rootstocks of the genera Xysmalobium and Schizoglossum.

LOGANIACE by Strychnos spinosa, S. alnifolia, and S. triclisioides, all shrubs or small trees.

BoragnaCe ey by Cordia Abysinica, a small tree, the undershrub Trichodesma Africanum, three or four weeds of the genus Heliotropium, etc.

Bignoniacese by Stereospermum Kunthianum, a small tree, and the Aduruku, Newbouldia laevis, confined to towns and rarely more than a tall, slender shrub ; the Rahaina or Rawuya, Kigelia Abthiopica, occurs, but in an interrupted distribution. 
Verberace by Vitex Cienkowskii, a fair-sized tree, V. diversifolia, a small tree or shrub, and underghrubs such as Lantana salvifolia, Lippia Ukambensis, and a few species of Clerodendron, etc.

EUPHORBIACE 4 by Uapaca Guineense, usually only a rather small tree in the deciduous forest, Bridelia ferruginea and $B$. scleroneura, both shrubs, Phyllanthus floribundus, forming sometimes thicket-like clumps, $P$. reticulatus, a shrub, Flueggea microcarpa, a white-berried shrub, Antidesma venosum, and very typically by the Jan yaro, Hymenocardia acida, a shrub which in these open regions has nearly always an ochre-red bark. Numerous herbs and half-woody weeds are common, belonging to the genus Euphorbia (E. pilulifera, $E$. Asgyptiaca, and congeners), Acalypha, Phyllanthus, etc., the Castor Oil shrub (Ricinus communis) and the Physic Nut (Jatropha curcas) are cultivated, while thoroughly representative through the whole area are the familiar cactus-like Tinya, Euphorbia unispina and $\boldsymbol{E}$. Poissoni, and the Kerana, $E$. Barteri, the latter at least never away from habitations.

Moraces by a host of species of the genus Ficus (or Urostigma) not yet fully elaborated botanically, e.g. Baure, Chediya, Durumi, Kauriri, Wa, etc.

Urmaces. A representative variety is Celtis integrifolia, a fairly large tree.

Salicaceze by one species of Salix.

LORANTHACE AS beven or eight species of the parasite Loranthus, called Kauchi, clothing deciduous trees with epiphytic foliage.

Orders represented mainly by flowering herbs, undershrubs, etc., are :

Menispermaces by the popular medicinal twiner Jibda kassa, Cissampelos Pareira.

NrMPHEACE 2 by at least four species of Bada or water-lily, Nymphoea.

Papaverace en by the Yellow Poppy, Argemone Mexicana.

Caryophyllace by species of Polycarpaca characteristic of the dry zone.

Gerantace a by the familiar weed Biophytum sensitivum.

Droseraces by the widely distributed Sun-dew, Drosera indica.

AmpeldDes by numerous vines of the genera Vitis, Cissus, and Ampelocissus, of which perhaps the most striking are Dodoriya, Vitis quadrangularis, and Dafara, Vitis pallida, while wild vines with edible berries called Tsiberi kinkini are generally of one or other species of Ampelocissus.

Cuctrbitacta by the familiar cultivated Kabeova or pumpkin, Cucurbita Pepo, and Duma, the bottle-gourd, Lagenaria vulgaris, with its endless varieties, the Guna or water-melon, Citrullus vulgaris, and by many wild and half-wild species, e.g. the Balsam Apple, 


\section{WEST AFRICAN FORESTS AND FORESTRY}

Momordica balsamina, the Loofah gourd, Luffa Algyptiaca and L. acutangula, Cucumis prophetarum, and one or more species of tuberousrooted Trochomeria.

FICoIDese by common succulent weeds, e.g. Trianthema monogyna, T. pentandra, and Giesekia pharnaceoides, and by species of Mollugo in river-beds, etc.

Composit 3 by some weeds of cosmopolitan distribution, e.g. Ageratum conyzoides, Eclipta alba, etc., and by very numerous herbs and suffrutescent plants, amongst which the genus Vernonia is the most abundantly represented, including one typical of the region, viz. V. nigritiana, with several species of Aspillia, Coreopsis, etc., and the chewstick shrub, Vernonia amygdalina.

Melastomaces by a few species of Dissotis and Osbeckia.

Campanduacere by a common little blue-flowered weed, Cephalostigma Perrottetii, and a water herb, Sphenoclea Zeylanica.

Hydrophyllacese by three or more species of Hydrolea, e.g. H. Guineensis, etc.

LENTIBULACEA by ten or more species of Utricularia.

ConvoLvULACE $z$, a conspicuous order, well represented by numerous species of Ipomaea, a few of Merrimia, and a few erect undershrubs of the genus Astrochlona, to which one may add the little blueflowered weed Evolvulus alsinoides, of wide distribution in the world.

Solanace $x$ by the "Thorn Apple," Datura Metel, by numerous species of Solanum, some edible, e.g. the several cultivated varieties of the native bitter tomato, Gauta, varieties of S. Melongena; others poisonous, e.g. Gautan kura, Solanum incanum, and others; also by two common weeds of the genus Physalis, and the popular herb simple, Dandana, Schwenkia Americana.

Scropholarace at by Scoparia dulcis, of world-wide distribution, and by several parasitic species of Striga, of which the most familiar is the Makasar adwa, S. Senegalensis. Besides numerous humble weeds of cosmopolitan genera, e.g. Moniera, Ilysanthes, etc., mostly occurring in damp places, two or three species of Sopubia may be taken as characteristic of the bush-lands.

ACANTHACE 2 by a variety of weeds, etc., of the genera Blepharis, Monechma, Justocoa, etc., to which the following may be added as characteristic of the Order in Hausalund: Nelsonia campestris, a soft herb of slightly acid taste, Peristrophe bicalyculata, an occasional fodder plant, and Dyschoriste Perrottetii, the mucilaginous seeds of which are used to remove spicules from the eye.

Pedaliace as by the locally cultivated Ridi, Sesamum Indicum, and other wild species of Sesamum, by the weed Ceratotheca sesamoides, and by the half-shrubby Rogeria adenophylla.

Labiate by several cultivated tubers, such as the Tumuku and 
Risga, by odorous species of Ocimum and Elolanthus, e.g. the Dodoya, Ocimum Americanum, the weed Acrocephahus polytrichus, and by many common herbs of various other genera.

Amaranthacece by the native spinage, Alayafu, Amaranthus caudatus, the Zaki banza, $A$. viridis, a wild species sometimes cultivated, and by several of the common weeds found in other countries-Celosia argentea, Pupalia lappacea, etc.

Thymelacaces by the poisonous Tururibi, Lasiosyphon Kraussii, a yellow-flowered, low, suffruticose plant with a woody rootstock, and by two of three species of Gnidia.

ARISTOLOCHACE e by the twiner Aristolochia albida.

LAdRACE $x$ by the leafless twiner Cassytha Guineensis.

The Monocotyledonous Orders may be said to be represented as follows :

HYDrocharitaCes by the yellow-flowered aquatic herbs Ottelia lancifolia and Boottia Abyssinica.

ORCHIDACE 8 by a fair number of tuberous terrestrial orchids, of which Lissochilus arenarius is the most typical, several Habenarias and Eulophias, and a very few epiphytes, e.g. Ansellia Congoensis.

Scipanrine a abundantly by Koempferia Afthiopica in open woods, Costus afer in shady ravines, and Fitta, the food-wrapper leaf, Clinogyne filipes, in streams, etc.

IRIDACE $E$ by several species of Gladiolus, e.g. G. quartinianus, and of Tritonia.

AMARYLLIDACE E by Crinum yuccoeflorum, the red-flowered Homainthus rupestris, Pancratium trianthum, and Curculigo Gallabatensis.

TACCACE 2 by the tuberous Tacca involucrata.

Droscoreace $x$ by Dioscorea prehensilis and other cultivated yams, chiefly in the South or on pagan hills, and by some species which are either wild or escapes.

LiLiaces by several species of Urginea, e.g. U. Nigritiana, $U$. Indica, etc., by other bulbous species of the genera Anthericum, Dipcadi, etc., by the climbing lily, Gloriosa superba, several species of Chlorophytum, Aloe Barteri, and by prickly scramblers such as Asparagus Pauli-Guilelmi, Smilax Kraussiana, etc.

Alismataces by some flowering water-plants, e.g. Burnatia enneandra, Lophotocarpus Guyanensis, etc.

Commelinaceas by various species of Aneilema-A. lanceolatum, A. Sinicum, etc., of Commelyna-C. nudiflora, C. umbellata, etc., and of Floscopa and Cyanotis.

PaLme by the Giginya, Borassus flabellifer, var. Athiopum, the Goriba, Hyphona Thebaica, chiefly in the North, and the Tukuruwa or Bamboo Palm, Raphia vinifera, in ravines only.

AROIDIE by Culcasia scandens, by the Kinchia with yellow rhizome, 


\section{WEST AFRICAN FORESTS AND FORESTRY}

Stylochiton Dalzielii, Amorphophallus Barteri and A. dracontioides, Anchomanes Dalzielii, and other species.

CYPRracex by very numerous species of Cyperus, e.g. the edible Aya, $C$. esculentus, and the uncultivated Aya aya, $C$. rotundus, $C$. Fenzelianus, etc., and several of Pycreus, Fimbristylis, Kyllingia, Bulbostylis, etc.

Gramines by the predominant tribe, Andropogonea, with numerous other genera-Eragrostis, Aristida, Digitaria, Pennisetum, Chloris, etc., and by a single locally distributed bamboo, Oxytenanthera Abyssinica. The chief cereal is Guinea Corn, Dawa, Sorghum vulgare; both species of sugar-cane, Rake, Saccharum officinarum, and Takanda, Sorghum vulgare, var. saccharantum, are cultivated.

The Furces are poorly represented by the widely distributed Adder's Tongue, Ophioglossum vulgatum, the water-fern, Cratopteris Thalictroides, by Adiantum lunulatum, A. Schweinfurthii, and a few species of Nephrodium asplenium, etc., by no means typical of the region.

Having thus given a bird's-eye view of the floral composition in the central region of Hausaland, one may proceed to examine the variations revealed in passing south to the semi-evergreen forests and north to the drier open savannahs.

Southwards the transition is gradual, and nowhere abrupt, from forest savannah with annual bush-fires and consequent tendency to revert to grass, to forests in which the number of species is greater and the deciduous element is more mingled with evergreens, either by the persistence of species which in a drier region are deciduous, but retain their foliage where the increased rainfall allows of this variation, or by the appearance of species which always possess the evergreen habit. Bombax buonopozense is an example of the former and probably also Afzelia Africana and several others.

Some of the added constituents either absent from or more rare in the area of lesser rainfall are :

Aronaces: Xylopia parviflora, Hexalobus Senegalensis, Poporvia Mannii.

Capparidactea : Ritchiea sp., Capparis viminea, etc.

Brxinear : Oncoba spinosa.

Sterculiacese : Cola laurifolia.

RUTAOEA : the Fasa kwari, Zanthoxylum Senegalense.

Menactas : Trichilia retusa.

ANACARDIACEA : Spondias lutea, Hamatostaphis Barteri, and the cultivated mango.

SAPINDACEA : Blighia sapida.

Convaracese : scrambling shrubs, e.g. species of Ageloea and Cnestic. 


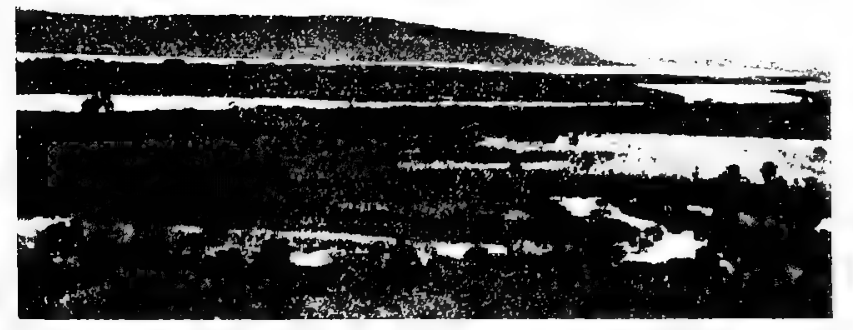

Fio. 38.-Marsh or "Fadama," with islets of foliage, Benné overflow, near Yola.

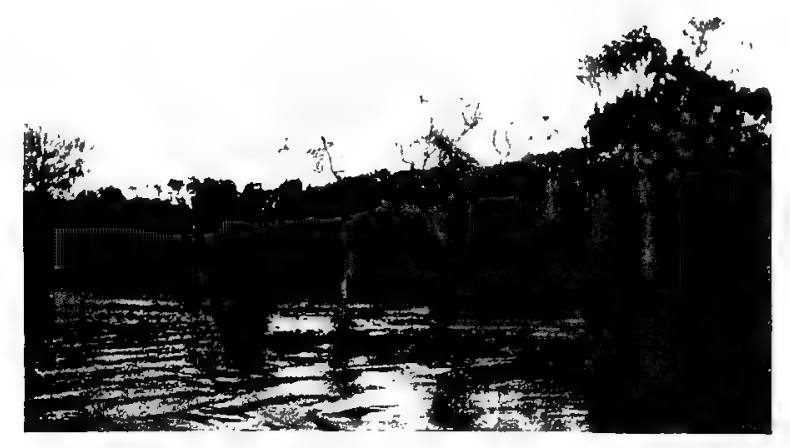

FIG. 39.-The Lower Niger in flood.

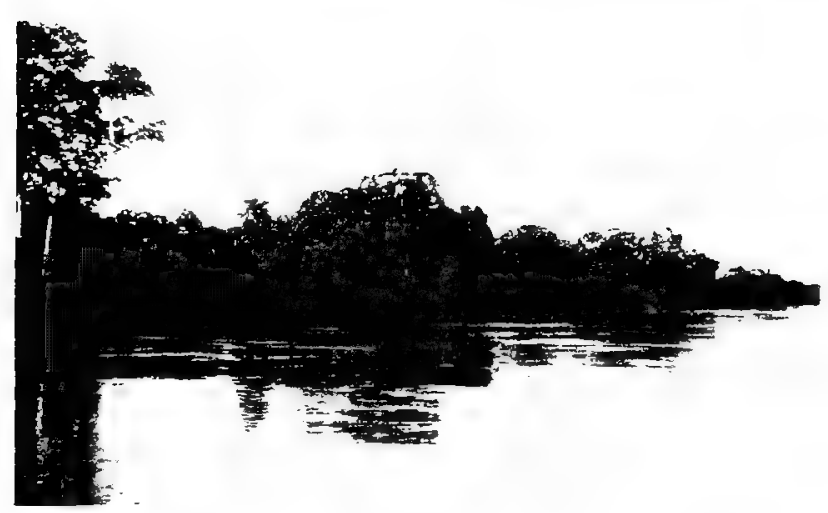

FIG. 40.-Fringing Forest on River Benué in the rainy season.

To tace p 196. 

Leadmnosex: Tetrapleura Thonningii, Piptadenia Africana, Erythrophlcum Guineense, Cynometra Vogelii, Pterocarpus esculentus, Dialium Guineense, Millettia sp. near M. Sanagana and other species of Millettia, Cordyla Africana, Berlinia Heudelotii, Casalpinia Bonducella, Lonchocarpus cyanescens, Baphia pubescens and B. nitida.

ROSACE : Parinarium subcordatum.

Combretace : several species of scarlet-flowered Combretum of climbing habit-C. racemosum, $C$. constrictum, etc.

MYRTACE : Napoleona Vogelii.

ROBIACE : Morinda citrifolia, Cuviera acutiflora, Canthium Vanguerioides, Ixora radiata, Uncaria Africana, Oxyanthus unilocularis, some species of Musscenda, etc.

RHzophoraces : Weihea Africana.

Sapotacese : Mimusops sp.

APOCYNACEA : Voacanga obtusa and V. Africana, Landolphia Owariensis and other spp., Carpodinus hirsuta, Plenisceras Barteri and the tree Wadda, Rauwolfia sp. near $R$. Welwitschii.

Logantacese: Anthocleista Vogelii.

Convolvdlace : Calonyction speciosum, Merremia umbellata, etc.

Bignoniacese : Spathodea campanulata.

Acanthaceze : Acanthus montanus, Asystasia Coromandeliana, etc.

Verbenace : Vitex chrysocarpa and V. Angolensis.

Piperace : Piper umbellatum and Piperomia pellucida.

Gesnerace es : Streptocarpus nobilis.

EUPHORBIACEA : Alchornea cordate, Mallotus oppositifolius.

MORACEA : Chlorophora excelsa, Ficus Vogelii and other spp., Myrianthus serratus.

Ulmacex : Trema Guineensis.

AMPELIDEXE: Leea Guineensis.

POLYGalace : the cultivated Polygala butyracea and the dwarf species, $P$. Clarkeana.

BALANOPHORACEX : the root-parasite Thonningia sanguinea.

Amongst Monocotyledonous Orders the Scitaminea are more in evidence, Palisota thyrsiflora (Commelinacea) appears (along with a Begonia on moist rocks-B. rostrata), and the water-loving Aroid, Cyrtosperma Senegalense.

The Oil Palm, Elceis Guineensis, becomes locally common, ferns become epiphytic, and the Elk's-horn fern, Platycerium Aithiopicum, appears.

Northwards the savannah forests, with plenty of broad-leaved trees and shrubs, or the open park-like formations with surface well covered with grasses and herbs, give way in some places to still drier Acacia forests, and in others to open areas of scrub, nearly treeless, the soil 
possessed by grasses and low, scattered shrubs, often thorny. Nevertheless, good pastures are often to be found, frequented by the Fulani in the comparatively short rainy season, and only at some points towards the French boundary do the conditions approach those described by Barth in the latitude of Zinder and Timbuctoo. For example, part of North Bornu, with a rainfall sometimes not exceeding 10 inches, may exhibit features entitling it to rank with the upper region of Chevalier's "Zone Sahélienne." A typical association in these scrub regions is familiar to the Hausas in three of the plants mentioned below, viz. the Sabarra, Guiera Senegalensis, the Magariya, Zizyphus jujuba, and the Dashi, Balsamodendron Africanum. Sokoto, with an average rainfall of 25 or more inches, still possesses thinly treed savannahs and bush-lands, with a vegetation composed of grasses, small sedges, low shrubs and the commoner leguminous and other weeds.

Nor does the transition occur evenly across the whole region. In the eastern part between Kano and North Bornu the Acacia type prevails, and whole areas may occur occupied largely by Acacia Seyal, with yellow or rusty ochrey bark. On the western side Acacias, though present, do not appear to prevail, and between Kano and Sokoto there exists a stretch of broad-leaved forest in which most of the species found in Central Hausaland reappear, but after all these differences may be found to hold only over limited areas.

The wide and well populated circle around large northern towns, highly cultivated and more or less stripped of trees to supply fuel does not quite display the natural conditions of the bush, where uncontrolled fires prevent natural regeneration of forest on cleared land, and where open grassy formations with stunted vegetation tend to encroach on the higher types of tree savannah.

The species more characteristic of the northern drier belt within the Soudan Zone-if an arbitrary limit is allowed we may place it about $12^{\circ}$ North latitude-may now be briefly indicated; though it will be understood that many of them are already present farther south.

Capparidace : most of the species of Capparis, Boscia and Marua existing farther south here prevail ; the low shrub Boscia Senegalensis is common, while Cadaba farinosa is a characteristic shrub.

Simarobe : the Aduwa, Balanites Agyptiaca, is a typical species of this region.

Burshraces : the Dashi, Balsamodendron Africanum, a shrub yielding African Myrrh, is familiar, with its congener B. pedunculatum.

Rhamnaceas: the Kurna, Zizyphus Spina-Christi, usually planted in towns, the Magariya, Z. jujuba, and the Magariyar kura, $Z$. mucronata, the last two being very characteristic of the open savannah.

Anacardiacese : the Danya, Spondias sp., a fair-sized tree with yellow, plum-like fruit having a leathery rind, is abundant. 
LEGUMrNosa : Acacias are the most typical, but are not as a rule markedly flat-topped, e.g. A. Seyal, A. Senegal, A. albida var. saccharata, Dichrostachys platycarpa, forming thorny thickets, while $E n$ tada Sudanica, Acacia Sieberiana, A. campylacantha, Albizzia Chevalieri and others are also evident. Parkinsonia aculeata is found in towns ; the Tripoli or Senegal Senna, Filasko, Cassia obovata, is common, and the Tsamiya, Tamarindus Indica, becomes a predominant tree.

Rosacese : the Ginger-bread Plum, Gawasa, Parinarium macrophyllum, is more familiar.

Combretacese: the Geza, Combretum sp. near C. altum, a shrub or small tree, with several gum-yielding trees of the same genus; the low shrub Sabarra, Guiera Senegalensis, is perhaps the most typical plant of the nearly treeless savannah.

Corcorbitacese : the half-wild Gurji, Cucumis Melo, var. agrestio, is common, and the Bambus, a variety of water-melon, is known in the North.

RUBIACE e : a characteristic species is Randia Nilotica, a thorny shrub ; Gardenia Sokotensis is a new species found on low rocky hills.

APOCYNACEAs: the Kariya, Adenium Honghel, an unarmed cactuslike shrub, deciduous, with rose-coloured flowers, planted in towns, is characteristic.

AsCLEPIADACE : the small milk-weed, Glossonema Nubicum, and the twiners Oxystelma Bornuense, Pergularia tomentosa and Leptadenia lancifolia, are all abundant, while the Karan masallachi, Caralluma Dalzielii, generally planted farther south, is found wild on bare rocky places.

EUPHORBIACE as : very typical are the two milk hedge Euphorbias, Aguwa, E. sepium, and Fidda sartsi, E. lateriflora.

Morace As: species of Ficus planted for shade grow to a large size, especially the Chediya, $F$. Thonningii, and the Durumi, $F$. syringifolia; other species generally start as epiphytes.

The Gramines is the prevailing Natural Order of Monocotyledons, and includes all types-little annuals, perennial-rooted Andropogons, etc., and the Burugu, Panicum stagninum, which blocks the streams. The fragrant Nobe, Cymbopogon Sennariensis, is a characteristic tufted species, whilst the bur-grass Karangia, Cenchrus catharticus, has long since spread far southward.

Rice and wheat are cultivated ; the Bulrush Millet, Gero, Pennisetum typhoideum, tends to displace Sorghum, and a wild rice, Oryza silvestris, is found. The cultivated sugar-cane is the Takanda, Sorghum vulgare, var. saccharatum.

Of LILIACE $x$ the onion and garlic are features of cultivation. Several bulbous herbs not peculiar to the North are common, e.g. Dipcadi occidentale, Urginea spp., etc. 
The Goriba or Dum Palm, Hyphane Thebaica, is predominant, accompanied also by the Giginya or Deleb Palm, while the Date begins to appear.

Within the limits of the Soudan Zone of vegetation many different types of savannah may be found, besides the expected alterations in botanical groupings resulting from the presence of perennial moisture or due to elevation and rocky outcrop. Leaving the latter out of account, a few notes may be made of some of the varieties familiar to travellers in the Northern Provinces.

\section{Tree Savannah or Savannah Forest.}

Across a considerable area of Central Hausaland, e.g. occupying a large part of the Zaria plateau west of the Bauchi Highlands, the country, where not cleared for farming, is covered with an open deciduous forest of fair height. This is a fairly closely wooded type, and although it contains few truly evergreen elements apart from those lining the streams, there is, perhaps owing to differing vegetative periods for different species and to the double flowering season noted for many trees in West Africa, practically always a fair amount of foliage present. A proportion of the trees have well developed stems and fairly high crowns, with a leafy canopy which filters but never excludes direct sunlight, and the average height of the larger trees is from 30 to 40 feet. In the best developed portions of such forest the grasses do not predominate, but frequent clearings or patches of stony outcrop lead to the open conditions in which hardy perennial grasses take root, and annual burning results in the encroachment and multiplication of areas of the lower bush savannah referred to below.

This variety of forest is typically seen in Zaria province, e.g. between the village of Ruka and the Koriga stream, near which point a sudden drop in elevation occurs, and is familiar in parts of South Sokoto, Kontagora and Nassarawa, ete. Lophira alata has its chief habitat here, but perhaps the prevailing and most characteristic tree is one called Doka, which has been identified as Isoberlinia doka, Craib, et Stapf. It has broad, shining leaves, and large, flat 5-6 seeded pods which dehisce with curling valves. It seeds abundantly, and young seedlings spring up quickly in the forest or by wayside clearings, etc. Along with it will be found its congener, the Fara doka, Isoberlinia Dalzielii, Craib, et Stapf., less abundant, and differing as to its more obvious features in having leaves not shining, a paler grey bark and a general slight degree of pubescence of all parts. Both species exude a coarse red resin, which does not appear to be of value.

Most of the arborescent species mentioned in the list of the average association detailed above are to be found, sometimes harbouring 
epiphytic Ansellias and a few woody climbers but no typical lianes, and an undergrowth composed of Leguminous and Composite herbs and undershrubs with some grasses. This type of forest probably at one time covered a much wider area and had a greater extension northward than at present. As mentioned above, a large proportion of its constituents may again be found in the Duru forest between Sokoto and Kano, while within the memory of officials of the present administration areas of woodland previously visible from Sokoto have been denuded for firewood. It tends progressively to give place to the following more open variety of savannah.

\section{Bush Savannah.}

This is probably the form of " bush" with which travelling officials, hunters, and others are most familiar in every province, and is, when not overloaded with tall grass, deserving of the term "open orchard savannah." It is composed of scattered shrubs and small trees of short growth and of a considerable sameness, the whole picture being practically filled in with grasses, which may grow to a height of 6 to 8 feet in the rains, but which are swept off by bush-fires in the dry period, leaving bare the intervening spaces, soon to be reoccupied by suffrutescent plants with persistent rootstocks, and later by weeds and the same grasses as before. This resurrection is not due to seeding, which is itself abundant, but mainly to the fact that the majority of bush grasses have perennial underground stems, which, once given occupation, are difficult to dislodge, and, assisted by the recurrent fires, which kill off the seeds and the seedlings of broad-leaved trees, have everything in favour of their natural progress to predominance.

The commoner bush grasses of this habit found here are: Andropogon Gayanus, Cymbopogon Ruprechtii, C. diplandrus, C. giganteum, C. hirtus, C. rufus, Andropogon tectorum, A. apricus, Rottboellia exaltata, Pennisetum pedicellatum, etc. In clumps, generally found in special situations, e.g. near river banks, etc., are Vetweria zizanoides, Saccharum spontaneum, Arundo donax, etc. It is possible that some of these species which now cumber the soil might be put to use in supplying the raw material for paper.

The prevailing shrubs and small trees of this formation are generally somewhat as follows : Bauhinia reticulata and B. rufescens, Detarium Senegalense, several species of Combretum with the dwarf $C$. herbaceum; also Afrormosia laxiflora and occasional Acacias, e.g. A. Sieberiana, Entada Sudanica, Dichrostachys nutans; bright flowering species, such as Cochlospermum tinctorium; several shrubby species of Hibiscus Cassia Arereh, C. Goratensis and other species, Lonchocarpus laxiflorus, Securidaca longipedunculata, Grewia mollis, Feretia canthioides; the Gardenias-G. ternifolia, G. erubescens, etc.; Sterospermum Kunthianum, Sarcocephalus Russegeri, Parinarium curatellafolium, Psoro- 
spermim Senegalense, Ximenia Americana, Anona Senegalensis, Pseudrocedrela Kotschyi, Strychnos spinosa and other spp., Bridelia ferruginea, Hymenocardia acida, Gymnosporia Senegalensis. Occasional larger trees will often be species of Terminalia, Prosopis oblonga, Butyrospermum Parkii, Lophira alata, Vitex Cienkowskii, Sterculia tomentosa, Pterocarpus erinaceus, or even Afzelia Africana and Paradaniellia Oliveri.

In the above association remark must be made of the Taura, Detarium Senegalense, which is here rarely of dimensions meriting the designation of tree, and therefore very different from the large timber known in the southern forests and found also on the forested slopes of Patti at Lokoja ; of the Makarfo, a tree of twisted habit, not often over 30 feet high, with flaking bark, apparently much inferior to the Afrormosia laxiflora, if it is this species, in the greater mixed deciduous forests farther south; and of the Tsada, Ximenia Americana, which is here unarmed, has rather thin, glabrous leaves, sometimes almost shining, and thus differs in habit from the coastal variety, if the identity is certain, which is spiny, has dull leaves sometimes half-succulent, and is appropriately called by the French "Citron de la mer."

\section{Park Savannah.}

The open park-like formation is another which is typical of this region. It is, perhaps, best seen where the population is not quite sparse, as in the latter case the previous type tends to take possession. The Shea Butter Tree is the one which more than any other gives the tone to this type, but Parkia filicoidea and, especially in the North, the Tamarind are perhaps equally representative. The two first-named, though not necessarily indicating the proximity of a village, have probably in most cases owners, and the intervening spaces may or may not be more or less cultivated. Open park-like country may, however, occur apart from any contemporary interference by man, and wide stretches of it appear alternating with scattered orchard bush or with open grass-land. The grasses are of the previously mentioned types, with many species of Eragrostis, Aristida, small annual tufted grasses and sedges, along with Cassia mimosoides, Oldenlandia grandiflora, $O$. Senegalensis and other Leguminous and Rubiaceous weeds. Other trees which well maintain the park-like appearance are Terminalia macroptera, occasional species of Ficus, Vitex Cienkowskii, Acacia Arabica and A. Sieberiana.

In flat, wide-stretching meadows which are often marshy in the rains, this formation also maintains its character, single trees or island-like clusters of tree and shrub dotting the expanse of heavy grass which is burnt to desolation by the yearly fires. These islets are generally found to be composed of Giyaiya, Mitragyne Africana, with shrubs such as Feretia canthioides, Sarcocephalus Russegeri, and 
scrambling undershrubs added thereto, while the edge of such a meadow or "fadama" is in some cases fringed with deciduous high woods, in which occasionally timbers like Khaya Senegalensis and Paradaniellia Oliveri may appear along with the vegetation characteristic of Type 1 .

\section{Evergreen Fringing Belts.}

Along the water-courses which intersect the savannah lands will be found dark evergreen strips of foliage, which, when extending beyond the stream-banks and forming a fairly dense canopy, whatever the nature of the underwood, are generally implied in the Hausa word "kurumi." The streams may not be always truly perennial, but the verdure remains because the moisture in the soil persists long enough to maintain the non-deciduous type, although bush-fires may reach their very margins. Where a perennial stream of any magnitude occurs, species will be found whose distribution in the Soudan Zone is confined to such localities, but which are widely represented in the South.

Instead of enumerating the constituents of these strips of fringing forest, we may briefly refer to the vegetation of the River Benué, which has been already indicated as in some degree marking the boundary between the semi-evergreen or mixed deciduous forests and the drier tree savannah and open bush lands. The evergreen galleries along the streams or fringing the swampy glades may be taken as on the whole botanically similar to the bank foliage of the Benué and its backwaters, creeks and tributaries. One feature of this type is the abundance of woody climbers, often concealing the foliage of their supports, and conspicuous to the eye in the flowering season are the Combretacea, which are here scrambling and climbing shrubs instead of erect trees, e.g. the flame-flowered Combretum racemosum, C. constrictum, etc., Quisqualis Indica and others; also two or three species of Landolphia with other rubber vines, and of Mussanda, scarletfruited Connaraceer, Uncaria Africana, climbing by its old flower-stalks becoming woody hooks, and Alchornea cordata, the most typical liane of these formations. Other twiners are the showy moon-convolvulus, Calonyction speciosum (Ipomcea bona-nox), the Cowhage, Mucuna pruriensis, Dioclea reflexa, Entada scandens and numerous Ampelidece. These tend to form a dense and sometimes impenetrable tangle, but where trees of timber size occur the undergrowth is more scanty and a variety of forest weeds appear, in which the Scitaminece may be prominent.

The Benué region is rich in trees, of which the following species may be mentioned : Goron ruwa, Irvingia Smithii, and Gedar kurumi, Pterocarpus esculentus, Trichilia retusa, the large timber tree called Kiriyar kurumi (undetermined), Erythrophlocum Quineense, Millettia sp., Sanagana and M. sericeus, Cynometra Vogelii, Anthocleista 


\section{WEST AFRICAN FORESTS AND FORESTRY}

nobilis, Berlinia Heudelotii, Baphia nitida, Chlorophora excelsa, Cola laurifolia, Parinarium subcordatum, Kigelia Aithiopica, Uapaca Guineensis (here a large tree and sometimes prop-rooted), Ficus spp. Smaller trees and shrubs are : Spathodea campanulata, Voacanga obtusa and V. Africana, Morinda citrifolia, Xylopia parviflora, Zanthoxylum Senegalense, Oncoba spinosa, Vangueria euonymoides, Ixora radiata, Polyspharia macrostyla, Garcinia ovalifolia, Myrianthus serratus, Elais Guineensis and Raphia vinifera. Not all of these extend far beyond the Benué, but the majority of them will be found in one or other fringing belt far into the deciduous region, and perhaps the two which best represent this extension of the semi-evergreen to the savannah are the woody climber Alchornea cordata and the tree Irvingia Smithii.

In a general view, Northern Nigeria, thus lying beyond the equatorial belt, possesses plant features which, apart from river and stream fringes, range between the mixed deciduous and xerophilus habit, and in the dry season the prevailing character of the open savannah forests is a monotonous drab or grey, intersected by the dark lines of greenery following the streams or encircling the swamps. The climate is largely of the continental type, with a temperature ranging from $120^{\circ} \mathrm{F}$. to $40^{\circ}$ or less (exclusive of thermometer readings on the Bauchi plateau), and a rainfall which throughout will usually fall between 30 and 50 or 60 inches, with diminution to 20 or even 10 inches in the most northerly provinces. Such a climate, with the concomitant regularity of two, not four, well marked seasons, the dry and the wet, is entirely that associated with the occurrence of savannah formations, scattered bush with prevailing grasses, suffrutescent herbs and small trees, much open grass or thinly timbered park-land, with stretches of thick woods which are generally not heavily grassed and never cumbered with impenetrable undergrowth.

Trees which are valuable timber species in the moist southern forests often scarcely attain reputable dimensions in the deciduous zone.

These conditions also, which are doubtless partly the result of illconsidered human operations, put certain definite restrictions on cultivated species and determine the character of the natural products of the wild. The staple cereal is Dawa or Sorghum, instead of maize, with Gero or Pennisetum typhoideum in the North. Possibly the limit of Guinea Corn as a staple of native cultivation is also the limit of the savannah forests, i.e. of the region of trees of secondary size, short of the region of Acacias, of Geza, Combretum altum, and of scrub, where Bulrush Millet is the commoner. Both species are generally cultivated along with beans, Vigna Sinensis. The sweet potato displaces the yam and cassava; industrial cultivation is represented by cotton and indigo. Of forest products, the most representative are Shea nuts and gum arabic, rather than rubber and large timber; and lastly, both 
cattle-grazing and horse-breeding are important industries proper to the region.

\section{Some Trems of Hadsaland}

By Dr. J. M. Dalziel.

A few notes on some of the better known trees of Northern Nigeria are here given, the Hausa name being appended in most cases.

Afrormosia laxiflora, Harms (Leguminosæ). Makarfo.

In the mixed deciduous forests towards the coast this appears as a large timber tree, in certain regions dominant both in abundance and size, and is also a constituent of the moist evergreen forests. In Northern Nigeria it never forms a straight stem, never attains the dimensions of a timber tree, and has generally a twisted stem and main branches. Its habit, therefore, rather than its mere presence, affords a striking instance of the changes accompanying the limited rainfall of the savannah forests, and its distribution probably does not extend beyond the northern boundary. The trunk has a somewhat pale piebald appearance, resulting from the flaking of large pieces of the bark exposing lighter portions below. The centre wood is so dark in colour as to have led European foremen of works to report it as lignum vitæ, and the wood is hard enough to earn for it in some districts, along with other trees, the designation "break axe." It has shining leaves, whitish flowers and thin, flat pods.

Afzelia Africana, Sm. Kawo; "African " or " Rhodesian " Mahogany, "Mahogany Bean," etc.

A large tree, common to nearly all types of forest in West Africa, tropical high forest, mixed deciduous and savannah. In Northern Nigeria large specimens may still be found, though these do not generally have tall, straight stems, but show' the wide-spreading umbrella crown common in drier regions.

Paradaniellia Oliveri, Rolfe. Kadaura or Maje.

This has previously been classed with Daniellia thurifera, Bennett, the so-called West African Copaiba Balsam Tree.

In the Northern Provinces of Nigeria it is one of the largest trees, 50 to 80 feet, with strong, straight stems and affording good timber for local use. The chief native use of the oleo resin is to fumigate garments. Its distribution probably stops short of the northern boundary.

Isoberlinia doka, Craib, et Stapf. Doka.

A tree which is the prevailing type in the savannah forests of Central Hausaland, generally 30 to $\mathbf{4 0}$ feet high, with broad, shining 
leaves, rather small white flowers and large flat pods containing five or six discoid seeds. The valves of the pods curl up after dehiscence, and young seedlings spring up vigorously where not choked by grass, farm clearings in Zaria province being often quickly occupied by them. bark.

A coarse red resin exudes from injuries or punctures of the

Isoberlinia Dalzielii, Craib et Stapf. Fara doka.

Another new species of similar occurrence and habit, differing in having a more grey appearance associated with a slight pubescence, leaves not shining and pods less smooth. A species of the wild silkworm, Anaphe Moloneyi, and perhaps others, are found on them.

Pterocarpus erinaceus, Poir. Madobia ; "Senegal Rosewood,"
"African Kino," etc.

A tree generally of $\mathbf{3 0}$ to $\mathbf{4 0}$ feet or more in open savannah forests, easily recognized by its bright yellow flowers, the regular venation of the leaves, and the bristly, flat, one-seeded pods. The blood-red resin is a variety of Kino, and in districts where the Camwood is not found, the bark of Madobia is sometimes sold as a substitute. The wood is hard and fine-grained.

Cassia Sieberiana, DC. and C. ; Kotschyana, Oliv. Marga or Gamafada.

These are small trees with conspicuous yellow flower racemes, having a superficial resemblance to laburnum. They are abundant in the dry savannah regions as well as in savannah forest, and flower freely in the dry season. The pods are long and cylindrical and do not dehisce. Cassia Arereh, Del., is similar, but the leaves are more acuminated and the pods split up longitudinally.

Detarium Senegalense, Gmel.' Taura.

A good timber tree in the mixed deciduous and higher savannah forests, as also in the mountainous peninsula of Sierra Leone. Fairly large specimens of timber dimensions occur in the rocky forest overlooking Lokoja, but the Hausa Taura, hitherto identified as botanically the same, is of a very different habit, abundantly represented in the open bush savannah as a shrub or small tree having somewhat flattened fruits, oval, less succulent than, and one-half or one-third the size of, those shed by the forest specimens.

Tamarindus Indica, Zinn. Tsamiya; "Tamarind Tree."

A very familiar tree in the northern Hausa States and Bornu, as well as in French territory to the north, but much less common on parts of the border-line between Southern and Northern Nigeria, so that probably its actual distribution is local and interrupted. Barth 
places its limit at Tagalel, in Damerghu, or about $15^{\circ}$ North latitude.

In Hausaland it is a conspicuous tree, less from its dimensions than from the beauty of its foliage, sometimes umbrella-spreading and at others compact, and giving a good deal of shade when in full leaf. The ground becomes littered with the small leaflets in the dry months, and as a rule little undergrowth is to be found beneath it.

In Sokoto and Kano provinces, and elsewhere in the North, specimens with a dense, compact and symmetrical crown are common, the branches often reaching to within 3 or 4 feet of the ground. The fruit has familiar medicinal and culinary uses, but rarely develops the soft rich pulp of the Indian specimens. One of the wild silkworms, Anaphe $s p$., feeds on the leaf, the silken nest being called "Tsamiyar Tsamiya." A familiar association which did not escape the notice of Dr. Barth is that of tamarind and baobab, in which case the former is often without a proper bole and spreads itself half scandent amongst the stout branches of the baobab.

Parkia filicoidia, Welw. Dorowa ; "West African Locust Bean."

A characteristic tree of the savannah forests, and one of the most typical members of the open park-like formations. It appears to be scarce in Bornu, but abundant from Zaria to Katsina, and its northern limit is probably about $14^{\circ}$ North latitude.

The pods afford both food and fodder, the fermented cakes called Daudawa, made from the seeds, being an article of local commerce. In the bush, far from villages, Dorowa trees are ownerless, but elsewhere they are generally private property.

Burkea Africana, Hook. Farin makarfo.

A tree of 30 to $\mathbf{4 0}$ feet, of irregular distribution in open savannah forests, fairly common between Yola and Bornu as well as in Southern Sokoto. It has light, silky foliage, flowers in pendulous, creamy spikes, and dark, almost black, bark. The hard wood is used for handles of axes and hoes.

Prosopis oblonga, Benth. Kiriya.

A common tree of the savannah region, extending beyond the Anglo-French boundary, but better developed in the Benué region, where fair timber specimens occur. The wood is hard, with red centre wood, and takes a beautiful polish. It is recognized by its acacialike foliage, spikes of creamy flowers and stout brown pods, with seeds sometimes used like those of Dorowa.

Bauhinia reticulata, DC. Kargo.

A shrub or small tree, one of the commonest constituents of the bush savannahs; readily recognized by the cleft leaves, rusty bark 
and flat, twisted pods. The tough bark forms an emergency tie-tie, and its long vast fibres furnish strong cordage, which is its chief use in Northern Nigeria. The bark and leaves, containing tannin, have astringent uses.

Acacia Sieberiana, DC. Fara kaya, or "White Thorn Acacia."

A very widely distributed species in the déciduous zone, not usually gregarious and occasionally flat-topped. It is easily recognized by its generally dark foliage and pale bark, the flowers not yellow, but in small, creamy-white balls, and by the long white thorns. It yields a soluble gum, which is perhaps not of the best quality.

Acacia Arabica, Willd. Bagaruwa; Indian "Babool."

One of the commonest species, especially in the northern Hausa States and Bornu, and a source of gum arabic. The flowers are in bright yellow balls and the foliage is a good camel food. The jointed pods are "Sant" or "Gambia" pods, used all over the Soudan for tanning.

Acacia Senegalensis, Willd. Dakwora.

Usually only a shrub, not often over 10 feet, sometimes gregarious, and characteristic of the thin bush savannahs; it has grey bark, flowers in white spikes, and three sharp recurved stipular heo at. the base of each leaf.

This species yields probably the best gum from Senegal to $\mathbf{S}_{3}$. and the root-bark affords a very tough fibre.

Acacia albida, Del., var. saccharata, Benth. Gawo.

A fair-sized tree, confined to the open dry country in the North, extending into French territory, and an important camel food, but not a gum yielder. The flowers are in creamy-white spikes and the pods are yellow and twisted. It is peculiarly deciduous in the wet season, and bursts into foliage just at the cessation of the rains.

Acacia Seyal, Del. Dussa ; "Talh of the Soudan."

A rather small tree, not often over 20 feet, but gregarious and very abundant in North-east Hausaland and Bornu, less common, but local, in Sokoto, etc. It has a yellow or ochrey bark, white thorns and brilliant yellow balls of flowers, and the pods are narrow, sickle-curved and constricted between the seeds. The gum is of good quality, but not equal to that of $\boldsymbol{A}$. Senegal.

Acacia campylacantha, Hochst. "Farichin shafu" (=Falcon's claw).

A fairly tall tree with white flower-spikes and strongly curved spines suggesting the native name. It is sometimes gregarious in limited forest patches, and the gum is said to be good in colour, cleanliness, etc. 


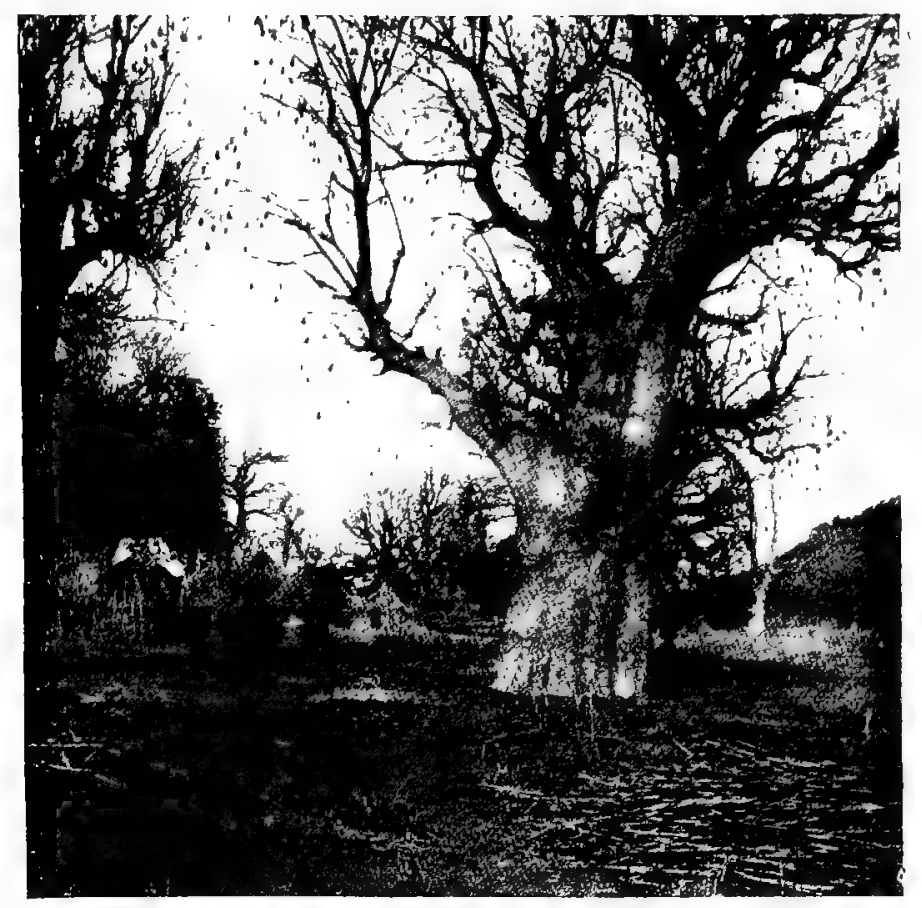

FIG. 41.-A Baobab (Adansonia digitata)

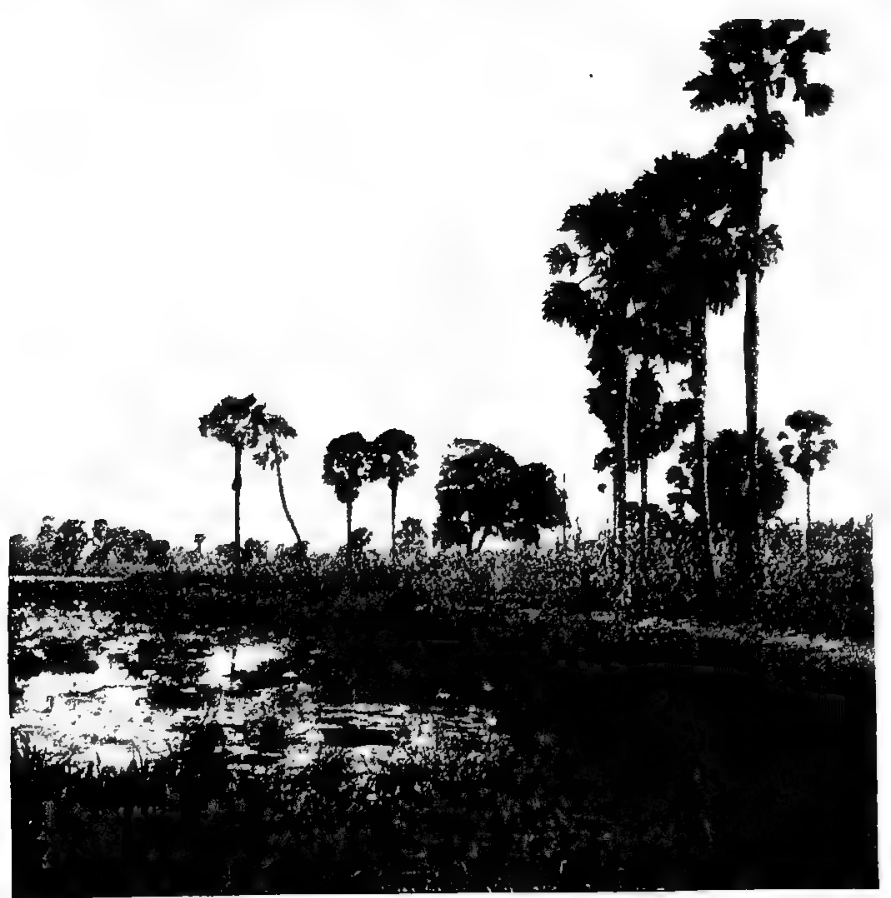

FIG. 42.-Giginga or "Fan Palm" (Borassus flabellifer, var. Exthiopum); with Water-lilies (Nympbreaceæ).

To tace p. 208. 

Albizzia Chevalieri, G. et P. Katsari.

A tree of $\mathbf{3 0}$ to $\mathbf{4 0}$ feet, common in the more open savannah formations, especially in the northern districts. It has whitish flower-balls, with long, pinkish stamens and thin, flat pods. The bark is sometimes used for tanning.

Entada Sudanica, Schweinf. Tawatsa.

A small tree of the savannah forests and open plains, easily distinguished by the peculiar jointed pods, each embossed seed section falling out and leaving the empty marginal frame. The flowers are in yellowish axillary spikes, generally two or three together.

\section{Mimosa asperata, Linn. Kaidaji.}

Forms dense thorny thickets fringing the open bush streams. The flowers are in pinkish balls, and the leaves possess the sensitive quality in a mild degree.

Lophira alata, Banks (Ochnaceæ). Mijin kade.

An "African Oak" and one of the most familiar trees of the savannah forests and open country. It is apparently very similar to Lophira procera, the " Red Ironwood" timber tree of the southern forests ; frequently stunted by forest fires. The seeds yield an oil and the bark is medicinal. The flowers are in handsome white panicles, appearing about November or December, and the leaf and habit often give it an appearance resembling the Shea Butter Tree, but the leaf is beautiful and finely veined. An extraordinary fact is the widespread belief of pagan tribes in the efficiency of the leaf as a charm.

Eriodendron orientale, Steud. (Malvaceæ). Rimi ; "Silk-cotton Tree."

A giant in the evergreen forests, and still a comparative giant in the dry zone. In Northern Hausa towns the only very tall trees are Rimi ; the wood is light and the stems are sometimes hollowed out for canoes : the floss of the seeds is Kapok, and has the usual local uses. Barth says its distribution eastwards stops at $11^{\circ}$ East longitude, and that it is therefore absent from Bornu proper.

Northwards it apparently scarcely extends beyond the AngloFrench boundary.

Bombax buonopozense, Beauv. Gurjiya; "Red-flowered Silk-cotton Tree."

A member of the evergreen forests, but quite a common tree of the open country and savannah forests, sometimes more or less gregarious, and extending at least beyond the Anglo-French border. It reaches about $\mathbf{4 0}$ feet or more in height, with crowded spines on the bark and tulip-like red flowers appearing during the deciduous period, generally after the middle of December and in January. 


\section{WEST AFRICAN FORESTS AND FORESTRY}

Adansonia digitata, B. Juss. Kuka ; "Baobab."

A characteristic tree of the dry savannah regions, often grouped in inhabited areas, with enormously stout stems, but in height limited to 40 to 60 feet. Specimens of 30 to 40 feet girth are not quite uncommon, the swollen stem, with soft, spongy wood, being an adaptation to a dry climate, by storing water to meet excessive transpiration by the leaves.

The bark is smooth and often has a shiny purplish tinge. Apart from fibre from both bark and wood, the dry fruit pulp and the seeds are prepared in various ways as food and drink. Large specimens are still found at Maradi, north of the Sokoto boundary, but chiefly stunted trees are met with at Zinder.

Sterculia tomentosa, G. et P. (Sterculiaceæ). Kukuki.

A member of the semi-evergreen forests and common also in the dry zone as a medium-sized tree with soft, palmate-shaped leaves and pods four or five together, splitting to expose the black seeds with yellow arils. A watery juice from the bark refreshes thirsty travellers and a kind of gum tragacanth exudes from the trunk.

Hannoa undulata, Planch. (Simarubeæ). Namijin gwabsa or Takandar giwa. (One of two species called by the latter name, vide Cussonia.)

A common tree of no great size in the savannah forest. The leaves are pinnate, with five to seven leaflets on long stalks, the flowers, in creamy, fragrant panicles, appearing in October or November, and the fruit is a black plum with unpleasant taste.

Irvingia Smithii, Hook. fil.

A tree of evergreen and mixed deciduous forests which invades the ravines and fringing belts in the savannah region as far at least as Kontagora. In the Benué region it is a fairly large tree of 40 feet or more, often gregarious, as in a patch of moist forest opposite Katsina Allah, along with Pterocarpus esculentus. The scarlet fruits are known as Goron ruwa or Goron biri (i.e. Water or Monkey Kola), and are eaten by monkeys.

Balanites Algyptiaca, Del. Aduwa; "Desert Date."

Typical of the Soudan and of the northern drier provinces of Nigeria and extending into French territory; characterized by its bifoliate deciduous leaves, spiny habit in dry soil and evergreen bark. The yellow oval fruit has a thin layer of sugary, bitter-sweet pulp, and the kernel yields Betu oil.

Boswellia odorata, Hutch., and B. Dalzielii, Hutch. (Burseracem). Hano or Ararabi.

Two new species of "Frankincense Tree," yielding a fragrant 
gum resin. They reach 30 feet or so in height, have white bark which peels off in thin sheets, racemes of white flowers and pinnate leaves with serrate leaflets.

Commiphora Kerstingii, Engl. Dali or Bazana.

A small tree, commonly used as a fence support around native compounds. The bark is smooth and green, and the soft wood can be hollowed out for quivers.

\section{Balsamodendron Africanum, A. Rich. Dashi.}

A shrub commoner in the northern regions, extending beyond the Anglo-French boundary. In arid regions it forms a good hedge, with some resemblance to the blackthorn. The leaves and bark are fragrant, and it yields a gum resin which is a variety of African myrrh.

Khaya Senegalensis, A. Juss. (Meliaceæ). Madachi; "West African Mahogany" of the dry zone.

A large tree for the dry savannah region, but one of the smaller of the mahoganies. In the North, where dry conditions prevail, it tends to favour the banks of streams or the edges of marshy meadows, and is never buttressed, but often acquires a good spreading crown. Good timber specimens have been found on the Gurara River, but apart from this, and perhaps some other favoured localities, it does not as a rule exceed about 4 feet to $4 \frac{1}{2}$ feet in girth. It occurs from Gambia to Nigeria and Kamerun, and is again found as a West African element in the flora of Uganda and Mozambique. Northwards it reaches North Sokoto, but apparently does not extend to Zinder. The bark is a reputed bitter tonic in native medicine.

Pseudocedrela Kotschyi, Harms. Toman or Tonas ; "Dry-zone Cedar."

In Northern Nigeria this is rarely more than a small to mediumsized tree of 20 to 30 feet, and not usually of good straight growth, probably from the effect of annual fires, but yielding a fine wood. The leaflets are undulate-margined, the flowers are in graceful panicles, appearing about February and March, and the dry, erect capsules, full of winged seeds, split from above downwards in five valves. Occasionally little copses of the species occur, as it seeds freely and numerous seedlings arise-most of them, however, doomed to perish in the next bush-fire. In protected localities it might be fostered into a useful timber tree. Natives find various medicinal uses for the bark.

Trichilia emetica, Vahl. Jan sayi.

A fairly common tree across Centrad Hausaland, not often much over 20 feet in height. It has medicinal properties; the white flowers are fragrant and used to rub the teeth, and the seeds yield a less important oil. 


\section{WEST AFRICAN FORESTS AND FORESTRY}

Trichilia retusa, Oliv.

A large timber tree with tall, straight stems, found in the Benue region. The flowers are white, appearing about January, in axillary racemes or below the leaves; the leaflets are generally five or three, with wide, shallow indentation at the tip.

Odina Barteri (Anacardiaceæ). Faru.

A fair-sized deciduous tree of the savannah forests, with pinnate pubescent leaves and inconspicuous flowers in pendulous, clustered racemes. It yields a sort of resin, and the small fruits, tipped with four sharp points, are eaten by birds.

\section{? Spondias sp. Danya.}

A very common tree of the drier savannah forests, very abundant in the North; it has light foliage of pinnate leaves with small leaflets and a yellow, very pleasantly flavoured fruit, with a tough rind like that of the mango. The fruits litter the ground in the months of May and June. The wood is very hard and used for making a heavy kind of basin known as akushi.

Anogeissus leiocarpus, G. et P. (Combretaceæ). Marike.

This is one of the "Chew-sticks" of Yoruba, and while occurring in fringing forests and evergreen patches, it is very common in the open savannah regions, but probably does not extend beyond the northern boundary. It may be $\mathbf{5 0}$ feet in height, and possesses light, graceful foliage, pale bark and small yellowish flowers in globose heads, forming tiny dry two-winged fruits. It affords an inferior gum and is much used medicinally.

Terminalia sp., near T. macroptera, G. et P. Baushe.

A fairly large tree, 40 feet or more in height, with the oval winged and embossed fruits of the genus, along with its congeners, e.g. $T$. Elliotii, Engl. and Diels, T. Baumanii, Engl. and Diels, etc., very abundant and typical of the savannahs of Northern Nigeria. Bows and sticks are made from the roots.

Terminalia macroptera, G. et P. Kandari.

A smaller tree with much broader leaves, typical of open parklike formations.

\section{Combretum spp.}

Several arborescent species of Combretum are truly characteristic of the open and bush savannahs, and are well represented even in the northern parts, where, however, in some districts, they are replaced by Acacias. They are practically all gum-bearing; the flowers are small and yellowish in axillary spikes, but the genus is generally 
easily recognized by the fruits having four papery wings and the usually whorled arrangement of the leaves. The Northern Nigerian species have not all been fully determined, and the native names are at present somewhat confused and may include more than one species. Most of them in this region are shrubs or small trees, occasionally reaching 30 feet or so, with smooth or hoary foliage. The Taramniya is generally $C$. leonense, Engl. and Diels; the Chiriri of Sogoto includes probably C. Hartmannianum, Schweinf., and other species; the Dalo is C. glutinosum, Perr., or near it.

Parinarium curatellofolium, Planch (Rosaceæ). Rura.

A small tree, very common in the bush and forest savannah, usually only about 10 to 15 feet high, with pale leaves and a dry, pear-like fruit. Of its congeners, $P$. macrophyllum, Sabine, the Gawasa or Gingerbread Plum, is its representative in most northerly provinces, and $P$. polyandrum, Benth., with grape-like bunches of purple not edible fruit, is common in the southern parts of the deciduous region.

Eugenia Owariensis, Beauv. (Myrtaceæ). Malmo.

A small tree, generally about 20 to 30 feet in height and always found in moist places, by streams, etc. It has shining, odorous foliage, white, fragrant flower-clusters, and a small black-purple, succulent fruit.

Cussonia Nigerica, Hutch. (Araliaceæ). Gwabsa or Takandar giwa.

A new species, occurring in the open and bush savannahs as a small tree from 10 to 15 feet in height, with peculiar bare, raking branches, producing at their ends clusters of digitate leaves or of long catkinlike spikes of inconspicuous flowers. Incisions in the rough, fissured bark yield a clear gum. (For the native name compare Hannoa undulata.)

Cratceva Adansonii, G. et P. (Capparideæ). Ingidido.

A small tree, occasionally 20 feet high, fairly abundant in the North, of local distribution and common in towns. The leaves are trifoliate and can be used as a vegetable; the flowers are white and the fruit yellow, spherical, and about the size of a small orange.

Zizyphus spina-Christi, Willd. (Rhamnaceæ). Kurna.

A small tree characteristic of the dry open regions and commonly planted in northern towns. It is generally about 10 to 20 feet high, spiny, with leaves three-nerved, and a rather dry, edible berry of pleasant taste.

Z. lujuba, Lam., is the Magariya, and is similar, but in these regions generally has less of a stem and is more shrubby and thorny, and is not, as a rule, planted, though the fruit is even pleasanter. 


\section{WEST AFRICAN FORESTS AND FORESTRY}

\section{Sarcocephalus Russegeri (Rubiaceæ). Tafashia.}

A shrub, or occasionally a small tree, common in moist meadows, but found also in the open dry bush. The flowers are in rather large creamy balls, and the coarse red, succulent fruit is the analogue of the Sierra Leone peach, S. esculentus, Afzel, which grows to a large tree in the evergreen forests.

\section{Mitragyne Africana, Korth. Giyaiya.}

This is a characteristic tree of swampy areas in the deciduous regions, found by streams and marshes or forming island-clumps with a few lesser shrubs and weeds in the grassy meadows, which dry up in the rainless months. It is generally from 20 to 30 feet in height and has close, spherical heads of whitish flowers and smooth, but not shining, leaves with regular venation.

\section{Crossopteryx Kotschyana, Fenzl. Kasfiya.}

A small tree of 15 to 20 feet, with foliage resembling that of Giyaiya, bunches of whitish flowers, and abundant small black, pill-like fruits, which remain attached long after they are ripe.

Adina microcephala, Hiern. Kadanyar rafi.

A fairly tall tree of $\mathbf{3 0}$ to $\mathbf{4 0}$ feet, found in stream-banks in the savannah region. It has whitish balls of flowers and tapering smooth leaves.

Morelia Senegalensis, A. Rich. Innuwar bauna.

An evergreen shrub 10 to 20 feet high, common on stream-banks, and found both in the semi-evergreen forests and in the fringing belts of the deciduous region. The flowers are white and somewhat fragrant, and the fruit is spherical, tipped by the tubular remains of the calyx.

Butyrospermum Parkii, Kotschii. (Sapotaceæ). Kadanya; "Shea Butter Tree."

A typical tree of the savannah hinterlands, and one which gives the park-like character to many parts of Northern Nigeria, it barely extends to the northern boundary, and is rarer on the Bornu side. It is generally 25 to 30 feet high or more, with a dense crown and a curiously corrugated bark. Flowers, in white, head-like clusters generally appear about December. The brown, chestnut-like kernels are ripe about July. The milky juice and the coarser venation of the leaves readily distinguish this tree from Lophira alata.

Diospyros mespeliformis, Hochst. (Ebenaceæ). Kanya or Kaiwa; "African Ebony."

A fairly large tree, up to about 40 feet in height, in the savannah forests and open country, extending north to beyond the Anglo-French 
boundary, larger in the mixed deciduous forests farther south and in fringing evergreen belts. The foliage is dark and the bark blackish; the inconspicuous whitish flowers, of separate sexes on different trees, are attractive to bees. The wood is white, with a black heartwood, and the spherical yellow fruits ("Monkey Guava") have a crisp rind and sweet edible pulp, with four or five seeds.

Strychnos spinosa, Lam. (Loganiaceæ). Kokiya.

A small thorny tree with opposite three- to five-nerved leaves, conspicuous by its round yellow fruit, which is orange-like, but has a hard rind and flat seeds embedded in a pleasant acid edible pulp.

Cordia Abyssinica, R. Br. (Boragineæ). Aliliba.

A shrub or small tree with broad leaves and white flowers, valued for the sweet yellow berries, which are used in making sweetmeats.

Kigelia Athiopica, Decne.; var. Bornuensis, Sprague (Bignoniaceæ). Rahaina or Rawuya.

A species of "Sausage Tree," of irregular distribution in Northern Nigeria, known in Solzoto, etc., but commoner in the Benué region and in Bornu (possibly more than one species occurring). It grows to a fairly large size, with dense foliage and pendulous racemes of lurid purple and spotted flowers and large, yam-like fruits.

Stereospermum Kunthianum, Cham. Jiri or Sansami.

A small tree of the savannah forests, with smooth pale bark, beautiful pink caducous blossoms and long slender pods.

Vitex Cienkowskii, Kotschii et Peyr. (Verbenacea). Dinya.

A fairly large tree, chiefly of open forest country and extending at least as far as the Anglo-French border. The bark is somewhat smooth, the crown of digitate leaves fairly dense, and the black, damsonlike fruits are used in making molasses and sweetmeats. The natives value the wood as strong and suitable for local use.

Uapaca Guineensis, Muell. Arg. (Euphorbiaceæ). Ka Jafogo.

In the open country a rather small tree, with the habit of a Ficus, but becoming a large tree, sometimes prop-rooted, in the Benué region and in some ravines.

Chlorophora excelsa, Benth. and Hook. (Moracex). The "Iroko" or "Odum."

Some of the splendid Nupé canoes are made of this, but the tree really belongs to the southern forests, though it occurs in the Benué region and perhaps in some northward extensions in river valleys. 
Celtis integrifolia, Lam. Zuwo or Dukki.

This is a fairly large tree of the savannah forest region, found as far north at least as Sokoto. The leaves are edible and are used as fodder.

\section{Ficus or Urostigma spp.}

This genus has not yet been fully elaborated, and the native names cannot in all cases be definitely applied to distinct botanical species. The following appear to be fairly established: Chediya, Ficus Thonningii, Bl., one of the commonest shade trees, planted in towns and abundant far North in French territory; Durumi, $F$. syringifolia, Warb., perhaps equally common, with shining heart-shaped and pointed leaves; Baure, F. gnaphalocarpa, A. Rich. (the rough-leaved species with soft figs which are sometimes considered edible); Uwar yara, F. Capensis, Thunb. (sensu lato), recognized by the wavy or indented-margined leaves, and especially by the figs being borne in dense clusters on the trunk; Gamji, F. platyphylla, Del. (the source of "Red Kano Rubber" and the host of one of the wild silkworms, Anaphe sp.). Kawuri probably includes $F$. lawuri, Hutch., and $F$. glumosa, Del. Wa is a species with broadly cordate leaves, strongly veined, and Shirinya is a narrow-leaved species. F. Vogelii, Mig., is a glossy-leaved rubber-tree, more abundant in ravines and in the moister forests farther South.

The Gamji and Shirinya, and perhaps some of the others, almost invariably begin life as epiphytes.

Most of the species have abundant aerial rootlets, and the latex of $F$. Vogelii, of Gamji, and perhaps of Kawuri and Shirinya, yields rubber of varying quality.

Raphia vinifera, P. Beauv. (Palmeæ). Tukuruwa ; "Bamboo Palm," "Wine Palm."

This well-known palm is found in ravines in the savannah region as far as Zaria province, but is a proper member of swampy patches and moist forests of the South. Roofing poles and palm-wine are its products most used in the North.

Borassus flabellifer, var. Asthiopum, Warb. Giginya; "Deleb," "Palmyra" or "Fan Palm."

The most characteristic palm of Hausaland, with tall, straight and often beaded stems. The germinating shoots from the planted nuts are a vegetable called muruchi, and the wood and leaves have the familiar uses in house-building, mat and basket weaving, etc.

Hyphone Thebaica, Mart. Goriba ; "Dum " or "Gingerbread Palm."

The typical palm of the more northerly Hausa provinces, characterized by its forked stems and obliquely fan-shaped leaves. The kernel 

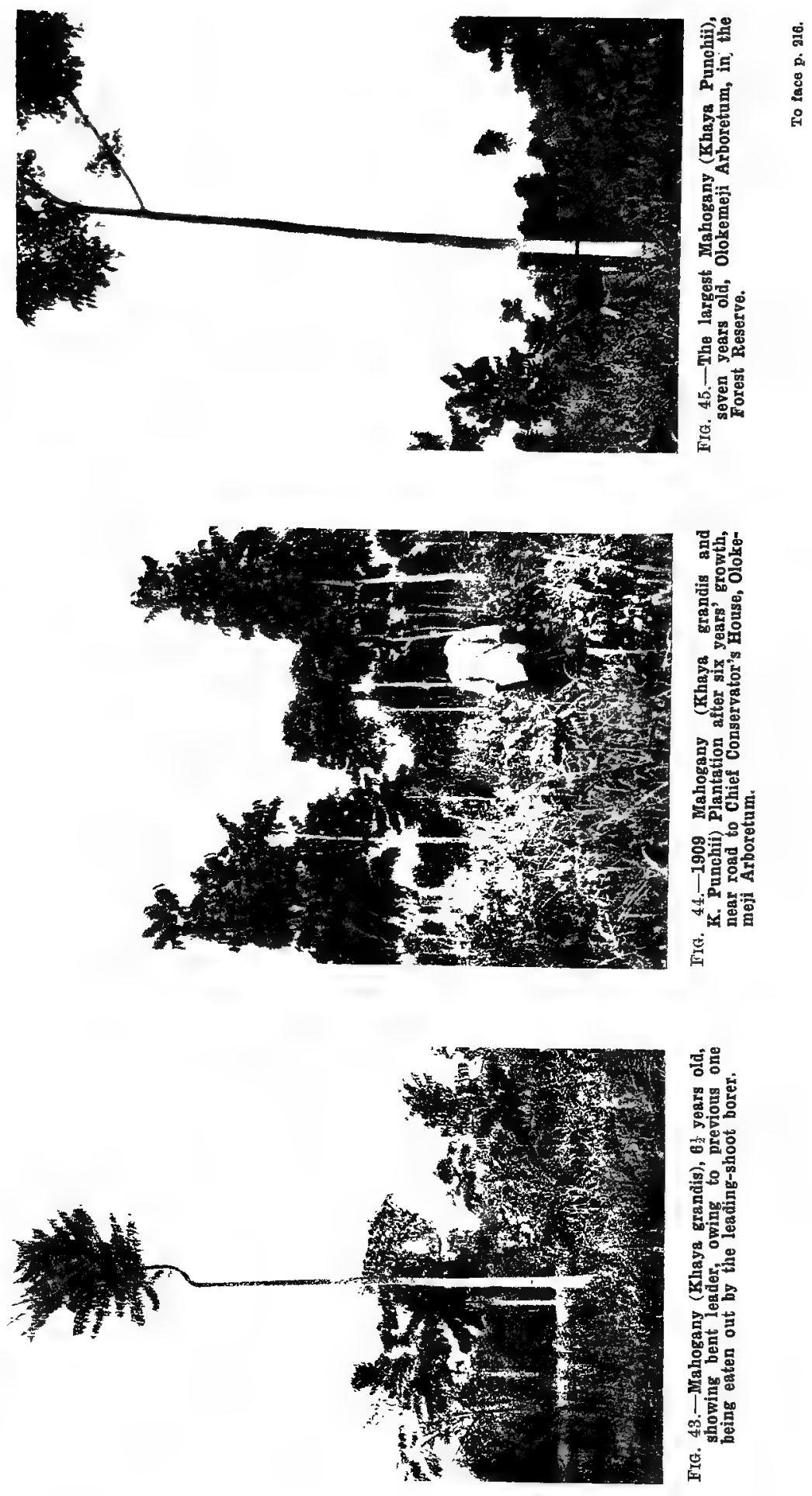

and the rind of the nut are used in certain food preparations, and the fronds have the usual applications for plaited utensils, etc.

Phoenix dactylifera, Linn. Dabino; "Date Palm."

Introduced by Arabs and confined (with a few exceptions, e.g. at Yola Mosque) to the Northern towns.

In Kano it may be possible to see the three palms, Deleb, Dum and Date, together, but the last is in no sense a tree of Hausaland. J. M. Dalzikl. 


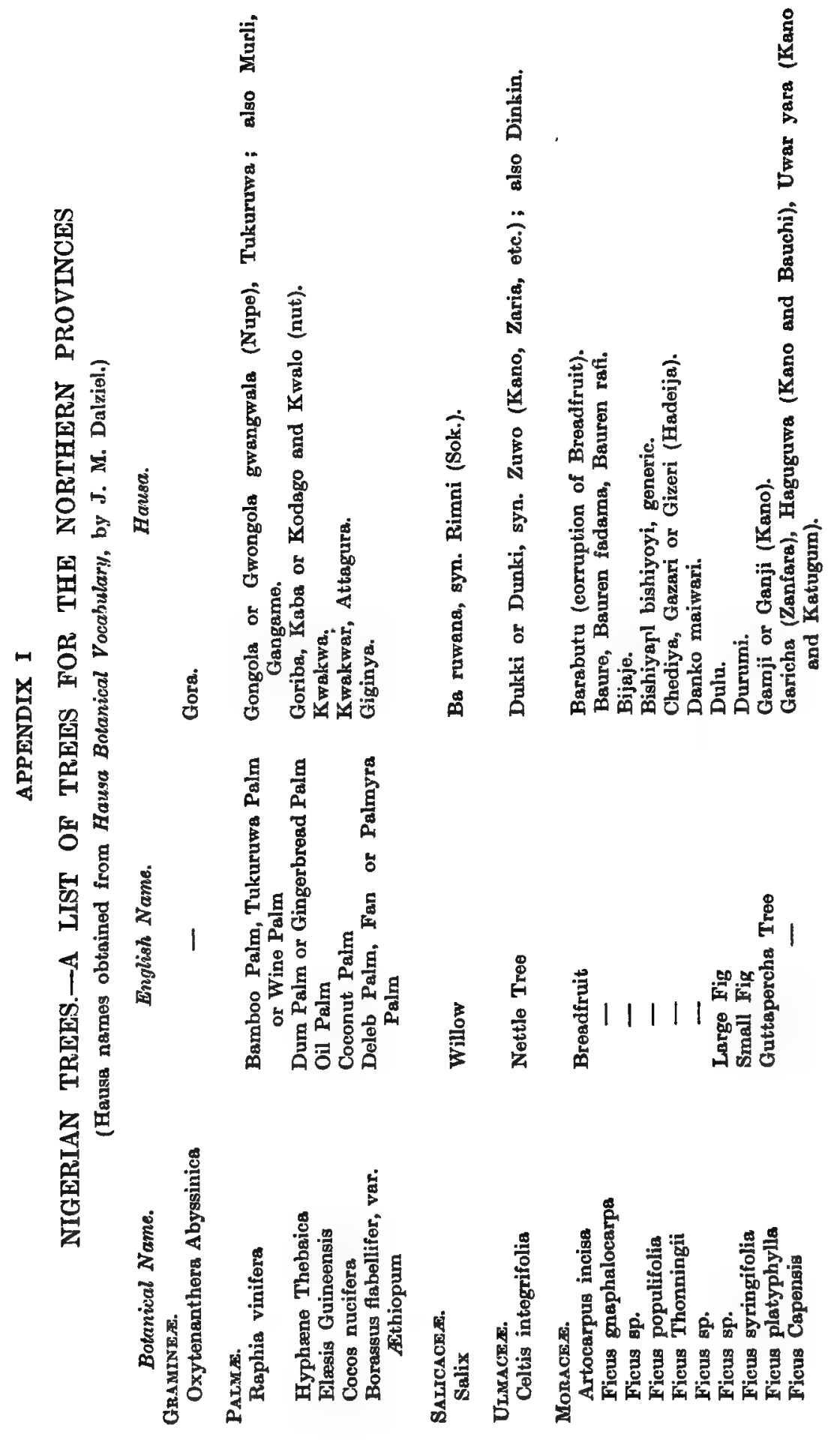




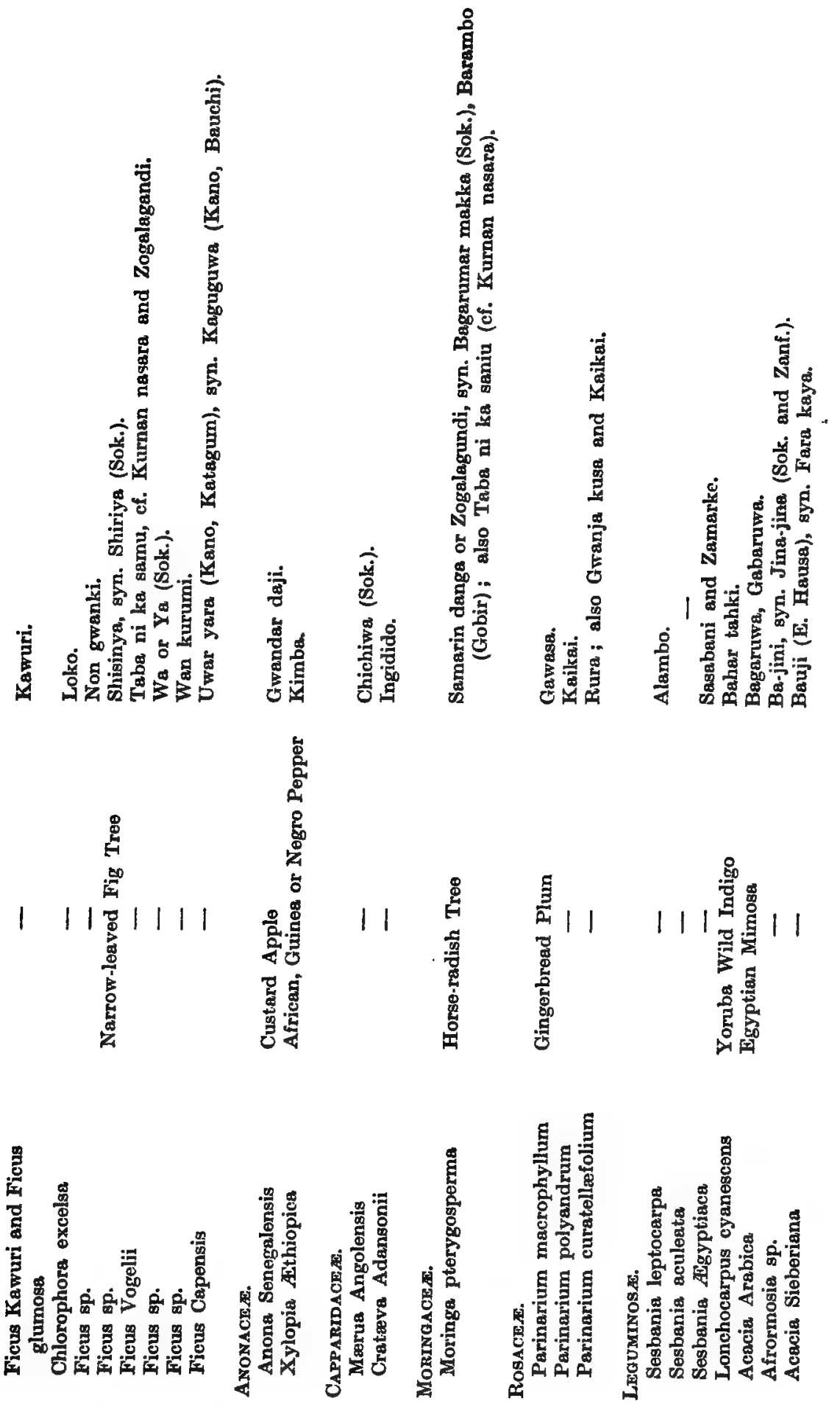




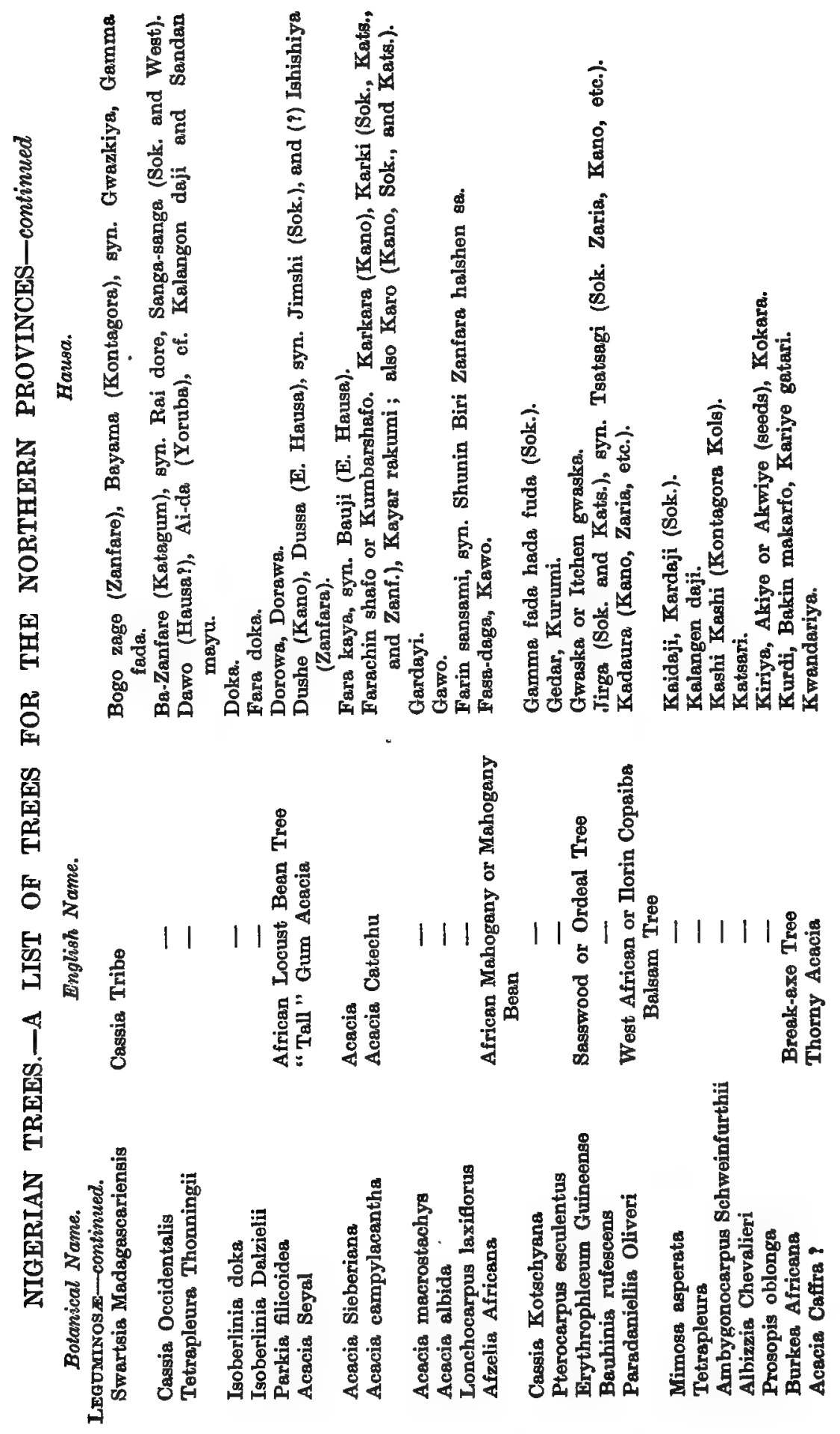



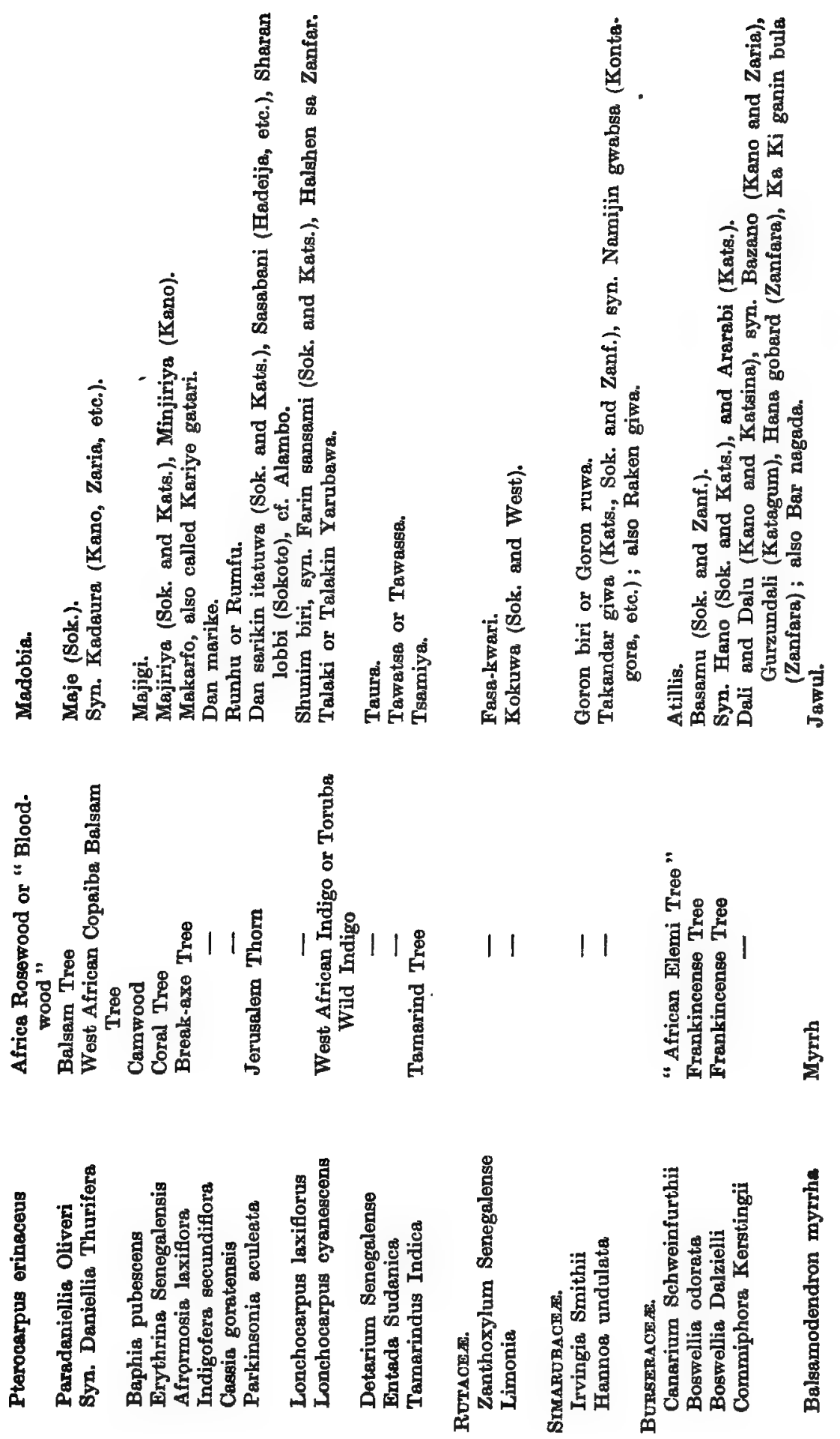


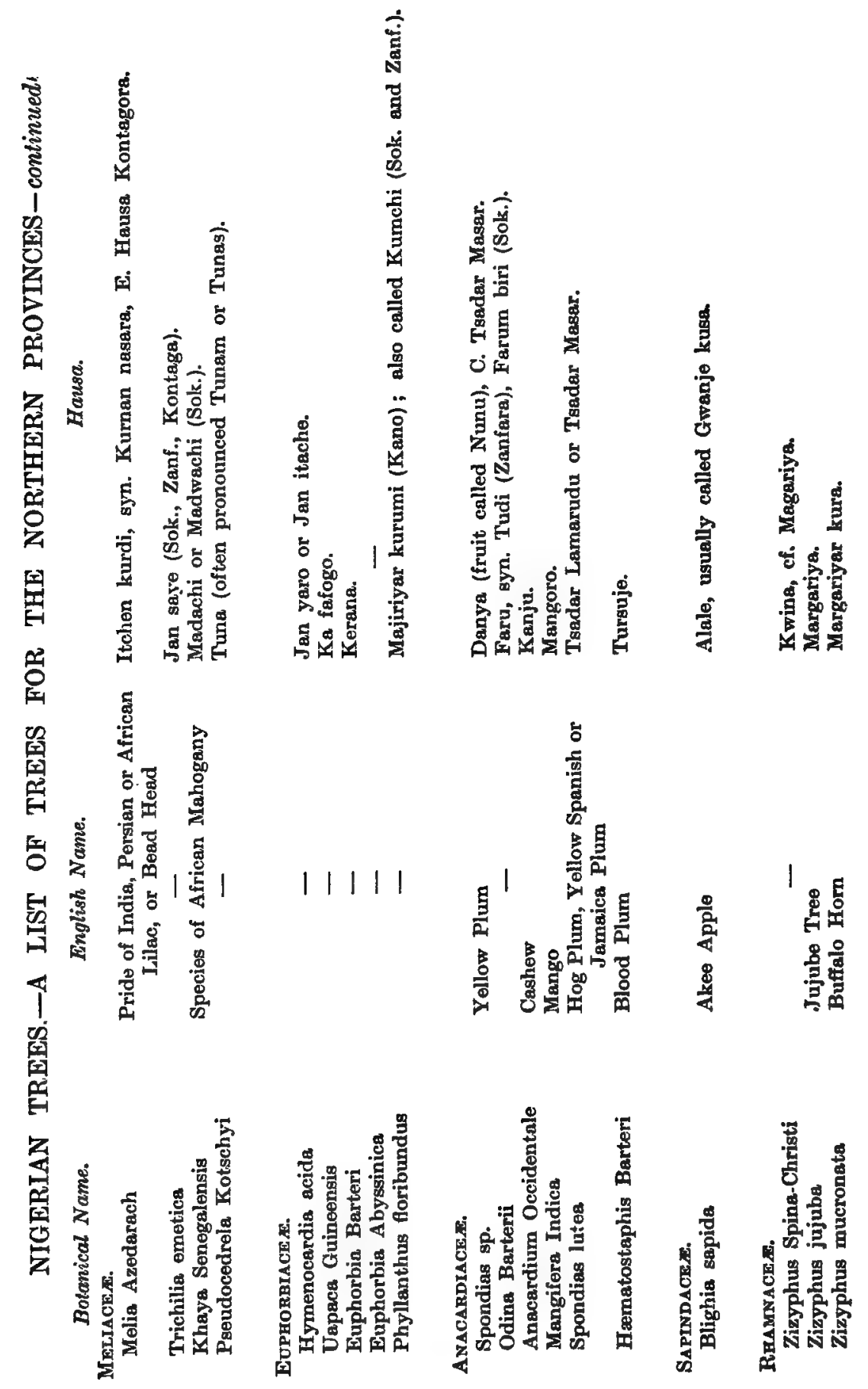



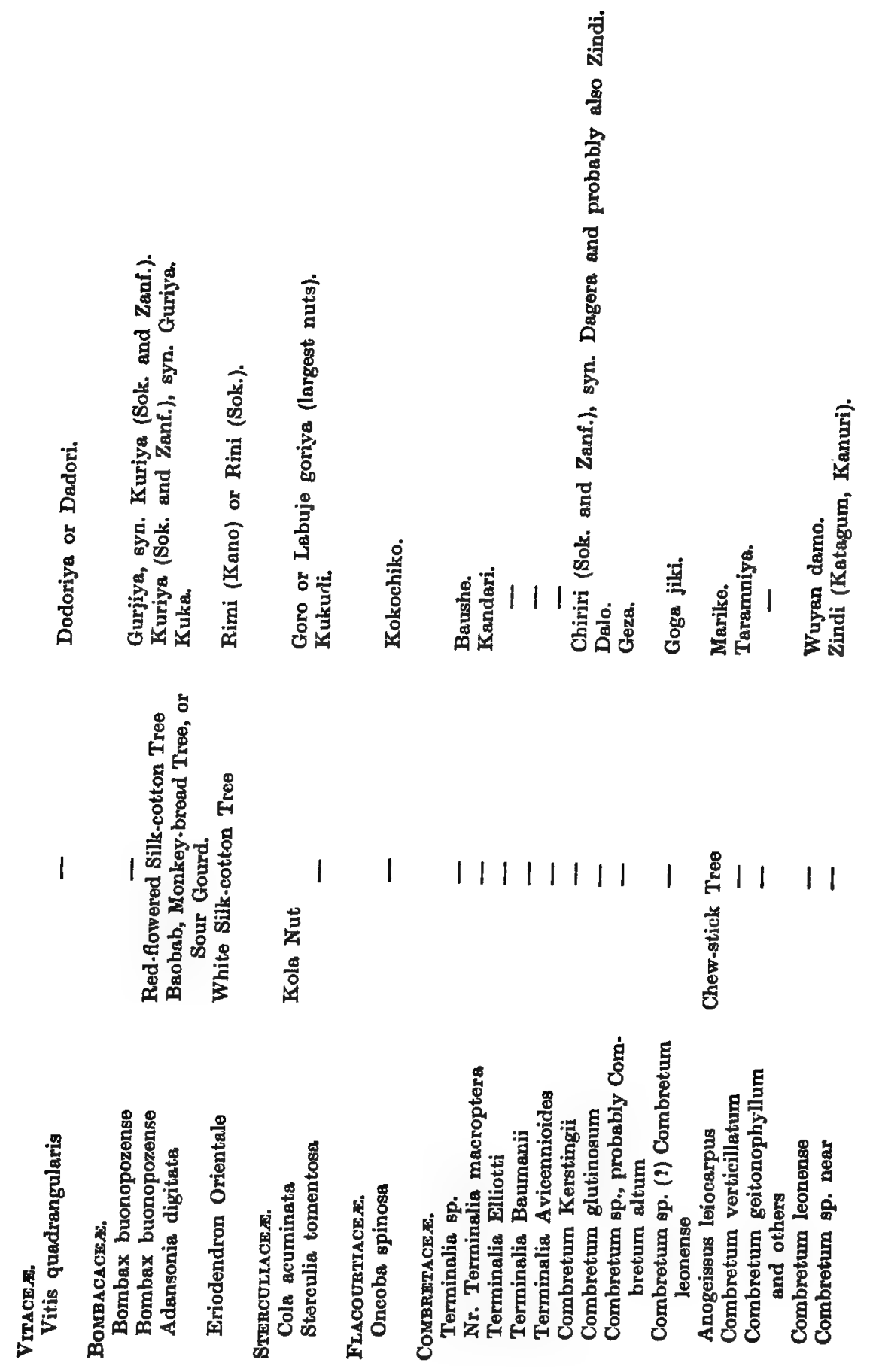


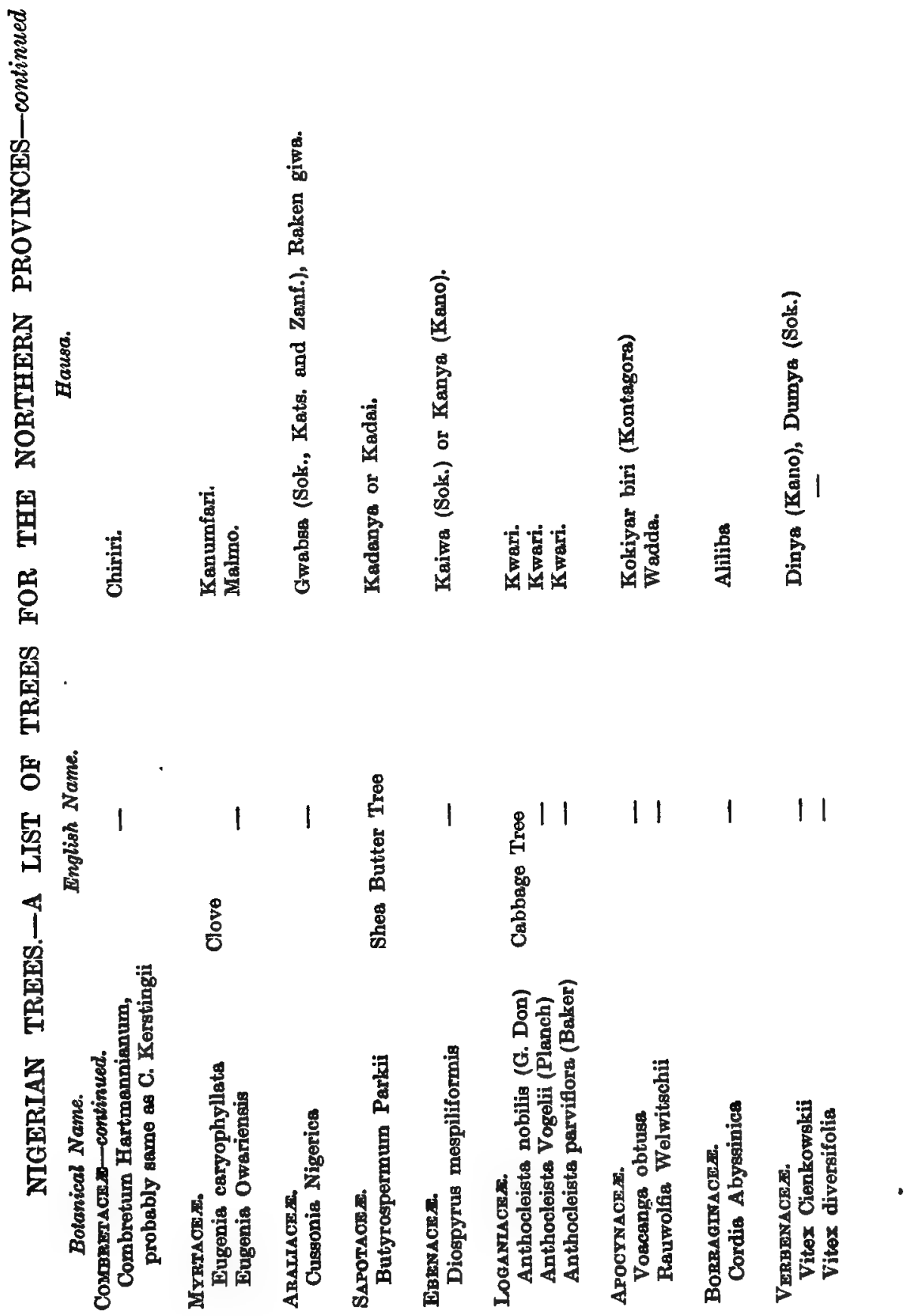



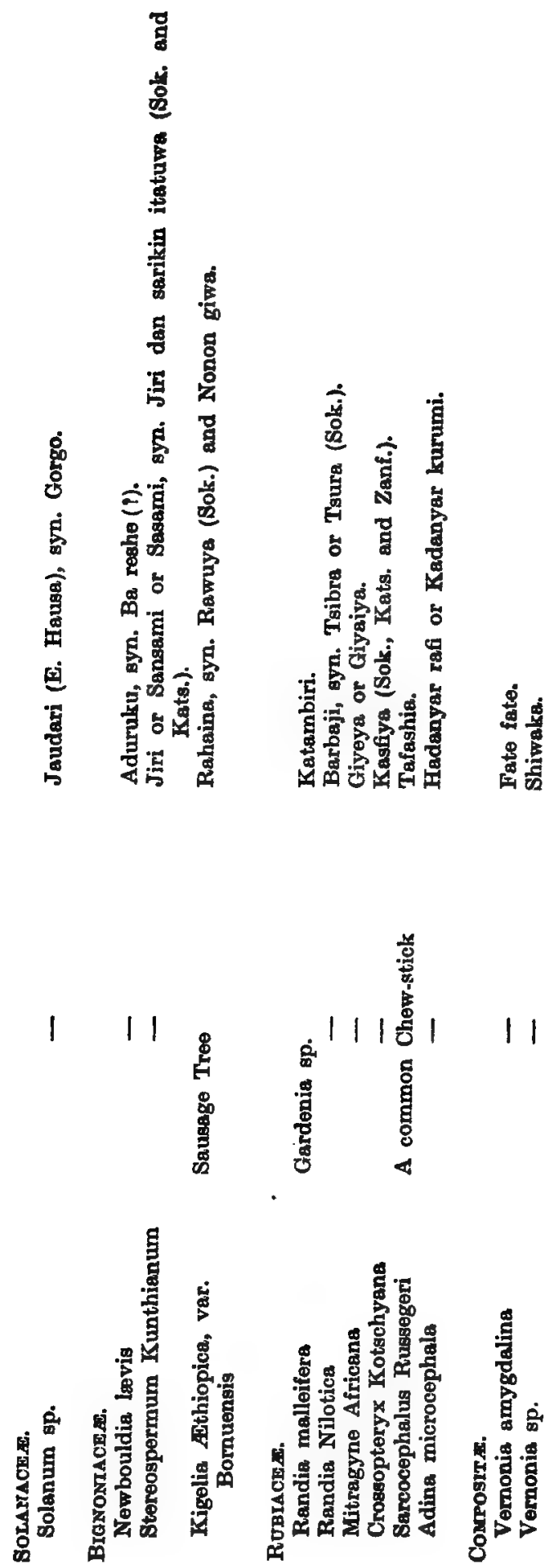


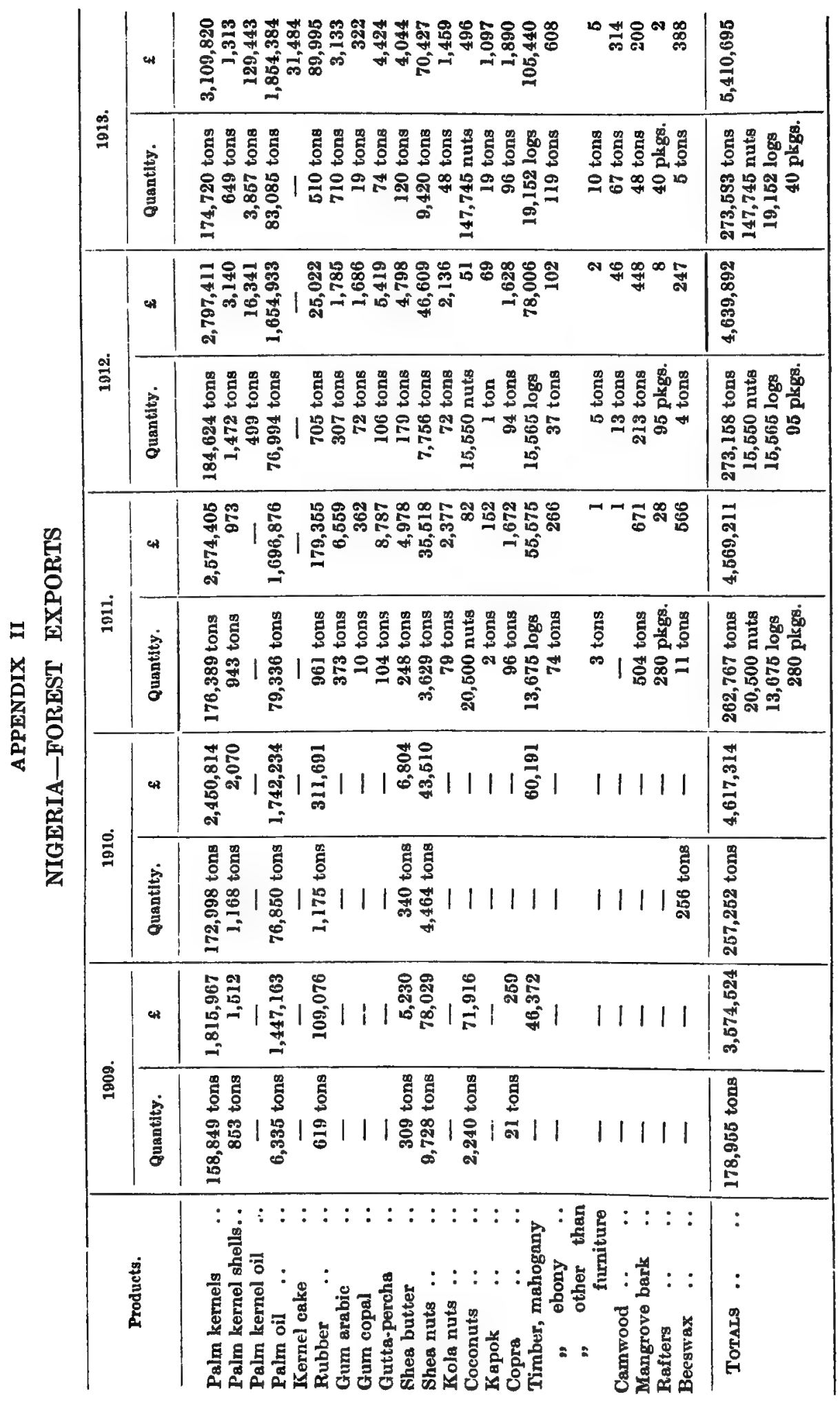


APPENDIX III

IMPORTS OF TIMBER INTO NIGERIA

\begin{tabular}{|c|c|c|}
\hline $\begin{array}{l}\text { Wood and Timber, Rough } \\
\text { Hewn, Sawn and Split. }\end{array}$ & Superficial Feet. & $\varepsilon$ \\
\hline $\begin{array}{l}1910 \\
1911 \\
1912 \\
1913 \\
1914 \\
1915 \\
1916\end{array}$ & $\begin{array}{c}5,754,135 \\
3,246,924 \\
3,815,004 \\
4,531,262 \\
6,094,126 \\
4,184,935 \\
\text { Information not yet available }\end{array}$ & $\begin{array}{c}\mathbf{3 4}, 166 \\
\mathbf{3 5 , 9 2 0} \\
\mathbf{3 7 , 9 0 4} \\
\mathbf{4 3 , 1 6 7} \\
\mathbf{5 4 , 6 7 3} \\
\mathbf{4 5 , 0 2 7} \\
-\end{array}$ \\
\hline Totars & $27,736,386$ & $\{250,847$ \\
\hline
\end{tabular}




\section{APPENDIX IV \\ NIGERIAN TREES PROTECTED UNDER THE FORESTRY ORDINANCE}

With the gracious permission of the Nigerian Forest Department and the Nigerian Government a copy of the schedule of protected trees under the Nigerian Forestry Ordinance has been inserted here.

\section{SCHEDULE A \\ PROTECTED TREES}

lst Class Trees.

Fee, 46s.; Royalty, 10s.; Total, 56s. per tree.

(a) 11 feet minimum girth limit.

Khaya. All species except $K$. Senegalensis. Mahoganies. Ogangwo (Yoruba); Gedu (Benin); Digiten (Brass); Dirinshi and Odala (Ibo); Efriyo-moniba (Efik).

Entandrophragma. All species, scented Mahoganies. Ijebo (Yoruba); Onomokyukyu and Ikwapobo (Benin); Eden (Efik); Etori (Ekoi).

Chlorophora excelsa. Iroko (Yoruba); Iroko (Benin); Odji (Ibo); Nsan (Ekoi); Efriyo (Efik).

(b) 10 feet minimum girth limit.

Gaurea Thompsonii. Walnuts. Obobonikwi (Benin).

Gaurea. All other species.

Lovoa Klaineana. Anamomila (Benin).

(c) 8 feet minimum girth limit.

Sarcocephalus esculentus. Moist forest form. Opepe (Yoruba); Obiache (Benin); Owessu (Brass); Awesu (Jekri).

(d) 6 feet minimum girth limit.

Funtumia elastica. Rubber trees.

Ficus Vogelii.

(f) No minimum girth limit.

Eløis Guineensis. Oil Palm. 


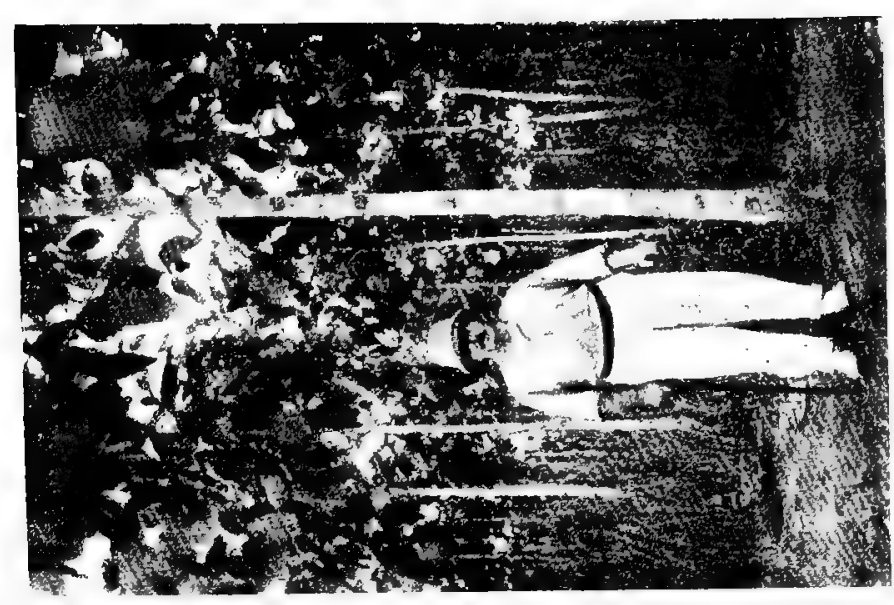

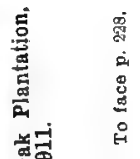

E⿹

总要

.

和

㟧兽

5

兽国

$\stackrel{+}{+}$

$\stackrel{5}{=}$

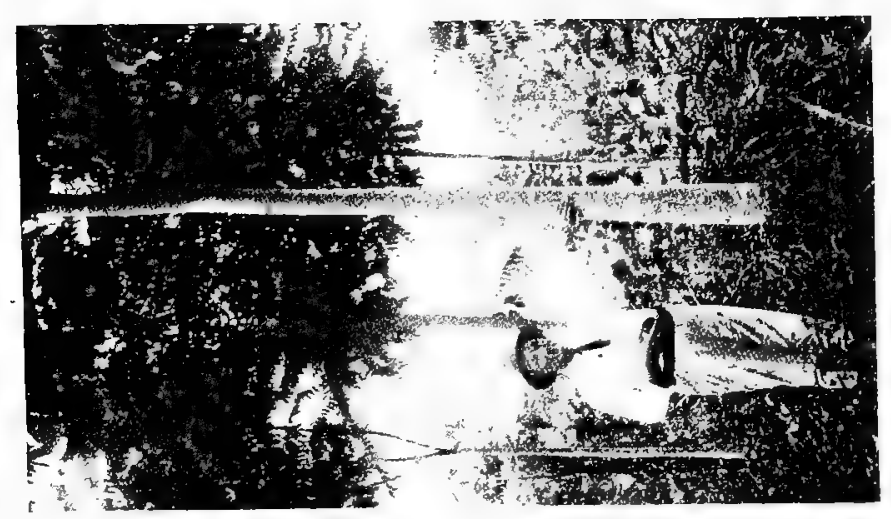

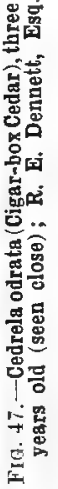

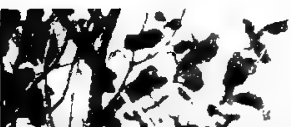

1. $10^{2}$ -

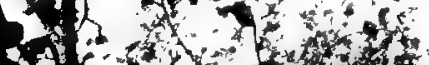

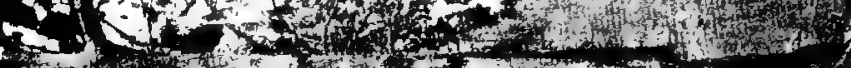

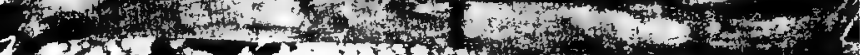

$7+3, y+2$

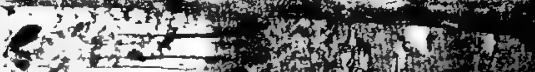

$=-7+3 x$

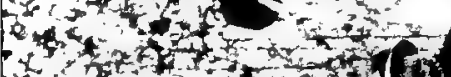

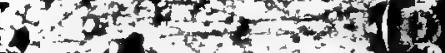

$2+12 x$

(1)
-7 ,

$<5$

, the

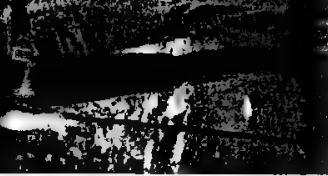

弯

5ू.

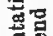

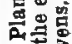

畨范

惫产.

品.

홓ํํำ

ธ후

娄흥

항

i这

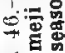

焉 

2ND Class Trees.

Fee, 288.; Royalty, 8s. ; Total, 36s. per tree.

(b) 10 feet minimum girth limit.

Mimusops Djave. Efam (Efik); Mfam (Ekoi); Ungu (Ibo).

Canarium Schweinfurthii. Eben-etridon (Efik); Njasun (Ekoi). Detarium Guineensis.

Piptadenia Africana. Agboin (Yoruba); Chen (Ibo); Ekhimi (Benin) ; Sanga (Ijaw).

Cylicodiscus Gabunensis. Anyan (Efik); Okan (Benin); Aja-igi or Olosan (Yoruba).

Agba of the Benis. Mobonran (Ijaw).

(d) 7 feet minimum girth limit.

Afzelia Africana. ${ }^{1}$ Apa (Yoruba); Kanwo (Hausa); Adja (Ibo); Ayin-bukbo (Efik); Aligna or Adya (Benin).

Blighia sapida. Ishin (Yoruba); Alale or Gwanja-kusa (Hausa).

Lophira procera. Eki (Yoruba); Eba (Benin); Kuru (Ijaw); Umowenek (Efik).

Tamarindus Indicus. ${ }^{2}$ Tsamia (Hausa).

(e) 6 feet minimum girth limit.

Mimusops multinervis. Emido (Yoruba); Apassa (Efik).

3rd Class Trens.

Fee, 18s.; Royalty, 6s. ; Total, 24s. per tree.

(b) 10 feet minimum girth limit.

Santiriopsis Klaineana. Incense Tree. Odonomo-kyu-kyu (Benin). Poga oleosa. Inoi (Efik); Inyere (Ekoi); Imonor (Ibo).

Brachystegia spicaformis. Ako or. Eku (Yoruba); Akpakpa (Ibo) ; Ukung (Efik).

(c) 6 feet minimum girth limit.

Carapa. All species. Ibegogo (Benin).

Albizzia fastigiata. Ayinre-eta (Yorúba).

Albizzia Brownii. Ayinre-bonabona (Yoruba).

Pterocarpus tinctorius. Camwood. Ukpa (Efik); Nkohen (Ekoi); Uhie (Ibo); Auchi (Brass).

Pterocarpus Osun. Barwood. Osun (Yoruba); Ukpa (Efik).

Khaya Senegalensis. Dry-zone Mahogany. Ogangwo (Yoruba); Madachi (Hausa).

Erythrophloum Guineense. Sasswood. Erun (Yoruba); Ifwan (Efik); Inyi (Ibo); Gwaska (Hausa).

Erythrophloeum micranthum. Ihi (Ekoi); Iringi (Ibo).

\footnotetext{
1 4th class in Northern Provinces.

- 6th class in Southern Provinces.
} 


\section{WEST AFRICAN FORESTS AND FORESTRY}

Schrebera Golungensis. Opele (Yoruba).

Afrormosia laxiflora. Yellow Satin Wood. Ainyesan (Benin).

Parkia biglobosa. ${ }^{1}$

Parkia filicoidea. ${ }^{1}$ Darowa (Hausa); Irugba (Yoruba).

Pseudocedrela Kotschyi. ${ }^{2}$ Tuna (Hausa); Emigbegi (Yoruba).

Irvingia Barterii. Oro (Yoruba); Okherli (Benin).

Mammea sp. Bolo (Ijaw); Bolo (Brass).

Casearia sp. Ebo (Yoruba).

Otutu of the Yorubas. Aiye (Ondo).

Klaineodoxa Gabonensis. Alukon-raba (Yoruba); Ifainaki (Egba); Odudu (Ondo).

Diospyros. ${ }^{3}$ Ebonies. Kainya (Hausa).

\section{4th Class Trees.}

Fee, 9s. ; Royalty, 38.; Total, 12s. per tree.

(c) 8 feet minimum girth limit.

Terminalia. All species except T. Togoensis.

Terminalia Superba. Afara (Yoruba).

Uputtu of the Benis.

Diospyros dendo. Obiletu (Efik).

Diospyros mespiliformis. Kanran (Yoruba).

Diospyros Mombuttensis. Ogan-pupa (Yoruba).

Diospyros atropurpurea.

Diospyros crassiflora. Aborpor (Benin).

Cordia Millenii. Omo (Yoruba).

Triplochiton Johnsonii. Arere (Yoruba); Obeche (Benin).

Triplochiton Nigericum. Arere (Yoruba).

Mitragyne macrophyllu. Uwen (Efik); Ebar (Brass); Ebar

(Ibo); Abura (Yoruba).

Daniellia Ogea. Ojia (Yoruba); Udeni (Ibo); Ozia (Benin).

Yinrin-yintin of Ijaws and Ikales.

Jebere of the Ondos. Alofin (Jebu).

(e) 6 feet minimum girth limit.

Berlinia acuminata. Apado (Yoruba); Ekpogoi (Benin).

Berlinia auriculata.

Cordia. All species except C. Millenii. Aliliba (Hausa).

Pausinystalia sp. Idagbon (Ondo); Wenren-wenren (Jebu).

Microdesmis sp.

Ohiomo of the Benis.

1 4th clags in Northern Provinces. $\quad$ th class in Southern Provinces.

4th class in Southern Provinces. 
Evai of the Benis.

Spondias sp. Ekika-aja, Opon (Yoruba).

Saxoglottis Gabunensis. Ndat (Efik); Tala (Ibo); Tala (Brass); Edat (Ekoi); Atala (Yoruba).

Sarcocephalus sp. Opepe-ira (Yoruba).

Pycnanthus Kombo. Akomu (Yoruba).

Oromosia monophylla. Akoriko (Yoruba).

Ashasha of the Yoruba.

Alstonia Congensis. Awun, Ahon (Yorubn); Dubu (Brass); Eba (Ibo).

Parkia filicoidea. ${ }^{1}$ Danowa (Hausa).

Parkia biglobosa. ${ }^{1}$

Acacia. ${ }^{2}$ All species. Gabarua (Hausa).

Butyrospermum Parkii. Shea Butter. Emi-emi (Yoruba); Kadanya (Hausa).

Pterocarpus erinaceus. Apepe, Ara (Yoruba); Madobia (Hausa).

\section{5th Class Trees.}

Fee, 4s. 6d. ; Royalty, 1s. 6d.; Total, 6s. per tree.

(b) 10 feet minimum girth limit.

Eriodendron. All species. Silk Cotton Tree. Araba (Yoruba); Ukum (Efik); Shakka (Brass); Olkha (Benin); Akpe (Ibo); Rimi (Hausa).

Bombax. All species. (Ibo).

Antiaris toxicaria. Oro (Yoruba); Nuwo (Ekoi); Odjiwawa

(c) 8 feet minimum girth limit.

Iya-Igbo of the Yorubas.

(e) 6 feet minimum girth limit.

Tetrapleura Thonningii. Aridan (Yoruba); Dawo (Hausa).

Erythrina. All species except $E$. Senegalensis.

Paradaniellia Oliveri. Balsam Copaiba Tree. Iya (Yoruba).

Pentaclethra macrophylla. Apara (Yoruba); Ukana (Efik); Ukpakara (Brass).

Lonchocarpus Zenkeri.

Daniellia. All species except $D$. Ogea. Gum Copal Trees. Iya (Yoruba).

Cynometra. All species.

Ricinodendron Africana. Erimmado (Yoruba); Okwen (Benin).

Uapaca Guineensis. Ile (Ibo).

Uapaca Staudtii. Akun (Yoruba).

1 3rd class in Southern Provinces.

-7th class in Southern Provinces. 


\section{WEST AFRICAN FORESTS AND FORESTRY}

Garcinia sp. Agberibede (Yoruba).

Scottelia Kamerunensis. Okilolo (Ijaw).

Oropa of the Yorubas. Odoko (Yoruba).

Erohun of the Ikales.

Xylia Evansii.

(f) 4 feet minimum girth limit.

Trichilia Heudelotii.

Pseudocedrela Kotschyi. ${ }^{1}$ Emigbegi (Yoruba).

Okpi-nikwi of the Benis. Enyin Mbukpo (Efik).

6Th Class Trems.

Fee, 28. 6d.; Royalty, 6d.; Total, 3s. per tree.

(c) 8 feet minimum girth limit.

Sterculia cordata. Ogugu (Yoruba).

(e) 6 feet minimum girth limit.

Sterculia oblonga.

Pentadesma butyracea. Candle Tree. Udia Ebiong (Efik).

Adina microcephala. ${ }^{2}$ Kadanyar rafi (Hausa).

Anogeissus leiocarpus. Ayin (Yoruba); Marike (Hausa).

Isoberlinia. ${ }^{2}$ Both species. Doka (Hausa).

(f) 4 feet minimum girth limit.

Chrysophyllum. All species. Osan (Yoruba).

Polyadoa umbellata.

Baphia nitida. Irosun (Yoruba).

Baphia pubescens. Ubara (Efik).

Baphia polygalacea. Mbomo-nkuku (Efik).

Parinarium macrophyllum. Gawasa (Hausa).

Parinarium mobola.

Funtumia Africana. Ako-ire (Yoruba); Bassa-bassa (Benin).

Tamarindus Indicus. ${ }^{3}$ Tsamia (Hausa).

Eugenia Owariensis. Malmo (Hausa).

Vitex. All species.

Sterculia Barterii. Eso (Yoruba).

Lophira alata. Ipawhaw (Yoruba); Namijin-kadai (Hausa).

Xanthoxylon Senegalensis. Ata (Yoruba); Fasa-kwari (Hausa).

(Hausa).

Spondias lutea. Hog Plum. Iyeye (Yoruba); Tsada-Masar

Cola. All species.

Ita of the Yorubas.

Hannoa Klaineana. Igbo (Yoruba).

Macrolobium. All species.

1 3rd class in Northern Provinces.

3 feet minimum girth in Northern Provinces.

a 2nd class in Northern Provinces. 
Ormosia laxiflora. ${ }^{1}$ Ba-fini, Makarfo (Hausa); Shedun (Yoruba). Prosopis oblonga. Kirya (Hausa).

Lonchocarpus sericeus. Ipapo (Yoruba); Njassi (Ibo); Obong (Efik).

Dialium Guineense. Awin (Yoruba); Ohiorme (Benin).

(f) 3 feet minimum girth limit.

Adina microcephala. ${ }^{2}$ Kadanyar Rafi (Hausa).

Isoberlinia. ${ }^{2}$ All species. Doka (Hausa).

Ormosia laxiflora. ${ }^{3}$ Makarfo (Hausa).

(g) No minimum girth limit.

Borassus Afthiopica. The Fan Palm. Giginya (Hausa).

7Th Class Trers.

Fees, Nil, except when taken under a Fuel Permit.

(g) No minimum girth limit.

Acacia. All species, when in Southern Provinces.

Anona. All species. Afe (Yoruba); Gwandar-daji (Hausa).

Conopharyngia. All species.

Deinbolia insignis.

Erythrina Senegalensis. Majiriya (Hausa).

Garoinia conrauana. Efiari (Efik); Odji (Brass).

Hannoa undulata. Ikwepokin (Benin).

Holarrhena Wulfsbergii.

Kigelia pinnata.

Millettia Thonningii.

Musanga Smithii. Umbrella Tree. Aga (Yoruba); Uno (Efik);

Oro (Brass).

Pachylobus edulis. Eben (Efik).

Parinarium. All species except those detailed in 6th class.

Pterocarpus esculentus. Gedar-kurumi (Hausa); Gbingbin (Yoruba).

Ochna multiflora. Toi-tsi (Ibo).

Rauwolfia vomitoria.

Spathodea. All species.

Sterculia. All other species except those detailed in other classes.

Terminalia Togoensis.

Treculia Africana. Afon (Yoruba).

Xylopia Atthiopica. Eru (Yoruba); Kimba (Hausa).

Chrysobalanus Icaco. Ikate (Yoruba).

13 feet minimum girth in Northern Provinces.

26 feet minimum girth in Southern Provinces.

24 feet minimum girth in Southern Provincea. 
8th Class Trees.

Minimum girth limit, 12 inches.

Fees-On trees over 24 inches in girth, 6d. per tree.

On trees 12 to 24 inches in girth, 3d. per tree.

Rhizophora racemosa. Red Mangrove. Egba (Yoruba).

Rhizophora mangle. Red Mangrove.

Avicennia Africana: White Mangrove. Ofun (Yoruba).

For the purposes of this schedule, the girths must be measured at a vertical distance of 4 feet 6 inches from the ground at the foot of the tree, or in the case of buttressed trees at the place where the highest buttress merges into the stem.

\section{SCHEDULE B \\ PROTECTED MINOR FOREST PRODUCE}

Ist Crass.

Fee, 158.; Royalty, 58.; Total, 20s. per permit.

Rubber-taken from wild rubber-yielding trees and vines.

2ND CLAss.

Fee, 78. 6d.; Royalty, 2s. 6d.; Total, 10s. per permit.

Bamboo poles-taken from the midribs of the Tombo palm (Raphia vinifera) or other species of Raphia. Piassava fibre from the stem and midribs (leaf stalks) of the Raphia and other species of palms.

And in the Northern Provinces:

Poles, gofas, etc., not to exceed 6 inches in diameter, taken from Isoberlinia sp., Anogeissus leiocarpus, Ormosia laxiflora, Lophira alata or Pterocarpus erinaceus.

\section{RD Class.}

Fee, 48. 6d.; Royalty, 1s. 6d.; Total, 6s. per permit.

Chew-sticks-or native tooth-brushes taken from the roots of the Iyin tree (Anogeissus leiocarpus).

Native sponges-made from the bast fibres of various species of vines and lianes.

Pandanus fibre (from the screw pine) and the leaf stalk of all species of Phrynium, taken for the manufacture of mats.

Gum copal.

Gum arabic-and other gums procured from Acacias. 

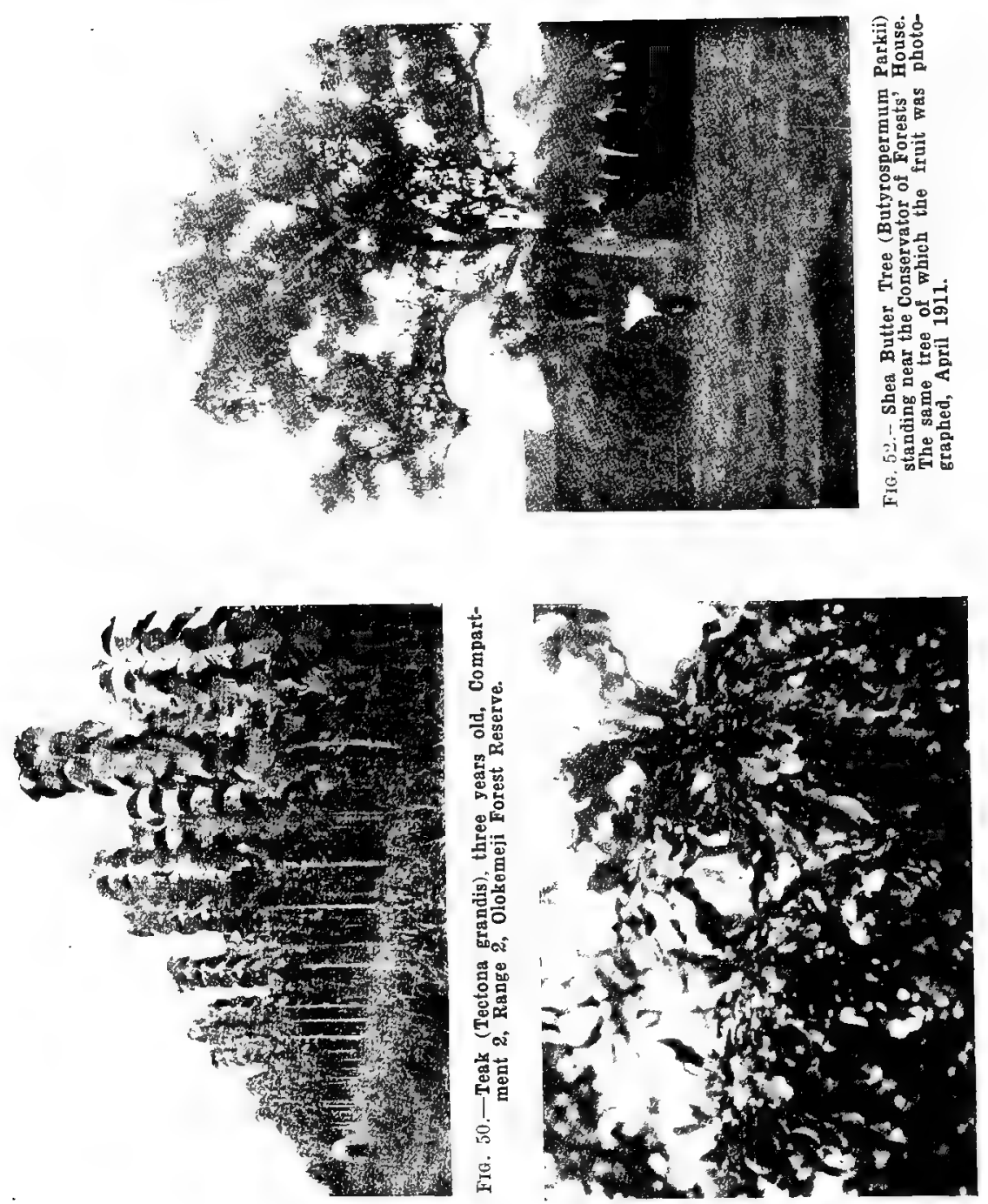

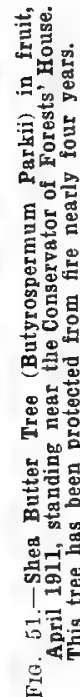

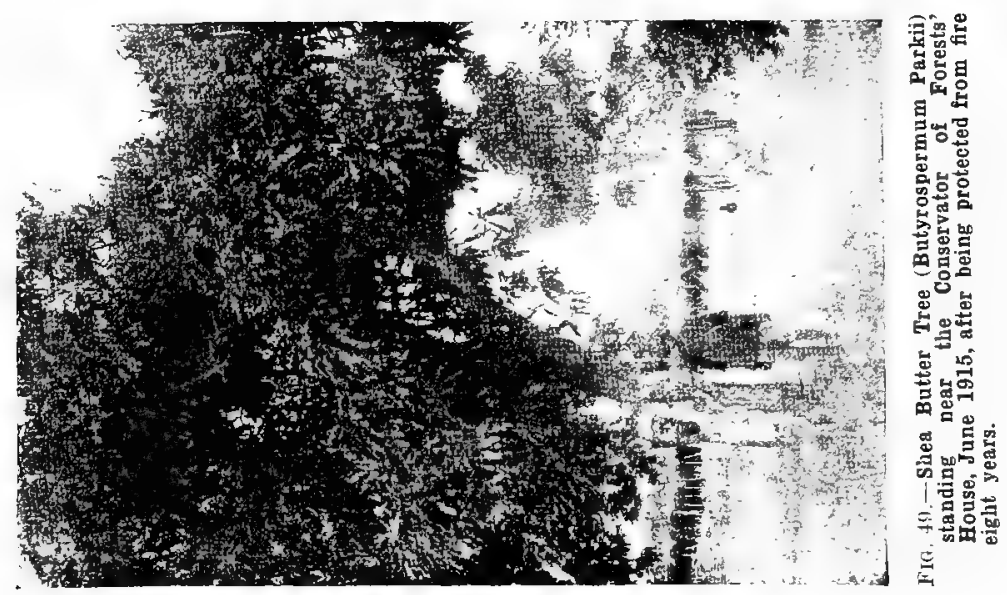





\section{CHAPTER IX}

\section{THE NIGERIAN TIMBER TREES}

\section{INDIGENOUS TREES OF NIGERIA}

\section{Palme.}

\section{B. Sotthern Provinces.}

Raphia Hookeriana. Hooker's Paln or the Piassava Palm. Aiko (Yoruba); Iya (Efik); Angor (Benin); Ori (Oban, Ekoi).

It is found chiefly in the Calabar, Warri, and Ondo provinces of Nigeria, mixed with $R$. vinifera at the edges of estuaries and rivers in the evergreen forest zone.

One of the main differences between this palm and $R$. vinifera is that the fruit is much shorter (at the most $1 \frac{1}{2}$ inches long and $\frac{3}{4}$ inch in diameter) and more stumpy in shape, coming abruptly to a point at the tip. $R$. vinifera, on the other hand, is much longer, reaching $2 \frac{1}{2}$ to 3 inches in length and $\frac{3}{4}$ inch to an inch in diameter, and it is very elliptical in shape. The bunches of fruit of this palm, $R$. Hookeriana, are much smaller, rarely exceeding more than a foot in length, and containing 50 to 75 nuts, whereas $R$. vinifera may have bunches 3 feet long, each containing 500 nuts or more. In the stem, too, this palm is smaller, often not reaching more than 6 to 9 inches in diameter, with a total height of 20 feet, whereas $R$. vinifera will reach over a foot in diameter and a total height of over 60 feet. The natural cleaning of the stem begins much later in this palm, and does not reach anything like the height of that of $\boldsymbol{R}$. vinifera. In many specimens, in fact, the stem remains always more or less covered with the very upward tending branches. In this respect it reminds one a little of $R$. Ruffia. The leaves, however, are more similar to $R$. vinifera, but only about half the size, especially in length; they are not quite so wide, nor are the leaf stalks quite so large.

The timber is very similar, but more fibrous and of a looser texture than that of $R$. vinifera. It is a little easier to cut. In the older specimens the foliage still retains its dark green colour compared with the dry, yellowish hue which $R$. vinifera takes on as it gets older. It is a somewhat slow- 
growing, shade-bearing tree. It likes a somewhat rich soil, but can, however, stand in water, and apparently withstands floods. Natural regeneration appears to be good.

The timber has not been cut for export nor for local use. The fronds are occasionally used for a similar purpose as that of $R$. vinifera, and sometimes the leaves also.

Native Use.-The fronds and leaves are used in a similar way to those of $R$. vinifera. The base of the leaf stalk is cut off into lengths up to 6 feet (it almost encircles the tree and extends much further up than in the case of $R$. vinifera) and laid in stagnant water. After the intervening substance between the fibres has got more or less soft and partly rotted away, the whole is taken out and the fibres cleaned with a kind of comb. These are then dried, and packed together in bundles of 20 pounds upwards, and sold to the European factory as Piassava. This industry is more widespread in the Eket district of the Calabar province, but it has taken a great number of years of thought and careful attention to bring it up to its present dimensions. The cutting of the leaves is undertaken mostly by the men and the rotting and cleaning of the fibre mostly by the women. Before the war Piassava fibre was rarely worth more than $\mathbf{2 8}$ per ton. It is now worth over $£ 70$. Unless, however, a price of at least $£ 20$ per ton is offered in Liverpool market for this fibre, it is doubtful if the industry can be made profitable for everyone concerned, producers included.

Raphia vinifera. The Palm Wine Tree, or Tombo Palm, or Bamboo, the last named being the name used by the English-speaking Jekris. Ako (Yoruba); Emmaha Augor (Benin); Oukot (Efik).

It is found in the Abeokuta, Ondo, Benin, Warri, Owerri and Calabar provinces and the Colony of Nigeria, at the edges of the streams and rivers in the evergreen forest zone, where it grows in large groups and pure forests.

It is a medium-sized palm, growing separately with one stem, which clears itself of the leaf fronds for about half its height between the twelfth and fifteenth year. The trunk then is comparatively smooth, except for the very large scars of the leaf stalk. The fronds are the longest of any of the African palms, reaching sometimes a length of 40 feet, roughly sickle shaped; in section they reach about 2 inches diameter at the broadest part, and are a yellow-brown colour. The leaves come out from the stalk almost at a right angle, thus making them much wider and, owing to their greater length, much finer and heavier foliage than that of the Oil Palm, or 
even the Coconut Palm. In fact, an isolated specimen growing well could be not unfavourably compared to the Royal Palm in the grandeur of its spread of leaf and the beauty of the outward-spreading, fan-shaped bold crown. Both the male and the female flowers are very conspicuous. The bunches of fruit, up to 3 feet in length, hang down like enormous elongated bunches of yellow grapes. The nuts are covered with a smooth yellow hard skin, set in scales very similar to those of a cone, except that each scale is tightly joined to the next. When the fruit decays, or is boiled, the scales come off as well as the yellow, fibrous matter, which gives a yellowish tinge to the water. The main difference between the base of the Oil Palm and that of the leaf of this tree is the extension of it more than half round the bole in the case of $R$. vinifera, and also flatily and smoothly down the stem. On the other hand, in the Oil Palm the leaf grows more abruptly out of and away from the stem. Owing to the Tombo Palm stem being smaller (on the average only 9 inches in diameter), the base of the frond extends nearly all round the tree, the lower one overlapping the higher one, and each placed in revolving fashion round the trunk, one above the other. The leaf scars of the Oil Palm are much smaller. Owing to the greater length of the leaf of this palm, the crown does not appear to be such a tuft of leaves at the top of the tree as in the case of the Oil Palm. In old age it appears more as a cylindrical mass of leaves occupying the upper half or third of the tree.

The timber is more fibrous and soft than that of the Oil Palm. The fibres, however, are dark brown, almost black when very wet or after they have lain in water for any length of time.

On the whole the tree is slow-growing, even slower than the Oil Palm. It stands a good deal of shade in the earlier stages, but later on is apparently a light-demanding tree. It grows in freshwater swamps and at the edges of such places. Although it thrives best in certain localities, it can be planted and does grow on solid and comparatively dry land near Calabar. In the Calabar province they are often planted as an avenue leading up from the main road through the farm to the house. It will stand floods. Natural regeneration is good, and with the spread of propagation it tends to be more widely distributed. In the Calabar and Ogoja provinces seeds were distributed to the natives for planting for the production of palm wine to take the place of that obtained from the Oil Palm. The timber has not been used for export, nor has it been out for local use. The leaf stalks, however, have been 
used for building labourers' lines and in some European houses. In a similar way the leaves themselves have been used as a roofing material after being made up into small mats.

Native Use.-The tree is tapped near the base of the leading leaves, or at the base of the male inflorescence, for the production of the sap, which is collected in calabashes. These are placed in position every evening and emptied every morning, and replaced in position. Occasionally the chimpanzees climb up the palms, drink the wine in the calabash and replace it. A native once shot a chimpanzee, finding it was the thief of his palm wine and not a human being. The wine is of a white, sometimes almost creamy colour, and when fresh is quite thin and foamy. It has a rather pleasant, sweet, and almost sharp taste. After being kept a few days it begins to ferment, and even moderate quantities are intoxicating. Either fresh or fermented, it is sold in bottles or calabashes in the local markets. The supply scarcely, if ever, exceeds the demand. The natives often put pieces of the bark of Tala, Saccoglottis Gabunensis, in the wine to give it a more bitter taste. Occasionally also the bark of mahogany and other trees is used. Tala, however, is the correct bark to use, and it forms an article of local commerce for this purpose. Owing to the comparative inaccessibility of some of the " stands" of this tree away in the swampy regions near the estuaries of some of the larger rivers, such as the Benin and the Siluko, there are still vast areas where neither the leaves are cut nor the palms tapped for wine. The seeds are boiled and placed in the bottom of a canoe, and when sufficient canoes have been got together, each with its quota of boiled nuts, these are trodden with the feet of those in the canoe, and both the nuts and the scaly shell as well as the small amount of yellow flesh are thrown in the water of a half-stagnant river. This yellow substance partly blinds and stupefies the fish, the smaller ones of which come half floating and swimming to the surface, the larger ones being washed along near the bed of the river. These are caught in convenient places where the river has been staked all across its width and bamboo netting put down, except for an opening where a flexible net is used. Some of the people go about in small canoes, netting the fish that come to the surface. One of the most famous spots to see this is in the Osse River, in the reach just below Noami, where the combined fishery forces of the Jekris and, to a lesser extent, Sobos and Ijors, for a day or two in succession in April each year, carry on this work. The catch of fish obtained is enormous. Unless, however, it can be soon 
smoked and dried, much of it goes bad. This method of getting fish is also used by individual natives in stagnant backwaters of rivers and in isolated pools. The poison apparently does not spoil the taste or other quality of the fish. Occasionally this palm is also used for getting out the Piassava fibre, but it appears to be more difficult, and it is doubtful if it is as valuable as the fibre obtained from $R$. Hookeriana. Owing, however, to the fact that both species grow in the same loculity and often quite mixed together, it is highly probable that part of the Piassava obtained is taken from this palm. In order to stimulate the flow of sap, a fire is often made at the base of the tree, which burns all the lower leaves and even part of the top, and thus induces an extra flow of sap, but of course to the detriment of a continual yield, as the tree subsequently dies.

In many parts of the country there is a regular local industry in the making of roofing mats from the leaves of this palm. The small ones, about 3 feet long, are, however, sold 25 for 3d. and the big ones, over 6 feet long, 25 for $6 \mathrm{~d}$. In some places they are cheaper. As a roofing material they are very durable, and will last at least seven years. If, however, they are put on very thickly, overlapping more than two-thirds of their width, and the roof is thoroughly smoked from the inside, it becomes nearly black, and will last fifteen years. For native houses it is one of the most used roofing materials, except in the Benin country, where the large Ewayon leaves are used. Roofing mats are, of course, being superseded by galvanized iron in the more civilized places. The leaf stalk is used both as a pole for pushing lighters or heavily laden canoes through comparatively shallow water, or as a boat-hook, or pushing and guiding pole for the smaller canoes in getting up swift, winding and comparatively narrow rivers.

Raphia Ruffia. Roofing Pulm.

Chief Characteristics.-It does not form a proper stem, like other raphias; the long, thin leaves sprout out from the ground, and only when the tree is some years old is there any trace of a stem, which is quite short. The petioles are thin, compared to the length, and the leaflets are thin and narrow.

Distribution.-It is found in the Calabar and Ogoja Provinces of Nigeria. It is often planted near watercourses in damp valleys to provide roofing material for the natives, who make mats from the leaves (Ikom, Obubra districts).

Phœnix reclinata. Swamp Date Palm. Elekikobi (Yoruba); Ukukon (Benin).

A common tree of the Warri province of Nigeria. It is 
usually found in or at the edge of the mangrove swamp, where it appears to thrive. It is often rather bont in shape, and does not exceed 10 feet in height. It is usually partially gregarious, though the groups of this species are much smaller than those of $P$. spinosa. The natives in this locality scarcely use it at all. The fruit is rather smaller, and it bears in a less prolific manner than $P$. spinosa.

Phoenix spinosa. Wild Date Palm. Okun (Yoruba); Ukukon (Benin).

It is a common tree in the Ogoja, Benin, Ondo and Ibadan provinces of Nigeria. In appearance more like a very thin stemmed Oil Palm, on nearer approach the bluish-green, almost silvery, more open, shorter and rather sharply pointed fronds resdily distinguish it from the Oil Palm group. The fruit is the shape of a very small date, many of which are borne on thin fibrous twigs of a very stout stalk. It is usually found in the open deciduous or savannah forest zone.

The natives use the stems for rafters and house-posts; the fruit and bark are used medicinally; and the leaves are used for making sieves, hats, mats and bags.

Calamus dearatus. Benin Cane or Rattan. Frogbo (Benin).

It is found in the Benin province of Nigeria. It is one of the rarer canes of the forest, has a yellow flower, and is found near Okenuhen. The canes are used for fences and housebuilding.

Eremospatha macrocarpa (Mann and Wenal). Small Benin Rattan. Ukan (Yoruba); Ikan (Benin).

It is found in the Benin, Calabar, Ondo and Abeokuta provinces of Nigeria.

It is a common $\frac{1}{2}$-inch thick cane, which attains a length of nearly 200 feet. It grows in clumps and climbs up over the surrounding trees. The fruit is yellow and rather like a small larch cone which has not opened. It is used for making rope and baskets, tying timber rafts, house-building, etc.; in fact, it is the best cane in West Africa.

Eremospatha sp. Large Benin Rattan. Okakan (Benin).

It is found in Ondo, Abeokuta, Benin, Warri, Brass, Owerri, Calabar and Ogoja provinces of Nigeria.

It is a large creeper, nearly an inch in diameter and attaining a length of nearly 200 feet. It is usually found partly growing on other trees in more or less open places at the edge of the forest, near river banks, in the evergreen forest zone; it is also found at the edges of swamps in the same region. It often forms dense cane brakes. One of the most typical features of this cane is the reddish-orange cone-like 


\section{THE NIGERIAN TIMBER TREES}

fruit, which is borne in large clusters on the terminal shoot of the creeper.

The light-yellow, long spikes of the male flowers are most conspicuous early in the season, especially when seen from a canoe when passing down a river like the Osse.

The natives strip off the bark and long shoots of fish-hooklike spines, and use the comparatively smooth canes as supports for the canoe mats and for making tying material for housebuilding; it is also used for making rope. When whole, it is used in making bridges as well as for joining logs together for rafting purposes. When cut into short lengths and bent at one end, it can be used for walking-sticks.

It is rather a slow-growing creeper, and usually ten or twelve grow out of one root stock. In 1904 this cane was examined in England as a substitute for rattan, but it was found to be more brittle, and the internodes were found to be too close together to be attractive as walking-sticks. Still later, in 1908, it was tried for basket work, but was found to be too coarse both in structure and texture of grain.

Elcesis Guineensis. The Oil Palm, the West African Palm. Ope, Ipa ukoro (Yoruba); Udin (Benin).

It is found in all the Southern Provinces of Nigeria and as far North as Zungeru, in the Northern Provinces. It belongs to the evergreen forest zone, though it will spread with cultivation into the mixed deciduous and dry zones.

It is the common palm of all the farms and forests of the moist and mixed zone of Nigeria. It bears a bunch of fruit containing as many as two thousand individual fruits in one drupe. In the drier parts there may be only as many as one hundred seeds. There is one forked palm on the right-hand side of the line about seven miles from Ibadan, just beyond Moor Plantation. This is a very rare occurrence, and I have only seen one in twelve years' travelling in Nigeria. The male inflorescence is not unlike a very close horse's tail, turned up on end. The orange-brown-coloured female flowers are very small, and do not last long (a few days). The male flowers always appear first, and above the female in each case. The natives say some trees only bear male flowers, but it is doubtful if this is ever true, except in very isolated cases. It bears fruit in the fifth year, and will go on for about a hundred years. There is a most marked difference in the height of a tree which has grown up in the "high forest" and one which has come up in an old farm, the former being fully 100 or even 150 feet high and the latter only 20 to 30 feet in height. In a similar way the bole of the forest-grown palm is only about 3 feet in 
girth, whereas the farm-grown palm may be over 6 feet in girth. It goes without saying that the latter bears larger bunches of fruit and the individual nuts are larger and also more numerous.

Between the twelfth and fifteenth year the tree begins to clear itself of the lower leaves, thus forming a clean bole up to the tuft of fronds at the top.

Owing to the fact that the bunches of fruit form in the axis of the leaf stalk, they are compressed very tightly, and thus ripen comparatively slowly. By cutting off the leaf immediately below the fruit, the ripening period is shortened by three weeks. This is, of course, partly due to the increased amount of light. Cutting leaves, however, above the fruit, or at all excessively in number, leads to a deceleration in growth, so that pruning should only be moderate. Both in the forest and in the open, epiphytic ferns, figs, and other plants grow amongst the leaves on the stem, and more especially later at the top of the tree. The trees are rarely, if ever, cleaned of these hindrances to healthy growth, but naturally they retard the flowering and ripening of the fruit. The leaves are also used for making brushes for sweeping the ground.

Native Use.-Oil is made from the pericarp of the fruit, and from the kernels, for rubbing on the skin. The leaf stalk is used for roof-poles.

Natural regeneration is good, although the Oil Palm thrives best in a deep, moist soil with considerable mineral content. It is, however, found growing amongst rocks on laterite and poor sandy land, and that in such case the rainfall is deficient, i.e. below 40 inches. A few small plantations have been made. It is noticeable that self-grown seedlings grow much slower than those transplanted. In the first year the self-sown seedlings 'grow only one pair of leaves, whereas those transplanted grow five or six in the same period Apparently the Oil Palm does not thrive unless the soil is kept well covered and a good surface tilth maintained. With a planting distance of 20 to 24 feet there is considerable scope for the planting of other crops between. The chief difficulty appears to be to grow these at a profit without impoverishing the soil or hindering the quick development of the Oil Palm. On suitable soil the most profitable crops appear to be the following: ground-nuts, beans (three or four kinds), Egusi Bara, Citrullus vulgaris.

A fuller consideration of this subject, and the Oil Palm generally, will be found in the separate section about it.

Eloesis Guineensis, var. Thompsonii. The Palm of Everlasting 
Life or King Palm. Eviromilla (Benin). This is the meaning according to the Benin name.

It is found in the Colony of Lagos, and Abeokuta and Benin provinces of Nigeria. On the whole, it is an uncommon tree, but there is no doubt of its being an indigenous tree to this part of Africa. The leaves are long and very compressed, being set at an acute angle to the leaf stalk and of smaller size than in any other species. It gives the palm almost the appearance of a Cycad. It also looks as if the leaves had closed up with the cold or were not fully developed. The leaves also are of a much darker green (almost olive-green) thdn the ordinary palm. Amongst the Benis it is considered the Sacred Oil Palm Tree, the nut obtained from it being especially revered. From the Resident's office is seen one of these trees which was planted in the Benin City Arboretum some nine years ago. It is a very slow-growing palm, having scarcely one quarter of the rate of growth of the ordinary oil palm. The stem is much thinner in proportion to the height than the ordinary oil palm; and it does not attain more than half the height of an oil palm. When growing in a group, it gives quite a funereal appearance.

The nuts are used by the natives as "Ju-ju" of divination to see into the future. It is said that " the nuts talk," in the Benin country, where the tree is held to be that of everlasting life.

Eloesis sp. Ope trumfo (Yoruba).

Abeokuta province, Yoruba country.

Elcesis sp. Small Oil Palm. Ope Ifu No. I (Yoruba); Ogiedi (Benin).

Abeokuta province, Yoruba country.

Elcesis Guineensis, var. Lisombe. Palm, or Lisombe Palm, or Soft-shelled Palm. Ogeddin (Benin).

The main difference of this species is in the small oblong, pointed fruit on a much smaller drupe, and the larger quantity of oil obtained from the-pericarp and the very small kernel in the nut. It is also much softer to crack. The foliage looks a fresher green than the ordinary variety; also the leaflets are placed at an acuter angle to the leaf stalk than the other.

It is not very prevalent in the Benin, Abeokuta, Calabar and Ogoja provinces of Nigeria.

Silviculture.-The nuts, when sown, do not germinate true to species, except for a few per cent. It is planted in the Indem country of the Ogoja province.

Native Use.-The oil is collected in a similar way to the other, but is liked more by the natives of Benin. The kernels are used for making oil as well. 


\section{WEST AFRICAN FORESTS AND FORESTRY}

Hyphane. Dum Palm or Forked Palm. Kaba, Kodago, Kwalo (nut), Goriba (Dr. Dalziel's Hausa list).

It is found in the Zaria and Niger provinces of Nigeria.

The only branched palm in West Africa. It attains a height of $\mathbf{3 0}$ feet. It is more or less gregarious in habit, though the individual groups of palms are not very large. It is apparently somewhat fire-resisting, though this may be due to its being found amongst the dry-zone vegetation. The stem is short and the two forks often crooked, so that little or no use is made of the wood by the natives. The seeds are turned into buttons, and so have recently obtained a value for this purpose. They were first sent to England from the Soudan, where apparently the tree is much more common than in West Africa.

Borassus flabelliformis, var. Asthiopica. Palmyra or Black Run Palm, Fan Palm, Bottle Palm, Arac Palm. Agbon, Olodu, Igoti (Yoruba); Oluwa (Benin).

It is a common tree in the dry-zone forest regions of Ibadan, Benin, Onitsha, and Ogoja provinces of Nigeria. This palm, with the swollen upper part of the bole making it appear more like a large inverted bottle, is thus not to be mistaken for any other. The huge fan-shaped leaves distinguish it from either the Coconut Palm or the Oil Palm. In the distance, too, the leaves appear more silvery-green, and not the yellow-green of the Coconut, or the bright, fresh green of the Oil Palm, or the sombre dark green of the Wine Palm. A large mass of coconut-shaped nuts, but with a smoother, more yellow surface, and more cylindrical in shape, without the ridges of the coconut, are another feature of this tree. At the base of each nut the old sepals of the flower remain, appearing like large dark-brown leaf scars. The young seedlings are easily seen amongst the grass, sticking up as they do like little silvery-green fans of varying size, in detail showing the folds of a fan most distinctly, the leaf opening out in a similar way to a fan. The bole is dark brown and practically smooth, showing no leaf scars, and only faintly lined vertically down the stem. The base is only slightly swollen, and the roots do not form a large mound round it, as is the case with the Oil Palm, and to some extent with the Tombo Palm. Inside the fruit there are two or three large, flattish nuts.

The timber is fibrous, hard, but very durable and quite termite proof. Although the upper part of the stem is hollow, long sectional pieces, four by two, and even thicker, can be cut out. It planes up with a smooth surface, and the grain looks very pretty with the thick fibres. It nails fairly well and splits longitudinally. 
It is a light-loving tree, moderately fast growing for a palm. It is usually found growing gregariously in groups of a few acres up to hundreds of acres in extent. However, it is rarely thick enough to thoroughly shade the ground. Natural regeneration is good, even though in most areas annual grassfires run through the trees and to some extent char the fruit. No plantations have been made of these species.

The timber has not been exported, but locally it has been used for house-building, as well as for fences near the railway. The natives occasionally use it for house-building, but they do not know how to tap it for the wine. The leaves are sometimes used for making temporary shelters. The fruit is sometimes eaten, and has a pleasant taste. The nuts might be exported for making into buttons.

\section{Cyanastracex.}

Cyanastrum cordifolium. Ikoto.

It has an edible fruit. Found in the Benin province of Nigeria.

\section{Liliaceæ.}

Draccena sp. Dragon's Blood. Ewanenimi (Benin).

It has a very long, thin leaf of the usual monocotyledonous type and with a somewhat branched stem, with thin papery bark.

It is fairly common in the Benin country. It is one of the few monocotyledonous trees of the forest, and thus easily distinguishable from other trees. The parallel veins of the leaf are very long and laid fairly close together. The stem is very porous and not woody, being more fibrous in type. It reaches a girth of about 4 feet and a height of 40 feet.

Native Use.-The leaves are used by the natives medicinally; and occasionally the sap is used to blind people.

Draccena surculosa. Dragon's Blood. Ope, Igbo.

Is found in Olokemeji.

Dracana cylindrica. Boundary tree. Peregun (Yoruba); Ukpogun, Ogihu (Benin).

Found in the Olokemeji Reserve.

Draccena cylindrica. Boundary tree. Peregun (Yoruba); UKpogun, Ogihu (Benin).

It has a wider and shorter leaf than the Ewanenimi tree, but again with the parallel veins, which are, of course, typical of the monocotyledon. It does not really form proper timber, but the stem is of a spongy, fibrous nature. It reaches a girth of about 5 feet and a height of about 50 feet. It usually has one stem, which is unbranched for a very considerable length, but sometimes a whole group will grow up in one place. 


\section{WEST AFRICAN FORESTS AND FORESTRY}

Both this and the former species are propagated very easily by cuttings. In fact, it is possible to take the end of a branch complete with the leaves and put it in the ground, when it will grow. It likes a comparatively deep moist soil, though it will stand any amount of drought without actually dying. It stands pruning well and grows moderately rapidly.

It is useful for making live fences.

Native Use.-Both Yorubas and Benis use the tree for boundaries, simply sticking cuttings in wherever it is wished to mark a place. "Ju-ju" places are also marked in this way. The leaves are used medicinally in Benin.

Dracana Perottetii. Boundary tree. Ope, Kanakan (Yoruba).

Found in the Mamu Forest.

Dracona sp. Boundary tree. Oro Igbo (Yoruba); Uruaro (Benin):

A common Dracæna found in the Benin and Abeokuta provinces of Nigeria. It is often used for making fences to farms and boundaries for village or farm land, and for marking special "Ju-ju" places. The Benin people state that it has more latex than the other species of this genus.

\section{Marantaceæ.}

Clinogyne, syn. Donax cusputata. Yoruba Soft Cane. Toto (Y.).

It is found in the Abeokuta province of Nigeria. It is a small soft cane which grows gregariously in groups from a quarter to half an acre in extent in the Olokemeji Reserve, to a height of about 5 feet, and has large, alternating, very fine parallel-veined leaves. Inflorescence, raceme or panicle-like bracts, deciduous. Some species yield starch or fibre. Toto is found quite abundantly in the middle of the Olokemeji Reserve. It is used for mat-making, and considered most valuable.

\section{Orchidaceæ.}

Polystachya sp. (Lindl.). Eme-ela (Yoruba).

It is found in the Olokemeji Reserve in the Abeokuta province of Nigeria.

Polystachya odorata. Afoma (Yoruba).

This is a parasitic plant, very similar to mistletoe, which attacks many kinds of trees and has recently been found on the six-year-old teak at Mamu and Olokemeji, in the Abeokuta province of Nigeria.

\section{Ulmacer.}

Celtis solenostigma. Hard Celtis (large). Ita (Yoruba); Ita, Uta (Ikale); Ohianamemme, Ohia (Benin); Omoin, Itako, Ita gangan (Egba). 


\section{THE NIGERIAN TIMBER TREES}

It is found in the Abeokuta, Ibadan, Ondo, Benin, Owerri, and Ogoja provinces of Nigeria, in the mixed deciduous forest zone, where it is usually very prevalent. In many places it is almost gregarious.

It is a large tree 10 feet in girth, with smooth stem and large, long, thin buttresses. It has a bigger leaf (6 inches) than the other Ita, with a very prominent mid vein on the leaf.

The fruit is dark coloured. The root buttresses are very long and thin, extending sometimes 15 feet up the trunk of the tree. They are, however, shallower and thinner than in the case of mahogany and cotton trees. They merge gradually at an angle of about 15 degrees into the stem. The bole may reach a length of about 90 feet, and is usually very straight. The crown is compressedly spherical, rather shallow in proportion to the size of the tree, but fairly wide-spreading. Occasionally, if the bark has a yellow tinge, especially in smaller specimens, the tree may be mistaken for Opele, Schrebera Golungensis.

Timber is white and very hard, and splits well when it is dry. When dry it is inclined to be brittle, though it shows considerable lateral strength. The texture of the grain is fine, and it planes up with a smooth surface. It is liable to split with nails, but it saws well. Under cover it is durable; in the open, unless very carefully dried, it is liable to decay. When thoroughly dry it hardens very considerably, and is not attacked by white ants, especially when used in a suitable place. When dry it will float, but the wood is liable to become discoloured by contact with water.

As firewood it burns slowly, gently and steadily, giving out much heat. It is a fairly rapid-growing tree, at first shadebearing and later somewhat light-demanding; in the older stages it scarcely protects the soil. $U p$ to the pole stage it is a soil-improving tree, the leaves making a rich humus. Natural regeneration appears to be good. It does not sprout from the stump. Considering its size it is fairly wind-firm. No plantations have been made of this tree.

The timber has not been exported, not has it been sawn up for local use. Considering its prevalence, it deserves a trial.

Native Use.-It is considered the best firewood in Benin, and also used as firewood among the Yorubas.

Celtis sp.? Soft Celtis (small). Ita ita (Yoruba); Ohia (Benin).

It is found in the Abeokuta, Ibadan, Ondo, Benin, and Ogoja provinces of Nigeria, in the mixed deciduous forest zone, where it is very prevalent. 
It is a medium-sized tree up to 4 feet in girth, with medium. sized, thin leaves and white-coloured twigs. The stem is slightly scaly and yellowish-green in colour, especially in the upper parts. A very common tree in the deciduous forest. With its yellowish-green bark in the upper part of the bole it is very similar to Opele, Schrebera Golungensis, and can often be mistaken for it. The trunk, however, is not slightly pitted, as is the case with Schrebera. On the whole, this tree is shorter, reaching a height of about 40 feet. The root buttresses are much slighter than in the case of $C$. solenostigma, though they are of a similar shape, being very thin and merging gradually into the trunk to a height of about 5 feet from the ground.

Timber is white and fairly hard, but not durable. It hardens somewhat on exposure to the air. The texture of the grain is fine, but occasionally cross-grained. It planes moderately well, and takes nails moderately well also, more so than $C$. solenostigma. It saws easily and splits well.

As a firewood it burns steadily and slowly, giving out great heat. It does not crackle nor cause sparks.

It is a moderately fast growing, at first shade-bearing, and subsequently a light-demanding tree. During most of its life it is a soil-protecting and soil-improving tree. Natural regeneration is good. It sprouts a little from the stump, but not strong enough for purposes of reproduction.

The timber has not been exported, nor has it been sawn up for planks for local use. Being smaller than $C$. solenostigma, after trial it may not be found so useful, but it could be used for similar purposes.

Native Use.-Firewood of the best kind, and occasionally used as side house-posts.

Trema Africana. African Elm. Ehunogo, Ehrunbogo (Benin); Affi (Ibadan and Oyo); Afoforo (Egba); Offun (Lagos).

It is found in the Abeokuta, Ibadan and Benin provinces of Nigeria, in the mixed deciduous forests, where it is moderately prevalent.

It is a medium-sized tree with nettle-like leaves, which wither rapidly. It has a very thin, smooth bark. The fruit is small, thin and long, and is eaten by pigeons. It grows up where old trees fall in the forest, and is also a common tree in old farms. Medium-sized specimens are in general appearance, from a little distance, very similar to Iroko, and it can be mistaken for this tree. The crown, however, is narrower, and the foliage is somewhat thicker, and the leaves and branches are placed rather closer together than those of Iroko. The bark 
is slightly fissured, and does not show lenticels like the Iroko, especially not on the roots. In proportion to the size of the tree, the root spurns are larger than in the case of Iroko. It it usually found growing singly, whereas groups of Iroko are often common, or anyhow several are found in one locality.

The timber is white and of medium hardness, but very durable indeed. It is termite proof. It planes well, but does not split easily. It saws well and takes nails fairly easily.

It is of fairly rapid growth, at first shade-bearing, and later a somewhat light-demanding tree, with soil-protecting and soil-improving qualities. Natural regeneration only appears to be moderate. It sprouts from the stump.

The timber has not been exported, not has it been sawn up for local use.

Native Use.-The timber is used amongst the Benis as rafters and ceilings for house-building, as it is uncut or squared.

Trema affinis or T. Africana. African Elm. Afofero (Yoruba).

Found in the Abeokuta province of Nigeria.

\section{Moracex.}

Antiaris toxiaria. False Oroko. Oro Aiyo, (Egba) (Yoruba); Ogiovu (Benin).

It is a common tree in the Calabar, Ogoja, Owerri, Warri, Benin, Ondo, Ibadan and Abeokuta provinces of Nigeria.

It is a large tree, reaching a girth of 15 feet and a bole length of 70 feet, of very cylindrical shape. There are large surface roots, which stick up out of the ground on roadsides, but form only low root spurns. The bark is grey, smooth and almost shiny in the sun. The crown is heavier and less open than Iroko, but otherwise in habit it is similar. The leaves on the whole are smaller and the foliage generally is of a lighter green than the Iroko, except when the latter puts on new leaves in February or March. The fruit is a little spherically shaped nut with a papery covering easily removed, disclosing a round nut with small markings all round it. Two kernels are found inside on cracking it. The slash is yellowish white, and gradually a little thin white latex exudes. The tree usually appears after a few years on abandoned farms. The leaf is rough to the hand, almost as bad as Ficus asperata, but there are no hairs on the under surface. On the whole the branches are much flatter than Oroko, though the top of the crown is round. The timber is soft and white all through. Termites attack it. It is very light and might almost pass as a substitute for cork. It has large and wide medullary 
rays, more especially in the root. In cross section the root looks almost porous.

Native Use.-Amongst the Yorubas the bark is used medicinally and the wood for doors, benches and matchet handles.

It grows very fast and likes light. Scale insects like to make their nests in a junction of a branch with the stem, where there is quite a hollow. In youth the firm and almost horizontal branches are quite a contrast to the long, up-shooting or drooping branches of Oroko. It has not been cut either for local use or for export.

The roots are used for making corks in the Calabar district.

It is used often as a "Ju-ju" tree, like the Iroko, chiefly in the Calabar Division. The hunters sit near the tree, when in fruit, because the Maxwell's Duika, Yellow-backed Duika, Red-headed Duika, etc., eat the fruit. The bark is used in sections for making bags by sewing the two ends together, as well as one side.

Antiaris sp. Ovu (Benin).

It is a common tree in the Benin and Ondo provinces of Nigeria. It is medium-sized, reaching a girth of 9 feet and a bole length of about 50 feet. The leaf is larger, but the crown appears thicker and heavier than Antiaris toxiaria. The seed is the same size as Antiaris T., but the root spurns are very slight, even less than Antiaris $T$. The branches spread out from the stem, thus making the crown longer and narrower than Antiaris T. In this respect the Antiaris sp. is more like the Oroko than the Antiaris T.

The timber is white and soft. No proper heartwood. It splits well.

It is a shade-bearer and is often found in the thick forest. It grows much slower than Antiaris $T$.

It has not been cut for local use or exported to Europe. Perhaps it could be tried for wood pulp.

In Benin the branches of this tree are used for making figures of their ancestors, which are placed outside the house. The bark is used for making bags in a similar way to that of Antiaris T. It is also used for making rope or string for tying bags.

Antiarus sp. Cedar-like Lauro. Oregbon I (Yoruba); Opputtu (Benin).

It is a common tree found in the Benin and Abeokuta provinces of Nigeria. It is very similar in habit and shape to the Antiarus toxiaria, but it does not attain nearly such a large size. The tree exudes very fine, white latex in a very small quantity. The timber is soft and white and not durable. 

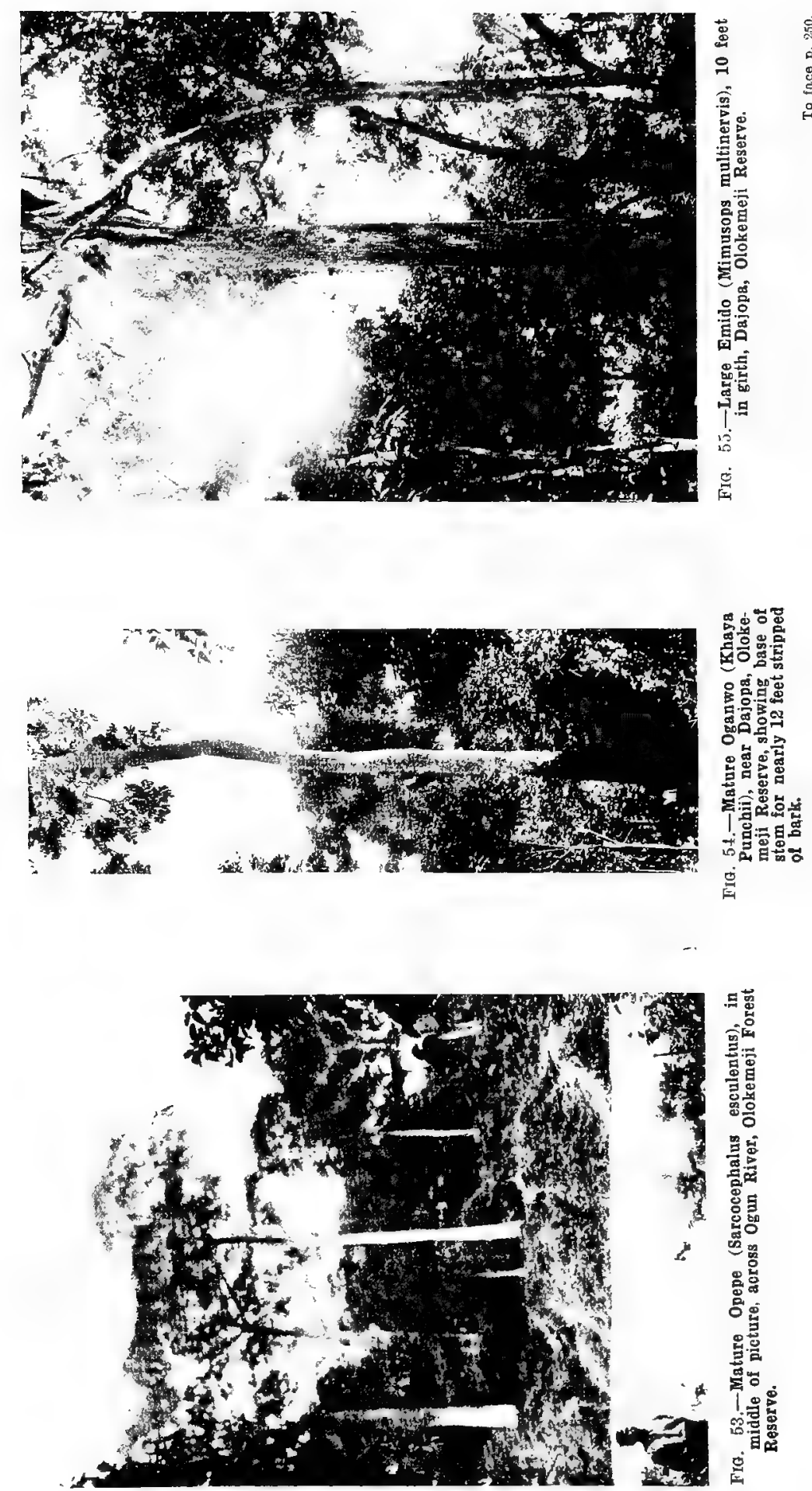

It is a soil-protecting and soil-improving tree, and stands a good deal of shade. The tree has not been cut for local use, nor has it been tried as a timber for export.

Ficus sp. Common Fig. Obobo (Yoruba); Ohau (Benin).

It is a common tree of the Calabar, Ogoja, Owerri, Warri, Benin, Ondo, Ibadan and Abeokuta provinces of Nigeria. One of the most typical features of this tree is its free growth, open crown, and green, yellow and orange-coloured bark from the base upwards. It is a medium-sized tree, attaining a girth of 10 feet. The small red-coloured figs attract pigeons especially, as well as other birds, to the trees in the fruiting season. The leaf is small for a Ficus and oval in shape. The wood is white and soft. The white latex which exudes from the trunk when cut distinguishes this tree from the satinwood, Afrormosia laxiflora, with which it might be confused owing to the similar shades of green, yellow and orange-colour of the bark. It is chiefly found in the secondary forest, also near villages in the evergreen forest zone. Owing to the parrots and pigeons carrying the seed, reproduction from this source, both in epiphytic and tree form, is very good, but it is most usually found growing alone in an open place, without any support from other trees. It is very fast growing and impatient of shade.

The wood has not been used locally nor for export, nor does the native apparently have any use for it, as it soon rots when cut down.

The native occasionally eats the ripe fruit.

Ficus exasperata. Emido, Oboba (Yoruba).

This tree is found in the Abeokuta province.

Ficus Thonningii. Opoto (Yoruba).

This is one of the smaller fig-trees of the mixed deciduous zone. As with the others, it is not used as a timber tree, but occasionally for fences.

Ficus triangularis. Abadan (Yoruba); Obadan-nikwi (Benin).

It is a common tree in the Benin, Ibadan and Abeokuta provinces of Nigeria. It is chiefly found in the mixed deciduous forests. It is of no use as a timber tree, but is used occasionally for fences by the natives.

Ficus Vogelii. Lagos, Abba or Abbo Rubber. Abadon (Yoruba); Obadan (Benin).

It is the common tree of the Calabar, Ogoja, Onitsha, Benin, Ondo and Abeokuta provinces of Nigeria. This is the most common fig-tree, and is usually found along the sides of roads in the native villages. The very large, shiny leaf (not quite as glossy as Ficus Indica) is one of the most typical features 
of this tree. In Benin it is usually deciduous for about thirtysix hours, and the pinkish tips of the fresh leaves and the great rapidity of their development are remarkable. The bark is dark brown and rougher than the other species. In the Benin Forestry Compound there is a large specimen. On the whole, it is less common in the evergreen forest than near villages or roads. In the forest it is most often found as an epiphyte growing on oil palms, Sasswood, and oil-bean trees. The timber is white and soft; it has not been used for local purposes nor for exports. The "Balata rubber" of the Upper Niger district is obtained by roughly coagulating the latex of this tree in the air, with or without reagents, such as the latex of Bauhinia reticulata, or salt. The natives use the tree for making fences by sticking in pieces of the stem of suitable length, and in a similar manner it is used as a shade tree on the sides of roads in the villages. This is more especially the case in the villages in the dry zone, where other shade trees are scarce. Pigeons and parrots spread the seed, and thus its reproduction is assured.

Ficus platyphylla. Gambia Rubber.

It is also found in the upper reaches of the Ogan River, in the Ogo province of Nigeria.

Ficus asperata. Sandpaper Leaf. Ekpin (Yoruba); Ameme (Benin).

It is a common tree in the Ogoja, Owerri, Benin, Onitsha, Ibadan, Ondo and Abeokuta provinces of Nigeria.

It is often found as a small, scrubby tree, though when fully grown it reaches a girth of 8 feet, especially in the Benin province. The rough leaves are harsh to the touch.

The pigeons are very fond of eating the fruit and seeds.

The wood is white and soft.

The leaf is of the usual Ficus style, with a short stalk and deeply dentated, making almost a five-lobed leaf.

The leaves might be useful as a substitute for sandpaper.

It has not so far been cut for export or local use.

Native Use.-The leaves are used for cleaning calabashes by the Yorubas and Benin people.

Ficus sp. Ograw (Yoruba).

Found in the Abeokuta province.

Musanga Smithii. Cork-wood or Umbrella Tree. Agbawo or Aga (Yoruba); Ogohen (Benin); Oro (Brass).

It is a very common tree, found growing in new clearings amongst the evergreen and mixed forests of the Calabar, Ogoja, Owerri, Onitsha (?), Warri, Benin, Ondo, Ibadan and Abeokuta provinces of Nigeria. 


\section{THE NIGERIAN TIMBER TREES}

It is a medium-sized tree with an umbrella-shaped crown. It is the most distinctly gregarious tree of any in the forest, often alone covering many acres of land, supported on a series of aerial roots, the centre one of which is really the tap-root. The tree looks altogether top-heavy when mature (it is shortlived). It reaches a girth of nearly 5 feet. The bark is thin and of a light brown colour, spotted here and there with large Jellow lenticels. The large pink sheath containing the immature staminate flower is often found lying on the forest pathway after the storm. The leaf is reminiscent of the horse chestnut, but with about eight digits. The young leaflet is of an orange-red colour. It is doubtful if it passes an age of thirty years.

The timber is white and soft, with no distinguishing heartwood, but with brown pith half an inch in diameter. When properly dried it has a fine, smooth grain and is usually free of knots. It dries much harder than when freshly cut. It splits well, but it is rather brittle.

It is the quickest growing of all the African forest trees, and certainly reaches timber size before any other. Regeneration by seed is prolific, seeds often germinating after lying dormant for over a hundred years, when a heavy forest is cut down. It is a light-lover, protecting the soil with its heary foliage, and enriching it by making a good mould when it falls to the ground. It will stand a little shade as a young seedling. Very few trees will grow under it, though it is a useful "nurse."

The timber is used for floating other wood heavier than water, but it has not been exported or cut for local use. The roots are used medicinally, and hunters tap the tree for water in the dry season.

Native Use.-As the Yoruba name implies, a group of the aerial roots is used for a native chair. Young 6-inch stems, split in half, cut about 4 feet long and dried, are used upright to form the walls of temporary farm-buildings. The wood is also used in place of cork, and for making matchets and knife scabbards in the Benin and Ibo countries respectively. Chlorophora excelsa. African Oak, African Teak. Iroko (male), Iroko (female), Oba's Tree, Rock Elm. Iroko (Yoruba); Uloko, Oroko Ulokoodigpe, Uloko-nushinogbon (Benin); Odji (Ibo, Asaba); Ofryio (Efik); Nsan (Oban, Ekoi).

It is a very large forest tree, reaching a girth of 30 feet and a bole length of 90 feet under favourable conditions. The male tree is usually thinner and of more compressed build, whereas the female shows more spreading growth and larger 


\section{WEST AFRICAN FORESTS AND FORESTRY}

size; it is also quicker growing than the male. The female has stout, finger-thick, solid catkins, whereas the male has thin, long, open catkins up to 6 inches long. The timber of the male is darker brown and closer grained than that of the female, and also harder. The sapwood is wider in the female tree, but there is also a very wide difference between trees of both genders when they are grown in the open, old farms, or in dense, high forest, the latter yielding the hardest and closest-grained timber. The crown is almost umbrella-shaped and open, so that the leaves appear large in proportion, and it is usually possible to see through it. Three or four large limbs form the mainstay of it (see plate No. 37). The yellow lenticels on the stem, especially in younger specimens, and also on the red roots, are typical of the tree. The slash is yellowish, with little red spots in it. A little white latex flows out too.

In proportion to the size of the tree the root spurns are not very large, reaching 3 or 4 feet up the tree, and being well rounded, do not spoil the shape of the base of the bole. In older specimens the bark becomes brown, and finally almost grey in colour, and scales off to a slight extent. Although it forms very large side roots, it has a tap-root going to considerable depth. The loose seeds are small and flat, being not unlike those of alder, but rather larger and thinner.

It is found in all the Southern Provinces of Nigeria, both in the evergreen and mixed forest zones, where it is none too prevalent.

Timber.-Sapwood is yellowish white, and the heartwood of a yellow brown to dark brown (oak to teak brown). It is moderately hard, very durable and termite-proof. It does not plane very well, being sometimes cross-grained; it can, however, be worked up to a smooth finish. The grain is rather open and the pores very long. It has, however, an oily feel, and a certain amount of sheen. It takes nails with difficulty, splits moderately well and saws easily. It soon darkens on exposure to the air and light, becoming in this respect much darker than oak in a similar period. When seasoned properly it does not warp excessively. If taken green from the forest zone into a drier climate it will split. In the past a good deal of timber has been used in this state.

It is a moderately fast-growing, at first shade-bearing and subsequently a light-demanding tree, with soil-protecting and soil-improving qualities. It is deciduous for a few weeks in the year, generally in February or March, but specimens vary a great deal in this respect. Natural regeneration is very 
good, and in suitable localities it tends to spread more and more with the advance of the native farms into the forest. It stands transplanting very badly. Nursery sowings, however, show an enormous percentage of germination, the seedlings often coming up more thickly than grass. The ground pig eats the roots of transplanted seedlings, especially in localities where there are less desirable trees. It will grow as much as 6 feet in one year, and wherever it has much light in the forest, selfsown seedlings will grow 3 or 4 feet each year. The leaves are attacked by a minute coccus which causes them to swell up into an irregular shape, including the bud, thus stopping the growth for that season. Inside each of these swellings there are several of the young insects. Only the younger trees are attacked, and from the pole stage onwards trees do not appear to suffer nearly so much. In localities, too, where the trees grow very rapidly they appear to be less attacked, if at all. It is not very susceptible to fire, though in the mixed deciduous the base of the stem is often burnt. It. is one of the most storm-firm of all the African trees. The bole is very cylindrical, especially if the tree which has been growing in the forest is given plenty of space to grow. The increment put on the bole is very great, being as much as 11 inches in circumference in one year.

In 1906 sample logs of this timber were sold in the Liverpool market as Iroko at 5d. per superficial foot, sale measure. Since that date it has been sold as African Oak and African Teak at a similar price, and appears now to be fairly well established in the market. As there are large supplies in many districts, such as the Yoruba country, Onitsha, Ahoada and Ogoja districts, there should be no difficulty in keeping the market supplied with moderate quantities year by year, at perhaps, though, slightly increasing costs. Locally the tree has been felled and sawn up for planks, scantlings, rafters, beams and general constructional work. By the Railway Administration it has thus far been considered the best wood for sleepers. Amongst the natives it is often worth more than it is to the European, the price varying from half a crown to 4 s. $6 \mathrm{~d}$. per cubic foot for sawn boards 12 feet long, 12 inches wide and 1 inch thick.

Native Use.-The most valued of all woods for wall-plates and door lintels, treasure-boxes, washing-basins for chiefs. Doors, too, are made of it in Benin. Women place little pieces of chalk, yams, plantains, cowries, coco yams at the base of the tree, and it is said they will be blessed with children. Chiefs sacrifice a goat with a mat and a fine white cloth to propitiate 
the witches, who are supposed to hold their court in the Iroko tree and try to catch one of the sons of the chief.

Treculia Africana (Dene). African Breadfruit. Afon (Yoruba); Ije (Benin); Ijeni (fruit).

This tree is usually found near the edge of the villages of the Calabar, Benin, Ondo and Abeokuta provinces of Nigeria.

It grows to a large size, with a bole length of 20 feet and a girth of 9 feet, but it is usually a rather open-crowned, spreading tree. For its size the foliage is not over-dense. The leaves are single and roughly lanceolate, with a dark-green and rather shiny upper surface. The most conspicuous feature of this tree is the huge green, perfectly spherical-shaped fruit. Immature fruits of all sizes, from a cricket-ball upwards to a size of 18 inches in diameter, are seen growing close against the stem of the trunk and bigger branches of the tree. Some years ago, one of these ripe fruits fell off a tree at the edge of the Benin market and struck a woman on the shoulder with such force that she died a few days later. The natives subsequently cut the tree down.

The chief use of the tree is the fruit, which is placed in water to rot so that the seeds can be more easily extracted from the concentrically arranged fibres growing from the centre of the fruit outwards to the periphery. These are subsequently cooked and eaten, often being beaten up in a soup. From the outside the fruit looks as if it were made up of thousands of little green fibres closely packed together from the centre of the fruit, with the ends sticking out on the surface, thus giving it a rough feeling to the touch and making it appear as if it were full of holes.

The junction of a branch with the stem shows a large swelling all round the base of the branch, which thins out to its regular size about 6 to 9 inches away from the trunk.

The tree is comparatively slow-growing, but of a soilprotecting and light-loving nature. In the dry season, great quantities of dew condense on this tree, so that underneath the soil is kept moist. Probably more dew falls on this tree than Myrianthus arboreus, which shows a similar feature.

Thus far the wood has not been used for any purpose.

Treculia sp. Small-fruited African Breadfruit. Izenagan (Benin).

Found in the Benin province.

Morus sp. Aye (Yoruba).

It is found in the Olokemeji Reserve of the Abeokuta province in Nigeria.

Myrianthus arboreus. Shapo Obibere (Yoruba); Ihege (Benin).

It is a small to medium-sized tree, with short stem rarely 
exceeding 8 feet in height, and a much-branched, heavy crown, with very large leaf, cut up in the form of a large digit, much more pronounced than the horse chestnut. The leaves, on falling, rot and form a heavy layer of black humus. In the dry season the dew condenses to such an extent on the leaves that the tree drips in the morning, and the neighbourhood of such trees is always moist when the rest of the forest is dry.

The large, rough, elongated, pear-shaped fruit, like an overgrown sweetsop, is quite characteristic of this tree.

It is found in the Ondo, Benin, Owerri, Warri, Calabar and Ogoja provinces of Nigeria.

It is scarcely big enough for timber, but would make a good undergrowth for a light-loving species such as mahogany or teak, and would kill all weeds on good soil. Usually found on good soil. The timber is white and soft.

No botanical name. Iragbo-Amuje (Yoruba); Igogo (Benin).

It is a large tree with almost hard white wood, more the texture of Triplochiton. The fruit is a drupe, with a small nut inside. Termites do not attack the wood. It is a quickgrowing tree, which comes up very frequently in old farms.

It is a common tree in the Benin country.

It is a shade-bearer.

Native $U_{s e .-I n}$ the Benin country it is used for door lintels and cross-pieces in house-building.

\section{Urticaceæ.}

Urera. Ela (Yoruba); Akinrankiri (Benin).

Found in the Yoruba and Benin countries.

\section{Proteacex.}

Faurea speciosa. Red-brown timber.

Found in the Calabar province.

\section{Olacaceæ.}

Heisteria parvifolia. White Nut (?). Ikereoha (Benin).

It rarely exceeds the height of about 8 feet and a girth of about 1 foot.

This is a small shrub with red flowers of four petals at right angles to each other, in the middle of which a white-coloured fruit forms. On peeling off the white skin, a black nut is disclosed, which is edible. It tastes more like a hazel-nut. The red flower is the most distinguishing feature, and makes this plant show up amongst the evergreen zone.

It is found in the Ondo, Benin, and Calabar provinces of Nigeria. 
It is a shade-bearing and slow-growing shrub, with soilprotecting and soil-improving qualities. It serves a very useful purpose amongst the undergrowth in the forest. Natural regeneration appears to be fair, but no plantations have been made with this species. The nuts have not been tested in the export market. Amongst the natives the nuts are very popular, and it is the only use which they have for this shrub. This chiefly refers to the Benin district.

Heisteria sp.?. Benin Nut, Edible Nut. Evialegbi (Benin).

It is found chiefly in the Benin province of Nigeria, though probably its area of distribution extends to the Ondo and Ogoja provinces as well. It is a tall, comparatively thinboled tree in proportion to its height. Attaining a girth of about 8 feet, the bole is 40 feet in length. The bark is dull green and not very thick, being more in the nature of cortex than real bark. The most typical feature of the tree is the fruit, which is a spherically-shaped nut with a pointed tip. When dry, it is marked with shallow groves about half a millimetre apart, all converging to the tip. When cracked, the kernel obtained is rather pleasant to the taste, with plenty of oil. The timber is a yellowish colour and moderately hard. It is fairly durable, though it is attacked by a small woodborer when it is left lying in the forest. It is a moderately fast-growing tree, but is a shade-bearing, soil protecting and improving tree. Natural regeneration appears to be poor. No plantations have yet been made with it, but its yield of nuts should be tested. The timber has not yet been exported, nor has it been cut for local use. So far, the chief use of the tree is the nut, but even here proper tests have not yet been made, and it is only the natives who really know the tree. The exact oil content has yet to be tested.

Coula edulis. Nkula in the Gaboon, Gaboon Nut. Omumu (Benin).

An edible nut containing oil. It is nearly round in shape, but slightly depressed at the top, with a soft shell.

Chief Characteristics.-The tree is of medium size, with narrow crown and small leaves, the fruit being borne on the upper side of the branches. It is moderately common near Ugo and also on the Siluko road (both in Benin). This is apparently a rare tree in reality, and it may be mistaken for Ivialegbi.

The timber is brown with a red tinge, almost hard.

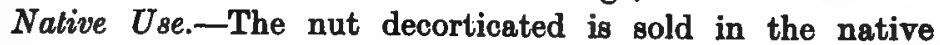
markets and eaten as a delicacy.

Value.-According to report made some years ago, it was 
valued at $\mathfrak{£ 7}$ per ton in Liverpool. It was difficult to get sufficient for a sample.

\section{Loranthacee.}

Loranthus leptolopus. African Mistletoe, or Red-flowering Loranthus.

Found in the Yoruba and Benin country.

\section{Menispermaceæ.}

Cissampelos Owariensis. Ebewaki (Benin).

A medicinal plant.

Cissampelos Pariera (L.). Jokoye (Yoruba).

It is found in the Olokemeji Reserve of the Abeokuta province of Nigeria.

\section{Anonaces.}

Enantia polycarpa (Kew). Abeokuta Bark, Kanda or Canta Bark. Ghido (Yoruba).

Found in the Egba province.

Enantia chlorantha. African Yellow Wood. Yaru (Yoruba); Ehranbabogo (Benin).

It is a common tree of the Ondo, Benin, Owerri, Ogoja and Calabar provinces of Nigeria.

It is a medium-sized tree, attaining a girth of 5 feet and a bole length of 25 feet. The most peculiar feature of the tree is the fruit, a bundle of reddish clubs all coming out of the twig at one point. The stem is dull green, with scattered lenticels here and there. The bole is uneven near the base and almost divided by large spurns, which makes it difficult to cut out a square log. Standing in dense shade usually, and often with a piece of the bark removed, showing the yellow cambium layer or wood, it is easily distinguished from other trees.

The yellow wood is similar both in the sap and in the heartwood. It splits well, even into tiny thin, lath-like pieces. It is soft, but planes up into a smooth surface. The medullary rays are often prominent, and make the wood look very pretty. The sheen of the wood also adds to its appearance.

The tree is a shade-bearer and rather slow-growing; perhaps in more open localities it would grow faster. Natural regeneration does not appear to be good, though more extensive observations on this point may reveal more. Small quantities of seed are borne each year. It sprouts a little from the stump, but this method of reproduction cannot be relied upon. Cuttings have not yet been tried. It likes a good moist soil of 
the evergreen forest and lower parts of the mixed deciduous forest. It has not yet received a place in the forest plantations.

Samples of the timber have been tried in England and used with good effect as a substitute for American "Whitewood," to which it is similar in texture. Its small size rather hinders its more extensive use. In the Benin district it is used as cross-pieces and rafters in building; wooden shovels are also made from it. It is occasionally used to make a yellow dye, especially the bark. Native caps are made from the bark, which is fibrous. It is also used for verandah-posts and door-frames.

Dennettia tripetala. Igberi (Yoruba); Ako (Benin).

It is a common tree in the Benin, Ondo (?) and Abeokuta provinces of Nigeria.

It is a medium-sized tree, reaching a maximum girth of 6 feet, with a short bole and a much-branched crown. Most commonly seen as a shrub-like tree in the mixed deciduous forest. The flower has three petals, with red colour inside and brown outside. The flowers grow on the stem or the twigs with little or no stalk, usually two or three in one place.

The timber, which is white and soft, is eaten by termites. There is no proper heartwood.

It is a shade-bearer, and rather slow-growing tree. It . likes good soil, and is rather an indication of a loose, good and deep soil.

It has not been exported or used locally.

Native Use.-The fruit, which has a peppery taste, is eaten. The chiefs only eat the fruit after it has become red and really ripe. The small boys use the new young leaves uncooked to make the mouth warm when the rain falls.

Dennettia sp. Agedegbo, Ako (Benin).

This tree was determined from specimens obtained in the early part of 1917 from Olokemeji, where it is somewhat common. Owing to the fact that only immature and mature fruiting specimens were sent, it may be identical with Dennettia tripetala. It is, however, a much smaller tree, and the fruit is not nearly so large and is a more oblong shape than $D$. tripetala. It is a small, much-branched tree and yields a hard, whitish-yellow wood which might be used as substitute for lancewood. The Benis eat the fruit, but the Yorubas have no use for the tree. Xylopia Athiopica. Negro Pepper. Eru (Yoruba); Unie (Benin); Atta (Efik).

Is a medium-sized tree with silvery smooth, grey trunk, 


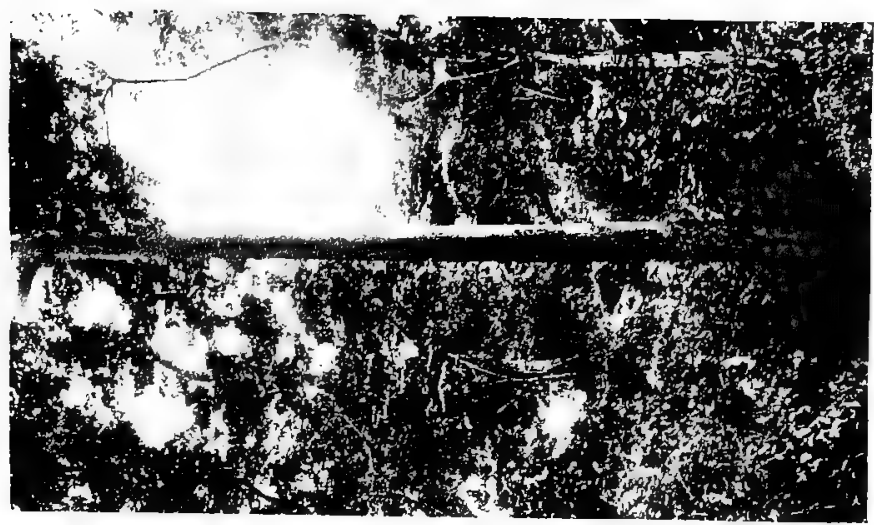

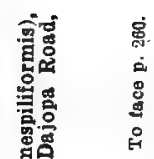
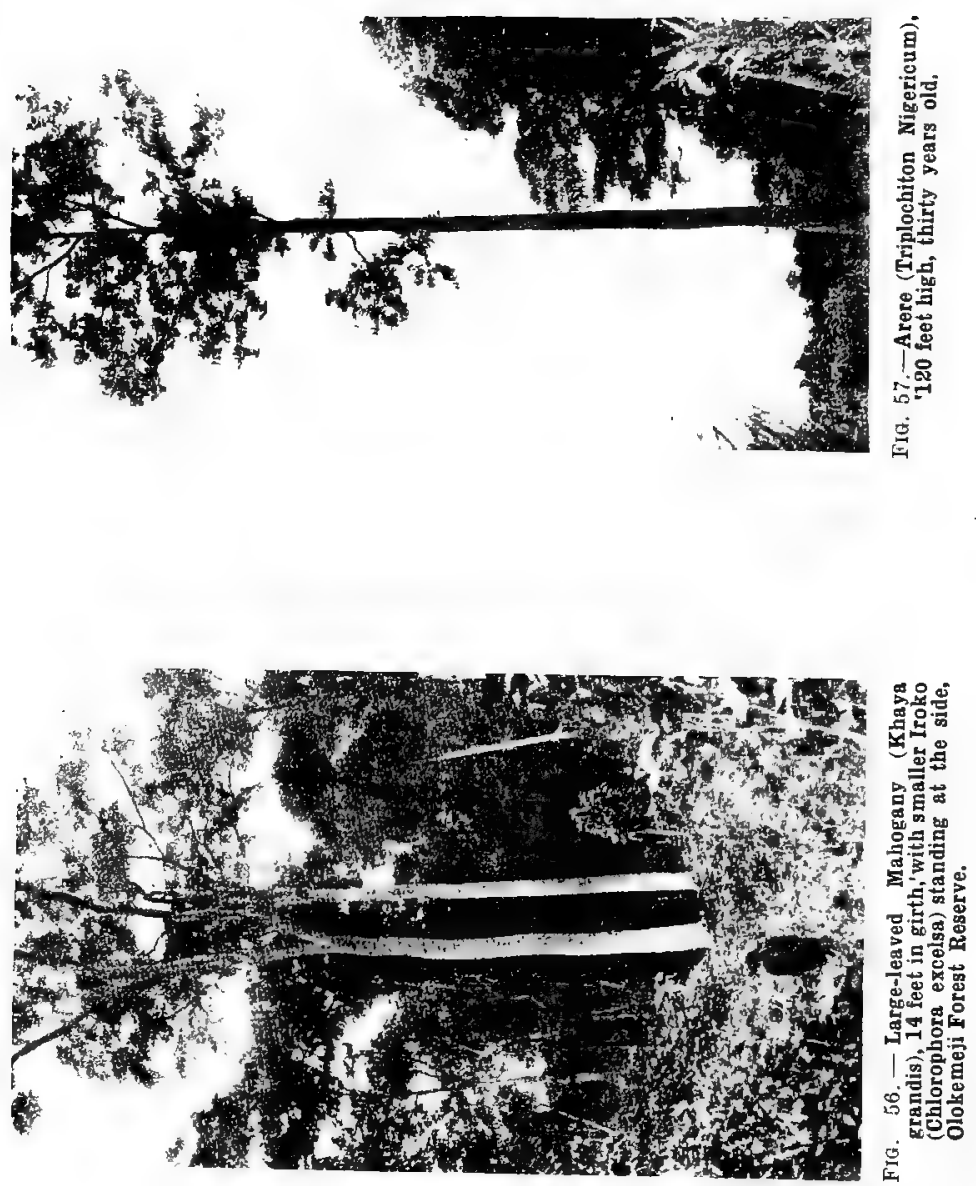

and found growing near the banks of rivers in all the southernmost provinces of Nigeria.

It is stated to be useful for oars and masts for small boats, according to the report on the Exhibition of 1867. Since that date, however, it has not been used for this purpose. The bole reaches a girth of about 5 feet and a length of about 45 feet. The crown is narrow and comparatively long, but rather compressed and compact. The foliage is dense and comparatively close together. The root spurns are slight and narrow, not extending very far up the bole. In proportion to its height the trunk is thin and very cylindrical in shape, though occasionally near the base it may not be absolutely round and tends to bulge out rather more on one surface than the other. The fruit, when ripe, is like a bunch of black keys, or little short, round-ended pieces of wood, all projecting out of one central stalk or fork, which is the most typical feature of the tree. The cortex is comparatively thin, and remains smooth even in the mature trees. The bole tapers only very slightly, and does not divide or send out any branches until the crown is reached.

The sapwood is white, as also the heartwood, except that the latter tends to have a very light yellowish-brown tinge, especially as it seasons. It is moderately hard, showing great elasticity; planing with a smooth surface, splitting moderately well, taking nails and not warping or shrinking to any great extent. Even fresh it is comparatively a dry wood. It saws well and shows considerable textile strength, as also strength in compression, is moderately heavy and termite-proof. The texture of the grain is very fine and even, and the grain is very straight.

This tree is somewhat slow-growing, shade-bearing, soilprotecting, and soil-improving. Natural regeneration is moderate. It does not sprout from the stump. It stands a certain amount of flooding, but it seems to demand a good soil with plenty of moisture, including a very moist atmosphere. No plantations have been made of this tree.

The timber has not been felled for export, nor has it been cut for local use, but it appears to deserve a trial as a substitute for lancewood, or other woods which show considerable elasticity. It should be noted that it belongs to the same family as that of the lancewood. Owing to the straightness and comparative evenness of the bole for a very considerable length, it might be suitable for shafts or even telegraph poles.

The fruit is used as a kind of comestible amongst most of the natives, as it has a peppery taste which is not unpleasant. 


\section{WEST AFRICAN FORESTS AND FORESTRY}

It is usually dried and sold in the native markets, several bunches for a penny. By some it is almost looked upon as a medicine.

Xylopia parviflora (Eng. and Diels). Small-flowering Negro Pepper. Sesedo, Issa oku (Yoruba); Aghako or Oziza (?) (Benin).

This tree is found in the Abeokuta and Benin provinces of Nigeria, where it is none too prevalent. It is a mediumsized tree with a very straight, thin and tall bole. Except for its size it is very much like $X$. Athiopica; the fruit is much smaller and scarcely to be seen from the ground. The timber is grey-white, and the heartwood, though occasionally a light brown, is scarcely to be distinguished from the sapwood. It is hard, durable, and said to be termite-proof. It does not take nails easily, nor does it split well, but it saws comparatively easily. Natural reproduction by seeds appears to be poor. It scarcely sprouts from the stump. It is a shadebearing, soil-protecting and soil-improving tree.

The timber has not been exported. The bark and roots are used medicinally.

It is used locally for house-building, as verandah-posts or supports for the roof. It has considerable tensile strength and stands compression better still.

Anona Senegalensis (Pers.). Wild Custard Apple. Abo (Yoruba).

This is found in the Oyo and Ogoja provinces of Nigeria. It is a small, shrub-like tree, with a short stem of about 4 or 5 feet, and has a very oval leaf, almost ovate in shape. It bears a yellow fruit which divides up into the typical segments common to this family. It resembles the Sugar Apple, has a delicious taste, and the fruit is most refreshing on a hot day at the end of the dry season. The tree is fire-resisting. Being deciduous, it is not a soil-improving tree. It is soil-exacting, but is also found in rocky localities. The tree is not very prolific, but sprouts very strongly from the stump and to a less extent with root suckers. The small timber is occasionally used for house-building.

Anona palustris (Foster). Alligator Apple. Afe (Yoruba).

The wood is supposed to be soft, and to have been introduced into the country some years ago.

It is found in the Abeokuta province of Nigeria. The fruit is edible, the foliage dense and heavy. In the dry season the dew condenses on the leaves and towards morning drips off on to the ground, thus keeping the immediate vicinity of the tree quite moist. The leaves, when decayed, make a rich humus. It is one of the most valuable soil-improving trees. 


\section{Anona Mannii.}

It grows in the forest region of the Central and South Provinces of Nigeria. It is a medium-sized tree bearing large green fruit close to the stem.

Popowia Mannii.

A specimen of this Popowia has been found in Alasko, near the Oha River in the Ibadan province of Nigeria.

Anona Afzelii. Probably the same as Dennettia sp. Ako, Aggedegbo (Benin).

It is found in the Abeokuta, Benin and Warri provinces of Nigeria.

It is a medium-sized tree of the more swampy parts or moister regions of the evergreen forest zone. The leaves are a very large size, often reaching a length of 1 foot. The wood is yellowish-white and soft and not very durable. Owing to the very dense foliage, quite a thick layer of humus is formed in the shade of the tree, so that its soil-improving properties are very great. It would be a valuable tree for underplanting mahogany or any deciduous tree, both with a view to providing soil cover and improving the soil.

The natives do not use this wood.

Hexalobus grandiflorus (Benth.) Afara (Yoruba).

Found in the Abeokuta province.

Uvaria Afzelii. Gbogbonshe (Yoruba).

It is found in the Abeokuta province of Nigeria. A small tree with hard wood.

Uvaria Busgenii. Paddlewood. Umaja or Umazza (Benin); Uruiju Arogu (Yoruba).

It is found in the Calabar, Ogoja (?), Benin, Ondo and Abeokuta provinces of Nigeria.

It is a large tree, and reaches a girth of about 10 feet with a good bole and limbs. The crown is narrowish, being formed by many small branches. The bark is light green, scaling off and leaving yellow patches with a red edge to each; otherwise it is smooth and almost shining. It is a common tree of the evergreen forest. With the exception of slight hollows near the base of the stem the bole is quite round.

The timber is a faint orange-colour with a reddish tint. There is very little difference between the heart and sap wood, except that the former is a lighter colour. It splits well and planes into a smooth surface. At the corner of a square block pieces are liable to split off. The grain is a little open and the pores are rather long.

Termites (white ants) make no impression on it. The 


\section{WEST AFRICAN FORESTS AND FORESTRY}

timber is hard, with a certain amount of rigidity, and yet has no resilience.

It is a slow-growing tree and shade-bearer. Judging by the number of small trees found, reproduction from seed must be good. It does not sprout from the stool, and root suckers are thrown up after the trees have been felled. It likes moist and deep soil, which must be moderately good, e.g. the red soil of Benin and sandy loam of Badagry district.

In 1906 samples of the wood were sold in the Liverpool market as Sabicu and realized 1s. to 2s. per superficial foot. It has also been used for European house-building in the Calabar province.

Native Use.-It is chiefly used for making paddles. It is also used for joists and posta by the Benin people.

Uvaria Chamo (Kew). Eruju (Yoruba). Island.

It is a large shrub with sweet-scented flowers. Lagos

Artabotrys sp. Ako gbogbonshe (Yoruba).

It is found in the Olokemeji Reserve of the Abeokuta province of Nigeria.

Monodora tenuifolia. African Nutmeg. Lakosin (?) (Yoruba); Unyenghen (Benin).

In younger trees there are a few narrow white streaks in the dull green bark, which gives it quite a distinctive appearance.

Chief Characteristics. - It is a medium-sized tree with yellow flowers tinged with white, most conspicuous after they have fallen to the ground. The flower has three petals with wavy edges, and reminds most people of an orchid. In fact, many have asked whether it is not an orchid. The leaves are light green, especially on the under-side, though darker as the rainy season advances. The fruit is a spherical drupe, containing several small nuts or seeds. The tree flowers before the leaves come fully out, so that it looks very handsome indeed. It is, in fact, one of the prettiest of all the flowering trees. It flowers at the end of February or at the beginning of March. It reaches a girth of about 2 feet and a bole length of about 10 feet, though it is often much branched from about 4 feet from the ground.

It is quite common in the Abeokuta province of Nigeria, especially in the Olokemeji Reserve and on the road between that place and Mamu, in the Benin province, as well as being found in the mixed deciduous forest zone.

The timber is hard and white and fairly durable. It is tough and does not split well.

Although it stands a little shade it is a somewhat slow- 
growing, light-loving tree, but does not protect the soil. Natural regeneration appears to be fair. It sprouts well from the stump, often in this way forming quite a clump. On these stool shoots it bears flowers and fruit early. It transplants badly, more especially when placed in the open. It is somewhat exacting as to soil, demanding a certain amount of moisture as well as depth. It is somewhat fire-resisting, sprouting out again after such injury.

As it does not really reach timber size, it is not of much use for local constructional purposes.

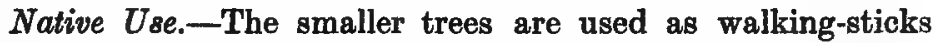
and the larger ones are sometimes used for hoe and axe handles. In clearing the land for farms, stool shoots are left standing, to act as supports for the tendrils of the yams after they have been planted.

Monodora myristica, var. grandifolia. Calabash Nutmeg. Lakoshe or Abo Lakoshe, Ilakosin, Igbo (Yoruba); Ukposa, Eddo Binoyoba (Benin).

It is found in the mixed deciduous forests of the Ibadan, Ondo, Benin, Owerri, and Ogoja provinces of Nigeria, where it is somewhat prevalent.

Chief Characteristics.-It is a large tree, up to 7 feet in girth, with open crown and thin foliage. The flowers are very conspicuous when they fall, having three very large pointed red petals streaked with white, almost reminiscent of an orchid. The edge of the petal is wavy, too. On the tree, the flowers hang from the under-side of twigs with very short petioles. It is the most handsome and largest flowering tree amongst the Monodoras. It is, however, never quite so much covered with flowers as the $M$. tenuifolia. The flowers are considerably larger, being quite half to one inch longer. The bole reaches a length of about 15 feet, but is often branched lower down. The fruit is a large drupe, containing a number of small nuts.

The timber is whitish, hard and somewhat tough, and does not split well.

It is a moderately fast-growing, light-demanding tree. With the exception of the period when it loses leaves, it is a soil-protecting and soil-improving tree.

Although it scarcely reaches timber size, it might be tried for smaller constructional purposes, such as handles, posts, or rails. The quantities, however, are not very large.

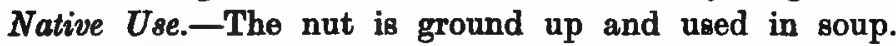

Monodora brevipes. Yellow-flowering Nutmeg. Ause, Lakosin (Yoruba); Iyoha (Benin). 
Grows abundantly throughout the Tropics. The seeds are useful as condiments or as medicine.

\section{Myristicacex sp.}

Pycnanthus Kombo. White Cedar. Akomu (Yoruba); Omocham (Benin).

It is found in the Calabar, Ogoja, Owerri, Benin, Ondo and Abeokuta provinces of Nigeria.

It is a very common tree, especially at the edges of roads and in old farms. It is not so common in the original forest. It grows up to 15 feet in girth. It has a very cylindrical bole, with long, straight, outstanding branches growing close together, more or less forming a flat crown. The leaves are large and pinnate, and the small fruit, which grows in clusters, half opens, disclosing a bright red interior with one round seed covered with pink, mace-like fibre. The slash is pinkishwhite, and heavy, sticky white latex streaked with red exudes very freely after it has been cut.

The timber is soft and white and not durable. It has not so far been used either for export or locally.

\section{Lauraceæ.}

Ocotea cf. Egg-shaped fruit tree. Agkwokhau (Benin). Found in the Benin province.

\section{Capparidaces.}

Cratava Adansonii (Guill. et Pierre). Egun oran (Yoruba).

Tree 30 feet high with yellow flowers. Found growing at Fiditi, Oyo province.

Cappiaris Thonningii. Ekkana, Awoa (Yoruba).

It is found in the Olokemeji Reserve of the Abeokuta province of Nigeria.

\section{Rosacex.}

Parinarium sp. Babu (Yoruba); Oria (Benin); Oko (Ibo, Owerri); Oguru (Brass); Edat (Efik); Ukpoi, Edat, Mpuri (Oban, Ekoi).

It is found in the Olokemeji Reserve of the Abeokuta province of Nigeria, and Asaba district, Benin province.

It is a large tree with irregular surface to the bole, muscularlike protrusions being seen here and there, as well as similar shaped depressions. The crown is wide and flattish, and of light foliage. The fruit is a large, nasty-smelling, appleshaped drupe.

The timber is white, with apparently little difference between 
sap and heart wood, and it is hard and tough, not splitting at all easily.

It is a somewhat slow-growing, shade-bearing, soil-protecting and soil-improving tree, said to be termite-proof. It has considerable resiliency, and stands a certain amount of bending strain.

The timber has not been used for export, nor has it been sawn up for planks for local use.

Native Use.-The Yorubas use the timber for making mortars for food.

Parinarium sp. Red Mahogany. Abue (Fgbado, Yoruba); Dabadogun (Benin).

It is plentiful in the Benin and the Abeokuta provinces of Nigeria.

Chief Characteristics.-It grows into a large tree, but is often seen as a small tree, suppressed by other quicker-growing trees. The dense, somewhat spreading crown is a typical feature of the tree. Its large leaves attract attention, especially compared to the size of the tree. The bole is often crooked and covered with dark green cortex, with only a limited amount of fine bark.

It has a hard, red wood, not unlike mahogany, but with a more fibrous grain. It is durable, especially when left in a wet place. It works up with a good surface and very pleasing colour, making it thoroughly worthy of being a substitute for mahogany. Being a shade-bearer, soil-protecting and soilimproving tree, it should eventually find a place in the forest plantations. Despite its slow growth, its other silvicultural qualities are worthy of attention.

It has not yet been exported, not has it been felled for local use. For the former it appears to deserve a trial.

Native Use.-It is used for firewood.

Parinarium robustum. Sometimes called Mähogany Nuts, Nikko Nuts ; Benin Mahogany. Ugibisaro (Benin); Aiyeni (Egbado); Aiye, Aghaghe, Aiyeni (Yoruba).

It is found in the Abeokuta and Benin provinces of Nigeria, in the evergreen forest zone, where it is not very prevalent. It is a large forest tree, reaching a girth of over 12 feet and a bole length of about $\mathbf{7 0}$ feet. In the dry season, in the distance, the leaves show the typical dried-up yellow appearance of the Parinariums, especially being somewhat shiny in appearance. The fruit is not unlike a very large, very dark green plum, but rather more flattened and not so round. The inside nut is compressedly spherical, showing five large eyes or holes out of which seeds germinate. 
The sapwood is yellowish-white and somewhat broad in proportion to the size of the tree, and the hard wood is mahogany-red coloured, but with more fibrous grain. It planes up with a smooth surface and splits fairly easily, especially when nailed. It is moderately hard and quite durable, and is not supposed to be attacked by white ants (termites). Like most of the Parinariums, the fresh wood smells something like honey, and the timber tends to darken on exposure to the air, thus improving in colour.

On the whole it is a shade-bearing tree and not very fastgrowing. It has soil-protecting and soil-improving qualities. Natural regeneration only appears to be very moderate. Like most of the Parinariums, the kernels of the fruit are pecked out by various birds. No plantations have been made of this tree.

Quite by accident, in 1906 some logs obtained from this tree were cut and exported, and sold in the Liverpool market as Benin mahogany at $4 \mathrm{~d}$. per superficial foot. Since then, however, none has been cut.

Amongst the Benin natives the timber is occasionally used for house-building.

Parinarium excelsum. Essago (Benin).

It is found in the Ondo, Benin, Owerri and Calabar provinces of Nigeria, in the evergreen forest zone, where in certain localities it is very prevalent.

In appearance it is like the rough-skin plum of Sierra Leone, but a larger and taller tree. The leaf usually looks dry and grey, especially underneath. The crown is oval and very dense, with a mass of large limbs. The bark is covered with white lenticels, which make it look grey. It usually bears a large crop of fruit each year.

It reaches a girth of over 12 feet and a bole length of about 50. In proportion to the height, the bole is not so long as in the cases of many other forest trees. The fruit is more uneven in surface than that of $P$. robustum, and the surface is also more or less speckled with little white raised lumps, giving it a roughness to the touch. The fruit inside is yellowishwhite, rather hard and not unpleasant to taste. Where it is found, especially in the more swampy parts, it is often almost gregarious in habit. It is an evergreen tree.

The wood when freshly cut smells like honey. The sapwood is yellowish-white and the heartwood is brown. On the whole it is much harder than $P$. robustum. Occasionally it appears cross-grained, and does not plane up with such a smooth finish. It saws less easily, and it is hard to drive nails 
into it. It does not split well. It is rather a heavy wood and does not float.

It is a somewhat slow-growing, shade-bearing tree, which thoroughly protects the soil and improves it with its leaf fall. Natural regeneration appears to be none too good. No plantations have been made of this tree.

It has not been felled for local use, but occasionally it has been used for firewood, which is of somewhat high calorific power. The fruit is occasionally useful to temporarily assuage hunger in the forest.

It was sold as African greenheart at 1s. 6d. to 1s. 9d. a cubic foot in the Liverpool market in 1906.

Native Use.-None, and the fruit is not eaten. Elephants eat the fruit.

Parinarium polyandrum (Benth.) (?). Plum. Ako Idofun (Yoruba).

Smaller fruit than $P$. curatellafolium and very hard; similar flowers, the leaves rough and only slightly grey-green on the under-surface. Stem reddish-brown with long lenticels, leaves larger and longer.

It is found in the Abeokuta province of Nigeria.

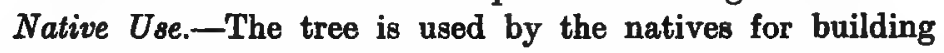
farmhouses.

Parinarium curatellofolium (Planch.). Abo-Idofun (Yoruba).

A small tree 10 feet in height and 1 foot in diameter, with large umbelliferous flowers of a white colour. The leaves are rough and shiny on the upper surface, and with more white underneath than the $P$. polyandrum.

Native Use.-The fruit is edible, though not usually eaten. No use as firewood. The wood is used for building farm-sheds.

Parinarium Gabunense. Mahogany Nut. Abere (Yoruba).

Found in the Ondo province.

Chrysobalanus sp. Niko Nut. Igata (Yoruba).

Found at Ebuttemetta.

\section{Leguminosæ (Cxsalpineæ).}

Cassia Sieberiana. Cassia. Aridan-toro (Yoruba); Ezzi, Apagban (Benin).

It is commonly found in Benin, Ibadan and Abeokuta provinces of Nigeria, more especially in the latter. It is a small tree bearing large and long racemes of yellow flowers in February, making it very reminiscent of the laburnum. The tree is leafless at the time, so that the flowers are all the more conspicuous. The almost rectangular branching habit of this tree, combined with the rather thin twigs, is very typical. It yields a hard, red wood, but the sapwood is yellowish-white. 
The natives use the fruit medicinally and the timber for housebuilding. The pods are usually about a foot long and half an inch in diameter.

Cassia toro. Cassia. Ako Kere (Yoruba).

It is found at Olokemeji, in the Abeokuta province of Nigeria. Its medicinal use as a remedy for ringworm is not known to the natives of that locality.

Cassia fistula. Cassia. Bembedo (Yoruba).

It is rather an uncommon tree of the Benin province of Nigeria, one specimen being found in the Idah district; the longer ( 1 to 2 feet) and stouter ( $\frac{8}{4}$ to 1 inch) pod is most typical of this tree. It is otherwise much the same size as Cassia Sieberiana. The natives use the fruit medicinally, but look upon the tree as a "great medicine."

Cassia podocarpa (G. and P.). Cassia. Asunwon (Yoruba).

It is found in the Olokemeji Reserve.

Shrub with yellow flowers.

Cassia occidentalis. Blackwater Plant. Rere (Yoruba).

It is a small shrub-like herb with large upright flowers, which is usually found growing in waste places at the edge of villages in the Yoruba country, in the mixed deciduous forest zone. A medicine to cure blackwater fever is made from this plant, though doctors now say it is not an infallible cure.

Ormosia laxiflora (Benth.). False Dalbergia. Shedun (Yoruba).

It is found in the Ibadan, Abeokuta, Onitsha and Ogoja provinces of Nigeria, chiefly at the edge of the dry-zone forest.

It is a small tree, 12 feet high and 18 inches in girth, with almost brick-red or orange-coloured bark, which is thin and often scarred by natives. It has a long, thin pod with thin, flat seeds. It reminds one very much of a small Dalbergia. It stands the annual fires well, though it gets singed each year. The base of the bole is often somewhat enlarged with the constant cutting of the bark both of the stem and the uppermost roots.

The timber is yellowish-red and not very hard, but rough to work up, being more in the nature of a turner's than a joiner's wood. The grain is often by no means straight, and the wood shows a little figure.

Withstanding the fires so well, it serves, or should serve, as a nurse for the introduction of more valuable species amongst the dry-zone trees, especially on the laterite soils. Natural regeneration is good and it sprouts well from the stump. Root suckers do not appear to be so prevalent as in many dry-zone species. It is a light-loving species, which does not protect 
the soil properly, though the foliage is comparatively dense for that type of tree. It is slow-growing. No plantations have been made.

It does not attain sufficient size for export, but it might be tried for local turnery work. It is useful for local hutbuilding.

Native Use.-House-building, and the roots when boiled are used in medicine as a tonic.

Afrormosia elata. African Satinwood, Yellow Satinwood. Ayin (Yoruba); Anyeran, Anyesan, Ehranobapotineddo (Benin); Egbi (Ibadan); Elo Uta (Ibo, Owerri).

A very conspicuous tree, with its orange-red trunk near the base, gradually shading off to yellow higher up, and towards the branches a light-green colour. Large, irregular-shaped pieces of bark fall off from time to time, in a similar way to the plane-tree of Europe, though with its reddish trunk it is not so much like the plane as Afzelia Africana. The root flanges or spurns are very thin and do not extend beyond about three feet up the stem of the tree. In plate No. 82 one of these trees, growing near Benin, shows the open, rather narrow crown with its few main limbs supporting it.

It is commonest in the Benin, but also found in the Ondo, Owerri and Calabar provinces in the moist evergreen forests. It is also seen in secondary forests of the same zone.

The timber planes well, but does not split. It saws easily, but takes nails with difficulty. It is sometimes figured, especially logs from the base of the tree.

It is pretty easily killed by fire at the roots, though otherwise it tends to spread with cultivation. The sapwood is almost white and the heartwood a yellowish-green, when fresh, but a dull yellow when dry. It is very hard and withstands the attacks of white ants (termites). Even the sapwood of a young tree had not rotted after six years near the bank of the Ogba, Benin province. It grows moderately quickly.

The flower is inconspicuous and small, and the pod is also small, being about $2 \frac{1}{2}$ inches long and $\frac{1}{2}$ inch broad, containing two or three flat seeds. The tree does not bear very heavily, and in consequence natural regeneration is not very good, though such seeds as actually form properly seem to germinate well. In youth it bears some shade, but in middle age seems to be almost a light-demander.

Although when freshly cut the wood does not float, when thoroughly dry it would not be difficult to float it with a lighter species. 
The timber was reported as satinwood and worth 3d. to 1s. per superficial foot in the Liverpool market in 1906, and that moderate quantities (of fair length and squares) would be taken.

Pterocarpus esculentus (Schum. and Thon.). Edible-fruited Padouk. Gbingbindo (Yoruba); Akpanagya, Uruhe (Benin); Nja (Efik).

It is one of the most common waterside trees of all the Southern Provinces of Nigeria; some of the rivers on the banks of which it is found are the Ovia, Ogun and Cross River. Belonging to the mixed deciduous forest zone, it is in the middle reaches of these rivers where it is most prevalent.

A typical feature of this small tree is the bright, yellowcoloured flower, which quite brightens up the banks of the rivers at the end of February or March. Another most peculiar feature is the odd, somewhat kidney-shaped fruit with its rough surface corrugations, containing inside a hardish nut about 1 inch in diameter. Either the nuts or the fruit are often seen floating down the rivers, especially where they are tidal. The leaves are more typical of the Pterocarps, otherwise the fruit is most unlike either those of the genus or even of the family. The bole of the tree is short, smooth and almost silver-grey in colour, though it is often discoloured with the mud from the perennial floods of the river. It is usually seen with more than one stem.

The timber is white and not over-hard. It is not very durable.

The tree is not very fast-growing, but is an evergreen, with a short period in which nearly all the leaves fall. It serves a most useful purpose in holding the banks of the streams wherever it is found, and it is noticeable that its roots appear to extend a long way back and that it is one of the last trees to be washed out by floods. It sprouts fairly well from the stump when cut, unless it is almost at once submerged by the floods, which points to the fact that it should be cut only at the beginning or towards the end of the dry season. Natural regeneration appears to be fair, but no plantations have been tried with this tree.

The nuts have not been examined to see what they contain, though they are of nutritive value.

For export it does not yield large timber, and for local use it is rather small, but for local huts it might occasionally be used where other timber is scarce, as in the dry zone. It makes a fair firewood in those places. Although the fruit is supposed to be edible, very few natives have tried it, and apparently it is only used in times of great scarcity. 

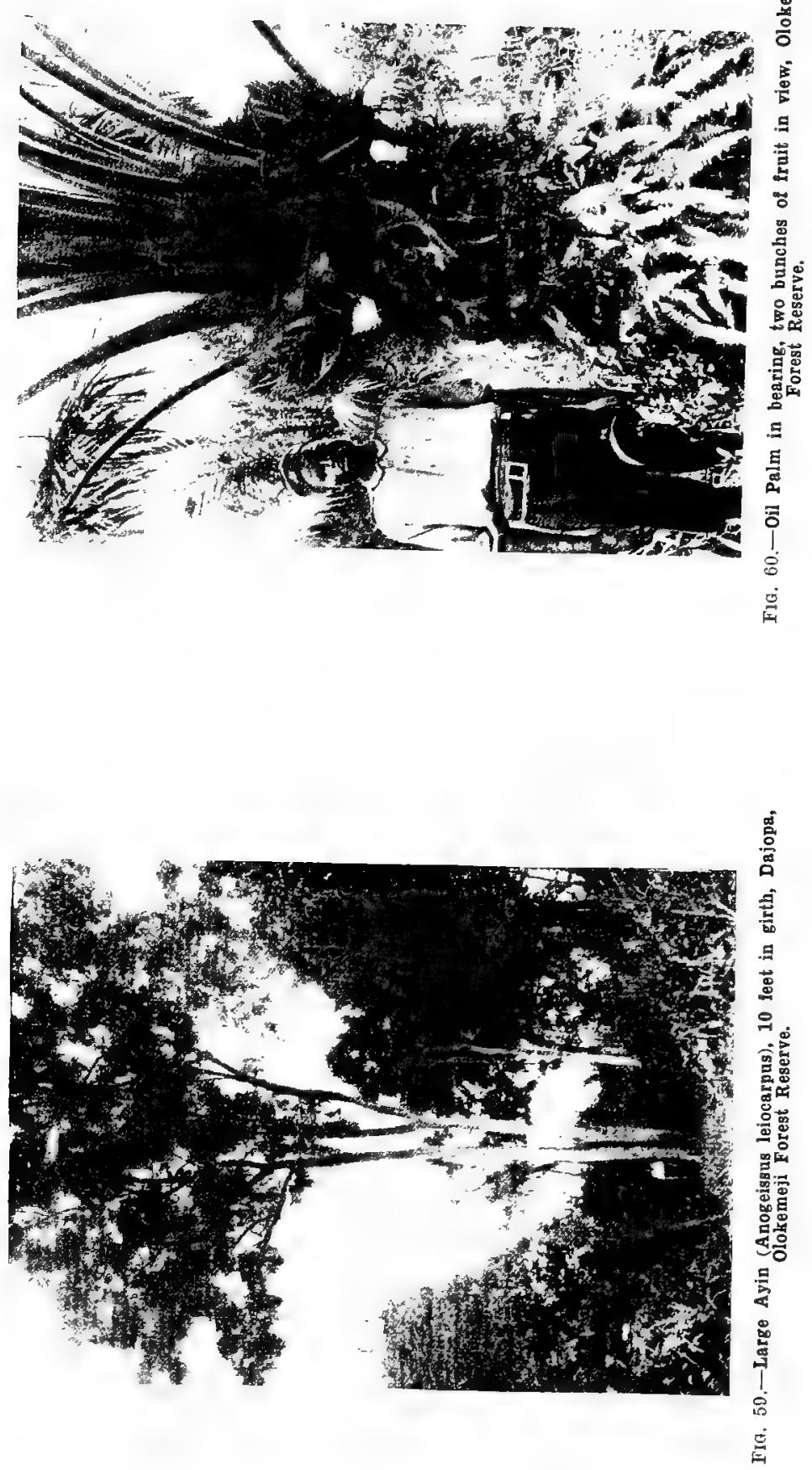

Pterocarpus Osun. African Padouk or Barwood. Osun, Osun dudu (Yoruba); Ume, Ureben (Benin); Opepe (Ikala, Ijor).

It is found in the Ogoja and Calabar provinces of Nigeria, in the mixed deciduous forest zone, where it is none too prevalent. A specimen was found near Ibami, in the Obubra district. It is a small tree with small yellow flowers and rather small leaves. The branches are placed close together and the crown is very dark and thick. The bole is short, rarely exceeding 15 feet in length, and the bark a dark brown colour. The bole reaches a girth of about 5 feet.

The sapwood is white and the heartwood of a dull-red colour, but in proportion the sapwood is rather wide. It is moderately hard, fairly durable, but not termite-proof. It planes well, saws easily, takes nails; it does not split very well.

It is a somewhat slow-growing, shade-bearing, soil-protecting and soil-improving tree. Natural regeneration does not appear to be very good. It is doubtful if it sprouts from the stump. It has not been cut for export, nor has it been felled for local use.

On the Cross River the Camwood was sold to the European merchants, at the rate of 409 billets per ton, for $f 410$ s., so that with the added cost of river and ocean freight and sale charges, there was no profit when it was being sold at $£ 6$ 10s. per ton in the Liverpool market. Better prices are always secured if it is shipped in squared logs, 24 inches square and 24 to 30 feet in length.

Apparently it is not the Camwood used by the natives, because plenty of trees are seen scattered about in the neighbourhood of Obubra untouched

Pterocarpus erinaceus. African Rosewood. Apepe, Ara (Yoruba); Oyo, Upeka (Benin).

This tree grows in the dry-zone savannah forests of the Ogoja province of Nigeria. It is of small size ; the flowers, which are yellow, appear in March. The timber is of little value, the tree not being large enough to yield a useful timber, but it has been sold as African Rosewood. It has a beautiful rose-red colour.

Pterocarpus sp. So-called Camwood. Osun pupa (Yoruba); Akume (Benin); also spineless fruited Camwood.

It is found in the Calabar, Ogoja, Benin and Ondo provinces of Nigeria. On the bank of the Cross River, near the Ossizza factory, there is a large spccimen, standing about 20 feet away from the water's edge.

It is not very common, and chiefly found near river banks in the evergreen forest towards their northern limit. It is a medium-sized tree, reaching a girth of 9 feet at the most 
and a height of 70 feet. The bole length does not exceed 40 feet. The bark is light-brown, almost yellow-brown, with rough fissures and fibrous surface, more like an elm, though thinner. The branches are thin and light-coloured. In flower the tree is a mass of little yellow peaflowers, and numerous bees swarm round the crown of the tree, indicating its presence. Again, when the fruit ripens the crown is a mass of yellowbrown winged fruits all fluttering in the wind. They are always in bunches near the ends of the twigs. The fruit is round and flat, with no hairs on it, with a thin papery wing completely surrounding and joined to it, which makes it rather thicker and stiffer than the other species. It is not at all typical of the Pterocarpus genus. The seed in the centre has a rough surface. The trunk usually is not quite straight, having a slight bend or two in its length. In habit, more like a Combretum or young elm to look at. The crown is round, almost spherical, and does not usually occupy more than one-third of the height of the tree.

The sapwood is white; the heartwood is of a dull purply colour, which is inclined to stain into the sapwood after the tree is cut down and exposed to rain. On the whole the colour of the wood is deeper than that of the other Pterocarpus, but it is said to yield a less fast and poorer coloured red dye than that of the other species, $P$. Osun. It is moderately hard. It planes well, and is sometimes cross-grained. It takes nails easily, but does not split very well, though it saws with comparative ease.

Although it stands a good deal of shade in its youth, it is apparently a light-demanding tree with soil-protecting and soil-improving qualities. It is not very fast-growing. Natural regeneration appears to be poor, chiefly, perhaps, owing to the fact that the seeds are quickly eaten by small boring insects soon after they fall to the ground. It is rather exacting as to soil, and prefers the deep, moist, sandy loam. Only isolated specimens are seen.

The timber has not been exported yet, and despite the fact that it does not reach such a large size as $P$. Osun, it deserves a trial. For local use it should find a place for house construction in a similar position to which the Osun and others are used by the natives.

It has not been cut or used as a dye root, chiefly owing to its poorer colour. It is, however, used in house-building. Pterocarpus. Cross River Camwood.

It is found in the Obubra district of the Calabar province of Nigeria. In habit it is very similar to the other Camwoods. 
Pterocarpus Soyauxii. Large Fruited Camwood. Arakpa, Ume (Benin); Ukpa (Efik).

It is found in the Ogoja, Benin, Warri (?), Ondo, Ibadan (?) and Abeokuta (?) provinces of Nigeria.

It is a common tree in the mixed deciduous forests, reaching a height of 80 to 100 feet, with a bole length of 50 feet and a girth of 10 feet. The bark is a darker colour than P. Osun, but a little rougher. The leaf is smaller than $P$. Osun, but is unarmed. The most typical difference in this tree is the fruit, which is the largest of all, $2 \frac{1}{2}$ to 3 inches in diameter, with plenty of prickly thorns in the centre of each surface. The wood is a much darker red, quite a dull, almost purple red. The root spurns on the whole extend higher up the trunk than $P$. Osun (up to 4 feet). The slash is white, but thin red latex soon exudes out of it.

The wood is hardish, but the sapwood is very white and soft. The wood does not make the same kind of stain as $P$. Osun, though apparently it keeps its colour much better than $P$. Osun. When exposed to light, $P$. Osun loses it very quickly and becomes a dull-brown colour. The grain is open and varies a little in colour, giving it a pleasing effect. Termites do not attack it. It splits well.

It sprouts from the stump slightly, but such shoots do not attain any size. Seedlings come up readily from fallen seeds. The seeds are liable to be eaten by the "ground pig" almost at once. It grows moderately quickly, but is a light-lover. It has an undivided stem.

Samples were sent to Liverpool in 1916 and sold as African Padauk, and it was reported that "small quantities sell" satisfaetorily. It has been cut for local use for buildings.

Native Use.-It is used for making wooden shovels, all out of one piece. Also in house-building as wall-plates at the top of the mud walls, also in the Oba's house for uprights.

Erythrophlceum sp. Sasswood. Inyi (Benin).

This tree was determined from material from the Central Circle.

- Erythrophloeum Guineense. Sasswood, or Sassy Bark, or Ordeal Bark. Erun obo (Yoruba); Oginyi (Benin); Akpa Etuidiwi (Efik); Arachi (Ibo, Asaba); Inyi, Ibo (Onitsha, Ibo, Owerri).

It is found in the Ibadan, Abeokuta, Ondo, Benin, Onitsha and Ogoja provinces of Nigeria in the mixed deciduous forest zone, where it is often very prevalent, more especially north of Ifon and Alabeta in the Benin province. 
It is a large tree, reaching a girth of over 10 feet and a bole length of over 30 feet. The crown, however, is large and wide-spreading, but generally spherical in shape. Comparatively low down, the bole divides up into three or four main limbs. The trunk is seldom very straight, usually having a twist in one direction or another. The root spurns are moderately large, but are rounded in shape. The bark is darkbrown and thick, scaling off to a slight extent in old age. The fruit is a pod about 3 inches long and an inch wide, containing six or eight flattish black beans, black to brown. These burst when ripe, but the seeds only gradually fall to the ground. The fine pinnate leaves are close together and open out into dense foliage most typical of the Leguminosem. The upper part of the limbs and trunk is light-brown. The flowers are minute and not often seen.

The sapwood is dull yellow and the heartwood a dull red-brown. It is very heavy and hard, but not as hard as red ironwood or the Yoruba ironwood. It is very durable and quite termite-proof ; although sometimes a little cross-grained, with good tools it can be worked up to a smooth finish by planing. Holes have to be made in it for nails. It saws well, but splits only moderately easily. In the saw mill it was found that the hardness of the wood blunted the saws, which needed constantly sharpening.

It is a slow-growing, shade-bearing, soil-protecting, soilimproving tree. Natural regeneration appears to be good, and it is moderately resistant to fire. Tends to condense dew in the dry season. It suppresses most other trees by shade. Amongst the dry-zone vegetation it clings to the banks of rivers, and is common on the upper banks of the upper reaches of the Ogun. No plantations have been made with this tree.

In 1906 sample logs of the sister tree, $\boldsymbol{E}$. micranthum, were exported and sold in the Liverpool market as a species of oak, so that this timber deserves a trial as a substitute for teak or oak.

It was cut for the Public Works Department at Onitsha and found very suitable for decking of bridges. The small bridge over the Nkissi, near Onitsha, was built entirely with this timber.

Brythrophloeum micranthum. Sasswood or Ordeal Bark. Ovinni (Benin); Erinji (Ijor); Ihi (Ibo, Owerri).

It is found in the Warri, Benin and Calabar provinces of Nigeria.

As a small tree, one of the first to appear when the mangrove swamp gives way to the evergreen rain forest near the coast. 


\section{THE NIGERIAN TIMBER TREES}

On solid land it attains a large size, even larger than that of $E$. Guineense. The pod is a little larger than that of $E$. Guineense, and the bark smoother. The crown is dense and very large, almost spherical in shape, and reaching more than one-third down the length of the tree.

The timber is very similar in its qualities to $E$. Guineense, but has a straighter grain in the larger specimens. It is very durable.

It is a slow-growing, shade-bearing tree, with soil-protecting and soil-improving qualities. Natural regeneration does not appear to be very good, though numerous pods are borne on the tree almost every year. No plantations have yet been made with it.

For local use, it has not been cut in a similar way to $\boldsymbol{E}$. Guineense. The natives occasionally use this tree for making canoes. In the 1906 timber report from the Liverpool market it was valued as a species of oak at 18 . $9 \mathrm{~d}$. per cubic foot, and was not considered so good as either red oak, Lophira procera, or white oak, Ostryoderris impressa.

Native $U_{B e}$. - The bark is boiled in water and a beautiful red-coloured liquid is produced. It is administered as an ordeal trial for witchcraft, and is not poisonous if given in large doses.

Brachystegia spicaformis. Agberigeddi, Ako (Yoruba); Okkwan (Benin); Etare (Oban, Ekoi); Ungu (Ibo, Owerri); Mpanju, Akpanya, Ikpanya (Efik).

This tree is found in the Abeokuta, Ibadan (?), Ondo, Benin, Warri, Owerri, Calabar and Ogoja provinces of Nigeria.

It is a rough, scaly-barked tree of huge size (see illustration), reaching a girth of 30 feet and a height of 150 feet. The crown is flattish, formed by a few wide-spreading limbs and numerous small branches. The foliage is moderate for a Leguminous tree. The yellowish flowers are almost unseen, being placed underneath the leaves. The dark-brown woody pods burst with a bang not unlike a gunshot, and release four or five flat black, shiny beans about $\frac{1}{2}$ inch across. The foliage goes almost black on reaching the ground, killing all the small plants. A brownish gum exudes from the tree when cut, and this hardens into a reddish, opaque mass similar to Almeidina, and in fact is the source of this gutta percha-like substance.

Timber.-It is a rather hard, light-brown wood with pretty, almost evenly distributed streaks of darker brown shade in it. It is very durable. The white sapwood soon rots on exposure to the weather. It is suitable as a furniture wood. 
Silvicultural Characteristics.-It bears a good deal of shade. It reproduces almost every year plentiful mature seed; grows fast, but not so rapidly as the cotton-tree, Ricinodendron and others. It is sometimes distinctly gregarious, as, for instance, south-west of Benin City.

European Use.-It has not been exported, but the P.W.D. have used it for verandah-posts and planks. It has been much admired for the good colour of the wood and the streaky grain.

Native Use.-By the Benin people it is not considered a good wood, but the gum is sometimes used.

Daniellia ogea. Gum Copal. Ogea (Yoruba); Ogea (Benin); Udeni (Ibo, Owerri) ; Mpanju, Ikpanya, Akpanya (Efik). Also known as $D$. oblonga and Cyanothyrsus ogea, but now called D. ogea.

This tree is found growing in the heavy-rain intermediary forest of Benin, Ondo country and Mamu Reserve. It is a very fine tree with straight rounded bole, often reaching a height of 120 feet before the first branch. The bark is light grey and slightly ringed. The flowers blue and not very noticeable.

Timber.-Of no commercial value, as it is soft and rots quickly.

Uses.-A good gum copal is obtained from it, the best in the ground, after the tree has rotted. It is used for varnish making; worth 30s. to $60 \mathrm{~s}$. a hundredweight.

Daniellia Fosteri. Gum Copal. Oguja or Ogea (Yoruba).

Found near Olokemeji and Ijebu-Ode. It yields a thirdquality resin according to Holland in The Useful Plants of Nigeria.

Daniellia Punchii (Kew). Gum Copal. Ajia (Yoruba).

Daniellia caudata. Benin Gum Copal. Mogbara, Ashuwole (Yoruba); Ogea (Benin); Agbara (Tkale.)

It is found in the Ondo, Benin and Ogoja provinces of Nigeria. The bole is the straightest and most cylindrical of any of the African forest trees. It often attains a height of over 100 feet before the first branches are reached. The cylindrical shape is further enhanced by the few quite concentric rings on the bark, horizontally arranged round the trunk of the tree. The bark is otherwise quite smooth and of a silverygreen or light-green colour; for the size of the tree it is very thin, and the tree may reach a girth of 25 feet, and the bark then is usually only $\frac{1}{2}$ to $\frac{3}{4}$ inch thick. The slash is yellowishwhite; the sapwood is white and scarcely distinguishable from the heartwood, which gradually takes a pinkish tinge when it is dry. The flowers are blue and not unlike those of the fuchsia, and the tree is easily seen at the end of the dry season 
by the bare crown with its blue flowers. The path later on is covered with these. There are practically no root spurns, the stem emerging straight away from the ground. The crown is very flat, and does not usually occupy more than one-fifth of the total height of the tree. The branches are few and of slight and almost feathery build. The timber is soft, not durable nor termite-proof. It saws easily, does not split very well, and considering its softness it does not plane at all well nor with a very smooth surface. Natural reproduction by seed appears to be poor, although plenty of seeds seem to ripen; there is one seed in each pod. It is a light-loving, deciduous tree, but for eleven months of the year it is certainly a soil-protecting and soil-improving tree. It demands a deep, moist and somewhat rich soil, though judging by the various localities in which it is found it is doubtful if it is really exacting as to soil.

In 1906 sample logs of this timber were sent to the Liverpool market and considered to be a species of mahogany, but of no value. Natives have not used it to any extent for local purposes.

Piptadenia Africana. Light African Greenheart. Agboin (Yoruba); Sanga (New Calabar); Iteruku (Efik); Ebbome (Oban, Ekoi); Ekhimi (Benin).

This is a common tree in the Abeokuta, Ondo, Benin, Warri, Owerri, Onitsha, Calabar and Ogoja provinces of Nigeria. It is one of the most prevalent trees in the evergreen forests, but is also found in the mixed deciduous forests, especially, in both cases, near the edges of the waterways. It is a very large tree, attaining a height of over 120 feet and a girth of over 12 feet. The bole is often 80 or 90 feet in length and perfectly straight. The crown is thin, ovally flat, but widespreading. The thick, heavily foliaged and drooping appearance at the ends of the branches makes the tree a most handsome ornament to a station. At the root, flanges are comparatively long and widespreading, reaching often over 6 feet up the stem, having root spurns quite 12 or 15 feet away from the tree. The stem divides up into a few large branches which form the crown; the bark is yellow-brown and smooth, but when the tree is growing in the sunlight it becomes a much lighter colour and sometimes almost grey. The slash is yellow, with a light-brown tinge; the flowers are quite inconspicuous when they appear in January or February, being formed of little narrow spikes. One of the most conspicuous features of this tree is the thin, flat pod, which may grow as much as 1 foot long and nearly 1 inch broad. Six to eight seeds 
are contained in each pod, and these, including the wing, are 2 inches in length. The flat seed, which is found in the centre, is brown and shiny, and is only about one-sixteenth to one-eighth of an inch in thickness. It has a tiny string-like attachment to the centre, which distinguishes it from Newtonia on the one hand and Cylicodiscus on the other. The young green foliage is also most distinctive and attractive in its freshly salmon-pink colour, also the greenish tips of the older leaves. The leaves themselves are bipinnate; there are often twenty to twenty-four pairs of pinnæ, each of which is about half an inch long.

The sapwood is white and comparatively wide; the heartwood is a pretty light-brown colour, a little darker when fresh, but still retaining a good light-brown colour when it is dry. Although at first rather heavy and hard, it seasons as a comparatively light and scarcely hard wood; it planes well and saws fairly easily; takes nails moderately well, but does not split at all easily, especially when fresh; has an open grain and the pores are comparatively long. It is a durable wood and is almost termite-proof, especially when it is quite dry. When moderately dry the logs float in water. It weighs 53 pounds per cubic toot.

It is a light-loving species which does not protect or improve the soil, except in so far as it is a leguminous tree and its roots thus improve the ground. It is a moderately rapidly growing tree which stands a little shade in its youth. Natural regeneration appears to be only moderate. It sprouts well from the stump, and stump shoots appear to be very persistent. It is rather sensitive to fire and is easily killed by placing rubbish near its roots and then burning the heap. No plantations have yet been formed for this tree. In the forest the seeds fall to the ground and are soon eaten by a small boring insect. It likes a comparatively good soil, but is found on eandy soil which has great moisture; it does not like flooding, but will stand a little.

Locally, it is occasionally used as a house-building timber. The bark is occasionally chipped off for use medicinally. Europeans have cut it up and used it as verandah-posts, joists and verandah handrails. However, in an unseasoned state the sapwood was attacked by termites, and thus it was not entirely satisfactory. The heartwood when quite dry does not warp and appears to be very durable.

In 1906 sample logs of this timber were sold in the Liverpool market as "Greenheart" at 28. 9d. per cubic foot. Since that date no regular supplies have been sent to the market, 
so that it has not been thoroughly tested as to its value as an export timber.

Isoberlinia Doka (Kew).

It is found in the Ogoja, Abeokuta and Owerri provinces of Nigeria.

It is a medium-sized tree with rather large, widespreading pinnate leaves. It is one of the few trees that are gregarious in habit, groups from half an acre to an acre in extent being found. The tree is used for house-building and withstands a certain amount of fire, as it grows at the edge of the dry-zone forest.

- Berlinia acuminata. Red Oak. Apado (Abeokuta), Ewon Pala (Ikale), Adugbin (Ibadan) (Yoruba); Eḳpagoi (Benin); Ajia (Ibo, Asaba); Obuba (New Calabar); Hanabali (Oban, Ekoi).

This is a common tree in all the Southern Provinces of Nigeria. Although it is found most frequently in the evergreen forest zone, a small, bush-like variety is also found in the open deciduous forest. The most conspicuous features of this tree are the large foot-shaped unripe pods; these stick out, isolated, at right angles to the general direction of the surface of the ground-this makes them appear all the more prominent and most odd in appearance. When the pods burst, the large flat beans are released, and each side of the pod curls up, but appears speckled white with round dull spots along the middle. The flowers are white, nearly 2 inches across, with one red streal in the centre. In the evergreen forest zone these flowers do not seem so conspicuous, but in the dry zone the tree is covered with blossom, making it one of the most beautiful. In the heavy forest zone the bole reaches the length of nearly 80 feet and the girth of over 20. With its smooth, shiny grey bark, at the first glance it is not unlike a beech-tree. The root spurns are usually quite small, and do not extend beyond 2 feet up the stem. The slash is white and of a yellow colour on the inner edge. The leaves are pinnate, with one odd leaf at the end, being usually nearly 3 inches long; the total length of the leaf is often over 1 foot. The freshly ripened beans are almost square in shape, flat, and nearly a quarter of an inch thick. Each side of the pod is usually the size of an average man's foot, and sometimes larger; it is also not unlike it in shape, but the curve where the instep should be is very slight. The crown is spherical and very large, often occupying one-third of the total height of the tree. The foliage is comparatively dense, and it is not possible to see through the top of it. The tree loses its leaves for a very short time each year. In the dry zone 
it is often not much more than a shrub, or at most a small tree 35 feet in height.

The sapwood is white and wide. The heartwood is of a deep-red colour, especially when freshly cut; when dry it still retains a good red colour, and from this feature it has been termed "red" oak. The timber saws fairly well, but splits badly ; it is somewhat hard to plane it up to a smooth surface, as it is sometimes cross-grained. The heartwood is termiteproof ; it takes nails only moderately well. It is a moderately hard and durable wood; it does not warp very much. When the logs are dry they will float in water. The weight of the timber is $\mathbf{5 5}$ pounds per cubic foot.

Considering the prevalence of the tree, natural regeneration is poor-rodents may account, of course, for many of the beans; it sprouts well from the stump. In the dry-zone forest region root suckers appear too. It is a shade-bearing and soil-improving tree; it does not grow very fast. No plantations have yet been made with this tree, though it deserves a place in experimental plantations. It demands a good soil, and the roots go down to a greater depth than many of the other trees.

Locally it is used as a house-building timber, and occasionally the dried pods are used as firewood.

In 1906 sample logs of this tree were sold in the Liverpool market as red oak at 2s. per cubic foot. It was not considered as good as Aligna or as Erumacie. Since that date no further shipments of this timber have been made. A further testing of the market by small trial shipments of logs would thoroughly reveal its value as an export timber.

Berlinia auriculata (Benth.). Red Oak. Ekpagoize (Benin).

Found near the Okwo River in the Siluko sub-district of the Benin province. It is not quite such a large species as the $B$. acuminata.

Parkia biglobosa. African Locust. Aridan Abatta, Irugbo Abatta Iru (Yoruba) ; Ubgori, Lakobemi, Enymi (Benin); Inya (Now Calabar); Ekok (Oban, Ekoi).

It is a very common tree in the Calabar, Owerri, Warri, Benin, Ondo (?) and Abeokuta provinces of Nigeria.

It is a large tree, with wide spreading fruit flanges. It has darker and heavier foliage and a wider crown than Parkia filicoidea. It often shows up on river banks with its lightred young leaves. It should be easily distinguished from other similar trees of this family by its cluster of beans, similar to French beans, when ripe. These are yellow, and the spicelike scent and the round balls of staminate flowers of a crushed 
strawberry colour are not easily forgotten. Often only the yellow pistil is found lying on the path. It likes a damp to wet soil, and is usually found growing at the edge of, or actually in, freshwater swamps.

Timber.-The wood is hardish, but is said to rot easily, though it appears to be rather doubtful, and probably only applies to unseasoned wood.

Natural regeneration by seed is good. The tree stands a good deal of shade in its younger stages of growth. No other trees will grow under it, and few can stand any or much of its shade.

European Use.-It has not so far been used by Europeans for export or local use.

Native Use.-The seeds are cooked and eaten to some extent by the Yorubas and Benin people.

Parkia filicoidea. African Locust. Irugba (Yoruba name for fruit); Igba the tree (Yoruba); Gumui (Mendi); Olibracha (Egba) (Yoruba).

This is a common tree in Abeokuta, Oyo, Benin, and Ogoja provinces of Nigeria. It is found in the deciduous forests. It reaches a height of over 60 feet, with a girth of 5 feet. One of the most distinguishing features of this tree are the very feathery leaves, which appear after the flowers. The large spherical balls of the red staminate flowers enliven the tree in the early part of the year; later in the year masses of pods, each about 9 inches long, hang down from the ends of the twigs. The base of the bole is often gnarled, partly with the slight root flanges and by the almost continual cutting of the bark by the natives. Normally the bark is brown and comparatively smooth. The bole is short, dividing about 20 feet from the ground into a large number of small branches. On the whole, as the tree advances in age the branches tend to become pendulous. The crown, spherical in shape, is inclined to be irregularly broken up-partly by the different length of the branches.

The sapwood is white and the heartwood a dull-brown colour; for the size of the tree the sapwood is wide. It saws indifferently well, splits badly ; it is hard to plane ; it is said to be termite-proof. The wood is hard and tough.

The tree is a light-loving but not soil-improving species, except in so far as the root globules take up nitrogen and free it for the use of other plants. Naturally, generation is none too good. Root suckers appear to some extent; it sprouts most readily from the stump. Perhaps the lack of young self-sown seedlings is due to the fact that the seeds are largely 


\section{WEST AFRICAN FORESTS AND FORESTRY}

used by the natives. In a fow places small plantations have been made with this tree. It is very fire-resisting, and apparently the fruit-bearing capacity of the tree is not reduced to any extent by the prevalence of the annual grass-fires in the localities where it is found. During the whole of its life it is a slow-growing tree.

The yellow pulp in the pods is eaten by the natives. The bark at the base of the tree is chipped off and used for making a tonic when infused with water. The tree is occasionally used locally as a house-building timber; for this purpose it is used chiefly as uprights in the main buildings.

The timber has not been tried for export, and it is doubtful whether its size warrants its use for this purpose.

Tetrapleura Thonningii. Angular Pod. Aridan (Yoruba); Igmikkia (fruit), Ikhememi (tree) (Benin); Osshosha (Ibo, Asaba).

The dark-green feathery foliage on its oval crown is very typical of this tree, especially when it is found near a roadside in the mixed forests. It is also often found on river banks at the edge of the dry zone or in other parts of the mixed forests. The indehiscent pods with four edges, leaving practically no centre, are most typical of the tree; they are shiny and have a peculiar medicinal smell. The fruit is known as Igmikkia, by which name the tree is most usually called by Europeans, in the Benin country.

The tree is prevalent in the Abeokuta, Ondo, Oyo, Benin, Onitsha, Owerri, Calabar and Ogoja provinces of Nigeria.

It is a shade-bearer and thoroughly protects the ground all the year round, except for about two weeks when the leaves fall. Natural regeneration does not appear to be good, seedlings being rarely found, and no plantations have been made with it, though if of more value it might be mixed with teak. The seeds always command a ready sale at a low price.

The wood is hard, brown, and splits badly. No use has yet been found for it. It is sometimes cross-grained, the sapwood white.

The natives use the timber for making doors, window-frames and benches. The seeds are sold in the Yoruba, Benin and Ibo markets; they are cooked for soup, which acts as a slight aperient or is of other medicinal value.

Millettia Thonningii (Baker). Ito (Yoruba); Ebakwe (Benin).

It is found in the Benin and Abeokuta provinces of Nigeria. It is a small tree really, reaching a girth of only 4 feet, with a short bole and a few somewhat slender and drooping branches. The twigs and new leaves are distinctly of weeping habit. In February, in the mixed forest, the bare tree shows up with 


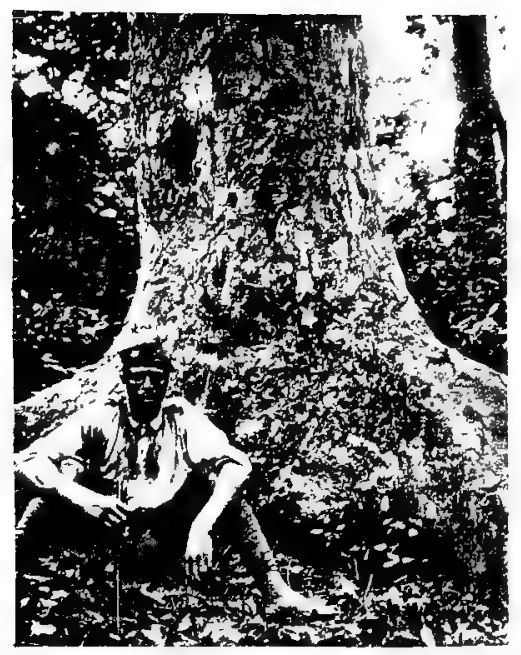

FIG. 62-Base of Bilinga (Afzelia Africana) 14 feet in girth, Dajopa Forest Reserve Olokemeji Reserve.

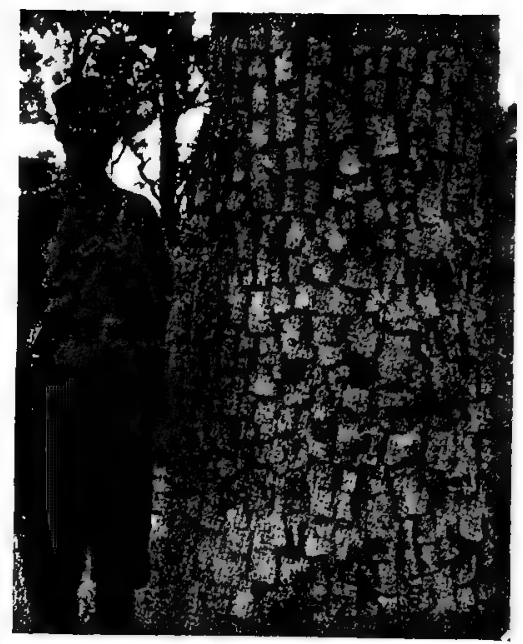

FIG. 62.-Shea Butter (Butyrospermum Parkii) 7 feet in girth, near Oniloku Road, Olokemeji Reserve.

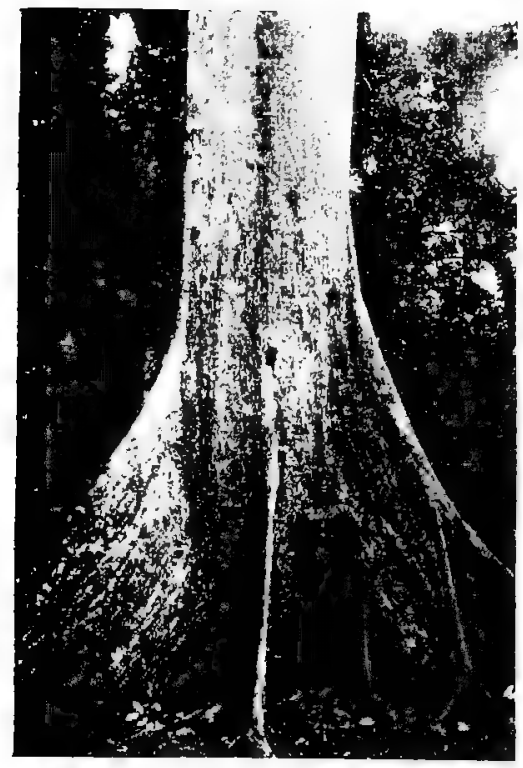

FIG. 63.-Afara (Terminalia superba), base of mature tree over 12 feet in girth, Olokemeji Reserve.

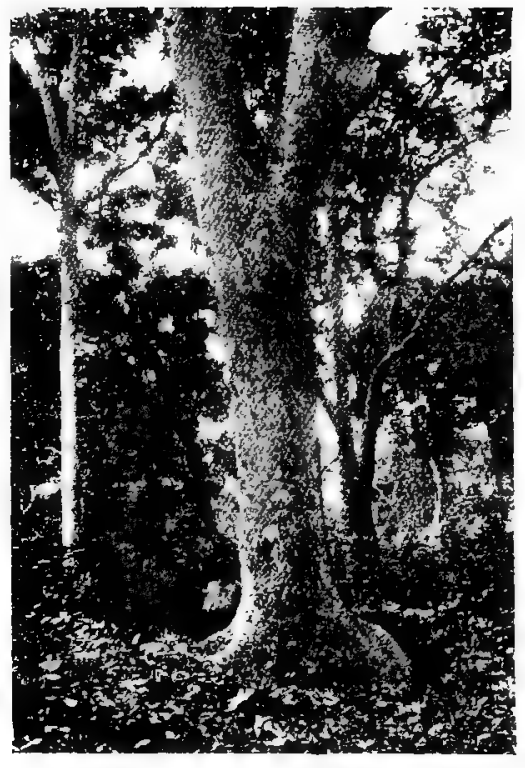

Fia. 64.-Afzelia Africana, 14 feet in girth, showing bole and usual fork, Ijaiye Range, Dajopa, Olokemeji Forest Reserve.

To face p. 284 

its beautiful clusters of lilac-coloured, pea-shaped flowers, and later in delicate contrast to the fresh, light-green leaves. The trunk is usually not quite straight, being bent about 8 or 10 feet from the ground. The bark is smooth, thin, and almost of a silvery-grey colour. The branches are very whippy and difficult to break.

Timber.-The wide sapwood is white and the narrow heartwood green-brown when freshly cut. It is very hard, of fine grain and texture, and planes with a smooth surface. It does not split; is very rough and flexible.

It is a shade-bearer and grows slowly. The fruit is a small black and pointed pod which opens when ripe, having about three or four beans inside. It is easily killed by fire, but sprouts freely from the stool. It does not crack nor warp.

It has not been exported nor cut for local use, but it should be a good wood for turnery.

Native $U_{s e .-I t}$ is used for knives and axe-handles.

Cynometra Afzelii. Waterside Cynometra. Akushunmajadin, Alade (Ikale); Iku (seeds), Aka, Eggi (Yoruba); Ogabezzi, Ogikiomi Tpakeka (Benin).

It is a common tree in the Benin province of Nigeria. On the whole it is smaller than $C$. Mannii, though it has a similar habit. It grows, too, in similar localities, though for the most part it is confined to the evergreen forest zone. It also grows more or less in gregarious groups. The shade of this species is just as dense, if not denser than that of the foregoing. The leaf of the Cynometra is distinguishable from most other leaves because the mid-rib of it is placed towards the inner or almost straight-sided edge of the leaf. In fact, if two leaves are held closely together, they almost look as if they were one which had been cut in half. Benin natives have no use for this tree except as firewood.

Cynometra Mannii. Waterside Cynometra. Ekkun (Yoruba).

It is a common tree on the banks of streams in the Ibadan and Abeokuta provinces of Nigeria. One of the most characteristic features of this tree is the pinkish-red colour of the fresh leaves, hanging at the ends of the drooping branches. In November each year the large, corrugated, single bean in each almost indehiscent pod is another curious feature of this tree. The trunk is usually short-in fact, often divided into three or four separate stems, almost at the base. Narrow fringes consisting almost entirely of this species are found on river banks. The dense shade cast by this tree prevents any other species from growing underneath. The timber is hard and difficult to split, and apparently it is not attacked 


\section{WEST AFRICAN FORESTS AND FORESTRY}

by white ants. The tree is a shade-bearer. Natural reproduction from the seed is good, it being distributed often by water. It also sprouts from the stump. A few root shoots also appear. The tree has not been cut for local use nor has it been used for export. The natives use the wood for making posts and doors.

Cylicodiscus Gabunensis. African Greenheart. Osho, Aja, Iji (Il.), Ajaigi (Yoruba) ; Okan (Benin).

Distribution.-In the Abeokuta, Ondo, Benin, Warri, Owerri, Calabar provinces of Nigeria.

Chief Characteristics.- It is a very large tree of the evergreen forest zone, attaining a height of 200 feet and a girth of 30 feet. It is armed in its earlier growth up to the pole stage, when all the brown thorns disappear. Its long, brown pods, up to 3 feet long and $1 \frac{1}{2}$ inches wide, opening from one side only, with their long, thin, papery seeds, are most typical of the tree.

Compared to its size the bark is thin, and in old age it is inclined to scale off in small pieces. In the distance it looks practically smooth. This is one of the most gigantic and impressive trees of the forest, with its enormous bole stretching cylindrically up amongst and over the other trees, with a large, widespreading, somewhat flatly shaped spherical crown. The leaves are pinnate, with three of four pairs of little ovate pinne, with one odd one at the end. The flowers are minute, forming little, thin, knitting-needle-thick spikes of yellow bloom. These last only a few days, and only once in thirteen years have I seen the flower. The tree and pod are unmistakable, even when it is a large one. The numerous brown pods hang down amongst the foliage and appear to be much longer than those of any other Leguminous tree. This feature alone distinguishes it from any similar species. The bole divides up into a few large limbs and many small branches, making the foliage lighter and thinner than many other Leguminous trees, but not so thin as that of Piptadenia Africana. The root spurns are very slight and rounded, merging into the bole of the tree 1 foot to 3 feet above the surface of the ground. At the base of the bole the bark is sometimes cut off by the natives for "Ju-ju" purposes, and then an additional swelling appears there.

The sapwood is white and narrow, the heartwood greenishbrown when fresh, and yellowish-brown after it has lain in the forest for a few years. It is very hard-in fact, one of the very hardest of African timbers. Under cover it is very durable. In the open it does not last so long. It is termite-proof. The 
sapwood, however, rots in the open, and the heartwood softens very considerably. It is somewhat fibrous, but it planes up well, with a smooth surface. It does not take nails, saws well, and splits moderately well. It has considerable elasticity. It makes a very hot-burning firewood, but is inclined to crackle and make sparks.

It is a moderately fast-growing, shade-bearing, soil-protecting and soil-improving tree. Natural regeneration appears to be fair, but the seeds are often eaten by little boring insects, soon after they fall to the ground. It appears to be rather exacting as to soil, liking a deep, moist loam sand with good drainage. It is scarcely a fire-resisting tree, but very storm firm-in fact, one of the safest trees.

In 1906 sample logs of this tree were sold in the Liverpool market as African Greenheart at 1s. 8d. per cubic foot, and were stated to be good greenheart. Since then none has been cut or shipped to England. With the exception of its use for verandah-posts for a public building in Benin city, it has not been cut or sawn up in planks for local use. Considering the comparatively large quantity available, it deserves a fair trial both for export and local use, more especially for heavy constructional work, such as bridges, piles, uprights.

Amongst the Benis it is sometimes a "Ju-ju" tree, and is said to impart strength.

Leptoderris.

Owerri province of Nigeria. It is a medium-sized tree found growing near the Imo River, but not very common. It has a hard wood.

Baphia nitida (Afz.). Awenu or Irosun. Borri Borri (Yoruba); Otwa (Benin); Ubara (Efik).

Is a small tree, which is usually found near villages, being left by the natives when land is cleared. The white flowers are almost of pea shape. It has a small leaf, and does not usually get any larger than about four inches in diameter.

It is found in the Ondo, Abeokuta, Benin and Calabar provinces of Nigeria.

The real Camwood of commerce.

It is very slow-growing, and is not a hard wood, with darkred heartwood of small size in proportion to the size of tree. It forms late, too. If the stem is wounded, even the sapwood becomes a rich red colour like the heartwood.

The probable origin of the word "Camwood" is taken from the Timani name, Cam, of the Baphia nitida tree in Sierra Leone. From another point of view this is all the more interesting, as the original exports of Camwood were made from Sierra 
Leone in the early part of the nineteenth century, and this name "Cam " brings together the tree from which the Camwood is obtained and the tree botanically known as Baphia nitida.

Native $U_{8 e}$.-A piece of the wood and a leaf are placed on the ground where a woman has borne a child, whether it be on a road or in the house. Not used in. Benin as a dyewood.

Baphia polygalacea. Walking-stick Camwood. Asana, Ossusu (Yoruba); Aswen (Benin); Mbomokuku (Efik).

It is found in the Abeokuta, Benin and Calabar provinces of Nigeria.

A small tree of typical Baphia habit, which is common in parts of the Benin district of the same named province. It has considerable elasticity, though it dries rather hard and does not give much in that state. It is a rather slow-growing tree, which lights the shade of the forest, and is also a soil-protecting and soil-improving tree. Natural regeneration appears to be good in several places. It sprouts slightly from the stump, when felled. No plantations have yet been made with this tree. The walking-sticks have not been exported to England for trial in the market.

The curiously shaped single root, sticking out almost at right angles to the stem, makes a good walking-stick; it is curved as well slightly, too. When the bark is peeled off and the stem partially charred, it looks very effective.

Baphia pubescens. Benin Camwood. Awewi (Lagos) (Yoruba); Ositwa (Benin).

It is a small tree, 30 feet high and 3 feet in girth, with usually half the bole sapwood white, and dark-red heartwood, which is hard and close-grained. The flowers are white, with yellow tips to the two petals. It is often seen just outside villages, or where two paths meet.

Native Use.-It is not used for dye, though apparently the wood is just as suitable as $B$. nitida.

Baphia sp. Camwood. Mogbara (Yoruba, Ikale); Owe, Aswen (Benin).

It has also been determined as Carpolobia lutea, and as one of the Oleaceæ.

It is a shrub with a stem of about 4 feet in height. The fruit is a small nut containing three small kernels. The wood is very hard.

Native Use.-The seeds are eaten.

Macrolobium palisoti. Ogaba (Benin); Nya (Efik).

It is a common tree of the Abeokuta, Ibadan, Ondo, Warri, Benin, Owarri and Calabar provinces of Nigeria. It only reaches a girth of about 2 feet and a height of 20 feet. The 
leaf has two pairs of pinnæ, with one end leaflet. The small pod containing two or three flat seeds is most typical of this tree ; the seeds are 8 inch in diameter and of a dark-brown colour; the flowers are white; the timber is cross-grained and rather hard; the sapwood is white and the heartwood of a dark brown. The tree is a shade-bearer, soil-protecting and improving. It is usually found amongst the undergrowth in the thicker parts of the evergreen forest zone. Natural regeneration is usually good. The wood is used locally in the Yoruba and Benin country for posts; it has not been sawn up for planks, nor has it been exported to England.

Macrolobium stipulaceee.

It was stated it was found in the Calabar province.

Nr. Macrolobium sp. Ogabeszi (Benin).

It is found in the Benin province of Nigeria. It is a small tree of the evergreen forest zone. The foliage is very dense. The tree has a short bole of about 15 feet, and the crown is much branched; the pod is rather larger than Macrolobium palisoti. According to the natives, this is the "Ogaba" of the waterside. The timber has not been exported to Europe, nor do the natives use this somewhat hard wood to any extent.

Dialium Guineense. Pulley Wood, Velvet Tamarind. Awin (Ib.) (Yoruba); Ohiorme (Benin); Amoyin (Egba).

It is found in the Ibadan, Abeokuta, Benin, Calabar and Ogoja provinces of Nigeria. In the mixed deciduous forests it is very prevalent in certain localities. Of medium size, it rarely exceeds a girth of 5 feet. Where found, it often comprises over 10 per cent. of the standing stock of the forest.

The wood is used for small boats in Senegal. It exudes a red-coloured sap in small quantities.

The fruit, with its flat and round, velvety little pods, is most typical of this tree. These are of a very dark chocolate colour, and in the distance appear almost black. The bole is usually silver-grey. The slash is light-red, and the reddish, latexlike substance exudes when the bark is cut. The crown is dense and compressed, being mainly made up of a number of small branches. In proportion the leaves are small and make a very dense foliage. The rusty-red slashing marks, or other marks caused by damage to the trunk of the tree, show up most distinctively, especially against the grey surface of the cortex, are one of the most distinguishing features of this tree.

The sapwood is white, the heartwood is dull-red, rather larger in proportion than we should suspect, compared with the size of the tree. It is hard and tough, and does not split well. 
It planes up, however, with a smooth surface, is very durable and termite-proof. It does not take nails well, but saws fairly easily.

It is a somewhat slow-growing, shade-bearing, soil-protecting and soil-improving tree. Natural regeneration appears to be good. It appears to be a little exacting in regard to soil. It is slightly fire-resisting, chiefly, perhaps, owing to the fact that few weeds or grass grow in its shade. No plantations have been made of this tree. It bears a good crop of fruit almost every year.

It has not been felled for export, nor has the timber been sawn up for local use. It was formerly used in the Congo for pulley-blocks, for which purpose it is said to be admirably suited. Amongst the natives it is sometimes used for housebuilding.

Nr. Newtonia. Boji Albizzia or Giant Pod.

It is rather an uncommon tree of the Boji Hills forest; the enormous flat, papery pod makes it easily distinguishable from any other tree.

The pod is about 15 inches long and 9 inches wide, with a slight depression in the middle of one side.

Pithycolobium altissimum. Bent Pod or Gambia Pod.

It is a medium-sized tree, found at the edge of swamps near the sea coast in the evergreen forest zone. It appears to stand a waterlogged soil.

The pods are used for tanning hides and making ink (Moloney). It has curious semicircular pods, which are typical of the tree, containing eight to ten seeds.

Afzelia $s p$. Waterside Ekpagoize. Ekpagoize (Benin).

It is found in the Benin province of Nigeria. It is a mediumsized tree, reaching a girth of 7 feet and a bole length of 40 feet.

This tree has often been confused botanically with Berlinia acuminata, but it is undoubtedly an Afzelia. The flowers are of a reddish colour and very pretty; the foliage is not quite so heavy as that of the other Afzelias; the pod is rather smaller than that of either Afzelia Africana or Afzelia cuanzensis. The wood is a reddish-brown colour, a little cross-grained, but more durable than the other Afzelias. It does not split well, and can only be planed with difficulty; the grain is very coarse and fibrous. Samples of this timber have been shipped to England and sold as red oak. The natives scarcely ever " use the wood, partly because the tree is not very prevalent. Afzelia cuanzensis. Bilinga, Red-arilled Afzelia. Aiyo (Yoruba); Aligna (Benin); Igbin (Brass) ; Onuru, Oshoshi (Ibo, Owerri) ; Mbarakun (Oban, Ekoi). 
It is found in the Benin, Ondo, Abeokuta, Calabar, Owerri and Ogoja provinces of Nigeria.

It is a medium-sized tree, with a pod, which is usually slightly crumpled or bent, containing about six or eight black nuts, with a red aril at the base, and each nut is pointed more, and less rounded, than in A. Africana. On the whole it is found more in the deciduous mixed forest than on the edge or in the dry-zone forest region, where $A$. Africana abounds. The bark does not scale off so much as that of $A$. Africana. It stands more shade than $A$. Africana. It does not reach such large dimensions, though logs up to 18 inches square and 24 feet in length could be obtained.

Up to the present the tree has not been cut to the same extent as $A$. Africana, though the wood is very similar and apparently just as durable.

No separate report has been made on the timber as to its value in the European markets.

Afzelia bella. Calabar Afzelia. Aligna (Benin).

It is found in the Calabar province of Nigeria. It is more common in the Cameroons.

It is a small tree, with large white flowers with a pretty, reddish streak in each petal. The pod is of usual Afzelia size and appears rather large for the size of the tree. The type specimen stands on the Calabar Golf Course, between the seventh and eighth holes. It is apparently uncommon, though more may be found on closer study of the forests. The fruits appear to have the same qualities as those of other Afzelias. In Nigeria it has so far not been utilized. The bark is not so scaly as that of $A$. Africana.

Afzelia pachyloba (nov. sp.). Forest Afzelia or Yellow Aril. Apa (Yoruba); Orodo (Benin).

It is a medium-sized tree, with long, pointed nuts with a bright sulphur-coloured aril instead of the orange-colour of Africana or red of Cuanzensis. It does not appear to be such a common tree as $A$. Africana, but much the same number of trees as that of $A$. cuanzensis.

It is found in the evergreen forests of Ondo, Benin and Abeokuta provinces of Nigeria.

The sapwood is white and the heartwood is brown. It is very hard, almost as hard as Lophira, according to the natives. Self-sown seedlings do not appear in large numbers.

It is used for similar purposes as $A$. Africana. It is a shadebearing and soil-improving tree.

No separate report has been made on the timber, and so far it has not been exported to the English markets. 
This may be the tree which yielded the so-called teak in the Benin forests some years ago, and fetched a price of $5 \mathrm{~d}$. per foot superficial.

The bark scales off in a similar way to Afzelia Africana. Afzelia bracteata (T. Vogel). Benin Bilinga. Ekpagoize (Benin).

It has a red flower, is found in the Benin province, but is apparently rather rare.

The Benin name indicates that it is the Ekpagoi or Berlinia of the waterside. It is usually found near or on the bank of a stream. It is a large tree, which is otherwise similar to the other Afzelias.

The natives have apparently not tried it for building purposes.

- Afzelia Africana. Yoruba Bilinga. Apa (Yoruba); Olokokima, Aligna (Benin); Ayibukpo (Efik); Adja, Arachi (Asaba Ibo).

Trade Name.-Bilinga, similar wood from the French Congo, so named for some years.

It is found in the Abeokuta, Ibadan, Ondo, Benin, Owerri, Onitsha and Ogoja provinces of Nigeria.

The round, orange-coloured aril at the base of the black nut is typical of this tree. It sometimes has a reddish tinge, but it is always round and completely surrounds the base of the nut, in contradistinction to $A$. cuanzensis, in which the aril is red and pointed and much thinner in build.

The spherically-shaped crown with its flattish top is most typical of this tree. The largish leaves and the paucity of their number make the foliage open, so that daylight can be seen through it. In the distance it appears dense.

The sapwood is white, and the heartwood a rich oak-brown colour. It is one of the most durable West African timbers. It planes well and can be worked up with a good finish. It does not split well. It is obtainable in logs up to 30 inches square and 30 feet in length.

Though slow in growth it would average that of many European trees. It stands a good deal of shade in its youth, but it is really more of a light lover than a shade-bearer. Selfsown seedlings are few; apparently rodents eat them. In a similar way it is difficult to make a plantation, many being eaten or dying in the transplanting. One of the most successful methods evolved is that of sowing seeds in lines about 4 feet apart; a large number then come up and provide ample for a crop on the same land. They are not transplanted. When of middle age it will stand fire and the shade of the tree keeps the ground moist.

It is a soil-protecting and soil-improving tree; good crops 
of seeds are borne almost every year. The flowers are reddish, with white edges to the petals. The reddish tinge is quite distinctive in this genus, the white being that of Berlinia.

The bark drops off in large scales in places on the trunk towards middle and old age, in a similar fashion to the European plane. However, they do not leave the stem as smooth, though the lighter patches where the bark falls off brighten the bole up and make it quite distinctive amongst the other trees.

The timber has been constantly used by the P.W.D. at Onitsha. In the Liverpool market it was stated that it might be marketable as oak, at a low figure, in 1906. A similar species was being shipped from Gaboon in 1914 and fetched a fair price. Albizzia fastigata (Oliv.). East Indian Walnut. Ayinre langara, Ayinre ogo (Eg.) (Yoruba); Uwowe Lugu, Uwowelabafun (Benin); Uyat (Efik).

It is a large tree, up to 7 feet in girth and of corresponding height. Fruit narrower than $A$. sp. ; only half an inch, with four or five seeds in each. This species has the most durable wood of all the Albizzias, but is not termite-proof, and has heartwood of a brown colour and white sapwood. The smallest leaf of all the Albizzias is met with in this tree, having very fine pinnæ.

Although not indigenous to Africa, it is now found almost everywhere in all the mixed deciduous forests of the Southern Provinces of Nigeria. The bark is rather rougher than that of $A$. Brownii. The basal root spurns are narrower, though they do not project more than 2 feet up the stem. On the whole the foliage is thicker, and the crown gives the appearance of being a little denser and not so feathery as that of A. Brownii.

The wood planes well, splits fairly easily, takes nails and saws well. It is what the carpenters would call a wood easy to work. The grain is of fine texture and has a certain amount of lustre.

It is a fast-growing, light-loving tree, which does not protect the soil. The leaves, however, form a rich humus, which enriches the soil. Natural regeneration appears to be good, and with the spread of farms this tree tends to increase its area of distribution. It will stand a little shade in its youth. A few plantations have been made with this tree.

Up to the present the timber has not been exported, but deserves a trial as an African Walnut, though it is difficult to obtain large-sized logs. It has occasionally been cut for local use. It is used by the natives for firewood, and occasionally, when split, for temporary house-building in the farms. 


\section{WEST AFRICAN FORESTS AND FORESTRY}

Albizzia Brownii. African Walnut. Ayinre, Ayinre Bona Bona (Yoruba); Owewe nolemare, Ikpawudu (Benin).

It is a large tree, up to 7 feet in girth, with wide fruit 2 inches across, containing four or five seeds. There are three or four pairs of pinnæ to each leaf, which is the largest of all the Albizzia leaves. The heartwood is more like walnut in colour, though of course softer and with more open grain. It could no doubt, however, be used as a substitute for walnut.

It is a common tree in the mixed deciduous forests of the Abeokuta, Ibadan, Benin, Owerri, and Ogoja provinces, where it is tending to widen its area of distribution with the spread of cultivation.

The fruit is very papery and almost transparent. It is rather larger than Albizzia sp., Shemusholoshi, but of about the same length. Its smooth, almost orange-coloured bark in the earlier stages is almost typical of the tree. As it gets older, a somewhat more corky bark forms in large scales which can be stripped off. The lop-sided shape of the pinnæ is very typical of the tree, making the leaves look almost like those of a true Gum Copal. The main vein is near the straighter side of the leaf.

The sapwood is white and the heartwood a mahogany brown. It has rather an open grain, but a good deal of lustre, and is easily worked. It planes well and takes nails easily. It splits fairly well and saws quite easily. It is not quite so durable as $A$. fastigata, but it is more durable than the other Albizzias, except A. sp., Shemusholoshi. It is not termite-proof. It has considerable tensile strength compared to the other species, and a certain amount of elasticity.

It is the fastest growing of all the Albizzias and a lightloving tree. It scarcely protects the soil, but the leaf fall makes a good humus. It stands a little shade in its youth. Natural regeneration is very prolific. No plantations have been made with this tree. It appears to be a little more exacting as to soil than the other Albizzias, but will grow on almost any soil.

The timber has not been exported, but deserves a trial as a substitute for walnut. Owing to the fact that there are considerable supplies, and that it reaches a size to produce logs of the requisite dimensions, it appears to offer some possibilities as an export wood. Locally it has often been used for cutting up into planks, and is liked among the Yorubas for this purpose. In other places it has been used as a housebuilding wood, as well as for firewood. It has also been used for making beams, planks and doors. The roots, leaves and 

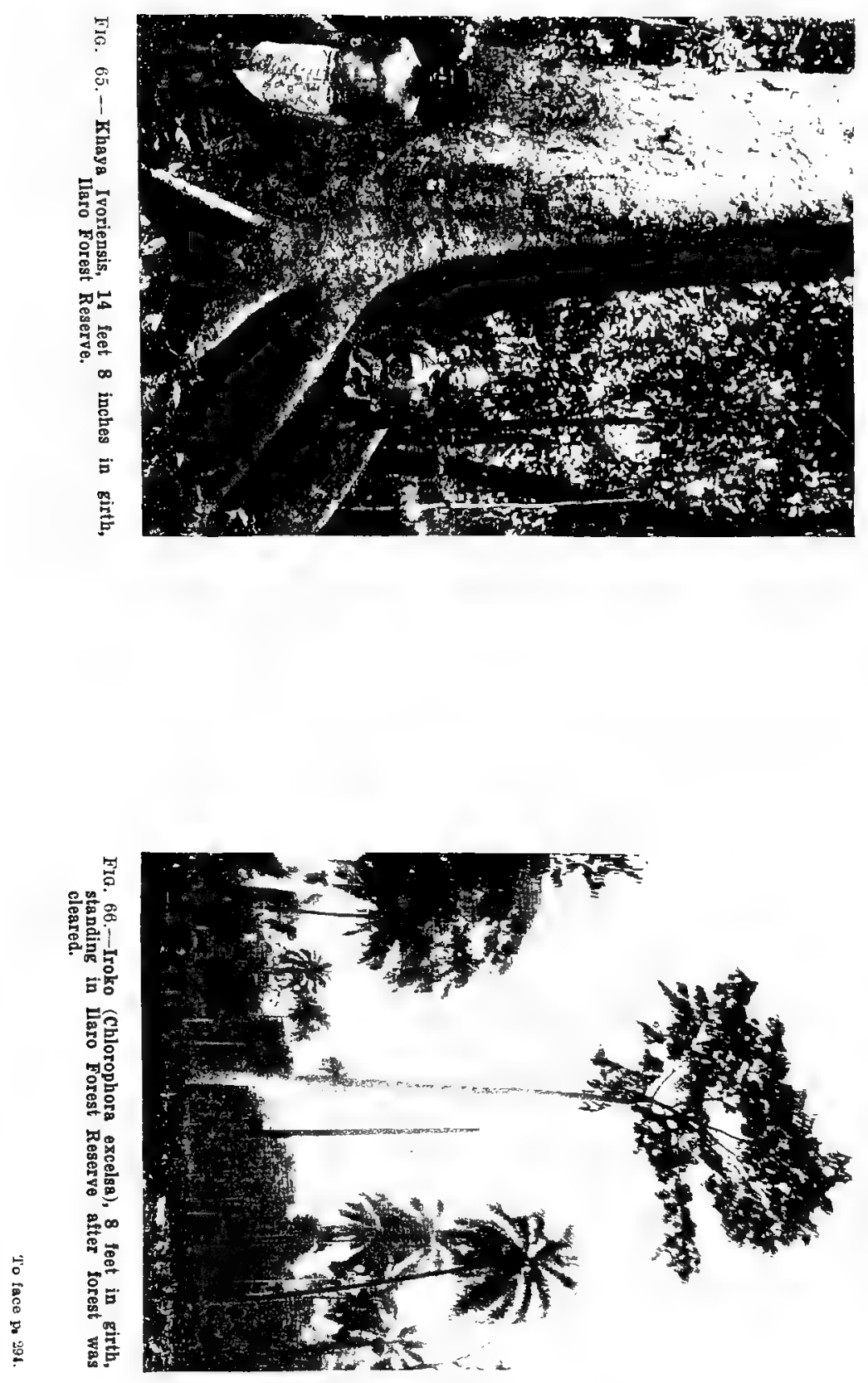

bark have been used amongst the Yorubas for medicinal purposes.

Albizzia sp. Walnut. Owewe nolemare (Benin); Ayinre (Yoruba); Semusholoshi (Jebu); Akkihien, also Owewe lagebon (Benin).

According to Mr. H. N. Thompson, Chief Conservator of Forests in Nigeria, who has seen the fruit of this tree, it is most certainly an Albizzia.

Chief Characteristics.-It has been described by a German as not unlike a solitary-standing pine, with its dark foliage of small pinnate leaves, which are larger than Piptadenia Africana and yet smaller than Cylicodiscus Gabunensis. In the above description it is very similar in habit to Piptadenia Kerstingii. The dark brown bark, which is roughish, is lightbrown on the upper part of the stem. The crown is flat, consisting of two or three wide, outspreading branches. It has the usual flat, papery pod. The leaves are used by the Benin people for soup.

Distribution.-It is found in the Abeokuta province of Nigeria.

Timber.-It is fairly close-grained, though not nearly so hard as either Piptadenia Africana or Cylicodiscus Gabunensis.

$U$ se.-The Yorubas use the bark medicinally as a stomachic, and the trunk is usually swollen at the base owing to the cortex being removed so often.

Albizzia rhombifolia. Walnut. Ayinre, Ayinre langara, Ayinre ogo (Yoruba) ; Owowe (Benin).

It is found in the Ibadan and Benin provinces of Nigeria, in the mixed deciduous forests, where it is quite prevalent. It is a medium-sized tree, attaining a girth of about 6 feet and a bole length of $\mathbf{3 0}$ feet. It is commonly seen in old farms, and usually more than one is found in the same locality. The thin, yellow, spiky flowers are rather pretty. The fruit is rather smaller than that of the other species.

The sapwood is white, and the heartwood is a light yellowgreen. It is soft and not very durable; it is attacked by white ants (termites). However, it saws well, planes well, takes nails easily and splits moderately well. It can be cut into good-sized planks.

Timber, yellowish-green, and yields large planks.

It is a fast-growing, light-loving tree, which scarcely protects the soil, and only slightly improves it with its leaf fall. Natural regeneration is good, the seedlings growing up rapidly in any open place in the mixed deciduous forests.

The timber has not been tried for export, nor has it been 


\section{WEST AFRICAN FORESTS AND FORESTRY}

used to any extent for local use. It deserves a further trial both as an export wood and as a wood for local floor-boards. Its qualities are far from properly known.

Among the natives it is used as firewood.

Albizzia sp. Walnut. Ayinre Ayinre, Ayinretta (Yoruba); Ikpawudu, Owawelugu (Benin).

It is a large tree, up to 6 feet in girth. It has rather narrower pinne, but of similar round shape to $A$. Brownii.

It is a common tree of the mixed deciduous forests in the Abeokuta, Ibadan, Ondo, Benin, Onitsha, Owerri and Ogoja provinces of Nigeria.

The root spurns are very small. The bark gets rougher than that of $A$. Brownii in old age, the crown is longer and more feathery, and the leaves appear to be more of a silvery green.

The sapwood is white and the heartwood is of a yellowishbrown colour, tending to become a light brown when exposed to the air. It is comparatively soft; is not termite-proof. It is easy to work, planing and sawing well, and taking nails easily and splitting fairly well. It is, however, less durable than $A$. Brownii or fastigata. When split and dried it is more durable than when cut up in the ordinary way. The wood hardens very considerably on exposure to the sun.

It is a light-loving, fast-growing tree. It scarcely protects the soil, but the leaf fall enriches it. Natural regeneration appears to be good. It tends to spread with the increase of farms, more especially on the poorer laterite soils. A few plantations have been made with this tree. The volume of produce per acre is less than in the case of $A$. Brownii, but apparently greater than any of the others. It is less rapidly growing than $A$. Brownii, but faster than the others.

The timber has not been used for export, and it is doubtful if it would repay the cost. Locally it has been used for planks, but it is not liked so much as that of $A$. Brownii or fastigata. By the local people it is used for firewood, and occasionally for building temporary houses.

Anglocalyx ramiflorus (Taub). Ekiyawa (Benin).

It is a large tree, attaining a girth of 8 feet, but the trunk is not over-long in proportion. It is a shade-bearing, soilprotecting and soil-improving tree. The bark is a dark olivegreen and smooth. It is found in the Benin province of Nigeria. Natural regeneration appears to be poor. The wood is yellowish-brown and floats when quite dry. The timber was valued at nothing in 1906 and stated to be a whitewood in the Liverpool market.

Native $U_{\text {se. }}-$ None. 
Ostryoderris impressa. White Oak. Awaw or Erumacie (Yoruba); Ori, Ehrurumesi, Erurunuesi, Awaw, (Usshin) (Benin).

It is a common tree in the Calabar, Ogoja, Benin, Owerri and Abeokuta provinces of Nigeria. To be seen along the Benin-Siluku Road, as also in the Badagry district on the Ayobo-Osuke Road.

It is a straight-boled, tall tree, with flattish crown made up of few straight branches with large pinnate leaves, making it appear flatter than it really is. The bark is slightly scaly with fine fissures. The slash is red, exuding a red latex. It reaches a height of 150 feet with a girth of 12 feet. The white, papery, pointed, flat, lozenge-shaped fruit, with a small kidneyshaped seed attached to the centre of the surface of one side, is most typical of the tree. The spurns are almost non-existent, so that the tree can be felled near the ground without trouble.

The timber is white in the sap and brown-white in the heart wood, but not over-hard, very tough and not splitting easily. It is hard to fell, being very flexible. It planes moderately well. The colour darkens with age.

It is a light-loving tree after the first few years. It grows moderately rapidly. It is a soil-improving and covering tree. Natural regeneration appears poor, though many seeds are usually seen on the ground. Insects appear to eat them rapidly. No plantations have been made with this tree, but experiments would show whether it grows well from seed.

In 1906 a sample log was exported and sold in the Liverpool market as white oak at 2s. per cubic foot, and it was recommended for shipment by the brokers.

Native Use.-It is used as posts for frames on which yams are tied in the Benin farms. In temporary houses, small trees are trimmed and squared for the forming of the walls, instead of dried mud.

Dalbergia saxatilis. West African Blackwood (?). Awow (Benin).

It is a small tree of the mixed deciduous forest of Benin; it is occasionally used by the natives for hoe and axe handles.

Dalbergia 8p. West African Blackwood. Emosobegan, Paran (Yoruba).

Found in the Olokemeji Reserve.

Dalbergia sp. North Benin Blackwood.

This is found near Aroko, in the Onitsha province, and near Ishoka, in the Benin province. It is a small tree with very hard wood. In habit very similar to Ormosia laxiflora, with its orange-coloured bark, which is rougher than $O$. laxiflora and not so scaly. The wood is used for axe and hoe handles by the natives. 
Dalbergia hostilis (Benth.). Yoruba Blackwood. Ogan Oga (Yoruba).

This Dalbergia is fairly common in the Olokemeji Reserve, in the Abeokuta province of Nigeria.

Copaifera sp. True Benin Gum Copal.

This tree is found near the Uhi, close to the source of the Ossiomo River, Benin province. This apparently is rather an uncommon tree. The Benin natives do not know how to tap the tree for gum, nor how to use the gum.

Cf. Copaifera. Enyenewu. Enyenewu (Yoruba).

Found in the Yoruba country.

Copaifera sp. Boji Hills Copaifera.

So far it has not been tapped for the gum, the local people apparently not knowing its value.

Bauhinia rufescens (Kew).

Found in the Oyo province.

Baukinia reticulata (D.C.). Dry-zone Bauhinia. Abafe (Yoruba).

This Bauhinia grows in dry, open country. It is a small, spreading tree bearing white flowers.

Uses.-The fibrous bark is used for tying, and an infusion from the leaves is used in coagulating rubber latex. The stem is occasionally used for making house-posts. It is a fireresisting tree and shades the soil.

Bauhinia Thonningii (Schum.).

This is a small shrub-like tree of the upper part of the Benin province of Nigeria. It is found near Agbede. It has red flowers. The sap of this tree has sometimes been used for coagulating rubber.

Physostigma venosum. Calabar Bean or Ordeal Bean. Eseri (Efik).

It is found growing in the Calabar district. The seed is poisonous; used in ordeals and medicinally.

The most noticeable feature is the furrow (about $\frac{1}{8}$ inch wide and deep) in the upper side of the bean. None of the closely allied Mimosa species show this peculiarity.

Entada scandens. Sword Bean, Match-box Bean, Mackay Bean. Kakoba, Akhuro (seed) (Benin).

This large creeper is found in the Benin and Calabar provinces of Nigeria. It is not very prevalent. The most remarkable features about it are the stoutness of the stem, which attains a diameter of nearly 1 foot and the total length of over 100 feet, and its immense pod, which is often over 3 feet in length. The pod is divided into segments, each nearly 2 inches square, and each containing one large bean, almost a square in shape, $1 \frac{1}{2}$ inches and nearly $\frac{3}{4}$ inch thick. These beans have occasionally been used for making match-boxes, for which they 
are admirably suited. The outer part of the stem of the creeper is very rough and almost corrugated, especially near its base; the leaves are very small, considering the size of the whole creeper. It is comparatively slow-growing. It grows in the dense evergreen forest, and when drawn taut over the first branches of one of the large trees it is not unlike the bole of a small tree itself. When cut, the two ends part with a bang, like the breaking of a ship's hawser. The natives use the smaller parts of the stem for fly-switches, for which they are very good and durable. The creeper is, however, not cultivated.

Entada Soudanica. Ogurohe (Yoruba).

Found in the Ibadan province.

Entada Abyssinica. Unwanwanis (Benin).

It is found in the upper part of the Benin province near Ishoka. It is a large creeper with rather smaller bean than $E$. scandens. The beans have been used for making small match-boxes in Europe. The natives consider the bean a "Ju-ju."

Dioclea reflexa. Ishe, Agbarin (Yoruba).

A climber, found in the Ibadan province.

Mucuna urens. Ox-eye Bean. Awipu (Benin).

Found in the Benin and Abeokuta provinces.

Mucuna sp. Preussii. Yerepe (Yoruba).

Found in the Olokemeji Reserve and Benin province.

Acacia pennata (Willd.). Acacia. Okwekwe (Benin).

It is found in the upper part of the Benin, Ibadan, Ogoja and Abeokuta provinces. It is a small, scandent shrub with very sharp thorns, but which yields one of the strongest fibres for making fishing lines or native rope. It forms almost impenetrable masses which are very unpleasant to go through without a matchet.

Acacia Sieberiana. African Rosewood. Sie (Yoruba).

This is a somewhat uncommon Acacia of the Oyo province of Nigeria. Being of medium size, its very handsome racemes of yellow flowers show up to great advantage. The bark is rough, the bole short, and usually divided 8 or 10 feet from the ground. The sapwood is white and the heartwood a rosepink colour, which makes it not unlike the typical rosewood of commerce. The heartwood is comparatively wide, and it is very hard, durable and termite-proof. It saws well and splits moderately easily, but does not take nails at all well. Reproduction by seed is apparently poor; it sprouts fairly well from the stump. It is a light-loving species, but being of the leguminous family it is a soil-improving tree. The wood has not yet been exported, but locally it has occasionally 
been used for house-building, the forked stem being much appreciated by the natives.

Acacia Farnesiana (Willd.). Farnesian Acacia. Bonni (Yoruba).

It is found in the Abeokuta province of Nigeria. It is a small tree growing up to 6 feet in girth. It has a small pod containing eight seeds inside. The inside of the pod is white and the seed is brown. The flower is yellow, and is used by girls in decorating their ears. Usually found in towns, where it is planted. The seeds are sold in the market.

The timber is dark-red, surrounded by a narrow white sapwood. It is hard, like ebony. The bark is very much fissured and peels off in large scales.

The seeds of this tree and Jagiri are used with water for soraping the leather for making the fells smooth. Sold at Itaku and Shapon markets.

Acacia campylacantha. Confectioner's Gum or African Catechu. Ede (Yoruba).

It is found in the Abeokuta, Oyo, Borgu, Niger, and Nassarawa provinces of Nigeria.

It is a very common tree, growing almost everywhere in groups. The stem is of a whitish to slight yellow colour, almost reminding one of the larch, but the whole tree is armed with short, sharp thorns. It reaches a girth of nearly 4 feet and a height of over 50 feet. The slash is light-brown, and a pale, yellowish-pink gum exudes from it. The tree usually forks about 20 or 30 feet from the ground, the other branches being rather crooked in shape. In February or March a mass of small yellow flowers appear, and in the autumn small pods cover the tree. The sapwood is white, and the heartwood varies from a dull red-brown to a rich, almost rosy red. In the latter case it is exceedingly pretty wood. The wood is moderately hard; it splits and planes badly, saws fairly well, and only takes nails indifferently. The wood dries rather harder and is more durable than when freshly cut and than would be expected. It is said to be termite-proof. A reddish colouring matter exudes from the heartwood, but this feature is typical of the cutch which is obtained from a similar tree in India.

Natural regeneration by seed appears to be good, hosts of young trees being found near the older ones. In fact, in localities of low rainfall it is tending to spread and fill up all vacant spaces after the annual grass-fires have burnt all the vegetation. It is a light-loving tree which does not protect the soil. The leaves are not unlike conifer needles, and enrich the soil to a certain extent, more especially as the tree is deciduous.

As a timber it has not been cut for export, but certainly 
the better-coloured wood, and that which has been more slowly grown, deserve a trial.

So far, the greatest use of this tree has been the production of the pink-coloured transparent gum which is one of the best of the confectioner's gums in Great Britain. Very large quantities are exported every year from the Northern Provinces. Large round tears or lumps form on the stem of the tree when it is cut. Locally the tree is used for house-building, but it is not considered a durable wood.

Leguminose (Mimosex).

Acacia ataxacantha. Benin Rope Acacia. Ewon (Yoruba); Okwenkwen (Benin).

A common creeper of the mixed deciduous zone. It is found in the Abeokuta, Oyo, Ibadan, Ondo, Benin, Warri, Onitsha, Owerri, Calabar and Ogoja provinces of Nigeria.

It is usually found growing in large impenetrable masses 3 to 4 feet high. It is armed throughout with short but very sharp, bent prickles.

It often grows up in waste places where the bush has been cleared in the mixed deciduous forest zone.

Both the Yorubas and Benis use the inside fibres of this creeper for making a very strong kind of rope-in fact, it is the strongest of all native-made ropes. It does not get so stiff or harsh as that made of Eso from the Firmania Barteri.

Distemanthus Benthaniami (?) (Baill.). Alinyan (Benin).

Found in the Benin province.

Erythrina suberifera (Kew). Attagbo (Yoruba).

It is a moderately common tree of the Abeokuta province of Nigeria. Its most distinguishing feature is the size of the leaf, which is similar to the tulip-tree. It reaches a much larger size than $E$. Senegalensis and has a girth of over 6 feet. The bark is a dark duck-egg-green colour, with a few white, shallow longitudinal fissures. The prickles on the stem are more scattered and much larger than those of $E$. Senegalensis. The slash is white and the bark thin when compared to the size of the tree. The wood is white and soft, and not durable. It cuts and saws easily, but does not plane well. It is a lightloving tree which does not protect the soil. It has not been cut for local use, nor for export. As a soft whitewood for interior use it ought to find a local market.

\section{Leguminosæ (Papilionaces).}

Erythrina Senegalensis (D.C.). Coral-flower. Ologun she-she (Yoruba); Esanigbakhehe, Ohehe (Benin).

It is a common tree in the upper part of the Onitshe, Benin, 


\section{WEST AFRICAN FORESTS AND FORESTRY}

Ondo, Ibadan and Abeokuta provinces of Nigeria. One of the most typical features of this small tree are the small, pink, coral-like flowers which appear in February. The tree is armed with a few thin but very sharp thorns; the foliage is alight and open. On suckers or stool-shoots the leaf is much larger and almost lyre-shaped. It is usually found in waste places or in open clearings in the mixed deciduous forest. It yields a soft wood which is not durable. It is sometimes used for making fences.

Tephrosia Ansellii (Hook). Boro (Yoruba).

It is found in the Olokemeji Reserve of the Abeokuta province of Nigeria.

Tephrosia Vogelii (H. K. F.). Fish-poison. Were, Igun, Laye Igu (Yoruba).

This small shrub is apparently indigenous to Africa, but is usually seen planted in the fields of the Abeokuta, Oyo, Benin, Owerri and Ogoja provinces of Nigeria. It is not unlike a large upright vetch, but with a strong, green stem, almost woody in growth. It reaches a height of about 3 feet and flowers very profusely, and bears a large number of pods, not unlike those of the runner bean. The plant is cut down and placed in the water where it is desired to catch all the fish, chiefly in stagnant pools of rivers or ponds. The effect of the poison from it blinds and stupefies the fish so that they are easily caught. Under the Game Preservation Ordinance, its use has been prohibited, but with its widespread cultivation and general utility it has been found very difficult to eradicate the custom or the plant. Incidentally. it is a very good green manuring crop for agricultural land. However, most natives are unaware of this fact, and it is usually only planted for the purpose of using it as a fishpoison.

Burkea.

A species of Burkea was found near the Oyan River in the Oyo province of Nigeria.

Lonchocarpus sericeus. African Wisteria. Ipapo, Apapo (Yoruba).

This tree is found in the Olokemeji, Ibadan, Ilesha and Calabar districts. It is a medium-sized tree, which bears lilaccoloured flowers. As the flowers appear before the leaves in the dry season, it is then very ornamental, and is in fact one of the prettiest flowering trees. The wood is very hard and the heartwood green when freshly cut.

Timber.-This is not of much service.

Uses.-Hoe-handles are made from the branches, and the bark is used in medicine. 


\section{THE NIGERIAN TIMBER TREES}

Lonchocarpus sp. Mamu Lonchocarpus.

Found in the Mamu Forest.

Lonchocarpus cyanescens. Yoruba Indigo. Elu or Ela (Yoruba).

This is one of the intermediate forest climbing shrubs, but has been cultivated throughout. the country.

Uses.-The well-known Yoruba blue dye is made from the leaves. The stem is sometimes used for house-building posts. It is a shade-bearing, soil-improving tree. Natural regeneration appears to be poor.

Casalpina Bonducella. Shayo (Yoruba).

The bean of this creeper is used in games amongst the Yoruba boys.

Mundulia suberosa (Benth.). Lakuta (Yoruba); Ugbehen (Benin).

It is rather an uncommon tree, found in the Olokemeji Reserve of the Abeokuta province of Nigeria. It is a small tree, a part of which is used for killing fish.

Indigofera hirsuta. Indigo. Epa ile (Yoruba).

It is found in the Mamu Reserve of the Ibadan province of Nigeria.

Indigofera stenophylla. Indigo. Aro Boro (Yoruba).

It is found in the Olokemeji Reserve of the Abeokuta province of Nigeria.

- Pentaclethra macrophylla. The Oil Bean. Apara (Yoruba); Opagga, "Ukpagga (Benin); Ataka (Ibo, Asaba); Opochala (Ibo, Niger).

It is a large-sized tree, reaching a girth of about 12 feet and a bole length of 40 feet. The root spurns are very extensive and often reach 4 or 5 feet up the stem, thus quite breaking up the base of the bole. The bark at first is a light yellowbrown, darkening in old age to a deep brown, and scaling off somewhat.

Chief Characteristics.-It has dense foliage and a heavy, branched crown, and very flat pods about 1 foot long and up to $2 \frac{1}{2}$ inches broad, containing seven or eight large, flat brown beans about 1 inch in diameter and inch thick. The pods open with a loud report not unlike the sound of a 12-bore gun.

Distribution.-It is found in the Lower Province of Nigeria, near the watercourses outside Abeokuta, Jebu, Ode, Benin, Onitsha, Owerri, Calabar and Ogoja.

Silvicultural Qualities.-The tree grows readily from selfsown or artificially sown beans, as is seen in the Avenue at Benin City, which was sown at stake in 1904. It bears pods in the twelfth year in the open, but later in the forest. It is usually very prolific, bearing at least some pods every year. The bole is not always very straight, and it has a distinct tendency to form strong side branches, and the crown is there- 
fore a large oval one. The flowers are little jellow spike, which are very inconspicuous; they are borne on the old wood rather on the underside of the twig, in November or December and later. The tree stands dense shade, and it thoroughly covers the ground and prevents the growth of weeds.

It has a tendency to branch comparatively low down, when growing as an avenue tree, and thus does not grow so tall. This, however, has an advantage that the large pods have not so far to fall to the ground, and thus are not so dangerous to passers-by. The oil-beans have been collected and sold in England in small quantities.

The sapwood is of a dirty white colour and the heartwood of a dark brown, forming comparatively early in the life of a tree. The wood is very hard, but sometimes rather softgrained, rather fibrous in texture, and the pores are somewhat wide and deep. It does not plane well, splits with difficulty; holes have to be made before nails can be put into it, and it saws none too easily. It is very durable and termite-proof. Considering its hard wood and comparatively early production of seed, and the huge pods, it is by no means a slow-growing tree. It reaches a height of 9 to 12 feet in twelve years. The pod is the stoutest and largest, but not the longest, of all African timber trees. The beans are collected in boxes and sold to the factories at $6 \mathrm{~d}$. to $9 \mathrm{~d}$. each. To be made quite safe for eating they have to be boiled nearly twelve hours, the outer husk of the bean being rather hard, though not very thick. The future will alone show whether this tree will prove of greater value for timber or oil production.

Uses.-The timber has been shipped to Europe and sold as greenheart at 1s. 6d. to 1s. 9d. per cubic foot. Locally, in the Benin City district and elsewhere, it is used for making mortars for beating yams and other food. The beans are eaten by the natives in most parts, though they are not considered a delicacy. The empty pods are used where firewood is scarce, as they burn well. It is, and has been, very extensively used as a shade-tree for public roads in the Owerri district, as well as in Afikpo and Benin. Some people object to the falling pods, but it is an excellent shade-tree, especially in the dry season, as it is an evergreen tree. It is a soilprotector, and would do for underplanting or interplanting teak.

Pterogopodium. Agba, Pink Mahogany. Asokale, Asu Kole (Ikale); Asre (Yoruba) (Egbado); Agba (Benin).

The scattering of the white flowers on the path or roadway is an indication of the presence of the tree, quite apart 


\section{THE NIGERIAN TIMBER TREES}

from the wonderful bole, exceeding nearly all others in cylindrical shape.

Chief Characteristics.-It is a very large forest tree, with clear bole of 90 feet and open crown formed with two or three large, upspreading limbs, flatly oval on the top. It is quite reminiscent of an old elm in the shape of the crown. The singleseeded winged fruit is most typical, no other species of Leguminoses having a similar seed except the nearly related Pterolobium (?). The bark is comparatively thin, silvery-grey in colour, with a few more or less well-defined ridges running horizontally round the trunk here and there. These are most typical, and it is the only tree which shows them. In some places they amount to small nodules of bark.

This tree is found commonly in the Benin and Ondo provinces of Nigeria, where it is prevalent, and in the northern part of the Benin province, and seen in almost gregarious patches in the secondary forest. The slash is yellowish-white, and in the younger trees a dirty pinkish sap exudes, but later on, especially from deep cuts, the gum copal forms and gradually hardens into solid lumps of various size.

Silvicultural Peculiarities.-It loves a deep soil with plenty of moisture, which may even be flooded or partially waterlogged during the rainy season. A chalky or limy soil seems to suit it best. It is a fast-growing, light-loving tree, though it stands a little shade in its youth. The light, feathery foliage does not shade the ground, though when in falls it enriches it. The root spurns are most slight, extending only from a few inches to 1 foot above the surface of the ground; in fact, sometimes the trunk appears to come straight out of the ground, like a round log on end. Natural regeneration is none too good, but this is chiefly due to lack of light in the mixed forests. No plantations have yet been made with this tree.

It has not been exported, but it deserves a trial as a furniture-wood for drawing tables and office equipment generally. It is sawn up into planks and boards at Koko Town, and contains a gum which makes the saws stick a little. It makes a good, soft wood for table tops, of a pinkish colour and clear, close grain. The gum is sold.

Native Use.-It has been used for canoe making in the Ondo province. The gum is used for an illuminant, and was at one time used entirely for this purpose. In 1906 logs of this timber were sold in Liverpool market as a kind of mahogany of light colour.

Prosopis oblonga. Yoruba Charcoal Wood.

It is found in the Ibadan and Ogoja provinces of Nigeria, 


\section{WEST AFRICAN FORESTS AND FORESTRY}

and may yet be found in the Onitsha and northern part of the Benin provinces. On the whole, it is not common, and is seen singly. Two typical specimens of this tree stand in the Olokemeji Reserve Arboretum. It has small, pinnate leaves, very much like tamarind, but they are almost silvery-grey and hang down, instead of being green and rigid, as the tamarind. The twigs and branches are very slight, compared to the thick ones of the tamarind. The bark of the trunk is grey, too, with thin cortex, which becomes slightly fissured in old age. The trunk is straight and tall, compared to tamarind. The crown is longish and thin, with a few small branches. It is somewhat feathery in habit and is delicate in build compared to most dry-zone trees. It is one of the most typical of dry-zone trees. The seed is small, about the size of apple-pips, contained in a papery pod, from 1 inch to $1 \frac{1}{2}$ inches long. It stands the annual grass-fires comparatively well, despite the fact that the bark is none too thick.

Timber.-Hard, white wood, termite-proof and very durable. The bark is thin but rough, and small pieces can be pulled off with the fingers. It is a deciduous tree, though it does not lose its leaves for a long period. It is a light-loving tree, which does not protect the soil, though the leaves (few as they are) make a good leaf-mould. It is slow-growing, and does not reach a girth exceeding 5 feet. Natural regeneration appears to be poor, but further observations on this point may disclose more. No plantations have been made with this tree, though, with its desirable qualities, some experiments seem to be indicated. It does not sprout well from the stump, nor do any root shoots appear before or after it is cut down.

It has not been exported, and has only been used occasionally locally.

Use.-The timber has been used for sleepers in Togo, where it has proved the most durable of all timbers for that purpose. In the Yoruba country it has been used for making charcoal of the best kind for iron-smelting.

Detarium Senegalense. Hard Mahogany. Ogwega (Benin).

This is none too prevalent a tree of the Benin and Ogoja provinces, where it is found in the mixed forests. It reaches a girth of over 12 feet and a bole length of over 40 feet, but in proportion to its height, the crown usually occupies more than half of it. The crown is usually widespreading and spherical in shape. The fruit is like a mango in form, but after the surface begins to decay, the fibres, instead of being fine and all coming out from the central nut, as in the mango, spread out vein-shaped all round the nut, starting more or 
less as thick veins at the base, and then subdividing into thinner ones, spreading round the nut in an irregular manner. The decaying fruit has a most unpleasant, not to say distinguishing, smell. However, this is more than compensated for by the pleasant taste of it when served as stewed fruit.

The sapwood is whitish-yellow, and the heartwood brownred. It is hard, with somewhat fibrous grain, yet planes up with a good surface. Takes nails, but does not split well. It is durable, and supposed to be termite-proof, except for the sapwood, which the white ants often destroy. It saws moderately easily. In older trees the wood sometimes shows a little figure.

It is a somewhat slow-growing tree and a shade-bearer, with soil-protecting and soil-improving qualities. In fact, in most cases it is only found on comparatively rich soil, and in this respect appears to be more exacting than many other trees. Natural regeneration does not appear to be very good, but this may be due to the fact that animals eat the seeds. No plantations have been made of this tree.

In 1906 samples of this timber were sold in the Liverpool market as mahogany at $2 \frac{3}{4} \mathrm{~d}$. per superficial foot, 3s. per cubic foot. It was reported to be of very hard texture, a dirty brown colour, and only one log sold. Since that date, however, none has been exported. It has not been felled for local use. The fruit can be stewed, and makes a nice addition to the other African fruits.

Native Use.-The shell of the nut is used for making prayerbeads and strung on a wire.

Druosia laxiflora. Shedun (Yoruba).

Found in the Olokemeji Reserve and Ibadan province.

Paradaniellia Oliveri. Ilorin Balsam, African Balsam of Copaivi, Balsam. Iya (Yoruba); Osia (Benin); Ozia (Ishan); Ozaba (Ibo Asaba).

Found in the dry zone of the Southern Provinces of Nigeria.

A common tree, growing to a height of 40 or 50 feet.

Usé.-Balsam of Copaiba.

Xylia Evansii. Bentpod.

It is found in the Ogoja province of Nigeria in the mixed deciduous forest zone, but it is by no means a very common tree.

A medium-sized tree, with the curious bent-shaped pod typical of the Xylia, found in the Obubra and Ikom districts of Nigeria, on the left bank of the Cross River. It has a hard, red wood, which splits well. The sapwood is white, but not very wide in an average-sized tree.

It is a slow-growing, shade-bearing tree, which thoroughly 


\section{WEST AFRICAN FORESTS AND FORESTRY}

protects the soil and improves it with its leaves decaying year after year.

The natives have not used the tree, nor has it been felled for local use by Europeans. It has also not been tried for export.

\section{Pandanaces.}

Pandanus candelabrum. Screw Pine. Ebbo (Benin).

In some rivers of the Abeokuta, Ondo, Benin, Warri, Onitsha, Owerri and Calabar provinces of Nigeria it is a common watershrub or small tree. Often it is seen only a tangled mass of long prickly leaves, armed with spikes all down each side and half floating in and above the surface of the water. Sometimes, again, it is seen as a tree with two or three more or less complete whorls of branches on the uppermost part of the stem and a mass of drooping leaves from the crown. The white stem is supported by several soft, corky-looking aerial roots. It seldom exceeds 2 feet in girth and 30 feet in height. The white flower is very conspicuous, with its cone-like shape, which becomes more pronounced as the fruit begins to ripen and turns green. The scent is very pungent and overpowering. The trees form almost impenetrable thickets at the edge of the more sluggishly flowing rivers. These often impede navigation and have to be cut away.

The stem is very porous when dry, and cannot be said to yield timber, though the cork-like material might serve for a light substitute for it.

Natural regeneration appears to be very good.

The fibre has not been exported in any quantity, but it is very tough, and apparently very durable and of moderate length (average 3 feet).

Native Use.-When dried the leaves are used for making mats for wrapping goods as well as for sleeping-mats. In the Benin and Jekri country, long (2 feet) thin receptacles are made which are used for salt, which is sold in these bags in the market. The bag keeps the salt dry. It is sometimes planted near villages in damp places for the purpose of obtaining the mat material locally, where it is not found naturally in the swamps.

\section{Humeriacez.}

Aubrya Gabunensis. Brass Mahogany-bark Tree.

This is a very large forest tree of the Brass district, with a bark very similar to that of mahogany, but to which it bears no relationship. 


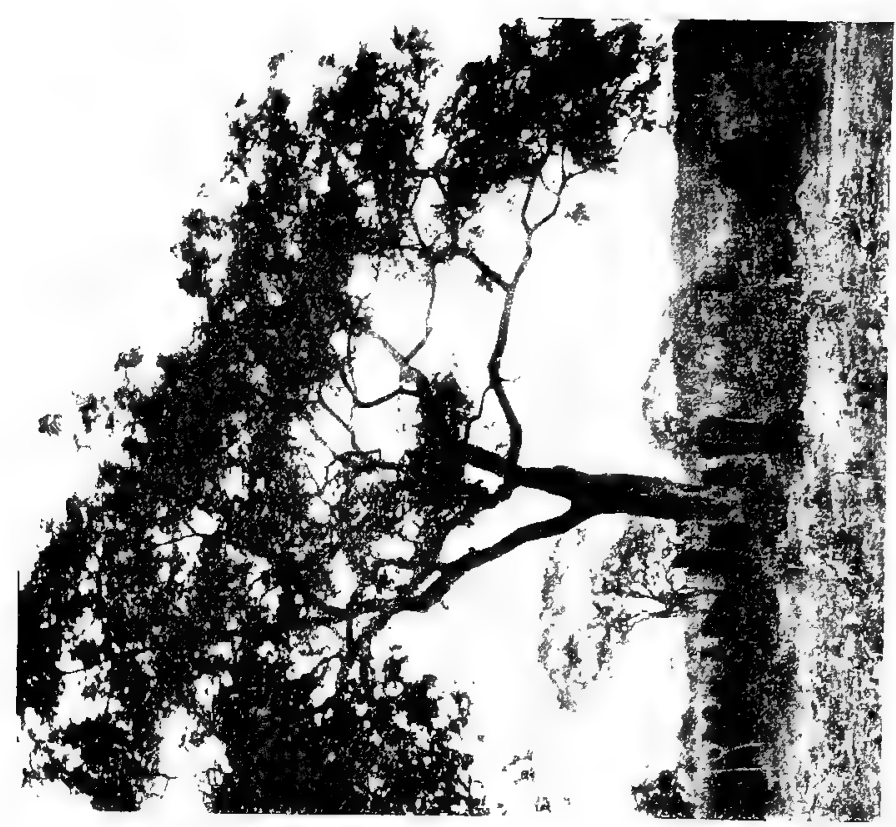

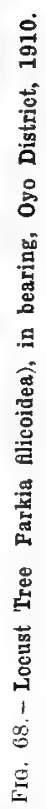

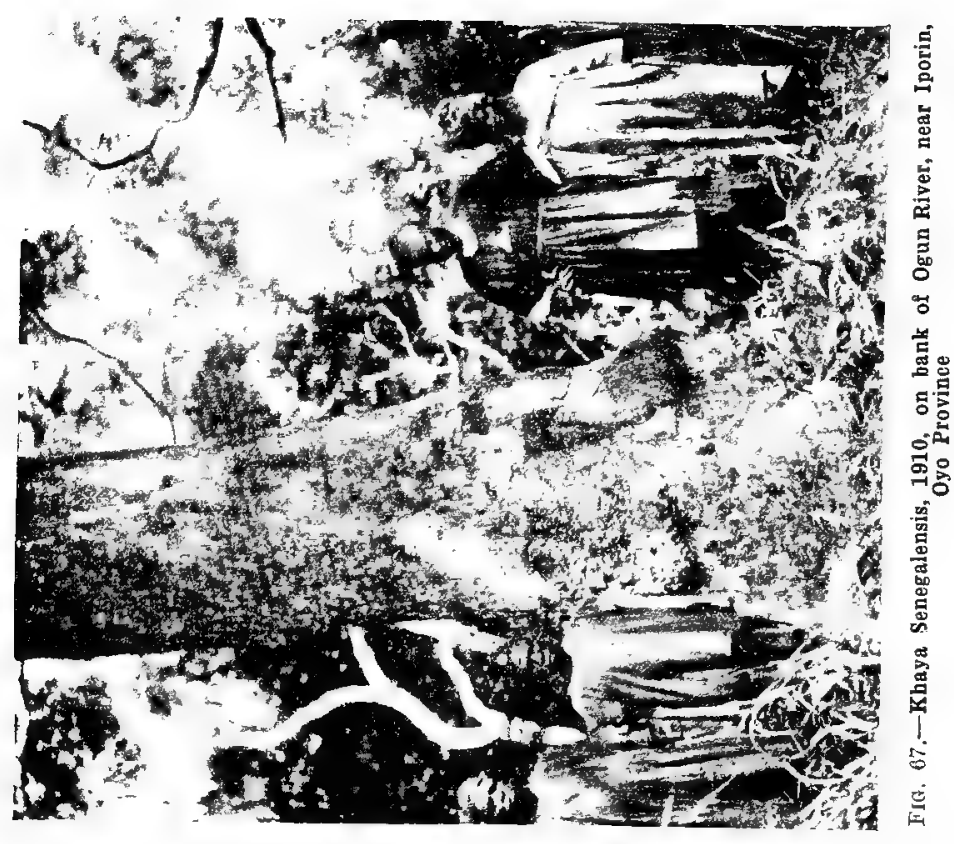



The trees are sometimes cut down by the natives and used for large dug-out canoes. The timber is termite-proof, and the natives say that canoes made from this timber are very durable, though rather heavy, and liable to become waterlogged when filled with water. It is of a dull reddish-brown colour and has rather a coarse grain.

\section{Rutaceæ.}

Zanthoxylum Senegalense. Dry-zone African Satinwood. Ata, Odan (Yoruba); Ughahan (Benin).

It is found in the Ibadan, Abeokuta, Benin, Onitsha and Ogoja provinces of Nigeria, at the edge of the mixed deciduous zone and the lower part of the dry-zone forest region. It is only a medium-sized tree, attaining a girth of about 4 feet and a height of about 50 feet. The bole always remains armed with short, woody protrusions, each having a black thorn at the apex. In the upper part of the bole and the branches there are only thorns. The pinnate leaf has usually three pairs of pinnæe and one end-leaf. All the leaves are broader and about only half as long as those of $Z$. macrophyllum. On the whole, this makes the foliage appear thicker, and, in fact, gives greater shade than $Z$. macrophyllum. In proportion the bole is shorter and the crown larger and more spread out than in the case of $Z$. macrophyllum. The bole has a greater tendency to divide lower down into three subsidiary stems, thus spoiling the length of it for timber. The bunches of small, black seeds are smaller than those of $Z$. macrophyllum, and if anything the seeds are also smaller too.

The timber is very similar to that of $Z$. macrophyllum, the sapwood and heartwood being the same colour, except that the heartwood is often of a little darker shade, and bears a greater proportion to the diameter of the tree than in the case of $Z$. macrophyllum. On the whole it is harder, and more often shows a little figure. Although it does not reach such a large size, in many ways it is superior, the grain being rather finer, and showing more sheen, and if anything it works up to a finer texture when planed. It is just as durable and termite-proof. It is a light-loving tree, but will stand a certain amount of lateral shade. Owing to the prevalence of grass-fires, it is slower-growing than Z. macrophyllum, but if anything it shades the ground better, and considering where it usually stands, it is a slight soil-improving tree. Natural regeneration is fair. No plantations have been made with this tree. Samples of this timber have not yet been exported, though, as it is a sister tree to the West 


\section{WEST AFRICAN FORESTS AND FORESTRY}

Indian Satinwood, it ought to command a similar price. It has not been felled for local use. The natives occasionally cut it for house-building timber, but it is not at all popular, owing to its being armed with spikes.

Zanthoxylum macrophyllum (Oliver). True Benin Satinwood. Atagbo (Yoruba); Ughahan, Okor (Benin).

It is found in the Abeokuta, Ondo, Benin and Calabar provinces of Nigeria, in the mixed deciduous forest zone, where it is very prevalent, especially in old farms.

Chief Characteristics.-It has a very large leaf, up to 6 feet long, with forty pairs of leaflets, each rather smaller than those of $Z$. Senegalense. There are no thorns on the branches, but many on the stem, which is thoroughly armed until old age, when most of the woody spikes drop off. It bears a large bunch of small, black, spherical-shaped seeds. It is a common tree in abandoned farms of the mixed deciduous forest zone. The thorns are more sharply pointed than $Z$. Senegalense and not so woody at first, but later form a thorn at the top of each wooden protrusion. One specimen found in the Olokemeji Reserve had very few wooden protrusions, each armed with a thorn, but there were larger leaves than $Z$. macrophyllum, though in all not quite so long. In old age the stem is almost smooth, and may reach a girth of nearly 6 feet and a length of over 30 feet. The crown is slender and broken up with three or four main branches. The base of the bole in old age is spotted with yellow lenticels.

It is a light-loving, quick-growing tree, which does not protect the ground, and only to a certain extent acts with its leaves as a soil-improving tree. Natural regeneration is very good, and on the whole, at the edge of the evergreen and mixed deciduous forest zone, with the increase of farms it is tending to spread in greater numbers than before, and in some places groups of them are found, whereas in the original forest only isolated specimens are obtained. No plantations have been made with this tree.

The sapwood is light-yellow and the heartwood of a darker yellow shade. In quickly grown trees it is not very large, but in the older trees comprises more than two-thirds of the diameter of the tree. The timber is hard, fine-grained, planing up smooth in texture. It does not take nails well, nor split well, saws, however, cleanly, and occasionally shows a little figure.

In 1906 samples of this timber were sold in the Liverpool market as Sabicu at 2s. to 2s. 6d. per foot, and reported of a very hard nature. Since then, however, none has been cut 
or exported. Locally it has not been used in any form. It should be noted, however, that this is a sister tree of the West Indian Satinwood, and considering that it grows to a larger size than that one, the timber should demand a still higher price.

Use.-In the Benin country the timber is used for making door-plates before putting dried clay on the top, and also used for doors.

Zanthoxylum sp. n. Dwarf Satinwood. Boji.

Chief Characteristics.-The fruit is a mass of red berries very similar to the Mountain Ash of Europe, but a small tree armed with a few scattered spines of short length, but not very woody, more in the nature of thorns. It attains a girth of 10 inches and a height of 15 to 20 feet.

Distribution.-It was only found on the summit of the Boji Hills from an elevation of 4,500 to 5,000 feet, where other vegetation gave out and only grass grew otherwise.

It has a very hard, yellow wood of the usual satiny nature. It made very good firewood on the mountain top.

Zanthoxylum sp. (Kew). Pterocarpus sp. African Satinwood. Urueben (Benin).

It is found in the Benin and Ondo provinces of Nigeria.

It is a common tree near the banks of rivers in the evergreen forest. It is of medium-size, reaching a girth of about 7 feet; the bole is long (40 feet); the root buttresses reach up the bole about 3 feet. The stalk has a few prickles, especially when it is small, but they disappear in old age. The leaf is smaller than $P$. osun, but much the same as Akume, Pterocarpus sp. The habit is typical of a Pterocarpus and not of Zanthoxylum. The bark is quite smooth and always unarmed. The fruit is ovoid and flat, with the seed at one end, rather different in this respect to Pterocarpus, and without the prickles on it. The slash is white, and soon red drops of latex-like fluid exude from the tree. The branches are upspreading and the crown is large, though narrow, the bole being about two-thirds of the total height.

The sapwood is white and the heartwood is yellow when young and dark-red, like $P$. osun, when old. It is hard, but splits well. Termites attack it. It is cross-grained and stands a little bending; otherwise it is brittle, when bent far.

It is slow-growing and a light-lover. It likes a good soil which is moist and has depth. It does not sprout from the stool. Seed reproduction is good, and the seedlings are found in the neighbourhood of old trees. It is a deciduous tree for three months in the year (dry season). 


\section{WEST AFRICAN FORESTS AND FORESTRY}

It has not been cut for local use or exported to Europe. It is used for making shovels for mud-puddling in the building of Benin houses; also for pegs in the walls of a chief's house.

Toddalia sp. Oie (Yoruba).

A climbing shrub common in Tropical West Africa. The fertile stamens are equal in number to the petals. Leaves digitate.

Uses.-Condiments and medicine.

Ȧgle Barteri. Calabash Orange. Shange, Bale (Yoruba).

This is a small tree growing near the villages, cultivated for its shade and for medicinal purposes. The fruit looks like an orange, but the shell is hard and it is not edible.

Clausena Amsata (Oliv.). Alapari, Obuko (Yoruba).

It is found in the Olokemeji Reserve of the Abeokuta province of Nigeria.

\section{Simarubaceæ.}

Irvingia Barteri. Dika Nut, Wild Mango. Oro, Auro (Yoruba); Ogwi (tree), Okherli (seed) (Benin).

It is found in the Abeokuta, Ondo, Benin, Warri, Onitsha, Owerri, Calabar and Ogoja provinces of Nigeria.

With its smooth, shining, small dark-green leaves it is quite distinguishable from other forest trees. The very spherical shape of the crown and the short bole are also most typical of the tree. It is often found near river banks or in damp localities. Wherever found, it is usually preserved by the natives, though not actually cultivated or tended.

The flower is inconspicuous, but the fruit is like a small mango, becoming quite yellow when ripe, though much harder and of a much sharper flavour.

The wood is hard and durable; the sapwood is yellowishwhite and the heartwood yellow. It is impervious to white ants.

The tree is a shade-bearer, especially in youth, but grows very slowly. Those planted near Leopardstown, Calabar, were only 6 to 8 feet high after ten years' growth. It is true they received little or no attention and occasionally the grass was burnt near them.

No regular plantations have been made, though one plot was planted in the Mamu Reserve in 1910. Further experiments in cultivation, and especially pruning and tending to see how early the tree will bear fruit, are worth undertaking. A method to increase the size of the fruit, and with it the size of the kernel, might be discovered and thus make it a profitable tree to grow in plantations. 


\section{THE NIGERIAN TIMBER TREES}

Reported on by the Imperial Institute in 1904, and kernels worth $\mathrm{f14}$ a ton then in London.

Native Use.-House-building. The fruit is eaten, and then the nut is cracked and the kernel beaten up and served as soup. Fruit or nuts or both are sold in the markets of Benin and Yorubaland.

Irvingia Smithii. Benin Dika Nut (?). Akwekwe (Benin).

It is found occasionally in the Benin province of Nigeria. It is a tree with similar growth to Irvingia Barteri, but reaches a larger size, up to 12 feet. The bole length is also greater, 40 feet. The fruit is larger than Irvingia Barteri, but of the same shape. It is rather uncommon in the evergreen forest. The crown is smaller and occupies only the upper third of the stem. The branches are larger, too, and of lesser number in proportion than Irvingia Barteri.

The wood is yellow in the sapwood and brown in the heartwood, and hard. It is hard to split. The heartwood is very small, being only about 1 foot out of a diameter of 4 feet. Termites do not attack the wood.

It is a shade-bearer and grows slowly. It does not sprout from the stool, but reproduction by seed is good. The duikas cat the fruit.

It has not been cut for local use nor exported to Europe.

It is used, by tying four seeds together like Ogwega, for a game. The fruit is not eaten because it is not sweet.

Irvingia sp. Pwekupweku (Benin).

It is a common tree in the Benin province of Nigeria. It is a large tree, reaching a girth of 15 feet and very tall. The fruit is yellow, and large as an African mango, but with a very much sweeter smell, and sweet taste. The branches are flattish, and so the crown is wide, with a long bole and shallow crown. It has a long, lanceolate leaf with insignificant veins. The wood is hard, with white sapwood and brown heartwood. It grows on good soil, which is moist and deep in the evergreen forests. It is a shade-bearer and grows moderately fast.

Native Use.-The fruit is used for killing rats after it has been cooked and mixed with palm oil chop. It is then given to them, and they at once fall down dead.

Simarubaceæ (Planch).

Hannoa undulata. Whitewood. Igigun (Egba); Igbo (Lagos); Orisi (Igbado, Yoruba).

It is found in the Calabar, Owerri, Benin, Warri, Ondo, Ibadan and Abeokuta provinces of Nigeria. 


\section{WEST AFRICAN FORESTS AND FORESTRY}

It is a very large tree, reaching a girth of 12 feet and a bole length of about 50 feet, which grows up very readily in old farms or clearings in the evergreen forest and lower parts of the mixed forests. It has a large, broad leaf, which is deciduous for about a month in the year. The flower, which is white in colour, is in the form of racemes (?). The bark is green, with grey streaks up and down, and the slash is white with yellow markings ; it smells sweet, too. The fruit is oblong and black, more like a plum. The spurns are very slight.

The wood is very soft and white all through. It dries without warping, but if not cut properly is liable to be attacked by small borers of the furniture kind. It planes with a smooth surface. It is very light, more so even than Musanga wood. The grain is fine, though such pores as there are, are long. It splits well and adzes well too. It shrinks considerably in drying, but this might be obviated by girdling and drying very gradually in shade when cut green.

It is a very quick-growing tree, almost as fast as Ricinodendron. It is a light-lover, and is rather intolerant of shade, except in its youth. It grows best from seed reproduction, as the power from the stool is very slight and soon dies back.

It was sampled in 1912 at Degema, but has not been exported to Europe. A trial as a wood for making pulpwood seems indicated. It is split up into flat pieces for doors and mantelpieces, also for making the walls of temporary houses, each piece being set upright to the other, with any round edge on the outside.

\section{Burseracez.}

Pachylobus edulis. Native Pear (Ohan), Incense Tree, Elemi Gum. Ibagho (Yoruba); Onumu (Benin); Eben (Efik).

It is found in all the Southern Provinces of Nigeria, chiefly as a planted tree in the neighbourhood of villages, and on the sides of the roads leading to them, being more prevalent in the Benin and Oban than the other districts. It is a mediumsized tree, reaching a girth of about 7 feet and a height of about 70 feet.

The gum, which exudes when the tree is cut with a matchet, smells very much like incense when burnt, and is of a white colour. It is always planted in the villages, partly for shade, chiefly for food, especially in the Oban country.

The fruit is first of all a grey, and then a purple colour, and a very cylindrical plum shape, in all about $2 \frac{1}{2}$ inches long and rather more than 1 inch in diameter. It is very much like turpentine to taste, especially when not quite ripe, and in 
the centre of the fruit there is an oblong nut rather more than 1 inch in length, more or less round, with four ribbed edges, all culminating at the apex. The leaves are large, consisting of four to six pairs of pinnæ, which are shiny and dark-green on the upper surface, and almost silver-grey underneath. The trunk is often very much cut about and chipped, and little pieces of the white gum are often seen in the old scars. It usually bears fruit heavily every year.

The sapwood is white and the heartwood is of a faint pink colour. It is not very hard, but more like mahogany in texture and character. Owing to its irregular growth and branching habit, it is often rather knotty and cross-grained.

It is a shade-bearing, somewhat slow-growing tree, which only partially protects the soil, but on the whole improves it with its fall of leaves. Natural regeneration appears to be rare, chiefly perhaps owing to the fact that the natives pick the fruit even before it is quite ripe, and take it away to eat in their houses. It is usually planted by the natives as a transplanted seedling, about 3 feet high. Considering the poor flavour of the fruit, it is rather surprising that it is so widely planted and comparatively speaking so much tended by the natives in certain districts. It is moderately fire-resisting and dew-collecting, especially in the dry seasons, the ground in the vicinity of the trees often being quite damp with the condensed dew falling off the leaves.

It has not been felled for export or for local use. The tree, however, provides grateful shade in the more open parts of the country, in the neighbourhood of villages.

The gum has not been collected for export, but is considered of value. However, no tapping experiments have been tried.

Native Use.-The fruit is called a pear, and is liked by most natives, who eat it raw. It is sometimes sold in the markets at five for one penny.

Canarium Schweinfurthii. Pink Mahogany, Bastard Mahogany. Sometimes sold as Gaboon Mahogany or African Elemi. Anikantuhu, Ako, Ibagbo (Yoruba); Onumukyukyu (Benin); also known as Ikwapbo. (The Benin name means Kyukyu or bird, Onumu or Incense-tree.)

Chief Characteristics.-Evenly striated bark of orange to light-yellow colour, turning grey on exposure to full rays of the sun. The seed is small and similar to that of Pachylobus edulis, but much smaller.

Distribution.-A few in the Western, more in the Central west and south of Benin, and most common in the Eastern 


\section{WEST AFRICAN FORESTS AND FORESTRY}

Circle, especially north of Calabar, in the mixed deciduous forest zone, and to lesser extent in the evergreen forest zone.

It is a large forest tree, with a girth of over 12 feet and a bole length of about 90 feet. Being more or less preserved by the natives when found in the forests, in clearing for their farms, it is often now seen on the roadsides. The slash is white, and as the roots beside the road are often cut by the natives, the yellowish-white gum exudes, forming a small white layer on the surface of the root. This has a most pleasant smell, and is not unpleasant to taste. It is closely allied to, if not much the same character as, the "Balsam of Tolu." The leaf is comparatively small, with three or four pairs of pinnæ, and growing more or less in tufts, this being reminiscent of the Mahogany family. The root spurns are very slight, and in this respect it is more like the European Ash, and usually there are one or two main roots which spread out, down the slightly enlarged bole at the base. Otherwise the tree is one of the most cylindrical in shape, falling away with the increasing height less than almost any other. It is a deciduous tree. The pores are very fine and rather longer than in the ordinary mahogany, and the wood is not so sheeny.

The sapwood is white, and in fast-grown trees often 6 inches through. The heartwood is of a delicately pink mahogany colour, darkening to a light-brown mahogany on exposure to the air and sunlight. It is not very hard, and splits fairly well. It planes up with a smooth surface. It saws well and also takes nails fairly well. It has very considerable elasticity. It is lighter than most kinds of mahogany. The logs will float as soon as at all dry.

In youth it stands a good deal of shade, but later on it is on the whole a light-demanding tree. It is a fairly quickgrowing tree, but tends to become very slow when left alone in the open. It needs a rich soil, but is also found on poorer land. It needs more moisture than many others. Although not a soil-protecting tree, the leaves yield a fair amount of humus in their annual fall. Natural regeneration is fair, but it is rather susceptible to fire, and much of it is thus killed. No plantations have been made of this tree.

In 1906 a sample was sold in the Liverpool market as Gaboon Mahogany at 18. 6d. per cubic foot full measure, and in 1907 sample logs of this tree were exported to the Liverpool market, where they were sold as light Benin Mahogany at $2 \mathrm{~d}$. per superficial foot. Since then none has been felled.

The natives occasionally cut the tree for planks, and use 
the wood for making canoes, chiefly owing to its lightness and elasticity.

Canarium sp. Rough-barked Canarium. Ekugbi, Ekugbo (Yoruba): Onumukyukyu (Benin).

Chief Characteristics.-A large tree, with larger fissures than $C$. Schweinfurthii, about 6 inches apart; the bark is inclined to scale off in between. The leaves are a little larger, but the gum is very similar and used for similar purposes.

Distribution.-It was found in the Olokemeji Forest Reserve.

It is deciduous for about three weeks in the year, chiefly November, but otherwise it is a soil-protecting and soil-improving tree.

The tree has not been felled for export or for local use. Nor do the natives appear to have used it for any purpose. Canarium Mansfeldii. Gaboon Mahogany.

This species is found on the banks of the Upper Cross River.

Canarium sp. Oyife (Yoruba).

Found in the Yoruba country.

Canarium sp., syn. Schweinfurthii. Incense Tree. Anikantuku (Yoruba); Onumukyukyu (Benin).

Found in the Ilaro district and Benin.

\section{Meliaceæ.}

- Carapa procera. Scented Mahogany Cedar, Crab Wood, Touloucouna Oil. Efu Iya, Abo-oganwo (Yoruba); Ibbegogo (Benin).

It is a common tree, found in the Calabar, Ogoja, Owerri, Warri, Benin, Ondo and Abeokuta provinces of Nigeria.

It is a small tree, growing to a girth of about 6 feet. The pinnæ and the whole leaf are both much larger than the mahogany leaf, even including that of grandifolia. It often grows with a divided bole, two small stems shooting upwards from about 3 feet from the ground. The leaves grow in very distinct tufts on the edge of the branches. The bark is smooth and a light-green colour, with a few vertical uprights when the tree is old. The fruit is a large, roughly round, woody drupe. The covering shell dehisces into eight parts, releasing about twenty hard, brown, round-cornered, almost square nuts. The seeds are eaten by porcupines. It is found in the freshwater swamps in the evergreen forest and in damp places of the mixed deciduous forest. The timber is pink when freshly cut, and the heartwood has the red-brown typical of the Mahogany family. The small size of the timber rather militates against its reaching the high value of mahogany.

The tree is a shade-bearer in its younger stages of growth, and even when older it still stands a considerable amount of 


\section{WEST AFRICAN FORESTS AND FORESTRY}

shade. Self-sown seedlings are not often seen. Perhaps this is due to so many of the seeds being eaten by animals. The stump scarcely sprouts after it has been freshly cut. Considering the size of the tree, a very fair number of nuts ripen each year.

No use has been made of the seeds, though they yield a similar oil to that of the Crab Oil Tree of South America.

In 1906 a sample of the timber was sold in the Liverpool

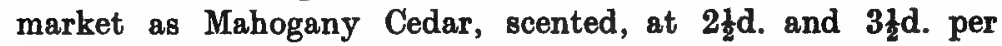
superficial foot.

Native Use.-The bark is used by pregnant Yoruba women and for sores and as a cough mixture. It is used underneath palm leaves as a roofing material in the Benin country.

Khaya grandifolia, later grandis (Stapf.). Big-leaf Mahogany, Benin Mahogany. Akor, Oganwo (Yoruba); Gadeau, Ogwangu (Benin); Odala (Ibo Asaba); Digiten (Brass); Dirinshi, Diki (Ibo Owerri); Asamogo (Ibibio); Upono (Efik); Obon (?) (Oban, Ekoi).

It is found in the Ondo, Benin and Ogoja provinces of Nigeria, at the edge of the mixed deciduous forest zone, where it is very prevalent in some places, such as at the edge of the Ifon Owo-Akure Road.

Chief Characteristics.-It is a large tree of the mixed forests. It attains a girth of 14 feet and a corresponding height. It is, however, taller in proportion than $K$. Punchii. It has long, upward-tending root flanges, though not so large as those of $K$. Ivoriensis or the Coast Mahogany. The crown is open compared to the other Khayas, except $K$. Senegalensis. It has conspicuously large pinnate leaves, with three or four pairs of leaflets quite 10 inches in length, each leaflet being 4 inches long. The stem is smoother than $K$. Punchii, and in that respect more like $K$. anthoteka. The leaves of this species are the most shiny of all ; in fact, the others appear dull beside them. The bole, on the whole, is cleaner than $K$. Punchii and longer, though it forks or divides into a head in the characteristic Mahogany way. The shininess of the leaves is one of the greatest characteristics of this tree. The capsule is somewhat larger than $K$. Punchii. It is also a little thicker, and the tip is not so long or sharp. It opens out into five segments, as a rule, but sometimes there may be only four. The seeds themselves are a little oblong in shape and not quite so square as in $K$. Punchii, although they are just as thin and flat.

The timber is the typical Benin Mahogany, with somewhat long pores, first of all rather pink, then a rich mahogany-brown colour. Occasionally the sapwood is very wide in proportion 

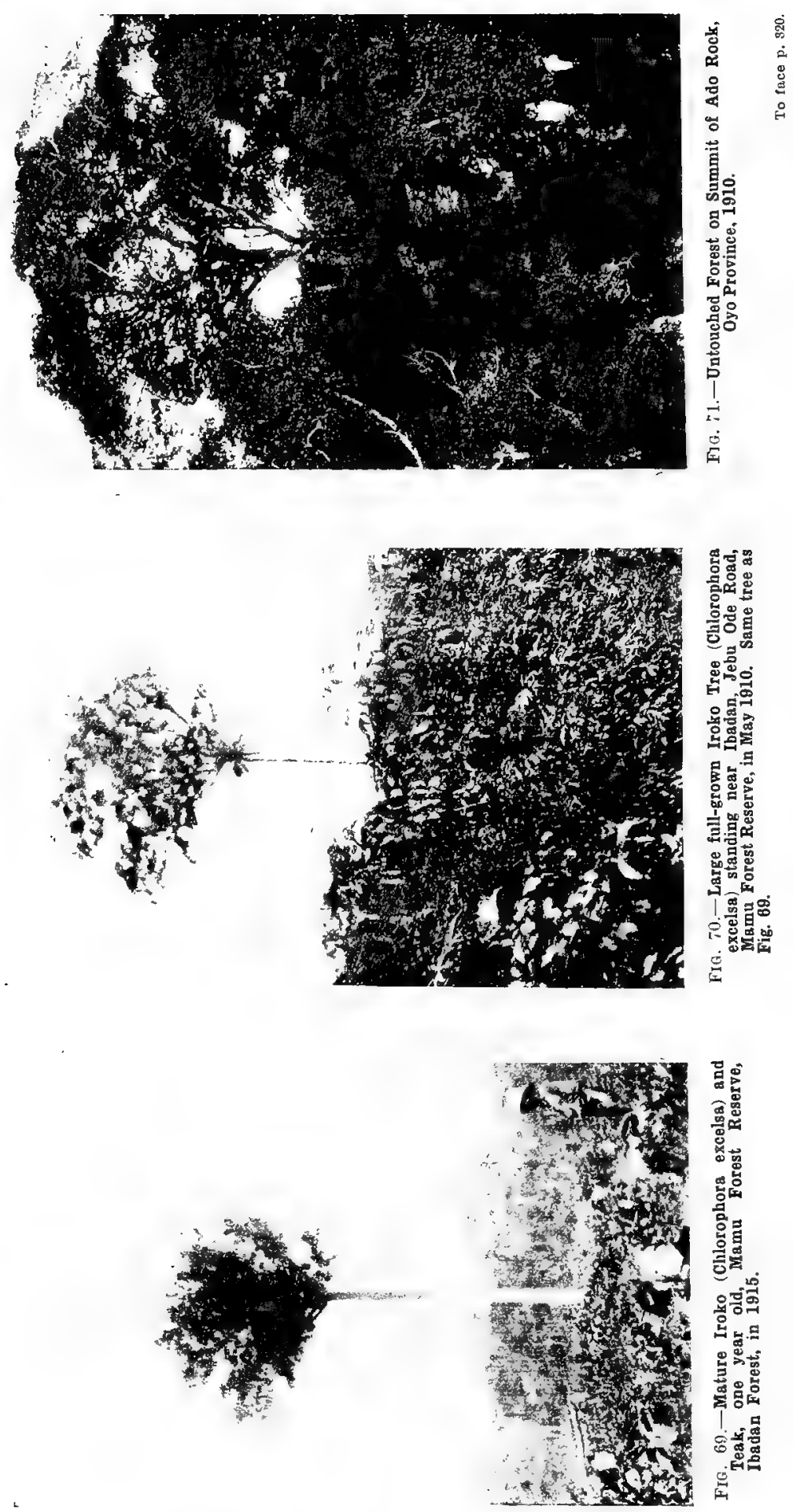

to the size of the tree, but this is more in the case of very quickly grown trees. It sometimes shows very rich figure of a "roey" nature as well as "fiddleback," more especially in the root buttresses. Here, owing to the storms to which the tree is exposed, the fibres of these buttresses become fractured and compressed, thus giving a broken and mottled appearance to the grain after it has been cut up lengthways. In this species the wood of the "curls" often shows a rather bolder roe than in the case of those obtained from $K$. Punchii or Ivoriensis.

On the whole this is the most quickly growing of all the Khayas. In its youth it stands a certain amount of shade, and, in fact, always, but it would appear to demand a good deal of light for its full and quick development. It is a thoroughly soil-protecting and soil-improving tree. The leaves make a rich humus. Natural regeneration is good, and, in fact, appears to be much better than in the case of the other Khayas. It sprouts from the stump a little. It appears to be somewhat exacting as to soil, preferring somewhat deep, rich.and moist sites. In plantations it has already found a place. It has also been planted, mixed with other species of Khaya, in the small nurseries, plantations and lines of trees made by the timber-lease holders. It does not seem to be attacked so severely by the leading-shoot borer as in the case of $K$. Punchii. Owing to the fact that the seeds usually fall on more open ground, it is not eaten so quickly by the little boring insects.

The timber is being constantly exported and mixed up with the other species of Khaya. Being lighter, it floats higher on the water than the other species, more especially Entandrophragma. It has occasionally been used by the natives for making canoes, as also for sawing up into planks.

Khaya Punchii. Uhi Mahogany, Benin Mahogany. Oganwo (Yoruba); Ogwangu (Benin); Eggi (Ibo Asaba).

This tree does not attain such a large size as either $K$. grandis or $K$. Ivoriensis, but it often exceeds a girth of 12 feet and a bole length of 70 feet. The bottom log of a tree is often found to show figured wood. This is perhaps owing to the bark being constantly removed, and to the succeeding occlusion of the wounds following at different times, according to when the bark is removed.

Chief Characteristics.-It has a comparatively small leaf, with five or six pairs of leaflets. It has slight root spurns, or protuberances, or even in some cases none at all. It is generally particularly rough at the base, owing to the bark having been continually removed by the local people. Higher 
up, the stem is covered with brown-coloured bark, which is slightly pitted. The leaves are in tufts, though to a lesser extent than either $K$. grandis or Ivoriensis. The large masses of small white flowers remind one of lilac. It is of the same white colour. It flowers in February, when it is also in new leaf. Compared with $\boldsymbol{K}$. grandis it usually has a shorter and somewhat more curved bole.

Distribution.-It is found in the Abeokuta, Ibadan and Benin provinces of Nigeria.

The capsule is of medium size, splitting open into five segments which remain attached at the base. On the whole it is rather thinner than $K$. grandis or Ivoriensis, but does not come to such a sharp point as either of those two.

The timber is very similar in grain and texture to the other Khayas, but if anything it is a little heavier and a little closer texture then either grandis or Ivoriensis, especially in those districts where it grows in the mixed deciduous forests, and where the base of the trunk is burnt with an occasional grass-fire.

Although not quite so fast-growing as the other Khayas, it is a fast-growing tree with soil-protecting and soil-improving qualities. Natural regeneration is fair, though the little thin, flat seeds are very soon attacked by a little boring insect when they fall to the ground. However, when rapidly gathered after having fallen, they retain their germinative capacity for a greater length of time than in the case of the Entandrophragmas. On the whole, if the locality is not too dry or fires too prevalent, this tree tends to widen its area of distribution with the spread of farms. The leading-shoot borer attacks this tree in its younger stages perhaps even more than the other Khayas, more especially when it is planted pure. In this connection it should be noted that this Khaya, as well as the others, is not gregarious in habit, being always found singly, though varying much in number per square mile. This factor rather indicates that pure plantations should not be made, or at any rate that it should only be planted in small groups mixed with other species, also in small groups, from a quarter to one acre in extent. In leased timber areas it has been planted mixed with other species. On the whole, it has not been exported so much as the other Khayas. It has been sold as Niger Mahogany.

Value.-3d. to 6d. per superficial foot from Sapoba, in the Benin province. The natives occasionally cut it for sawing into planks.

Khaya anthotheca?. White-barked Mahogany or White Mahogany, 
King of the Timber. Funfun (Yoruba); Ogwangu Nufwa, Ogigedu (Benin).

Many specimens of this tree are found in the mixed forests on the banks of the Ovia River in the Ifon district of the Benin province, and also isolated trees near the banks of the Owena River in the Ondo province.

The chief characteristic of this tree is the speckled white bark, which gives the stem generally a light, almost white or grey colour. The white patches in the bark occur irregularly scattered all round the bole, being chiefly confined to the lower half of it. In young trees the four very strong lateral roots show up prominently above the ground, leading away from the tree more or less at right angles and remaining above the surface of the ground for two or three feet. This feature to some extent persists even in old age, but then it is not so pronounced, as these roots tend to form more or less stout buttresses similar to the others, but coming out more abruptly and forming a more shelf-like protuberance from the stem.

The timber is supposed to be lighter, and of a lighter colour than that of the other Khayas. However, it appears to be only rather more of a pinkish-brown when freshly cut, taking on the typical mahogany-brown once it is exposed to the air. So far, it has always been sold mixed up with the other species cut in the same area, and realizes similar prices. It may perhaps have even helped towards the scoring of the higher average price of 6d. per superficial foot which was obtained from one area where this species is found.

Khaya n. sp. Mahogany. Ogwangu (Benin).

This was found in the Benin province of Nigeria. In the wood, it shows a considerable difference to the other Khayas, being a much lighter red-brown colour and of more open texture.

Khaya Ivoriensis. Coast Mahogany. Obi, Oganwo, Akpakor (Yoruba).

This species is supposed to be that from which most of the coastal mahogany is obtained, more especially in the more low-lying regions. The wood is of a richer and darker colour and somewhat heavier than that of the other species. The most typical feature, though, is the very sheeny nature of the wood and the very considerable size of the medullary rays, which, however, are not conspicuous, as in the wood from Nigeria.

Khaya Senegalensis. Dry-zone Mahogany. Oganwo (Yoruba); Ogwangu (Benin).

Chief Characteristics.-The tree has an open crown with a few upspreading branches, and apparently much less foliage 
than its " confrères." The leaves are small, very grey, specially on the under-surface, giving them almost the character of Eucalyptus leaves. The bole is shorter than the other Khayas, with a slightly scaly bark and only a small thickening of the base and no root buttresses at all. The bark is darker than Khaya Punchii, though the scales are often grey. The capsule is almost frequently four-sectioned, though this is not an absolute rule, as other Khayas have been found bearing capsules dividing into three, four and five sections. It does not exude gum so readily as Khaya Punchii, and the gum is of a redder colour. Illustration No. 67 shows the lower part of the bole of a tree 10 feet in girth.

Distribution.-It grows on the banks of the Ogun River above the Ireyin-Oyo Road, Ibadan province, Akure, Benin and Ogoja provinces of Nigeria. It is found as one of the most prevalent trees near Obudu and in the Onitsha province north of Ogrugu.

Timber.-It is of redder brown colour than either Khaya Punchii or grandis, and has a greater sheen. The texture of wood is a little closer, and, owing to the annual grass-fires burning the stem, is slightly figured. Logs could not be cut much more than 20 feet in length, owing to the bole not always being straight, though the large branches would make small ones and curls.

Silvicultural Qualities.-It stands a great deal of drought, though in its drier area of distribution it is usually to be found near river banks. The seed keeps a high percentage of germination for some months after being picked. It demands more light than either of the other Khayas, and grows freely from the beginning. It has also a greater tendency to branch than the other Khayas, but this may be due to its being attacked more by the leading-shoot borer than the other species, as more of these insects are found in the open than in the mixed forests. It is almost gregarious, as groups of trees are usually found together.

Khaya sp. Orro (Yoruba); Geduloha (Benin).

This tree is found in the Ilaro district of the Abeokuta province. There appears to be some doubt as to whether this is really a distinct species, but the fact remains that the wood is very much darker and of rather a duller colour than most of the other Khayas. It shows also a very rich, wide roe, and in this respect the wood is more valuable than that of many other species. It is somewhat similar to the best counter-top wood obtained from the Entandrophragmas. It does not appear to be a very common tree, but it attains a girth 


\section{THE NIGERIAN TIMBER TREES}

of over 12 feet, and the bole is straighter and considerably taller than most of the Khayas.

Pseudocedrela Kotschyii. Dry-zone Cedar. Hard Cedar Mahogany. Emi gbegeri (Yoruba, Ibadan).

It is found in groups and isolated specimens in the Ibadan province of Nigeria, in the dry-zone forest and at the edge of the mixed deciduous areas, more especially in the Olokemeji Forest. With its somewhat regularly fissured bark, showing a criss-cross pattern, it is distinguishable from the other dry-zone trees. The silvery pinnate leaves in tufts and the charred base of the stem, combined with the grey trunk, all help to identify it. The little mahogany-like capsule, covered with silvery hairs when unripe, is another feature. When these burst open, leaving the empty capsule on the tree for a time, there is no doubt about its being of the Mahogany family. In the distance the grey, almost silvery-coloured bark makes it stand out as compared to others such as Dwarf Ironwood or the Shea Butter Tree. Reaching a girth of about 6 feet and $a$ bole length of 25 feet, it is one of the largest dry-zone trees.

The sapwood is pinkish-red, when fresh, and the heartwood a rich red-brown, darkening slightly on exposure to the light. It is harder than mahogany and heavier. The grain is closer and on the whole finer, but with a similar sheen. It often shows a little figure. It saws well, planes smoothly, takes nails, and has a good appearance in the plank. It is said to be termiteproof. It is considerably stronger than mahogany.

Somewhat slow-growing, even from naturally growing root suckers, it is a light-loving tree, giving scarcely enough shade to protect the soil. In, its youth it is a soil-improving tree. Natural regeneration is poor, root suckers being the strongest form of reproduction. It sprouts slightly from the stump, but not sufficiently for reproduction of a crop. A fair crop of seeds is found each year, but usually, owing to grassfires, much of this is destroyed. Plantations are being made, but natural growth has been encouraged in places, and gives further promise of better growth.

It has not been exported, but it is occasionally felled for local use. It is one of the most valuable trees of the dry zone.

Entandrophragma utilis. Short-capsuled Mahogany, Sapeli or Heavy Mahogany. Ijebbo, Jebu, Ashuwole, Papala (Yoruba); Ogipogo, Ubilesan Onamakyuku, Plekkogo (Benin); Eplekgo (Jekri); Edem (Efik); Atori (Oban, Ekoi).

This tree is found in the evergreen and mixed forests of 
the Ondo, Benin, Calabar and Ogoja provinces of Nigeria. It is one of the most common mahoganies of the forest, and reaches the largest girth of any of the African trees. The biggest of all showed a girth of 56 feet, measured above the top of the buttresses, and one which showed 437 rings of growth had a girth of 52 feet, measured at 20 feet above the ground. This one, too, yielded 15 logs of various sizes.

The leaves are rather smaller and show the ribs rather more prominently than in $E$. cylindrica, but the growth, which is in tufts, is similar. It is deciduous for about three weeks in the year, in November, when inconspicuous flowers first appear and then the leaves. The capsule is about 3 inches long and nearly 1 inch in diameter. It is of the usual pentagonal shape, and there are five seeds, placed one over the other on each side of the central pentagonal core. The seeds are nearly square in shape, with a rounded back about an eighth of an inch thick. The wings are four times the length of the seed, making each about $2 \frac{1}{2}$ inches long. The seeds lose their germinative power in about three weeks, and are always attacked by a small boring insect.

The bole has comparatively slight root spurns, which terminate at about a maximum height of 20 feet from the ground. It is very straight, and may attain a height of 90 feet. The stem is, however, much more pitted than that of $\boldsymbol{E}$. cylindrica. The bark is of a green to grey colour, very reminiscent at times of a beech-tree, especially at a distance. The crown is flatly spherical, being composed of a few very large limbs. The slash is white and brown; the sapwood is white and the heartwood of a red-brown colour, with a very strong cedarwood scent when freshly cut. Even when the wood is seasoned and freshly planed, this scent is very noticeable. It saws and splits easily, planes up moderately, and takes nails fairly easily. It is not termite-proof, but the most common attack is by a lymexylon, if the logs are left lying unsquared in the forests. Many figured logs have been obtained from this species of tree. In the younger stages, the sapwood is comparatively wide. Natural regeneration is very good in some places. The tree grows very rapidly indeed. In its youth it stands a certain amount of shade, but later on it is a lightloving tree. It is a soil-protecting and soil-improving tree. Isolated trees have been planted and small plantations made in various parts of the country. Planted under proper conditions and with favourable seasons, an average growth of 6 feet in beight may be expected. The young trees are occa- 
sionally attacked by the leading-shoot borer, but this is not very serious, particularly if a suitable mixture with other trees has been formed.

This timber has been one of the main export products of the Sapeli and South Benin forests. The chief market for this wood was, previous to the war, in Hamburg. However, from Hamburg, the markets of Copenhagen, Sweden, Finland, Russia and Austria were also supplied. Being almost half as heavy again as Khaya Mahogany, it costs more in proportion to bring over to Europe. Owing to the better and larger size of the logs which can be obtained from these huge trees, there was in these markets a greater demand for this timber for counter-tops than for Khaya timber. This to some extent counterbalanced the disadvantage of the extra weight. This timber was also considered of a duller colour and more liable to split than the Khaya wood. However, as many of the trees from which the largest logs have been obtained are mature, and over-mature, it is natural that the wood cannot be in a prime condition.

The timber is very popular amongst the local people for the making of canoes and for house-building.

Entandrophragma cylindrica. Heavy Mahogany or Cedar Mahogany. Jebu, Oro, Issisi, Alepo, Alopa (Yoruba); Ikwabobo, Agiekpogo (Benin); Atore (Efik).

It is found in the Abeokuta, Oyo, Ondo, Benin, Calabar and Ogoja provinces of Nigeria. It is one of the common mahogany-trees of the evergreen and mixed deciduous forest zone. It is the tallest of all African trees, the bole alone often attaining a height exceeding 100 feet. It is also one of the straightest and most cylindrical trees in Africa. The root spurns are very slight compared to the size of the tree, and do not extend usually more than 10 feet up the stem. The bark is smooth and not unlike the beech; in old age, however, it becomes slightly pitted and the bark scales off in places. The crown is deeper and more spherical than in the case of Entandrophragma utilis. The ends of the branches are most conspicuous, with their most pronounced tufts of leaves. The leaf is often about 4 inches long, but in young shoots may attain a length of nearly 3 feet, with over thirty pairs of pinnæ. The slash is white, with small, yellow, stone-like granules in it. The bark is thick.

The capsule is nearly 6 inches long and an inch in diameter. It is similar in shape to that of Entandrophragma utilis, and opens in a similar way. The seeds are rather larger and the wings considerably longer. It is deciduous for about a week 
in November, when the flowers, which are of a light-greenish colour, appear, and then the leaves.

The sapwood is white and comparatively wide, except in very old trees. The wood, when freshly cut, smells slightly like a red herring, and in colour is not unlike the flesh of kippered herring.

The heartwood is of a red-brown colour, rather dulling on exposure to the air and becoming a dark-brown colour. The pores are very long, much more so than either in the $E$. utilis or the Khaya genus. The timber splits well, saws easily, and takes nails moderately well. It is not always easy to plane it down to a smooth surface. It has a distinct tendency to warp unless properly seasoned. It is not termite-proof, but the attacks of the white ants are slow. The sapwood is more commonly attacked by a lymexylon. For interior work it is very durable ; sometimes it has a very pretty, dull-brown wavy sheen.

Natural regeneration is good in many places. Isolated trees have been planted and small plantations made in different parts of the country. The growth on the whole is even more rapid than in the case of $E$. utilis. In favourable localities it will exceed an annual height growth of 7 feet. Although it will stand a considerable amount of shade in its youth, it is more of a light-loving tree in old age. It is a soil-protecting and soil-improving tree.

This is one of the chief mahoganies exported from the Benin and Sapeli forests, but it does not attain such an average high price as that of the Khaya genus. However, from all accounts it appears that the majority of figured logs have been obtained from this species; this compensates to some extent the disadvantage of this being the heaviest wood of all the mahoganies. It often floats just level with the water, and has sometimes been known to sink. In pre-war days it used to fetch 4d. per superficial foot, and the best market for it was in Hamburg; but, as also in the case of $E$. utilis, the wood was supplied to the markets in Austria, Russia, etc. It is common to make three logs each 30 feet long from the bole. Both this tree and $E$. utilis yield some of the best curls which are obtained from the mahogany.

The local people used to be very fond of using this tree for making canoes, and I have seen a canoe over 80 feet long and having a draught of over 6 feet. It has also been largely used in house-building.

Lovoa Klaineana. African Walnut. Abuwe (Yoruba); Ikwahobo, or usually known amongst the timber men and forest officers as Anamomilla in Benin, Apobo (Jekri, Ijor). 
It is one of the most prevalent trees on the banks of the Ogba stream in the Benin province, and it is also found in the Ondo, Abeokuta, Owerri and Calabar provinces of Nigeria.

This tree grows to a large size, reaching a girth of over 12 feet and a bole length of over 60 feet. The root spurns are slight compared to Mahogany, extending only from 4 to 6 feet up the stem.

Chief Characteristics.-The small, almost quadrangular-shaped capsule, which splits open with four sides and centre square in section with only eight seeds, two placed on each face, is about the size of a little finger. At its base the bole is not entizely circular in shape, but tends to form four distinct narrow small buttresses, giving it almost a quadrangular shape. The bark is a dark brown colour, which gets rougher with old age and scules off to a small extent. Compared to the size of the tree it in not very thick. In the younger trees it is quite smooth and more of a yellow-brown colour. The leaves are pinnate, with three or four pairs of pinnæ. The four-sided capsule is a most typical feature of this tree, and distinguishes it from Entandrophragma. The leaves are of a dark colour.

The sapwood is white and the heartwood is a good walnutbrown, sometimes with very striking dark-brown or black streaks in it. The sapwood is comparatively narrow and the heartwood forms comparatively early in the life of the tree. The wood is only moderately hard; it planes well, and takes nails; it saws easily, and splits moderately well. It is, however, attacked by termites, but not when used for interior work. It shrinks but little and does not warp very much. The grain is rather finer than that of the ordinary mahogany, but the pores are often much longer. It has a pleasant lustre, but tends to darken a little with age, especially when not exposed to the brightest light. The tree is a moderately fast-growing, shadebearing species, vith soil-protecting and soil-improving qualities. Natural regenention appears to be moderate. It sprouts slightly from the stump. Seed years are none too frequent. The seeds themselves are soon eaten by boring insects when they lie on the ground; even when picked up they soon lose their germinative sapacity, and should be planted within a month of being gathered as they are so liable to get dry. The tree is a little exacting in regard to soil, apparently demanding plenty of moistue, depth and a good deal of humus. No plantations have leen made with this tree, but a great number of isolated trees have been planted by timber-lease holders in their areas.

In 1906 samples of this timber were sold in the Liverpool 
market as African Walnut at 1d. per superficial foot. Since then, however, the qualities of this timber have become better known, and it now finds a ready sale at rates varying from $2 \mathrm{~d}$. to $5 \mathrm{~d}$. per superficial foot. Although it is a mahogany by family, it is usual to sell it as African Walnut, as the colour and texture of the wood are very similar to walnut.

Native $U_{8 e .-I n}$ the Benin province it has been used for canoe-making.

Guarea Thompsonii. Cedar Mahogany, Cedar or Close-grained Mahogany. Sidu (Yoruba); Obobonikwi (Benin); Akpaku (Ibo Asaba).

It is a large forest tree of the evergreen forest zone, attaining a girth of 12 feet, which is most commonly found in the Benin district of Nigeria.

Chief Characteristics. - The trunk is dark.brown with smoothish bark, which has a tendency to scale off a little. The pinnate leaves are shiny and form very distinctive tufts at the ends of the branches, though not quite so much as in Entandrophragma.

The fruit, which is quite soft, is a dehisent capsule, of a dark brown colour; when ripe, three blakk seeds covered with red pulp are released. The seeds are ellipsoid in shape and smaller than those of $G . s p$., Obobonu'wa. The seed is nearly half an inch long and covered with white streaks following round its narrowest circumference. The crown is very thick and dense compared with $G$. sp., Obobonufva. The bole length is shorter, and the shape of it is not so regular nor so round

as that of $G$. sp., Obobonufwa. The crown is flatly spherical in shape, reaching fully a third of the total height of the tree. The flowers are yellow and borne in long spikes about 1 foot in length.

The sapwood is white and the heart of a mahogany-brown colour, with a slightish red tinge when freshly cut, which rapidly goes a light brown colour, though not such a light brown as in the case of $G$. sp., Obobonifwa. It has a strong cedar scent when freshly cut, and ever the old wood retains this scent when planed up afresh. The grain is fine, though a little fibrous. The pores are long and spen. It has, however, a nice sheen, giving a better appearance than that of $G$. $s p$., Obobonufwa. It planes easily, but does not split very well. It takes nails fairly easily and saws wihout difficulty. It is not termite-proof. It has considerable tensile strength and elasticity. In proportion the heartwood is very large and forms comparatively early in the life of thi tree. It has a closer grain than any of the mahogany of the Benin district. 


\section{THE NIGERIAN TIMBER TREES}

The tree is a fast-growing one, at first shade-bearing, and later a more light-demanding species, with soil-improving and soil-protecting qualities. Natural regeneration appears to be fair, though the seeds are eaten by insects, and they do not appear to keep their generative capacity for a great length of time. It appears to be rather exacting as to soil, liking one with a fair degree of moisture, mineral content and of considerable depth. No plantations have yet been made of this tree, but isolated specimens have been planted by the timberlease holders. It bears good crops of seed every few years.

Owing to the comparative shortage of mahogany trees on some areas, this tree is now felled as a timber for export, and is sold as Scented Mahogany at 3d. to 6d. per superficial foot. Locally it has been cut for planks.

Guarea sp. Cedar Mahogany, Scented Mahogany. Sida, Sendar, Odogbo, Akokogbo (Yoruba); Obobonufwa (Benin); Akpaku (Ibo Asaba).

It is a large forest tree of the evergreen zone, attaining a girth of over 12 feet, which is most commonly met with in the Benin district of Nigeria.

Chief Characteristics.-The bole is covered with smooth grey bark, which peels off very gradually in large pieces more like a plane; it is sometimes relieved by patches of yellow or red lichens. It has tufts of pinnate leaves at the end of the branches.

The fruit is a greyish-brown coloured, dehiscent capsule, which contains three large seeds covered with orange-coloured flesh. The seed is black, and wider and thicker than the $G$. Thompsonii, though the length is about the same; this makes it flatly ovate. The seed is covered with white streaks in the same way as Guarea Thompsonii. The root spurns are narrow and extend further up the stem than in the case of $G$. Thompsonii, though in the younger trees the stem is very cylindrical. The silvery-coloured bark is most typical of this tree, thus distinguishing it most clearly from G. Thompsonii. It is very similar in appearance to Sidercxylon Aylmeri of Sierra Leone, so that indeed it may be a species of Sideroxylon, or even the same.

It is found in the Ondo, Abeokuta and Benin provinces of Nigeria.

The sapwood is white and narrow and the heartwood light-brown, rapidly darkening to a more mahogany brown. When freshly cut it has a strong cedar scent, which goes off to a certain extent when it is dry, but on planing the wood up again there is always a slight cedar scent. It is closer grained 
than $G$. Thompsonii, but it has not so much sheen. On the whole the colour is poorer. It is not considered quite so durable as $G$. Thompsonii, nor is it termite-proof. It planes well and saws easily, splits moderately well, and takes nails without difficulty. It is of a very light colour for mahogany. It has a good, mellow texture.

It is at first slightly shade-bearing, but later a lightdemanding tree. It grows comparatively rapidly. It thoroughly protects the soil and enriches it with its leaf fall. Natural regeneration appears to be only moderate, perhaps owing to the fact that the seeds soon lose their germinative capacity or are eaten by animals. It appears to be somewhat exacting as to soil, liking one with considerable depth, mineral content and a fair degree of moisture.

In 1906 sample logs of this timber were considered of a lower value than mahogany, and were sold as Scented Mahogany at $3 \frac{1}{2} \mathrm{~d}$. to $3 \frac{3}{4} \mathrm{~d}$. per superficial foot. Since that date the timber has been regularly shipped from the Benin district and sold as Scented Mahogany, and it is usually worth from $2 \frac{1}{2} \mathrm{~d}$. to $6 \mathrm{~d}$. per superficial foot. Owing to the comparative scarcity of large girth mahoganies (Khaya sp.) in some localities, it is being felled in increasingly large quantities.

Trichilia Heudelottii. Rere, Ako Irere, Asana (Yoruba); Ovallo (Benin).

It is found in the Abeokuta and Benin provinces of Nigeria.

It has a smaller leaf than Trichilia sp., and is rather a smaller tree than $T$. Prieuriana. The heartwood is brownred and very hard; the sapwood is white.

It is a slow-growing, shade-bearing, soil-protecting and soil-improving tree of the mixed forest zone.

Occasionally it is used as a house-building timber, when there is nothing else available.

Trichilia sp. Iseko (Yoruba); Ogiovalo (Benin).

It has a larger leaf than $T$. Heudelotii. It is found in the Abeokuta, Ondo and Benin provinces of Nigeria. The heartwood is brownish-red and the sapwood is white. It reaches rather a larger size than $T$. Heudelotii, attaining a bole length of about 15 feet and a girth of 5 feet. The seeds are very similar to those of $P$. Prieuriana. It is termite-proof.

It is a somewhat slow-growing, shade-bearing, soil-protecting and soil-improving tree. Natural regeneration appears to be slight It apparently demands a good soil, and is found in the mixed deciduous forest.

It has not yet been tried as an export timber, but it might be useful as a hard mahogany, both for export and for local use. 
Amongst the natives it is occasionally used as a housebuilding timber, the tree having a fork at a convenient distance from the ground.

Trichilia Prieuriana. Awe, Eriagbo (Yoruba); Igogo (Benin); Somabari (Oban, Ekoi).

Chief Characteristics.-It is a dark-foliaged tree, usually found dominated in the mixed forest, with thin, scaly bark and thin, long leaves, with four or five pairs of pinnæ. The seeds are reminiscent of Guarea.

Distribution.-It is found in the mixed deciduous forests of the Abeokuta, Ibadan and Benin provinces of Nigeria.

Timber.-It has a hard, red heartwood of close grain and white sapwood; it does not shrink nor warp to any extent.

It is a slow-growing, shade-bearing, soil-protecting and soil-improving tree. Natural regeneration appears to be poor, perhaps owing to the fact that the seeds decay very rapidly when lying in the ground.

In the dry season the dew condenses very readily on this tree, and thus makes the ground very moist underneath.

It does not reach really export timber size. It has not been used either for export or locally. However, for smaller constructional work it deserves a trial.

Turraea Vogelii. Asha omode (Yoruba); Ovioza (Benin).

It is rather an uncommon tree of the Benin province of Nigeria. It is quite small, only attaining a girth of about 2 feet. It usually stands in the shade as part of the undergrowth of the evergreen forest.

The natives have no particular use for it.

Turrcea heterophylla.

This tree is found in the Abeokuta province of Nigeria. It is a small tree which has been specially noticed in the Ilaro Forest Reserve. The Yorubas do not have any special use for this species of Meliaceæ. It is considerably harder than either mahogany or cedar mahogany.

Ekebergia Senegalensis (Juss.).

It is a medium-sized tree found in the Abeokuta province of Nigeria. It is distinguished by its white flowers, and is found growing in the Olokemeji Arboretum. The leaves are large for Meliacex, but the position of the flower-stalk and the bark are typical of this family. The natives have not used the wood thus far. It would make rather an ornamental shrub-like tree in a garden.

Melia Azedarach. Bead Tree or Persian Lilac. Eke Oyinbo (Yoruba). 
A tree found growing plentifully. It is of medium size, bearing a very ornamental flower. It yields timber, gum, oil and medicaments, and is also used in the preparation of liquors. The fruit is poisonous.

? Mahogany. Onyemo (Benin).

This tree is somewhat uncommon in the Benin province of Nigeria. It is closely allied to the African Walnut. It is apparently a mahogany, so far as the texture of the timber is concerned, and the grain is very similar too. It is a mediumsized tree with a bark less pitted than that of the Entandrophragmas and with a more greenish tinge. The slash is white, the sapwood whitish-yellow and the heartwood light-brown, becoming darker on exposure to the air. It has occasionally been cut in Benin and used as mahogany.

\section{Polygalacex.}

Carpolobia lutea (Don). Oshunshun (Yoruba).

It is found in the Abeokuta and Benin provinces of Nigeria A shrub-like tree.

Polygala arenaria. Okuturupu (Yoruba).

It is found in the Olokemeji Reserve of the Abeokuta province of Nigeria.

\section{Dichapetalacez.}

Chailletia floribunda (Planch). Kukumarugbo (Yoruba).

This is a small tree of the mixed deciduous forest zone. It is a shade-bearing and soil-protecting tree.

The timber is hard and durable. Locally it has not been used to any extent, though it might find a place in temporary buildings as verandah-posts or window-frames. The timber is said to be termite-proof. The flowers are very conspicuous and quite enliven the forest with their bright colours.

\section{Euphorbiacez.}

Ricinodendron Africanus. African Wood Oil Nut. Erimado, Ekku (Ib.) ; Funfun Puttuputtu (Yoruba) ; Okkwen, Okwenseva (Benin).

It is a large or more often medium-sized tree with smooth grey bark, rather thin branches in more or less whorls, and open crown. The fruit has two lobes, with one seed in each lobe. The leaf is digitate, with a varying number of digits, from three to five. The leaves are rather smaller and much thinner and finer in texture than those of $R$. Rautenii. The root spurns are smaller, and do not appear much more than 1 foot to 2 feet above the ground, nor do the roots themselves usually extend above the ground. It reaches a girth of about 8 feet. 


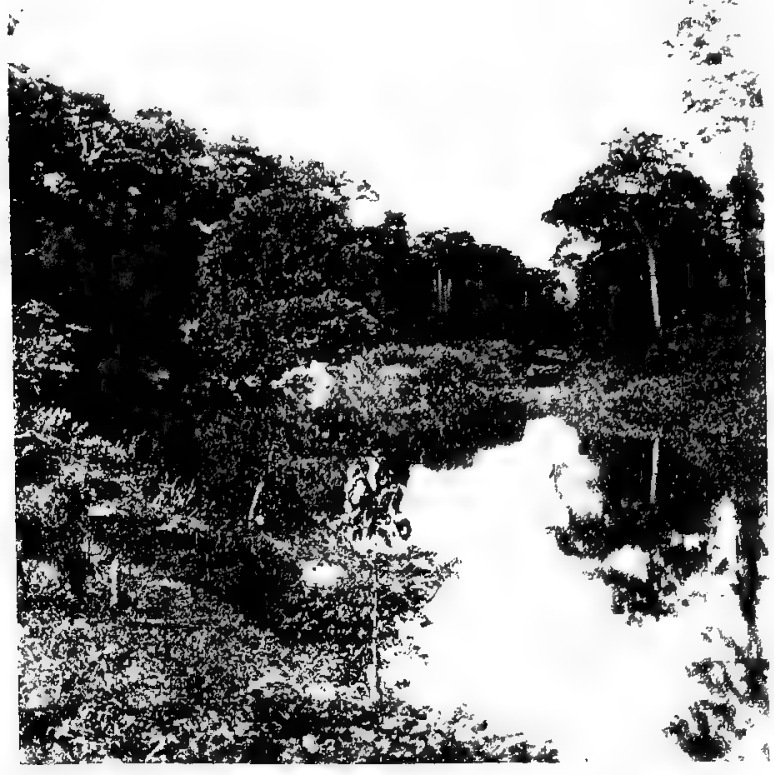

IIG. 72.-Forest on banks of Oshun River, looking downstream, Oshun Forest Reserve.

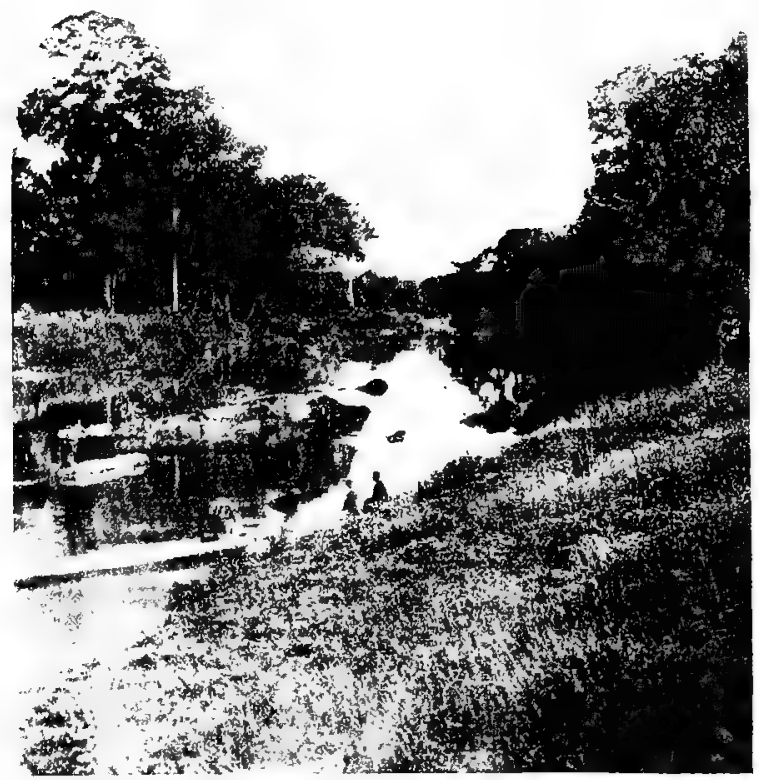

1G. 74.-Forest on banks of Oshun River, looking apstream, Oshun Forest Reserve, Jebu Ode District.

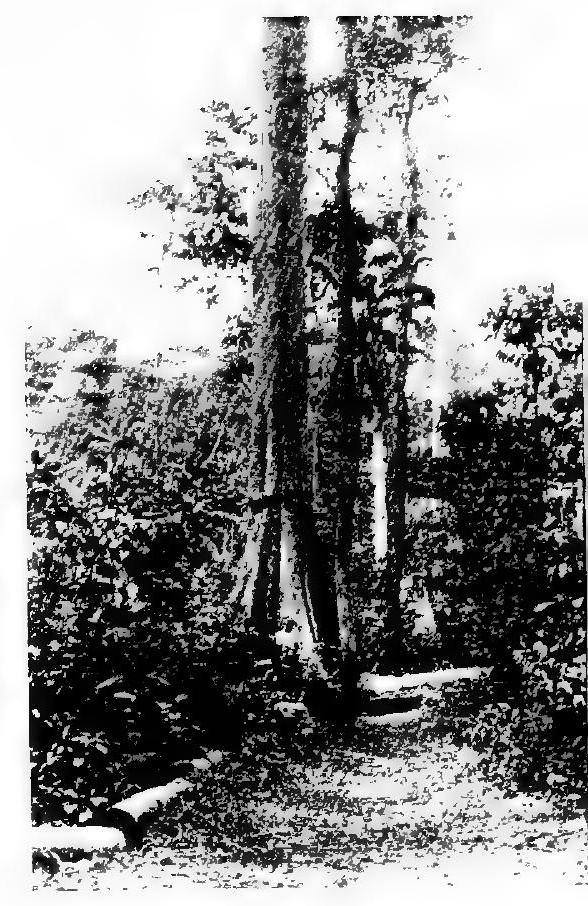

FrG. 73.-Large Arere Tree (Triplochiton Nigericum), already girdled and dead.

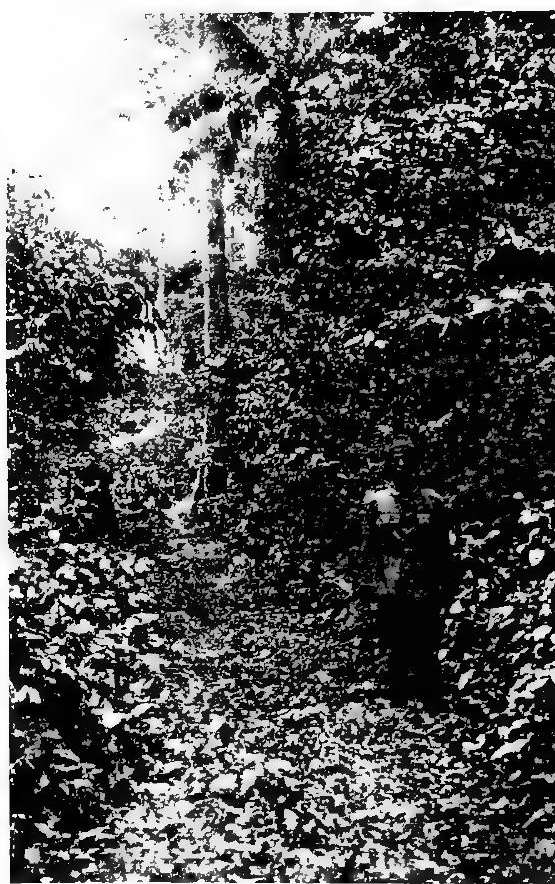

Fig. 75.-Ride between Compartments $C$ and Mamu Forest Reserve, Funtumia seedlings either side, six to eight years old. 

The timber is a little more closely grained than that of $R$. Rautenii, but otherwise very similar. On the whole the bole has a less good shape, tapering rather more in proportion to its height. The timber length of the tree does not usually exceed 25 feet. Natural regeneration is very good, though this tree does not bear seed so heavily as the sister species. It sprouts well from the stump, but the stump does not last. In its youth it will stand a little shade, but is really a lightloving tree, with soil-protecting, soil-improving qualities. It is not quite so rapid a growing tree as $R$. Rautenii, even though it is one of the quickest growing trees. It appears to like a moist, comparatively rich soil.

In 1906 samples of this timber were sold in the Liverpool market as a species of mahogany. It is, however, probable that these were logs from a different kind of tree, as the wood is too dull a brown colour to be really like mahogany. Locally it has not been sawn up for planks, but deserves a trial as a box-making and pattern-making wood.

Native Use.- It is felled indiscriminately with $R$. Rautenii and used for a similar purpose.

Ricinodendron Rautenii. Yoruba Coffin Wood. Ekku, Puttuputtu (Yoruba); Okwen-seva, Okkwen nebo (Benin).

A large tree, up to 12 feet in girth, with stout branches and roughly fissured bark reminding one of oak. The fruit is slightly three-lobed, containing three seeds. The leaf is digitate, with the number of digits varying from five to seven. The leaves are larger and thicker and with a rougher surface than those of $R$. Africanus. The crown is thicker, more widespread, and roughly spherical in shape. The roots usually come out of the ground near the base of the tree and form rough root spurns, extending 3 or 4 feet up the bole of the tree. The bole reaches a length of 30 feet.

It is one of the commonest trees in the moist secondary forests and at the edge of the mixed deciduous forests in Benin, Abeokuta, Calabar.

The timber of this tree was described as a "species of mahogany" and suitable for the Liverpool market in 1906.

Native Use.-By the Yorubas it is cut down and sawn up into planks for making coffins. Mostly medium-sized trees are used for this purpose. None of the natives apparently know how to use the nuts.

Ricinodendron sp. Species of Mahogany. Okwen seni (Benin).

The African oil-nut, with four nuts in each fruit, appears to be the same, but this larger number of nuts is the specially distinguishing feature, and has been given a distinct name 


\section{WEST AFRICAN FORESTS AND FORESTRY}

by the Benin people. It is, however, rather doubtful if it is really a different species from $R$. Rautenii.

Native Use.-It is used in much the same way as the other two species.

Uapaca Heudelotii. Mahogany. Yeye (Yoruba); Oyen (Benin); Ile (Bonny and New Calabar).

It is found in the Owerri and Yoruba provinces of Nigeria. With its slightly curved trunk and large mass of widespreading aerial roots, extending almost to a quarter up the height of the tree, it is distinguishable from other trees of this zone. Usually found growing near water, or in regions that are flooded periodically. It sends out fresh red-coloured aerial roots. The leaves are somewhat shiny and give a greyish appearance in the distance. The bark is finely fissured and dark brown. Often covered with moss at the base. It attains a girth of about 10 feet and a bole length of about 25 feet.

It is a somewhat slow-growing, shade-bearing tree. It protects the soil and enriches it with the fall of its leaves. Its mass of aerial roots tends to moderate the speed of the flooded river and holds the banks up, preventing corrosion, and in many cases tends to help the formation of higher and more solid banks, owing to the deposit of sand between and near the network of aerial roots.

The timber is very similar to mahogany in grain, though a little harder. It has considerable elasticity. It is finely fibrous, and does not plane up with such a smooth finish, nor does it split well. It is termite-resisting and moderately tough. It saws with difficulty. The sapwood is stained with reddish colouring matter, and the heartwood is a dull redbrown. The pores in the timber are longer, and resemble mahogany in this respect; though, being fibrous to the touch, the difference is shown.

The timber has not been exported, nor has it been sawn up for local use. Occasionally it is used by the natives for house-building, and some of the crooked roots and branches are used as ribs for boats and building up canoes.

Uapaca Guineensis (Much. and Arg.). False Mahogany. Abo Emido, also known as Yeye and Yere (Yoruba); Onye (Benin).

Chief Characteristics.-Large aerial roots supporting the bole at a height of 8 to 10 feet from the ground. When cut, the slash is red; the sapwood is whitish, tinged with the red colouring matter of the heartwood, which is a dull red.

Distribution.-Banks of the Ogun, Olokemeji Forest Reserve. In most respects the timber is similar to that of Heudelottii. 


\section{THE NIGERIAN TIMBER TREES}

On the whole, however, this species is a little harder than the other.

This tree is somewhat slow-growing and stands less shade than the Heudelotii. It is of the greatest value, with its aerial roots, in protecting and increasing the height and stability of the river banks at the edge of the dry forest zone. It is one of the few trees that are not washed out of the banks in the flood season, and even when they do fall over into the river they remain attached to the bank and lessen the force of the current. Natural regeneration is none too good.

The timber has not been exported, nor has it been felled locally for conversion into planks. Occasionally the natives use the smaller trees for house-building. They also consider the places in the rivers immediately near or overhung by one of these trees as the best localities for fishing.

Bridelia micrantha. Yoruba Ironwood. Ira Odan, Asa Gidi (Yoruba).

It is found in the Ibadan and Abeokuta provinces of Nigeria.

It is a small tree or shrub up to 8 feet high, with a large alternate leaf. The bark tends to be fibrous and can be stripped off in a similar way to the other Bridelias.

The timber is very hard, moderately durable, and said to be termite-proof. Its small size and somewhat crooked nature hinders its more extensive use.

It is occasionally of use for house-poles in temporary buildings, and makes good firewood, giving intense heat. The leaves yield a rich humus and improve the soil.

Native Use.-The bark is mixed with Hausa salts and then drunk with lime and water as an aperient.

Bridelia Zenkeri, syn. atroviridis. Yoruba Ironwood. Asha, Asha ragha (Yoruba); Oviaruza, Assivi, Ogangan (Benin).

It is a comparatively common tree of the Abeokuta, Oyo, Benin and Owerri provinces of Nigeria. The roughly fissured bark, scaling off in criss-cross fashion, in papery or fibrous layers, is most typical of the tree. The bole is short, seldom reaching a greater length than 15 feet. It is usually forked about this height and then spreads out, rather reminiscently of the elm. It yields the hardest wood of all the African trees, except perhaps Okuta (the stone).

It is occasionally used for house-building by the natives.

Bridelia stenocarpa. Benin Ironwood. Arasha, Asha, Aroro Ashasha (Ondo), Aireygbo (Eg.) (Yornba); Assivi (Benin).

This tree is found in the Benin and Calabar provinces of Nigeria; where it is somewhat prevalent, but found always singly in the forcst. In habit it is not at all unlike the wych 
(lm. The leaf is of similar size and shape, the bark peels off in fibrous layers, but is otherwise fissured in lattice-work fashion. For the size of the tree the bark is comparatively thin; the slash is light-brown, sometimes a whitish-grey. The sapwood is white and the heartwood is dark-brown and very hard. It saws well, but is almost impossible to split, and it will not take nails. It has a short bole of about 20 feet, is deciduous for a few days in the year, but is otherwise a soilprotecting and soil-improving tree. Samples were at one time on the way to be exported, but were sunk by accident, the wood, of course, being much heavier than water.

The natives occasionally use it for house-building.

Excoecaria sp. Orupa (Yoruba).

It is a small tree, up to 18 inches in girth, with smooth, yellowish-red bark, and has maple-like seeds in pairs joined at the base. The stem gives a greyer impression than that of Ormosia laxiflora, and it is also much smoother.

Distribution.-It is found in the dry-zone forest of the Ibadan, Abeokuta and Onitsha provinces of Nigeria.

Timber.-Not very hard and of a yellowish colour.

Native Use.-The bark and roots are used medicinally. It is sold in the Lagos medicine market.

Antidesma venosum. Aroro (Yoruba).

It is a small tree, about 9 feet high. Found in the Olokemeji Reserve.

Antidesma sp. Ogbamaton (Benin).

Found in the Benin province.

Tragia Manniana. Esisi (Yoruba); Ogangan (Benin).

Found in the Ondo and Benin provinces.

Microdesmis puberula (Hook.). The Benin Apata Wood. Apata (Yoruba); Ehranpata, Esanpata, Omomeran (Benin).

It is found in the Abeokuta, Ibadan and Benin provinces of Nigeria.

It is a small tree with hard wood of a brown colour. It reaches about 15 feet high with a girth of about 12 inches.

On the whole this is a slow-growing, soil-protecting and soil-improving shrub. It serves a useful purpose in the undergrowth and is of local value as well.

Native Use.-The wood is used for making the musical instrument known to the Benin as Apata, a kind of harpshaped frame made of wire, but much smaller.

Microdesmis sp. Essunsun, Ubelluname, Ubellunowe (Benin); Njorgora (Oban, Ekoi); Akiti (Ibo Owerri).

It is a common tree of the Benin, Ondo, Ogoja and Calabar provinces of Nigeria. A medium-sized tree of about 6 feet 
in girth, attaining a bole length of about 40 feet. Its small, pretty five-petalled flowers fall off the tree and cover the path or neighbouring bushes; their scent is very pleasant and is reminiscent of honey and flowers.

The sapwood is white and the heartwood light red brown, rather hard, of close grain and close texture; it planes moderately well, but it is rather hard to saw and does not split. It is durable under cover, but does not last when exposed to the weather. It hardens very considerably when exposed to the air. The timber was used for verandah-posts in the Calabar district, but did not prove very suitable, as a large borer often attacked it. The timber is not absolutely termite-proof. The natives occasionally use the wood for house-posts.

Phyllanthus reticulatus. Iranje (Yoruba).

Found in the Olokemeji Reserve.

Phyllanthus sp. Awe, Erigaba (Yoruba); Eghogho (Benin).

Found in the Olokemeji Reserve.

Cyclostemon. Oyen (Benin). This may be the same as Uafaca Heudelotii.

It is a medium-sized tree of the Abeokuta and Benin provinces of Nigeria. It has aerial roots and likes a damp, moist soil. It has red flowers which come out in February. It yields a hard, reddish wood, which is rather fibrous.

Manniophyton Africanum. Ebumen (Benin).

This is a small creeper similar to that known as Okwe by the Benis.

Manniophyton sp. Okwe (Benin).

This is a long creeper found in the Benin and Ogoja provinces of Nigeria.

The nut of this creeper is most commonly seen in the cooked state in the markets, when it appears like a dark-coloured marble. The soft shell can be cracked between the fingers, and the hardish white nut is seen inside, being about 1 inch in diameter and very meaty. A few of these almost take the place of a meal. Thus far the plant has not been cultivated, the natives only picking the fruit as they find it in the forest. The fruit is four-cornered and contains one nut.

Palissya cordata. Ipa (Yoruba); Unwonwen (Benin); Abo Asha (Ibadan).

It is found in the Benin forest. A medium-sized tree, which might be examined with a view to being a source of dyeing material.

Macaranga Barteri. Arasa (Yoruba).

A small tree or shrub found in Tropical West Africa.

Claoxylon Barteri (Hook.). Itakun, Okare (Yoruba).

It has small flowers. Found near Ipetu. 


\section{Anacardiaces.}

Spondias lutea. Non-indigenous Hog Plum or Yellow Plum. Iyeye, Akika Aka (Yoruba); Ogikan or Ogege (Benin); Nsukakara (Efik).

Although indigenous to India, it has become very widespread in its area of distribution in Africa, where it is found, partly planted or as a "garden escape," in all the Southern Provinces of Nigeria. It is a medium-sized tree, reaching a girth of about 5 feet and a height of about 50 feet. The very evenly and comparatively deeply fissured bark, in comparison to the size of the tree, is the most typical feature of it. A very open crown, and few straight upward- and outward-tending branches, with very slight side branches and twigs also distinguish this tree from many of the forest trees. The little yellow fruit, about 1 inch long and $\frac{3}{4}$ inch in diameter, is very much like an elongated Mirabel plum. It is between an eighth and a quarter of an inch of yellow flesh when the nut or stone is reached inside. The leaves are thin and pinnate, with ten to twelve pairs of pinnæ on each leaf. Sometimes the bark is rough and almost prickly. The branches and cortex in smaller trees are more or less covered with little nodules which sometimes develop into small thorns. The fruit is sweet, but rather sharp to the taste, almost tart. It is, however, refreshing in the hot weather whilst on the march.

The timber is whitish-yellow, not very hard, although it is scarcely attacked by white ants, chiefly perhaps owing to the fact that any green piece of wood with some bark on it will grow when lying on the ground. It planes well, splits easily, and takes nails.

It is a rapid-growing, light-loving tree which does not thoroughly protect the soil nor enrich it very much with its foliage. Natural regeneration is poor. It is most readily propagated by means of cuttings, which may even be about 6 inches in diameter and quite as long as posts. With the spread of farms and other buildings it tends to become more widely distributed over the country. It demands a moist soil with a fair amount of depth.

The timber does not show such qualities as to justify its export, but occasionally the larger trees might be sawn up for planks for local use. It is very useful for making live fences, which grow fast and do not cast much shade. In fruit the tree also looks very pretty.

Native Use.-The tree is used for live fences for gardens and farms. The fruit is eaten, but not to an enormous extent, 
as it is said to form tartar on the teeth. Amongst the Yorubas, parts of the roots and branches are used for axe and hoe handles.

Spondias sp. Ekika Aja (Yoruba).

This tree may be the same as Pseudospondias microcarpa, but it has only been determined from a specimen obtained from the Oshun Reserve. This is somewhat further south and in a moister region than the Pseudospondias microcarpa.

Pseudospondias microcarpa. Okika (Yoruba).

It is a somewhat rare tree in the Abeokuta and Ibadan provinces of Nigeria. Apparently there is a small-fruited tree of this species in the Olokemeji Reserve. The tree itself attains a larger size than $S$. lutea, reaching a girth of 8 feet and a bole of 20 feet. The growth is less free and the bark is much darker and more fissured than $S$. lutea. It has not been felled for export; the natives have no particular use either for the wood or the fruit.

Anacardium Occidentale. Non-indigenous Cashew Nut. Kaju (Yoruba).

This tree has become a garden escape on the Ekoi plains near Lagos, where it forms dense thickets. It is not indigenous to West Africa. The tree bears well, and the Brazilians resident in Lagos make a jam out of the fruit. The nuts are roasted and regularly sold in the market, to Europeans chiefly. The branches of the tree are sometimes lopped off and cut into short pieces for firewood. It is usually of very sprawling habit, with a short bole only 3 or 4 feet long. It is not found in the forest proper.

Botanical name unknowon. Blacksmith's Charcoal Wood. Akkun (Yoruba) ; Azimommon, Onyenu (Benin).

It is found in the Benin and Abeokuta provinces of Nigeria, Obagie Reserve and Oyon River.

It is a large tree, with large leaves and compact crown. It has a very small, berry-like fruit; found growing on moist soil in the evergreen forest, sometimes found in the fringing forest of river banks of a dry zone.

Timber.-The timber is very hard, grey in colour and perhaps flexible. The bark is rough and finely fissured. It is inclined to peel off. The slash is pink. The wood is very fibrous, and in the cross-cut section the pieces between the fibres look like very small pinholes. The wood when freshly cut has a sweet, rather pleasant smell.

European Use.-It has not, so far, been sold for export or local use.

Native Use.-The stems of the small trees are used for axe- 


\section{WEST AFRICAN FORESTS AND FORESTRY}

handles, and this tree is esteemed by the blacksmith for making charcoal. It is also cut into planks.

Anacardia sp. Rat Poison Mango. Akkum (Yoruba); Pweku Pweku, Azemome (Benin).

The Benin native name means literally " Rat-kill, rat-kill," but $I$ have never been able to discover exactly how the poison is used. It is rather a rare tree of the Benin forest of the Benin province. It reaches a height of about 80 feet and a girth of 9 feet. It bears a large fruit about the size and shape of a good mango. This is certainly one of the best fruits of the native trees. It has a much sweeter scent than that of the mango, and the taste is also much sweeter. From experiments made it is not poisonous to chickens, goats nor sheep, but none of them, except the chickens, took it at all willingly. The fruit is said to be very poisonous to man, but its delicious flavour tempts the tasting of it. Certainly, in very small quantities it is not poisonous, and it would be interesting to know in what quantities it is so. The slash is yellowish-white. The sapwood is white and the heartwood of a dull brown colour. It is a hard and heavy wood. It saws with difficulty. It is a shade-bearing and soilprotecting tree. The natural reproduction appears to be poor.

The timber has not been used locally, nor has it been sampled for export.

\section{Celastracez.}

Gymnosporia Senegalensis. Shepolo-hun (Yoruba).

It is found in the Olokemeji Reserve of the Abeokuta province of Nigeria.

\section{Icacinacez.}

Pyrenacantha sp. nov. Abara (Yoruba).

It is found in the Epe Colony of Lagos, Nigeria.

\section{Sapindacex.}

Lecaniodiscus cupanoides. Akika. Aka-Ishin (Yoruba); Utan-tan (Benin).

It is found in the Abeokuta, Ibadan, Ondo, Warri, Ogoja and Calabar provinces of Nigeria. It is a small, shrub-like tree, reaching a girth of about 1 foot and a height of 15 feet. The leaves are very small, the timber extremely hard and cross-grained. The wood is used by the natives for rafters, hoe-handles and sometimes mortar-pestles; the root is said to have medicinal properties. 
Blighia sapida. Akee or Akee Apple. Ishin Ishin-oka (Yoruba); Ukpi nufwa (Benin).

It is found in the Southern Provinces of Nigeria. It has an edible aril, which is yellow in colour. It is cooked before being consumed. It is a very ornamental tree, and bears fruit when quite young, which, being orange-coloured, looks very pretty amongst the green foliage.

The fruit is more or less triangular in shape, and when ripe splits open up to the base, releasing three black nuts with a yellow aril. The fruit is orange-coloured with a pink flush. It is a medium-sized tree, reaching a girth of about 6 feet and a height of about 60 feet. The bark is smooth and grey in colour and comparatively thin. The crown is oval in shape and much more open than is the case with Phialodiscus sp. It has a moderately large pinnate leaf with two pairs of pinnæ. The flowers are small and comparatively inconspicuous. It is found chiefly in the mixed deciduous forest zone. It is most frequently seen in the neighbourhood of villages, where it has probably been planted.

The sapwood is white and the heartwood brown, moderately hard, durable and termite-proof. It planes well, though occasionally it is cross-grained. The wood is of fine texture and has a certain amount of sheen. It saws well, but does not split easily. It takes nails only moderately well. It tends to darken a little on exposure to the air.

This tree is moderately fast-growing, at first shade-bearing and subsequently light-demanding. It is also a soilprotecting and soil-improving tree. It appears to like comparatively rich soil, though it may also be seen on poor ground, where it does not thrive. Natural regeneration is not good, chiefly owing to the fact that many animals eat the seeds, besides human beings. It will bear fruit in the fifth year, more especially from stump shoots. It sprouts well from the stump and stands a great deal of pruning.

The timber has not been cut for export, and only occasionally has it been sawn up for local use. It is, however, worthy of further attention as a local building timber. As an ornamental tree it is worthy of a place in a large garden. With its open crown it is a comparatively clean tree, and does not harbour flies and insects.

Native Use.-In places of timber scarcity it is occasionally used for house-poles. The aril of the fruit is eaten after being cooked, but apparently this custom is much more prevalent in the West Indies amongst the descendants of the African slaves. In many parts of Nigeria it is quite unknown as an edible fruit. 


\section{WEST AFRICAN FORESTS AND FORESTRY}

Phialodiscus sp.?. Bush Akee. Awewe, Ishin Oko, Isinko (Yoruba); Ukpi nikwi (Benin).

Identified from a specimen in the Forestry Arboretum, Calabar.

Chief Characteristics.-The capsule splits into three and allows three black seeds to escape, with small yellow aril round the base. The whole fruit and the individual seeds are much smaller than Blighia sapida, though, as the Benin name indicates, this is so similar that it is called the black variety of Ukpi. The fruit is triangular in shape, otherwise very much the same size as African Oak, Oldfieldia Africana.

Found in the Calabar, Owerri, Benin, Ondo and Abeokuta provinces of Nigeria.

Blighia sp. Ishin Oko, Oko Ishin (Yoruba); Ukpi nikwi (Benin).

Distribution.-Ibadan, Abeokuta, Jebu Ode, Benin, Owerri and Calabar provinces of Nigeria. Probably same as Phialodiscus sp.

Chief Characteristics.-The very insignificant white flowerspikes, hidden away amongst the leaves, but attracting numerous bees in February and March, characterize this variety. It is a medium-sized tree, with light-green foliage, thin, lanceolate leaves, a thin grey bark, smooth and close and oval-shaped crown, through which one cannot see. The capsule is dehiscent, with three black seeds with yellow arils, smaller than Blighia sapida, but otherwise quite similar in shape, except that the capsule is more triangular than that of $B$. sapida, and shorter also and of a dark brown colour. It is not unlike the fruit of the real African Oak, Oldfieldia Africana, except that this is quite spherical in shape.

Timber.-White sapwood and light-brown heartwood, which is moderately hard. It does not plane well, and is sometimes cross-grained; the texture of the wood is fine, but is a little fibrous. It saws easily, but does not split well. The bole being very cylindrical in shape, comparatively long, ovenwidthed planks can be cut out of it.

It is a somewhat slow-growing, shade-bearing, soil-protecting and soil-improving tree. Natural regeneration does not appear to be good. It is somewhat exacting as to soil, and does not thrive in a moist sand. It is somewhat fire-resisting. In the dry season a good deal of dew is condensed on the leaves, but not so much as in other genera, such as Anona.

The timber has not been cut for export, nor has it been sawn up for local use. It deserves, however, further trial as a local building timber. A specimen, from which the tree was determined, stands in the forest region of Calabar.

Use.-Native implements of various kinds. 


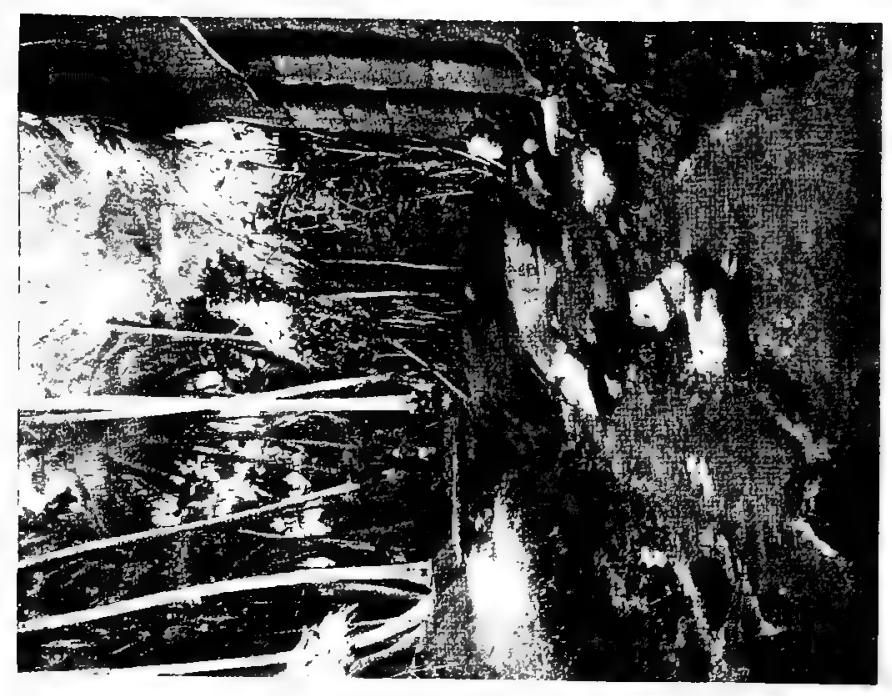

通

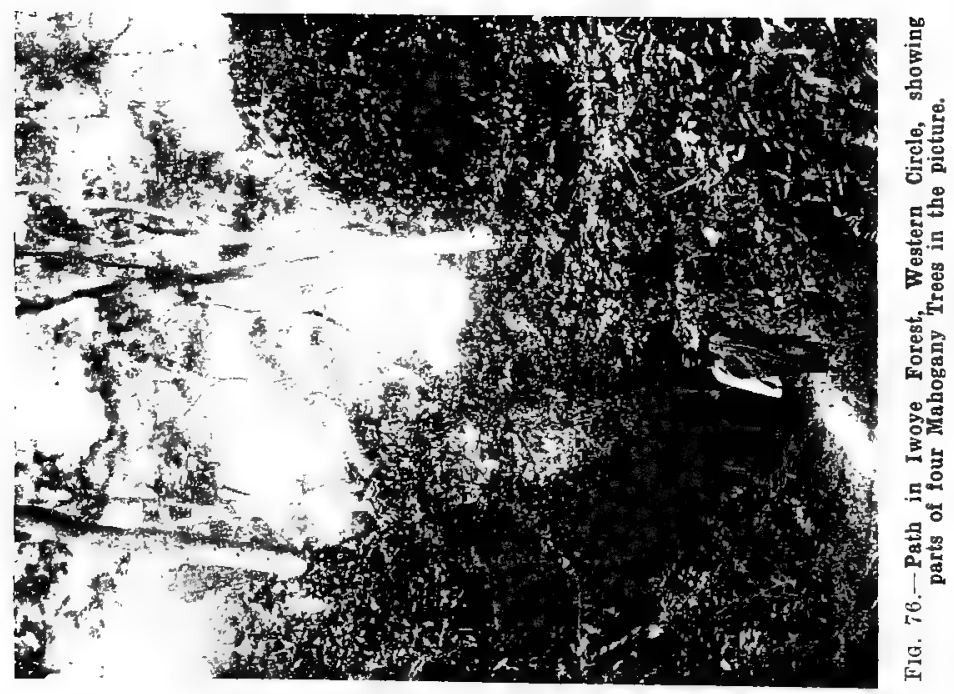



Deinbollia primata. Oju Agbigbo (Yoruba); Ebegogogbo (Benin). It is a small, shrub-like tree found in the Abeokuta and Benin provinces. The small orange-brown-coloured seeds aro of similar shape to, though smaller than, Blighia sapida; they are, however, more elliptical. The stem of the tree, if found with the proper crook in it, is used for making hoe-handles. The leaf is pinnate. This tree only attains a small size, and is found as undergrowth in the mixed deciduous forest zone.

Cupania akeesia. Small Ukpi nufwa. Ishin-jeje, Ishin-gege (Yoruba); Ukpi nufwa (Benin).

This is a small, shrub-like tree, common in the Abeokuta and Benin provinces of Nigeria.

\section{Rhamnaces.}

Zisyphus mucronata (Willd.). Walking-stick Wood. Ekanesie adie (Yoruba).

This is a shrub-like tree of the dry-zone forest, but does not bear such a nice fruit as that of $Z$. jujuba.

\section{Tiliacex.}

Glyphea Grewioides (Hook.). Atori (Yoruba) ; Uwenyriotan, Uwemriotan (Benin).

It is a small tree, not much more than a large shrub, with small leaves, and very common in the undergrowth of the evergreen forest. It is not a hard wood.

It is found in the Benin, Calabar, Abeokuta, Ondo and Ibsdan provinces of Nigeria. It is usually found as one of the smaller trees forming the undergrowth in the evergreen forest. It yields a strong, hard wood near the junction of the roots with the stem, though otherwise it is soft.

It is a shade-bearer, and usually grows in a moist place. Reproduction by seed, judging by the amount of self-grown seedlings found, must be good. It thoroughly protects the soil and enriches it. It thus serves a useful purpose in the undergrowth of evergreen forests.

Native Use.-It is used as a "Ju-ju" whip in Benin and for walking-sticks. Small stump shoots can also be used for yam supports and for making hoe-handles.

Cistanthera sp. False Hill Mahogany. Oro, Apata (?) (Yoruba); Abolo (?) (Benin).

It is found in the Abeokuta and Benin (?) provinces of Nigeria. It is a very common tree on the hill-sides of the Olokemeji Reserve, and to a lesser extent in the Ilaro Reserve. It is a medium-sized tree, reaching a growth of 8 feet and the bole length of about 40 feet. The bark is very curious, with 


\section{WEST AFRICAN FORESTS AND FORESTRY}

occasional very small, long and narrow fissures and tiny pits scattered more or less a foot apart up and down the stem. It is almost gregarious in habit.

The timber is a red-brown colour with a white sapwood. It is very similar to mahogany and could probably be sold as such. It is moderately durable. A tree which fell down in the Olokemeji Reserve during 1910 was not absolutely unsound in 1915.

It is apparently a slight shade-bearer and rather slow grower. Reproduction by seed is evidently rather doubtful, as few or no self-sown seedlings are found in the neighbouring forest. It has not been cut for local use, nor for export, though sample logs should be tried on the Liverpool market to test its value.

The natives use the roots for medicinal purposes, but they do not use the timber.

Grewia carpinifolia. Itakum Okere (Yoruba).

Olokemeji.

Grewia tetragastris. Ora-Igho (Yoruba).

It is a shrub, reaching a height of about 5 feet, of the mixed deciduous forest in the Abeokuta province of Nigeria (Olokemeji Reserve).

Triumfetta rhomboidea. Boko pupa, Akobolobolo, Ilasa omodo (Yoruba); Nesuwa (Benin).

Triumfetta cordifolia. Esura (Yoruba).

Triumfetta sp. Apiko (Yoruba).

Corchorus acutangulus. Abo-jaga (Yoruba).

Corchorus olitorius. Eyo, Ganbe (Yoruba).

These are common plants in the Ogoja and Abeokuta provinces of Nigeria.

They yield long-stapled fibre worth about $£ 27$ a ton. Owing to the fact that they grow wild and are not cultivated by the natives, the difficulty is to be able to collect sufficient quantities in one locality to pay for the cost of retting, baling, etc., to make the fibre production a paying proposition.

\section{Malvacex.}

Hibiscus esculentus (F.). Okra or Achro (fruit).

In most provinces of Nigeria.

Hibiscus Greuioides.

Yoruba country (?).

Hibiscus quinquilobus (C. Don). Onegozi (Benin).

Benin.

Sida carpinifolia (Linn.). Oshopotu Dudu (Yoruba).

It is found in Abeokuta province of Nigeria, and is used by the local people for making fibre. 
Urena lobata. Bolobolo Fibre. Bolobolo (Yoruba).

It is found in the Olokemeji Reserve of the Abeokuta province of Nigeria.

It is a comparatively well-known fibre-plant, but has not, however, been cultivated, the natives having many other profitable crops to grow.

\section{Bombacaceæ.}

Eriodendron Orientale. White Silk-Cotton Tree, Blind Wood or Kapok, Cotton Tree. Araba, Eggun (Yoruba) ; Okha (Benin); Ukum (Efik); Akbo (Ibo, Asaba) ; Shakka (Brass).

It is a common tree in all the Southern Provinces of Nigeria, though it is not found in the most northerly part of the drier ones. With the exception of a few scented mahoganies, this is the largest African forest tree. Its huge root buttresses reach up over 20 feet from the ground. Its giant limbs, as thick as an ordinary tree-trunk, stretch out almost 100 feet from, and are supported on, the great column of the bole, often itself over 100 feet high. Large muscular-like protrusions join up the limbs with the trunk and the latter with the root buttresses, giving the tree a peculiar look. The flowers are white, with yellow stamens. The fruit is a soft, oblong, dehiscent capsule, opening when ripe and releasing black seeds about twice the size of B.B. shot. Attached to this seed is a ball of white fluff. This last is known commercially as Kapok. At the time of the bursting of the capsule of this tree the whole air near by appears filled with white flakes, and the ground later is white as if after a fall of snow. It is almost the quickest growing of all the African forest trees. It grows in the evergreen forest as well as in the mixed deciduous forest.

The timber is white and soft and inclined to have little yellow streaks. When dry it is brittle, though very fibrous to cut when fresh by either axe or saw. It soon rots when exposed to the weather. Natural regeneration by seed is good, especially on the banks of rivers. It tends to extend its area of distribution with the clearing of the heavy forest area in making farms. It is a light-demanding tree.

In Germany, before the war, African Kapok found a ready sale at about 9d. per pound. Samples of Kapok were sent to England and were valued at less than those of the East Indian variety.

The timber has been used as a " blind " wood for furniture, and had a regular market at Hamburg before the war. It has been tested in England for pulp-making, but the fibre is stated to be too short, and so it is of no use for this purpose. 


\section{WEST AFRICAN FORESTS AND FORESTRY}

Native Use.-The Kapok is used for stuffing pillows, for which 1s. apiece is charged. Large oblong pieces of the root buttresses are used as native doors and as drying slabs for fresh dyed clothes. Whenever timber fails it is used for fishing canoes (the cheapest kind).

Eriodendron anfractuosum. Cotton Tree, similar to Orientale. Araba Eggun (Yoruba); Okha (Benin); Shakka (Brass).

Was determined from Western Province material, but it is doubtful whether it is a different species from that found in other parts of Nigeria.

Bombax reflexum. Red-flowering Cotton Tree. Ponpola, Lauro (Ibadan, Yoruba) ; Obokha (Benin); Onihokha, Benin (when in flower); Titiro (Egbado).

It is found in the Abeokuta, Ondo, Benin, Owerri and Ogoja provinces of Nigeria, where it is often seen in the mixed forests and in clearings in the evergreen forest zone.

Chief Characteristics. - It has a larger leaf and thorns than the other Buonopozense (?) (Onikokha of Benin). The most typical feature is the very thick, tulip-like red flower of this tree. This falls to the ground, and is seen on roadways and pathways, indicating the presence of this tree. In February or March, when the flowers appear, the tree is bare, so that the bright-red flowers make it all the more striking. The tree is smaller than the Eriodendron Orientale, attaining a girth of about 12 feet and a bole length of 50 feet. The root spurns are much slighter, in most cases scarcely amounting to small buttresses. The cortex is more soft and spongy than $E$. Orientale.

The timber is white, very soft, not quite so tough nor fibrous as $E$. Orientale, but rather more porous. It planes more easily, dries rather better, splits with less difficulty than $E$. Orientale, and saws with less trouble.

It is a very fast-growing, light-loving tree, which does not protect or enrich the soil very much with its leaf fall. Natural regeneration appears to be fair, though, considering the enormous number of flowers almost each year, it is surprising that the tree does not spread more rapidly in new clearings in the forest.

The timber has not been tried for export nor for local use.

The bark, roots and leaves are used amongst the Yorubas for medicinal purposes. The bush deer eat the flowers, when they fall: the Benin native says if he does not call the tree Onihokha, the deer will not come and eat it.

Bombax sp.?, Bombax buonopozense?. Ponponla (Tbadan, Yoruba); Obokha, Onihokha (Benin). 


\section{THE NIGERIAN TIMBER TREES}

It is found in the Abeokuta, Ibadan, Ogoja and Benin provinces of Nigeria, in the mixed forests, where it is not very common.

Chief Characteristics.-Compared to Bombax reflexum it has a smaller leaf, smaller thorns, but not so many on the stem. It has a similar red flower, opening, however, much more widely. It reaches about the same size as the Bombax.

The timber appears to be very similar in most ways to $B$. reflexum. It has not been felled for export, nor has it been used for planks for local use. Occasionally the leaves are used for medicinal purposes.

There appears to be some doubt as to whether this is really a separate species from that of $B$. reflexum. It is, however, sufficiently different to be considered quite a distinct variety, though perhaps not actually a different species.

Adansonia digitata. Monkey Bread, Baobab. Ose (Yoruba); Usi (Benin).

It is a moderately common tree in the Onitsha and Abeokuta provinces of Nigeria. Isolated specimens are also found elsewhere. The most typical feature of this tree is the huge thick trunk, tapering up into the branches, out of all proportion to the length of these and the twigs. These are much thicker than the branches and twigs of other trees. The green, elongated spherical-shaped fruits hang by a stalk, giving the tree the appearance of one decorated for a Christmas festival. The leaves are truly digitate and not unlike those of the cottontree, though they are thicker and darker in colour. The bark is very thick, spongy and fibrous, and of a light-grey colour. The bark, seeds and roots are used medicinally. The fruit is eaten in time of scarcity.

The fibre is used in England for paper-making.

\section{Sterculiaceæ.}

Sterculia Rhinopetala. False Chestnut.' Ekko Okpon, Orodu or Orodo (Yoruba); Enwiwan (Benin); Otutu (Jebu); Awraw (Egbado).

It has a smooth, light-green bark, which remains soft, but is whitish with age. The wood is white and soft, and apparently there is no difference in the heartwood. It has a small seed with a wing on each side of it. For external work it is not durable, but when seasoned for internal fittings, such as doors or ceilings, it is more useful.

It is common in the Oyo, Benin, Calabar and Abeokuta provinces. It is found in the mixed deciduous forests, especially in the Mamu and Ilaro Forest Reserves. Also, wherever 


\section{WEST AFRICAN FORESTS AND FORESTRY}

it is found there is a comparatively large number, though it is not gregarious in habit.

It was stated to be of no commercial value in the Liverpool market in 1906, but in a subsequent report it was said to be worth 1s. to 1s. 6d. a cubic foot, as walnut, though there must have been some mistake in the name.

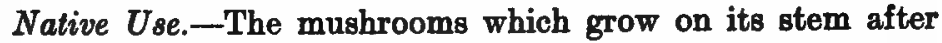
it is cut down are used for soup. These are known as Epweperu. Sterculia tomentosa. Okagbo (Yoruba); Ukpiwenwan (Benin).

This tree is found in the Abeokuta and Benin provinces. It reaches a height of from 40 to 50 feet. The fruit is ripe in December and January ; it is kidney-shaped and covered with a dense collection of very fine reddish hairs. It grows in clusters.

Sterculia sp. Iwu (Yoruba).

It is found in the Abeokuta province of Nigeria and is a medium-sized tree which yields a white wood which is none too hard nor soft.

Sterculia tragacantha. African Tragacanth. Owun, Omunu, Omar, Ogidu (?) (Yoruba); Oporipor, Iporipor, Okoko (Benin).

Chief Characteristics.-It shows a brown slash when cut. The bark is very fibrous and the white sapwood is full of large open pits, which gives the wood the appearance of being entirely fibrous. It yields a pink-coloured gum, which hardens after a few days. It bears large oval-shaped leaves, which tend to be bunched at the end of the twigs. The pods are less than half the size of Sterculia cordifolia and are covered with lightbrown velvety hairs on the outside. These pods open, making each appear coracle-shaped, with eight to ten small brown seeds attached to the bottom rib of the pod. The foliage looks almost grey-white from underneath. The bole of the younger trees is greyish-white and usually for 30 to 40 feet free of branches. It reaches a girth of about 8 feet. The wood is white and softish, planes easily and works up to a neat finish. Silviculturally, the tree stands between the light-lovers on one hand and the shade-bearers on the other, although it is usually seen growing comparatively free from other than natural shade. It does, in fact, stand a considerable amount of shade in the younger stages of growth as well as later, when it may be overgrown by larger growing trees. It is usually found in groups at the edge of the forest.

It sprouts again from the stump, but almost each year large crops of seeds are borne on the tree, and this would seem to be the chief method of reproduction.

The tree has not been cut for local use, nor has it been 
exported. The Yorubas and Benis use the smaller trees as poles for house-building, but it is not considered a good wood.

Sterculia cordifolia. Heart-shaped-leaved Sterculia. Okporoporo, (Akure); Ogugu, Ogungun or Ogrugru, Oburuburu (Yoruba); Idogoho, Okoko, Okokwo (Benin); Dikir (Efik); Ibitoto (Bembi).

Distribution.-It is found in the Jebu Ode, Abeokuta, Ibadan, Benin, Onitsha, Owerri, and Calabar provinces of Nigeria. It is one of the most common trees in the mixed deciduous forests.

Chief Characteristics.-The large heart-shaped leaves and the curious twist to the lower part of the stem, which makes the root protuberances quite angular. It is never quite straight and forms a heavy oval crown.

The very large, oval, soft, almost fleshy, dehiscent pod, with its large winged seeds, is most typical of this tree. The crown is supported by three or four large limbs with comparatively few side branches. The foliage is very dense, though even in a tall tree the individual heart-shaped leaves show up quite distinctly. It is almost gregarious in habit, usually groups of four or five being found in one place. It is nearly always found on the banks of small streams which may dry up in the dry season. It is a shade-bearer, though moderately quick in growth. The wood is cross-grained, and emits rather an unpleasant smell when cut: The sapwood and the heartwood are both white, with a reddish tinge through it. It is soft, but becomes much harder when dry. It sprouts from the stump when cut down. Reproduction by seed is moderate. It has not been used locally, nor has it been exported. The natives in the Benin and Yoruba countries use the butt of medium-sized trees, especially those with a fork, for housebuilding. It is not attacked by white ants.

Sterculia nr. oblonga. Opepe (?) (Yoruba); Orodo (Benin).

It is a common tree of the Benin province of Nigeria, found in the evergreen forest.

It is a question whether this species is the one with a very hard, leathery, half-dehiscent pod, showing about ten orangecoloured oblong seeds inside it. These seeds have sometimes been termed Okoko by the Benis, but they are, no doubt, not obtained from the fruit of Sterculia cordifolia. These seeds also are not winged, and are comparatively fleshy and soft compared to the dry, rather hard, large winged seeds of Sterculia cordifolia.

Sterculia cinerea. Tartar Tree. Lakole (Yoruba); Ururata (Benin). 
It is rather an uncommon tree of the Benin province of Nigeria. It is found at the edge of the mixed deciduous forest with the dry-zone area of vegetation.

Firmania Barteri. Rope Tree. Eso or Esho (Yoruba); Akoko, Nihau (?) (Benin).

It is a large tree with duck-egg-green bark and an uneven buttressed base, with a bole length of 30 or 40 feet and a girth up to 12 feet.

Distribution.-It is one of the most prevalent trees in the Olokemeji Reserve in the Abeokuta province of Nigeria, and found all thirough the mixed forests of the Western Circle and also in the Obubra division of the Calabar province, but it has so far not been found in the Benin province.

Use.-A fibre, worth $£ 14$ to $£ 20$ a ton, is made from the bark of young trees attaining 3 inches in diameter.

A most conspicuous tree in October and November, as it is covered with small red flowers and is leafless at the time. It has a papery fruit with a small round seed attached to the base. These fruits are also most conspicuous in February and March, making the tree look as it were covered with red flowers' for a second time. The large, poplar-shaped leaves with comparatively long stalks often tremble in the slightest breeze in a similar way to the aspen. The wood is soft, white and fibrous, with no distinguishing colour between sapwood and heartwood. It splits comparatively easily, though, once it is dry, with difficulty. It is easy to plane, though difficult to obtain a smooth surface owing to the grain often being twisted. The light seeds almost float in the air, the result being that they are spread everywhere, and thus come up chiefly in the open spaces and at the edges of rides and roads, almost to the detriment of any other species. It is one of the fastest growing of all the African trees, and being a light-lover as well, rapidly covers all the available ground. In fact, in the mixed deciduous forests it tends to gain in its area of distribution year by year. In an enumeration in the Olokemeji Reserve, instead of finding a fow thousand trees, as in the case of most species, hundreds of thousands of this one were found.

The branches of the young tree grow more or less in whorls at right angles to the trunk, and, combined with the comparatively large leaves, thoroughly cover the ground near by. Stump sprouts grow after a tree has been felled, though natural reproduction by seed is by far the most prevalent method. It has not been felled for local use nor has it beon exported. The Hausas living in Nigeria cut down the small trees (saplings 1 to 2 inches in diameter), peel off the bark, dry it, and spin 


\section{THE NIGERIAN TIMBER TREES}

it into rope, which is used for tying loads of Cola or other produce. When freshly made it is soft and pliable, but when it is dry the fibre becomes very harsh and rather difficult to tie.

The wood is used for floats for fishing on the Niger.

Heritiera $s p$ ?. Oviegikwe (Benin).

It is found in the Benin and Ondo (?) provinces of Nigeria.

The tree is large, reaching a girth of about 12 feet. The seed is papery and full of air, so that when trodden upon it collapses. The leaf is of medium size, more or less pinnate. The timber is white and soft; termites attack it. It has not been exported or used for local buildings.

Native $U_{8 e}$.-The leaf is used medicinally, and the timber is used for making drums (the frame) by hollowing out the trunk of a tree. It is also used as walls for a temporary house (when dried or not); for this purpose it is split in pieces.

Heritiera sp.?. Igoso (Benin).

It is an uncommon tree of the Benin province of Nigeria. It is found in the evergreen and mixed deciduous forests. The fruit is considerably smaller than Oviegikwe.

The natives apparently have no use for this tree. However, timber obtained from trees of this genus has proved so useful and durable that a trial of the wood of this species seems advisable.

Triplochiton Johnsonii (Ch. Wright). African Maple, Bush Maple. Arere (Yoruba); Obechi (Benin).

This is one of the common trees of the Abeokuta, Ondo and Benin provinces of Nigeria; it is found in the mixed deciduous forest zone, more especially in the moister regions of these forests. Like T. Nigericum, it is one of the largest of all the forest trees, reaching a height of over 120 feet and a girth of 25 feet. The leaf has five lobes, and is thus distinguishable from $T$. Nigericum, which has seven. The bole is long and clean and most cylindrical in shape ; the buttresses, as a rule, do not reach such a great height as in the case of $T$. Nigericum. On the whole the bark is smoother and, especially in the younger specimens, almost shiny. The flowers and fruit are very similar to $T$. Nigericum.

The timber is white, both heartwood and sapwood, and shows a considerable amount of elasticity ; rather liable to warp when seasoned. It works up well and takes a satiny sheen. The grain is comparatively fine-in fact, a little finer than that of $T$. Nigericum; the pores are long and very narrow; it works up well with a plane, takes nails easily, does not split well ; it saws with great ease ; it is not termite-proof. If freshly 


\section{2 WEST AFRICAN FORESTS AND FORESTRY}

cut and placed under cover, it suffers most severely from the attacks of a very small weevil which reduces the wood to a fine powder; it is noticeable that when the timber is entirely dry the surface hardens very considerably and it is less liable and almost immune from attack. When thoroughly dry the wood weighs 35 pounds per cubic foot.

It is a very rapid-growing, at first slightly shade-bearing and of recent years an eminently light-loving tree. It has soilprotecting and soil-improving qualities. Natural regeneration appears to be very good. Self-sown seedlings show a heightgrowth of over 6 feet per year. It likes a moist soil, which need not be very rich, but it must have considerable depth. It is rather liable to be blown by the wind or sometimes broken, if in an exposed locality.

Locally it has been used for boxes and other articles, which have proved quite durable; it has been used as inside planking and other interior work, and so long as it is carefully seasoned it does not warp very badly; it is probable that it is one of those timbers that would yield better results by kiln drying. In the Central Circle it has been sawn up as planks for a considerable time, but they have been attacked to a great extent by a small weevil. The local people use the bark for making roofs and the wood for doors for their houses.

In 1906 sample logs of this timber were sold in the Liverpool market as Satinwood, but were not considered equal to Anyeran (Afrormosia elata). Since that date no more trial shipments have been made, so it remains to be seen whether under the altered conditions and the pressing demands for timber in Europe a market cannot now be found for the vast quantities of this timber from Nigeria and other West African countries.

Triplochiton Nigericum. Soft Satinwood. Arere (Yoruba); Kpa (Efik).

It is found in the Abeokuta, Ondo, Owerri and Calabar provinces of Nigeria; it is a common tree of the mixed deciduous forests. One of the distinguishing features of this tree are the maple-like leaves. This species has seven lobes to the leaf; the leaf itself is softer and almost velvety compared to the true maple leaf. The lobes themselves are not quite so sharply pointed and the leaf stalk is considerably thicker. The fruit also is very much like that of the maple, but is a quadruple samara instead of being only a double one. The tree is one of the largest of the whole forest, reaching a height under favourable conditions of nearly 150 feet; the bole alone may reach a height of 90 feet with a girth of over 20 feet. The 
trunk is very cylindrical in shape, showing a well formed figure, but not so good as either that of Agba or Gum Copal. It is only broken up by the root buttresses, which often reach 10 to 12 feet from the ground before they merge into the stem; the bark is grey, sometimes almost white and almost smooth; in old age, shallow fissures sometimes form. The slash is greenish-white, and a little watery sap moistens the cut after a short interval. The crown is ovally spherical and occupies over one-third of the height of the tree. The flowers are mottled pink and white.

The sapwood is white and the heartwood is the same colour, with no great distinction between them except the greater dryness of the heartwood. The timber is soft and not durable, and is not termite-proof; it does not split very well, saws easily, and planes fairly well and takes nails comparatively well; does not plane up to a very smooth surface.

It is a very rapid-growing, at first shade-bearing, and during the last few years a light-loving tree; it has soil-protecting and soil-improving qualities. It is deciduous for a short time each year; flowers in February or March, and the seeds are borne towards the end of the rainy season. Natural regeneration is very good; it sprouts very strongly from the stump. It is really somewhat exacting as to soil, liking a moist soil of good depth and with plenty of drainage; it will not stand in waterlogged ground, though an occasional flood does not hurt it. Plantations have been made with this tree, and the growth thus far has been very rapid; self-sown seedlings, however, show greater development in the same period of time.

Locally, the root flanges are used for making doors and occasionally the tree has been cut for planks; it is said that the timber is not supposed to be quite so durable as that of $T$ Johnsonii, but in reality there is very little difference between them.

Triplochiton n. sp. Bush Maple. Obechi (Benin).

This tree was found in 1906 in the forest near the Anwai, not far from Onitsha Olona, in the Asaba district of the Benin province, and is very similar in habit and growth to the other two species.

Buettneria. Obechi (Benin).

Benin.

Pterygota. Poroporo (Yoruba).

It is found in the Abeokuta province of Nigeria. It is not very prevalent in the mixed forests of the Olokemeji 


\section{WEST AFRICAN FORESTS AND FORESTRY}

Reserve, and is a large tree, 8 to 10 feet in girth. The wood is said by the natives to be durable.

Cola cauliflora (F.). Cola Mahogany. Isienwe (Benin).

It is common in the Benin province of Nigeria, in the mixed deciduous forest zone, where it is not very prevalent. It is a medium-sized tree, reaching a girth of 6 feet.

The seed is a small nut. The leaves are very dark and are comparatively large. The bole reaches a length of about 20 feet.

The sapwood is whitish and the heartwood of a red-brown, similar to mahogany. The texture is, however, not quite so fine and a little more fibrous. It planes fairly well and takes nails fairly easily, but it does not split well. It is durable and is said to be termite-proof. It is a somewhat slow-growing, shade-bearing, soil-protecting and soil-improving tree. Natural regeneration is only moderate, and it sprouts slightly from the stump. It is somewhat exacting as to soil, and is usually found in a loamy sand, with plenty of moisture and depth.

It was valued at $2 \mathrm{~d}$. to $2 \frac{1}{2} \mathrm{~d}$. a superficial foot as mahogany of fair character in the Liverpool market in 1906. But since then no more has been felled or exported.

The natives use it as firewood in the Benin country. It has not been felled for local use.

Cola laurifolia. Laurel-leaved Cola. Foma (Yoruba).

It is an uncommon tree, found in the Olokemeji Reserve of the Abeokuta province of Nigeria. A small tree with small flowers.

Cola acuminata (Beauv.). Common Cola. Obi Abata (Yoruba); Eve (Benin).

It is a common tree of the Calabar, Ogoge, Owerri, Warri, Benin, Ondo, Ibadan and Abeokuta provinces of Nigeria.

It is the ordinary Cola of the Benin villages, but it is also found in the forest. In other parts of the country it has been planted along the sides of the roads leading into Egbado, Jebu, Ode, Ondo, Ikale and Ilesha villages.

Always standing in the shade and with a heavy evergreen foliage, the cream-coloured flowers with a pink streak on each petal show up very clearly when the tree comes into bloom in February or March. According to the native ideas, the tree must never be pruned, nor, in fact, should it be cut either partially or wholly under any circumstances. However, in passing to and from their farms, boys and young uen often chip the trunk of the tree with a matchet. This, they say, has the effect of making it produce more fruit; otherwise the tree always looks very dirty, and often the trunk and the branches 

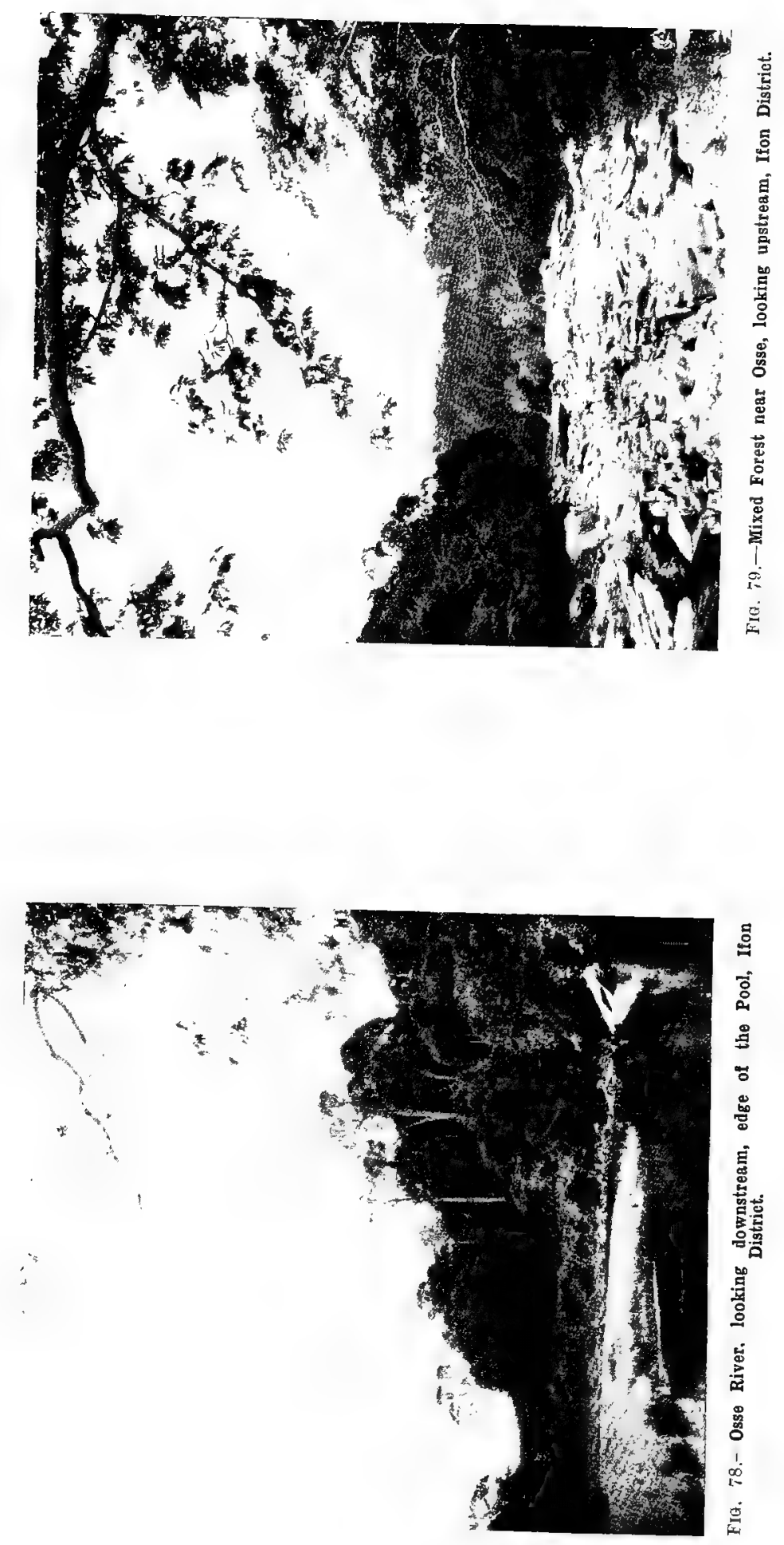

are covered with epiphytic ferns or orchids. Occasionally, once a year or once in two or three years, the branches of the trees standing nearest to a Cola are cut away and the ground immediately surrounding a Cola tree is cleared of undergrowth. The crop of fruit borne varies very much from year to year. One year a native may make a pound or so from his Cola tree, whereas in another he perhaps makes very little.

The sapwood is white and the heartwood a dull whitishyellow. It is moderately hard, very close grained and of fine texture, with a dull lustre; is moderately durable, but is liable to be attacked by a very small furniture borer. It is termiteproof. It planes well, does not split easily, takes nails and saws well. It is apparently an excellent wood for carving. It does not shrink nor warp very much. It is more durable for interior work than for outside, where it is liable to get soft and to crumble away. It is sometimes brittle; it does not burn well.

Native Use.-The fruit is eaten and is used as an article of export both to the Northern Provinces and also to the Continent. The wood is used for making "Ju-jus" (Esu-the Devil) (Images of the King); otherwise it is not cut in the Benin country.

Cola Afzelii. Monkey Cola Tree. Obidu, Obiedun, Ebidun (Yoruba) ; Awohebitan (Benin).

The brilliant red fruits, about twelve joined together in a spherical bunch, are usually quite a feature of the small tree. The leaves are digitate, but joined at the base, so in reality only a single leaf. It is a much-branched tree with yellowishgrey bark. The crown is much divided, and sometimes the. branches almost appear as if in large whorls.

It is found in the Oyo, Abeokuta, Ondo, Benin, Owerri, Calabar and Ogoja provinces of Nigeria.

The wood is white and softish and not durable. It is most common at the edge of the evergreen forest. It attains a girth of about 6 feet and a bole length of about 15 feet. It is a light-lover, though it stands a considerable amount of shade in its youth.

Native Use.-The wood is used for the stock of a cross-bow in the Benin country, and the seeds are eaten at any time.

Cola sp. Obiedum (Yoruba); Ewoha (Benin).

This is a comparatively common tree of the Benin, Abeokuta and Ondo provinces of Nigeria. It is the original Cola of the forest; a medium-sized tree with the typical Cola foliage, found growing singly. It does not appear to bear very heavily, and apparently in some places the local people 
utilize the fruit, while in others they say it is of no value. It appears to be a whiter and softer Cola than that of the other species, and it does not seem to have such a strong flavour.

The timber is hard and white; it is a shade-bearing and soil-protecting tree. Natural regeneration appears to be poor.

The wood is occasionally used by the local fetish-maker for certain types of fetish in the Benin country. It is considered the most suitable and, in fact, the only wood for this purpose. Although the ordinary Cola which is planted may not be cut, this species is not immune, but it is certainly considered most proper if only the image-maker cuts it.

Dombeya Buettneri. Ewe ofo (Yoruba).

It is found in the Abeokuta province of Nigeria, especially in the Olokemeji Forest Reserve. It is a small, shrub-like tree, varying from 7 to 15 feet in height. The bark is fibrous. In 1908 samples of the fibre were submitted to the Imperial Institute for valuation. Owing to its being rather harsh, woody and weak, it was stated to be worth from $£ 7$ to $£ 8$ a ton.

\section{Ochnacez.}

Ochna multiflora. Canoe Tree. Uruk (Efik); Tei tei (Tjor); Tei tei (Brass); Elili (Ibo Owerri).

It is found in the Owerri, Warri and Ondo (?) provinces of Nigeria. It is one of the prevalent trees in the evergreen and brackish swamp forest zone. The tree reaches a girth of 15 feet and a bole length of about 60 feet. It has a large digitate leaf, making the foliage of the tree very heavy and dense. The bark is thick and fissured longitudinally. The crown is long and egg-shaped. The fruit is large, roughly spherical in shape, but ribbed in five places on the surface. It is a shade-bearer, and reproduction is chiefly by seed. The wood is reddish-brown and moderately hard. This is one of the most favourite trees for canoe-making amongst the Brass people. Having a straight grain, the log opens out well into a canoe once it has been hollowed out in the centre.

Ochna sp. Sama (?), Duma name.

It is found near Obudu, in the Ogoja province of Nigeria. It is a small tree of the open deciduous forest, growing at an altitude of about 1,500 feet. The flowers are umbellate and of a pretty red colour. It is a light-lover and grows at the edge of the forest.

The natives apparently have no use for either the wood or other parts of the tree.

- Lophira procera. Red Ironwood, African Oak, Red Oak. Ela, Ekki (Yoruba); Eba, Ebba (Benin); Eleba (Jekri); Kuru 
(Brass) ; Okikopom (Ibibio); Enwan, Umpenek (Efik); Okut Okot (Oban, Ekoi); Kuru (Ibo Owerri); Okut (Kwa).

Chief Characteristics. - It is a very large tree, up to 6 feet in diameter, with orange-coloured bark, when in the shade of the evergreen forest where it is found, but this soon becomes quite grey when exposed to the sun. The flowers are white, with five petals, and are very fragrant, smelling like musk, covering the ground and scenting the forest in November and December. In October and November the tree is very conspicuous with its brilliant new red foliage, which almost appears like flowers in the distance. On the banks of the Calabar River, above the town of the same name, this is seen to advantage. The fruit is winged, but with one wing twice as long as the other and also broader ; the seed is sharply pointed and almost conical in section, and not so meaty as that of $L$. alata. The crown is spherical, but open; the branches are very twisted and reminiscent of oak. The trunk reaches a length of 90 feet and is almost perfectly cylindrical in shape, with only the slightest indication of spurns at the base.

Distribution.-It is found in the Abeokuta, Jebu, Ode, Benin, Owerri, Ogoja (?) and Calabar provinces of Nigeria. It is one of the commonest trees in the very moist parts of the evergreen forest zone.

Timber.-The sapwood is whitish red, but the heartwood is of a dull red colour with large, long, open pores, partially filled with siliceous salts. This often gives the wood an almost speckled appearance. In a tree of 12 feet girth, the sapwood is usually only 3 or 4 inches thick, making it a very fullwooded tree and thus reducing the amount of wood wasted in squaring the logs. It planes well, with a smooth, shiny surface. Strong shoots often come up from the stump, though owing to the natural seed distribution being good, this latter is the chief means of reproduction. It is a light-lover, with a natural tendency to grow straight up. It is a slow-growing tree, and the leaves, nearly a foot long and almost tongueshaped, are very large for such a hard-wooded tree. Even when planted 16 feet apart it grows up straight, with only three or four perpendicular branches or even only a fork in the stem. It resists white ants, and the teredo worm does not bore into logs when lying in the water. It is almost gregarious in habit, usually groups being found in one locality, or, as in the moister regions, it is next to mahogany the commonest tree found in the forest. It will withstand floodsin fact, there is an island several square miles in extent in the Oshun River covered with only this species of tree. It is also 
found again on the upper edge of the mangrove forest where the first solid land begins.

The seeds have not been tested as to the proportion of oil contained in them, but no doubt they contain a similar quantity, in proportion to the size, as those of $L$. alata.

In 1906 samples of this timber in the round were sent to the Liverpool market, where it was valued as red oak at 28 . to 3s. per cubic foot. It was also stated to be worth shipping in good lengths. Owing to its weight and the hardness of the wood, and thus the extra cost of squaring logs, little or none has been shipped to Liverpool since this report was made. Locally it has been used for piles for wharves and bridges, decking for bridges, wall-plates for bungalows, and occasionally as verandah-posts. It can be floated with Musanga logs or those of Hannoa undulata. Canoes made of this wood are of the most durable kind, so that perhaps it might be tried for boat-building.

The people of Benin use the wood for making pestles for their Fufu mortars, and occasionally it is used as wall-plates. Amongst the Brass people it is sometimes used for making canoes, and amongst many tribes for making food-mortars. Near Lagos it is used for house-building.

Lophira alata. Niam Fat, Small Red Ironwood, Meni Oil, African Oak. Ipawhaw, Ponhon, Ipahan (Yoruba); Awigbi, Ugbeberi, Ishan (Benin).

Small or dry-zone Red Ironwood.

It is found in the Ogoja, Owerri, Onitsha, Benin, Ibadan and Abeokuta provinces of Nigeria.

It is a very common tree in the open deciduous forest of the dry-zone form of vegetation. Often found in groups, but it anyhow is the most prevalent tree wherever found. It does not usually grow straight, but the stem is gnarled and crooked, reaching a girth of about 5 feet. The tree itself only grows to a height of about 30 feet. In appearance it looks like a small oak, but the Shea Butter Tree, Butyrospermum Parkii, is still more like it. However, with its reddish-green tonguelike leaves with wavy edges, it is in reality quite different. The branches spring out of the stem in a more upward direction than $B$. Parkii, and are more irregular in growth. The bark is orange-coloured and almost scaly on the younger trees, though it goes a grey or black colour when exposed to the light or the annual grass-fires. The flowers are white, sweetsmelling and much more conspicuous than on $L$. procera. The seed is placed between two wings, one nearly three times the width of the other. The smaller wing is more pointed 


\section{THE NIGERIAN TIMBER TREES}

than the larger; the seed, while being pointed, is stoutly coneshaped and rather more than a quarter of an inch in diameter at the base, and of a light brown colour.

Timber.-The sapwood is narrow and white in colour and the heartwood is a dull red. It is very hard and tough, but not so heary as $L$. procera. It planes only with a rough surface.

Silvicultural Characteristics.-This is one of the few trees which successfully resist the annual grass-fires. Its otherwise prolific seed-bearing capacity is, however, often very much diminished, if not completely spoilt, by the flowers being burnt in January and February, the usual time of the grass-fires. It is a light-lover, but for the reasons already given is a very slow-growing tree. On the whole, although the seeds germinate well, stool and root shoots are probably the chief means of reproduction. The soil under these trees is only partially protected during the growing, and quite exposed to sun and wind during the dry season.

Commercial Value.-Samples of these seeds were sent in 1909 to the Imperial Institute for valuation, when they were found to be worth about $£ 10$ a ton; 43 per cent. of oil can be obtained from the kernels, and this is said to be suitable for soap-making and to be worth $\mathbf{2 2 5}$ per ton. Commercial quantities, however, have not yet been exported.

Meni oil was formerly obtained from the seed.

Native Use.-Amongst the Yorubas the tree is used for house-posts, especially when the stem is forked about 10 feet above the ground. The leaves, bark and roots are all sold in the native markets for medicinal purposes. An infusion of the bark of the roots is supposed to be a cure for jaundice (yellow fever, according to the natives). Strangely enough, the seeds are not used as a source of oil.

Gomphia insculpta.

Found at Olokemeji.

Gomphia glabriana.

It is a shrub found at Olokemeji.

Gomphia nr. offinium.

Found at Ilugbro.

\section{Guttiferz.}

Garcinia conrauana. False Cola, Bitter Cola. Orugbo (Yoruba); Edun (Benin); Odji (?) (Brass); Efiori Efrie (Efik); Efrie (Kwa).

It is found in the Calabar, Benin, Ogofa and Abeokuta provinces of Nigeria. 
It is a medium-sized tree with close, spherical-shaped crown. The branches and leaves are comparatively small. The bole is short and the branches very persistent. The most typical feature of the tree is the large apricot-like fruit, of an orangeyellow colvur. The bark is smooth and brown in colour. It is found in the evergreen forest. The nut is oblong, of a very dark brown colour with small white streaks all over it. It grows in moist soil.

The timber is very hard and close-grained, with yellow sapwood and light-brown heartwood. It is said to be durable and planes with a smooth surface. It is often found at a considerable elevation - up to 3,000 feel towards the northern part of Calabar province.

It is a shade-bearer, though it is often found growing alone, having been left isolated when the original forest was cleared to make a farm. The tree grows very slowly but bears comparatively early, and trees are often seen quite laden with the yellow fruit.

The timber has not been exported, but has been cut for local use. It was used by the Public Works Department, Calabar, and proved useful for wall-plates. The nuts have occasionally been exported, but they are comparatively valueless compared to the real Cola.

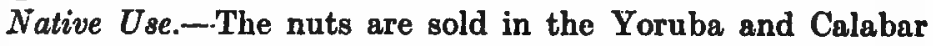
markets and 100 to 200 for 3d. in the Benin market. The fruit is also eaten. The roots are used for chewing-sticks (the best in Benin), and taste like quinine. The nuts are ground and used medicinally for headache.

Garcinia Kola.

A little known. species, found in the Eastern Provinces, Uwet. It was subsequently determined as Garcinia conrauana. Garcinia Mannii.

This tree is found in the Western Provinces.

Uses.-Chew-stick is made from the root.

Garcinia, var. nov. brevipedicellata.

This tree grows in the Eastern Circle.

Pentadesma sp. ?. Hardwood, Duika's Chop Fruit. Oglia (Yoruba) ; Ekuso or Ikujo, Efiari (Benin).

This tree is found in the mixed forests of the Benin province of Nigeria. One of its chief characteristics is that it has little or no bark, but the cortex is comparatively thin, and rentains of a duck-egg-green colour even in trees of comparatively large size. It reaches a girth of about 6 feet and a bole length of about 20 feet. However, it is usually very much forked comparatively low down, and often the stem is by no means straight. 


\section{THE NIGERIAN TIMBER TREES}

The root spurns are not very large, but spoil the shape of the bole at the base.

It is a slow-growing, shade-bearing, soil-protecting and soil-improving tree. Natural regeneration is poor, chiefly perhaps because the Duilka eat the fruit; in fact, the Benin name means the chop or food of Uso or Duika.

In 1906 samples of this timber were sold in the Liverpool market as a hardwood, which was considered hard and heavy. Since then none has been shipped, nor has it been felled for local use. Perhaps with the changed conditions in the demand for timber, both hard and soft, a further trial would now show whether it was of any value as an export timber.

\section{Pentadesma grandifolia.}

Distribution.-It is found in the Oban Reserve of the Calabar province of Nigeria.

Characteristics.-It is a medium-sized tree, with large oblong leaves having numerous glands and lateral nerves which are about a tenth of an inch apart. The leaves are larger and the exterior sepal shorter than in $P$. butyracea.

Silvicultural Qualities.-It grows in the evergreen forest, is a shade-bearer, and comparatively slow-growing tree.

Utility.-Although the fruit has not yet been collected, it it probable that the nuts would contain a similar oil to those of $P$. butyracece.

Pentadesma butyracece. Butter or Tallow Tree. Okarora, Ossa (Ondo); Ekuso (Yoruba) (Ikale); Ijeni Udegbu, Agba (west side), Udegbi (Benin); Orugbo erin (Ondo); Amu Ne (New Calabar); Ikakama Udia Ebian (Efik); Ikakama Udia Ebian, Igbofia (Ibibio); Ntini Nyok (Kwa).

Distribution.-It is found in the evergreen forests of the Jebu, Ode, Benin, Warri, Owerri and Calabar provinces of Nigeria. It is quite prevalent in its typical locality and very damp, almost swampy, regions of the forest near small waterways, even comparatively near the sea.

Chief Characteristics.-It is a thin, tall tree, with dark bark and flatly compressed crown consisting of four or five tiers of branches, very close together in almost true whorls. The foliage is very thick and the leaves thick and leathery. It exudes a mass of gamboge-like latex as soon as slashed, and the slash is orange-red. The latex solidifies on exposure to the air. The large pear-shaped fruit has a soft rind, which usually is pierced by the fall to the ground, and the Cola-shaped seeds are embedded in a soft, yellowish-white pulp. The large sepals at the base of the flower are quite typical, in their persistency often being found at the base of unripe fruit. 
Timber.-It has yellowish-white sapwood and light-red heartwood of firm texture, with a certain amount of waviness in it, especially if the tree has been barked in its earlier years. It is not hard, and is easy to work ; it does not appear to warp or shrink.

Silvicultural Qualities.-It is a shade-bearer with very persistent evergreen leaves. It will stand in waterlogged land and grow almost to perfection. The branches are also very persistent, and it is only when growing in close proximity to other heavy foliaged trees that the bole clears itself of branches for two-thirds of its length. The stump shoots sprout up when the tree is cut down. The more prevalent form of reproduction is by seed. The mature tree bears quite prolifically almost every year. The timber has not been felled for export, but the seeds are worth $f 8$ a ton on account of the oil that they contain, which is considered suitable for soapmaking.

Pentadesma Nigritana. Odgebu (west side) (Benin).

Distribution.-It is found in the Oban Reserve of the Calabar province of Nigeria.

Characteristics.-It is a medium-sized tree with black bark on the branches. The leaves are glabrous coriaceous, $3 \frac{1}{2}$ to $4 \frac{1}{2}$ inches long and 1 to $1 \frac{1}{2}$ inches broad.

Silvicultural Qualities.-It grows in the evergreen forests, is a shade-bearer and comparatively alow-growing tree.

Utility.-The fruit has not yet been collected, but, judging by the locality in which this tree is found, the seeds would contain similar quantities of oil to those of $\boldsymbol{P}$. butyracece.

Haronga Madagascariensis (Kew). Benin Roof-pole. Itue (Benin).

It is a non-indigenous tree (exotic) which is now found in the Abeokuta, Ibadan, Ondo, Benin, Warri, Owerri, Ogoja and Calabar provinces of Nigeria.

It is commonly seen growing up in old farms in the heavier soils of the evergreen and mixed deciduous forest zones. The slash, which is brick-red and exudes a yellowish-red latex, is most typical of this tree. The tree is almost gregarious, forming groups nearly half an acre in extent; the bark peels very easily, leaving a clean white stem which hardens very much on exposure to the air. It is a small tree, attaining a girth of about 2 feet and a height of about 40 feet. The wood is quite white, with a small pink pith about a quarter of an inch in diameter; it is a very light wood and most durable when under cover.

The leaves are of a medium size and rough to the touch. When 2 to 4 inches in diameter the natives cut the trees, clean 
and strip off the bark, and use them for rafters in house-building, especially in the Benin and Yoruba countries.

Symphonia globulifera (Kew). Hog Gum.

It was reported from the Calabar province.

Allanblackia floribunda. Orogbo erin (Yoruba); Izeni or Iyockan (Benin); Atta (Efik); Egba (Ibo, Owerri).

Distribution.-It is found in the evergreen forests of the Jebu Ode, Benin, Owerri (?) and Calabar (?) provinces of Nigeria. This tree usually grows on less moist soil and further away from water than $P$. butyracece, though it likes a moist and deep soil.

Chief Characteristics.-The long, hard, brown, enlarged sausage-shaped fruit hanging on a stalk shows, when cut, large seeds scattered in white pulp, and is thus different in this respect to Pentadesma, which has dark-brown seeds embedded in a soft, yellowish pulp. The slash is yellow, but only exudes a little yellow latex at first. The branches are not so verticillate in form as Pentadesma, but are more pendulous, especially when the tree is in fruit. They also are further apart and give the crown a more open appearance. The fruit is three times the length and the diameter rather more than that of $\boldsymbol{P}$. butyracee.

Timber.-The sapwood is whitish-yellow and the heartwood yellowish-red and moderately hard. It is not attacked by white ants; it does not split easily, but planes with a smooth surface. It is a medium-sized tree, reaching a height of about 80 feet, with a bole length of 20 feet and a girth of 8 feet.

Silvicultural Qualities.-It is a shade-bearer and grows comparatively slowly. Natural reproduction is chiefly by seed, though fine and succulent stump shoots appear when a tree is cut down.

The timber has not been exported nor has it been used locally; the natives occasionally cut the bark for medicinal purposes, but otherwise apparently have no use for the tree.

Ochrocarpus Africanus? sp. of Allanblackia. African Mammee Apple, Mahogany (Calabar). Igoda (Benin); Ereruku, Edeng Edem (Calabar); Baulan Bolo (Degema, New Calabar); Okut and Otun (Oban, Ekoi).

Distribution.-It is found in the Calabar, Owerri and Ogoja provinces of Nigeria, occurring sparsely in the evergreen forests in several localities, where it takes the place of Khaya, which is not prevalent in such places.

Chief Characteristics.-It is a large tree, with orangecoloured bark, especially in young specimens, and a little scaly. In habit otherwise rather like Mahogany, after which the 


\section{WEST AFRICAN FORESTS AND FORESTRY}

timber has been named. It is much harder and has little resin canals typical of the order. It is not attacked by white ants. It reaches a height of 100 feet, with a bole length of about 40 feet and a girth of 12 feet. The root spurns are only slight. The large, elongated, spherical-shaped fruit, with rough, pale orange-coloured rind, speckled brown in several places, is most typical of this tree. Generally speaking, it could easily be mistaken for Mahogany Entandrophragma by anyone not very familiar with both species.

T'imber.-The sapwood is white, with a pinkish tint, and the heartwood a dark red, with small medullary rays as well as very prominent resin-like canals which, when dry, are filled with a yellow substance.

Silvicultural Qualities.-It is a shade-bearer, but likes a certain amount of overhead light in middle age. On the whole it is slow-growing, except for a short period when the chief height-growth is put on. A few stump shoots sprout when the tree is cut down, but the more common form of reproduction is by seed.

Utility.-It has not been felled for export, but the Public Works Department felled and converted a good deal at the Etehetem sawmill, and it was favourably reported on as a hard mahogany. It has occasionally been used by the natives for making canoes.

No botanical name. Oshusi (Ibo, Owerri).

Distribution.-It is found in the Owerri province of Nigeria. It is a comparatively common tree in the evergreen swamp forest.

Characteristics.-The timber is not over hard, but it reaches a height of 100 feet and a girth of 8 feet. The bark is smooth.

Silvicultural Qualities.-It is a shade-bearer and a comparatively slow-growing tree. The most prevalent form of reproduction is by seed.

Utility.-It has not been felled for export, but was used in the construction of the Imo railway bridge as piles.

Buronona (New Calabar).

This is a medium-sized tree of the Owerri province, and is found near the Imo, not far from the railway bridge. Several piles of the temporary bridge were made from the timber of this tree.

Ochrocarpus sp.?. Ebattan, Ehranezi (Benin); Buronona (New Calabar).

Distribution.-It is found in the Owerri, Benin (?) and Ondo (?) provinces of Nigeria.

Chief Characteristics.-It is a very straight, thin-stemmed 


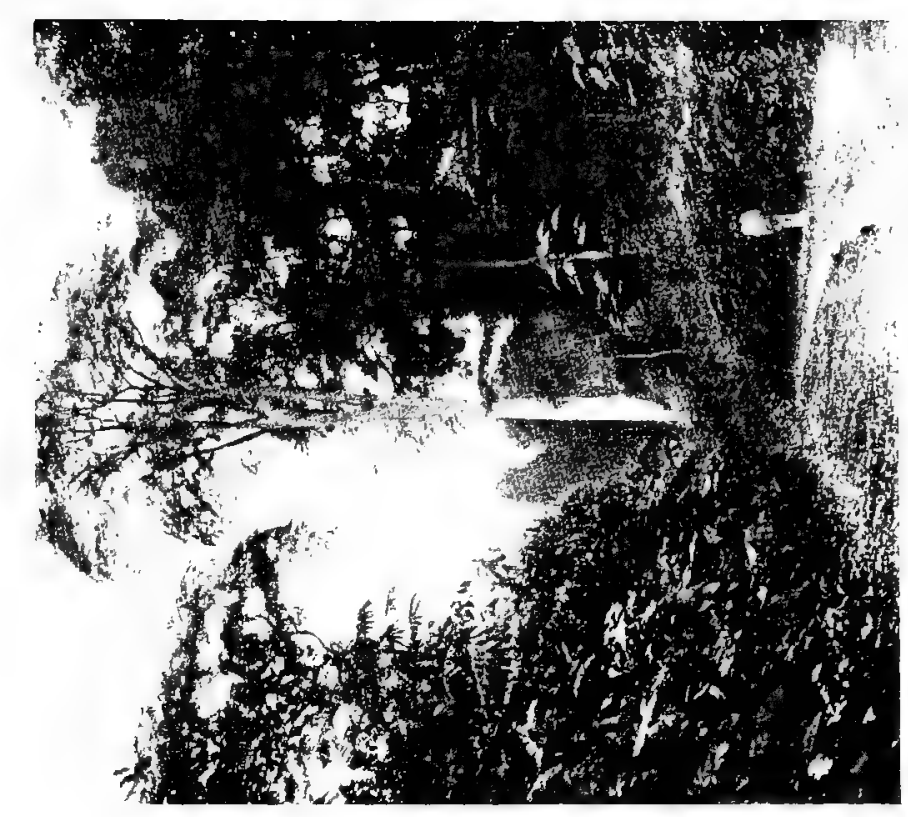

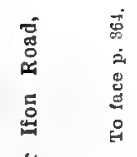

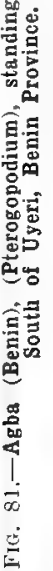

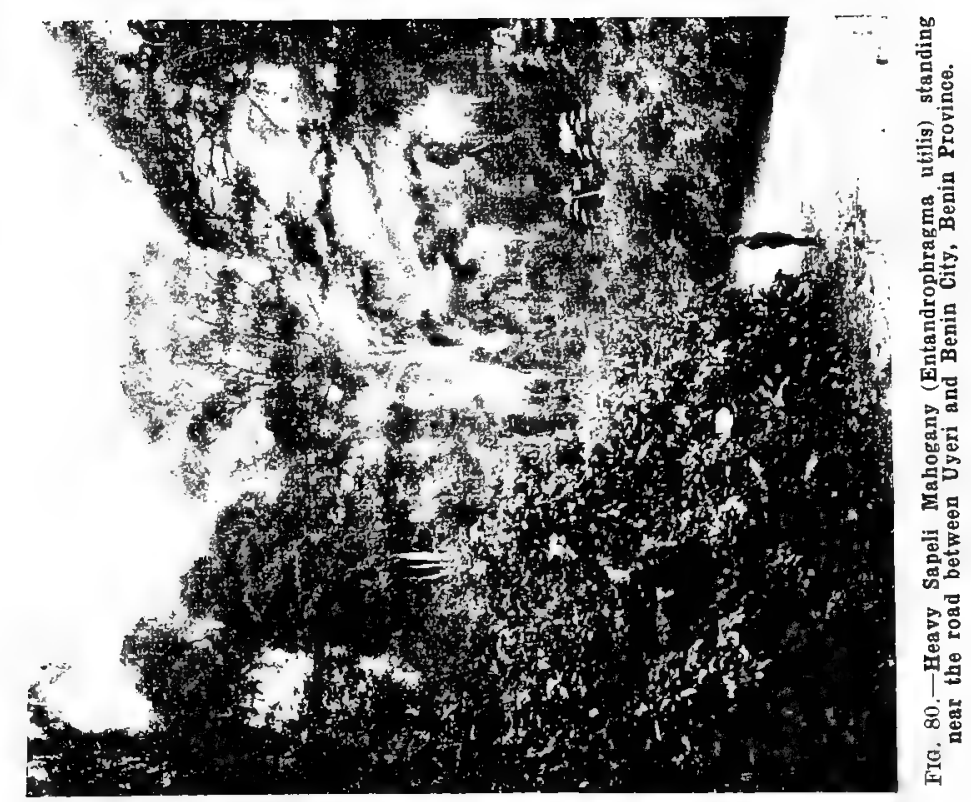



tree, with several whorls of branches near the top of the tree, very much compressed together. The flowers are red sprays, which look very pretty at the beginning of the dry season. It occurs near the freshwater swamps, comparatively close to the sea. In many places it is almost gregarious in habit, more especially near Degema. It reaches a height of 100 feet, and a girth of 6 feet, often with a bole length of 50 feet.

Timber.-The sapwood is white and the heartwood is light brown; both appear to be equally durable. It is termiteresisting. It planes with a smooth surface; the grain is very fine. A red latex exudes when it is cut.

Utility.-It is chiefly used for door and window frames, and does not warp nor crack, even when put in green. It attains a large enough size to be used as piles, some of which were used in the construction of the temporary railway bridge at Imo. The natives do not use the wood, and it has not been felled for export.

Silvicultural Qualities.-It is a shade-bearer and a comparatively slow-growing tree, though on less wet soils it seems to grow faster. The more prevalent form of reproduction is by seed. Weak stool shoots also come up after the tree is cut down. The foliage is dense and persists for several years.

\section{Biracex.}

Bixa orellana.

This tree grows well in the Olokemeji Arboretum. It is found up to a height of 10 feet, and is cultivated for the sake of its seeds, which yield the orange dye called "annatto." The tree bears pods very freely. Samples were sent to the Imperial Institute in 1906 and were valued at about 5d. a pound.

\section{Flacourtiacea.}

Smeathmannia pubescens. Moyida (Yoruba).

It is a medium-sized shrub found in the Western Provinces.

Soyauxia sp. Ogohomeh, Oyohomeh (Benin).

This tree was found on the mountain slope above Ogabi in the Obudu district. The fruit is edible.

Soyauxia sp. Aye (Yoruba); Owowe, Owawe (Benin).

It is found in the Ondo, Benin and Ogoja provinces of Nigeria, growing at the edge of the evergreen forest. It is a medium-sized tree, with a bole length of about 30 feet and a girth of 6 feet; on the whole, it is of more slender build and habit than the Terminalia, to which it is apparently closely allied. The flower is very small, white and spherical, being 
only a quarter of an inch in size; it is most frequently seen lying scattered about in patches on the path or roadway, giving out a very sweet scent. The seeds are double winged, like Bougainvillea. The leaf is smaller than that of the Terminalia and the foliage generally less dense; the sapwood is white and somewhat wide, the heartwood of a light-brown colour, and on the border-line of being a hardwood. The wood is not very durable unless under cover; it is not very common, though where it is found there are a fair number of trees which would form a good supply of timber for local purposes. The natives do not use this wood, as they say it is liable to attacks by white ants.

Oncoba dentata (Oliv.). Parisha (Yoruba).

It is found in the Abeokuta province of Nigeria. It is a small, shrub-like tree, armed with moderately long thorns. It belongs to the evergreen forest zone. The flowers are large, white and conspicuous.

Oncoba glauca (Foster). Kakandika (Yoruba).

Found in the Olokemeji and Abeokuta provinces.

Oncoba spinosa (Rich). Kakandika (Yoruba).

This is a small, shrub-like tree found in the Abeokuta province of Nigeria. It is moderately common, and several hedges have been made with it in the Olokemeji Arboretum. The most distinguishing feature of this plant is the large, spherical-shaped white flowers. The petals are large and conspicuous, with a mass of yellow stamens in the centre. In habit it is not unlike the thorn; the ends of the twigs are armed with a short spike.

It stands trimming pretty well. Each year it flowers fairly regularly, so that it makes quite an ornamental plant. It bears green fruits with a conspicuous bunch of the old sepals at the top. This fruit is rather smaller than a tangerine orange, but quite spherical in shape, with a hard, woody rind.

Flacourtia Ramontchii. Abeokuta Plum. Oshere (Yoruba).

It is found in the Olokemeji Reserve of the Abeokuta province of Nigeria.

Flacourtia flabescens (Kew). Niger Plum.

Found in the Western Provinces.

Uses.-Edible plums, medicine and hedge plants.

Homalium, cf. H. Africanum (Benth.). Atu or Abo Ako (Yoruba).

This is a hard-wooded tree of the Yoruba country, which is used to some extent locally. It is also found in Benin.

Being a shade-bearing and soil-protecting tree, it is of value in the forest, apart from the production of timber. It is a slow-growing tree apparently. 


\section{Lecythidaceæ.}

Napoleona Whitfieldii. Ito (? Yoruba); Uruhe (Benin).

It is doubtful if these are the correct native names for this species.

Napoleona imperialis. Speckle-fruited Napoleona. Boi Boi (Yoruba).

It is found near Ode district, Oban and Igbeshe, in the Ibadan and Abeokuta provinces of Nigeria.

It is a deciduous shrub with pretty white flowers, very shiny leaves, which are alternate, and bears a spherical, orangecoloured fruit (with a russet-like surface having white lenticels scattered nearly all over it), which ripens in March at the Olokemeji Reserve.

This shrub protects and enriches the soil with its fall of leaves. Considering the attractiveness of the flower and the fruit, it is surprising that it has not more frequently been planted in gardens, where it should be placed in a shady corner. It is slow-growing, and does not need much light. It likes a moist, fairly deep. good soil, especially near a river bank.

Native Use.-The stem is occasionally used for making hoe or axe handles, for which it is suitable, as the wood is comparatively tough, close-grained and hard. The knottiness of it is an advantage either for the handle or for fixing the hoe or axe head.

Napoleona Vogelii (Hook). Orokwa, Ogemme (Benin).

It is a common tree in the Calabar, Benin, Ibadan and Abeokuta provinces of Nigeria.

Chief Characteristics.-It is a medium-sized shrub-like tree, with orange-shaped fruit, though not quite spherical, having small white lenticels on the surface and roughness like a russet apple. It does not attain a girth of more than 3 or 4 feet. It is usually found in the mixed deciduous forests, though more often in clearings in the forests; however, it stands a good deal of shade. The wood is comparatively hard, but it does not reach much size. The tree protects and enriches the soil with its fall of leaves, and serves a very useful purpose as a shrub amongst the undergrowth of the forest. It might be planted in gardens, where both the flower, which is large and white, and the fruit would be admired. It usually bears a large number of both. It is rather a slow-growing tree. The natives use the wood for making matchet handles.

Napoleona Owariensis. Adere, Isiurem (Lagos).

Found in the Olokemeji Reserve. 


\section{Rhizophoracex.}

Weihea sp. (Spreng). Odu (Yoruba).

This tree is found in tropical West Africa.

The flowers have an involucre of two bracteoles. The fruit is fleshy; seeds with an aril.

Weihea $8 p$., cf. Africana. Odu (Yoruba); Itobo (Ibibio); Munon (Efik).

This tree grows near Lagos.

Rhizophora racemosa. Red Mangrove or Salt Mangrove. Egba Ibadudu (Jeb. Yoruba); Ehrodo, Ibadudu (Benin); Odo (Jekri).

Poga oleosa. Inoi Nut, African Brazil Nut. Iku (Yoruba); İnoi (Benin); Inoye (Efik); Ikoi (Oban); Inoi (Ekoi); Ekom (Ibo Owerri); Imonon (New Calabar).

It is found in the Benin (?), Owerri, Calabar and Ogoja (?) provinces of Nigeria, in the evergreen zone, both of the level and hill country. On the whole, it is more prevalent as the eastward side of the country is approached. In the forest its presence is usually indicated by the heaps of broken shells left lying near the roots of neighbouring trees, on the path or roadside. The reddish-brown interior and cross-section of the inner covering of the shell is a most typical feature. The nut itself is roughly spherical in shape, with a surface almost evenly covered with little nodules, giving the nut very considerable resiliency against cracking. It is nearly half an inch thick, and inside there are two or three kernels. Each of these is a chocolate-brown colour with thick (almost three thirty-seconds to one-eighth of an inch) red-brown shell. Each is about $\frac{1}{2}$ inch long and rather more than $\frac{1}{4}$ inch thick. This thick shell quite spoils the flavour of the nut, which is sweeter and contains more oil than the Brazil nut. It can, however, be removed with a pen-knife. The trunk of the tree is lightgrey, with comparatively thin cortex. It reaches a girth of about 12 feet and a bole length of about 60 feet. It usually forks at about 50 or 60 feet from the ground, and this is one of the typical features of the tree. The crown is rather open, with several main limbs and comparatively fow branches. Another place where it is commonly seen, both in the Degema and Calabar districts, is in the old farms, standing as isolated specimens, or standards overshadowing all the secondary growth. It is one of the few trees that are preserved when a fresh clearing is made for a farm. The fruit is the shape of a large greengage, the fleshy part of which soon breaks away, leaving the hard nut inside. The fleshy pericarp is about a quarter of an inch in thickness. 
The sapwood is white, tinged with pinkish stripes, and the heartwood pinkish-red, with very wide and numerous medullary rays, which are most numerous, and in fact more so than in any other tree, and are very typical of this timber. The wood is soft, splits well, is of somewhat open texture and rather fibrous grain. It planes up well with a smooth surface, takes nails well, and saws well. It is liable to be attacked by white ants. The sapwood is fairly narrow.

It is a moderately fast-growing, shade-bearing, soil-protecting and soil-improving tree. Natural regeneration only appears to be slight, chiefly owing to the fact, perhaps, that most of the nuts are gathered and eaten by the natives. It is somewhat exacting with regard to soil. It appears to like one that is somewhat rich, deep, moist and with good drainage. In waterlogged areas it becomes stag-headed. No plantations have been made of this tree.

The timber has not been exported, not has it. been cut for local use. It appears, however, to be worthy of a trial as a substitute for light cedar or mahogany, especially from wind falls, which are not infrequent owing to the way it is left standing in the forests.

Native Use.-The nuts are used by the natives, and are considered very valuable, in the most out-of-the-way parts of the forest, as a source of food. They used to be sold in the Calabar market 250 for 3d. Further notes as to the oilbearing properties of this nut will be found in the section dealing with the oil seeds and nuts.

\section{Combretacer.}

Terminalia sp. Yellow Terminalia, Black-bark Terminalia. Idigbo, Opepe, Epepe (Yoruba); Egoyn nebbi, Egoyn nikwi, Egoyn lukan (Benin).

According to the Yorubas this is the Idi of the forest.

Distribution.-It is found in the Ondo and Benin provinces of Nigeria.

Chief Characteristics.-It has a slightly fissured bark, increasing in age, light-brown in colour in youth, but darkening with age, almost appearing black in the distance, rather forming a criss-cross pattern. It flowers in May with small spikes or thin, stiff racemes, each with little yellow balls of staminate flowers. It has a compressed crown of two or three whorls of branches, but not so typical as that of $T$. scutifera. It is, however, much more widespreading, chiefly due to the fact that the tree on the whole is shorter and stouter than $T$. scutifera. The trunk is much more cylindrical, and the root 
spurns are very slight, and not buttress-shaped as in $T$. scutifera. The contrast between the light-green foliage and the darkcoloured bole is so great that the tree is quite unmistakable in this respect. The only one at all similar in this is False Shea Butter, Mimusops Djave, but even the trunk of this one appears lighter than the former. The slash is dark-brown, almost black, on the outer edge and yellow on the inside. The fruit is not unlike a large hazelnut, but the shuck is of looser build, and the interior seed can be more easily seen than in the case of the nut.

The sapwood is a faint yellow colour and the heartwood a good yellow. It is of the hardness of an ordinary softwood, with a straight, even grain and somewhat open pores. It planes well, takes nails, splits very easily and saws well. For outside work it is not durable unless very thoroughly dried. For interior fittings it is very durable. It is liable to attacks by termites outside. It seasons well, with only a small amount of shrinkage and slight liability to warping.

It is a fast-growing, slightly shade-bearing tree, with strong soil-protecting and soil-improving qualities. Natural regeneration appears to be fair. It sprouts from the stump, but is not very strong. It likes a good soil, with fair drainage but a good deal of moisture. It will stand a certain amount of flooding. It is occasionally almost gregarious. No plantations have been made with this tree. It reaches a girth of over 14 feet and a bole length of about 70 feet.

The timber has not been cut for export, but occasionally it has been sawn up for planks for local use. It deserves, however, a further trial for export as a floor-board and for local use for a similar purpose. There are comparatively large supplies, and the dimensions of the tree are such that large planks and boards could be cut out of it.

Native Use.-The tree is occasionally felled for making canoes, but it is not taken unless there is a shortage of other harder kinds.

Terminalia sp. Orange-barked Terminalia. Ayo, Aiyo (Yoruba); Ayo, Ulazo (Benin).

Distribution.-Ibadan and Abeokuta provinces of Nigeria. It is one of the typical trees of the mixed deciduous forest zone, though it appears to be confined to certain localities, such as the Olokemeji Forest Reserve and other places.

Chief Characteristics.-Moderately thick bark, rather reminding one of Triplochiton, but with a certain amount of roughness and slight fissures. The crown is very pointedly oval and long, the leaves appearing only slightly terminal and not 


\section{THE NIGERIAN TIMBER TREES}

typically so. The branches tend to flatten out in old age, though they are slightly pendulous at the tips. The bole reaches a girth of about 10 feet and a height of 50 feet. The light patchy, orange-coloured bark is a most typical feature of this tree. Satinwood is the only one at all similar in this respect, but it is much smoother.

Timber.-White, with a faint yellow tint; the pores are much shorter than those of the other Terminalias, such as $T$. scutifera and Togoensis. The grain on the whole is finer and of closer texture. The timber is somewhat harder than either $T$. ocutifera or T. sp., but not so hard as that of T. Togoensis. It planes well, takes nails, saws easily, but does not split so well. It is attacked by termites, but is durable for interior work. It is somewhat more brittle than $T . s p$.

It is a moderately rapid growing, light-demanding tree, with soil-protecting and soil-improving qualities. Natural regeneration does not appear to be good. It sprouts, but poorly from the stump, and if at all shaded dies away. It likes a moderately good soil, with a fair amount of moisture and depth.

The timber has not been cut for export, and only occasionally has it been felled for cutting into planks for local use. It deserves, however, a trial as a local flooring board. The available quantities so far discovered are not large enough to justify its trial as an export wood.

Utility.-The wood is used for planks and for canoes. It is likely to furnish timber for the home markets.

Local Use.-It has been used for making canoes, and also for sawing up into planks for house-building.

Terminalia scutifera. Shingle Wood. Afara (Yoruba); Oaha Egoyn, Egoyn nufwa (Benin).

It is a common tree in the Calabar, Ogoja, Owerri, Warri, Benin, Ondo and Abeokuta provinces of Nigeria.

The chief characteristics of this tree are the thin and far up-reaching root flanges and its thin, grey-coloured bark. It attains a height of about 200 feet and a girth of about 16 feet. The bole length often exceeds 100 feet. The crown is compressed and flat, with few main branohes. It is usually found near water.

The timber is light-brown to almost yellowish-white, with darker streaks. The sapwood is almost white, but when dry is barely distinguishable from the heartwood, though when freshly out the heartwood appears drier, and thus shows up against the damper sapwood. The wood is soft and planes easily, though not always giving a smooth surface. It is also 
easy to saw or cut with a chisel and splits well. It is attacked by termites.

On the whole the tree is a light-lover, and even the young self-sown seedlings only grow in comparatively open places near rivers, where there is no shade directly over them, though there may be trees to one side or the other. It is one of the typical trees of the evergreen and mixed deciduous zone, growing always on damp and deep soil. Natural reproduction by seed is good. Stool shoots grow, but do not persist for a great length of time. It often forms small pure groups in the secondary forest, and in suitable localities tends to be more prevalent in the secondary than in the primeval forest.

In Nigeria it has been used as planks, but is not considered very good. On the Gold Coast it has been used for shingles.

The natives occasionally use the tree for making canoes, also for bowls, plates, and native doors in the Benin country, but owing to its softness it is not considered of much account.

In figure No. 108 there is a picture of a very large specimen found in the Ikrigon Forest Reserve.

Terminalia Togoensis. Dry-zone Terminalia. Idi, Idi Odan (Yoruba).

Found in the Oyo, Benin and Ogoja provinces of Nigeria. It is a very common tree, with slight foliage and small stem, which is usually forked about 10 feet from the ground. The slash is yellow and almost dry, which is most typical of the tree.

The wood is soft, though harder than most of the other Terminalias. It works easily, but does not split well. The sapwood is white and the heartwood of a pale yellow colour. The bark is rough and widely fissured. Natural regeneration by seed does not appear to be good, though stump shoots appear when the tree is cut down. It stands a considerable amount of fire, but it is a light-loving tree.

The local people find the stem useful for house-building posts, as it is comparatively durable and forked in shape.

Terminalia avicennioides.

It was stated it was found in the Calabar province.

Terminalia Brownii. Inya joko (Yoruba).

Found in the Abeokuta province.

Combretum racemosum. Ogan pupa (Yoruba); Akoso, Orsorsor (Benin).

Found in Olokemeji and Benin. Climbing shrub with red flowers and white bracts.

Combretum Lawsonianum. Ome (Benin).

It has red flowers and is found at Agege. 
Combretum mucronatum. Okan pupa (Yoruba).

It is found in the Mamu Forest.

Combretum Zenkeri. Ogan (Yoruba).

It is found in the Yoruba country.

Combretum micranthum. Okan (Yoruba).

It is found in the Yoruba country.

Combretum glutinosum.

Combretum paucinervium.

Combretum Hartmannium.

These are climbing Combretums found in the Yoruba country.

Anogeissus leiocarpus (G. and P.). Yoruba Chew-stick. Ayin (Yoruba).

Distribution.-It is found in the Oyo and Abeokuta provinces of Nigeria.

Chief Characteristics.-This tree reaches a height of about 70 feet in favourable localities and a girth of 9 feet. With its birch-like foliage and the drooping and sweeping of the pendulous branches in old age, it is certainly the "Lady" of the African "open woods." The little spherical fruits cover the ground in the early part of the dry season. The comparatively smooth bole, giving way to small scales of lightbrown bark as the tree gets older, is a typical feature. It is often forked, especially low down. The bole is thin and slender in build, with upward tending branches, also very slender in build, but dark in colour. A blackish gum exudes when it is cut. The slash is yellow before the gum runs out.

Timber.-The sapwood is yellowish-white and the heartwood dark-brown to almost black in some specimens. It is hard, durable and termite-proof. It does not plane nor split well, takes nails with difficulty, but saws fairly easily.

Silvicultural Qualities.-It is a light-loving species, though in its youth it will stand a little shade. It is one of the first trees to appear on disused land, so long as the soil is good. Its foliage is a little acid, as it kills all grass, even Ekon, and for this purpose is invaluable as a tree for admixture with more valuable species. It is somewhat exacting as to soil.

Once it gets started after being planted, or as a self-sown seedling on good soil, it is a rapid-growing tree, which is only hindered in its growth by the annually recurring grass-fires. Wherever it is protected it develops into a straight-boled, large tree. The branches are very persistent, so that close planting is most necessary. Several plantations have been made with this tree.

Utility.-The tree is burnt for its ashes for fixing native 


\section{WEST AFRICAN FORESTS AND FORESTRY}

dyes; the roots are used for chewing-sticks, and the bark is used medicinally by the natives.

It yields a good firewood which gives great heat. The smaller poles make very useful hut-building timber, as it is so often forked.

It should find a place as an avenue tree, owing to the delicate green, the drooping nature of its foliage, and the moderate amount of shade cast on the road.

The timber has not been tried for export, but with its dark black and sometimes streaky coloration it is worthy of a trial. Locally it has occasionally been cut for planks and for house-building. It is not liked because it is so hard. The sapwood is rather wide. The timber is sometimes rather knotty, especially containing dry knots. It is sometimes attacked by a large borer, making large holes in it.

Laguncularia racemosa. White Mangrove or White Button.

This species is found growing in the swamp regions, also on the coast. It yields timber, tanning, dyeing materials and medicaments.

\section{Myrtaces.}

Eugenia Owariensis (Beauv.). West African Allspice. Adere (Yoruba).

It is a common tree of the Olokemeji Reserve and the Abeokuta and Oyo provinces.

With its comparatively short bole (about 8 feet) and wide, almost spherically-shaped crown, it is one of the largest and most conspicuous of the dry-zone trees. The tree attracts the pigeons, but not so much as the wild fig. The flowers are very minute and insignificant. The fruit is very small and poor.

Reaching only a girth of about 4 feet, it does not yield very large timber. Although moderately hard and durable, it has not yet found a place in the local market. It is doubtful if it is termite-proof. It might be used for making boxes or for small articles of furniture in localities where wood is searce.

It is a comparatively olow-growing tree, almost soilimproving, and of a light-loving nature.

Owing to its comparatively dense foliage partially shading the ground and thus killing the grass, it is a distinctly helpful species in the protection from fire of a dry-zone forest.

Natural reproduction by seed is only moderate, but stump shoots are strong, and it appears that root suckers also come up in certain places. 


\section{THE NIGERIAN TIMBER TREES}

Eugenia Owariensis. Isinren (Yoruba).

This tree is found in the dry-zone forests -a spreading tree which flowers in February.

It yields timber, edible fruits and medicaments.

\section{Melastomacex.}

Memecylon sp., nr. Barterii.

It is found in the Olokemeji Reserve in the Abeokuta province of Nigeria.

\section{Araliacex.}

Cussonia Nigerica (Hutch.). Elephant Sugar-cane. Sigo (Yoruba). This is an evenly and rather deeply fissured small tree of the dry-zone forest, which has in the main only a great tuft of large digitate leaves at the top of the stem. It is occasionally branched, when it gives an appearance of bearing all the leaves at the end of the stem. It is fairly common in the Olokemeji Forest Reserve of the Abeokuta province. This tree is one of the few digitate-leaved trees of the dry zone, and is certainly one with the largest; it is a fire-resisting tree. The natives occasionally use the stem for house and verandah posts.

\section{Umbelliferæ.}

Heptapleura Mannii. Found in the Oban Reserve.

\section{Sapotacex.}

Mimusops multinervis. Emido or Sleeper Wood. Ako Emido (Yoruba); Aganokwi (Benin).

This species is found in the Abeokuta and Oyo provinces of Nigeria; it is most common, and, in fact, forms almost half the crop in the belt of forest just on the south side of the railway four to six miles east and west of Olokemeji Station. The most distinguishing feature of this tree is the grey, thick, deeply-fissured bark. With its comparatively short bole and stout, crooked branches, it is not unlike an oak. It reaches a height of about 80 feet and a girth of about 15 feet. The root spurns are practically non-existent. The trunk tapers off quite abruptly after each series of branches. The crown is rather long and sometimes almost pear-shaped. The foliage is dense, and, for the size of the tree, the leaves are small. The flowers are small and white and conspicuous. The fruit is a small round nut, about half an inch in diameter. The leaves are a very dark green colour, but on the upper surface are often shing. 
The sapwood is white and, for the size of the tree, comparatively narrow. The heartwood is a deep red colour, which it retains even after the wood is dry. In sections from older trees it exhibits isolated white streaks, scattered here and there through the heartwood. This is made of a small mineral deposit which is closely allied to apatite. It is one of the hardest of the African woods and also the most durable; it splits most satisfactorily; it saws very cleanly, planes well, but owing to its extreme hardness takes nails with difficulty. It is termite-proof. It is just as durable in, as out of the ground. It burns with a fierce heat and, in fact, makes the hottest fire of any of the West African woods. The grain is very close, though sometimes it shows some figure. The knots in the wood produce some pretty " curl" effects.

The tree is a shade-bearing, soil-improving species of the mixed deciduous forest. It is very slow-growing, often not showing a greater height-growth than 6 inches per year. In its youth the branches grow more or less in whorls of three or four branches; these branches are very persistent. Natural generation good ; it demands a good soil, but will stand a great deal of moisture, not to say flooding of the area for several months of the year. It flowers in February; the roots are comparatively deep-growing and there is a distinct tap-root. Some plantations have been made with this tree. It has been tried as a species to mix with ebony, and for this it seems suitable. In similar localities this species and ebony are often found.

Locally it is used as a house-building wood and occasionally for firewood. The timber has been cut up into sleepers and found to be most durable. When it was used in an unseasoned state, and in very dry territory, it was found to split-but this was scarcely a fair test of the wood. It has also been used as joists and for the framework of buildings, for which purposes it has proved very useful. Local carpenters have complained about its hardness, but usually the tools used have not been of such high quality necessary to give the best results when working on this wood.

The timber has not been used for export, but it deserves a trial, especially for railway sleepers.

Mimusops Djave. African Pearwood, False Shea Butter Nut, Cross River Nut. Aganokwi No. I. (Benin), Nyam (Efik).

It is found in the Benin, Owerri, Calabar and Ogoja provinces of Nigeria. It is also known as Cherry Mahogany. It is a moderately common tree in the evergreen forest zone, up to the end of the mixed deciduous forest zone. It is 

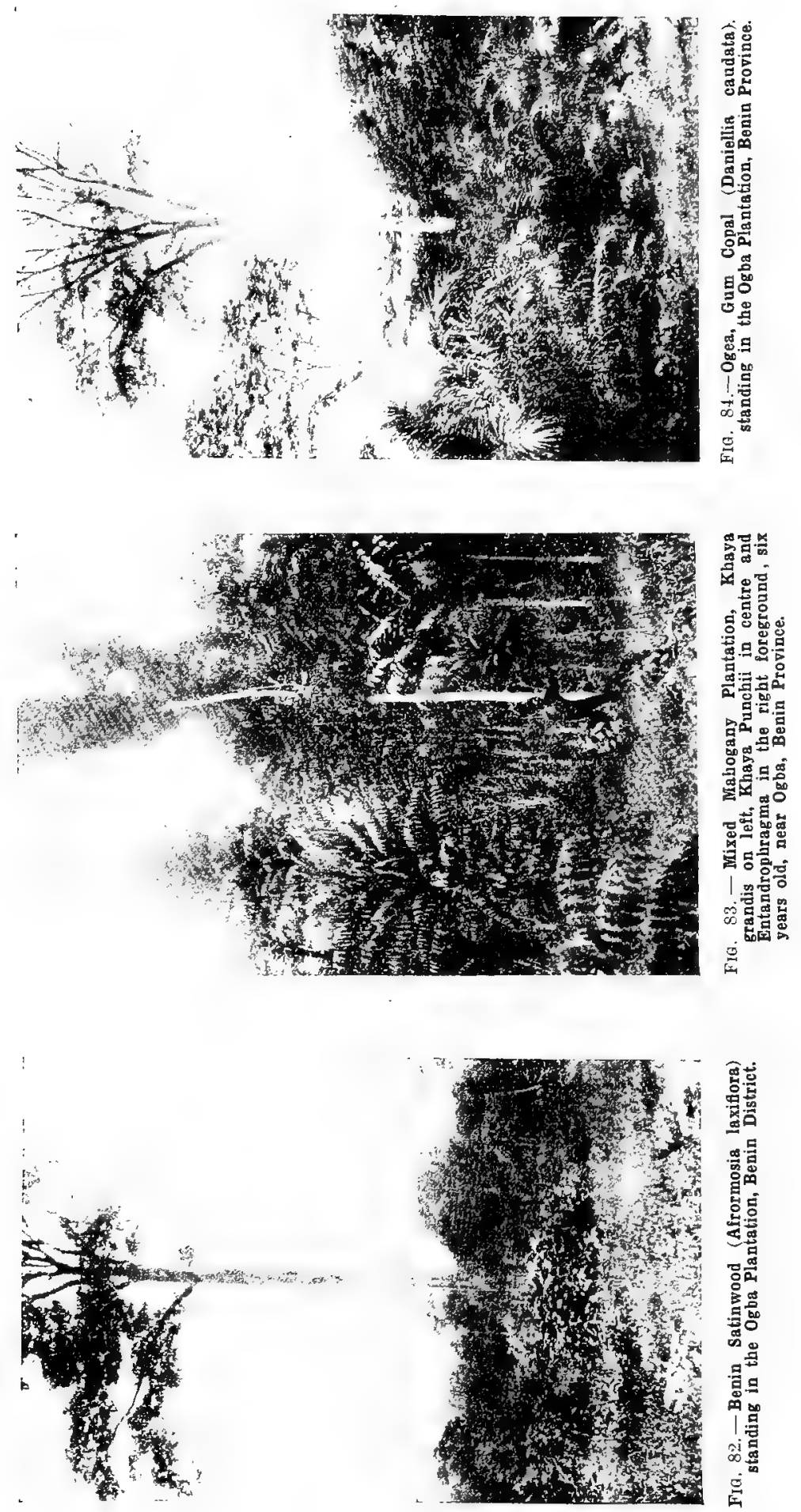

one of the giant forest trees, attaining a girth of over 30 feet and a height of over 200 feet; its bole is one of the straightest of African trees, the trunk often reaching over 100 feet without a branch. The crown is flattish and almost symmetrical in its roundness; it is formed with three or four main limbs spreading out at almost right angles to the trunk. The foliage is heavy and the sword-shaped leaves almost appear as though they were digitate, looking at them from the base of the tree. From a short distance the trunk looks almost black, but on closer inspection the bark is seen to be deeply fissured in a comparatively even lattice-work fashion. The slash is white and a thick white latex exudes. The root spurns are only slight, except in old age; otherwise the bole is one of the most cylindrical of African trees. (In illustration No. 100 a tree of about 8 feet in girth shows the very straight and even thickness of the bole.) The fruit falls to the ground about the beginning of November, and crushes on contact with the ground, showing the yellow floury pulp inside. The pulp has an extremely dry, sweet, almost nauseating taste and is inclined to stick in the throat. This huge fruit, the size of a man's fist, is almost like a huge plum, with rough opaque surface and almost spherical in shape ; inside, embedded in the pulp, are two, three or four lobed nuts, smooth and shiny on the more rounded face and rough on the other; in some respects they are roughly kidney-shaped when looked at sideways. The flowers are white and small ; the tree loses its leaves for three or four days, when fresh ones come out again.

The sapwood is white and the heartwood of a rich red colour, often showing figured rosy grain ; it is very hard, heavy and very durable, and is sometimes cross-grained, though usually the texture is fine and planes up with a smooth surface; it saws well, but is too hard to take nails, except in very thin wood. The sapwood is usually only two or three inches wide; the heartwood forms comparatively early in the life of the tree. On the whole, this tree has a more open grain than the other Mimusops.

Although the tree can stand a little shade in its youth, it is really a light-loving species : after the first year the heightgrowth rapidly increases when trees standing in a plantation have plenty of light. In illustration No. 93 some trees only twelve years old show how rapidly they develop under suitable conditions. None of these trees have yet come into the nut-bearing stage, but it appears that in favourable localities the trees will bear fruit between the fifteenth and twentieth year.

It is a soil protecting and improving tree-in fact, the thick 


\section{WEST AFRICAN FORESTS AND FORESTRY}

leaves form some of the finest soil found in the forest. Natural regeneration is not usually very good, because the seedlings have little or no light, growing as they do from seeds which have fallen under the parent tree. Duika and various other animals spread the seeds in old farms where the trees have a chance of growing up. The timber has occasionally been shipped to Europe and has been sold at Hamburg as pearwood at 6d. per superficial foot, but the more rosy and figured wood has also found a sale in Liverpool, as it sometimes looks almost like a pinkish mahogany ; it is, however, by no means well known, and further trials with the wood should certainly be made. Small consignments of the nuts have been exported from the Cross River and sold in Liverpool as a substitute for Shea nuts; they are found to be of a similar nature and of similar value for making an edible oil. The original cost was rather high, so that the nuts did not yield a profit on the transaction; however, with greater quantities being brought the cost should not be so high, and also, since this first experiment was made, the price of all oil nuts has risen enormously, so that at the present time there is an ample margin between the cost of production and the selling price. In the Cameroons the Balong natives dry the nuts, which they split open in two pieces, pick off the thin shell and boil out the thick buttery-like substance, which is used for cooking.

On our tour through their country we also tried it in place of lard, and found it quite suitable and quite pleasant to the taste and only about half the cost. In Nigeria, only the Oban people apparently know anything about making this butter from the nuts; in other parts it is quite unknown. The tree is not felled, but, on account of its size and all-inspiring form, is considered "Ju-ju"; pieces of the bark are chipped off and used as medicine to increase a person's strength.

By the way, the constant cutting away of the bark at the base of the tree and the continual struggle of the tree to overgrow these wounds causes the grain to grow quite unevenly and wavering, thus forming figured wood.

Mimusops lacera. Benin Pearwood. Aganokwi (Benin).

In 1906 samples of this timber were sold in the Liverpool market as mahogany of a good, rich colour. It is found in the swamps near the Osse and Cross Rivers.

Dumoria Heckeli (A. Chev.). Oban Mahogany.

It is found in Tropical West Africa. It yields a fair timber. An immense tree of the Oban Reserve, similar to Mimusops Djave. 
Omphalocarpum procerum. Ikassa (Benin), Apassa, Ukpassa (Efik). It is found in the Calabar, Benin and Ondo provinces of Nigeria.

It is a common tree of the evergreen forest. It reaches a height of 60 feet with a girth of 28 feet. The bole is short and the crown long, but narrow. The huge, flatly sphericallyshaped fruits, quite 9 inches in diameter and 6 inches thick, are most characteristic of the tree. These protrude just from the trunk or heary branches with little or no stalk. The depression in them, top and bottom, is quite an inch deep. There are about sixty seeds inside, more like nuts. The leaf is large.

The sapwood is white and heartwood is brown-red. It is very hard.

It grows slowly and stands the shade. The seeds germinate well. It does not sprout from the stump nor do root shoots appear. Elephants and other animals, porcupines especially, eat the fruit.

The seeds are used in playing Ikbo, a Benin game. The seeds also are used, tied in front of Apata sticks, for making a musical instrument, or tied to the ankles of small boys to make a noise like a rattle when they start to walk.

Butyrospermum Parkii. Shea Butter Tree, Dry-zone Oak. Emiemi or Emi-gidi (Yoruba).

This is one of the most prevalent trees of the Oyo province of the Southern Provinces of Nigeria and of the Borgu, Niger and Nassarawa provinces of the Northern Provinces of Nigeria. In places it is almost gregarious, but it is most commonly found in mixture with the Dwarf Red Ironwood, Lophira alata. In appearance it is most like a gnarled old oak, except that the base is often burnt and partially hollow. It is a large tree, reaching a height of about 40 feet and a girth of over 10 feet. The root spurns are comparatively short and rounded ; the bole is short, attaining a length of up to 25 feet ; the crown is almost spherical, but rather inclined to be broken up by three or four main branches; these are very thick in comparison to the size of the tree, but not so much in proportion as in the case of the Baobab. The bark is grey and very deeply fissured, more or less in criss-cross fashion, and even with deeper and wider fissures than that of the oak. The slash is white, and a small amount of thick white latex exudes very slowly from the cut. In the case of the Dwarf Ironwood scarcely any ordinary sap exudes and no latex. The leaves are about 10 inches long, a very dark green and shiny, and not unlike the hart's-tongue fern, but somewhat broader at the end; the greenness of the leaves, their shininess, and the greater thickness dis- 
tinguish them from those of the Dwarf Red Ironwood. The under surface of the leaf is whitish, sometimes almost grey ; the flowers are white and come out in December; the fruit is like a small green plum and ripens in May. The leaves persist over one season. The green pericarp covering the nut can be eaten and is not unpleasant to the taste. The nut itself is not unlike a chestnut in its being brown and shiny; the shape, however, is more oval, with one comparatively sharp ridge.

The sapwood is white and comparatively wide ; the heartwood is a rich dark-red colour; it is very hard and durable; it is termite-proof; it splits very badly, does not take nails well ; it is hard to plane and is sawn none too easily. It does not warp or crack to any extent while it is seasoning under proper conditions; it burns with great heat, but rather less than in the case of Emido.

It is a rather slow-growing tree, with soil-protecting and soilimproving qualities; as a light-loving species takes up a good deal of space. Natural regeneration appears to be poor, and may be due to the fact that the flowers appear, or before the young fruit has only just set, as the annual grass-fires run through the open deciduous forests where this tree is found. On the other hand, root suckers grow in great profusion. It also sprouts well from the stump. It is one of the most fire-resisting trees, and the thick bark no doubt protects it from its worst ravages. It may be considered one of the most typical trees of the drier parts of the open deciduous forests. A few sample plots have been tried with this tree, but it does not stand transplanting at all well. Rodents such as the cut-grass (ground pig) are very fond of the nuts, and no doubt destroy a great number whilst they are germinating. Fire-protecting root suckers and other young trees have thus far proved the most effective method of increasing the number of mature trees. It does not appear to be very exacting as to soil, but no doubt the growth is best on moist alluvial flats so long as they are well drained.

Locally the most valuable part of the tree is the nut, from which the Shea butter is boiled out after three days; it is a general article of diet instead of palm oil, in those districts where the latter is hard to obtain. Locally, also, the largest trees are cut down and made into mortars for beating food; these fetch a price of 2s. 6d. to 3s. 6d. apiece; they are considered not only the most suitable, but also the most durable, except those made of the wood of the Oil Bean (Pentaclethra macrophylla). In other places it is used as a house-building timber. 
As far as Europeans are concerned, the chief value of the tree lies in its nuts, which are either exported quite unprepared or in the form of the butter as the natives make it, in large elliptical-shaped sausages about 2 feet long and 9 inches in diameter. For these purposes it has become a regular article of commerce, and only lack of suitable means of transport prevents much greater quantities being collected and exported to the European markets. In Europe its most suitable use is said to be as a medium or inside substance of chocolate creams. The butter itself has a most peculiar and rather nauseating flavour, which is removed on its being refined and purified. The timber has not been tried for export.

Chrysophyllum sp. ?. Round Star Apple. A species of Star Apple. Agoma (Benin).

The fruit is quite spherical and supposed to be larger than C. Africanum. It is somewhat similar to $C$. Kainato. The natives squeeze the fruit in order to eat it.

Chrysophyllum Africanum. African Star Apple or Edible Star Apple. Osangbalumo (Yoruba); Otien (Benin).

It is found in the Abeokuta, Ondo, Benin, Warri, Owerri, and Calabar provinces of Nigeria. It is a medium-sized tree, often found growing at the roadside at the edge of the villages or as an avenue leading up to them.

The most characteristic feature of this tree is the silvery underside of the leaf, which is formed by minute white hairs. In the fruiting season, another characteristic is the goldencoloured, pointedly pear-shaped fruit, which bursts on falling to the ground. A white latex exudes from the fruit ; this latex is sucked out and is tartly sweet to the taste. Inside the fruit are five thin, elliptic-shaped seeds; these are brown and very shiny. Their position inside the fruit probably gave rise to the English name.

The wood is white and soft; it cuts easily and planes well, but does not split well. The grain of the timber is fine and the texture smooth. It is a moderately fast growing tree and the wood is not durable. The slash is white, and the tree exudes a white latex when cut; the foliage is very dense, and the dark upper surface of the leaves is a great contrast to the underside. It is a soil-protecting and soil-improving tree. The timber has not been exported to Europe. It is occasionally used by the natives for making " Ju-jus" such as the devil.

Chrysophyllum sp. Monkey Star Apple or Monkey Otien. Osang Palambi, Osang Edan (Yoruba); Ekuso (?), Ekpuro, Otiemmie (Benin). 
This is a moderately prevalent tree in the Calabar, Ogoja, Benin, Ondo and Abeokuta provinces of Nigeria.

It is a medium-sized tree with a small leaf. It attains a girth of about 8 feet. The golden-brown of the underside of the leaves is most typical of this tree and makes it easily distinguished from Chrysophyllum Africanum; in fact, in passing through the forest this is one of the few trees having brown tomatose hairs on the underside of the leaf. The crown is broad and flat and heavy. The bole is not too long and is covered with a smooth light-brown-coloured bark.

The Benin native name means that it is the Monkey Otien, that is to say, not the one that men may eat. It is usually found in the evergreen forest.

The timber is white, light and soft, and is attacked by termites. It has not so far been cut for export or local use.

Native Use.-The fruit is sometimes eaten by the Benins. Chrysophyllum albidum (Don.). White Star Apple. Osum Agbalumo (Yoruba).

This is one of the Star Apples of the Yoruba Forest, where it is found chiefly in the Abeokuta province. It is not very prevalent. The fruit is not so esteemed by the natives as that of Osangbalumo. The bole is somewhat straighter and less branched than that of $C$. Africanum. The wood is white and soft ; the stem is not absolutely round, being somewhat fluted at the base, with narrow and thin spurs which extend 4 to 6 feet up the stem. The natives occasionally use the wood for household utensils. It has not been cut for export.

Chrysophyllum Welwitchii.

This so-called Forcados Star Apple was found in the forest just behind the station of Forcados. It is not a very common tree.

Malacantha sp. nov. Akala (Yoruba).

It is found in the Olokemeji Reserve and neighbouring parts of the Abeokuta and Ibadan provinces. In many places it is very prevalent, though it does not grow actually gregariously. It reaches up to a medium size. The bole does not exceed a length of much over 15 feet and a girth of 5 feet. With its four narrow, somewhat long (up to 4 feet) buttress root spurns, the base of the stem forms a rather irregular shape. The bark is roughish and soales off to a slight extent as the tree becomes older.

The leaves are inclined to be placed at the terminals of the shoots and twigs, and the main veins are very prominent, giving the impression that the leaf has only comparatively recently opened. The leaf is a little rough to the touch, and 


\section{THE NIGERIAN TIMBER TREES}

rather dry and thickish. It is a distinctly yellowish-green colour. The foliage is very sparse.

With its none too straight stem and comparatively slight amount of foliage it presents a poor appearance.

The wood is of a pleasant light-yellow colour and comparatively hard. It planes up with a smooth surface and saws easily. It does not take nails well, nor does it split easily. It is termite-proof.

Natural regeneration appears to be slight, but stool and root shoot reproduction seem to be strong. The seeds are very small and appear like little round, spherical nuts. Although it will bear a slight amount of shade in its youth, it is a light-loving species later on.

Occurring as it does in the mixed deciduous forests, near the lower edge of the dry-zone vegetation it should prove a useful tree, especially as it is comparatively fire-resisting.

Although comparatively slow-growing it attains sufficient size to be cut up into verandah-posts and banister rails and uprights.

On the whole, quite a respectable quantity of timber could be obtained in the aggregate from the large number of trees found growing in the forests.

Pachystela cinereum (Pierre). Osan odo, Orban igba (Yoruba).

Found in the Abeokuta province.

\section{Ebenaces.}

Diospyros Mombuttensis, syn. Sinensis. Walking-stick Ebony or Yoruba Ebony. Ogan pupa, Aggan Egbo (Egba) (Yoruba); Ungungmekkan (Benin).

It is a small tree with reddish-coloured stem and very thin, scaly bark, often branching near the base and usually forming several stems up to 18 inches in girth instead of one main stem. It has a large, alternate leaf, with large leaf scars, amounting to projections from the twigs. The fruit is like an acorn, but of reddish colour, with a very small, low-rimmed cup. The twigs are reddish colour too, which is most typical of the tree.

It is common in the Benin, Abeokuta, Ibadan, Oyo and Ondo provinces of Nigeria.

Timber.-Very hard, whitish-brown wood.

E. Use.-Walking-sticks, as it often grows forming a natural handle.

Native Use.-Walking-sticks.

Diospyros sp. Benin Ebony. Owegbo (Benin).

A medium-sized tree, yielding a black ebony, which is prevalent in the Benin forests. The bark scales off like $D$. atro- 


\section{WEST AFRICAN FORESTS AND FORESTRY}

purpurea. It is a larger tree, though, than the last named. It likes the dense forest with a deep, damp soil.

In proportion the sapwood is white and very wide.

The tree is slow-growing, shade-bearing, with soil-protecting and soil-improving qualities. Natural regeneration is weak.

The timber has not been exported, nor has it been sawn up for local use.

Native Use.-Firewood.

Diosypros mespiliformis. Monkey Guava or Yoruba Ebony, Kanran, Etini (Yoruba); Igedudu (Benin).

From the similarity of its fruit to a medlar it obtains its botanical name.

It is found in the Abeokuta and Ibadan provinces of Nigeria, in the mixed deciduous forest zone. In places such as the Olokemeji Forest Reserve and neighbourhood it is very prevalent and almost gregarious in habit. As regards height, and almost always as regards girth, it is the largest of almost all the ebony-trees, with the exception of one species found near the Niger, reaching a girth of over 14 feet and a bole length of 70 feet. At the pole stage, and as it gets older, the bark is evenly fissured, vertically and horizontally, breaking up into small black-edged sections of about 2 inches long and $\frac{1}{2}$ inch wide. Until it is much over 2 feet in girth the cortex is smooth, dark-green or black. After this it becomes rather rough, with small fissures. Although often very cylindrical in shape, the bole sometimes has very considerable taper-in fact, more so than many other trees. The branches come out almost at right angles to the stem and are very persistent, still remaining as short snags for many years after they have been broken off by storms or other agencies. The leaves are smallish and lanceolate in shape, and almost appear to be silvery on the under surface and very dark green on the upper surface. The thinner branches appear silvery-grey, though they are very similar, but thinner in comparison to $M$. multinervis, which are found in the same locality growing side by side. The leaf has a few fine veins. The fruit is flatly spherical, and is like a little medlar with its russet-brown rough surface and the dried-up sepals of the flower on it. It is, however, larger than than of Multinervis.

The sapwood is white and narrow and the heartwood darkbrown to black, sometimes even green-black. It is very hard-in fact, almost the hardest of all African woods, with perhaps the exception of Yoruba Ironwood, Red Ironwood, and African Greenheart. It splits fairly well. It is inclined to be brittle, especially in timber from larger specimens, planes well and saws well, but is difficult to nail. It is termite-proof. Occs- 

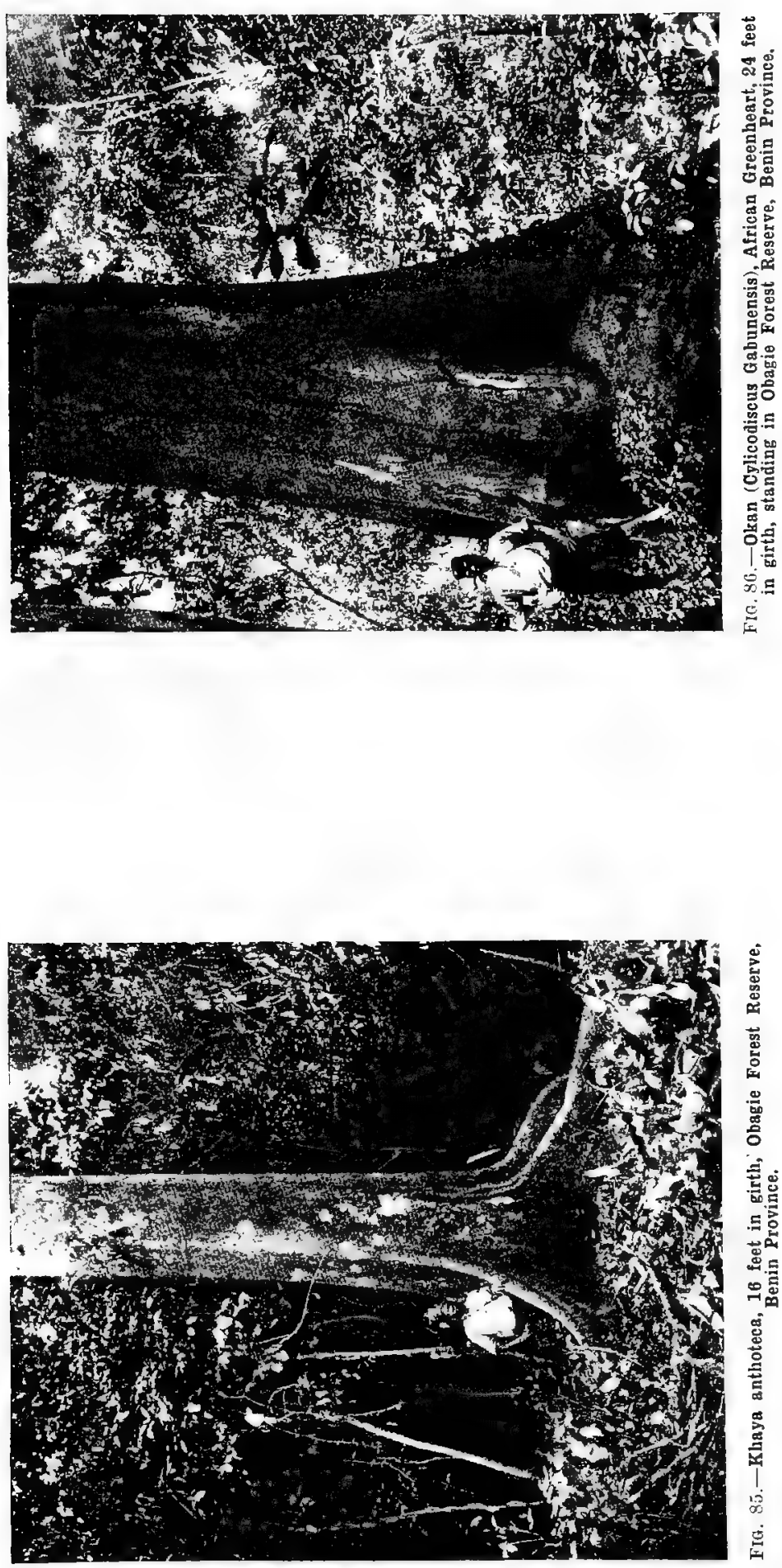

sionally a large boring beetle burrows into the wood when it is lying on the ground. However, the grubs which do this damage are considered a delicacy by the natives, so that wherever found they are soon collected and eaten. The younger tree grows with branches more or less in whorls, but not so regular as those of $M$. multinervis. When fresh it is liable to warp. It keeps its colour better than most of the ebonies. It occasionally shows a little figure. In proportion it has the largest heartwood of any of them, and for this reason is a most valuable tree.

Diospyros Kamerunensis. Cameroon Ebony.

This tree has been found in the Boji Hills Forest as well as in the Cameroons. Although not of great size, it yields a comparatively large and black-hearted ebony. The fruit is much larger than that of most other species. It is comparatively prevalent at an elevation of about 1,000 feet in the Boji Hills. Up to the present it is doubtful if it has been worked at all. The natives have no use for the tree.

Diospyros Barteri. Ebony Nut or Yam Stick. Ivioha (Benin).

Small ebony-shrub of the Benin province of Nigeria, found near Okomo in rather moist ground. The natives have no use for the wood.

Diospyros bipendensis. South Cameroon Ebony.

It is supposed to be found in the Oban Reserve.

Diospyros crassiflora. Benin Ebony. Aborkpor (Benin).

It yields the black ebony of the Benin country and is somewhat prevalent. Found in the Benin, Abeokuta and Onitsha provinces of Nigeria. A tree with a small leaf.

It forms almost pure groups or even small stands, of half a mile and less in extent, near the banks of the Niger. It can stand swampy ground. It used to be cut in the Onitsha district.

Diospyros sp. Benin Ebony. Isanhianme or Ehrenyegbo (Benin).

A common tree of the Benin province of Nigeria. It is supposed to yield a good ebony. It does not reach a very large size. It is a soil protecting and improving tree. Locally it is used for house-building.

In 1906 samples of this timber were sold in the Liverpool market as mahogany at 18. 6d. per cubic foot. Since that time it has not been exported.

Diospyros atropurpurea (Gurke). Brown Ebony. Igedudu (Yoruba) ; Igedudu (Benin).

It is a small tree, attaining a girth of about 4 feet. The heartwood is usually brown with black streaks, giving it a curious and diverse streakiness, not unlike black marble or 
Indian Blackwood. The flower is reddish-purple coloured and quite conspicuous, growing out of the upper surface of the twig without a stalk of any kind. The bark is almost black and peels off in very thin, oblong-shaped flakes; the cortex underneath is green. In old age it is hollow at the first branch joint.

It is found in the Benin and Abeokuta provinces of Nigeria. About one-third of the diameter of a mature tree is heartwood. Apparently a slow-growing tree, though none have been planted. It is a shade-bearer in the evergreen and mixed forest; natural regeneration is not good. A large cerambix or other borer makes finger-thick holes in the sap and heartwood of old trees.

It should be an export timber of value, but it was only valued at $\mathfrak{E 5}$ to $\mathfrak{£ 1 0}$ a ton in 1906 . It has been used for mirror frames.

Native Use.-For firewood in the Benin country, where it is considered very good.

Diospyros suaveolens. Benin Ebony. Oohoo (Benin).

It is a small-sized tree, with very small heartwood and a small, oblong, almost lanceolate leaf. The bark, which is quite black, has slight fissures and is much harder than that of D. atropurpurea.

It is prevalent in the Benin country, Nigeria.

It likes to grow near water, but not in a swampy place. It is a slow-grower and shade-bearer, being found as an undergrowth in the high forest. It is not attacked by white ants. The wood is hard and durable.

Native Use.-It is used for house-building as rafters, as well as for axe-handles of any kind. Small trees are used for making bows (long) for shooting birds.

Diospyros verrucosa.

This tree, although named from the Cameroons, is found in the Abeokuta and Benin provinces of Nigeria. The twigs are very rough compared to the other species.

Diospyros dendo?. Cross River Ebony. Ebubri etu, Obiliteto (Efik); Itiuyang (Oban, Ekoi).

It is a medium-sized tree with dark-green, smooth bark, with large lanceolate leaves and strong upward-spreading branches, which makes the bole shorter than it would otherwise be. The fruit is almost pear-shaped, containing four long, thin, wedge-shaped seeds, brown outside and white inside.

It is found in the Calabar and Ogoja provinces of Nigeria, in the evergreen forest zone of the hill forests.

The crown is rather irregular in shape, being supported 
with two or three main limbs from the bole. It reaches a girth of about 6 feet and a bole length of 12 feet.

The sapwood is wide and white and the heartwood black. The tree is occasionally attacked by a large borer, which makes large holes nearly 3 inch in diameter. The timber is very hard, but if the tree is killed by fire it becomes a little more brittle than is usually the case. In old trees which may be left lying in the forest, the middle of the heartwood often decays away with ground-rot. It planes well and saws well. Nails often split it. It splits moderately well, especially when free of knots.

It is a very slow-growing, shade-bearing, soil-protecting and soil-improving tree. On the whole, it is more exacting as to soil than most other trees, being usually found on a good loam rich in humus, which is moist and with fair drainage. Natural regeneration is none too good. Stump shoots are very weak, and often do not occur. It has not yet been planted. It is very susceptible to fire-in fact, more so than perhaps any other tree. The timber has been exported for many years from Calabar, but of late in decreasing quantities, owing to the exhaustion of the nearer sources of supply, and to the fact that only small billets under 3 feet in length, not square, and only 3 or 4 inches in cross-section were cut. The usual native method of procedure is very curious. On making a clearing for a farm, any ebony standing there gets killed with the fire, and having comparatively few roots and being very heavy, the tree falls down. Before abandoning the farm the native may put a mark on this tree, or at any rate make a mental note of its existence. After a year or two, if he is in need of money to buy clothes, or wishes to purchase anything, he goes back to this old farm, finds this tree, perhaps externally somewhat charred, and perhaps the centre of the heartwood rotted away; he proceeds to cut it into lengths of about 10 or 12 feet. These he then splits lengthways into segments with a rounded side of about 5 inches, the two split sides about 4 inches, and the inner surface about 3 inches. In order to get these long pieces of suitable dimension to carry to the nearest factory or trading station, he cuts them into three or four billets; two or three of these, according to weight, are tied together and carried to the factory. It is sold by weight, and sometimes 200 billets go to the ton, though a smaller quantity of a larger size would be better and secure a better price. This method should be compared with the superior one adopted by the natives of the Cameroons. Compared to the usual price of $£ 6$ or $£ 7$ per ton for Calabar ebony, Cameroon wood usually fetches $£ 10$ to $£ 12$. 


\section{WEST AFRICAN FORESTS AND FORESTRY}

Diospyros xanthoxyplamys. Okahimi (Benin).

This is one of the Benin ebonies and is not very prevalent. It is said to yield a good ebony.

Maba Mannii. Benin Maba.

It is a common tree in the Benin and Ondo provinces of Nigeria. It only reaches a girth of 4 feet and a short bole of about 10 feet. It is much branched, even low down, the branches being persistent and crooked. The leaves are small, rather less than ebony itself. The leaf is really a long, pinnate one, with thirty pairs of pinnæ. The fruit is white, soft and oblong, with small seeds.

The tree has a white sapwood with a black heartwood, rather small in proportion to the size of the stem. It does not split well. Termites do not attack it, but occasionally the gigas borers make holes in it. It grows slowly and stands a good deal of shade. It sprouts well from the stool and the seed also grows fairly well. It grows in the damp, deep soil and does not stand fire at all. It belongs to the evergreen forest zone.

This tree has not been cut for local use or exported to Europe. It is used as firewood, and is considered better than most other woods, even Ohia, Celtis sp.

\section{Oleacea.}

Schrebera Golungensis. Hard Yellow Wood. Opele (Yoruba); Udegwoga (?) (Benin).

It is found in the Abeokuta province of Nigeria, Olokemeji and Ilaro Reserves.

It is a large tree, reaching a girth of about 10 feet. The smooth, light-green bark with yellow patches differs from the Celtis species, which is rougher, and the Afrormosia species, which is orange-red and peels off. The leaves are small for the size of the tree. The crown is narrow and long and the branches forming it slender. The curious small pear-shaped dehiscent fruit, showing four oblong niches for seeds, is most typical of the tree. In other respects the habit and build of the tree is similar to the Celtis species, especially with the root spurns slightly corrugating the base of the bole. It is not a common tree, but usually a fair number of specimens are seen in any locality where it has been found. The bole is very straight and free from branches for quite a height of the tree.

The timber is a dull-yellow colour, fine grain, of smooth texture and moderately hard. It planes to a smooth, almost shining surface. It scarcely shrinks or warps when drying. 
It sprouts slightly from the stump, though the shoots do not seem to have much strength.

The timber has not yet been exported, though its valuable quality should assure it of a market. Sample planks used at Olokemeji proved most durable.

Native Use.-The fruit is used by the Yorubas for divining the future.

\section{Loganiaceæ.}

Strychnos densiflora (Baill.). African Strychnos Tree. Attako (Yoruba) ; Egbeda (Benin).

It is found in the dry-zone forest of the Ibadan and Benin provinces of Nigeria, where it seems to be very prevalent.

Chief Characteristics.-It is a small tree or shrub, up to 12 feet high, with small leaves and very hard wood.

It is of slow growth, but on the whole is a shade-bearer and soil-protecting and soil-improving tree. Natural regeneration appears to be poor.

It has not been planted.

Apparently the seeds have not yet been examined as to their value. The timber is too small for export or local use, except for hut-building.

Use.-The Benin natives use the stem for making snares for Duika and the branches for making brooms, as they are very tough.

Anthocleista nobilis. Ogugu, Sapho, Apa Oro (Yoruba); Orrimogungun, Oriweni (Benin).

It is found in the Ibadan, Abeokuta, Benin and Ogoja provinces of Nigeria.

It has huge soft leaves, and is one of the first plants to appear on a clearing in the dry-zone or mixed forests. In old age the leaf is much smaller, and the mass of white flowers along the uppermost branches is most typical of the tree. It is often almost gregarious, and in most places more than one tree is found in the immediate neighbourhood. Reaching a girth of about 3 feet, its stem does not exceed 20 feet in height. There are usually two or three main branches into which it divides. The wood is soft and white.

It is a light-loving, rapid-growing tree, which is soil-protecting and soil-improving in youth, but is too open in crown after a few years. It should, however, prove a useful nurse for superior species in the dry zone.

Native Use.-Firewood in places where wood is soarce. 


\section{Apocynacez.}

Alstonia Congensis (Eng.). Pattern Wood, Stool Wood. Ahun, Awun, Ogudugbu (Yoruba); Ukhu (Benin); Ekuri Ebu (Ibo Owerri); Abo, Idu (Efik); Ofemm (Bembi); Etiap, Oguk (Oban, Ekoi).

It is a large tree, growing up to a height of 100 feet and 10 feet girth. The white lenticels on the bark are very typical of the tree, and give it the appearance of having a rust disease. The crown is formed of two or three whorls of branches and is very flat in old age. The tree grows always in whorls, though it may have more than one stem. In the distance the leaves appear to be digitate, but in reality three to seven are found to be growing out of the end of one stalk, all being much the same size. The crown is flatly umbrella-shaped. It has comparatively few branches. The root flanges are slight, soon merging into the trunk. At the base of the bole, however, they are not absolutely round in shape, but have two or three large ridges, sometimes almost subdividing it. The slash is white, with yellow spots. A chalky white latex exudes when it is cut, rapidly running down the stem like a streak of whitewash.

It is found in the Abeokuta, Ibadan, Ondo, Benin, Owerri, Calabar and Ogoja provinces of Nigeria in the evergreen and mixed deciduous forest zone. It is a very common tree throughout this region and is usually found growing singly.

The timber is white, there being little or no difference between sapwood and heartwood. When dry, it is very light and soft. It splits and planes easily, saws well, and takes nails easily. The grain is close and fine and very even in texture. Although dull, it works up to a smooth finish. It is attacked by termites. It is not durable in the open, but under cover it lasts quite well. In drying it is liable to shrink and warp a little, but with care this can be avoided. It seasons comparatively quickly. It cuts easily with a knife or chisel and might take the place of lime as a carving-wood. From its texture it should take stains very well.

It is a very fast-growing, at first slightly shade-bearing and latterly a light-loving tree, which thoroughly protects the soil and enriches it with its leaf fall. Natural regeneration appears to be good, as it sprouts well from the stump. It seems to like a good soil with plenty of moisture, and will even withstand floods. It is not fire-resisting. The crown and branches are liable to be broken with a high wind.

In 1906 samples of this timber were sold in the Liverpool market as a whitewood, but it was considered to be of no value. 


\section{THE NIGERIAN TIMBER TREES}

It deserves a further trial as a pattern-wood, comparatively large quantities being available. Locally it has not been sawn up for planks.

In Calabar the timber is used for stools, which are carved ont of large solid blocks of this wood in one piece, without a joint.

Native Use.-In the Benin country the timber is used for doors and the roots for medicine.

The box of the musical instrument Asologun, a kind of zither, is made of this wood in the Yoruba country. The latex is used for mixing with real rubber latex of the Anyo or Funtumia elastica tree.

Voacanga Africana (Stapf.). Cloth Shrub. Dodo, Giwini (Yoruba); Igbo (Benin).

It is a common shrub-like tree in the Ogoja, Onitsha, Benin, Warri, Ondo, Ibadan and Abeokuta provinces of Nigeria. The tree is usually noticeable from its white wax-like, trumpetshaped flowers, which have a very fragrant scent, and which very rapidly wither when cut. The bark is thin and extremely fibrous and hard to break, so much so that the natives of the Asaba district make grass-like fibre out of it and mix it with a silk fibre to make a very durable kind of cloth, which the natives wear. It grows in waste places and requires light. It spronts well from the stump.

Conopharyngia durissima.

This tree is found in the Western Provinces. It is of a similar size to $C$. pachysiphon, and the timber is just as durable.

Conopharyngia pachysiphon. False Boxwood. Dodo? (Yoruba); Ibbu (Benin).

It is a common tree in the Calabar, Warri, Benin and Ondo provinces of Nigeria. A small tree, attaining a girth of only 4 feet, with a large leaf, bearing large spherical-shaped fruits in pairs. The large creamy-white, strongly scented flowers are conspicuous to both sight and scent. The bark, even in its younger stages, is covered with small yellow lenticels. The wood is hard and yellow in colour, and there is no difference between sapwood and heartwood. The latex has sometimes been used as an adulterant for rubber. It is a shade-bearer, and is found at the border of the evergreen and mixed deciduous forests.

The natives of the Benin country use the roots for medicinal purposes.

Farquharia elliptica. Onanisankianmon (Benin).

This is a member of the new genus of Farquharia found by 
Mr. Farquhar in the Benin province of Nigeria, near Ugumu. It is not stated whether the natives use this as a source of rubber or not.

Landolphia florida (Benth.). Rubber Vine. Ibugidi, Ibo-akitipa (Yoruba).

A vine found throughout Southern Nigeria, though most abundant in the dry-zone fringing forests and in the intermediate forests, and at Ottoa, Benin province. It bears white flowers having yellow centres.

Uses.-Milky juice is obtained from this vine, but it is not good rubber, and has no market value.

Landolphia scandens. Ibo (Yoruba) ; Ubamiogon (Benin); Otopoi. Otanta (Ibo Asaba).

Ilaro.

Landolphia Owariensis, var. rubiginosa.

Found Anwai River, Asaba district.

Landolphia Owariensis. White Vine Rubber. Ibo tabong (Yoruba); Ubamiogon, Ubgo (Benin); Otta farfridi (Ibo Asaba).

Found Benin City and Mamu.

Landolphia Senegalense. Ibo akitipa (Yoruba).

It is found in the Oyo province of Nigeria, and it is supposed to be one of the sources of vine rubluer.

Landolphia Thompsonii (Ches.). Corrugated-fruited Rubber. Ibogidi (Yoruba); Ugbamiogun (Benin).

Abeokuta, Benin and Calabar provinces of Nigeria.

A vine growing abundantly throughout the rain and fringing forests. It has white flowers with yellow centres and a bright-yellow edible fruit. No rubber is obtained from it, but only a pasty mass from the latex.

Landolphia Petersiana. . Large-fruited Landolphia.

Found in the Oban Reserve and Benin province.

Landolphia bracteata. Autopoi (Ibo Asaba).

Found at Idanre, Anwai, Asaba district.

Carpodinus hirsuta (Stapf.), var. djenge. Flake or Paste Rubber, Root Rubber, Brown Cluster, or Brown Medium. Ibo Ilecki (Yoruba); Uboto, Obo, Ubanakwi, Ake. Abache (Benin).

It is found in the Onitsha, Benin and Warri provinces of Nigerin. It has a mauve-coloured flower with a musk-like scent.

The rubber was bought near the Niger until the vines from which it was taken were destroyed.

Carpodinus Barteri, syn. Clitandra Barteri. Mauve-flowered Vine Rubber. Ibo (Yoruba); Akhe (Benin); Akwarri, Offonkwari (Ibo Asaba).

Anwai River. 


\section{THE NIGERIAN TIMBER TREES}

Carpodinus fulva. Pear-shape-fruited Rubber. Ikwian (Benin).

Found in the Asaba district, Benin province.

Clitandra elastica. Brown Medium Rubber. Ubabikpan (Benin); Beckindanko (Hausa).

Benin province.

A vine of the dry zone, found in the Okwoga district and at Adani in Awka district. It also yields root rubber.

It yields a good rubber, sold on the Niger for Is. 3d. to 1s. $6 \mathrm{~d}$. per pound (1911). Extracted by tapping and coagulated by boiling, also with salt.

Clitandra visciflua (Hall. Fil.). Ubake (Benin).

Found in the Benin province.

Clitandra Togolana (Hall). Ibo, Agba (Benin).

It is a large tree, up to 60 feet high (?). Olokemeji.

Clitandra cirrhosa. Oban Rubber.

This is one of the commoner vines of the Oban Forest Reserve.

In recent years, owing to the low price of rubber, it has not been tapped to any extent. The cost of collection to the natives is rather high, with the extended preparations and amount of food they must take with them in this forest. Added to this there is the cost of the licence and the cost of taking it over the long distance to the market, so that they do not think it pays to collect this rubber.

Rauwolfia vomitoria (Afzel). Swizzle-stick. Iraigbo, Asofeyeje (Yoruba); Akata (Benin).

It is found in the Abeokuta, Ibadan, Ondo, Benin, Warri, Owerri and Calabar provinces of Nigeria, in the evergreen and mixed deciduous zone, where it is very prevalent.

It is a small tree of 12 feet in height and 18 inches in girth, with almost always four branchlets to each branch, forming regular whorls in this manner. It has a soft, thin leaf and a round, small green fruit. The stem is usually forked near the ground, and each side branch is forked again and the uppermost branches divided into four separate twigs, making thus a most convenient shape for a swizzle-stick. The stem is more or less dotted with a few white lenticels. The bark peels off very readily and cleanly with a knife, leaving the bare white stem, especially in the smaller branches.

The wood of the smaller branches is soft, showing a small pith in the centre, but that of the stem in the larger specimens is comparatively hard, and more like an inferior type of boxwood. The sapwood is usually a little softer than the heartwood.

It is a moderately fast-growing, shade-bearing, soil-protecting and soil-improving tree. Natural regeneration is good. It 


\section{WEST AFRICAN FORESTS AND FORESTRY}

sprouts well from the stump, and a certain number of root suckers appear. It stands pruning well.

The tree does not really reach a large enough size to yield export timber, or to be of much value for local use. It is, however, commonly used as a swizzle-stick.

In places where building timber is scarce, it is occasionally used in house-building. It could be, and sometimes is, used as a live fence.

Polyodoa umbellata (Stapf.). Oak or Boxwood. Aini (Egba); Erin (Yoruba); Osu (Benin).

It is a medium-sized tree which grows to a girth of 4 feet. The young stem is easily recognized by the longitudinal strips of lenticels, joined together with the dark-green cortex, showing between each strip. When older, lenticels appear on the stem and it may be quite grey or white.

The wood is a dirty yellow colour and very hard, resembling box in the fineness and the hardness of its grain. It is used by the natives for making combs for the hair; these combs have six prongs about 6 inches long and are sold at $6 \mathrm{~d}$. to $1 \mathrm{~s}$. apiece. It is used for house-building, and is considered the most durable timber for this purpose ; it is forked about 15 to 20 feet from the ground. The bark is used medicinally by the natives (Yorubas).

The leaves are a yellowish-green, gradually turning a rich dark-green. The small greengage-sized fruits appear in pairs at the ends of the shoots, and occasionally in threes, but this is rare.

It likes moist ground, though it will stand a long dry season, so long as it has the shade of other trees. It is a distinct shadebearer, though it grows a fair height when it has a chance. Tho flowers are white and have a very pleasant smell.

Only a very small quantity of latex exudes when the tree is cut, and so does not give the impression of belonging to the rubber family of Apocynaceæ.

The sapwood is a similar colour to the heartwood. It is not always straight, but this is owing to its slow growth causing it to be amongst the dominated trees. In older trees the stem is usually quite white, except where the bark has been removed.

A sample was sent to England in 1914 and was said to be valueless as a substitute for boxwood. In 1906 samples were shipped to Liverpool, where it was sold as a species of oak at 1s. 9d. per cubic foot, but it was not considered as good as that obtained from Awaw, Eba, Lophia procera or Ostryoderris impressa. 
Native Use.-The chief tree for all tool-handles and houseposts. The most durable kinds are in Egba, and they are not attacked by white ants.

Alafia Landolphioides. Ubamiagon (Benin); Ata frifridi (Ibo Asaba).

Found at Illushi, Asaba district, Oke Igbo, Ilesha district.

Carissa edulis.

It is found in the Olokemeji Reserve of the Abeokuta province of Nigeria. The fruit is edible.

Motandra Guineensis (A. D.C.). Bodekadun (Yoruba).

It is found in the Olokemeji Reserve of the Abeokuta province of Nigeria.

It has not been used for making rubber.

Strophanthus Preussii. Elephant Poison. Isha gere, Isha kekere (Yoruba).

Found in the Shagamu, Lagos and Calabar districts.

A climbing shrub, attaining the beight of 12 feet. The flowers are creamy in colour, deepening to orange, with purple spots and streaks.

Strophanthus bispidus (A. D.C.). Isha fere (Yoruba).

Found in the Ilesha district, Oyo province.

Holarrhena Wulfsbergii (Stapf.). The Male Rubber Tree or False Rubber Tree, according to the Yorubas, or sometimes known as the False Ireh Tree. Ireh-ibeji, Ireh-ako, Ako-ireh (Yoruba).

This tree being found in the Abeokuta and Oyo provinces of Nigeria, it is not very prevalent, nor does it grow in large numbers in any one place. With its smooth, dark-green bark, speckled irregularly all over with white spots and lenticels, it is easily distinguishable from the almost silver-white or grey beech-like stem of the true West African Rubber Tree.

At a height varying from 10 to 15 feet the bole sometimes divides and forms two very straight stems, one much smallar than the other. In the African Rubber Tree (Funtumia elastica) usually only one stem is formed.

Again, in its sparse and rather drooping foliage it is very different from the real rubber-tree. The leaves are much longer, more sharply pointed, and in fact more lanceolate than those of $F$. elastica. The foliage often gives the appearance of being withered or that the tree is drying up.

Large raceme-like masses of small flowers appear in February or March, which are much more prominent than those of $F$. elastica, these being more hidden among the leaves, although individually having larger blossoms. Later on, a thin round pod, nearly 2 feet in length, forms in pairs, which hang down and make the tree look most grotesque. On the other hand, $F$. elastica pods are stout and short and almost hidden by the foliage. 


\section{WEST AFRICAN FORESTS AND FORESTRY}

The tree reaches a girth of 36 inches and a total height of about 50 feet.

The slash is greenish-white, and a very little white, rather watery latex exudes from the cut. The wood is white, soft, planes easily, and splits comparatively easily. It saws fairly well and takes nails with comparative ease. It is not termiteproof.

It is a moderately fast-growing tree of a light-loving nature. Natural reproduction by seed appears to be fair. It sprouts slightly from the stump.

Being found in odd and poor places in the mixed deciduous forests at the edge of dry-zone vegetation, it should prove useful for temporary house-building purposes and for cutting up as cratewood for bananas, etc.

Pleiocemus Barteri (Baill.). Irena, kekere (Yoruba).

The fruit is very much like a Cola and fairly common in the forest. It is very sticky to the taste.

It is a medium-sized tree, in habit similar to the Cola-tree, and most people would classify it from its external appearance as a species of Cola.

It is found in the Benin and Abeokuta provinces of Nigeria.

Picralima Klaineana?. Agege (Yoruba).

Found at Agege, Yoruba country.

Oncinotis gracilis. Ornamental Rubber Vine. Allerle (Benin).

Found in Ogodo Dry-zone Forest.

Name unknown. Ikwian (Benin).

An uncommon tree of the Benin province of Nigeria. It attains a medium-size and bears large fruits. The wood is used as firewood.

\section{Borraginacex.}

Ehretia cymosa (S. and H.). Ija oke (Yoruba).

Found in the Olokemeji.

Cordia sp., ? Platythyrsa. Drum-wood Cordia. Ako Ledo (Yoruba).

It is found in the Olokemeji Reserve of the Abeokuta province of Nigeria.

Cordia Irvingii. Acorn-like-fruited Cordia.

It is a medium-sized tree, similar to Cordia Millenii. It is found in the Abeokuta province of Nigeria.

Cordia Millenii. Omon or Omo (Yoruba); Omah (Benin).

This tree is found in the Abeokuta, Ibadan, Ondo, Benin, Owerri, Calabar and Ogoja provinces of Nigeria.

It is an irregularly shaped tree, often with more than one stem. The light-coloured bark, especially when it is scaly, often gives the impression that the tree is luminous at night. 


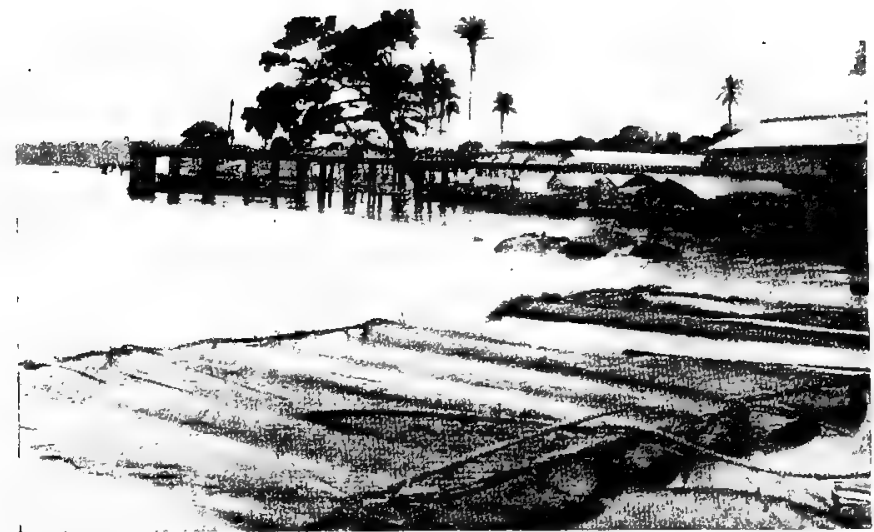

FIG. 87,-Koko Town, with raft of mahogany logs moored near the bank.

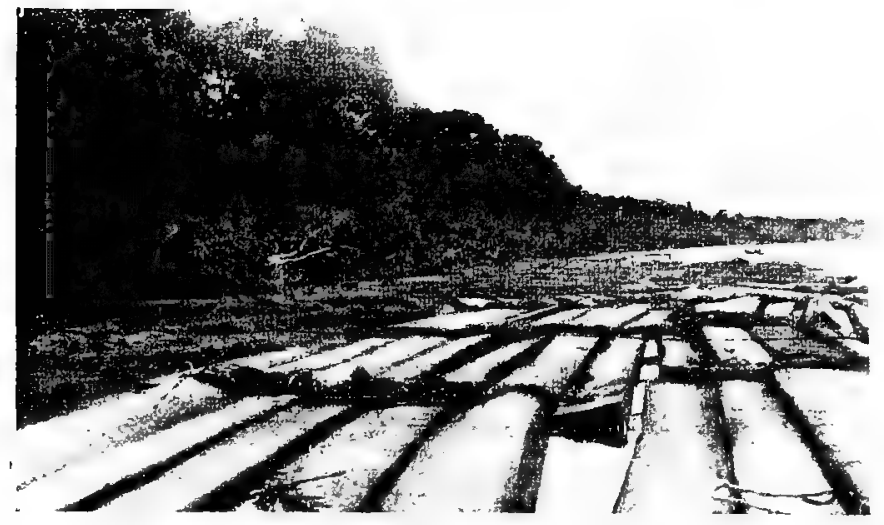

FIG. 88.-Mahogany logs floating in the river above Kolo Town. 

The leaf is large. It is a common tree in the Benin district, of medium-size.

It yields a softwood, which has a certain amount of resonance. The sapwood is white and the heartwood a midbrown colour. It is not very durable, except under cover.

It stands a good deal of shade. It sprouts well from the stump. It bears fruit irregularly, and seedlings are scarce in the forest. The wood has not been exported, and none of its qualities so far assure it of finding a good market in Europe.

Native Use.-The natives use the wood for making drums.

\section{Vorbenaceæ.}

Avicennia Africana. White Mangrove. Ogbun (Lagos); Ede, Eyhrodo (Benin); Odonumon (Efik).

It is found in the Colony, Ondo, Warri, Owerri and Calabar provinces of Nigeria. It is seen partly in pure groups, and also mixed more or less in groups with the other areas of Red Mangrove and Laguncularia sp.

It is a small tree, growing up to 2 feet girth and about 40 feet high.

The bole appears silvery grey and the branches very slender. The leaves are of a lighter green than those of the Red Mangrove. The aerial roots are smaller and not so extended as in the case of Racemosa. On the whole, it occurs in the quieter and less exposed localities, away from the sea, and it seems to appear only secondary to $R$. racemosa, which is the first tree to appear in the mangrove formation. The slash is white; the cortex is thin.

The sapwood is white and the heartwood a light brown when freshly cut. Is moderately hard, and durable when dry and used away from water. It is termite-proof. In structure it is similar to teak, being a member of the same family, but the grain is more open and the pores are considerably larger and longer, giving the wood a more open texture. It planes up with a smooth surface, splits well, takes nails moderately well and saws easily.

It is a somewhat slow-growing, at first shade-bearing, and later on a light-demanding tree. Natural regeneration is good, but it does not appear to be extending as fast as $R$. racemosa. It sprouts from the stump ; root suckers and aerial root shoots grow in considerable numbers. On the whole, it tends to die out sooner when the ground becomes dryer than $R$. racemosa, and its area of distribution from the coast inland is much less wide.

The timber has not been exported, nor has it been sawn 
up for local use. For the natives this tree forms what is considered the best "salt bush" in the Jekri country. It is still used for the manufacture of salt, which is considered much stronger than and superior to imported salt. It is also used for poles, house-building, boat and canoe houses and wharves.

Vitex grandifolia. Ori (Yoruba) ; Owenkundignon, Oriri Ogikiomi (?) (Benin).

It is found in the Benin, Onitsha, Owerri and Ogoja provinces, in the open deciduous forest zone.

The digitate leaf is much larger than that of $V$. Cienkowski, and on the whole the tree is larger too, reaching a girth of 10 feet and a bole length of $\mathbf{3 0}$ feet. The fruit is rather larger, but similar in shape and taste to the former. The branches are very persistent, and coming out more or less in whorls from the bole, give the tree a most distinct appearance.

The sapwood is white and the heartwood at first lightbrown, and then darker brown. It is rather more open-grained than the teak. It does not split very well, but can take nails; neither does it plane easily, but can be worked up to a smooth finish. It is very durable and termite-proof.

At first fast growing and later rather slower, it is on the whole a little faster growing than V. Cienkowski. It withstands the fires in an extraordinary manner, and only occasionally does the bole get so deeply burnt that the tree becomes hollow. It bears a large crop of fruit almost every year.

The timber has not been exported, nor has it been sawn up for local use. It deserves further attention than it has received up to the present, more especially as it is of the same family as the teak.

Native Use.-The fruit is eaten, and occasionally the smaller trees are used for house-building.

Vitex Cienkouskii. Ori, nla (Yoruba).

It is a medium-sized tree, attaining a girth of about 8 feet and a bole length of about 25 feet. The bark is rough, divided up with long, narrow vertical fissures, which are more or less regular in their distribution. The crown is spherical, somewhat widespreading, and usually occupies about half the height of the tree. The large, shiny, dark-green digitate leaf is most characteristic of the tree. The fruit, not unlike a large acorn without the cup, is edible and has a slight honey taste. It attracts the bees from far and near.

This tree is found in the Oyo and Abeokuta provinces of Nigeria.

Timber.-Hard, brown wood, very similar to teak. It is often rather knotty and sometimes cross-grained. 
At first fairly fast-growing, later on it is rather slow. It is very fire-resisting, but does not thoroughly protect the soil. It has not been felled for export, nor has it been sawn up for local use. It serves a useful purpose amongst the dry-zone vegetation, and is one of the larger trees of that zone.

Vitex Fosteri. Ori-eta (Yoruba); Obuban, Ibang (Benin); Ogi (Calabar).

Chief Characteristics.-It is a medium-sized tree with thin, white bark and voluted stem, which is not overstraight beyond 15 or 20 feet, soft and fibrous; one of the common trees in the mixed forest, though also found in the evergreen forest. It has a thin, digitate leaf. It usually stands as one of the dominated trees in either forest. The leaves often look silvery, but this is an optical illusion, owing to their being so thin and white on the underside.

Distribution.-It is found in the Abeokuta, Ibadan, Jebu, Ode, Benin and Calabar provinces of Nigeria.

Timber.-It is a hard, white wood of even texture and smooth grain, which is apparently durable for interior work. It is somewhat like hornbeam, though not quite so hard. It works up with a smooth surface.

Silvicultural Qualities.-It is a shade-bearer, though, if planted pure, it is doubtful whether its foliage would thoroughly protect the ground, owing to its being so thin. Natural regeneration by seed is apparently good.

Use. - It would probably make good verandah-posts, doorframes and window-frames, but so far has not been tried. As there is plenty of it, proper supplies could be obtained in the provinces named.

Value.-At present doubtful, as it is an untried wood; however, belonging to the same family as teak, it should find a place amongst the valuable small timbers for local use.

Vitex diversifolia.

It has been noted from the Oban Reserve.

Clerodendron Thonningii. Egwa, Oriakuku (Benin).

It is an ornamental shrub of the Benin province of Nigeria, found near the Osse River.

Clerodendron Thompsonii. Egwa oviakuku (Benin).

A medium-sized shrub with woody stem found in the Benin province.

Clerodendron scandens (Beauv.).

It is a large shrub with hard wood of the Benin province of Nigeria.

Clerodendron volubulu. Ebenote (Benin).

Found in the Benin province. 


\section{0 WEST AFRICAN FORESTS AND FORESTRY}

Clerodendron splendens (Kew). Adabi (Yoruba).

A medium-sized shrub found in the Abeokuta province. The stem yields small wood for farm implements.

\section{Labiatæ.}

Ocimum viride (Willd.). Efinrin (Yoruba); Aramoho (Benin). Found in the Yoruba and Benin country.

\section{Scrophulariaces.}

Cycinium camporum (Engl.). Arojoku (Yoruba).

Flowers white. Found at Obba on the Hill, Ondo province.

\section{Bignoniaces.}

Spathoidea campanulata. Red Tulip Tree. Oruru (Yoruba); Okokwi

Okwekwe (Benin); Essenim (Efik); Osukaregigi (Bembi).

This tree grows in the fringing and intermediate forests.

It is of medium size and has large trumpet-shaped flowers, not unlike those of the tulip.

Uses.-This tree is often used for ornamental purposes. Timber, edible seeds and medicaments are obtained from it.

Stereospermum accuminatissimum. Osualong (seed), Okwekwe, Aguana (Benin).

This is a somewhat common tree of the Benin province of Nigeria, and certainly with its red flowers it is one of the most handsome. It is not unlike the so-called African Tulip Tree, Spathoidea campanulata. On the whole, it is a smaller tree, with a round, almost spherical crown; the wood is soft and white and not durable. It bears a large number of seeds, but few appear to germinate. It sprouts feebly from the stump, is a light-loving tree, and also a soil-protecting and soil-improving species. It deserves greater attention for planting in gardens and at the edges of recreation grounds of all sorts.

Stereospermum Kunthianum (Cham.). Ayagdo (Yoruba).

This tree is found in the Abeokuta province and Erin, Ilesha. It is very similar to the tulip-tree, but has a more orange-coloured flower.

Kigelia Africana. Sausage Tree. Orora, Pandoro (Yoruba); Ogiahimi, Esiskwi (Benin).

It is a common tree of the Ogoja, Owerri, Onitsha, Benin, Ondu, Ibadan and Abeokuta provinces of Nigeria. The most typical feature of this tree is the long sausage-shaped fruit, which hangs by a stalk about 10 inches long; the flowers are red, the leaves large and open. It is a small tree, often very much branched. It is usually found in old clearings at the edge of the mixed deciduous forest. The wood is not 
durable. The natives use it for fences, and the roots are mashed and used by Benis for cuts in the fingers. The bark and fruit are also used medicinally by the Yorubas.

Markhamia tomentosa. Iru, Aya, Iwe (Yoruba).

It is found in the Abeokuta province of Nigeria, in the mixed deciduous forest zone.

It is a tree 4 to 6 feet in girth, with a large leaf having five pairs of pinnæ, the lowest being very small, like stipules. A deciduous tree bearing small fruit. A very common tree.

The timber is a soft, white wood, which is not used. It is attacked by white ants, and is not durable except under cover.

The tree is a light-lover, quick-growing, and non-soil-improving. Natural regeneration is moderate, so that it does not spread too much. The tree has not been felled for export timber, nor has it been cut for local use.

Newbouldia laevis. Benin Ju-ju Tree. Akkoko (Yoruba); Ikhimi (Benin).

It is found in the Calabar, Ogoja, Owerri, Warri, Onitsha, Ondo, Benin, Ibadan and Abeokuta provinces of Nigeria.

It is a small tree, scarcely exceeding 4 feet in girth. It has a large, oblong, dark leaf. It is most commonly seen in the middle of a compound with a pot at the base of it. The flowers are trumpet-shaped, white-coloured at the base and rose-red at the mouth. The fruit is a long, thin black pod, which opens releasing many flat, winged seeds. The seed is yellow and in the middle of the wing.

The timber is white and soft.

It has not been exported or cut for local use.

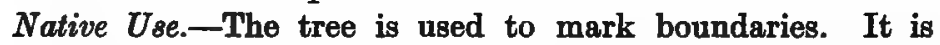
a " Ju-ju" tree, both in and outside the compound. It is sometimes used for fences. It is used by the Yorubas for rafters.

\section{Acanthacee.}

Thunbergia Vogeliana (Benth.). Blue Benin Thunbergia. Ohwohiro (Benin).

This is a shrub with handsome blue flowers; it is moderately common in the Central Circle.

\section{Rubiacee.}

Sarcocephalus eu-esculentus. Sierra Leone Peach. Egbesi (Yoruba) ; Aragbaihi (Benin); Amellaky or Egbessye of Sierra Leone.

It is found in the Abeokuta, Ibadan, Benin, Onitsha, Owerri and Ogoja provinces of Nigeria, where it is common in the open deciduous forest. 
In habit it usually takes more of the shape and form of a shrub rather than a tree, though where it is protected a longish main leader grows up, but even this droops. It rarely attains a height of more than 15 feet and a girth at the base of about 18 inches. The leaf is large and oval, opposite, and rather leathery to the touch. The fruit is not unlike a peach, except that its surface is not smooth, but is pitted in small depressions, giving it a more special peach colour. The flesh is very woody and tough, interspersed with small seeds not unlike those of the strawberry. When ripe the birds eat them. The roots are of a yellowish-brown, especially when the cortex is rubbed. The slash is yellow. The leaf is very shiny.

It does not really reach timber size, but the sapwood is a light yellow and the heartwood a darker yellow.

It is a moderately quick growing, light-demanding, soilprotecting and soil-improving tree. Natural regeneration is poor, but reproduction by root suckers and stool shoots is very strong. It is very fire-resisting, and recovers easily from any effects of fire.

Native Use.-In cases of scarcity of building-timber, occasionally short sections are obtained from it for hut-building. It is, however, usually too short. The roots are used medicinally in the following way: roots about a inch in diameter and upwards to inch are thoroughly washed in water and cut up into sections of about 4 inches long and boiled in water. The solution thus made is strained off, and is drunk either hot or cold in fairly large doses for the relief of venereal disease (G.) in its earlier stages. Most of the natives affirm that it gives great relief, though they acknowledge that it does not prove a cure for it.

Sarcoeephalus esculentus. Weatherboard Wood. Opepe (Yoruba); Obiache (Benin); Awessu (Jekri).

It is found in the Abeokuta, Ondo, Benin and Calabar provinces of Nigeria, where in certain localities it is very prevalent.

It is a large tree of the evergreen forest zone, which attains a girth of 12 feet and a corresponding bole length. The bark is slightly rough and scaly, but in an even manner. It bears a large edible fruit 2 inches in diameter. The fruit is not unlike a peach in shape and colour, but with a rougher and softer skin. It is very closely and finely pitted with tiny holes in its surface. Inside, the flesh is pinkish-white. It is commonly Been at the edge of treshwater swamps in the Benin, Ifon and Ondo districts. It likes soil with good drainage, but it may be very moist. 
The bole is very straight, and not unlike that of real African Oak in appearance. The leaves are rounded and moderately large, and inclined to be leathery in texture, with two stipules at the base. In the young seedlings the stem is more quadrangular in shape than round, and there are a few almost straighter furrows running vertically up it.

It tends to spread with the opening up of the evergreen forest. The root spurns are very slight and round, merging into the stem a foot or so above the ground. The slash is yellowish-white, and a rather dirty colour. Mucilage-like latex gradually exudes from the cut.

Timber. - The wood is very durable indeed, both for exposed places and for interior work. It is moderately hard, a little open and fibrous in grain, of a yellow to orange colour, with slight variations in its distribution through the wood. It planes well and saws easily ; splits fairly well, takes nails, and does not warp or shrink very much. There is only a slight difference in colour between the sapwood and heartwood, but the sapwood is not quite so durable. It is termite-proof. It is usually very straight-grained, free of knots and other internal defects-in fact, it is one of the cleanest of all the African timbers.

It is a very fast-growing, at first slightly shado-bearing and later light-loving tree, which thoroughly protects and enriches the soil with its leaf fall. In fact, after the first two years it is very impatient of shade, and grows very slowly, if it is at all under large trees. In suitable places natural regeneration is very good. Fair crops of seeds are borne almost every year. In some places, notably north of the Ikoha in the Benin province, it is almost gregarious in habit. It sproute well from the stump. Here again, unless there is sufficient light, it does not grow rapidly, and even tends to die down. In the nursery, seeds generate readily, but often fall a prey to the Duika, which eat the young seedlings. The tree does not stand transplanting very well, as it throws back its development very considerably. Small plantations have been made in one or two places. Close planting appears to be the correct method, as the branches are rather persistent and liable to form knots or places of decay in the stem, if they do not drop off when they are quite small.

In 1906 samples of this timber were sold as a hardwood in Liverpool market, where it was considered to show little or no merit. However, since that date there have been increased demands for all good timbers, so that it seems worthy of a further trial. Locally it has been used for making canoes, or 


\section{WEST AFRICAN FORESTS AND FORESTRY}

has been cut up for planks. It has also been used for bridgebuilding and other constructional work, and being one of the most durable, ever wider use is being found for it, quite apart from any likely demands for export.

Native Use.-It is felled for sawing up into planks and making canoes, and is considered one of the best of all local timbers, except Iroko.

Sarcocephalus sambucinus (?), Yellow Wood. Opepe (Yoruba); Ebengiku, Obiache (Benin); Eben (Jekri).

It is found in the Ondo, Benin and Warri provinces of Nigeria.

It is a medium-sized tree of the swamps, both near rivers and near the sea coast-in fact, it will grow in waterlogged places-whereas the Sarcocephalus esculentus, to attain large dimensions, likes drained soil.

The fruit is only an inch in diameter, but of the same colour as the former. The pitting of the surface is more widely distributed and the pits are shallower. The bark is less scaly, with a very slight roughness or fissured surface. The wood is not so durable as the former, especially in exposed places. On the whole, the leaves are larger than $S$. esculentus and a little thinner.

The sapwood is whitish-yellow and the heartwood of a deep yellow colour. It is more fibrous and rather more opengrained than that of $S$. esculentus. The pores, too, are longer. On the whole, it is easier to work, a little softer, planes well, takes nails, splits well and saws easily. It is doubtful if it is termite-proof.

Although really a light-loving tree, it can stand more lateral shade than $S$. esculentus. It is a thoroughly soil-protecting and soil-improving tree, the foliage making a very rich humus. It is much more slow-growing than $S$. esculentus, though on the whole it will stand closer together, and yet grow well. It sprouts well from the stump. Natural regeneration appears to be good. It is sometimes almost gregarious in habit, and in some places one of the few valuable trees in the swamp region. It is also often one of the fow of merchantable size. No plantations have been made with this tree.

In. 1906 samples of this timber were sold in the Liverpool market as cedar, but it was only considered of poor quality. It deserves, however, further trial now. Locally it is occasionally sawn up for planks.

Native Use.-It is sometimes used for making canoes, but it is not liked by the natives, because they say it is not so durable as $\boldsymbol{S}$. esculentus. 
Sarcocephalus sp. Swamp Opepe. Oppepera (Yoruba); Eben Obiache (Benin). Perhaps the same as the foregoing species. Morinda sp. Brimstone Wood.

Ekiti district, Ondo province.

Morinda lucida. Brimstone Wood. Oruwo (Yoruba); Obiache (Benin).

Found in the Yoruba and Benin country.

Morinda longiflora. Ekiti Morinda.

Found in the Ekiti district, Mamu Reserve.

Pausinystalia sp.

It is found in the Eastern Calabar province of Nigeria. It is a medium-sized tree found growing in old farms. It has globular-shaped flowers with yellowish-red anthers, making it very pretty and conspicuous. It has a hard, yellowish-white wood.

Saccoglottis Gabunensis. Mahogany, Tala. Ugu (Benin); Attalla (Jekri); Edat (Efik); Tala (Brass); Tala (New Calabar); Edat (Oban, Ekoi).

It is a large tree, attaining a girth of 15 feet and a height of 150 feet. Nearly. always found on swampy ground, or anyhow where the rainfall is high, as, for instance, in the Oban district. One of the first trees to be seen in the forest immediately behind the mangrove swamps. The bark is roughly fissured like elm, but more regularly, and the slash is red. The fruit is an indehiscent nut with small nodules on it, about the size of a walnut, which exudes a liquid not unlike honey. Bees often frequent the tree for that reason. A reddish sap exudes when the tree is cut.

It is found in the Benin, Warri, Owerri and Calabar provinces of Nigeria.

The wood is hard and dark-red, with a fairly close grain, though easy to work. The sapwood is usually very narrow and yellowish-red.

It is evidently a shade-bearer, and stands a good deal of shade in its youth. Natural regeneration is fairly good where the rainfall is high. It seems a moderately fast grower, though no actual measurements have yet been taken. It is almost gregarious, especially in Oban. In 1906 it was valued in the Liverpool market at $3 d$. to $6 d$. a superficial foot as a mahogany of mild texture and fairly good colour. It has, however, not been used by the Public Works Department.

Native Use.-In the Benin, Warri and Calabar provinces the bark is stripped off in rolls about 3 feet long and sold for making gin bitter, by placing it in the liquid. A bundle of bark is sold for 5s. at Calabar. In the Degema and Brass districts it is one of the common canoe trees. 
Mitragyne macrophyllum. False Opepe. Burokossa, Bulokossa, Ugbodokossa (Benin); Ebar (Brass); Ebar (New Calabar); Ubuen (Efik).

It is found in the Abeokuta, Ondo, Benin, Warri, Owerri and Calabar provinces of Nigeria.

It is a large tree, attaining a girth of over 12 feet and a height of over 100 feet. It has a very large leaf. The tree is often more or less gregarious, more especially in the moister or almost swampy parts of the evergreen forest zone. The bark is of a dull-green colour, comparatively thin, and only slightly fissured in a large tree.

The sapwood is yellowish-white and the heartwood of a pale yellow colour. It is almost a hardwood, does not split well, planes up smoothly and saws comparatively easily. It hardens considerably on seasoning and is very durable under cover, but not so much on exposure to the air. The dense foliage makes a thick layer of humus under the trees, as a few of the leaves fall off each year. It is thus a soil-improving and soil-protecting tree. It would probably be found to make a good mixture, in groups of about half an acre in extent, with mahogany in the evergreen forest zone. In the Brass district it is one of the commonest trees which is used for making canoes; it has also occasionally been sawn up for planks. It has not yet been exported to England, but at any rate locally it should command a wider use in house-building of all kinds.

Mitragyne Africanum. Akpakossa (Benin).

It is found in the Benin, Ondo, Warri and Calabar provinces of Nigeria.

It is a somewhat common tree on the borderland of the mixed deciduous forest and the dry-zone vegetation. The tree is of small size, attaining a girth of about 6 feet and a bole length of 25 feet; the leaf is very large, but does not reach the size of $M$. macrophyllum. It is most frequently found in the awampy places at the edge of the deciduous forest; like the sister tree, it is more or less gregarious, though the groups are usually not very large.

The timber is of a dull yellowish-white colour, and planes well; it does not split very easily and is very durable.

This speoies is a shade-bearing tree of soil-protecting and soil-improving qualities, owing to the dense bed of leaves, which in turn makes a bed of humus at the base of the tree, and thus grass-fires are very much hindered in spreading. The timber has not been exported to Europe and the natives scarcely ever use this wood. 
Randia malliefera. Buje nla (Yorubs).

Found in the Olokemeji Reserve.

Randia octomera (Hook.). Buje (Yoruba); Assun (Benin).

It is found in the Benin province. It is a shrub with spherical-shaped fruit like an apple, with the sepals projecting from the top. The fruits yield a black dye which is used by the natives.

Randia cladanthra (K. Sch.).

It is found in the Benin province of Nigeria. It is a woody shrub having a hard wood, and rather pretty red flowers in the autumn, which brighten the evergreen forest very much.

Randia maculata (Kew). Buje, Buji dudu (Yoruba).

A shrub having large, trumpet-shaped flowers. It is very ornamental.

Randia cordata. Blue Dye. Buje (Yoruba).

It is a small tree, 15 to 20 feet high. Found in the Olokemeji Reserve.

Randia macrantha. Kan Kan (Yoruba).

Found in the Ondo province.

Nr. Randia. Ukape (Benin).

Found in the Benin province.

Mussaenda erythrophylla (Bch. and Thonn.). Kamatete (Ibo, Owerri).

Found in Obudu, Ogoja province.

Mussanda termiflora (Benth.). Mamu (Yoruba).

Found in the Mamu Reserve.

Mussaenda Isertiana. Igi Ira (Lagos) (Benin).

Lagas.

Pavetta Baconia (Hiern). Idofun, Igbo (Yoruba); Akapano Iyokheze (Benin).

It is a common tree in the Calabar, Warri, Benin, Ondo and Abeokuta provinces of Nigeria. A small, shrub-like tree, reaching about 3 inches in diameter, most common as an undergrowth plant in the evergreen forest zone. Many specimens are found in the Obagie Forest Reserve. It stands the shade well, is moderately hard, and sprouts well from the stump. The natives of the Benin country cut young specimens very largely for use as yam-sticks.

Hymenodictyon bractealum. Obadon (Benin).

Found in the Benin province of Nigeria.

Corynanthe paniculata (Welw.). Olikiba Anikiba (Benin).

So far it has been found in the Benin province of Nigeria, but either this species or Johimbe should be found in the Calabar and Ogoja provinces. 


\section{WEST AFRICAN FORESTS AND FORESTRY}

It is a medium-sized tree of the mixed forest zone, which is moderately prevalent in certain localities.

The timber is brown, hard and durable. It planes well and splits moderately well. It takes nails and saws moderately easily for hard wood. It is considered termite-proof by the natives.

It is a somewhat slow-growing tree, a shade-bearer, a soilprotecting and soil-improving tree. Natural regeneration only appears to be slight. It does not sprout very prolifically from the stump. No experimental plantations have yet been made.

This is a sister species to $C$. Johimbe, which yields the bark containing the very useful alkaloid Johimbin, but as yet the bark of this tree has not been tested for a similar substance.

In the timber report of 1906 it is valued at $2 \frac{1}{2} \mathrm{~d}$. to $3 \frac{1}{2} \mathrm{~d}$. a foot as a species of gummy mahogany, and in another case as fancy wood at 1d. per superficial foot or 1s. 6d. to 1s. 9d. a cubic foot.

Amongst the Benin natives it is used for wall-plates, for which purpose it is highly esteemed.

Crossopteryx Kotschyana. Ayeye (Yoruba).

A small tree found in the dry-zone forests, of no special value. The fruit is leathery; the flowers grow in panicles.

Native Use.-Parts of the tree are used in medicine by the natives.

Sabicea calycina (Benth.). Agan Aparo (Yoruba).

Found in Iro.

Canthium glabriflorum (Hiern). Attan (Benin).

It is a common tree in the Calabar, Ogoja, Warri, Benin and Ondo provinces of Nigeria, also in the Cameroons.

It is a medium-sized tree, reaching a girth of 9 feet, but with a bole length of about 60 feet, rather longer in proportion to the girth. The flat, wide crown is typical of this tree, as are also the large tripinnate leaves and the brown, stringy bark with slight fissures. The branches spread out almost in two or three whorls near the top of the tree. The light can be seen through the crown. The flower is white, in large, umbel-like masses of small flowers, borne on the upper side of the branches. It flowers in November.

The sapwood is white and fairly broad and the heartwood is brown, like cedar. Termites attack in the open.

It is a light-lover and grows quickly, in old farms especially. It sprouts well from the stump, but there are no root shoots. Seed production is good, and seedlings appear in near open spaces.

It has not been cut for local use or exported to Europe. 


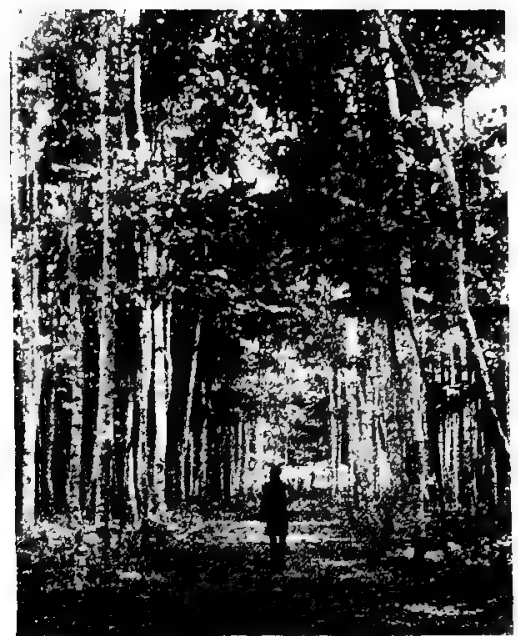

FIG. 89.-Funtumia Rabber Plantation on both sides of the road, Igwoshudi, Benin.

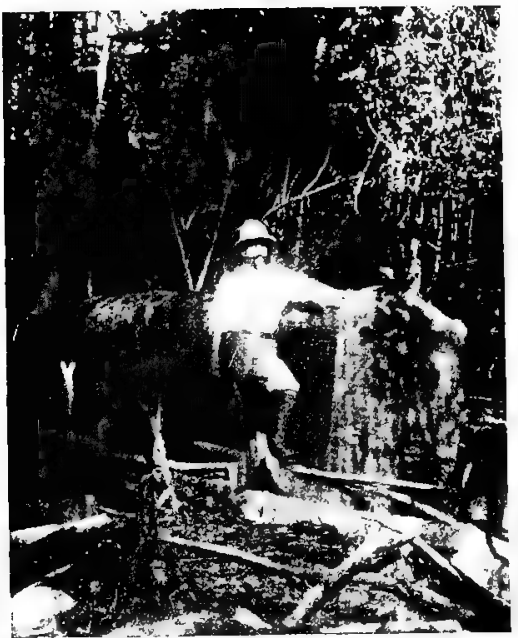

FIG. 91. - Entandrophragma Iog with three sides already squared and fourth partially cut resdy for squaring.

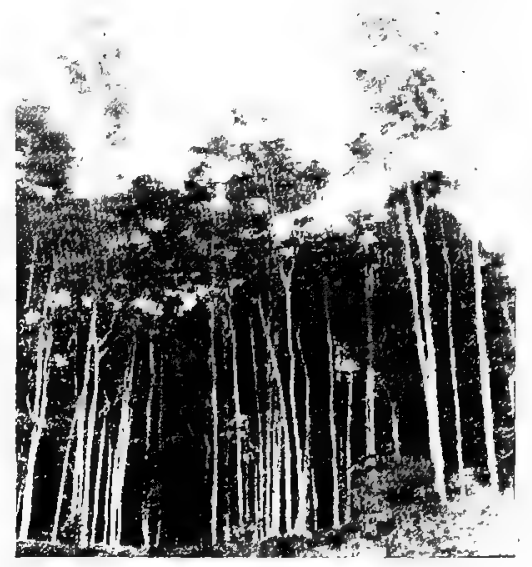

FIG. 90.-Mahogany Plantation (Khaya Punchii), twelve years old, near Noami, on the banks of the Osse River, Benin Province.

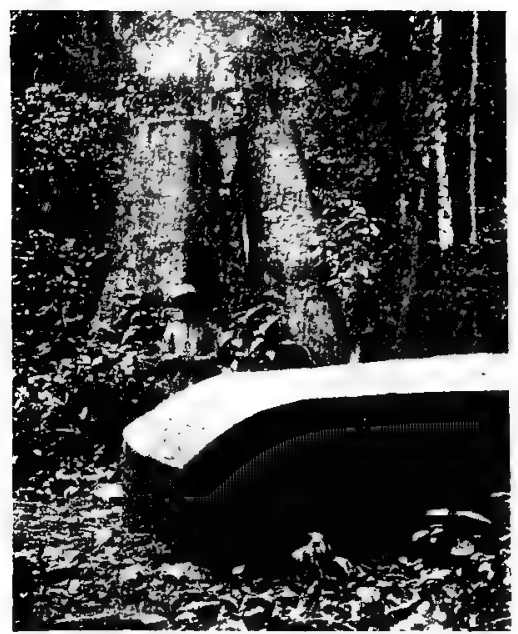

FIG. 92.-Stump of Khaya Panchii with log at base, left in the Benin Forest. 

The branch is used. It has to be placed on a boy's head and is said to make him grow. The boys do it themselves in the Benin country. The wood is also a firewood in Benin.

\section{Compositæ.}

Vernonia conferta. Big-leaf African Cabbage Tree. Onimagugun, Shapo (Yoruba); Orimagugu, Oriweni, Onamagungun (Benin).

It is found in the Abeokuta, Ibadan, Benin, Onitsha and Ogoja provinces of Nigeria, in clearings at the edge of the mixed deciduous and dry-zone forests. It is a very common small tree or large shrub, springing up in all old farms. The very large bright-green leaves, set opposite to each other on a small, comparatively, stout, green, succulent stem, are most typical of this plant. The fresh leaf, especially on the smaller plants, is not unlike a very open cabbage leaf, but of a lighter green hue. As the plant gets older the leaves do not attain such a size. The flowers are small, but grow on large, open and much-branched spikes. The stem is comparatively soft and pithy, scarcely forming a real woody tissue. When dried they can be used for firewood and kindle easily. Occasionally it is used for making live fences.

Vernonia Nigritana (O. and H.). Bitter Leaf. Ewuru or Oko (Yoruba); Ihagobo (Benin).

This is found in the upper part of the Benin province of Nigeria, near Sabongida, in the deciduous zone. A small shrub-like tree, the leaves of which are used for soup. The dried stem is used for kindling wood. The roots are sometimes used as chew-sticks.

Vernonia amygdalina. (Del.). The Bitter Leaf. Ewuru (Yoruba), Oriwu (Benin).

Yoruba Chew-stick, also known as the Chew-stick of Ewuro, thereby clearly showing the Yoruba origin of some of the inhabitants of Sierra Leone, as Ewuro is also the name of it in the Sierra Leone country.

It is found in the Abeokuta, Ibadan and Benin provinces, where it grows in openings in the mixed forests.

It is a small shrub, reaching a height of about 5 feet, having soft leaves, with rather a greyish tint, which are covered with very fine silvery hairs. It is commonly found in old farms and by the side of the roads, usually in small bushes or clumps.

It sprouts up when cut down, and thoroughly shades the ground. However, it is sometimes so thick that it rather hinders plantation operations, though once the other plants are established it acts as a useful little " nurse." The leaves are picked off by the natives and cooked in water for making 


\section{WEST AFRICAN FORESTS AND FORESTRY}

soup. They have a distinctly bitter flavour, but make a very heslthy vegetable soup. The leaves are often sold in the local markets. This shrub is occasionally left more or less in line as a small living fence.

Vernonia cinerea (Les.). Ash-coloured Fleabane. Elegbe Oju (Yoruba).

It is found in the Olokemeji Reserve of the Abeokuta province of Nigeria. A large, woody shrub, one of the chewstick family, the leaves of which are sometimes used for making soup.

\section{Lycopodacese.}

Lycopodium phyllamaria (Linn.).

This is a small Lycopodium found in the Benin province of Nigeria. It was obtained from the uppermost branches of a very tall tree, growing at the edge of a deep valley about 8 miles north of Benin City.

\section{NON-INDIGENOUS TREES OF NIGERIA}

\section{Myrtaceæ.}

Eucalyptus amygdalina.

A specimen of this tree stands on the old beach at Akassa, Warri province.

Eucalyptus tereticornis.

Lagos Island.

Eucalyptus rudis.

Lagos Island.

Eucalyptus tessitaris.

Lagos Island.

Eucalyptus citriodora.

A specimen of this tree stands in the Botanical Gardens at Calabar.

\section{NOTES ON NIGERIAN TREES OF WHICH THE BOTANICAL, NAMES ARE NOT KNOWN}

Itufiak or Etufiak (Efik). Essunwoi (Yoruba); Ilako (Benin).

It is a medium-sized tree of the freshwater swamps, with heavy dark-green foliage; it grows quite gregariously in stands of one to ten acres in extent. The trunk reaches a girth of about 7 feet and a bole length of about 30 feet. The roots spurns are comparatively slight, and do not extend much over a foot up the bole. The foliage is very heary and it casts a most dense shade, making patches of this forest the darkest of almost any in Africa. 


\section{THE NIGERIAN TIMBER TREES}

It is common on the banks of the Itunkpe Creek, a tributary of the Kwa River, near Calabar, in the same named province, and also in the Owerri province of Nigeria. It belongs to the evergreen forest zone.

The timber is a reddish-brown hardwood of close grain, which would saw into sizeable planks. It is a somewhat slow-growing, shade-bearing, soil-protecting and soil-improving tree. The leaves yield a thick bed of humus. It appears to be one of the most valuable trees in this respect. It is moderately hard, with even, close-textured grain. It planes well, saws fairly easily, takes nails, but does not split well. Natural regeneration appears to be good. It also sprouts from the stump.

The timber has not been exported, nor has it been cut for planks for local use. It appears to deserve a trial as a local timber for floor-boards or for the making of boxes. Considering that so often many trees are found in the same place, it should not be difficult to obtain adequate supplies.

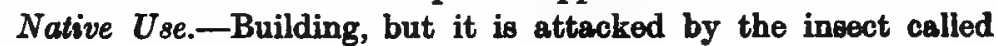
Efiak.

Musk Tree. Owi (Benin).

It is found in the Benin province of Nigeria, in the evergreen forests. It is a medium-sized tree, reaching a girth of about 8 feet with a short bole of about 10 feet. The crown is large but rather elongated, and reaches down two-thirds of the height of the tree. The fruit is large and more like an avocado pear in shape and colour. The leaf is very large and wide, more like a teak leaf, but of stronger texture, the midrib especially being very thick.

The timber is hard, with white sapwood and green heartwood. It splits well and takes nails fairly well. It is a little fibrous in texture, but can be planed; it saws fairly easily.

It is a somewhat slow-growing, shade-bearing, soil-protecting and soil-improving tree. The leaves make a rich humus. Natural regeneration is none too good. Stump sprouts do not appear to be very strong.

It has not been exported or cut for local use, but would be worth trying for house-building.

Native $\bar{U}_{8 e .-T h e}$ fruit is kept for four days and then the inside large kernel is eaten. The young leaves are used for curing boils, as an external plaster to draw the poison.

Ekkiowa (Benin).

It is a small shrub which is found in the Benin district of the same named province. It is not very common.

Native Use.-The seed is used medicinally for the hands in case of sores which are red or raw. 
Satinwood. Okwaba (Benin).

This tree is found in the mixed forests of the Benin province of Nigeria.

In 1906 sample logs of this timber were sold in the Liverpool market as satinwood, but were not considered worth shipping. Since then, however, none has been cut for export or for local use. Perhaps owing to the increased demands for all kinds of timber a further trial should be made with this one for satinwood. Natural regeneration is poor. It is a somewhat slow-growing, shade-bearing, soil-protecting and soil-improving tree. It reaches a large size.

\section{Vbellu, genus? Annamamilla (Benin).}

It is found in the Benin province, Nigeria.

It is a small tree, the name often confused with the mahoganywalnut, Lovoa Klaineana, which is also sometimes known as Annamamilla in the Benin country. The leaves are imparipinnate. It is a softwood with light-brown heartwood and little black, spherically-shaped fruit, unarmed.

Native Use.-Firewood of good quality. Not used otherwise.

Big Hardwood. Arugbo (Yoruba); Eto (Benin).

It is a very large tree with a wide crown. The timber is of a brown colour, but the sapwood is white. It is extremely hard and durable; even when felled in the farms it will be six years before it has rotted away. The bark is a dark-green with white lenticels scattered over it.

It is rather a rare tree in the Benin province of Nigeria. Standing a good deal of shade, it is a soil improver and protector. Natural regeneration does not appear to be very plentiful.

It does not sprout up when coppiced.

Native Use.-None.

Ifon (Yoruba). Owehe (Benin).

Is a small tree which has scented wood. It reaches a girth of 20 inches only. Before going to market, according to the natives, the feet, hands and body should be washed with a solution prepared from the bark of this tree mixed with soap. The object of this operation is to effect quick sales at the market.

Ewayron (Yoruba).

A leaf for wrapping up food, found in the Yoruba country, also used in Benin for roofing houses. 


\section{THE NIGERIAN TIMBER TREES}

Mahogany. Alode (Benin).

This tree is found in the mixed deciduous forests of the Benin province of Nigeria.

In 1906 samples of this timber were sold in the Liverpool market as a species of mahogany of a soft nature. Since that date none has been felled. Perhaps with the changed conditions with regard to the demand for all timbers similar to mahogany a further trial with the timber of this tree should be made. Natural regeneration is not very good. It is a rather slowgrowing, soil-protecting and soil-improving tree.

Spiny Tree. Oaha (Benin).

It is a small tree found in the Benin, Ondo and Abeokuta provinces of Nigeria. The small, rather thin and longish spines on the stem are the most typical feature of this tree. It usually grows with aerial roots. It reaches about 3 feet in girth, and on the whole is more common in the secondary forest than in the primeval. The wood is moderately durable, especially when used for inside work, such as verandah-posts,

Native Use.-It is sometimes used for small poles for hutbuilding.

House Post. Ewai (Benin).

A common tree in the Benin and Abeokuta provinces of Nigeria. It is a slow-growing tree which has a very hard brown wood; it is a shade-bearer. The seed is a small nut. The wood is used by the natives of Benin for building-posts, rafters and small planks.

It is found in the moist evergreen forest zone and is somewhat common in the Obagie Reserve of the Benin district.

Ussehin Chew-stick. Okuta (Yoruba); Okuta, Opahan (Benin).

It is rather a rare tree of the Benin, Ondo and Abeokuta provinces of Nigeria. The name means "a stone," and has apparently been given because of the hardness of the wood. It is a medium-sized tree, reaching a girth of about 5 feet. The wood is almost white, and there is little difference between sapwood and heartwood. In the Ussehin country of Benin it is used as a chew-stick. The Yoruba states that it is the hardest of all native woods.

Akpo (Benin). Hardwood.

It is rather an uncommon tree of the Benin province of Nigeria, also a very hard wood, a medium-sized tree. The brown 


\section{WEST AFRICAN FORESTS AND FORESTRY}

heartwood is used by the natives for planks. It is thought rather highly of by the Benin natives, especially for wall-plates and joists. In the past it has been only hewn by them, but not sawn.

\section{Ukpaigwi, Okpaigui (Benin).}

Rather an uncommon tree of the Benin province of Nigeria. It grows to 10 feet in girth and yields a soft wood which is attacked by white ants. It is a shade-bearer and soil-protecting tree. The roots are used by the natives for medicinal purposes.

\section{Oruru (Benin).}

It is a tree found in the Benin province of Nigeria.

It is a small tree, reaching a girth of 2 feet. After three years it comes up in an old farm. The slash is red and a little red sap exudes slowly. It is usual to find thirty small ones in one place, from root suckers, but also from stool shoots if a tree has been cut down before. It is similar to Eranpata in this respect. The fruit is round and small and like peas, only a little larger. The flower, which is white and quite small, grows in small clusters.

The wood is not hard and white all through. It is attacked by termites, except when placed in the house, where it is more or less protected.

Reproduction by stool shoot is the best method.

It is a shade-bearer and grows slowly. It grows in good soil of some depth and also in the evergreen forests. When it appears in old farms, it stands the fires well.

It is a soil-improving and soil-protecting tree, and tends to spread with the extension of cultivation, especially in the evergreen and mixed deciduous forest zone.

As it does not reach timber size, it is not worth trying as a building timber.

The fruit is edible; after eating it the tongue becomes almost of a blue colour. The root is used medicinally. The branches are used as pegs in the top of the walls of the houses in Benin, partly for fixing the roof. 


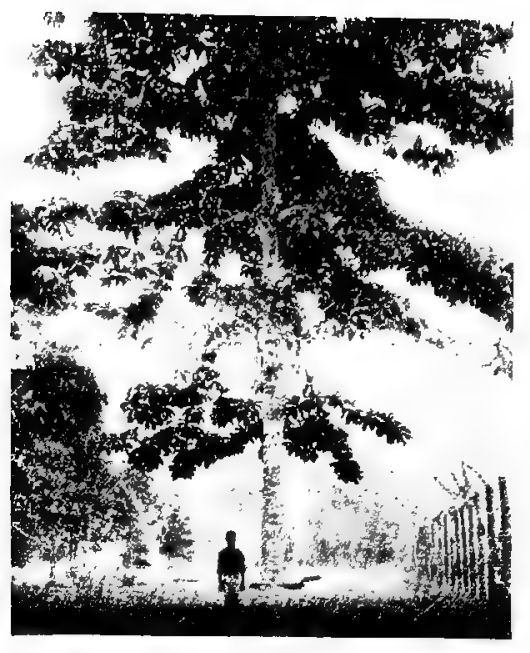

FIG. 93.- Mimusops Djave, about twelve years old, standing near Prison, Degema Station, Eastern Circle.

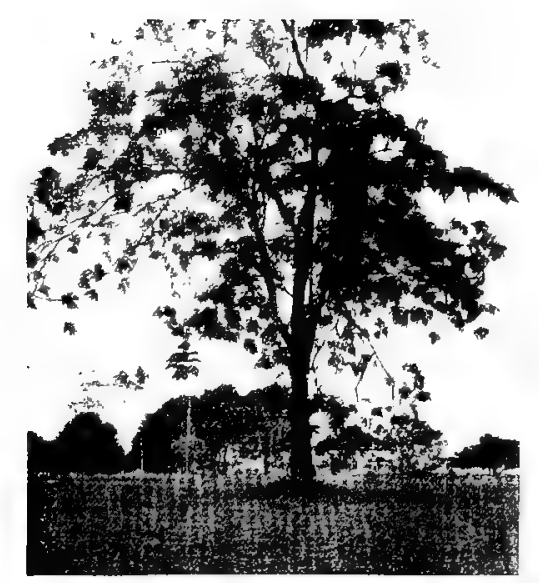

FIG. 95.- Young Oil Bean Tree in bearing (Pentaclethra macrophylla), Degema Station.

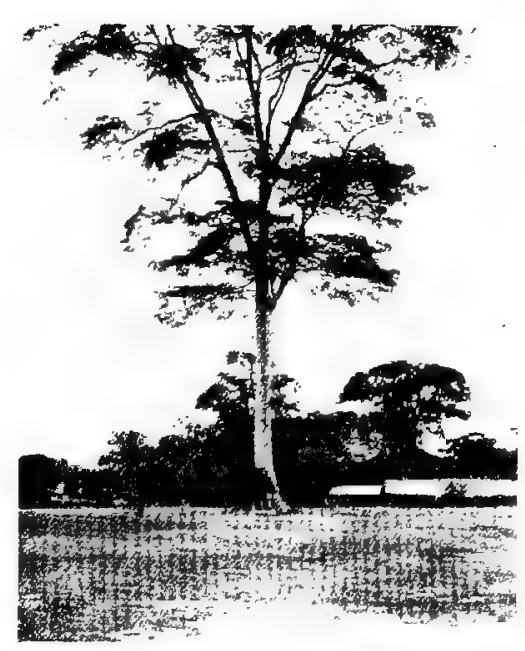

FIG. 94.-Mature Light African Greenheart (Piptadenia Africana) standing in the middle of Degema Station.

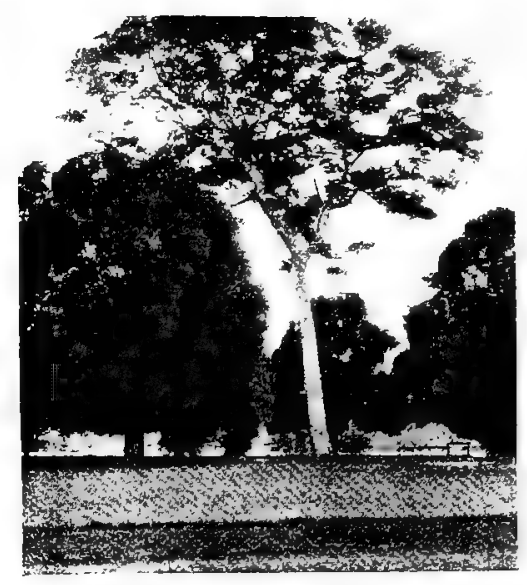

FIG. 96.-Red Oak (Berlinia' acuminata), 20 feet in Girth, standing near the Sombreiro River, Degema Station. 



\section{CHAPTER $\mathbf{x}$}

\section{THE FORESTS AND TIMBER PRODUCTION OF THE BRITISH SPHERE OF THE CAMEROONS}

Ronwive parallel with the Nigerian boundary, a strip averaging 75 to 90 miles in width, and running back from the coast about 300 miles, we have the British sphere of the Cameroons, in all, an area of about 31,000 square miles. From the forest-zone point of view this land area can be divided into really three different zones. First of all, nearest the coast, there is Victoria, the Cameroon Mountains, followed by the bank of the Mungo. Past the crest of Kuppe and the Manengube Mountains and onwards along the Mbo, Foto and Bambuto Ranges round to the headquarters of the Cross River and to the Nigerian boundary, we have about 7,000 square miles of an almost unbroken evergreen forest zone.

The second area comprises a beautiful open grassland with only scattered trees, covering largely the Chang, Bamenda; Kontsha and more northern districts of the British sphere, in all about 17,000 square miles.

The third section comprises the heavy evergreen and deciduous forests on the banks of the more northern rivers, such as the Mo, the Cam, and covers approximately an area of 7,000 square miles.

From the forestry point of view, the most accessible, and therefore the most valuable, of these areas are situated in the first-named zone, therefore we will consider this area more in detail.

To begin with, it can be subdivided into three almost distinct forest divisions; following the watersheds or basins of (1) the Mungo River, (2) the Cross River, (3) the Akwayefe, Ndian, Moko, Meme Rivers and the Rio del Rey district. Taking the third arca first, we have comparatively large areas of forest covering both level and hilly country up to an elevation of about 3,000 feet, but with the sides of the valleys less timbered than in the Mungo River forest zone. Amongst the species of trees which have been felled and exported from this area are the following: Mahogany Sarcocephalus, Bitter Bark, Saccoglottis Gabunensis, Light Mahogany, Khaya Euryphylla, Ebony, Diospyros Kamerunensis, Red Ironwood or Bongossi, Lophira procera, Long-capsuled Mahogany, Entandrophragma Rederi.

Amongst the more prevalent trees of the lower lying land, including 


\section{WEST AFRICAN FORESTS AND FORESTRY}

the Tiko plain, are the following: Mahogany, Khaya Klainei, Longcapsuled Unscented Mahogany, Entandrophragma Condollei, Scented Mahogany, Entandrophragma utilis, Cedar, Guarea sp., Red Ironwood, Lophira procera, Canarium Schweinfurthii, Brown Ebony, Diospyros sp., Terminalia, Scutifera, Afzelia pachyloba, Berlinia sp., two kinds of Camwood, Walnut, Lovoa Klaineana, Pterocarpus tinctorius, as well as the valuable orange-coloured wood of Sarcocephalus sambucinus and Mahogany-like species of Guttiferæ and Uapaca Staudtii.

Some of the "stands" of this timber, and especially on the hill slopes of the Cameroon Mountains, are very thick and dense, more especially near Debundscha, with its annual rainfall of 423 inches.

One of the most interesting and unique stands on the mountainside is that of tree-fern, about $\mathbf{3 0}$ feet high, as an undergrowth, and heavy mahogany, Entandrophragma Rederi, and Ongekea Kamerunensis, chiefly at an altitude of 3,500 to 4,000 feet, also quite untouched except in the neighbourhood of Buea.

Only the smallest part of all this area, and in fact only that on the bank of the Meme, had been at all operated upon before the war, and the forests on the banks of the Akwayefe were quite untouched. All the higher slopes and the northern sides of the Cameroon Mountains, and beyond as far as Mount Gonistan, were also quite unused. All through this part the villages are comparatively few and far between, and even in those parts where they are closer together, the population in each is very small, and the forest growth is so thick that they make little impression upon it. Added to that, the chief crop grown by the natives is the cacao-yam, for which only comparatively small areas are necessary, and in many cases this is grown in small spaces in the shade of giant forest trees. Also, all through this area only comparatively small patches, compared to the whole, have been cleared and planted with cacao. Again, the area occupied by the European-owned cacao and rubber plantations is very small, and chiefly found near Victoria and a little both westward and eastward at the base of the Cameroon Mountain (Mount Fako).

Turning now to the Mungo River region, we have in some ways an even more valuable forest area. Here, indeed, one German firm had actually made a felling over an area of nearly one square mile and had sold nearly all the timber' in Germany.

Amongst the more prevalent species found are the following : Bush Oak, Chlorophora excelsa, Black Ebony, Diospyros Gilgiana, Pearwood, Mimusops Djave (which is found in immense specimens on the edge of the Kumba road), Inoi Nut, Poga oleosa, with its light-reddish wood with wide modullary rays; African Greenheart, Cylicodiscus Gabunensis, a magnificent tree; Shinglewood, Scented Mahogany, Guarea glomerulata, Brown Teak, Brachystegia cynometroides, Longcapsuled Mahogany, Entandrophragma Condollei, the Oil Bean, Penta- 
clethra macrophylla, Red Ironwood, not quite so prevalent; Lophira procera, Paddle Wood, Uvaria Busgenii, Gum Copal, Pterogopodium $s p$., Wild Mango, Irvingia Barteri, Light African Greenheart, Piptadenia Africana, Camwood or Barwood, Pterocarpus santalinoides, Wood Oil Nut, Ricinodendron Africanum, Hard Yellow Wood, Coula edulis, and Ironwood, Bridelia stenocarpa. Although the Bakundu and Balong natives are more active in their farming operations near the banks of the Mungo, there are still very large areas of comparatively untouched forests, and more especially in the upper regions of the river. In four separate places beyond the crossing of the Bakossi Road there are four different rapids or waterfalls on the river, which would provide water-power for saw-mills, or other wood-using industries. On the left bank of the river, beyond the Bakossi crossing, there is an area almost without population in which there are large numbers of Oil Palms, as well as other forest trees. On this road, too, is seen the very picturesque waterfall and narrow gorge of a tributary of the Mungo, which is also suitable for generating power for one kind of mill or another.

Turning now to the Bakossi forests, which culminate in the more or less isolated peak of Mount Kuppe (altitude 6,300 feet), the land is all covered with forest with the exception of some rooky points on the eastern side. A small amount of land has been cleared at an altitude of about 3,000 feet, for the making of tobacco plantations, but the rest, with the exception of the taking of a few trees for local felling, remains intact. The Bakossis have made large farms in the valleys, and are very industrious, but still the forests situated higher up are largely untouched. It is interesting to notice that the walls of the round and conically roofed houses are made with about five circular rows of tree-fern stems, cut to the length of the height of the wall and placed one behind the other. These are most durable and are a most unique example of the utilization of the produce of these forests, although many of the tree-fern "stands" have been cut down and have quite disappeared; a few remain in isolated places.

Some of the more common species found in this forest are the following: Bush Maple, Triplochiton schleroxylon, Ebony, Diospyros, Mahogany, Khaya Euryphylla, Bush Teak, Chlorophora excelsa, Gum Copal (Copaifera Demeusii), Bilinga (Afzelia Zenkeri), Hardwood (Millettia sp.), Scented Mahogany (Entandrophragma Candollei), Light Mahogany (Canarium Schweinfurthii), Hardwood (Dialium Standtii and Newtonia Zenkeri), Yellow Hardwood (Ongokea Kamerunensis), African Whitewood (Enantia chlorantha), Camwood (Pterocarpus Soyauxii).

There is less forest near the Manenguba Mountains, most of it being situated on the banks of the Mo and Mbu Rivers (tributaries of the Cross River). Continuing along the boundary line between the grass country and the tree-fern forest, we have the Mbo and Foto Ranges, 


\section{WEST AFRICAN FORESTS AND FORESTRY}

with their dense evergreen forests up to an altitude of 5,000 feet. Amongst the more valuable trees are the Cola (Cola laterita), Camwood (Pterocarpus Soyauxii), Albizzia species, Ibadan, Ficus Vogelii. Below this point, at about 4,000 feet, Iroko, Chlorophora excelsa, Corkwood, Musanga Smithii, and tree-ferns reappear, as well as Acacia Farnesiana. The Wild Date, Phanix sp., occurs again about this altitude. The Oil Palm occurs again in the valleys. On the lower slopes there are Ricinodendron, Bombax, Sarcocephalus, and Trema.

Continuing farther northwards we have the Bambuto Ranges, with their fringing forests on the banks of the streams, and the bamboo groves at an elevation of about 8,000 feet. Willows and small Abyssinian plants are found, and with the flowering of Delphiniums in the grass we might almost be in Europe. Toward the Cross River side, the mountains are very steep, and isolated peaks, such as that of Monkwa Rock, stand out in solitary grandeur amongst the lower forested mountains of the Cross Piver. In the Cross River basin we have mainly six large rivers, all joining the Cross River. On the right or northern bank these are the Manyu, Mo, Manya, and Oyi, above Mamfe, and on the left or southern bank the Mbu and Manja, as well as the Awa, joining below Mamfe. All except one of these rise amongst the forests, and it is on the banks of these that the finest forests are situated, although in some parts, such as near Tinto, the natives have been more active in farming and have cleared large areas of them. This is more the case nearer the villages, and nearer the roads, even where the forest has been cut down, there are almost continuous groves of Oil Palms, less than a quarter of its produce having as yet been collected or sold. Amongst the most valuable timber trees of these forests are the Ebony (Diospyros), Bush Teak (Chlorophora excelsa), African Whitewood (Enantia chlorantha), Camwood (Pterocarpus Soyauxia), Bilinga (Afzelia Africana), Hardwood (Millettia sp.), Sapeli Mahogany (Entandrophragma Candollei), Light Mahogany (Canarium Mansfeldii), Hardwood (Newtonia Zenkeri), Wild Mango (Irvingia Barteri), Mukonja (Terminalia superba combretacea), White Cedar (Pycnanthus Kombo), Red Oak (Berlinia acuminata), Berlinia species with very large pod, three species of Walnut, Albizzias, Red Ironwood (Lophira procera), African Wood Oil Nut Tree (Ricinodendron Africana), Parinarium sp. (Dialium).

The range of hills Nda Ali is also forest-covered and is situated in the Cross River basin.

More or less adjacent to these areas, and partly between these and the Meme River forest, are those of Gonistan and the Rumpi Mountains. These again are quite untouched, although, lying some distance away from navigable rivers, they may subsequently prove of greater value when eventually opened up with the forest tramway or other means of transport. The species of trees found here are very 
similar to those found in other parts. On the whole, Red Ironwood (Lophira procera) is most prevalent in Ogu and Mbu, as also both Mahoganies, Camwood (Pterocarpus sp.), African Greenheart (Piptadenia Africana), Corkwood (Musanga Smithii), False Iroko (Chlorophora excelsa), Hog Plum (Spondias lutea), Wild Mango (Irvingia Gabonensis), Hard Mahogany (Detarium Guineense). Numerous small Oil Palms occur in places. On the banks of the Fi, Cedar (Carapa procera), Hard Mahogany, Trichilia, an anacardiaceous tree; the hard whitewood Akboro (Benin), the brown hardwood, Microdesmis, African Greenheart (Piptadenia Africana), Heritiera sp., Scented Mahogany, Guarea Thompsonii, Chrysophyllum Africanum, and a very hard wood known as Alikongeba by the Yorubas are found. Near the Rumpi Mountains the following are more prevalent; the Sarcocephalus sp., Berlinia, Piptadenia Africana, Cylicodiscus Gabonensis, Oroko, Lophira procera, Satinwood, Zanthoxylum macrophyllum, Patternwood, Alstonia Congensis, Shingle-wood, Terminalia scutifera, Pearwood, Mimusops Djave, Corkwood, Musanga Smithii, Scented Mahogany, Guarea sp., White Cedar, Pycnanthus Kombo, Camwood, Pterocarpus sp., brown hardwood, Microdesmis, Wild Mango (Irvingia Gabunensis), Gaboon Mahogany, Canarium Schweinfurthii, Bilinga (Afzelia pachyloba), and Walnut.

Out of the total of 14,000 square miles of forest, 6,000 must be deducted as being inaccessible for many years to come. Again, out of this 8,000 square miles, 4,500 square miles will be made accessible as soon as those areas lying nearest the rivers have been opened up for timber extraction. Therefore only these last areas will be taken into consideration at the present time.

The chief timber forests comprised in this area are those situated between the Mfu and Fi, the Fi and Mbu, and the Manja and Mak Rivers.

On the whole, in the Cross River basin there is an area of fully 2,000 square miles of exploitable forests, within reach of streams or rivers deep enough to float logs in the rainy season. In the Akwayefe, Ndian, Moko, and Meme River valleys there is another 700 square miles. Again, on the banks of the Mungo and its tributaries there is an area of about 800 square miles suitable for the extraction of timber. In all, then, there is an area of 3,500 square miles of forest which could be utilized at the present time. Assuming that only one tree on every four acres is of value for export, and that each tree is worth a nominal amount of $£ 1$, therefore the whole forest is worth $\mathbf{5 7 5 , 0 0 0}$. In addition to these there are many other trees which would become valuable either for export or for local use as soon as the forests were opened up and utilized, and this would at least double the value of the forest. This, also, is one of the last remaining large tracts of forest where the population is smaller and the requirements 
for forest products less than those to be had in the forest. There is thus a surplus for export. Up to the outbreak of war, out of all this area only 47,000 acres, or $73 \frac{1}{2}$ square miles, had been, or was being, leased as timber areas. Outside these areas some 285,000 acres, or 445 square miles, had been alienated, chiefly on the lower slopes of the Cameroon Mountains and in the neighbourhood of Mount Kupe. Under the old German law, ten marks per ton was charged on Ebony, Mahogany, Bush Oak, and one or two other species, and five marks on all soft woods, except certain trees which had proved unprofitable to export. Compared with those in force in Nigeria, these fees were very low, and despite the fact that on the average the Cameroon forest would be more difficult to exploit than the average one in Nigeria, there should still be more profit in the former; also, with the considerable number of water-power sites available, timber conversion could be undertaken, and thus the cost of transport cheapened in comparison with the value of the product to be transported. Well-squared logs, large flitches or planks of timber could be cut and transported. Under the German Colonial land law, with the exception of 15 acres per head allowed to each native, all the land could be declared Crown land, so that no difficulty would be involved in leasing land to timber companies; that is to say, it was first declared to be Crown land and then subsequently leased to timber companies. The natives, however, then received no royalties on the trees which were felled. Thus those in the immediate neighbourhood had no incentive to work in the forests as they do in Nigeria. Sufficient emphasis was not laid on the fact that a timber company should possess ample capital.

In afforestation a great deal had been planned, but only a small amount had been executed. In the north, at Fontwans, in the Dschang district, a 40-acre teak plantation had been made. At each of the stations themselves, Dschang, Mbo, Djutisha, various experimental plots of trees had been planted. Nearer the coast, at Kumba, valuable test plantations, aggregating some 400 acres, had been planted with Ebony, Diospyros suaveolens, Umbrella Tree, Musanga Smithii, Casuarina, Casuarina equisitifolia, Cigar-box Cedar, Cedrela, Iroko (Chlorophora excelsa), Djave Nut (Mimusops Djave), Teak (Tectona grandis), Para Rubber (Hevea Braziliensis), Cacao (Theobroma cacao), and Oil Palms (Elcesis Guineensis), Red Ironwood (Lophira procera), Mahogany (Khaya euryphylla), and Heavy Mahogany (Entandrophragma sp.).

At Mussake at an elevation of 6,000 feet on the side of the Cameroon Mountains, there was a quinine plantation. At an elevation of 3,000 feet at Buea there were small experimental plantations of tea, Ceylon and ordinary, quinine and Casuarina. Several of the roads had been planted with avenues of cypress and Biota trees. On the coast at Victoria, small Casuarina plantations had been made. 
For the furtherance of all agricultural and forestal interests, the very extensive Botanical Gardens had been made. Not only is it the largest, but it contains the most extensive collections of plants of economic value and for ornament of any place on the West Coast of Africa. The very numerous test plots of most of the tropical commercially known plants, such as Nutmeg, Rubber, Cocoa, Cola, Cocoanut Palms, Oil Palms, Vegetable Ivory Palms, demonstrated how these grew in the Cameroons.

Then the agricultural areas of Cacao-yams, Casada, Sugar-cane, Rice, one and all were destined to demonstrate the value and possibilities of growing these products in the Cameroons. Then again the forest tree plots of Teak, Casuarina, Mahogany (Swietenia macrophylla), Trinkomalee Wood (Berrya ammomilla), Gum Copal (Copaifera Demeusii), Candle Nut (Aleurites Moluccana), Balsam of Peru (Toluifera Pereirce), Terminalia sp., Dillenia Indica, show how these trees will thrive in this locality. In growth, an avenue of Indian Almond, Terminalia Catappa, could not be compared with those at Lome.

Again, all showed what forest products and forest trees were most suitable to that climate.

In the garden Museum, there were collections of timbers, fibres, rubber, gums, resins, as well as mineral products; also very full collections of the seeds, nuts and fruits of the trees and plants. Finally, there was the large and well-equipped building of the Experimental and Agronomical Institute, where chemical analyses of the soil and other processes could be undertaken and tested. Here also all the very full meteorological results were tabulated, as well as other observations on the spot. This served also as a centre to which planters or Government officers could send specimens or material to be named or to be examined as to their value. Allied with this, but having a separate building, was the Agricultural School, where pupils were trained in the elements of agriculture and forestry, so that they might subsequently act as instructors at the different Government stations and also serve as assistants on the plantations.

Although economically much more backward than Nigeria, and with a smaller population in a proportionate area than that in the Southern Provinces, the possibilities in the development of the forest products are even greater, especially in regard to that of palm kernels and all the various kinds of timber for which West Africa is gradually becoming well known. The main difference in working would appear to be that owing to the lack of population, much greater use of animal and mechanical means of transport, and especially mechanical appliances, as well as machinery, are necessary to make the labour most productive, as well as to economize without upsetting the present agricultural system and the very necessary production of food-stuffs for the local population, as well as for sending to the larger towns. 


\section{THE CONGO FRANÇAISE, OR THE FRENCH GABOON}

To English-speaking mahogany producers and users the latter name conveys more, and reminds them of one of the chief products, Gaboon Mahogany, Oukoumea Klaineana, which had but a poor name in the London market. This rich French colony, however, should mean a great deal more to us with its huge extent, upwards of 300,000 square miles, and its comparatively large open waterways all flowing into the giant Congo. Its comparatively thin population per unit of area, and its almost impenetrable forests make it one of the largest of the last remaining primeval forests of Africa. Already before the war it was the largest timber exporting country of the West Coast of Africa. However, its somewhat ill-regulated timber trade had one or two drawbacks and laboured under several disadvantages. Most of the timber was shipped in the round-i.e. round logs. This means, of course, that in stowing these logs in the ship space is lost between them, and that space is charged for by the shipping company, despite the fact that it is often filled with "dunnage" in the shape of Ebony billets or even Camwood. In the round $\log$, too, there is all the sapwood, and for this the merchant does not expect to pay much, if anything, and there is no doubt that it tends to depress the value of the timber, whatever it may be. The mere fact that the log is in the round is sufficient. Quite apart from that factor, too, a round $\log$, even when it is a beautiful bit of redwood, never looks so well nor so workmanlike as a hewn squared $\log$ with clean-cut sawn ends. The sapwood, being softer than the heartwood, is more easily damaged than the heartwood in the squared $\log$, so this is an additional reason why the round $\log$ often does not look as well as a squared one.

Amongst the most important timbers exported from the French Gaboon which are known and have been found suitable to the English market are the following :

1. Okoume or Angouma. Gaboon Mahogany. Oukoumea Klaineana.

2. Zaminguila or Ombega. Mahogany. Canarium?.

3. Duika. Mahogany. Irvingia Barteri?.

4. Kambala. Oak. Chlorophora excelsa.

5. Mandji or Bilinga. Afzelia Africana, or sometimes said to be Sarcocephalus Pobegundii.

The first named has always sold at a cheaper rate in the London market than the timber obtained from the other genii of West African Mahogany, such as Khaya, Entandrophragma, Pseudocedrela and Lovoa. First of all, as with other timbers, the Gaboon Mahogany is shipped in round logs, which are cut none too straight at the ends, owing to the rough usage they get in the long transport by water; before and when reaching the port of shipment they are often much 
damaged externally, which gives them a bad appearance. The wood is not only lighter in weight but also lighter in colour than the other West African Mahoganies, and both these qualities detract from its value. The grain is more open; it rarely if ever shows any figure, in comparison to the highly figured logs from Benin and Bassam. Having been tested very thoroughly as to tensile, torsion and compression strengths since the beginning of the war, it has not proved to be nearly as strong as the other West African Mahogany. These tests having been conducted with scientific accuracy and impartiality, they are to be trusted. Thus, for some purposes, such as aeroplane propellor construction, Gaboon Mahogany has proved unsuitable. However, it is only the very best, very strongest and most durable kinds of mahogany that will stand the most severe strains, such as wood is subject to when used in this work. However, that does not preclude the wood from being used for similar purposes as the other kinds of West African Mahogany, where the strains and stresses are not so great and where the lighter colour is no advantage. In fact, in many positions a greater lightness in the weight of the wood would be a distinct advantage, which should be pressed for all it is worth.

Zaminguila is becoming better known, though previous to the war it could not be said that it had an established place in the market.

Duika Mahogany is scarcely known, and may be the wood of Irvingia Barteri.

Kambala or Oak, which is also known as African Teak, is much better known now, and in fact there is a steady demand for it, chiefly under the Nigerian name Iroko, which has been exported from Benin and Lagos in Nigeria in the form of "squared" logs.

Thus far very few forest regulations have been issued in the Congo Française and very little replanting has been done. However, for the present, the supplies appear to be very large, but they will no doubt get more costly as the timber has to be cut and obtained from the much more distant and inaccessible forests. Apparently there is little or no Khaya Mahogany in those regions, so that there is little fear of real competition between the main species of Mahogany found in the different West African countries. The natives work the timber chiefly, cutting and bringing it to the ports themselves.

\section{THE BELGIAN CONGO}

This, the greatest and largest river system in Africa, gives its name also to the largest compact forest area of that country. Of the 800,000 square miles, probably 700,000 are covered with forests of one type or another. From the mangrove swamps on the islands at the mouth of the Congo, through the dense evergreen forests of the Upper Congo to the dry-zone open deciduous or almost treeless areas of Katanga, 


\section{4 WEST AFRICAN FORESTS AND FORESTRY}

an almost illimitable amount of unused sylvan wealth is to be found. Despite the obvious advantage of the Congo River, with its 3,000 miles suitable for timber transport and its hundreds of tributaries with many more thousand miles of streams, capable of floating logs, only the smallest quantities of mahogany are exported from the Belgian Congo.

No doubt the large size of the river and the great distance of some of the forests from the sea have hindered a more rapid and intensive exploitation of the forests. In fact, Mahogany (Khaya sp.) as an export timber is not really so well known as Redwood (Pterocarpus $s p$.), though the former has been shipped in the round. In the past a better known Belgian wood was blockwood or boxwood, known as Polyadoa umbellata or Dialium Auincense. Other forest products, however, such as Gum Copal (Daniellia sp.), are found in huge quantities, in large blocks weighing over a hundredweight, and have been exported for many years.

Large quantities of rubber, too, have been exported, and Oil Palm products, such as kernels and oil, are of increasing export importance, especially since Les Huileries de Congo have started working up the Oil Palm forests with modern means of transport and machinery on three different tracts of 10,000 hectares each.

The railways of the Congo, supplementing as they do the waterways, have also not been used to any extent for the shipment of timber, though vast quantities of firewood have been burnt on them as well as conveyed to the various stations both near and on the River Congo. To some extent the paucity and low density of population per unit of area has tended to hinder the working of heavy produce such as timber, which is difficult to transport compared to rubber, with its higher value per unit of weight. Owing to this fact, too, near the mouth of the Congo there is an almost savannah forest on the banks of the river, which has given the country the appearance of not being an afforested one. In the past the system of huge, exclusive trading concessions over specific areas being granted only to one firm also hindered any free development of the more lowerpriced forest produce such as timber.

\section{SPANISH GUINEA}

From Eloby, a little-known port situated in the middle of the coast of the Spanish possession south of the Cameroons, a great deal of Gaboon Mahogany (Oukoumea Klaineana), Redwood (Pterocarpus Soyauxia), and several other timbers have been exported. Despite the fact that the forests are not extensive, but almost untouched, and very rich in mahogany, a comparatively small number of firms have been working these areas. Apparently there are no forest laws, 


\section{BRITISH SPHERE OF THE CAMEROONS 425}

and there is little or no security for any forest rights one may acquire from the natives. It would be perhaps advisable to work areas here in conjunction with those in the Southern Cameroons. It is supposed to be more unhealthy in this part than in others, though probably this is due to the local conditions. Khaya is less common than elsewhere, while Redwood (Pterocarpus Soyauxii), Gaboon Mahogany (Oukoumea Klaineana) and Bilinga (Afzelia sp.) are common woods. Again, Canarium Schweinfurthii and other species are also very prevalent.

\section{Palmæ.}

\section{NOTES ON THE CAMEROON TREES}

Raphia vinifera (Raph.). Wine Palm.

It is found in the district of Victoria. The leaves are 60 feet long. Palm wine (called Mimbo) is obtained from this tree, also piassava fibre.

Elasis Guineensis (Jag.). The Oil Palm.

It is found in the Buea and Victoria districts chiefly, but is one of the most widely spread trees of the Cameroons. Oil, kernels and cake are obtained from it, also palm cabbage from the growing shoots at the top. The oil is collected by the primitive efforts of the natives.

Phonix reclinata. Swamp Palm.

It is largely used in the Dschang and Ossidinge districts for making palm wine, by tapping near the root.

\section{Commelinaceæ.}

Palisota hirsuta.

Found in the Victoria district.

\section{Iridacex.}

Antholyza Zenkeri.

Found in the district of Dschang.

\section{Ulmacex.}

Trema Africana.

Found in the district of Buea.

\section{Moracex.}

Chlorophora excelsa. Bush Oak. Vai (Bali); Abwang (Bare); Ntong (Fontem and Bangwa); Emang (Bakossi); Obang (Bafo); Bobang (Balong); Mokongo or Momangi (Bakundu); Momangi (Bakwiri); Bang (Duala).

One or two found on an area of $2 \frac{1}{2}$ acres in the dis-

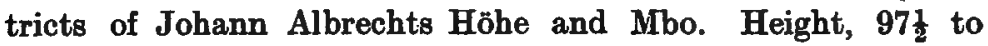
162 feet. Time of flowering, December to February. 
Musanga Smithii (R. Br.). Umbrella Tree. Ikomba (Bare); Ekombo (Bakossi); Ekomba (Bago); Bokombo (Bakundu); Lisengi (Bakwiri); Bosenge (Duala).

The wood is soft and like cork in texture. Found in the district of Dschang and along the coast. Height, 971 feet.

Myrianthus arboreus. Bokukulende (Bakossi); Wokeku (Bakwiri); Bokeku (Duala).

Found in the Undu districts of Buea and Dschang.

Treculia mollis (Engl.).

Height, 483 to 65 feet. Found in the Bipindi district.

Treculia Africana. Boembe (Bakundu); Bwembi (Bakwiri).

Found in the districts of Buea and Dschang.

Myrianthus arboreus. Wokaka (Bakwiri).

Found in the district of Fako, Buea.

Ficus populifolia.

Found in the district of Johann Albrechts Höhe.

Ficus Capensis. Ekol (Bakossi); Ekolo (Bakundu); Monja (Bakwiri).

Found in the districts of Buea and Dschang.

Ficus courania. Wotenge (Bakwiri).

Found in the district of Buea.

Ficus Schimperia. Njondji (Bakwiri).

Found in the districts of Dschang and Buea.

Antiaris toxicaria.

Found in the district of Buea.

\section{Olacacex.}

Ongokea Kamerunensis (Engl.).

It grows to the height of $97 \frac{1}{2}$ feet and has a yellowish heartwood. Found in the district of Johann Albrechts Höhe.

Strombosiopsis tetrandra.

Height, $32 \frac{1}{2}$ feet to $97 \frac{1}{2}$ feet. Found in the district of Johann Albrechts Höhe and Bipindi.

Coula edulis. Bokumia (Bakundu); Bonwula or Woula (Duala); Wokomea (Bakwiri).

Height, 48 to $97 \frac{1}{2}$ feet. Found in the district of Johann Albrechts Höhe. Time of flowering, October. This is a good building wood.

Strombosia grandifolia (Hook.). Ifondo or Wofondo (Bakwiri).

Grows in the Dschang district chiefly, but spreads over the Cameroons.

Strombosia glaucescens (Engl.).

Height, $32 \frac{1}{2}$ to 65 feet. Found in the Bipindi district. 


\section{Anonacex.}

Enantia chlorantha (Oliv.). The Yellow-wood Tree. Bopalo or Bololo (Bakundu); Woyoyo (Bakwiri); Nje or Banuke (Duala).

Height, 48 $\frac{3}{4}$ to 65 feet. The wood is a beautiful yellow and is used in furniture-making and carpentering, and the bark for building native houses. Found in the district of Johann Albrechts Höhe.

Uvaria Busgenii. Bopanda (Bafo); Bopande (Bakundu); Wofe (Bakwiri); Bope (Duala).

Found in the district of Johann Albrechts Höhe.

Uvaria microtricha (Diels).

Height, 65 to $97 \frac{1}{2}$ feet.

Monodora myristica (Dun.).

Found in the district of Fako, Buea.

Hexabolus megalophyllus (Engl. and Diels).

Height, 65 to $97 \frac{1}{2}$ feet. Found in the Bipindi district.

Hexabolus salicifolius (Engl.).

About 65 feet high. Found in the Bipindi district.

Hexabolus grandiflorus (Benth.).

65 to 811 feet high, widely spread over the Cameroon country.

Xylopia parviflora (Guill. and Perr.), (Engl, and Diels).

65 to $81 \frac{1}{4}$ feet in height. Found in Bipindi and Johann Albrechts Hõhe districts.

Isolona pleurocarpa (Diels).

Height, 48 to $81 \frac{1}{4}$ feet. Found in Bipindi district.

\section{Myristicaceæ.}

Pycnanthus Kombo (Warb.). Nutmeg. Ngitsa (Fontem or Bangwa); Pitchong (Ossidinge); Ngosame (Bakossi) ; Bosambe (Bakundu); Esamba (Bakwiri); Bokondo (Duala).

Found in the district of Johann Albrechts Hohe. It is a tall tree. Used for building purposes.

Staudtii stipitata (Warb.).

Height, $97 \frac{1}{2}$ to $123 \frac{1}{2}$ feet. Found in the district of Johann Albrechts Höhe. The wood is hard.

Staudtii Kamerunensis (Warb.).

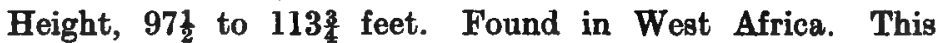
tree has a hard reddish wood.

\section{Lauraceæ.}

Tylostemon crassifolius (Engl.).

Found in the Johann Albrechts Höhe district. This tree has a very hard yellowish-brown wood. 


\section{Rosaceæ.}

Parinarium chrysophyllum (Oliv.).

Height, $48 \frac{8}{4}$ to $81 \frac{1}{4}$ feet. Found in the Bipindi and Johann Albrechts Höhe districts.

Parinarium (small). Ndikombo (Fontem or Bangwa).

Found in the Ossidinge district.

\section{Leguminosx.}

Piptadenia Africana (Hook.). Redwood. Erundu or Wunga (Bakundu); Edundu (Balong); Jondo (Bakwiri); Bolondo (Duala).

Found in the district of Johann Albrechts Höhe. It flowers in October and changes leaf December to January. Height, $97 \frac{1}{2}$ to 195 feet.

Piptadenia Winkleri (Harms.).

$9 \frac{3}{4}$ to 39 feet in height. Found in the Duala district.

Millettia sp. Bongongi (Bakundu); Bongongi (Duala); Bongongi (Sanaga River).

Found in the Johann Albrechts Höhe district.

Hylodendron Gabunense (Taub.). Bokata (Bakundu).

Found in the districts of Johann Albrechts Höhe, Bipindi,

Minifia and Gabun. Height, 65 to $97 \frac{1}{2}$ feet.

Platysepalum. Djengu (Bakwiri); Tada (Duala).

Found in the district of Buea.

Lonchocarpus Zenkeri. Sosong (Bakossi); Epuepue (Bakwiri).

Macrolobium Preussii (Harms.).

65 feet in height.

Macrolobium Mannii. Mokowa (Bakwiri).

Found in the district of Buea.

Macrolobium Zenkerii (Harms.).

65 feet in height. It grows in the Bipindi district.

Oxystigma Mannii (Baill.), (Harms.). Softwood. Bosipi (Duala).

Height, 130 feet. Found in the district of Victoria. The wood is used in building.

Pterocarpus Soyauxii (Taub.). Bo (Balong); Boa (Bakundu); Muenge (Duala); Hiol or Mbia (Bakoko).

Found in the district of Johann Albrechts Höhe. Height, $81 \frac{1}{4}$ feet to $97 \frac{1}{2}$ feet. The wood is mediumly heavy, blood-red in the heartwood, difficult to plane; used in making heavy furniture.

Copaifera Demeusii. Bobanja (Duala).

Found in the district of Johann Albrechts Hōhe. Height, $97 \frac{1}{2}$ feet. 

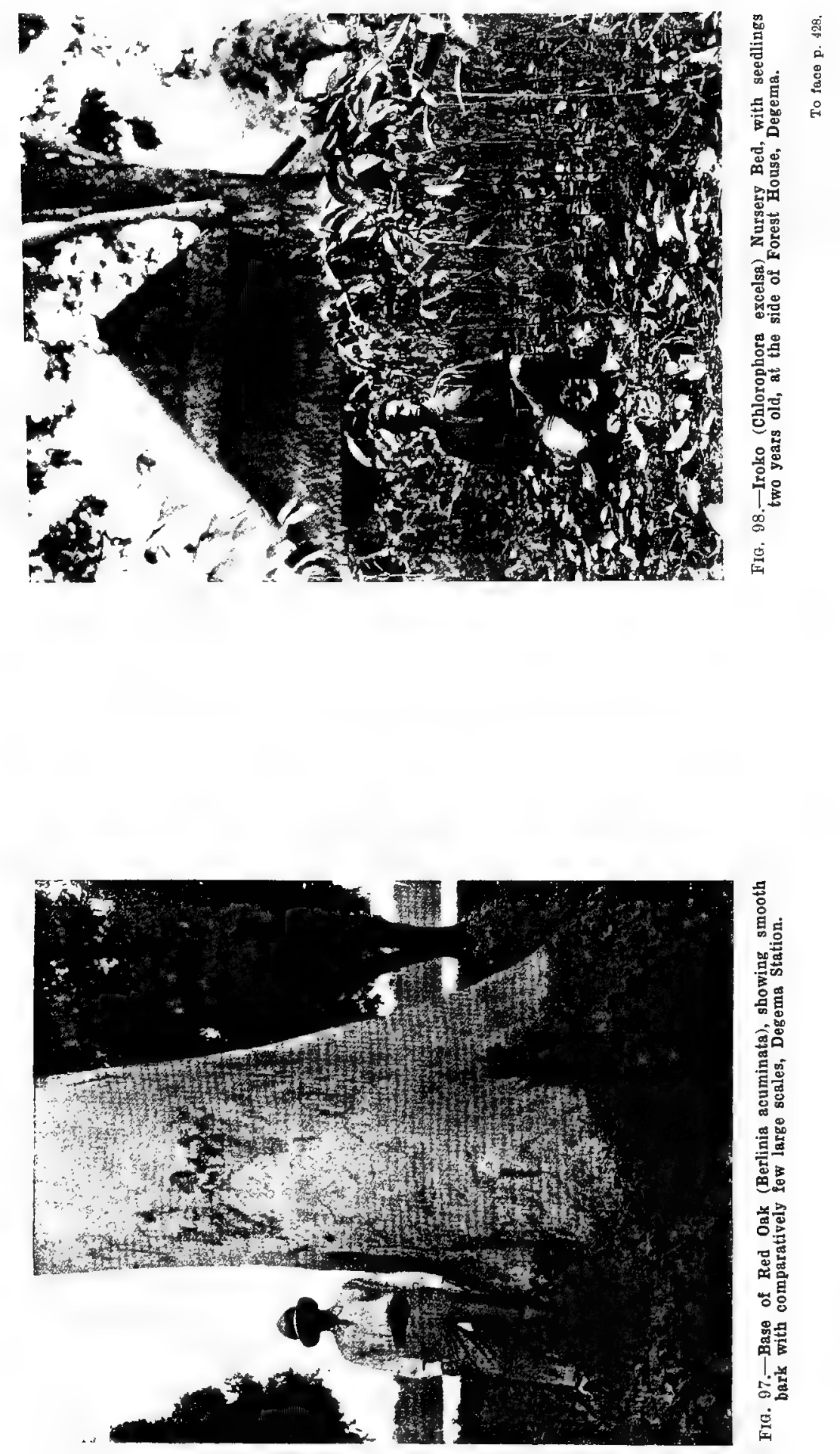

Tetrapleura Thonningii (Benth.). Kombolo (Duala).

Found in the district of Johann Albrechts Höhe. Height, $48 \frac{3}{4}$ feet.

Pentaclethra macrophylla (Benth.). Combolo (Duala).

A huge tree, over 65 feet in height, with tough, fibrous, reddish wood. Found in the districts of Johann Albrechts Höhe, Bipindi and Jaunde. It yields Owala oil.

Albizzia Welwitschii (Welw.). Goo (Bali); Esang (Bakossi); Elund (Balong); Isaka (Bakundu); Esakasaka (Bakwiri); Bobai (Duala).

Found in the Johann Albrechts Höhe district.

Albizzia Brownii (Walp.), (Oliv.). Isaka (Bakwiri).

Height, 65 to $97 \frac{1}{2}$ feet. The wood is hard and much used in building. It grows in the districts of Bipindi, Mimifia and Johann Albrechts Höhe.

Albizzia fastigata (E. Mey.), (Oliv.).

Height, 97 $\frac{1}{2}$ feet. Found in the district of Johann Albrechts Höhe. The wood is moderately hard.

Berlinia auriculata (Sol.).

Height, $32 \frac{1}{2}$ to 65 feet. Found in the Batanga and Bipindi districts.

Berlinia acuminata (Sol.). Mbava (Bakwiri).

Found in the district of Teko (Buea). Height, 48 $\frac{3}{4}$ to $81 \frac{1}{4}$ feet.

Erythrophloum micranthum (Harms.).

65 to 130 feet in height. Found in the Bipindi district.

Erythrophtoum sp.

Found in the district of Johann Albrechts Höhe.

Erythrophloum Guineense (Don).

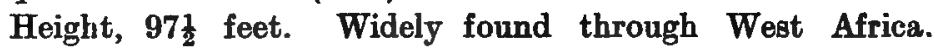

The wood is much used for house, bridge and ship building.

Ostryoderris impressa.

Found in the Johann Albrechts Höhe district.

Cynometra Mannii (Oliv.).

A high tree found in Victoria and Bimbi and on the coast.

Cynometra multynge (Harms.).

Over 65 feet in height. Found in the districts of Johann Albrechts Höhe and Bipindi.

Scorodophlous Zenkerii (Harms.).

Found in the districts of Johann Albrechts Höhe, Bipindi and Urwald. Height, 48 feet.

Parkia Zenkerii (Mim. Harms.).

Fonnd in the districts of Johann Albrechts Höhe and Bipindi. Height, 48 $\frac{8}{4}$ to 65 feet. 
Wacuminata. Baphia.

Found in the district of Johann Albrechts Höhe.

Found in the district of Rio del Rey.

Baphia Barombiensis.

Found in the district of Johann Albrechts Höhe.

Pterogopodium sp.

Found in the district of Johann Albrechts Höhe.

Afrelia Africana (Smith).

Height, $32 \frac{1}{2}$ to 65 feet. Found in the Batanga, Lokundje, and Bipindi districts.

Afzelia Zenkeri. Lom (Bakoko); Bobolo (Malimba).

Found in the district of Johann Albrechts Höhe. A giant tree with edible seeds.

Brachystegia cynometroides (Harms.).

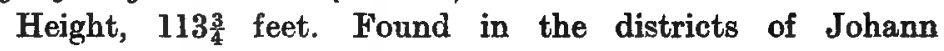
Albrechts Höhe and Mimifia.

Erythrina excelsa. Mokamu (Bakwiri).

Found in the district of Buea. Height, 65 feet. Time of flowering is December and January.

Dialium Staudtii (Harms.).

Found in the district of Johann Albrechts Höhe.

Dialium Guineense (Willd.).

Height, $81 \frac{1}{4}$ to $97 \frac{1}{2}$ feet. Widely spread through the Cameroon country.

Dialium Zenkeri (Harms.).

About 321 feet high. Found in the Bipindi district.

Distemonanthus Benthamiasus (Baill.).

Height, $97 \frac{1}{2}$ to 130 feet. Found in the districts of Johann Albrechts Höhe and Mimifia.

Distemonanthus $s p$.

Found in the district of Johann Albrechts Höhe.

Calpocalyx Dinklagei (Harms.).

Found in the districts of Johann Albrechts Höhe and Bipindi. Height, 32 to $48 \frac{3}{4}$ feet.

Newtonia Zenkeri (Harms.).

Found in the districts of Johann Albrechts Höhe and Bipindi. Height, $97 \frac{1}{2}$ to $113 \frac{8}{4}$ feet.

Adenocarpus Mannii.

District, Fako, Buea.

Detarium macrocarpum (Harms.).

Height, $81 \frac{1}{1}$ to $97 \frac{1}{2}$ feet. Found in the Bipindi district. Indigofera Africeps.

Found in the district of Fako, Buea.

Phutophyllum mirabile.

Found in the district of Rio del Rey. 


\section{BRITISH SPHERE OF THE CAMEROONS}

Galium aparine.

District, Victoria.

Daniella caudata.

District, Johann Albrechts Hōhe.

Afrormosia laxiflora.

District, Johann Albrechts Höhe.

Cylicodiscus Gabunensis (Harms.). Edum (Bafo); Emang (Bakossi).

District, Johann Albrechts Höhe. A tree with enormous trunk and bark resembling the pine; the wood is reddish. Height, $97 \frac{1}{2}$ to 130 feet.

Trachylobium $s p$.

District, Johann Albrechts Höhe.

Fillaeopsis discophora (Harms.).

Height, 48 $\frac{3}{4}$ feet. Found in the Bipindi district. Called

by the Kameroon Holz Syndicate "Milletia." A big tree with huge paper-like pods.

Stemonocoleus micranthus (Harms.).

Height, $81 \frac{1}{4}$ to $97 \frac{1}{2}$ feet. Found in the Bipindi district. Pithecolobium allissimum (Oliv.).

Height, $48 \frac{3}{4}$ to $81 \frac{1}{4}$ feet. Found in Bipindi.

Stachyothyrsus Staudtii (Harms.).

Height, 81 feet. Found in the Mimifia and Bipindi districts.

\section{Linaceæ.}

Phyllocosmus sessiliflorus (Oliv.).

Found in the district of Johann Albrechts Höhe. Height, $48 \frac{3}{4}$ to $81 \frac{1}{4}$ feet.

\section{Erythroxylacex.}

Erythroxylon Mannii (Oliv.).

Height, 48 $\frac{3}{4}$ feet. Found in the districts of Johann Albrechts Höhe and Bipindi.

\section{Rutacee.}

Fagara Rederi (Oliv.). Wongo (Bakundu); Woongo (Bakwiri).

Found in the district of Buea.

Fagara altissima (Engl.).

Found in the Bipindi district. Height, $48 \frac{1}{2}$ to $81 \frac{1}{4}$ feet.

Zanthoxylum Senegalense. Nitone (Fontem or Bangwa).

Found in the Johann Albrechts Höhe district.

\section{Simarubacese.}

Irvingia Barteri (Hook.). The so-called Wild Mango. Bope (Bafo); Bopek (Balong); Weke (Bakundu); Bwiwa (Bakwiri); Bwiba ba mbale (Duala).

Found in the Johann Albrechts Höhe district specially, but widely spread through West Africa. 
Irvingia Gabunensis. Etue or Etu (Bakossi); Botuba (Bafo); Bopala (Bakundu).

Found in the Johann Albrechts Höhe district.

Odyendea Gabunensis (Pierre).

Found in the Johann Albrechts Höhe district. Height, 65 to $97 \frac{1}{2}$ feet.

Klainedoxa Oabunensis (Pierre).

Found in the Johann Albrechts Höhe district. Height, 65 to $97 \frac{1}{2}$ feet.

Klainedoxa grandifolia (Engl.).

Found in the Johann Albrechts Höhe district.

Pierreodendron grandifolium.

Found in the Rio del Rey district.

\section{Burseracez.}

Pachylobus Zenkeri.

Found in the Johann Albrechts Höhe district.

Pachylabus edulis (G. Dom). Bosao (Bakundu); Sao or Bosao (Duala); Bokuka (Etam).

Found in the Johann Albrechts Höhe district. A fruit tree of about 65 to $97 \frac{1}{2}$ feet in height, having dark-green, alternating, bipinnate leaves, smooth bark and reddish to greyyellow wood. The wood is used to make axe-handles; the tree also yields resin.

Pachylobus var. (Mbafo according to Engler). Bosao (Bakundu).

A fair-sized tree with reddish and greyish-yellow wood.

It has a good heartwood, used for the axles of wheels; also for calabashes. Found throughout West Africa.

Canarium auriculatum. Bweii (Bali); Wotua (Bakwiri).

Found in the Victoria district.

Canarium Schweinfurthii (Engl.).

Height, 113 to 130 feet. Found in the Johann Albrechts Höhe district principally, but is fairly common throughout West Africa. The wood is white and is used for building. Canarium Mansfeldianum.

Found in the Ossidinge district.

\section{Meliacez.}

Entandrophragma Rederi. Njokubwele (Bakundu); Won (Bakwiri). Found in the Johann Albrechts Höhe district.

Entandrophragma utilis.

Found in the Johann Albrechts Höhe district.

Entandrophragma Candollei (Harms.).

Height, $97 \frac{1}{2}$ to 130 feet. Found in the Johann Albrechts Höhe district. The wood is similar to mahogany. 


\section{BRITISH SPHERE OF THE CAMEROONS}

Guarea glomerulata. Bobe ba ndiko (Bakundu); Lilualamombe (Bakwiri); Timba or timba nundi (Duala).

Found in the Johann Albrechts Höhe district. This wood is, like mahogany, used for furniture, also window-wood. This tree is frequently attacked by boring insects.

Trichilia rubesilus (Oliv.). Ifassoa (Bakwiri).

Found in the Buea district. Height, $17 \frac{1}{2}$ to $32 \frac{1}{2}$ feet.

Trichilia Prieureana (Juss.).

Found in the Johann Albrechts Höhe district. Height, $32 \frac{1}{2}$ to 39 feet.

Khaya Klainii (Pierre).

The most valuable mahogany is obtained from this tree.

It is abundantly found in West Africa.

Khaya euryphylla (Harms.).

From $97 \frac{1}{2}$ to 130 feet in height. Found in the districts of Johann Albrechts Höhe and Buea.

Khaya Senegalensis.

Found in the district of Victoria.

Turracanthus Zenkeri (Harms.).

Found in the Jaunde and Buea districts. Height, 65 feet. Carapa procera (D.C.).

Height about 65 feet. Found in the Johann Albrechts Höhe district. It yields a wood very like mahogany, useful in building and carpentry.

\section{Euphorbiacex.}

Ricinodrendron Africanum (Mull. Arg.). Esango (Bakossi); Wonjasanga (Bakundu); Wonjangasanga (Bakwiri); Njangsang (Duala); Ehan (Bakoko).

Height, 48 to $81 \frac{1}{4}$ feet. Found in the Johann Albrechts Höhe district.

Lepidoturus occidentalis. Longoso (Bakundu) ; Longoso (Bakwiri) ; Joloso (Duala).

District, Mbo.

Macaranga sp.

Found in the district of Buea.

Macaranga rosea. Boka (Bakundu); Njon bwele (Duala).

Found in the district of Johann Albrechts Höhe. Time of flowering, November.

Bridelia stenocarpa (Mull. Arg.). Esenge (Bakundu); Mosenge (Bakwiri); Tata (Duala).

District, Johann Albrechts Höhe. It flowers in February and changes leaf in December and January. The wood is light yellow with large, open pores. 


\section{WEST AFRICAN FORESTS AND FORESTRY}

Bridelia macrocarpa. Esenge (Bakundu).

Found in the district of Johann Albrechts Höhe.

Alchornea floribunda (Mull. Arg.).

Sometimes found over $81 \frac{1}{4}$ feet in height. It is widely spread over the Cameroons.

Alchornea cordifolia. Dibobonga (Duala).

Found in the district of Johann Albrechts Hohe.

Antidesma lacimiatum. Liwoma (Bakwiri).

It grows in the Buea district.

Claoxylon Preussii (Pax.).

It is found in the district of Buea.

Croton pyrifolius.

Found in the district of Buea.

Phyllanthus discoideus.

Found in the district of Buea.

Uapaca Staudtii (Pax.). Bosambi (Bakundu).

Found in the district of Buea.

Hevea.

A rubber-tree which needs less soil than the Funtumia. Its extension has been hampered by lack of seed. It suffers much from root diseases. The tree is found in the Buea district.

Sapium Mannianum (Mull. Arg.), (Bth.).

Height, 48 to $97 \frac{1}{2}$ feet Widely spread over the Cameroon country.

Grossera paniculata (Pax.). Nama tubave (Bakundu).

It grows in the Bipindi district. Height, 48 疋 to 65 feet.

\section{Anacardiaces.}

Sorindeia trimera (Oliv.).

Height, 48 feet. Very plentiful throughout the Cameroons.

Pseudospondias microcarpa (A. Rich., Engl.).

Height, $32 \frac{1}{2}$ to $48 \frac{3}{4}$ feet. Found in the Buea district and throughout the Cameroons.

Trichoxypha Bipindensis (Engl.).

Height, 65 to $97 \frac{1}{2}$ feet. It is found in the Bipindi district.

\section{Sapindacez.}

Phialodiscus Zambesiacus.

Found in the Johann Albrechts Hohe district.

Deinbollia pycnophylla. (Gilg.).

Height, 65 feet. It is found in the Bipindi district.

\section{Tiliaces.}

Desplatzia Dewewrei.

Found in the (Boanda) Buea district. 
Grewiopsis globosa. Ebonga evodi (Duala).

This is a small tree having yellow fruit, the size of a man's fist, used as food for elephants.

District, N.W. Africa.

Grewiopsis discophora.

District, N.W. Africa.

\section{Malvacex.}

Pavonia Schimperiana.

Dschang and Buea district.

\section{Bombacaceæ.}

Ceiba pentandra. Silk-cotton Tree. Monga (Balong); Mungongo (Duala).

Yields timber, bast, tanning materials, wool for stuffing, oil, etc.; fruit woody.

Adansonia digitata. Baobab. Sometimes called "Asses Bread."

It yields timber, fibre, tanning materials, etc. The pulp of the fruit and the seeds are edible. Found in the savannah forests and also near villages.

Eriodendron. Silk-cotton.

District, West Africa.

Bombax buonopozense. Silk-cotton.

District, West Africa. 'The tree yields timber, wool for stuffing, fibre, oil, etc.

\section{Sterculiacex.}

Sterculia oblonga (Mast.). Engele or Ongele (Balong); Bongele (Bakundu); Ekonge (Bakwiri); Bongele or Bopum ba nji (Duala).

It grows in the district of Johann Albrechts Höhe. A large tree having opposite leaves and smooth bark, which rapidly turns red when exposed to the air. The wood is much used for planks.

Sterculia tragacantha. Poose (Bakundu); Ndototo (Bakwiri); Pio (Duala).

Found in the district of Johann Albrechts Höhe. It flowers in November.

Sterculia grandifolia. Kamdjok (Osaidinge).

Found in the districts of Johann Albrechts Höhe and Ossidinge.

Sterculia cordifolia. Lom (Bakoko).

Found in the districts of Johann Albrechts Höhe and Ossidinge. 


\section{WEST AFRICAN FORESTS AND FORESTRY}

Sterculia acuminata, syn. Cold acuminata (?).

Much cultivated in the Johann Albrechts Hohe district and on the mountain slopes. The nut of this tree is very much used in chocolate-making and is very refreshing.

Sterculia rhinopetala (K. Schum.).

Height, 811 to 113 feet. This tree yields an excellent building wood.

Cola $s p$.

Found in the districts of (Muea) Buea.

Cola suleata.

It is found in the district of (Boanda) Buea.

Cola altissima (Engl.).

Height, 65 to $97 \frac{1}{2}$ feet. Found in the Bipindi district.

Cola marsupium.

Found in the district of (Boanda) Buea.

Pterygota Kamerunensis.

Found in the district of Mungo River.

Xeropetalum Dombeya.

Found in the Dschang district.

Triplochiton sceleroxylon (K. Schum.). Nkom (Bakossi); Ejuong (Jaunde).

This tree yields a good timber and furniture wood. The leaves are very similar to those of the maple. Found very plentifully in the Cameroon country.

Theobroma cacao. Cocoa Tree.

There are about twenty species of this tree. The Cameroon country is the richest in the world for cocoa. It grows chiefly in the low-lying country of the Mungo, Wari and Sanaga Rivers, in the Duala and Yabassi districts and Edea; also on the slopes of the Cameroon mountains. It is much attacked by cockchafer grubs (brown rot) and bark bugs. The world's supply from $T$. cacao has been going on for five hundred years, and consequently has developed varieties showing a marked difference from the original type.

\section{Syctopetalaceæ.}

Oubanguia Klainei (Teigh.).

District, Buea. Height, 48 ?

\section{Ochnacex.}

Lophira alata (Banks). Ironwood. Boko (Bakundu); Ndonge (Bakwiri); Bongossi (Duala).

Found in the districts of Johann Albrechts Hohe and Mbo. Diameter, $7 \frac{1}{2}$ to $10 \frac{1}{2}$ feet. Height, $162 \frac{1}{2}$ feet. The time for flowering is December and January and February for ripe fruit. A good, very hard wood, used for stair treads. 


\section{BRITISH SPHERE OF THE CAMEROONS}

Ouratea monticola.

Found in the Buea district.

\section{Guttifera.}

Endodesmia calophylloides (Bth.).

Height, 81 to 130 feet. It grows abundantly throughout the Cameroon country.

Garcinia punctata (Oliv.).

Height, 65 to $81 \frac{1}{4}$ feet. Plentiful in Cameroon, specially in the Johann Albrechts Höhe district.

Pentadesma butyraceum (Dom.).

A very high tree. Common throughout Cameroon.

Haronga paniculata. Konkwa (Bali); Worolongo (Bakwiri); Tolongo (Duala).

Found in the districts of Dschang and Buea.

Symphonia globulifera (L. fil.).

Height, 65 to $97 \frac{1}{2}$ feet. Found throughout the whole of West Africa.

\section{Flacourtiacee.}

Flacourtia Ramintilii. Wondo (Bakwiri).

Found in the Dschang district.

Barteria aromatica.

Found in the district of Johann Albrechts Höhe.

Barteria fistulosa. Ant-trees (Musimba).

Found in the Buea district.

Lindackeria dentata.

Found in the Buea district.

Scottellia Mimfiensis (Gilg.).

Height, $48 \frac{3}{4}$ to $97 \frac{1}{2}$ feet.

\section{Caricacez.}

Carica papaya.

Found in the district of Victoria.

\section{Thymelacex.}

Lasiosiphon glaucus.

Found in the district of Victoria.

\section{Rhizophoracese.}

Poga oleosa. Njove or Njole (Rio del Rey).

District, Johann Albrechts Höhe.

Poga conophora (named after Muller). Njove or Njole (Rio del Rey).

Found in the district of Johann Albrechts Höhe. 
Rhizophora mangle (Roxb.). Mangrove. Tanda (Duala).

It grows freely on the cosst of West Africa. The bark is much used in tanning.

Alangiacea.

Alangium hegonifolium.

District, Buea.

\section{Combretacea.}

Combretum cinerea.

It grows in the Dschang district.

Terminalia superba (Engl. and Diels). Nkom (Bakossi); Bokome (Bafo); Bokome (Bakundu); Djombe (Bakwiri); Mukonja (Duala).

Height, 65 to $97 \frac{1}{2}$ feet. It grows abundantly throughout the Cameroon country, but especially at Johann Albrechts Höhe. The wood is hard, light yellow and close grained; much used for making windows and shutters.

\section{Melastomacea.}

Amphiblemma polyneuron.

District, Johann Albrechts Höhe.

Memecylon macrodendron (Gilg.).

Height, $48 \frac{3}{4}$ to 65 feet. Found in the Bipindi district.

\section{Araliaces.}

Schefflera Hookeriana (Harms.).

Found in the Buea district.

\section{Myrsinaceæ.}

Masa lanceolata.

Found in the Dschang district.

\section{Sapotacex.}

Mimusops sp.

Mimusops Djave (Laness), (Engl.). Nsab (Bare); Bonjabi (Bakundu); Njabi (Duala).

Found in the districts of Johann Albrechts Höhe and Mbo. Height, 178 $\frac{3}{4}$ feet. Diameter, 6t feet. There is frequently a clear bole of $97 \frac{1}{2}$ feet, containing 6,380t cubic feet of wood (181 cubic metres). The nuts are much valued locally as food. Chrysophyllum Africanum.

District, Johann Albrechts Hohe.

Chrysophyllum macrophyllum. Wonjanja (Bakwiri).

District, Johann Albrechts Höhe and Buea. 


\section{BRITISH SPHERE OF THE CAMEROONS}

Omphalocarpum Radlkoferi (Pierre).

Height, 65 feet. Found throughout West Africa. This tree yields timber and a sort of gutta-percha.

Butyrospermum Parkii (Kotschy.). Shea Butter.

District, N. West Africa. This tree yields a gutta-perchalike resin, edible fruits, and from the seeds a fat (Shea butter). Omphalocarpum Pierreanum (Engl.).

Height, 65 to $81 \frac{1}{1}$ feet. Found in the district of Bipindi.

\section{Ebenaceæ.}

Diospyros sauveolens (Gurke). Ebony.

Height, $32 \frac{1}{2}$ to $48 \frac{3}{4}$ feet. Found in the district of Johann Albrechts Hōhe.

Diospyros atropurpurea (Gurke). Ebony. Efindofindo (Bafo); Findefinde (Balong); Epindepinde (Bakundu); Findefinde (Balswiri); Epindepinde (Duala).

District, Johann Albrechts Höhe, Bipindi and Buea, and Muyuke. The tree flowers in April and May; the fruit is ripe in October. It yields timber, tanning and dyeing materials, mucilage, edible fruit (date-plums), fish-poison and medicaments. The wood is very hard and of a yellowish colour, the bark black. It is principally used for furniture.

Diospyros megaphylla (Gurke).

Height, $32 \frac{1}{2}$ to $48 \frac{3}{4}$ feet. It grows near Bipindi.

Diospyros Bipindensis (Gurke).

Height, 48 feet. It is found in the Bipindi district.

Diospyros Kamerunensis (Gurke).

Height, 48 $\frac{3}{4}$ feet. Found in the Bipindi district.

Diospyros Dendo (Welw.).

Height, $48 \frac{3}{4}$ to 65 feet. It is found throughout the Cameroon country.

Diospyros Gilgiano (Gurke).

Height, 48 $\frac{3}{4}$ to 65 feet. Found in the Bipindi district.

Diospyros nsambensis (Gurke).

Height, $48 \frac{3}{4}$ to 65 feet. Found in the Bipindi district.

Diospyros mamiacensis (Gurke).

Height, $48 \frac{3}{6}$ to 65 feet.

Diospyros aggregata (Gurke).

Over 65 feet in height. Found in the Bipindi district.

Diospyros incarnata (Gurke).

Height, $32 \frac{1}{2}$ to 39 feet. Found in the Bipindi district. Diospyros mespeliformis (Hochst.).

The sapwood is yellowish-white and close-grained. It is very useful in turnery. The tree is found widely spread over West Africa. 


\section{WEST AFRICAN FORESTS AND FORESTRY}

\section{Loganiacex.}

Nuxia Mannii (Oliv.).

District, (Fako) Buea.

Anthocleista Zenkerii, also known as Bopolo-polo.

Found in the Johann Albrechts Höhe district.

Strychnos gnetifolia (Gilg.).

Height, 65 to $97 \frac{1}{2}$ feet. Found in the Bipindi district.

\section{Apocynaces.}

Kicksia elastica. Dinjongo (Bafo); Dinjongo (Bakundu); Manjongo (Bakwiri); Ebonga manyongo (Duala).

Found in the districts of Johann Albrechts Höhe and Buea. Ranwolfia macrophylla or gonioclada. Enonge (Bakundu); Kanja (Bakwiri); Bandonge (Duala).

Found in the district of Johann Albrechts Hōhe. The time of flowering is October and March.

Rauwolfia vomitosia.

Found in the district of Johann Albrechts Höhe.

Alstonia Congensis. Kuge (Bakossi); Bokuk (Balong); Kanja (Bakundu); Wokuka (Bakwiri); Bokuka ba mhale (Duala).

Found in the district of Johann Albrechts Höhe. The wood is used for making stools in the Kamerun country.

Polyadoa umbellata.

Found in the district of Johann Albrechts Höhe.

Funtumia elastica. Ireh Tree. (Lagos rubber.)

Found widely throughout West Africa. The chief rubberyielding tree. The tree suffers from the attacks of stag-beetles. Landolphia Dawei. (Savannah rubber.)

Found in the primeval forests of West Africa. Several species yield rubber, dyes and edible fruits (from which drinks are made).

\section{Convolvulacex.}

Ipomoea involvucrata.

District, Rio del Rey.

\section{Borraginaceæ.}

Cordia Irvingia. Bola (Bakundu); Womba (Bakwiri); Bomba (Duala).

Found in the district of Johann Albrechts Höhe.

Cordia yombomba. Jom (Ossidinge); Yombomba (Bakwiri).

Found in the district of Johann Albrechts Höhe.

\section{Verbenaces.}

Avicennia tomentosa (Jacqu.). White Mangrove. Bunja (Duala). Found in the district of Johann Albrechts Hōhe and very 


\section{BRITISH SPHERE OF THE CAMEROONS 441}

frequently among coast vegetation. Height, $32 \frac{1}{2}$ to $48 \frac{8}{4}$ feet. The wood is very beautiful.

Vitex cuneata.

Found in the district of Johann Albrechts Höhe.

Vitex Bipindensis (Gurke).

Height, $32 \frac{1}{2}$ to $48 \frac{3}{4}$ feet. Found in the Bipindi district.

Clerodendron. Mumbambe (Bakwiri).

Found in the district of Buea.

\section{Scrophulariaces.}

Selaginella Vogelii.

Found in the district of Victoria.

\section{Bignoniacex.}

Spathoidea campanulata. Jon (Bali); Etutu (Bakundu); Mbako

(Bakwiri); Bwele ba Mbongo (Duala).

Found in the Dschang district.

Kigelia acutifolia. Sosong (Bakossi); Wulule (Bakwiri).

Found in the Dschang district.

Markhamia lutea. Abbe (Bakossi); Mawelu (Bakwiri); Mabanga (Duala).

Found in the Dschang district.

\section{Acanthacex.}

Thomandersia laurifolia.

District, Rio del Rey.

\section{Rubiaceæ.}

Adina macrophylla (Lepr. and Guill.), (K. Schum.).

Found in the district of Victoria, Height of tree, 483 to

$81 \frac{1}{4}$ feet. A yellowish wood, used in building and very good for furniture.

Sarcocephalus sambucinus (Wint.). Tabu (Bali).

A very common tree in West Africa. It is a good building wood.

Plectronia glabriflora.

District, Dschang and Buea.

Oxyanthus speciosus. Wyfongo (Bakwiri).

District, Dschang and Buea.

Canthium glabriforum.

District, N.W. Africa. This tree has grey bark and is like a palm in appearance. It yields resin, and calabashes are made from the fruit.

Morinda citrifolia (L.).

Height, $48 \frac{3}{4}$ to 65 feet. It has a yellowish wood. A very common tree in West Africa. 
Randia cladantha ( $K$. cladantha).

Height, 65 to $81 \frac{1}{4}$ feet. Very common throughout the Cameroon country.

\section{Compositæ.}

Vernonia frondosa (Oliv.). Bopolopolo (Duala).

Found in the district of Rio del Rey.

Vernonia conferta. Bopolopolo (Duala).

Found in the district of Rio del Rey.

Helichrysum foetidum (Cass.).

Found in the districts of Victoria and Buea.

\section{SOME CAMEROON TREES ONLY KNOWN BY NATIVE NAMES}

Abange (Jaunde).

Adom (Jaunde).

Akaka (Jaunde); Ikaka (Bakundu). The wood is soft and nutbrown; it smells like pencil-wood.

Akondog (Jaunde).

Ase (Jaunde); Njokubore (Bakundu). The fruit is similar to the Entandrophragma (Meliaceæ), the root buttressed, and the leaves with rosettes on the branches.

Awong (Jaunde).

Bosambai (Jaunde).

Dibanga (Jaunde). A mediumly hard, greyish-brown wood with brown medullary rays; it is used for making furniture.

Ebe (Jaunde); Borimba (Bakundu). A giant tree with oval leaves, smooth on the top and having brownish hairs underneath.

Ehemba (Jaunde).

Ejan (Jaunde).

Ekoah (Jaunde).

Enjog (Jaunde).

Esang (Jaunde).

Lawonong (Jaunde).

Lobog (Jaunde).

Otungue (Jaunde).

Ebunja (Bakundu).

Ekambamba (Bakundu).

Enjenju (Bakundu).

Esok (Bakundu).

Idjnake (Bakundu).

Mbonda pondo (Bakundu). A very close-grained, hard wood.

Mondoa (Bakundu).

Bowasa (Duala). 


\section{BRITISH SPHERE OF THE CAMEROONS 443}

Bwiba ba njon (Duala). A hard wood used for stair treads. At the Basel Mission the timber worked at was $£ 2$ per 35 cubic feet-Steyer and Pingel, at the rate of 10 shillings per 35 cubic feet-the latter firm working all kinds of wood of medium size.

Ebon (Duala).

Etotum (Duala).

Palambanja (Duala).

Tabako (Duala).

Eselebaka (Bakoko).

Ewnon (Bakoko).

Mpang (Bakoko and Basa).

Sibugang (Basa). 


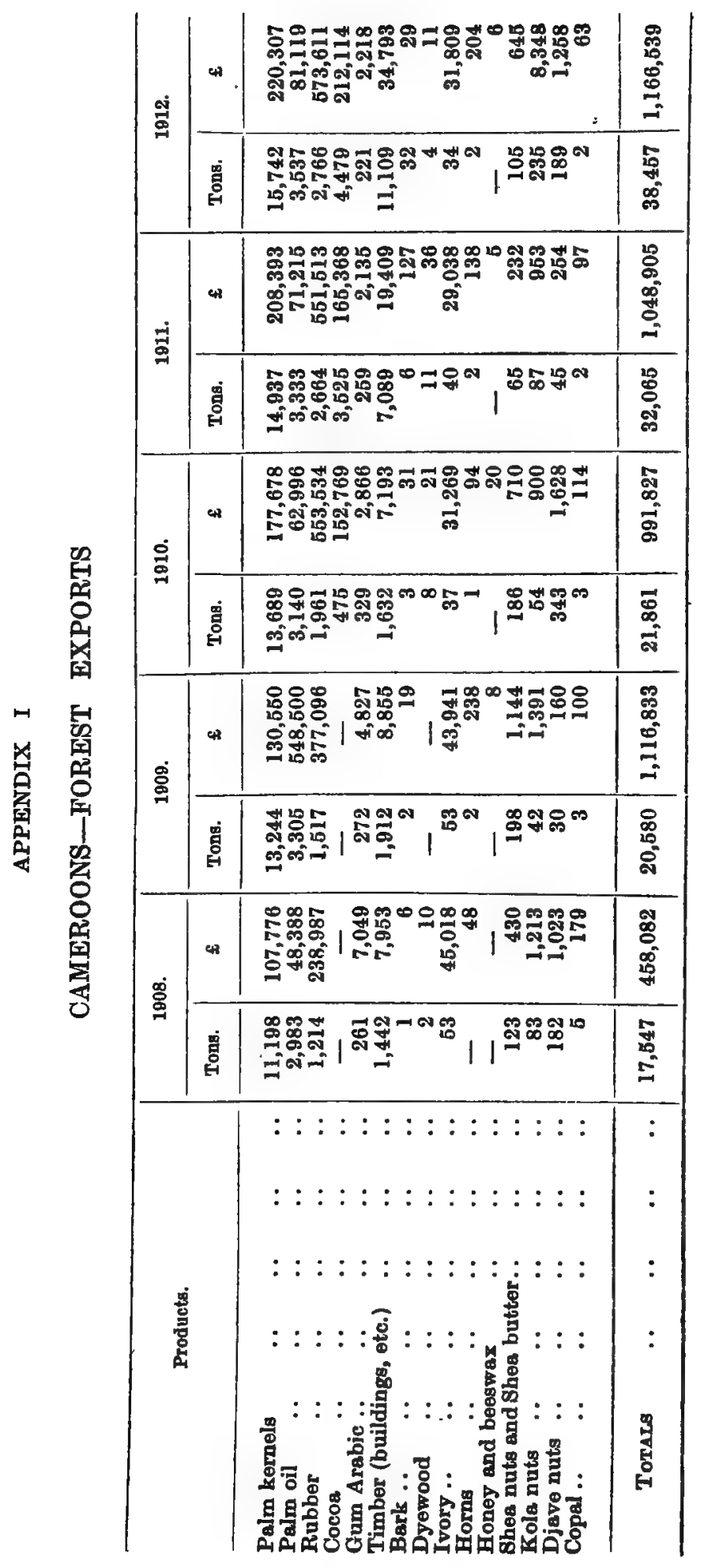




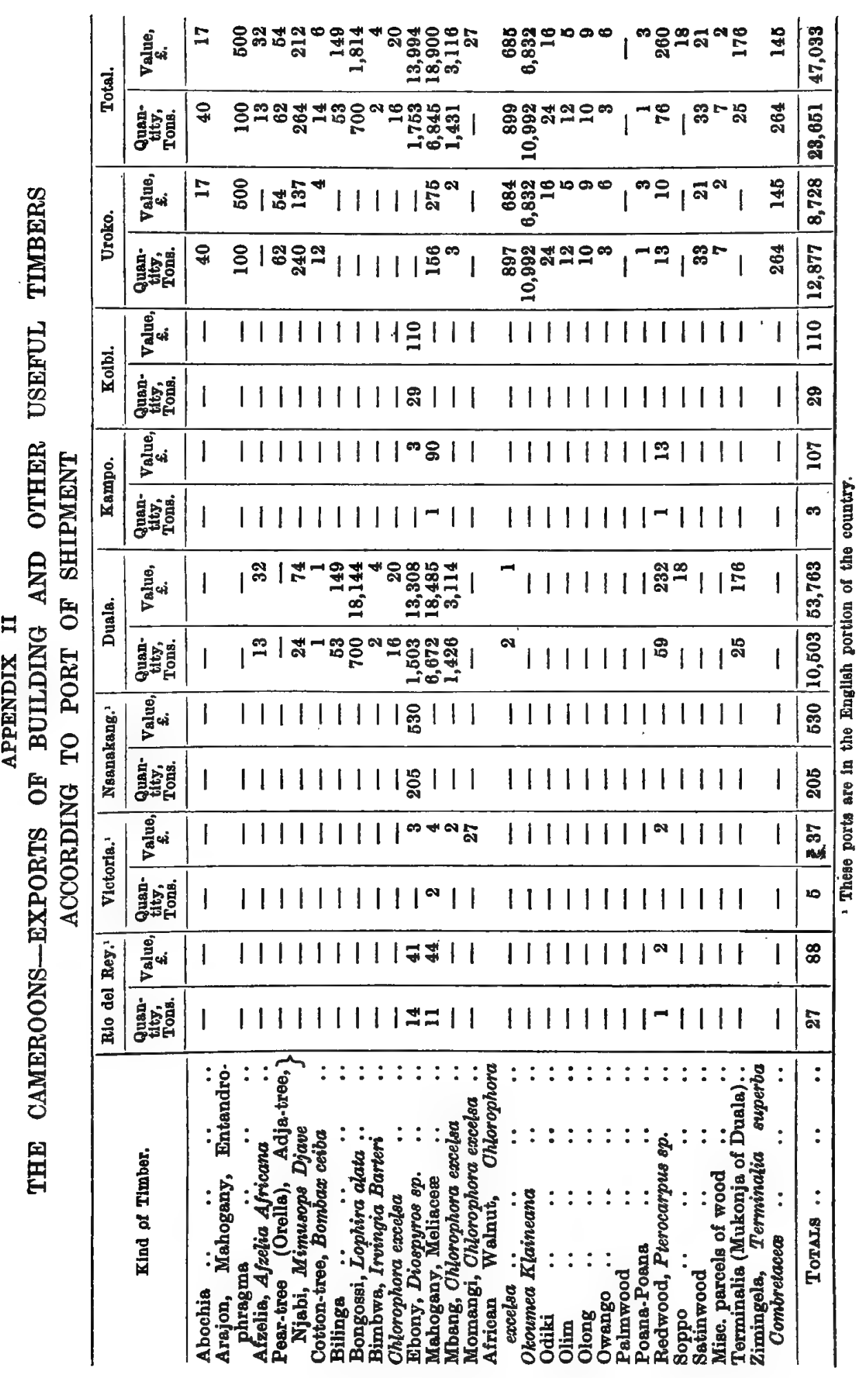




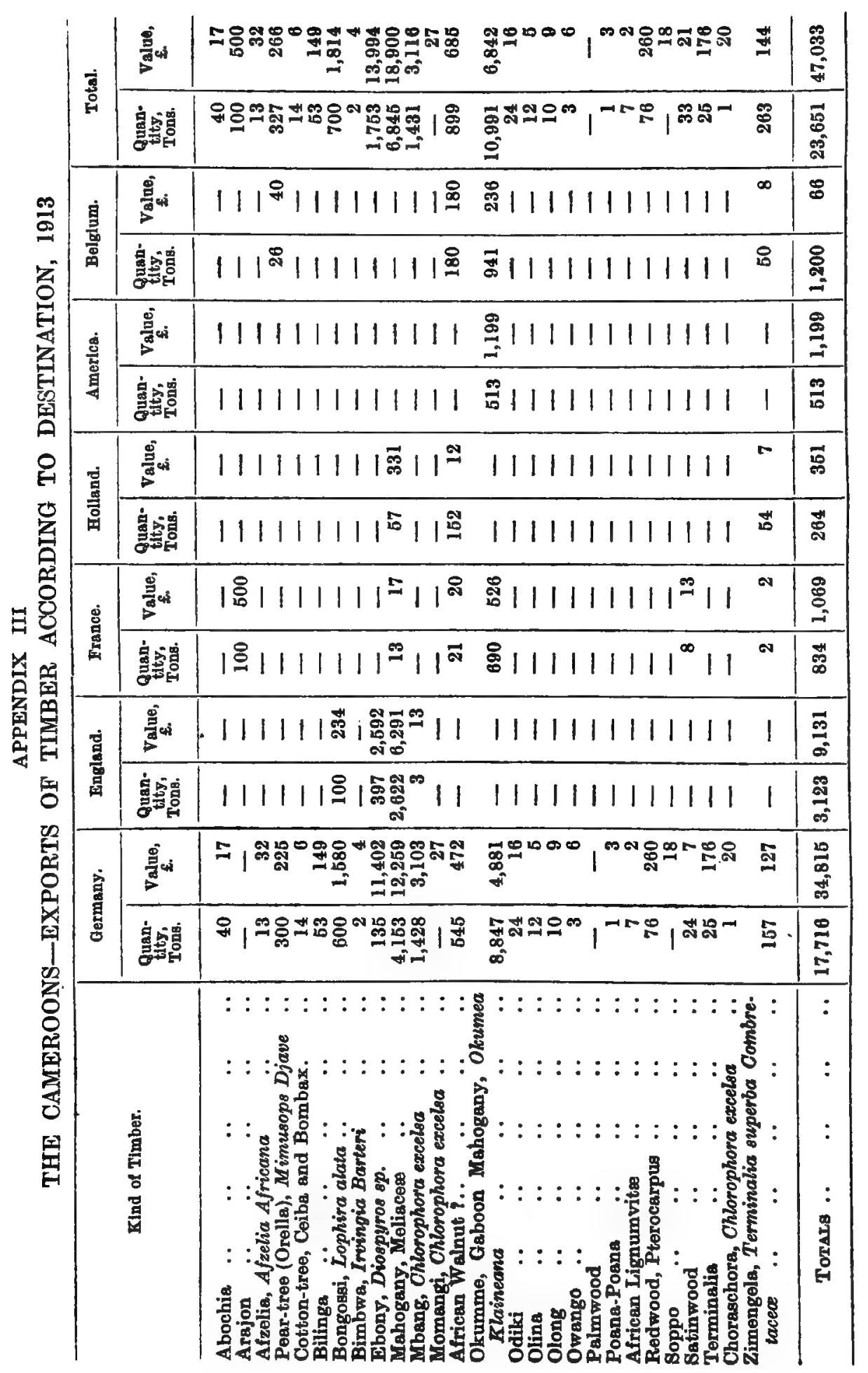




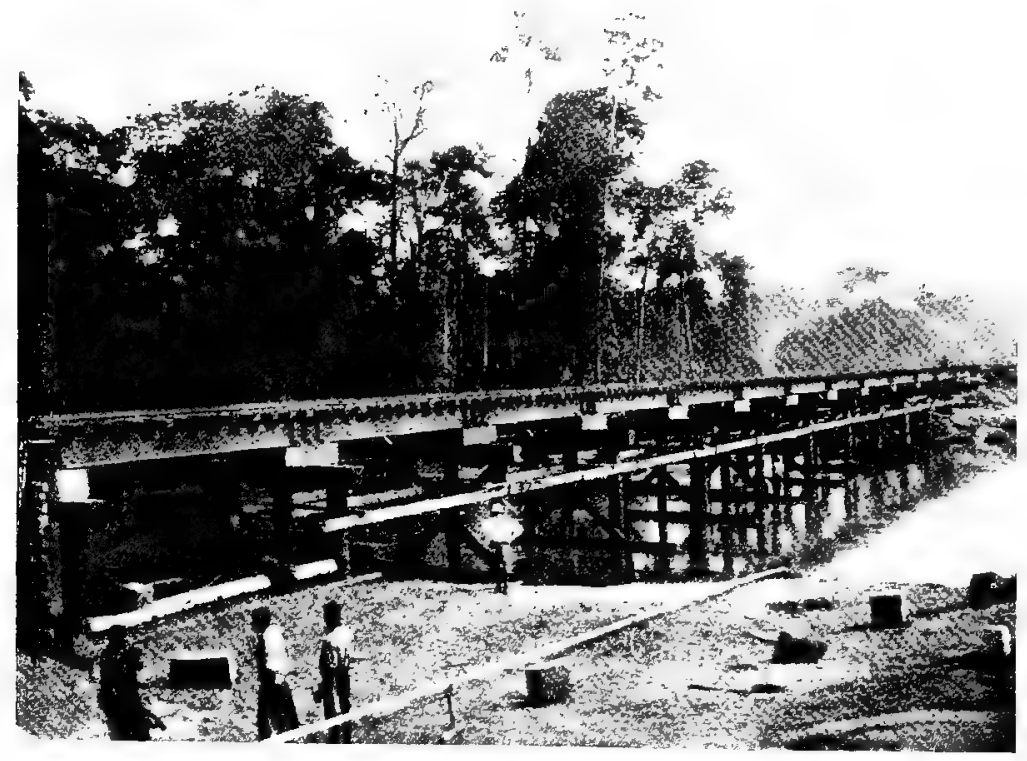

FIG. 99.- The temporary Wooden Bridge over the Imo, on the Eastern Division, Nigerian Railway. Note, only native, locally grown timber ased in its construction.

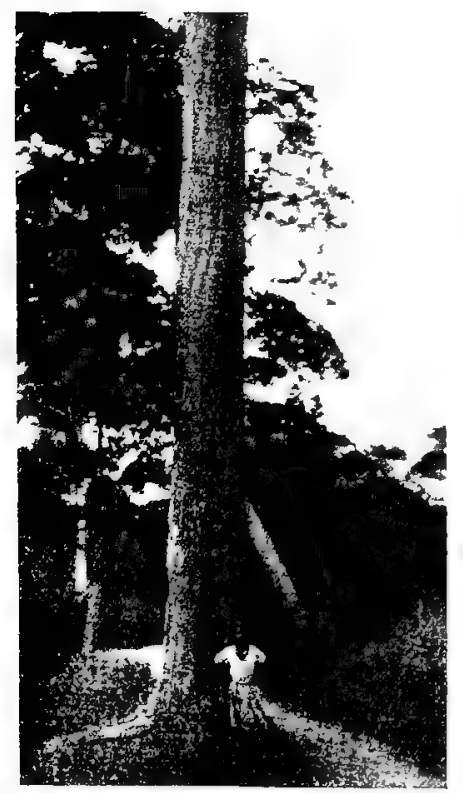

FIG. 100--Medium-sized African Pearwood (Mimusops Djave) standing in the middle of the roat outside Degema station, on the road to
nlimema, since felled, and logs sold in England.

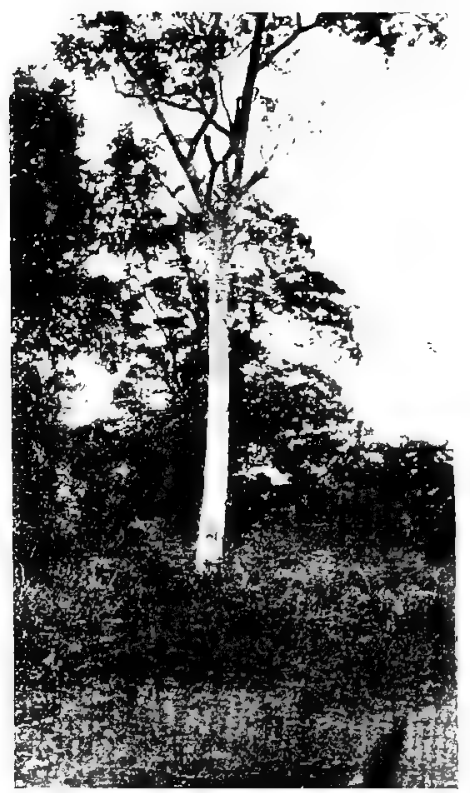

FIG. 101. - Inoi Tree (Poga oleosa) standing at the edge of the Degema Station grounds. 



\section{CHAPTER XI}

\section{THE OIL BEANS, SEEDS AND NUTS OF THE FOREST}

IN a separate chapter the Oil Palm and its produce are more fully considered, so that we give here a detailed account of the other important Oil Seeds and Nuts. Oil-bearing nuts and seeds are usually found in great profusion in the Tropics, and West Africa is no exception to the rule.

Amongst the botanical families in which the plants yield oil-seeds or nuts are the Palmæ, Leguminosæ, Euphorbiaceæ, Ochnaceæ, Sapotaceæ, Rhizophoraceæ, Meliaceæ and Guttiferæ. As far as the Protectorates of Nigeria and Sierra Leone are concerned, the "Oil Bean" (Pentaclethra macrophylla) is one of the most important. According to the data in the Niger district, oil beans have been bought for some ten years from the natives. They are also known as Owala beans. The natives prefer a price of 1s. per case, but the minimum of $6 \mathrm{~d}$. and the maximum of $9 \mathrm{~d}$. per case was about the limit for the nuts in pre-war days. Even then only a small profit was made by the European merchant at the prices then ruling for the nuts in England. With the much greater, almost universal demand for all kinds of oil-nuts and seeds, it is probable that higher prices will be paid for these nuts now that the war is over, provided a reasonable charge for freight can be arranged. The natives themselves say that the nuts should be cooked for twelve hours to be good for eating. There are six or seven beans in each pod.

Now that many roadsides in the Owerri province and other districts have been planted with Oil-bean trees as a shade tree, there will be a continual supply of nuts each year. The tree starts bearing in the tenth year, and almost every year bears a fair crop. An example of one of these avenues is seen on the Ikpoba Road, just outside Benin City. The pods are used as a firewood, which makes a hot, rapid fire. In Sierra Leone they are known as Fai beans. The beans are large and fiattened, covered with a hard brown seed-coat. They may be from one and a half to two and three-quarter inches in length, and from one to one and three-quarter inches in breadth, and one-third to nearly half an inch in thickness. The kernels are white and soft and contain a quantity of oil. 
According to the very valuable investigations of the Imperial Institute :

The proportion of hard seed-coat (by weight), 20.7 per cent.

The proportion of kernel in bean (by weight), 79.3 per cent.

The amount of oil contained in the whole, $31 \cdot 2$ per cent.

The amount of oil contained in the kernels, 39 per cent.

When the oil is left to stand it deposits a quantity of solid fat. On trial, the oil was found to yield rather a soft soap, and was stated to be worth only about $£ 21$ per ton. The cold-pressed oil was of a golden yellow colour, and the hot-drawn oil a dull yellow and rather thick. From analysis it was found that the meal was very nutritious, containing over 39 per cent. of proteids, and if it could be used as a feeding-cake it would bo worth from $£ 5$ to $£ 510 \mathrm{~s}$. per ton (pre-war rates).

The constants of the oil from the Southern Nigerian seeds are:

$\begin{array}{llllll}\text { Iodine value } & \ldots & \ldots & \ldots & \ldots & 87 \cdot 07 \\ \text { Acid value.. } & \ldots & \ldots & \ldots & \ldots & \mathbf{1 4} \cdot 3 \\ \text { Titer test } . . & \ldots & \ldots & \ldots & \ldots & 50 \cdot 15^{\circ} \text { C. }\end{array}$

The composition of the meal after extraction of the oil is as follows :

\begin{tabular}{|c|c|c|c|c|c|c|c|}
\hline Moisture & .. & $\cdots$ & . & $\because$ & .. & .. & $\begin{array}{l}\text { Per cent. } \\
12 \cdot 9\end{array}$ \\
\hline Ash & .. & .. & .. & .. & .. & .. & $\mathbf{3} \cdot \mathbf{5}$ \\
\hline Proteins & .. & .. & .. & .. & $\ldots$ & .. & $34 \cdot 8$ \\
\hline Fibre & . & . & $\ldots$ & .. & .. & .. & $6 \cdot 8$ \\
\hline \multirow{2}{*}{\multicolumn{2}{|c|}{ Dugar (cexuruse) . }} & ... & $\therefore$ & $\cdots$ & .. & . & $6 \cdot 2$ \\
\hline & & other & than & agar) & .. & .. & $33 \cdot 7$ \\
\hline
\end{tabular}

The oil on analysis gave the following results :

Specific gravity at $15.5^{\circ} \mathrm{C} .\left(60^{\circ} \mathrm{F}.\right) \quad \ldots \quad \ldots \quad 0.9194$

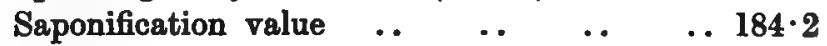

Free fatty acids, per cent. .. $\quad \ldots \quad \ldots \quad 0.7$

Analysis of pressed cake :

\begin{tabular}{|c|c|c|c|c|c|c|c|}
\hline Oil .. & . & .. & $\cdots$ & .. & .. & .. & $\begin{array}{c}\text { Per cent. } \\
12 \cdot 0\end{array}$ \\
\hline Moistur & .. & .. & .. & . & .. & .. & $9 \cdot 9$ \\
\hline \multirow{2}{*}{\multicolumn{2}{|c|}{$\begin{array}{l}\text { Crude proteins } \\
\text { Carbohydrates }\end{array}$}} & .. & .. & . & .. & .. & $33 \cdot 2$ \\
\hline & & .. & .. & . & .. & .. & $34 \cdot 8$ \\
\hline \multicolumn{2}{|c|}{ Fibre $\quad$.. } & .. & .. & . & .. & .. & $5 \cdot 7$ \\
\hline Ash. . & .. & .. & .. & .. & $\ldots$ & .. & $4 \cdot 5$ \\
\hline
\end{tabular}

The oil would make a first-class edible oil. The value of the beans is stated to be about $£ 6$ per ton c.i.f. London, August 1909, 
and subject to being shipped in lots of fifty to one hundred tons at a time. No regular plantations have been made with this tree, but it is probable that with cultivation an earlier and quicker yield of nuts could be obtained, also with further grafting and seed selecting the thickness of the shell over the kernel could be considerably reduced, and also the thickness of the pod, and thus make the product more valuable in proportion to its size. A small tree will bear half to one bushel of beans, and a large tree will bear two. On the smaller and younger trees the pods are narrower and shorter than on the older trees, and the beans are much smaller, being only about half the size and a third of the bulk of those from fully-grown trees. The pods, which also contain a certain amount of oil, are not to be despised as a source of fuel, especially as time goes on and the population increases.

In this place also should be considered the beans of Xylia Evansii. This is also a Leguminous tree. The natives apparently have no use for the small, flattened round beans, which are about half to threequarters of an inch in diameter and an eighth of an inch thick, and sometimes less. The beans have not been collected or sold, neither have they been examined chemically as to their oil or other content.

Another oil-bean-bearing tree of this family is Berlinia acuminata, which has large beans rather more than an inch and a half long, an inch broad, and a third of an inch thick. Further examination would show whether the oil content is such as to justify their commercial exploitation. The Benin name is Ekpagoi and Yoruba Apado.

Closely allied to this one is Macrolobium palisoti, the Ogaba of the Benis, which also yields a flat, almost square-shaped bean, nearly an inch in length and an inch in width. The exact oil content of this bean is unknown.

The beans of Cynometra Afzelii and Cynometra Mannii are much larger and stouter, but also contain a certain amount of oil of unknown value. The Benin name is Upakeka and Yoruba Eggi or Ekku.

Then we have the small, almost black, button-like beans of Brachystegia spicaformis, which, despite their large quantity, have remained uncollected and unused. A proper chemical examination would reveal the oil or other content of the beans. The Benin name is Okwan and the Yoruba Ako.

Still considering this same family of plants, the Leguminoser, there are the brown beans of Erythrophloeum Guineense and E. micranthum. These are of a brown colour, about half an inch long, onethird of an inch wide, and an eighth of an inch thick, and of a more or less round shape. Here, again, further investigation would reveal the oil content of these beans. The Yoruba name is Oginni or Inyi and Yoruba Erunor Obo.

It is also not known whether the nuts of the various Afzelias, 
known as Apa by the Yorubas and Aligna by the Benis, contain a valuable oil or other commercial product.

It has been stated that the beans and pods of Pithecolobium altissimum have been used as a kind of "Dividivi" for tanning leather, but further experiment with these would prove or disprove the point.

Finally, there is the Calabar bean or Eseri bean, Phyostigma venenosum. It is known to the Efiks as Eseri. The deep furrow on the upper side of the bean is most typical of it, and differentiates it thus from the various Mucuna species. It contains two alkaloids, Calabarine and Eserine. These beans are comparatively well known. Besides being used locally as a medicine and for witchcraft, they are collected and sold for export. The bean used in games, Mucuna urens, has yet to be examined as to its value.

Amongat the other important families containing nut-bearing trees are the Rhizophoraceæ. The Inoy nut, Poga oleosa, is obtained from a common tree in the Owerri and Calabar provinces of Nigeria. The local people of the Oban and Calabar districts are very fond of the nut, and leave the tree standing when making their farms. The nuts sell in the Calabar market at the rate of 250 for 3d. They were examined in England and favourably reported on by the Imperial Institute in June 1905. The hard shell is against their general use, as it is so particularly tough and hard to crack. The shell on the nut itself is about one-fifteenth of an inch thick. The kernel is soft, white, and very oily. It has a better flavour than even the Brazil nut, and is pale-yellow in colour. The kernels were valued in May 1906 at from $£ 9$ to $£ 10$ in England. They contain about 60.8 per cent. of oil, which showed the following constants according to the investigations of the Imperial Institute:

\begin{tabular}{|c|c|c|c|c|}
\hline \multicolumn{2}{|c|}{ Specific gravity of $15^{\circ} \mathrm{C}$. } & & & 0.896 \\
\hline Saponification & & . & .. & $184 \cdot 49$ \\
\hline Iodine value & . & - & .. & $89 \cdot 75$ \\
\hline Hehner value & $\cdots$ & $\cdots$ & - & $93 \cdot 00$ \\
\hline Reichert-Meiss & & - & - & $1 \cdot 45$ \\
\hline Acid value .. & .. & .. & .. & $39 \cdot 7$ \\
\hline Titer test & .. & $\cdots$ & .. & $22^{\circ} \mathrm{C}$. \\
\hline
\end{tabular}

After extraction of the oil the meal gave the following result:

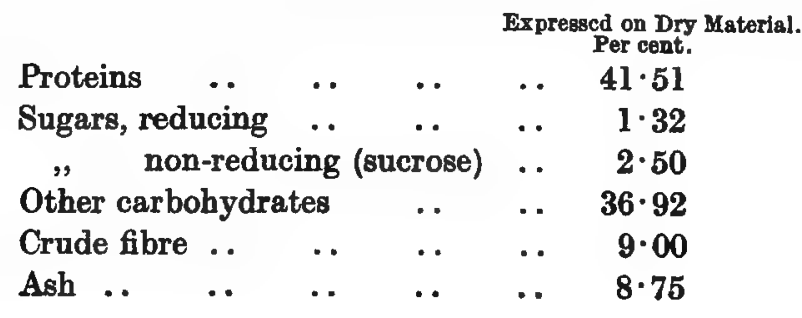




\section{OIL BEANS, SEEDS AND NUTS}

"Inoy" kernels would yield a nutritious cake for feeding cattle.

Thus far no use has been found for the round small, pear-shaped, nut-like fruits of the Red Mangrove, Rhizophara racemosa. Considering the large quantity found floating about in the creeks and rivers, further investigation seems warranted.

In the Euphorbiaceæ family the Nsa-sana (Efik) or Okkwen nuts of the Benis have been found to contain 45.2 per cent. of oil by the Imperial Institute. ${ }^{1}$ This nut is obtained from Ricinodendron Africana and $R$. Rautenii, and is known to the Yorubas as Erimado. In each fruit there are two, three, or even four nuts. The flesh of the fruit soon dries or rots away, leaving the uncracked nuts among the debris. The shell of these is hard and thick, and the inside a bright white colour. In some experiments carried out on a comparatively large scale at the end of 1907 and at the beginning of 1908, in Benin, it was found that more than half the kernels were broken in the cracking of the nut. However, in the Cameroons, where the nuts are used for alimentary purposes, they are boiled for a short time, and then it is possible to crack them quite easily without damaging the kernel inside. Further experiments at Benin showed that six boxes (gin cases) of green fruit yield one box of nuts containing actually 7,528, which weigh $35 \mathrm{lb}$. $4 \mathrm{oz}$. One box of fruit contains 418 seeds and yields 720 nuts. An average of 7,419 seeds is contained in each box, 155 nuts weighing $1 \mathrm{lb}$. Each fruit contains on the average two and one-ninth seeds. On the average 9d. per box was paid for fruit, and 1s. per box for uncracked nuts. Twenty boys cleaned and got ready $2 \frac{1}{2}$ boxes of uncracked nuts per day at the cost of 5s. Paying at the rate of 1s. a case for the uncracked nuts, the cost would be $\mathfrak{f 1 7}$ per ton. However, with regular quantities being brought in, no doubt this cost could be reduced. In a similar way, if the nuts were boiled in quantity and immediately cracked, the kernels would be got out at a cheaper rate. The native working for himself, as with the palm nuts, would turn out greater quantities in a shorter time.

The yield of the oil pressed from the kernels was 47 per cent., or 14 per cent. on the whole nut. It is light yellow in colour and has a pleasant taste, very much like that of the ground nut. The chemical examination showed a resemblance to Tsung oil (Chinese wood oil). It possesses the same property of drying on exposure to air under ordinary atmospheric pressure. The oil could be used for similar parposes, or for the making of soft soap, and would be worth from about $£ 18$ to $£ 20$ per ton for this purpose, and it appears that the oil would have a ready sale in England, and have a value, equal to linseed oil, of about £2l per ton. According to the investigations

1 Colonial Report, 88, Oil, Seeds, Fats and Waxes, Imperial Institute, 1914. 
at the Imperial Institute, the analysis of Nsa-sana kernels and Tsung oil showed:

\begin{tabular}{|c|c|c|c|c|}
\hline & & & 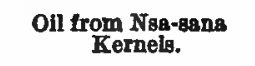 & Commercial Tsung Oil. \\
\hline $\begin{array}{l}\text { Specific gravity } \\
\text { Saponification value } \\
\text { Iodine value .. } \\
\text { Hehner value } \\
\text { Titer test ... }\end{array}$ & $\begin{array}{l}\ldots \\
\cdots \\
\cdots\end{array}$ & $\begin{array}{l}\cdots \\
\cdots \\
\cdots \\
\cdots\end{array}$ & $\begin{array}{c}0 \cdot 9320 \text { (at } 20^{\circ} \mathrm{C} . \text { ) } \\
191 \cdot 6 \\
147 \cdot 7 \\
95 \cdot 2 \\
35 \cdot 7^{\circ} \mathrm{C} .\end{array}$ & $\begin{array}{c}0 \cdot 933-0 \cdot 942\left(\text { at } 15 \cdot 5^{\circ} \mathrm{C} .\right) \\
190-197 \\
149-165 \\
96 \cdot 3 \\
37 \cdot 1-37 \cdot 2^{\circ} \mathrm{C} .\end{array}$ \\
\hline
\end{tabular}

Despite the large quantities of nuts available, especially in the Abeokuta, Benin and Calabar provinces, the difficulty of cracking the nuts satisfactorily and buying them cheap enough has so far precluded an export trade from being built up. Owing to the low percentage of oil in the whole nut it is evident that it would not pay to ship the uncracked nuts. So far no plantations have been made with this tree, but it comes up very readily and plentifully in old abandoned farms of the mixed forest zone. In open localities, with plenty of light, the tree begins to bear between the seventh and tenth year, and almost each year there is a large crop of fruit. From larger trees the yield appears to be over one bushel of nuts per tree per annum.

The curious nut-like fruits of Ubellu, Benin, supposed to be a species of Microdesmis, have not been examined as to their oil or other content. Soon after falling to the ground they break up into a white putty-like substance, which has a very peculiar, almost sulphurous, smell, and sometimes rather phosphoric. The nuts are spherical and rather more than half an inch in diameter. The tree is found chiefly in Benin, also in the Abeokuta and Calabar provinces.

Among the Euphorbiaceæ is the creeper, Manniphyton sp., known as Okwe to the Benis. The spherically shaped fruit with four raised ribs on its surface is cut open and contains one large round nut. It is about one inch in diameter. This is boiled for a few hours and is then edible, after the thin dark-brown husk has been removed. It can be peeled off with the fingers. The nut has a pleasant mealy taste and is very satisfying. Further examination would show whether it contains a valuable oil, and in what quantity. So far it has not been cultivated.

Of the Cucurbitacer, the seeds of Citrullus vulgaris, known as Ikpan by the Efiks or Egusi bara by the Yorubas, have been examined at the Imperial Institute ${ }^{1}$ and found to contain from 40 to 41 per cent. of a pale-yellow oil. It is a common plant in the more open farms of the forest and does not demand a very high rainfall-45

1 Colonial Report, 88, Oil Seeds, Fats and Waxes, Imperial Institute, 1914. 


\section{OIL BEANS, SEEDS AND NUTS}

inches. The natives use the kernels, after they have removed the hard skin, for making soup. It makes an excellent dish with rather a sweet taste. According to the investigations of the Imperial Institute ${ }^{+}$an analysis of the oil gave the following results :

\begin{tabular}{lcccc}
\multicolumn{2}{l}{ Specific gravity at $15^{\circ}$ C. .. } & $\ldots$ & 0.9184 \\
Acid value .. & $\ldots$ & $\ldots$ & $\ldots$ & $5 \cdot 5$ \\
Saponification value & $\ldots$ & $\ldots$ & $194 \cdot 0$ \\
Iodine value & $\ldots$ & $\ldots$ & $\ldots$ & $106 \cdot 0$ \\
Hehner value & $\ldots$ & $\ldots$ & $\ldots$ & $95 \cdot 5$ \\
Titer test .. & $\ldots$ & $\ldots$ & $\ldots$ & $36 \cdot 0^{\circ} \mathrm{C}$.
\end{tabular}

The oil could be used for soap-making, and was valued at $£ 29$ per ton.

In the family Moringex there is Moringa pterygosperma, the Ben oil-seed tree. It is a common tree of the upper part of the Oyo, Benin and Ogoja provinces of Nigeria. It is also found in Borgu and other of the Northern Provinces. On examination by the Imperial Institute the kernels were found to contain 38 per cent. of oil, pale-yellow in colour and of a pleasant taste. The kernel is difficult to extract. At the Imperial Institute ${ }^{1}$ the analysis showed :

\begin{tabular}{|c|c|c|c|c|c|c|}
\hline & & \multicolumn{2}{|c|}{$\begin{array}{l}\text { No. } 1 \text { from } \\
\text { Extracted Oil. }\end{array}$} & \multicolumn{2}{|c|}{$\begin{array}{l}\text { No. } 2 \text { from } \\
\text { Decorticated Seed. }\end{array}$} & \multirow{2}{*}{$\begin{array}{c}\text { No. } 3 \text { from } \\
\text { Undecorti- } \\
\text { cated Seed. } \\
\begin{array}{c}\text { Hot } \\
\text { Pressed. }\end{array}\end{array}$} \\
\hline & & Liquid. & Solid. & $\begin{array}{c}\text { Cold } \\
\text { Pressed. }\end{array}$ & $\underset{\text { Pressed. }}{\text { Hot }}$ & \\
\hline \multicolumn{2}{|c|}{ Specific gravity at $15 / 15^{\circ} \mathrm{C} .}$. & 0.914 & - & $0 \cdot 902$ & $0 \cdot 898$ & 0.913 \\
\hline Acid value & . & $15 \cdot 3$ & - & $49 \cdot 7$ & $100 \cdot 5$ & $2 \cdot 3$ \\
\hline Saponification value & . & $189 \cdot 2$ & $194 \cdot 4$ & $179 \cdot 2$ & $178 \cdot 7$ & $186 \cdot 0$ \\
\hline Iodine value $\quad \ldots$ & .. & $70 \cdot 7$ & $68 \cdot 3$ & $100 \cdot 3$ & $88 \cdot 0$ & $67 \cdot 7$ \\
\hline Unsaponifiable matter. & .. & + & - & $1 \cdot 67$ & $2 \cdot 69$ & - \\
\hline
\end{tabular}

\section{Composition of Cake from Ben Seeds.}

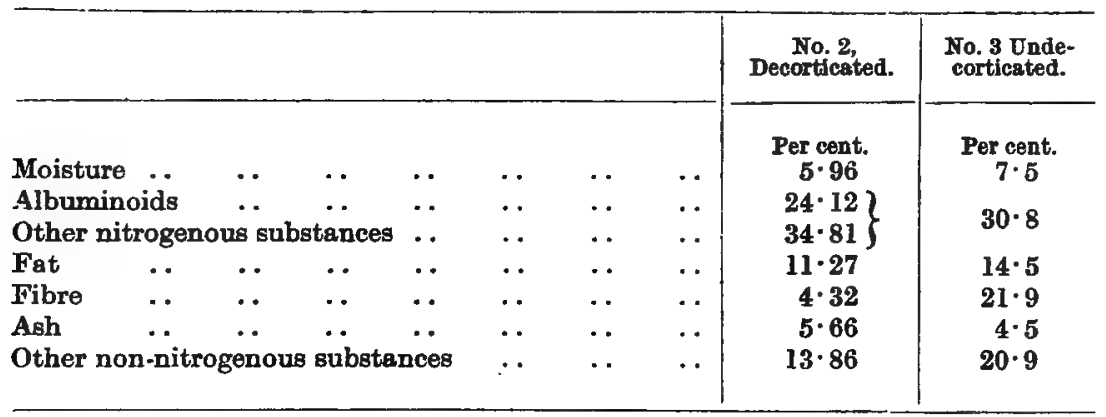

From the Simarubeæ there is Balanites Algyptica, Betu oil-tree of the Northern Provinces of Nigeria. Although it yields 58.7 per cent.

1 Colonial Report, 88, Oil Seeds, Fats and Waxes, Imperial Institute, 1914. 


\section{WEST AFRICAN FORESTS AND FORESTRY}

of oil, the exploitation of it is almost impossible; owing to the difficulties in removing the husk, the external sugary pulp, and then the thick fibrous shell under the pulp. At the Imperial Institute, ${ }^{1}$ Betu oil on analysis showed :

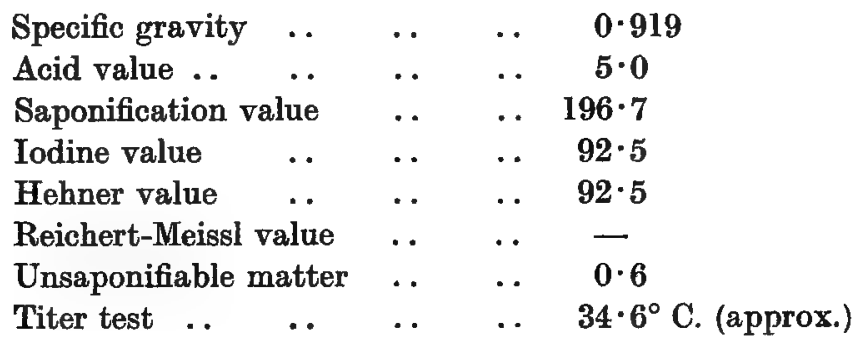

The oil is a mixture; the results of analysis are as follows :

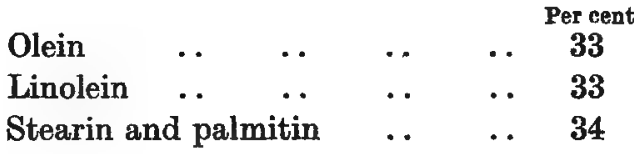

The family of Simarubeæ also contains the trees Irvingia Barteri and $I$. Smithii. These yield the Dika nut, or, as it is sometimes called, Gaboon chocolate. The sun-dried kernels keep in a perfectly good condition for some time. According to the investigation of the Imperial Institute ${ }^{1}$ the kernel contains about 43.5 of "Dika fat." It would be useful either for soap or for candle making, and be worth from $£ 25$ to $£ 27$ per ton, and the Dika kernels are valued at from $£ 10$ to $£ 12$ per ton. Locally, however, they are often worth as much as this, but no doubt increased production would mean a reduction in price. So far the tree has only been planted in isolated instances, and otherwise is a forest tree which has been protected by the native for the value of its fruit. The decortication usually takes place near the tree, or in an open place where the nuts are split in half with a sharp matchet, which releases the kernel in the centre, and though often cut in half by this method, it apparently does not mean a large loss of oil to the kernel. According to the analysis of the Imperial Institute ${ }^{1}$ the kernel showed:

\begin{tabular}{|c|c|c|c|c|c|c|c|}
\hline \multirow{2}{*}{\multicolumn{4}{|c|}{ Yield of fat (on kernels) per cent. }} & \multirow{3}{*}{$\ddot{\cdots}$} & \multirow{2}{*}{$\frac{\begin{array}{c}\text { Sample } \\
\text { No. } 1 .\end{array}}{54 \cdot 3}$} & \multirow{2}{*}{$\begin{array}{c}\begin{array}{c}\text { Sample } \\
\text { No. } 2 .\end{array} \\
60 \cdot 1\end{array}$} & \multirow{2}{*}{$\frac{\begin{array}{c}\text { Sample } \\
\text { No.8. }\end{array}}{66.3}$} \\
\hline & & & & & & & \\
\hline Specific gravity at 100 & $0 / 15$ & & . & & - & 0.863 & - \\
\hline Acid value $\quad \ldots$ & $\therefore$ & .. & .. & . & $6 \cdot 6$ & $12 \cdot 6$ & $1 \cdot 8$ \\
\hline Saponification value & . & $\because$ & .. & .. & $244 \cdot 5$ & $250 \cdot 0$ & $243 \cdot 8$ \\
\hline Iodine value .. & . & $\therefore$ & .. & . & $5 \cdot 2$ & $\mathbf{3} \cdot \mathbf{3}$ & $4 \cdot 2$ \\
\hline Unseponifiable matter & & . & . & $\ldots$ & $0 \cdot 7$ & - & - \\
\hline Titer test $\quad$.. & .. & . & . & . & $34 \cdot 8^{\circ} \mathrm{C}$ & - & - \\
\hline Melting-point of fat & - & . & . & . & -- & - & $39 \cdot 2^{\circ} \mathrm{C}$ \\
\hline
\end{tabular}

1 Colonial Report, 88, Oil Seeds, Fats and Waxes, Imperial Institute, 1914. 
Apparently an oil seed, probably Philiodiscus, a member of the Sapindaceæ family, has been examined at the Imperial Institute and has been found to contain a non-drying oil, which was free from taste and smell. It should, therefore, be of value for eating or for making a white soap.

Sapotaceæ, Butyrospermum Parkii.-In recent years larger quantities of Shea nuts, which are the product of this tree, have been exported from West Africa, especially Nigeria, as also Shea butter, which is manufactured locally from the nuts. In the varieties Tengba and Bomo the quantity varied from " 54.5 per cent. to 48 per cent.," and these were obtained from the Southern Provinces of Nigeria. In the two varieties exported from the Northern Provinces, those known as Eko showed a length of nut varying from 1.5 to 2.5 inches, and the Giddouchi variety 1.4 inches long. Owing to the wide prevalence of this tree much larger quantities could be exported, but many of the forests containing it are situated far away from means of transport, and no very suitable method has yet been found of manufacturing the butter on a big scale locally. At present it is made by certain women who know the process, which takes nearly three days to complete. According to the Imperial Institute the results of the analysis of Shea butter are: 1

\begin{tabular}{|c|c|c|c|c|c|}
\hline & & & From Lagos. & $\begin{array}{l}\text { Fat from } \\
\text { Untreated } \\
\text { Kernels. }\end{array}$ & $\begin{array}{c}\text { Fat from } \\
\text { Kiln-dried } \\
\text { Kernels. }\end{array}$ \\
\hline \multicolumn{2}{|c|}{ Specific gravity at $100 / 15^{\circ} 5^{\circ} \mathrm{C}$} & .. & $0 \cdot 862$ & - & - \\
\hline Acid value $\quad . . \quad \ldots$ & . & .. & $18 \cdot 0$ & $33 \cdot 9$ & $26 \cdot 2$ \\
\hline Saponification value .. & .. & .. & $179 \cdot 0$ & $181 \cdot 2$ & $180 \cdot 2$ \\
\hline Iodine value .. $\quad .$. & .. & .. & $58 \cdot 7$ & $59 \cdot 4$ & $55 \cdot 8$ \\
\hline Hehner value ... .. & .. & .. & $96 \cdot 5$ & - & - \\
\hline Unsaponifiable value. . & .. & .. & $1 \cdot 7$ & - & - \\
\hline Titer test $\quad \ldots \quad \ldots$ & .. & .. & $52 \cdot 0^{\circ} \mathrm{C}$ & - & - \\
\hline
\end{tabular}

The fat obtained from the Northern Provinces and the Gold Coast shows very similar contents.

Mimusops, sp. Djave?.-The nuts of this species closely resemble those of the Shea Butter Tree. The nuts are a light-brown colour, about two inches long, and one to one and a half inches in diameter, with roundly pointed ends. Rather more than half the surface of the nut is smooth and shiny, and the other half is rough and dull, and the whole of it is very hard. When dry it is, however, comparatively easily separated from the kernel. The fresh kernels are creamcoloured. According to the Imperial Institute ${ }^{1}$ the yield of fat extracted by solvents is 60.2 per cent., or 37.7 per cent. from the

1 Colonial Report, 88, Oil Seeds, Fats and Waxes, Imperial Institute, 1914. 
whole nut. The fat is solid at ordinary temperatures. In 1913 some of these nuts were shipped from the Cross River and were valued in Liverpool as Shea nuts, only at a rather lesser rate. According to the Imperial Institute the analysis showed:

\begin{tabular}{|c|c|c|c|}
\hline Specific gravity at $100 /$ & $5^{\circ} \mathrm{C}$. & & $0 \cdot 860$ \\
\hline Acid value $\quad \ldots \quad \ldots$ & . & . & $25 \cdot 3$ \\
\hline Saponification value. . & . & . & $187 \cdot 6$ \\
\hline Iodine value .. $\quad$. & $\cdots$ & . & $56 \cdot 2$ \\
\hline Hehner value & .. & - & $95 \cdot 4$ \\
\hline Reichert-Meissl value & .. & 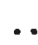 & Nil \\
\hline Unsaponifiable matter & . & . & $2 \cdot 6$ approx. \\
\hline Titer test $\quad \ldots \quad \ldots$ & . & .. & $47 \cdot 8^{\circ} \mathrm{C}$ \\
\hline
\end{tabular}

Dumoria Heckeli? (Baco or Abaku).-Although the Gold Coast name is given, these nuts are also found in the Oban forest. The nuts are large, considerably longer than those of Mimusops, but rather thinner. They are of a pale-brown colour, with a thick, hard, woody shell, most of which is smooth and shiny, only one small part of the surface being rough and forming almost a nodule. According to the Imperial Institute ${ }^{1}$ analysis of the Gold Coast samples, the whole nuts contain 21 per cent. of fat or 60.5 per cent. in the kernels alone. The fat is solid and of a creamy white colour. The soap-makers reported that it was about equal to middling quality palm oil. It is also stated that dried kernels in good condition would be worth $£ 13$ per ton. According to the Imperial Institute ${ }^{1}$ analysis the fat showed :

\begin{tabular}{|c|c|c|c|}
\hline Specific gravity at 100 & $5^{\circ} \mathrm{C}$. & & $0 \cdot 855$ \\
\hline Acid value $\ldots$.. & .. & .. & $34 \cdot 7$ \\
\hline Saponification value.. & . . & .. & $188 \cdot 4$ \\
\hline Iodine value .. $\quad$. & - & - & $51 \cdot 3$ \\
\hline Titer test $\quad \ldots$ & . & .. & $51 \cdot 2^{\circ} \mathrm{C}$ \\
\hline Unsaponifiable matter & .. & . & $1 \cdot 3$ \\
\hline
\end{tabular}

The small nuts of Mimusops multinervis and $M$. lacera have not been examined as to their oil or other content. The hard nuts of $M$. lacera appear to contain a fair proportion of oil.

In this family, too, are the nuts of Chrysophyllum Africanum and other species, for which a use has yet not been found. Finally, there are the numerous and fine seeds of Omphalocarpum elatum, known as Ikassa by the Benis, which are probably also oil-bearing.

The next important family is the Olacacer, Heisteria parvifolia, known as Ikereoha by the Benis. It yields an edible nut which is white on the exterior and has a black-coloured shell over the actual

1 Colonial Report, 88, Oil Seeds, Fats and Waxes, Imperial Institute, 1914. 


\section{OIL BEANS, SEEDS AND NUTS}

nut inside. It has not yet been exported or valued. The Benin and other natives are very fond of eating it.

Then there is the nut of Ivialegbi (Benin), which is edible and has a pleasant taste. It is rather smaller than the Gaboon nut, and its surface is slightly striated from the sharp point of the nut to the base.

In this family is found, too, Coula edulis, or the Gaboon nut. This is chiefly found in the Cameroons, but owing to similarity in the vegetation it is very probably growing in the Oban forest of the Anom range. The shell of the nut is very rough, and the outside is smoother than the inside. The shell can be cracked comparatively easily with a somewhat powerful blow with a hammer or axe-handle.

From the Anonaceæ:

Monodora tenuifolia, African Nutmeg.

$M$. myristica, var. grandis, Calabar Nutmeg.

$M$. brevipes, Yellow-flowering Nutmeg.

None of these nutmegs have yet been placed on the European market. Although they are all much smaller in size than the nutmeg of commerce, a proper examination would reveal any value they might possess.

Although the Myristicaceæ, Pycnanthus Kombo, yield fat-bearing nuts, they have not been exported to the English market. The nut is the size of a small oval plum. The outer husk is hard and thick, but is comparatively easily broken. The inner nut is covered with a red aril spread out over it, similar to the mace over the common nutmeg (Myristica fragrans). The kernel is white inside, with dark rays penetrating it from the outside. The tree is very prevalent, and yields a large number of nuts. According to the investigation of the Imperial Institute " ${ }^{1}$ the yield of solid fat was 54 per cent. It has an orange colour and a bitter taste." The fat was stated to be suitable for soap and candle making and the meal as a manure. In Sierra Leone the nuts were known as Kpoye, and are identical with those known as "Kafu." According to the chemical analysis made at the Imperial Institute the following results were obtained :

\begin{tabular}{|c|c|c|c|}
\hline Specific gravity at 10 & $00 / 15^{\circ} \mathrm{C}$ & & $0 \cdot 886$ \\
\hline Melting-point & .. $\quad$. & . & $48 \cdot 5^{\circ} \mathrm{C}$ \\
\hline Saponification value. & & . & 235 to 245 \\
\hline Acid value $\ldots$. & .. & .. & $21 \cdot 0$ \\
\hline Hehner value. . & -. & . & $90 \cdot 8$ \\
\hline Iodine value .. & $\cdots$ & .. & $48 \cdot 9$ \\
\hline Titer test $\quad$. & .. & . & $45 \cdot 8^{\circ} \mathrm{C}$ \\
\hline
\end{tabular}

1 Colonial Report, 88, Oil Seeds, Fats and Waxes, Imperial Institute, 1914. 
analysis of Fat from Sierra Leone Kombo Seeds.

\begin{tabular}{|c|c|c|c|c|c|}
\hline & & & & Fat as Sent. & $\begin{array}{c}\text { Fat Extracted } \\
\text { from Kernels at } \\
\text { Imperial Institute. }\end{array}$ \\
\hline $\begin{array}{ll}\text { Specific gravity } & \ldots \\
\text { Acid value .. } & \ldots \\
\text { Saponification value } \\
\text { Iodine value .. }\end{array}$ & $\begin{array}{l}\ldots \\
\ddot{.} \\
\cdots\end{array}$ & $\begin{array}{l}\ddot{.} \\
\ddot{*} \\
\cdots\end{array}$ & $\begin{array}{l}\cdots \\
\because \\
\cdots\end{array}$ & $\begin{array}{l}0 \cdot 887 \\
33 \cdot 0 \\
231 \\
67 \cdot 6\end{array}$ & $\begin{array}{l}0 \cdot 880 \\
31 \cdot 4 \\
236 \\
59 \cdot 0\end{array}$ \\
\hline
\end{tabular}

Of the Meliacex there is Carapa Guineensis (C. procera, D.C.), which yields the Carapa oil. The nuts are roughly tetrahedral in shape, having a rough reddish-brown shell enclosing one large kernel covered with a pale-brown papery skin. Good kernels yield about 57 per cent. of oil by extraction with solvents and 46.7 per cent. by pressure (27 per cent. on cold and 22 per cent. on heating); it is of a paleyellow colour and has a bitter taste. The commercial value of the oil was stated in 1907 to be $£ 2010$ s. per ton according to the valuations made by the Imperial Institute, ${ }^{1}$ and from the same authority we find the Carapa cake is of a very low manurial value, and is only stated to be worth about 22 per ton. Some dark-coloured kernels were bought in 1909 at $f 11 \mathrm{5s}$. per ton, and light kernels at f11 10s. per ton. According to the Imperial Institute the results were as follows :

\begin{tabular}{|c|c|c|c|c|c|}
\hline & & & & Cold Pressed Oil. & Hot Pressed Oil. \\
\hline Specific gravity at $40^{\circ} \mathrm{C}$. & . & .. & .. & 0.9179 & 0.9174 \\
\hline$\Rightarrow \quad " \quad 15^{\circ} \mathrm{C}$ & .. & .. & . & $0 \cdot 9272$ & 0.9327 \\
\hline Saponification value & .. & .. & .. & $197 \cdot 1$ & $196 \cdot 4$ \\
\hline Iodine value .. .. & .. & .. & .. & $75 \cdot 6$ & $71 \cdot 2$ \\
\hline Reichert-Meissl value & .. & .. & $\therefore$ & $3 \cdot 5$ & $3 \cdot 1$ \\
\hline Unsaponifiable matter & .. & .. & .. & $1 \cdot 5$ & $2 \cdot 0$ \\
\hline Titer test $\quad . . \quad \ldots$ & . & .. & . & $35 \cdot 4^{\circ} \mathrm{C}$ & $36 \cdot 1^{\circ} \mathrm{C}$ \\
\hline
\end{tabular}

$$
\begin{aligned}
& \text { Carapa Cakf. } \\
& \begin{array}{llllll}
\text { Moisture } & . . & \ldots & \ldots & \ldots & \begin{array}{c}
\text { Per cent. } \\
\text { Ash }
\end{array} \\
\text { Nitrogen } & . . & . . & . . & . & \mathbf{5} \cdot \mathbf{9} \\
& . & . . & . . & \ldots & \mathbf{2 . 9}
\end{array}
\end{aligned}
$$

The ash contained:

$$
\begin{aligned}
& \text { Potash, } \mathrm{K}_{2} \mathrm{O} \\
& \begin{array}{llllll}
\text { Iime, } \mathrm{CaO} & \ldots & \ldots & \ldots & \ldots & 1 \cdot 91
\end{array} \\
& \text { Phosphoric anhydride, } \mathrm{P}_{2} \mathrm{O}_{5} \quad \ldots \quad 0.51
\end{aligned}
$$

1 Colonial Report, 88, Oil Seeds, Fats and Waxes, Imperial Institute, 1914. 


\section{OIL BEANS, SEEDS AND NUTS}

Apocynaceæ.-Although the seeds of Funtumia elastica yield oil, it was not favourably reported on. Perhaps now, with the greater value of all the oil seeds, some use could be made of it.

Ebenaceæ, Diospyros Barteri.-This yields the Ebony nut, which is small, but edible. The Benin natives are very fond of it. It has not been exported.

Diospyros crassiflora or Diospyros dendo have a fruit about the size of a large green plum, which contains four long, thin, almond-like nuts, which have rather a bitter taste. Although evidently oil-bearing, they have not been properly examined or tested as to the exact content of oil or other products.

Rosaceæ.-Although the Chrysobalamus sp., or Niko nut, is comparatively well known, it is by no means fully utilized. Then there is Parinarium Gabunense, yielding the Mahogany nut, of uncertain value.

Anacardiaceæ.-The Anacardium occidentale, yielding the Cashew nut, is so far only utilized near Lagos, where it is growing as a garden escape. No proper plantations have yet been made of this tree.

Amongst the Palmx, besides the Oil Palm, we have the Bottle Toddy or Fan Palm, Borassus flabellifer, yielding three or four nuts in each fruit. These are oil containing, but of unknown value. Considering the large areas in all the West African Colonies where the Fan Palm is found, some use should be made of the large number of nuts produced.

Then we have Hyphæne, the Doum Palm, which yields a nut used for making buttons. Here, again, the large quantities which are found in Africa ensure a steady amount of produce being placed on the market, provided a remunerative price is always paid for the nuts. Finally there is Phoenix dactylifera, the Date Palm. Although this is more of a fruit than a nut, it is included here, as it is found in the forest groves of the North. Considering the value of its produce and the constant demand there is for it, a wide extension of its area of cultivation is to be recommended.

Ochnaceæ, Lophira alata.-This is the dwarf Red Ironwood tree, which yields the "Niam" fat or "Meni" oil. The fruit is roughly conical, consisting of a reddish-brown fibrous shell, enclosing one kernel. The kernel is conical in shape, and about five-eighths of an inch in width. The inside is a pale-yellow colour. The fruit has two uneven-sized wings, the larger being over an inch in length and nearly half an inch in width. According to the Imperial Institute ${ }^{1}$ the fat is semi-solid and of a yellowish colour. The kernel contains 31.1 to 43 per cent. of fat. The fat is suitable for soap-making.

According to the analysis of the Imperial Institute the results were as follows: For soap-making it is considered to be of the same

1 Official Report, 88, Oil Seeds, Fats and Waxes, Imperial Institute, 1914. 
value as palm oil, i.e. in November 1911, at Liverpool, $£ 30$ to $£ 31$ per ton. The cake obtained from it closely resembled Shea-nut cake and was of a similar value, i.e. about $£ 3$ per ton in Liverpool. The decorticated kernels, which contained about 40 per cent. of oil, were valued at about $£ 10$ per ton c.i.f. at Liverpool in October 1911. These kernels should find a ready market in Europe for soap-making, and the cake to be used as a manure. As the tree is one of the commonest in the dry-zone forests, ample supplies of the nuts should be always forthcoming, providing an adequate price to pay for the cost of production is paid for them.

TABLE I.

Yield of Fat.

\begin{tabular}{|c|c|c|c|c|c|}
\hline & A. & B. & c. & D. & E. \\
\hline $\begin{array}{ll}\text { Product received } & \text {.. } \\
\text { Condition of kernels } & \ldots\end{array}$ & $\begin{array}{l}\text { Fruits } \\
\text { Mostly } \\
\text { sound }\end{array}$ & $\begin{array}{l}\text { Kernels } \\
\text { Good }\end{array}$ & $\begin{array}{l}\text { Fruits } \\
\text { Many } \\
\text { partly } \\
\text { decom- } \\
\text { posed }\end{array}$ & $\begin{array}{l}\text { Kernels } \\
\text { Good }\end{array}$ & $\begin{array}{l}\text { Kernels } \\
\text { fairly } \\
\text { good }\end{array}$ \\
\hline $\left.\begin{array}{c}\text { Yield of fat (per cent. } \\
\text { calculated on weight } \\
\text { of kernels used) }\end{array}\right\}$ & $31 \cdot 19$ & $43 \cdot 0$ & & $41 \cdot 16$ & $41 \cdot 76$ \\
\hline
\end{tabular}

TABLE II.

Constants of Fat.

\begin{tabular}{|c|c|c|c|c|c|}
\hline & A. & B. & c. & D. & E. \\
\hline Specific gravity & $0 \cdot 9105$ & $0 \cdot 9044$ & 0.9044 & 0.9019 & 0.9016 \\
\hline Acid value $\quad .$. & $18 \cdot 54$ & $25 \cdot 9$ & $33 \cdot 2$ & $47 \cdot 5$ & $48 \cdot 0$ \\
\hline Saponification value .. & $195 \cdot 6$ & $181 \cdot 5$ & $194 \cdot 6$ & $180 \cdot 7$ & $183 \cdot 3$ \\
\hline Iodine value $\quad . . \quad$. & $68 \cdot 4$ & $69 \cdot 8$ & $70 \cdot 3$ & $72 \cdot 1$ & $72 \cdot 5$ \\
\hline Reichert-Meissl value.. & - & 0.9 & 0.9 & 0.8 & 0.8 \\
\hline Unsaponifiable matter. . & $1 \cdot 49$ & 0.5 & - & - & $0 \cdot 86$ \\
\hline $\begin{array}{lll}\text { Titer test } & \ldots & \ldots\end{array}$ & - & $49 \cdot 0^{\circ} \mathrm{C}$. & $47 \cdot 0^{\circ} \mathrm{C}$ & $47 \cdot 5^{\circ} \mathrm{C}$. & $48 \cdot 5^{\circ} \mathrm{C}$. \\
\hline
\end{tabular}

Closely allied to the above is Lophira procera, the Red Ironwood Tree, which yields the Kaku or Ebba kernels. The fruit is usually more sharply conical in shape than that from $L$. alata. The fruits are small, owing to the fact that these large forest trees grow elosely amongst others, and the fruits are not so fully developed or filled out as those of $L$. alata. L. alata usually grows in the open freely, or at most only just touching a neighbouring tree, and thus the fruit has 

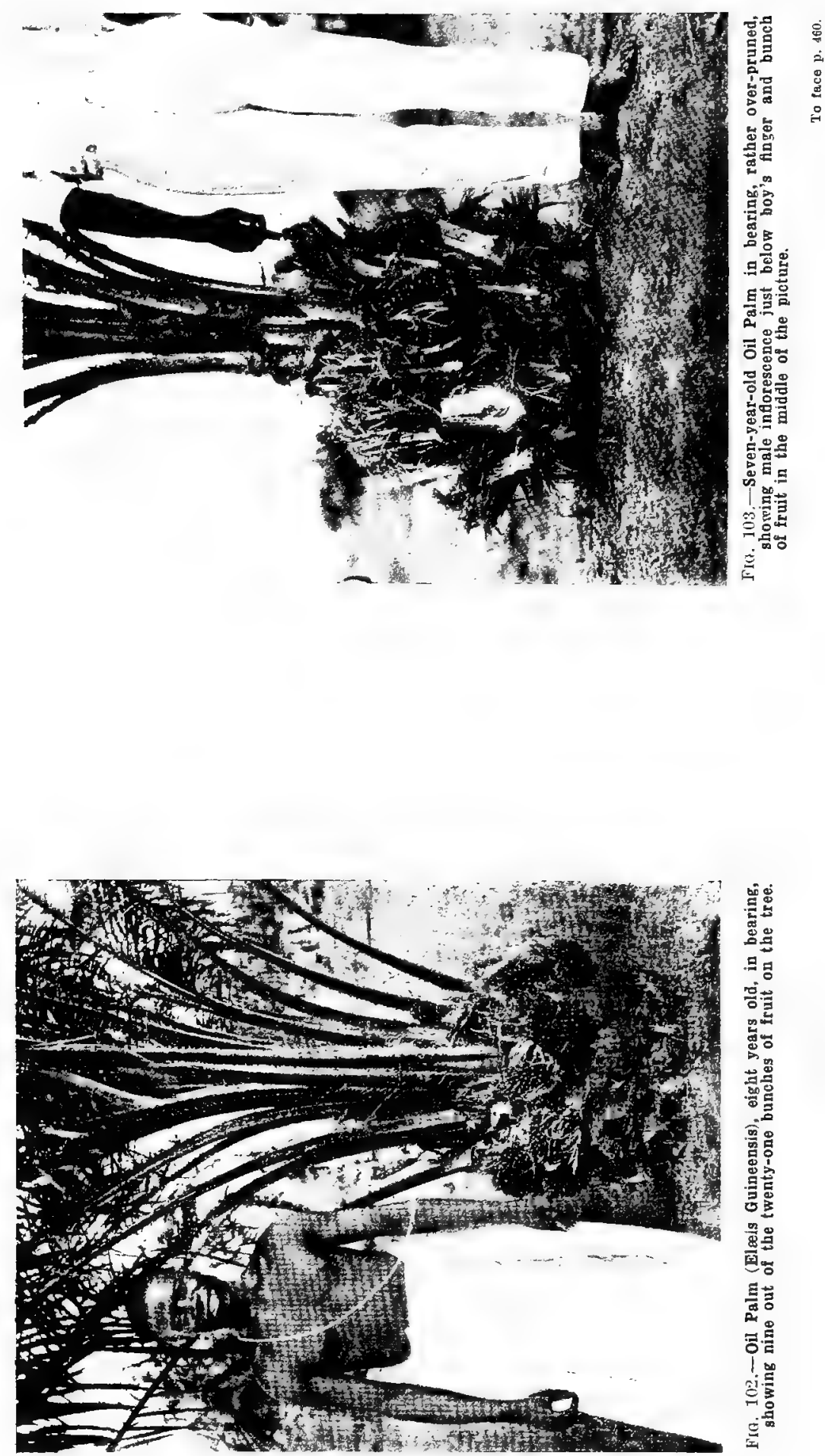

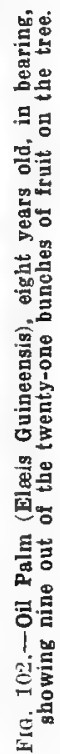



ample light for its development. According to the investigations of the Imperial Institute, the nuts were found to yield 55.2 per cent. of fat, which was solid and cream-coloured. Owing to the fact that this is a larger yield than that obtained from the nuts of $L$. alata, the decorticated kernels were valued at $£ 12$ per ton c.i.f. Liverpool. This tree is one of the most prevalent in the evergreen forests of Nigeria, the Gold Coast, and Sierra Leone, so that very considerable amounts of the seeds could be obtained, provided a remunerative price is paid to cover the cost of production. According to the analysis made at the Imperial Institute ${ }^{1}$ the kernels contain :

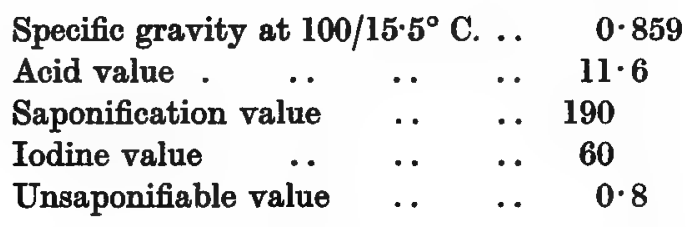

Guttiferæ, Pentadesma Butyracea.-The Tallow Tree. From this a large number of fat-yielding kernels are obtained from each fruit. The nuts are irregular tetrahedral shape. The shell is not very thick and easily broken when the nuts are dry. When fresh the kernel is lightish-yellow in colour, and the nut is brown. According to the investigations of the Imperial Institute the fat obtained is of a pale-yellow colour, and has a pleasant smell and taste. In smell, in fact, it is very much like Shea butter.

On analysis it showed:

\begin{tabular}{|c|c|c|c|}
\hline & 0.859 \\
\hline \multicolumn{3}{|c|}{$\begin{array}{llll}\text { Acid value .. } & . & . & .\end{array}$} & $3 \cdot 6$ \\
\hline Saponification value & & & $190 \cdot 1$ \\
\hline Iodine value $\quad$.. & .. & & $41 \cdot 8$ \\
\hline & .. & & $50 \cdot 7^{\circ} \mathrm{C}$ \\
\hline alue $\quad .$. & .. & & $95 \cdot 0$ \\
\hline able matter & .. & & $1 \cdot 7$ \\
\hline Reichert-Meissl value & .. & .. & Nil \\
\hline
\end{tabular}

The samples from the Southern Provinces of Nigeria showed rather a lower saponification and iodine value.

From its appearance and chemical constants it seems possible that this fat might be used in the manufacture of edible fats. The kernels were valued, when in good and dry condition, at from $£ 8$ to $£ 10$ per ton in the United Kingdom.

Allanblackia floribunda. - The numerous nuts or kernels from the large fruits of this tree have not yet been used for any commercial purpose. They appear to contain an oil. In this family, too, there

1 Official Report, Oil Seeds, Fats and Waxes, Imperial Institute, 1914. 
is Ochrocarpus Africanus, which has the large edible fruit known as the African Mammee Apple. This also yields large nuts of an uncertain value, which are apparently oil or fat bearing.

Garcinia conrauna.-The nuts of this, the false or bitter Cola, besides yielding an edible fruit, are used locally, but further investigations would show whether they would obtain a regular market as an export product.

Polygalaceæ, "Cheyi" seed, Polygala butyracea, Heck.-This is a common herbaceous plant of West Africa. The seeds yield a valuable edible fat. They are about a fifth of an inch long and a tenth of an inch broad. The seeds are of a brownish-black outside and a greenish-yellow inside. According to the inrestigations of the Imperial Institute " the seeds yielded 39.7 per cent. of a soft yellowish fat. The taste of it was pleasant, and there was no odour." According to the Imperial Institute analysis the "Cheyi" fat showed:

\begin{tabular}{|c|c|c|c|c|c|c|}
\hline & & & & & Present Sample. & $\begin{array}{l}\text { Results previously } \\
\text { Recorded. }\end{array}$ \\
\hline \multirow{2}{*}{\multicolumn{2}{|c|}{ 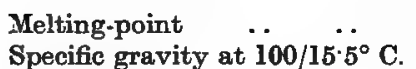 }} & $\ldots$ & .. & $\ldots$ & $36^{\circ} \mathrm{C}$ & - \\
\hline & & $\ldots$ & 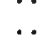 & $\cdots$ & 0.866 & - \\
\hline Acid value .. $\quad \ldots$ & . & .. & .. & .. & $1 \cdot 24$ & $11 \cdot 4$ \\
\hline Saponification value & .. & .. & .. & .. & $251 \cdot 0$ & $253 \cdot 0$ \\
\hline Iodine value $\quad .$. & .. & .. & .. & .. & $52 \cdot 5$ & $49 \cdot 4$ \\
\hline Titer test ... & .. & .. & .. & .. & $37 \cdot 85^{\circ} \mathrm{C}$ & - \\
\hline Hehner value $\quad$.. & .. & .. & .. & .. & $85 \cdot 6$ & - \\
\hline Reichert-Meissl value & .. & .. & .. & .. & $45 \cdot 6$ & $45 \cdot 5$ \\
\hline
\end{tabular}

"The edible fat manufacturers stated that 'Cheyi' fat was suitable for their purpose if it could be proved that it did not contain a poison, and valued the seeds at $£ 13$ to $£ 14$ per ton. The oilseed crushers valued the seeds at $£ 12$ per ton in the United Kingdom."

N.O. Bixaceæ, according to Thonner, Flacourtiaceæ, Oncoba echinata, Otiver.-This tree bears a large number of seeds, which are known as "Gorli " seeds. The seeds are long and irregularly shaped, and vary from a quarter to three-eighths of an inch long, and from one-eighth to three-sixteenths of an inch broad. The stift husk is brown in colour. The seeds without husks are white, waxy and soft. According to the Imperial Institute investigations the seeds contain 46.6 of fat, which is hard, white and crystalline. Although the soap made from it was satisfactory, it did not lose the very peculiar odour which the fat has. The cake and fat cannot be used as a food because of the large amount of chaulmoogric acid contained in it, an acid which causes vomiting. The fat might possibly be of value in candle-making. According to the Imperial Instituto analysis tho seeds showed: 
ANalysis of "Goril" Seeds.

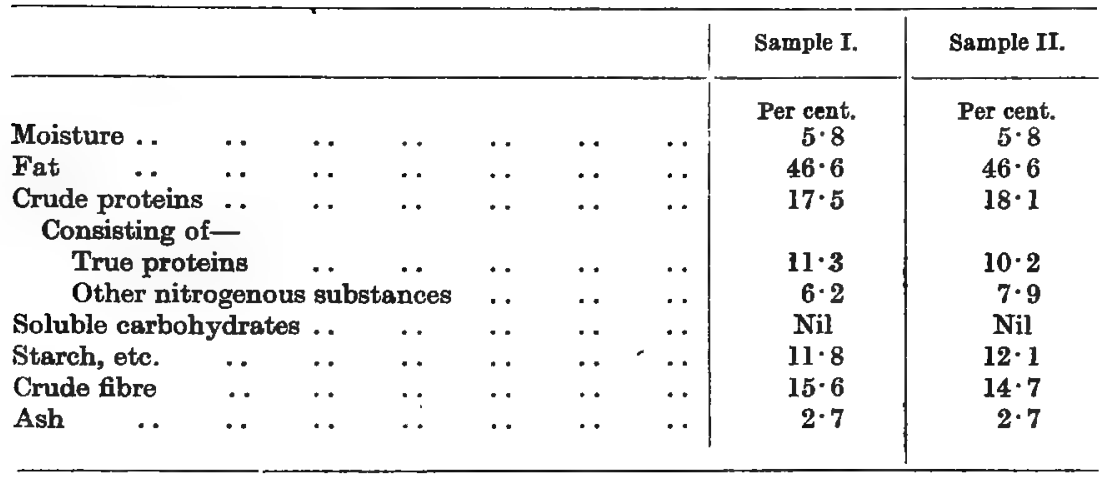

ANaLysis OF "GoRul " Fat.

\begin{tabular}{|c|c|c|c|c|c|c|c|c|}
\hline & & & & & & & No. I. & No. II. \\
\hline \multicolumn{3}{|c|}{ Specific gravity at $15 \cdot 5^{\circ} \mathrm{C}$. } & .. & .. & $\cdots$ & .. & $0 \cdot 898$ & $0 \cdot 896$ \\
\hline Acid value & . & .. & .. & .. & .. & .. & $4 \cdot 5$ & $22 \cdot 4$ \\
\hline Saponification & velue & .. & .. & .. & . & . & $192 \cdot 4$ & $193 \cdot 9$ \\
\hline Iodine velue & .. & . & . & .. & . & . & $99 \cdot 7$ & $96 \cdot 8$ \\
\hline Titer test & .. & .. & .. & . & .. & $\ldots$ & $57 \cdot 8^{\circ} \mathrm{C}$ & $57 \cdot 8^{\circ} \mathrm{C}$. \\
\hline Hehner value & . & .. & . & . & . & . & $96 \cdot 5$ & $96 \cdot 5$ \\
\hline Reichert-Meiss & value & . & . & . & . & . & $\mathrm{Nil}$ & Nil \\
\hline Unsaponifiable & matter & .. & .. & . & . & . & $1 \cdot 6$ & $1 \cdot 3$ \\
\hline
\end{tabular}

The nut of Ogbogo, a Benin tree, is as yet unvalued, though it appears to be an oil-yielding fruit. There is, too, the long almondshaped nut of Oktobun. Although it has a somewhat hard shell, the nut is very large in proportion, and the kernel seems to be rich in oil. So far no use has been made of it. 


\section{THE OIL PALM AND PALM KERNEL INDUSTRY}

1. Astrhetic Aspect.-A most familiar sight to everyone visiting a farm in the southern part of Nigeria is the charming grace of the fronds of the Oil Palm in the clearings near the house. The long, straight, cylindrical, undivided stem, crowned by a large tuft of broad green palm leaves, easily distinguishes the Oil Palm (Elais Guineensis) from the Tombo (Raphia vinifera), which has a thinner stem, clothed from the base to the top with 40-feet long heavy fronds, the undersides being silvery and the upper part light green. In certain times of the year huge bunches of yellow grape-like fruits hang quite 4 feet down from the narrow crown of this tree. It is most noteworthy that the Tombo Palm is found growing in or near a swamp, and only occasionally planted as an avenue tree on drier land, whereas the Oil Palm is usually found in the hard and drier ground and only occasionally in the swamp. The Oil Palm is much larger than another Wine Palm, Raphia Hookeri, which is similar but smaller than Raphia vinifera, the growth being similar but the seeds smaller.

Raphia Ruffia is a small swamp palm, with practically no stem, but a large number of long, thin, and somewhat light, pendulous fronds.

Most visitors to West Africa are quite familiar with the huge casks of orange-coloured or yellow oil, which often leaks on to the deck of the ship, and the. peculiar, rather nauseatingly pungent odour of the "sweating" kernel bags.

1a. Greneral Drgoription of the OIl Patm Tree, Frutt and Not.-From the railway carriage we can see numerous groves of Oil Palms, as well as isolated specimens, almost continuously for the first 60 miles from Lagos, and more isolated for the next 180 miles. With few exceptions the Oil Palm is a single stemmed tree, one notable forked tree being seen on the northern side of the Nigerian Railway, a little more than three miles before reaching Ibadan. In this case an oil palm nut may have become embedded in an old leaf stalk sheath and subsequently sprouted, thus forming a separate tree growing on the other, which in the course of time has become joined up.

It will be noticeable that in passing through the heavy forest near Olokemeji few or no Oil Palms are seen. This forest, however, is 
situated really within the area of the natural distribution of the Oil Palm. The Oil Palm, however, needs a good deal of light for its development, and those trees seen in the heavy forest are very tall, often over 100 feet high, with comparatively short leaves and a small number of them forming the crown of the tree (see illustration 102). On the other hand, wherever a clearing has been made in the forest, for instance near Awowo, the older Oil Palms are shorter in stem, often being not more than 20 feet in height. Another instance of this is seen in the farms near Badagry, where the trees are often only 15 to 20 feet high, and the stem itself only 10 feet in length. In each of these cases it will be noticed that the trees are standing quite free, with no overhanging vegetation. From the first they have been in this position, and the leaves have had room to spread almost 20 feet all round, thus giving the tree the maximum amount of moisture and other food material.

Amongst these trees, Oil Palm seedlings will be seen to spread out over the ground almost at once, even when only the secondary and tertiary leaves have grown. In the forest, however, the leaves go almost straight up, and only after some years have elapsed spread more as they dominate, or try to overgrow, other seedling forest trees.

2. Botantcal Description of Tree, Frott, mtc.-An Oil Palm starts male flowers when three years old, and these are borne one to three years before the female flowers appear. The male and female flowers are both found on the same tree, the male above the female in the axils of the leaves. There are two cycles of leaves younger than the female flower. The Oil Palm fruit is formed first by the kernel surrounded by shell, then the fibrous pulp containing the palm oil. The ripe fruit is of a brilliant brick-red colour, the unripe fruit being always black at the point and only red near the base, where it is covered by neighbouring fruits. When ripe they fall from the bunch, and it is especially noticeable that each bunch of fruit grows out of alternate leaf axils, alternating also with the whorls or cycles of growth (illustration 60).

The female flowers are very minute, and in the earlier years each bunch is rather smaller than a man's hand. The centre of the flower is orange, coloured with a bluish tip, and scarcely lasts a week. On the other hand, the male inflorescence is like a compact horse's tail, composed of closely packed pollenated stamens. Owing to the different years in which the male and female inflorescence appear, it is probable that cross-fertilization takes place.

2a. Distribution of the Orl Palm.-The Oil Palm is found from Sierra Leone to Lake Chad, down to Ambriz, and eastward to the borders of German East Africa.

The Palm Belt, according to Millbourne, is 3,000 miles in length, and varies from 150 to 300 miles in width. 


\section{WEST AFRICAN FORESTS AND FORESTRY}

It is estimated that there are six or seven million Oil Palms behind Loanda inland, though this sounds rather exaggerated.

In Nigeria it is most widely distributed in the Southern Provinces, and the densest " stands" are found in each of the river basins wherever the forest has been cleared (see illustration 103).

Wherever the dry season is very prolonged and the locality shows a shallow soil, overlying laterite or rock, the Oil Palm first of all appears after the forest has been cut down. After a few years the trees are subject to annual grass-fires, and while still bearing fruit they begin to fail and scarcely last half the ordinary period of their life. Localities of that nature are found in the Afikpo, Onitsha, Ifon, and parts of the Ibadan districts.

The Oil Palm is also one of the first trees to appear after the mangrove swamp and Tombo Palm region is passed in going through the forest zones from the coast inwards.

2b. Varieties of the OIL PaLM.-These, according to Professor

O. Beccari, of Florence, are as follows :

Elacis Guineensis.

Var. albescens. White Oil Palm: Abe-fita or Abe-fufu (Gold Coast).

Angulosa. Oleporo Eyop (Old Calabar).

Ceredia. Adi-be (Gold Coast).

Communis. Udin (Benin).

Communis forma, dura. Ade-pa (Gold Coast).

Idolatrica. Sacred Palm. Abe-Obene (Gold Coast).

Intermedia.

Macrocarpa.

Marcrocarya. Abubube (Gold Coast).

Pisifera.

Repandra. Kessede.

Rostrata. Mbana Oyop (Old Calabar).

The Benin people differentiate the Udin or ordinary palm from Ogedin or the King Palm on account of its having smaller bunches of fruit, each fruit being longer and having a softer shell. They also treat Evirommilla or the Palm of Everlasting Life as a separate species. The Yorubas, however, consider that there are three species of Oil Palm.

According to the German experiments in the Cameroons, the Lisombe or soft-shell Oil Palm does not come up true to type, approximately only 5 to 10 per cent. growing to the true variety. From the locality in which the Lisombe Palm was and is found, it looks as if the high rainfall (over 300 inches) had really been one of the main factors in evolving this type of Oil Palm. In fact, natives who know the ordinary Oil Palm and the soft-shell Oil Palm say it is rather 
a matter of taste as to which is the better of the two. Apparently it depends on what commodity the native is dealing in, kernels or oil, as to whether it pays better to get plenty of oil, and obtain the kernels more easily from the soft-shelled Oil Palm, or an average amount of oil and larger kernels obtained with more difficulty from the ordinary Oil Palm. On the whole, the Lisombe Palm does not seem to yield on an average more pericarp oil than the ordinary Benin or Yoruba Oil Palm growing in a farm in the usual moist-zone climate. Certainly the kernel of the Lisombe Palm is much smaller than the ordinary Oil Palm. A further point to be considered, too, is that the bunch of Lisombe Oil Palm fruit is smaller on the average than the bunch of the ordinary Oil Palm.

However, it may be noted that the natives of the southern part of the Ogoja district, especially the Ndeh and Befun people, plant a species of soft-shelled palm near the villages. Of course, in this locality the Oil Palm is not found in very large quantities, and the seeds for these groves were obtained from a good distance away, probably near the Cross River.

3. The Growing of the OLl Palm-Distribution of Seed By Farmers, Parrots, Monktys.-In the forest country a clearing is made some distance away from the village by the native to make a new farm. In clearing and cutting down the forest, few or no Oil Palms are met with, so that the farmer's wife brings palm fruit or oil to the new farm, in order that they may have palm oil to eat. Having made the oil, the nuts are put out in the open to dry, with the intention of their being cracked later on. However, they lie about some months, and rodents of various kinds, such as rats and the hyrax (a squirrel-like animal), carry some of these away into the farm. Some farmers, too, pick up a few and scatter them over the farm. In the course of a year or two Oil Palm seedlings appear, where they are left amongst the other vegetation when the farm is abandoned. In this way, instead of the original thick. forest there is a more or less dense grove of young Oil Palms. In other places the parrots may bring nuts from the neighbouring forests or other old farms, and these, falling in the clearing, also help to make a palm forest.

The native also, after he has picked the bunches of fruit, puts them down in some convenient place on the roadside. Some of the nuts become scattered, which subsequently sprout and form additional groves of palms, especially where the larger trees near the roadside fall, or are cut down, thus giving more light to the young seedlings.

Again, when the bunch of fruit is ripe on the tree, it is not often immediately cut off, and many of the ripe nuts thus fall to the ground. These subsequently grow, forming almost thickets of Oil Palms, instead 
of the one from which the original seed was obtained. A similar process takes place on a bigger scale in the more distantly situated forests, where the natives do not collect the fruit at all. Here, all the nuts gradually fall off the tree, more or less forming a circle 10 to 15 feet away from the trunk. If any clearings take place in these localities, they rapidly appear to become filled up with Oil Palms, which in reality were already there as little tiny seedlings amongst the herbs and undergrowth, ready to make use of any additional light or growing space to develop fully.

4. Frtit-bearing Aas of OIr Palm.-Under these conditions, where the seedling Oil Palms stand only a few inches, or at the most 4 or 5 feet apart, the growth is very constricted, with the result that no flowers or fruit appear before the fifteenth or twentieth year. Each stem is excessively thin, and tends to grow upwards like an ordinary forest tree, rather than forming a very short, almost negligible length of stem, but nearly 1 foot in diameter, as is typical of the palm family in the earlier years of its growth. Contrary to the above, where the Oil Palm comes up in a more open place the leaves do not tend upwards, but outwards, arching over with the leaf stalk at an angle of about $45^{\circ}$ to the ground. The leaves themselves, instead of being long and thin and with a long length of green stalk, soon spread out fully 20 inches on either side of the main stalk, thus giving the plant more food material and making it grow more quickly. Then, in the fourth or fifth year, bunches of fruit, each containing from twenty-five to thirty nuts, are formed out of the female flower. Each bunch, which is the size of a man's fist at this age, increases to nearly 2 feet in length and 1 foot in diameter at maturity. Howerer, each bunch of fruit, having been formed against the stem of the palm and in the axil of the leaf stalk, is very much compressed, especially at the base. As an experiment, when the fruit is beginning to ripen, the leaf stalk just immediately below the base of the fruit stalk is removed; gradually then the bunch of fruit droops a little and develops more fully at the base, owing to having more space. More light thus reaches the fruit sideways, and the period of ripening is accelerated by three weeks.

5. Orl Palm Plantations and Crops.-As a result of the greater spreading out of the leaves of the young palm and the more sessile habit of the stem in the earlier stages of growth, light penetrates more intensely into the fruit-bearing axils of the tree, thus increasing the size of each bunch.

In the Calabar Arboretum, some Oil Palms were cleaned and the ground thoroughly cultivated in two successive years. In the first year one tree bore fourteen bunches of fruit, and in the second year it bore twenty-two bunches. No manure was placed on the ground, and the soil was distinctly poor and sandy-in fact, the natives in 
the locality said the land was of no use and could not be used for farms (see illustration 102).

In another case, in Benin, the Oil Palms, which were first sown at stake and subsequently transplanted, bore fruit in the fifth year. Contrary to expectation, the transplanted Oil Palm seedlings developed the secondary and tertiary leaves within a few months after the transplanting had taken place, whereas those sown at stake continued with only two spiky leaves for almost the first year of their growth. As the tree gets older, the number of bunches of fruit borne gets less, though each bunch is fully five times the size of the first fruiting bunches of the fifth year.

In most districts about five bunches of fruit ripen each year, and each bunch bears from 1,200 to 2,000 nuts (from the best trees). It is always noticeable that the palms growing in the open, free from surrounding trees, produce the finest bunches and the greatest number of nuts. On this point of the yield of bunches per annum further investigations are necessary, as it is by no means proved that an average of five bunches per annum is the maximum number for a mature Oil Palm.

In the Togo Plantations (251 acres), it was noticeable that in the more favourable climate of Atakpame and Bassari the Oil Palm bore in the fifth year, whereas in the drier climate of Jendi the trees first bore fruit in the seventh year. In illustration No. 19 the amount of growth shows clearly from year to year, more especially in the difference in the size of the leaf. The relative shortness of the stem is distinctly seen, showing up when compared with the natural forest-grown Oil Palms in illustration 20. In addition, there is the Agu Plantation in Togo. Thus far very few Oil Palm plantations have been made, those in the Cameroons being the most extensive. However, these are almost too young, or to some extent mixed up with the original forest-grown Oil Palms, for conclusive results to be shown.

In the Central Circle in 1906 a communal plantation was made at Okokwo, but the natives have not yet found the necessity of extending it.

Between the Kwa and the Akwayefe Rivers, going along th Akpaboyo Road, the Oil Palms are so evenly distributed that they almost appear to be one great plantation. However, the locality is very favourable to the Oil Palm; the original forest has been largely cut down and the natives have allowed the Oil Palms to stand wherever they did not hinder farming operations. Owing to the fact that the Oil Palm has spread, and is spreading, in those parts of the Southern Provinces of Nigeria and elsewhere where the rainfall is between 60 and 150 inches per annum, there has thus far, from the native point of view, been no incentive to plant more Oil 
Palms. In fact, with the increasing amount of general work going on, combined with the comparatively high price obtained for palm oil and kernels, there is less necessity for the native to gather all the palm fruit that has grown. It has been noticed that the cultivated Oil Palm, or Oil Palms growing in an open place, only reach about one-quarter the height of the forest-grown Oil Palms, which attain a height of over 100 feet (see illustrations 60).

With cultivated trees it is possible in the earlier fruiting years to stand on the ground and gather the fruit from the palms, and even in later years only a short ladder is necessary in order to reach it. It is really on this problem of the height of the palm-tree that the chief collection of the fruit depends, and also the total output from the Oil Palm forests. Further investigations are necessary to decide as to how far it is possible to retard the height-growth of the Oil Palm for as long as possible, while accelerating the radial growth, or at any rate increasing the thickening of the stem. Varying planting distances have been tried, such as 16 feet 3 inches each way, 17 feet 9 inches in the German experiments in Togo, but 23 feet each way in the Cameroons. In one case teak (Tectona grandis) had been mixed with it. On the whole, in ordinarily favourable localities, a planting distance of 24 feet each way appears to be the most suitable. For the first five to ten years at least agricultural crops could be grown in between, until the Oil Palms had spread out so as to cover the ground almost entirely. Few or no experiments have yet been undertaken in selecting and planting only the biggest nuts of the most prolific variety, which, according to Mr. Farquhar's report, The Oil Palm and its Varieties, is the A-sog-e-jub, which contains 48 per cent. of pericarp oil.

It has at any rate been demonstrated by the natives that Oil Palms which have been tended yield bigger bunches and bear larger nuts, but only by actual experiments in selected areas or plantations can it be proved exactly how much more produce is obtained, and the extra financial yield over and above the increased cost of cultivation, etc.

According to various commercial calculations, it has been estimated that only $\mathfrak{1}$ per ton can be paid for the ripe fruit at the oil or kernel crushing mill.

Owing to the comparative wide distance (24 feet) at which the Oil Palm should be planted, for the first few years it is possible to plant some catch crops. One of the cheapest ways of forming Oil Palm plantations would be to take over an area fairly well covered with self-sown Oil Palms up to 12 or 15 feet in height. After choosing the best and marking these, the rest should be gradually thinned out by tapping them for palm wine, which could be sold. A crop of watermelon, or Egusi bara (Citrullus vulgaris) of the Yorubas, could be 


\section{OII PALM AND PALM KERNEL INDUSTRY}

planted over two-thirds of the ground between the Oil Palm plants and trees, leaving sufficient space for their growth and about equal to the spread of their foliage in each case. After this crop has been gathered in August or September, a crop of Awuje (Yoruba name) beans could be planted, which would again be ready for picking by December. In each case the haulms and dried leaves of the plants, after the crop is gathered, should be burnt in small heaps and the ashes scattered over the soil. At the beginning of the following year the ground could be got ready again and a crop of maize sown in a similar way, covering a half to two-thirds of the ground between the plants. This could be followed by another crop of water-melon, which would act as soil-covering during the rainy season, and again another crop of beans in the autumn. In turn this could be followed, after similar treatment as before, at the beginning of the third year, by a crop of yams (Dioscorea sp.). Probably owing to the growth of the palms it would only be possible to have one row down the middle of the line between the palms. The species of yam should not be too large, so that the ridges or yam heaps could be heaped up if necessary with a plough and not by hand, as is usually done. The following autumn another crop of beans could be planted, and the next year, if the soil was light and suitable, a crop of ground nuts could be grown as a double row between the Oil Palms. In the following autumn a crop of beans could be grown again. In the following year, the fifth, some of the Oil Palms would be in bearing and yield the first returns. Bananas could then be planted as a single row between the lines of Oil Palms and would bear in the following year, thus supplementing the second yield of oil and kernels. By these means the whole cost of cultivation should at any rate be covered by the sale of the produce grown, partially to the labourers and otherwise outside, for export, and perhaps even a profit made over and above the cost. In the eleventh or twelfth year the bananas would be practically or entirely covered by the Oil Palms, and thus have to be cut down and to some extent uprooted. Their leaves, however, would form a good mulch for the soil, and at any rate act as an effective soilcovering, thus preventing the growth of weeds.

It is doubtful whether it would be wise to plant bananas right from the start in even one line, not to speak of two amongst the Oil Palms, owing to the extraordinary amount of moisture taken from the ground by the banana. In some cases, on the better soils, they might be introduced in the third year. Cassava, Manihot utilissima, is rather too exacting a crop to be suitable for planting amongst the Oil Palms. It is very liable to impoverish the soil. Then, too, as far as Nigeria is concerned, it is not a very paying crop, yielding at the most about $14 \mathrm{~s}$. per acre after all expenses have been paid. In all the above cases we are taking it for granted that the Oil Palm has 
been planted at, or thinned out to, a distance of 24 feet between each tree. On the poorer soils the distance might no doubt be 18 to 20 feet, and on the very best probably a distance of 30 feet will not be found excessive. Where lime or other manure is available and comparatively cheap, and in some cases heaps of humus from the outskirts of villages, it would pay to put this on the land in the late autumn when the ashes from the previous crops are being spread on the land. In addition to these crops, careful surface cultivation round each Oil Palm is essential, not only to prevent the growth of weeds but also to keep the aeration of the soil good, prevent the desiccating effects of the dry season, and accelerate the growth of the Oil Palm. Besides planting these crops by directly paid labour under European supervision, using as many modern labour-saving appliances as possible, parts of a plantation could no doubt be let out at a nominal rent to the natives, even to some of the labourers, to work it in their own time, but only planting such crops as would fit in with the rotation and not lead to the impoverishment of the soil. Apparently the greatest danger to the tropical soil is to leave it bare for any length of time. In the rainy season all the mineral matter and tilth is liable to be washed away, and in the dry season fissures are formed in it, and if it is at all argillaceous it is liable to be dried out for a depth of over 2 feet. Constant covering is thus necessary to ensure the growth of the Oil Palm.

6. Denstruction of On Palms.-This is carried out for the following purposes: For farming (Onitsha) and making palm wine. Sometimes many of these trees are destroyed by fire in the Ahoada Okigwi, North Owerri, Afikpo, Abakaliki, Ogaya, and Obudu. Grubs, too, are a very frequent source of destruction among them. The trees are tapped in the Yoruba country to obtain palm wine, but it is not known exactly to what extent this reduces the yield of palm oil and kernels. On the whole it is harmful, owing to the fact that insect and other pests can obtain entrance to the tree through the holes made in tapping it. With the steadily rising price of gin the tapping of the Oil Palm is increasing annually, resulting in a destruction of many thousand trees each year, chiefly in the Obubra and Ikom districts, and to a lesser extent by tapping the trees in the Yoruba country. Wherever the rainfall does not exceed much over 50 inches and the soil of the locality is shallow over laterite or some rock formation, the fires become usually an annual occurrence. The Oil Palms which at first come up on the clearing of the forests then get burnt, and after a few years cease to grow faster than the leaves are burned each year, and subsequently die. In a similar way the young seedlings which may come up are very easily killed by these annually recurring fires, and thus the whole district is impoverished. This process can be 


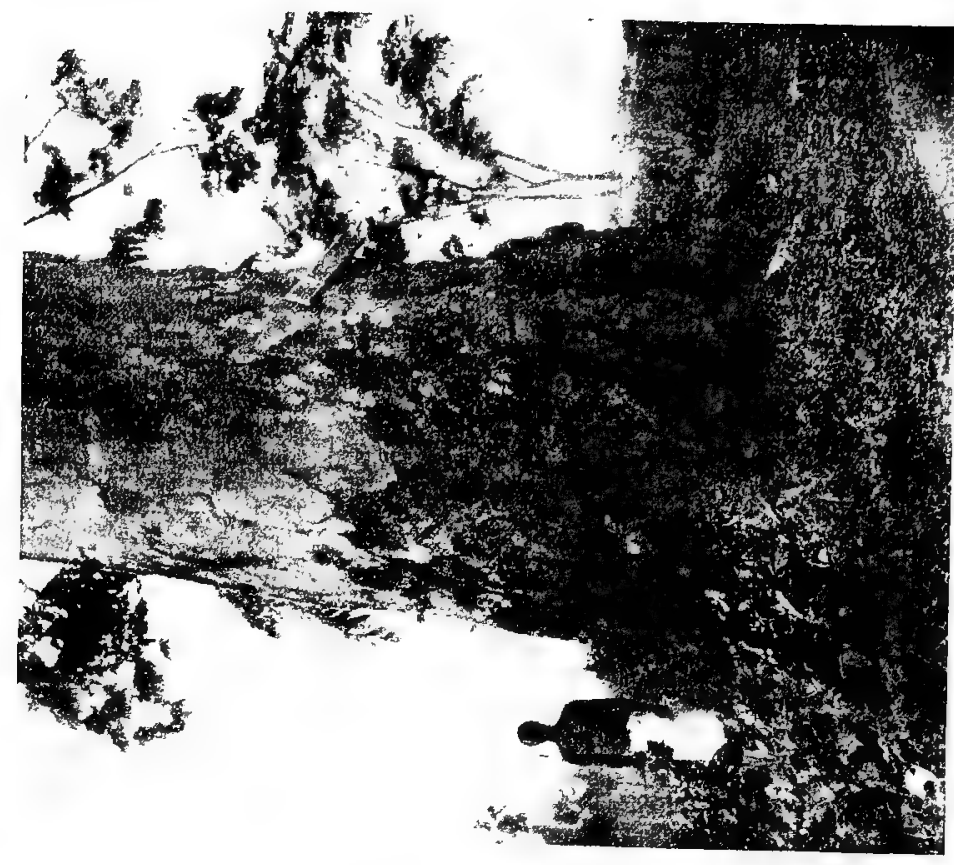

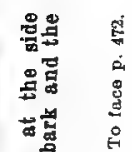

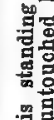

물

홍형

营虫。

몀롱흘

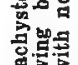

䓀宫

造它

㝵嵒

으여용

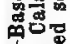

T.

응영

点

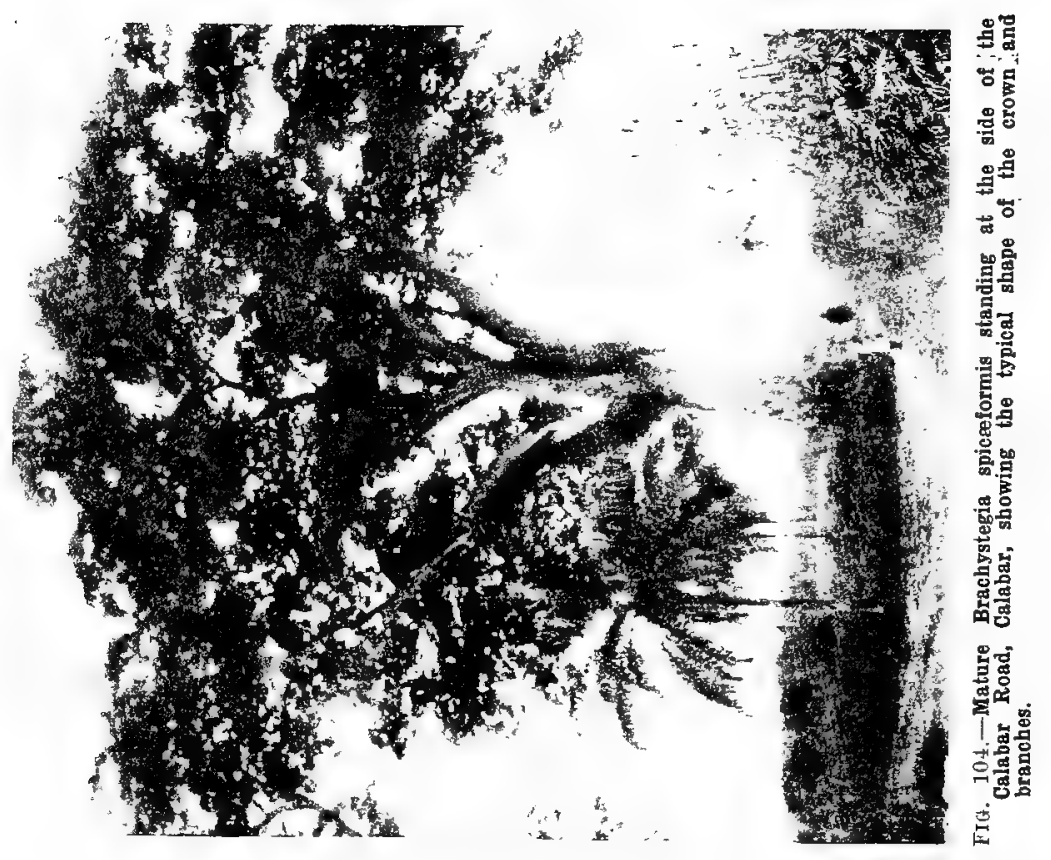



seen going on in parts of the Afikpo, Owerri, Abakaliki, Onitsha, Ifon and Ibadan districts. It is a serious menace to the future development of the Oil Palm industry.

6a. Native Method of Collectivg Frott.-The native, to collect the fruit, climbs the tree with a specially made rope round his waist, by which he gradually hoists himself up. With a rough chisel, like a piece of iron with a handle, he first cuts off the leaf just above the fruit and then severs the bunch, letting it fall to the ground. Many of the fruits drop out in the transit, but these the native does not trouble to gather up.

It is usual for the Chief to close the forest for a certain time until the Oil Palm fruit is more or less ripe, and then the natives can gather it all at the same time. Owing to the difference in the time of the ripening of the individual fruits at the top of the bunch and those at the base, many fall to the ground before the bunch is actually cut off the tree. These are not gathered up, and are taken away by rodents or birds, or come up in the same place.

7. Native Method of Making OIL and Kernegl Inspection.The native cracks the palm kernel almost entirely by hand, the nuts being first dried in the sun on the ground in open spaces, surrounded roughly with little billets of wood, or in small sheds. When dry, they are taken out and cracked on rocks (if they happen to be in the neighbourhood) with a piece of stone in the cracker's hand. Should the spot be devoid of rock, a piece of wood or stone takes its place, and then a piece of iron or stone is used by him in the right hand. Good workers, usually small girls or women, can crack about 15 to $20 \mathrm{lb}$. a day in this manner.

An inspection fee on palm kernels and oil has undoubtedly helped to improve the product immensely and not reduced the output.

The kernels are picked out at the same time, the shell remaining more or less where the nut is cracked. A certain amount of shell adheres to the kernel, and if it is an excessive amount the native picks it off. Anyhow, when he reaches the factory the shell contents must not exceed 5 per cent. Although they are not actually dried, they are usually kept in a dry, cool place, until sufficient have been collected to sell either in the local market or straight to a European factory. The inspection of the palm produce, both oil and kernels, takes place at the factory, where the produce is bought by the Inspectors of Produce under the Customs Department.

7a. KINDS of Ord.-Most of the oil is soft, but as some hard oil

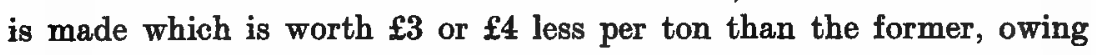
to its having about 8 per cent. less of glycerine, and both are made by a different process, both methods will be described.

Hard oil is made chiefly near Onitsha and Ikpa markets, east of 


\section{WEST AFRICAN FORESTS AND FORESTRY}

the Niger, by the Ibos, and the following is the process employed in those districts.

The fruit is left on the bunch in the bush, covered with leaves, for ten days; it is then brought into the village or place where the fruit is cut or knocked off the bunch. Large earthenware pots with a little water in the bottom are then filled with the fruit; this is then heated, but the water does not actually boil, or even steam very much. The fruit is then taken out and beaten in an old canoe or hard mud trough until all the fibre is fairly well macerated and detached from the nut. The whole mass is then placed in a shady place for four days to enable the oil to "get strong," as the local people say. On the fifth day the oily fibre and nuts are placed in the trough again, and cold water is poured in until it is about a foot deep. The whole mass is pounded with the bare feet of children, girls or women, so that gradually the oil becomes detached from the fibre or from adhering to the nuts, and floats on the surface of the water, especially near the edges of the trough. It is then skimmed off with the hand and put into calabashes. The nuts and fibre having sunk to the bottom of the trough, the oil is left comparatively free from impurities. The oil in the calabashes hardens to much the same degree as dripping, and is ready for sale.

On the banks of the Niger, where it is sold to European firms, the natives are often obliged to boil it to purify it still further, and to enable it to be poured into the puncheon in which it is shipped to England. This oil, even when cleaned and boiled, has a bitter taste, which the natives do not like when they have been accustomed to soft oil. When this oil arrives in England it is quite hard again.

Soft oil is made in Nigeria, as well as in Sierra Leone and the Gold Coast Colony. The Lagos and Benin oil is the best, so the method employed in that part of the country will be described. The fruit is cut off the tree in much the same way, but the loose fruit is generally collected from the ground as well as the bunches, which are then carried to the oil-making place, which is usually situated near a running stream for the convenience of the manufacture of the oil. The fruit is cut or knocked off the bunch, cleaned of any extra stalk or dirt, and placed in earthenware pots, in the bottom of which is a little water. These pots are then put over a bright fire until the water not only boils, but has quite steamed away. It is then considered that the fruit is thoroughly soft and ready for crushing, when it is placed in earthen troughs or old tree trunks which are used for this purpose. Cold water is then poured over the fruit to about a foot in depth, and the fruit is pressed by the feet of women or girls standing in the trough. The oil rises to the surface of the water, is skimmed off with the hand or a flat piece of wood, and put into earthenware calabashes; all fibre is thoroughly squeezed and rinsed to obtain the 
oil out of it. The oil is now thoroughly boiled, and when quite thin and of a reddish-orange colour is poured off carefully into clean pots. A fine residue of fibre and particles of dirt remain in the pot in which the oil was boiled; this is used for native lamps by dipping a twisted fibre into it.

The clean soft oil is now ready for sale, and is carried in old kerosene tins or other receptacles to the nearest market. Despite the very large loss which occurs, owing to the breaking of calabashes on the road to market, still very large amounts are carried in vegetable calabashes or earthenware pots. By the time this oil reaches Europe it is partially hardened in the cask, though usually there is a certain amount of liquid on the top.

Sale of Produce.-The palm oil is sold by the kerosene tin (one gallon), by the keg, or by the puncheon. It is also sold by the bottle in the markets for local use.

The palm kernels are sold by the calabash in the districts further away from the markets, but more usually by the coulah (Jekri). They are also sometimes sold by the bag, weighing either $25 \mathrm{lb}$. or nearly $50 \mathrm{lb}$. in weight. The natives find old salt bags of different sizes very convenient for this purpose, more especially when the kernels are to be conveyed some distance to the nearest factory.

7b. At the beginning of 1915 hard oil was worth $f 32$ per ton, and soft oil $£ 36$ 10s. per ton, whereas at the beginning of 1918 soft oil was being sold at $£ 365 \mathrm{~s}$. to $£ 47 \mathrm{10s}$. per ton, whilst the official maximum price for unbleached palm oil is $£ 44$ per ton, and $£ 50$ per ton bleached.

7a and 11. Utility of THE Om Palm.-From the Oil Palm are obtained the following products : Palm oil, palm kernels, palm wine and yeast from the fermented palm wine. The shells of the nuts are used by blacksmiths, as they give out great heat. The growing head of the palm is used as a vegetable-palm cabbage. The stems of the leaves are useful as rafters or house posts in the Yoruba country, the leaves for making mats for roofing, and the midribs as brooms.

To obtain the wine, the tree is either tapped below the male inflorescence in Ibadan, Yoruba, etc., or when the tree is felled and the crown cut off. A calabash is placed so as to catch the outflowing sap, which is the palm wine.

The natives frizzle the kernels in an iron pot and obtain an oil which is used as an emollient for wounds and rubbing on bruises or sprains. It has a burnt smell. Only small quantities of kernels are used for this purpose in Nigeria.

Tapping is sometimes effected at the base of both inflorescences, but this is a more unusual method.

So far no use has been found for the wood, though it is uncommonly tough and very fibrous. 


\section{WEST AFRICAN FORESTS AND FORESTRY}

8. Amount of Produce Used, Eaten, and Amount Growing.There is probably only 5 per cent., or at most 15 per cent., of the total possible trade done in this product from West Africa.

The amount of the oil used by the natives per annum is as follows :

Three gallons of oil per head per annum for food.

Half-gallon of oil per head per annum for illuminant in the Eastern Circle, according to Gilman, and half-gallon used mixed with camwood for rubbing on the skin per head per annum.

Allowing this amount for the total population of $8,000,000$, we have a total of $32,000,000$ gallons used locally per annum. This means the produce of at least $128,000,000$ trees, taking into consideration the very poor or underbearing state of many of the trees. Some also are immature and not in full bearing when utilized. Even so, this represents only a part of the total possible crop, which might be $100,000,000$ gallons and 500,000 tons of kernels. Although the above small percentage of the amount of trade done will eventually prove to be an exaggeration, partly owing to the cutting down of Oil Palms in making farms, there is nevertheless clear evidence that a great many more palm kernels especially could be obtained if there were an increased number of plants available for cracking the nuts in various parts of the country. Then, too, in those places where the trees stand too closely together, an increased yield would be obtained after they had been thinned out. Allowing for an area of about 7,000 square miles in the dry zone, where the Oil Palms are not found, and 12,000 square miles for mangrove swamps, rivers, roads, railways, town and village sites, also where there are no Oil Palms, and about 10,000 square miles of heavy evergreen and mixed deciduous forest areas where there are few or no Oil Palms, this leaves an area of about 50,000 square miles on which they are found growing. The density varies from over 200 per acre down to only one, or in isolated cases to one to ten acres. With the increased amount of the tapping of the Oil Paln, as well as cutting it down both to get the palm wine and for making farms for food as well as cocoa crops, there is a great danger of the total amount being reduced. Everywhere on the West Coast of Africa where other produce has been introduced, such as in the Congo and in the Gold Coast, the export of palm produce tends to fall very rapidly. Owing to the fact that such a large anount of palm oil is used for alimentary or other purposes locally, and a great deal is exported to the Northern Provinces, the export of palm kernels to Great Britain and Europe generally forms the better basis in calculating the amount of palm produce now actually produced in the country. The small number of kernels used for making an oil for 
local use is really quite a negligible quantity, and will no doubt almost die out when there are larger amounts of pomade and other skin emollients available for the natives to buy.

9. Edropean Machinery for Extraction (Pericarping),-Mr. E. W. J. Trevor, of 87, Maida Vale, claims two machines for detaching and removing the pericarp of palm fruit with abrading, and has devised also a means by which the fruit is held in place and has along in line, an endless band or chain. It is not stated, however, if this is successful.

Another apparatus with knife-blades for decorticating the pericarp has been patented by Mr. H. Beckwith, of 2, Rumford Street, Liverpool. It is called the depericarping machine. Dr. Hupfeld's oil process is carried out at Agu (Togo).

Haake, a Berlin firm, constructed a machine called the wet process. The fruit is heated with water and freed from the pulp in special machines. The pulp is allowed to drain, and then heated again and put under presses. The nuts are cracked in a large centrifugal machine, and the shell is separated by a drum-like sieve or by brine. With this process $100 \mathrm{lb}$. of fruit yield $15 \mathrm{lb}$. of oil and $14 \mathrm{lb}$. of kernels. Four or five tons of fruit can be treated daily by fifteen or twenty men. The natives only extract 7 per cent. of the pericarp oil. This oil contains over 30 per cent. of fatty acid and is only used for soaps

The Government has set up kernel-cracking machines in various places in West Africa.

10. Edropean Nut-Cracking.--Several plants have been put up latterly to deal with the cracking of kernels by machinery.

One of the first of such factories was started at Benin River, Warri province, where the shells after the nuts had been obtained from them were used for firing the engines of the machinery. Another factory exists at Abonnemma, Owerri province, and yet another was started at Yenagoa in 1914. The natives seem very willing to bring in the nuts to be cracked, especially where the population is not large enough to both make the oil and crack the kernels, as in the Brass and Degema districts. Brine is often used for separating the kernels from the shell.

Some hand-machines have been brought out by Miller Brothers which crack the nuts, but both shell and kernels fall to the ground at the same time. A certain number of the kernels are broken in the process, but of recent years an improvement has been made in this respect. The cost of the hand-machine, amounting as it does to $\mathfrak{3 0}$, is almost prohibitive for the native, unless a system of hire-purchase were to be adopted. Only a few of these machines (comparatively) have been sold to them.

Yield of Oil and Kernels from Whole Fruit by Machinery.-It has 


\section{WEST AFRICAN FORESTS AND FORESTRY}

been variously estimated that out of a hundred tons of whole fruit the native obtains by his methods:

7 tons of oil worth (pre-war rates) $£ 12$ per ton $=£ 84$.

15 tons of kernels worth (pre-war rates) $£ 6$ per ton $=£ 90$.

Again, out of the whole fruit, the result of various investigations shows that the pericarp comprises 30 per cent., shell 56 per cent., the kernels 14 per cent., and that there is 50 per cent. of oil in the pericarp. It has also been estimated that out of a hundred tons of whole fruit, a maximum of 15 tons of oil and 14 tons of kernels can be obtained by machinery. These at the pre-war rates would be worth

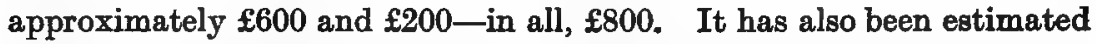
that the crushing of the fruit, the various freights, the carriage by rail and ocean, cost of bags, shipping, landing charges, insurance and general expenses would amount to $f 4$ per ton, or in all about $f 400$. This leaves about $£ 400$ to pay for the fresh fruit and allow for a profit; thus, paying $£ 1$ per ton for the fresh fruit, there would still be $£ 300$ left for profit, or in the case of paying $£ 2$ per ton there would be $£ 200$ left. However, so far $£ 1$ per ton has proved too low a rate for the natives to accept, and in most places it has been refused. It is doubtful whether $£ 2$ per ton will attract them sufficiently to bring in the large bulk of farm produce which is available. From an average closely stocked Oil Palm area the fruit could not be collected at a cost of $£ 1$ per ton, and it is very doubtful if it could be done for £2 per ton. So far, it appears that the native working for himself in his own time will always do things at a cheaper rate than paid labour under European supervision. Further investigations will, however, prove what a high price can be paid for the fresh fruit at the factory and yet leave sufficient margin to make a profit on the extraction of the pericarp oil, and also of the cracking of the nuts. In this connection the crushing of the kernels is considered rather a separate economic problem, as several other market factors come in which do not apply to the case of the pericarp oil and the uncrushed kernels. The machinery for the crushing of the kernels on the whole is much more intricate, costly, and requires much more highly-trained European supervision.

10a. Percentage Oil and Kernirls.-According to the investigations of the Imperial Institute, the composition of the fruit is as follows:

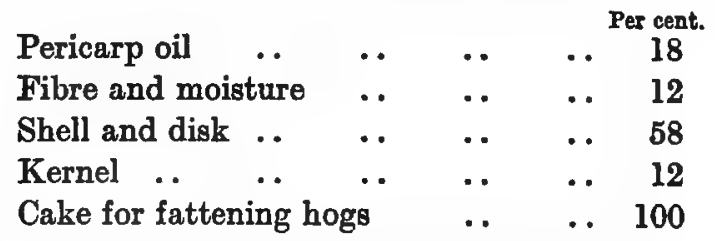

The kernel contains 46 to 53 per cent. of oil. 
10b. Pericarp Palm On Analysis.-This is as follows:

\begin{tabular}{|c|c|c|}
\hline Specific gravity $15 / 15^{\circ} \mathrm{C}$. & & $0.9209-0.9245$ \\
\hline Melting-point $\quad$. & & $24^{\circ}-42 \cdot 5^{\circ} \mathrm{C}$ \\
\hline Saponification value.. & & $196 \cdot 3-205 \cdot 5$ \\
\hline Iodine value $\quad$. & $\cdots$ & $53-57 \cdot 4$ \\
\hline Reichert-Meissl value & & $0 \cdot 86-1 \cdot 87$ \\
\hline Hehner value $\quad$. & $\cdots$ & $94 \cdot 2-97$ \\
\hline
\end{tabular}

The solidifying-point of fatty acids varies from $35.8^{\circ}$ to $46.4^{\circ} \mathrm{C}$. usually $44.5^{\circ}$ to $45^{\circ} \mathrm{C}$.

(See also $7 a$, Uses; see also 12a.)

11. European Uses of Oil and Kernels, Palm Wrne, Palm Cabbage, ETC.-From 46 to 53 per cent. of oil is contained in the kernel.

Palm oil is used in Europe for making margarine, vegetable butters, chocolate and cooking fats. It makes a good butter-substitute. Palm oil is chiefly used for making soap and candles in England, according to Mr. Dennett's paper. Tin plates are covered with palm oil to prevent oxidization. The leakage from the casks of oil on board ship is used for making metal polish. Railways use it for greasing axle-boxes on railway carriages.

1la. Nigerian Exports, OrL and KrRnels.-The exports of palm kernels have been increasing almost continuously for years, owing to the gradual opening up of the country to trade, and also to the natives finding out the value of the kernel as an article of barter; nevertheless, more still could be obtained if hand-cracking machinery and more nut-cracking mills were introduced at suitable spots.

The following table shows the exports for the years 1909 to 1916 of

PatM Kerners.

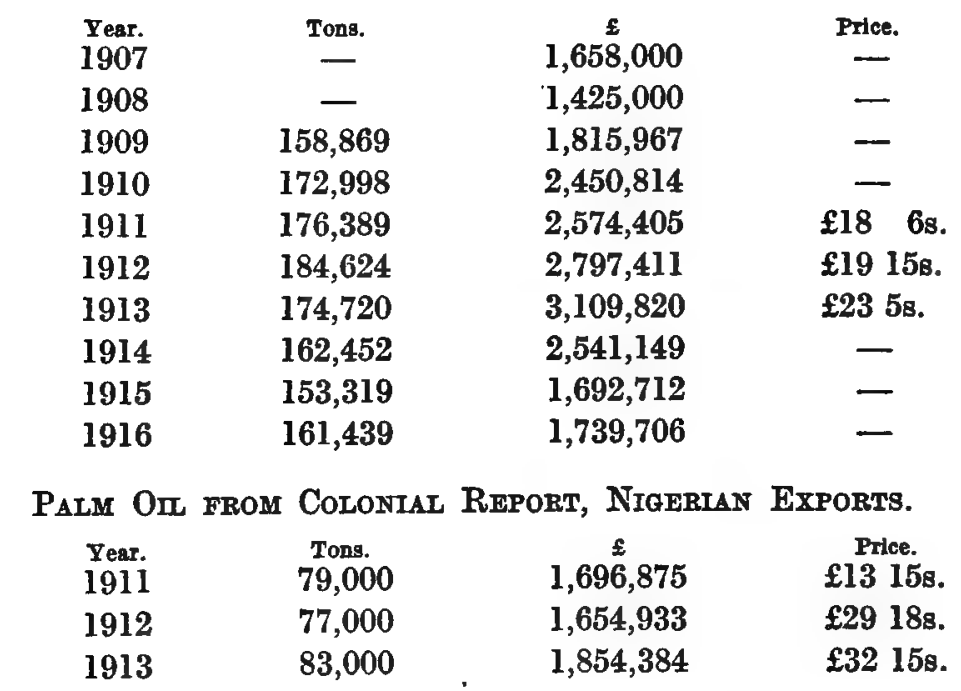


The following is quoted from Sect. 2, Mr. R. E. Dennett's paper on British Trade in Nigeria. Valuable notes have been obtained from this paper with regard to the palm products.

\section{Palm Kernel Exports to Germany.}

About $£ 5,000,000$ worth went to Germany before the war.

$\begin{array}{cc}\text { Year. } & \text { Tons. } \\ 1911 & 262,680 \\ 1912 & 283,536 \\ 1913 & 241,961\end{array}$

12. VALUE OF OIL AND KERNELS.-Since the war, the price of oil first went down $£ 5$ per ton and kernels $£ 15$ per ton up.

With kernels at $£ 17$ to $£ 18$ per ton, the oil is worth $£ 36$ 15s. per ton.

Glycerine is worth $£ 50$ per ton, and pericarp oil contains about 8 per cent.

At the beginning of 1918 the price of palm kernels varied from $£ 25$ to $£ 26$ per ton, the latter figure being the official maximum for it.

12a. Descrirtion of Kernet Ort.-It is white or pale-yellow in colour, with a pleasant nutty taste. By suitable treatment kernel oil can be divided into liquid oil, olein, and solid palm-kernel oil, stearin. It is used for soap and candles, edible fats-such as palmine, margarine-cooking fats, vegetable butters and chocolate fats.

13. Import PoRts IN ENGLaNd aNd U.S.A. FOR OIL aNd KERvels.-Hull.-Congo kernels go to Hull by the Cie Congo du Belge line, run by Elder Dempster \& Co. In the first six months of 1915, 20,821 tons of kernels were imported into Hull. In most statements on Hull the price of palm kernel cake is omitted, whilst those of linseed, Bombay cotton-seed, and Saga Bean are always quoted. Hull imported between 40,000 and 50,000 tons in 1915 (from January to November only, 31,723 tons); 200,000 tons were taken by Germany before, and hence are available now.

Bristol.-Bristol as a port is prepared, according to its seed-crushers. to try kernels, but they asked the Colonial Office for protection from Germany.

Liverpool.-For the first six months of $1915,87,366$ tons of palm kernels were imported into Liverpool, against 73,000 tons in 1914 .

U.S.A.-In 1915, 4,000 tons of kernels were shipped direct to the States.

14. The Crushing of Palm Kernels in Africa and England. -The largest seed-crushing and oil-extracting centre in Great Britain is at Hull.

Most of the crushing used to be done in Harburg, near Hamburg, Germany, and only a little at Liverpool-some 70,000 tons out of 300,000 tons. Since the war began Hull and London (Erith) have 


\section{OIL PALM AND PALM KERNEL INDUSTRY 481}

taken up the crushing of kernels. Bristol and Manchester have both thought about it.

Crushing has been tried in Africa, but has not been very successful so far, the cost of the operations having proved too high. In the Congo, however, it is still being done.

The crushing plants in Nigeria are situated at Opoba and Apapa, near Lagos.

14a. Other Methods of KmRnel Crushina-Solvents.-Commercially, kernels are heated with solvents or pressure is used to extract the oil. According to Mr. Dennett the first expression takes place at a temperature of $45^{\circ}$ to $50^{\circ} \mathrm{C}$., and the second at $55^{\circ}$ to $60^{\circ} \mathrm{C}$. The double pressing is necessary owing to the amount of fat in the oil. By solvents, all or only a part can be taken out of the kernels. If all is taken, then they are almost valueless as cake, owing to its lack of oil.

15. Palm-kennel Produce.-Palm-kernel cake used to contain 20 to 22 per cent. of fibre and 10 per cent. of oil, which went rancid, so was not liked here.

This was the main reason why palm-kernel cake was not used to any extent by farmers in England before the war.

15a. Yifidd of OtL, Kernels and Cake.-From 46 to 53 per cent. of palm-kernel oil is obtained from the kernels.

Roughly speaking, a ton of kernels yields half a ton of cake, according to Mr. R. E. Dennett.

According to the Bulletin of the Imperial Institute 1 ton of kernels yields $1,000 \mathrm{lb}$. of oil.

Palm-kernel Cake and Oil Exports.-Palm-kernel cake was exported to Denmark in September 1915-18, 863 bags.

15b. Analysis of Kernel Cakt.-This, according to a recent analysis in the Field by Frank J. Lloyd, is :

\begin{tabular}{|c|c|c|c|c|}
\hline Fibre.. $\quad$.. & .. & .. & $\cdots$ & $\begin{array}{c}\text { Per cent. } \\
14 \cdot 80\end{array}$ \\
\hline Mineral matters & . & . & . & $3 \cdot 55$ \\
\hline \multicolumn{5}{|l|}{ Nutrients- } \\
\hline Oil & .. & . & . & $6 \cdot 17$ \\
\hline Albuminoids & .. & .. & $\ldots$ & $16 \cdot 12$ \\
\hline Carbohydrates & .. & .. & . & $48 \cdot 51$ \\
\hline \multirow[t]{2}{*}{ Water } & $\therefore$ & . & . & $10 \cdot 85$ \\
\hline & & & & $100 \cdot 00$ \\
\hline
\end{tabular}

A further analysis shows:

\begin{tabular}{lllll} 
Oil $\quad$. & & & \multicolumn{1}{c}{ Per cent. } \\
Albuminoids & $\ldots$ & $\ldots$ & $\ldots$ & $5 \cdot 5-10$ \\
Carbohydrates & $\ldots$ & $\ldots$ & $\ldots$ & $\mathbf{1 5 \cdot 8 - 1 8 \cdot 5}$ \\
& $\cdots$ & $\ldots$ & $\ldots$ & $\mathbf{3 6 - 5 0}$
\end{tabular}


or per food unit it works out to $£ 416 \mathrm{~s}$. per ton. Indigestible fibre reaches 10 per cent., or in older samples of ten years ago 28 per cent., which is far too high. As a unit it costs 1s. 4d., against $2 \mathrm{~s}$. $7 \mathrm{~d}$. for cotton-seed meal.

According to E. D. News the analysis is :

\begin{tabular}{|c|c|c|c|}
\hline Albuminous matters & & . & $\begin{array}{r}\text { Per cent. } \\
17-30\end{array}$ \\
\hline Fatty matter $\quad$.. & & . & 10-18 \\
\hline Gum, sugar and starch & & .. & $30-40$ \\
\hline
\end{tabular}

15c. KeRnel ANALYsis.-According to the investigations the analysis showed :

\begin{tabular}{|c|c|c|}
\hline Specific gravity at 9 & $0 / 15^{\circ} \mathrm{C}$ & 0.873 \\
\hline Iodine value ... & . $\quad \ldots$ & $10 \cdot 3-17 \cdot 5$ \\
\hline Saponification value & .. & $242-255$ \\
\hline Titer test $\quad \ldots$ & .. & $20 \cdot 0-25 \cdot 5^{\circ} \mathrm{C}$ \\
\hline Hehner value & . & $91 \cdot 1$ \\
\hline Reichert-Meissl test & $\ldots$ & $5 \cdot 0-6 \cdot 8$ \\
\hline
\end{tabular}

16 and 17. Valde of Palm-kernel On and Cake.-Palm-kernel cake is sold at $7 \mathrm{~s}$. per cwt., and only 10 per cent. of the food ration is given to cows or calves for the first time.

According to the Oil and Colours Journal, in September 1915 palmkernel oil was worth $£ 37$ 10s. per ton first hand, and $£ 48$ in March 1916. According to this journal it is the lowest priced of all the cakes.

The price of the cake is $£ 7$ to $£ 75 s$. per ton.

The cake is sold at $\mathfrak{f 7}$ 5s. free on rail per ton at Hull. At the beginning of 1918 it was worth $£ 13$ 15s. per ton, but in Surrey it could

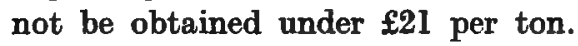

Palm-kernel oil is worth about $£ 40$ per ton.

At the beginning of 1918 , palm-kernel oil extracted by solvents was worth 151 per ton; crushed, $f 52$ per ton; refined, 167 per ton - which were the official maximum prices.

17. Uses of Palm-kgrnel Cakk.-Kernels worked by solvents make a more digestible meal -80 per cent. against 73 per cent. of crushed kernels, and containing 19 per cent. of protein and 2 per cent. of fat, against 18 per cent. of protein and 8 per cent. of fat for crushed kernels. It is used for feeding young pigs and milch cows in Germany.

18. Results of Feeding Experiments with Kernel Cake.The weekly gain in live weight with kernel cake ration was $8 \mathrm{lb}$. at the West of Scotland Agricultural College. The cost worked out at $4 \mathrm{l} \mathrm{d}$. per lb., and $3 \mathrm{lb}$. of kernel cake gave better results than $4 \mathrm{lb}$. of bran.

At the East of Scotland College, a gain of $2.04 \mathrm{lb}$. per day was recorded, the cost. being $f 6$ 6s. per ton. 
Experiments conducted in Scotland showed that cattle increased 1.95 lb. per day with palm-kernel cake, against only $1.84 \mathrm{lb}$. with linseed cake. No difficulty was found in keeping the cake, and it did not go rancid.

The cattle fed on palm-nut cake were stated to look glossier, carry more bloom, and have a looser skin than those fed on cottonseed cake. It is also claimed that the fat content of the milk is increased, though the amount of extra butter-fat produced per day cannot be demonstrated.

A mixture containing $3 \mathrm{lb}$. of palm-nut cake is recommended per day for milch cows, and one containing from $\frac{1}{4} \mathrm{lb}$. to $\frac{1}{2} \mathrm{lb}$. for sheep and pigs.

Ten per cent. of the ration should be given to cows or cattle the first time. Only $2 \mathrm{lb}$. of cake per day is given to animals.

According to the Cambridge University Department of Agriculture the feeding value of palm-kernel cake for bullocks is practically the same as that of linseed cake.

The feeding experiments demonstrated that the palm-kernel cake gave equal results to linseed or cotton-seed cake, and paid better because of the lower price of palm-kernel cake for milch cows and cattle. It is recommended for pigs too. The cost of feeding for eighty-four days was 43s. $4 \mathrm{~d}$. for palm-kernel cake against 5ls. $6 \mathrm{~d}$. for linseed, and a gain of $164.5 \mathrm{lb}$. in weight against $167 \mathrm{lb}$. Hesh weight with linseed cake. Cattle do not take to it readily at first, but afterwards like it.

According to Wyndham R. Dunstan, palm-kernel cake costs 1s. $5 \frac{1}{2} \mathrm{~d}$. per food unit as compared to $2 \mathrm{~s}$. $4 \mathrm{~d}$. for hay, hay being $£ 5$ per ton.

According to Thomas Fawcett, L.M.R., A.S.E., it is a question of what is relatively cheaper. British farmers have always bought linseed cake at $£ 1010 \mathrm{~s}$. per ton, when beef was only $10 \mathrm{~d}$. to ls. per lb. Relatively, it would be better to go in for more cows being fed with palm-kernel cake. He also states that kernels only came in irregular quantities.

The cake, according to Lancashire County experiments, must be given as part ration, as milk yield goes down with kernel cake alone.

18a. Palm-nut Meal: Experimental Results of Feeding.In 1879, in Agricultural Chemistry, by Johnson and Cameron (2nd edition), palm-nut meal from England and the Continent is mentioned and recommended as the cheapest meal for cattle, especially calves. The Royal Agricuttural Society of England in 1878 also published a pamphlet for the Paris Exhibition, in which a mixture including a large proportion of palm-nut meal is recommended, and the experience in feeding young animals is given, showing that it is far cheaper and that linseed cake is really very expensive. 


\section{WEST AFRICAN FORESTS AND FORESTRY}

Fourteen beasts fed on linseed cake averaged at eighteen months old $13.5 \mathrm{lb}$. live weight the week, or only $\$ \mathrm{lb}$. less than the heaviest at the show, on less food, especially using palm-nut meal.

According to others, meal is not recommended owing to its going rancid and its indigestibility.

19. Mandrtal Valde of Karnel Cake.-The manurial value of palm-kernel cake is $£ 1 \mathrm{4s}$. for the ration as given per ton.

20. Wesp african Shipping in Relation to Farm Produce.Before the advent of the German line, the West Coast was at the mercy of the Shipping Combine, as it is now, freights being arranged accordingly.

Since the Government has fixed maximum freight rates, shippers now know the largest amount they will have to pay, but even so freights are extremely high, and with no outside competition are unlikely to be brought down very much.

21. Bibliography of the OIL Palm.-Monsieur Chevalier's Les Végétaux Utiles de l'Afrique tropicale française, Fasc. VII ( $1^{\ominus}$ partie), " Documents sur le Palmier à Huile," contains a great deal of valuable information on the subject of the Oil Palm. The Oil Palm, by J. H. Farquhar, summarizes the results of a year's investigations as to the growth and yield of the Oil Palm in the Southern Provinces of Nigeria.

In the monograph Oil seed and Feeding Cakes, issued by the Imperial Institute, a complete account is given of the new British palm-kernel industry. 


\section{CHAPTER XIII}

\section{THE FOREST IN RELATION TO AGRICULTURE}

THE intimate and very important connection between Agriculture and Forestry is not at all widely recognized, so it is desirable to bring out more fully exactly how the one reacts on the other: the value of forests from the climatic point of view to agriculture, the economic effects on it, as well as the population connected with it.

In all the older civilized countries, such as France, England and Russia, and the United States and Canada of the newer ones, definite and almost exactly fixed quantities of land are used for agricultural purposes on the one hand and for Forestry on the other.

In the Gambia, Sierra Leone, the Gold Coast and Nigeria, however, with the exception of about 1,500 square miles of forest reserves and certain native land planted with rubber or cocoa, all the land (even when covered with finest mahogany forests) is liable to be farmed for a time and then abandoned for another piece of forest-land under the system of shifting cultivation. In practice, this means that every year thousands of square miles of forest are ruthlessly cut down, in order that the land may be used for agricultural crops, for one, two, or at the most three years' crops. In the drier parts of the countries named, through such forests as exist, grass-fires annually burn, and destroy many trees in order to provide poor grazing for herds of the nomads' cattle.

It might be argued that in the comparatively damp and hot climate which attains in a great part of the Gambia, Sierra Leone, the Gold Coast and Nigeria, which are also to some extent still covered with forest, it would be most advantageous to clear as much land as possible. This, however, is a delusion resting on false impressions, notably that the countries named are so much covered with thick forest. In most places this so-called "forest" is in reality an almost worthless secondary growth, consisting chiefly of umbrella trees (Musanga Smithii), soft-wooded Hannoa, creepers, grass, with isolated half-burnt or decayed trees from the original forest. Again, too, this system of clearing new land is quite haphazard, so that, after the first crop has been taken off, the land may be found to be too poor to be planted again; the natives then abandon it. In some places, chiefly in the Benin and Oban districts, they even 


\section{WEST AFRICAN FORESTS AND FORESTRY}

go so far as to put a "Ju-ju" on the land, which is in effect a notice to say that the land is of no use for a farm. However, this is usually forgotten in a generation, so that the same thing may happen again, only that insufficient time has elapsed for a proper forest to be grown, as the cutting of the original forest may have so altered the climatic factors of the locality that not only different species of trees but also grasses have come in, and choked nearly all the self-sown foresttree seedlings. The main beneficial effects of the forest may be summarized as follows :

1. The rainfall of the locality is increased, according to the figures of the Indian rainfall stations. This may amount to as much as 16 to 28 per cent. increase on the annual rainfall.

Afforestation on the Russian steppes has shown that more rain now falls on the planted area than in former years.

In Western Canada it is generally said that its climate is altering, and a general increase of rain has been noticeable since plantations have been made on thousands of farms and what forests there were originally have been rigorously protected from annual fires.

2. The rainfall both above and in the ground is more regularly distributed.

First of all, nearly 23 per cent. of the rain which falls on the trees in a forest is re-evaporated into the air and does not reach the ground at all. This in itself increases the humidity of the atmosphere, tends to form clouds, and thus induces further rainfall. The clouds tend to protect the plants from excessive sun at what may be a critical period in the growing season. The extra humidity of the atmosphere does not necessitate the plants transpiring so much moisture as they would otherwise have to do, to keep them in growing condition. Compared to that in the open, only 22 per cent. of the amount of evaporation takes place in the forest, added to the fact that it occurs under the canopy of the trees, thus creating the more humid atmosphere which is so suitable, for instance, for the growth of cocoa and other such crops. In other words, we can take one hundred parts as the amount evaporated in the open, of which not a quarter is evaporated in the forest. Again, as we have seen, twice as much of the rainfall soaks into the ground in the forest as in the open, and owing to the tree-roots and general covering of the soil the water can only flow away gradually. On the other hand, in the open, if the ground is at all sloping, more than half of the rain which falls to the ground runs away immediately, or lies on the land, flooding it and making planting impossible.

The trees then act as a rainfall distributer and also as a rainfall regulator. The roots of the trees act like a sponge, absorbing a great deal of the rainwater besides preventing it from running away. It has been calculated that it takes nearly six months for the rainfall 

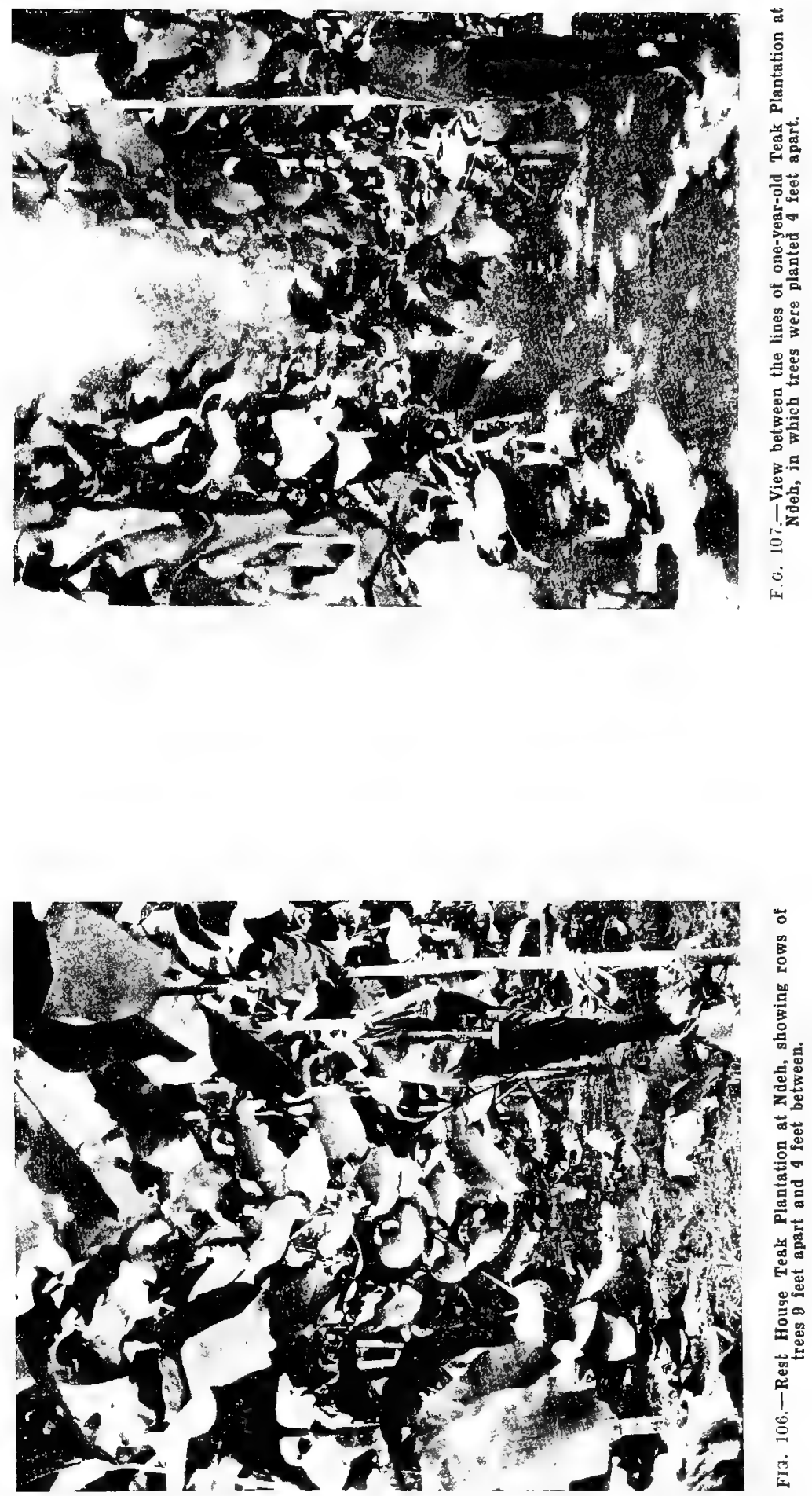

to come out in the springs of a forest. This also to some extent accounts for the saying that if the wells are full in October in the Temperate Zone, or at the end of March in the Tropical Zone, there will be sufficient water the whole year round. With a varied distribution of forests in the country, the above two effects are naturally felt on neighbouring agricultural land, and in many cases make possible the growing of certain crops, such as cocoa, Cola and rubber, which otherwise could not be attempted. An interesting example of this is seen in the way in which the natives of Ilobe, in Nigeria, have planted Cola trees just inside and on the edge of the Ilaro Forest Reserve boundary.

3. The forest protects the land against corrosion. In most countries, wherever the ground is sloping and bare the annual fall of rain washes away large masses of good soil as well as stones and other debris, in many cases destroying pasturage or agricultural land, and in any case silting up the rivers with sand-banks and bars, thus hindering navigation. It has often been said that, for its size, the Cross River carries in the rainy season much more material in suspension and rolled along its bed than many other African rivers. The main reason apparently for this fact is that several of its tributaries, such as the $\mathrm{Mbu}$, the $\mathrm{Fi}$, the $\mathrm{Mfu}$ and the Bago, rise at what are now partially grass-covered mountain slopes, but which no doubt were a short time ago covered with fine evergreen forests.

The immediate effect of clearing such slopes is that the water, to the extent of nearly 90 per cent., rushes unchecked down the mountain slope, gaining momentum with every mile and taking grass, soil and even whole mountain slopes (1,500 feet in height) along with it. On the other hand, if such slopes are covered with forest trees 25 per cent. of the rainfall is re-evaporated into the air before reaching the ground, 10 per cent. is evaporated from the ground into the air of the forest, and fully 65 per cent. soaks into the ground.

An instance of this last effect can be seen in the Cross River Divide from the Bambuto Mountains, on the Nigerian border. In a few places the native farmers understand this effect and make the terraces on which they plant parallel with the contour of the hill-side ; however, this is insufficient when the whole mountain slope has been cleared of forest. Only a definite distribution of the land between forest and farm would prevent the undue corroding of hill-sides. The unrestricted rush of the rainwater off the hill-sides has yet a further effect on the lower ground of the country, in that it causes the streams and rivers to flood and overflow their banks. This, in turn, prevents huge acreages of land from being cultivated for many months in the year, and other large areas lower down from being cultivated at all.

Yet another effect is that a vast mass of water hurries down into the sea where it is not required, and where there is already plenty of 
evaporation; whereas the greater part of it might have been stored up in the forest to form perennial, almost unaltering springs, streams and rivers. Two interesting examples of this are seen in the slight, almost negligible rise in the Okwo and the Igbagon streams of the Benin province. Both of these rivers rise in thick forest, and thick forest is also found on their banks.

In a similar way, instead of the water of the rivers being used for irrigating land which is sandy and dry in the dry season, it rushes away into the ocean for nothing. The flooding of much of the land near the rivers also kills many large forest trees and causes a rank growth of shrubs, creepers and grass, which form the breeding-places for tsetse and other harmful flies. It is rare to find any infected tsetse flies near a clear perennial stream in the forest.

4. The forest improves the soil of a locality, whether in the primeval or the planted forest. The trees stand at least eighty years, and sometimes for several hundred, on the same land, before being cut down. During this period the tree roots with their root-hairs are penetrating far and wide into the soil, subsoil, and even underlying rock, gradually causing the two latter to weather into finer and better constituent parts. For instance, nothing appears so solid as a mountain of granite; nevertheless, at the base and to the lee-side of each boulder, more especially if there is any tree-growth there, a beautiful little bed or pocket of blackish soil will be found. Then, again, besides this weathering of the subsoil and rock, the tree leaves, even from evergreen trees, fall down, gradually decay, and form a thick layer of humus. This in itself forms an almost ideal seed-bed. At the edge of forests this humus is washed out on to the agricultural lands and thus enriches them ; furthermore, dry leaves are blown out of the edge of the forest on to neighbouring agrcultural land, become dug in, or drawn into the land by insects, and so tend to enrich it. In many civilized countries a regular business is done in taking litter and leaf-mould out of the forest to neighbouring garden and farm lands.

It is a well-known fact that when a forest is cut down after some hundreds of years many plants appear in the clearing which did not exist in the forest before, or, in fact, were not known in that locality, the seeds having lain dormant during the whole period of time. This clearly shows that the forest soil is an ideal medium for preserving seeds, and that it improves rather than deteriorates, which is the case with bare land. An instance of this from the Tropics is seen in the way in which the Corkwood or Umbrella Tree (Musanga Smithii) comes up after the mahogany and evergreen forest has been cleared. No Musanga trees are usually found in the primeval forest. A parallel example from Europe is seen in the way in which Atropa belladonna almost invariably appears when a beech forest is cut down.

Planting trees and thus forming a forest, though expensive, is 
another way of clearly proving the beneficial effect of the forest, or ameliorating the condition and plant-food content of the soil. On the comparatively worn-out and poor soil near Ibadan a firewood plantation was started some years ago; now already, in the shade of the Ayin, Anogeissus leiocarpus and Cassia Siamea trees, the fallen leaves have decayed and formed a layer of humus, killing out the lalang grass at the same time. Needless to say, it is a very expensive method to wait until the forest has been destroyed, the soil imporerished, and trees again planted, before an improvement in the soil conditions can be expected.

5. Individual trees, and thus trees in the aggregate, viz. forests, take less mineral matter out of the soil than agricultural crops covering a similar area. It has been calculated that the trees on an acre of land only take one-twelfth of the amount of mineral matter out of the ground which is required by an agricultural crop on the same area. It follows from this that trees, and in the same way forests, may be left standing upon or be grown on land which is nearly or absolutely worthless from an agricultural point of view. In the more civilized countries this is seen, for instance, in the way in which the mountain ranges of Germany have remained covered with forest and the sandy Landes district of France has been planted with forests of pine. In Canada, the Spruce Hills Reserve, near the Canadian Pacific Railway in Manitobr, is another example of the setting aside of poor, almost worthless agricultural land as a permanent forest area. In Nigeria, the Oban Forest Reserve and the forest-covered hills of Olokemeji are further examples of the practice of this principle.

Generally speaking, in fact, in most civilized countries there are really three types of land, viz. :

(a) Absolute farm-land, which comprises the very richest and best land of the country, in which forests should only be allowed to stand, as an exception.

(b) Relative forest-land, comprising land which can be used permanently for agriculture, but requiring a great deal to be spent on improvements or manures to make it suitable for the purposes, but which in its natural state carries a heavy stand of timber, could be used for forests indefinitely.

(c) Absolute forest-land, comprising land which, owing either to its elevation, aspect, soil or position, cannot be used for the permanent cultivation, or in some cases even the temporary cultivation, of crops.

6. The forest protects agricultural land against storms and insect pests. In many places, owing to very strong winds, certain crops cannot be grown. For instance, it is said bananas cannot be grown at Zaria owing to the prevalent strong winds. In the Chang district of the Cameroons the natives only plant plantains near their houses 
or behind the very high fences or hedges which mark off one man's compound from another. Apparently this is done in order to protect the plants from the wind, which otherwise tears their large leaves into shreds and prevents their proper growth.

Some years ago, in the Ibadan district, a fierce tornado cut a path about 100 feet wide and nearly a mile long through a forest, but the agricultural land beyond was untouched. It goes without saying that had all the land been under crops in this locality most of them would have been destroyed, whereas the forest took the brunt of the storm, and the force of the wind outside was thus weakened and comparatively harmless.

7. The forest protects the soil and its physical properties. In the open it is noticeable that the native rarely clears the land properly, many stumps both of forest trees and shrubs being usually allowed to remain standing. It is true some of the shoots from the stumps are left on purpose to be used as supports for the yam tendrils or other crops which may be grown. Nevertheless, it is a fact that the native always says that the land must not be absolutely cleared of all stumps and roots or it will be useless for the growing of crops. Then, again, the native speaks of a piece of ground as being "spoilt," and that he cannot stay there any longer. As an example of this, in the Oban district, the people of Ekong left the village site because they said the ground was too stony and was no good, and they went right away into the forest. On an examination of the land being made, it was found that where they had cleared the forest and farmed for a few years all the humus, tilth and other soil had been washed away, with the result that boulders as well as the underlying rock had to some extent come to view. Needless to say no attempt had been made at farming under a rotation of crops, nor had any manure, green or otherwise, been applied to the soil. On the other hand, in the forest the soil is not washed away, the aeration of it is almost perfect, the mineral content is always high, and it usually has considerable depth, even where there are rock outcrops, for these become covered with dead leaves or humus, which in their turn help to weather the rock and thus make more soil.

8. The forest tends to regulate the temperature, almost preventing extremes of heat and cold. Accurate measurements taken over a period of forty years have established the fact that in the warmest season the temperature of the forest is $5^{\circ}$ to $10^{\circ}$ lower, according to species (altitude taken to be the same), than the air in the open over agricultural land. In a similar way, in the coldest season of the year the temperature of the forest is $5^{\circ}$ to $10^{\circ}$ higher than in the open over agricultural land. Most readers will have experienced the feeling of freshness and coolness in passing through the forest zone near Olokemeji on the Nigerian Railway, or, if on leave in England, in passing 
through the New Forest on the Bournemouth road. This is only the effect which is expressed in this difference of temperature: as with other effects, so this one affects the neighbouring lands near the forest. Even a dry wind on reaching a forest must take up some moisture, and thus be less dry when it reaches agricultural land farther on. It can often be seen how the grain in the drier parts of the country planted near the edge of a forest sprouts up sooner than that right in the open. Again, certain crops, such as cacao-yams, cocoa, and Cola trees thrive best amongst trees. Without the forests the Cola plantations of the Mlesha district would cease to exist, or at any rate bear very small crops.

9. The forest increases the humidity of the air. According to accurate measurements taken over a period of forty years, it has been proved that the forest increases the humidity of the air up to 10 per cent. No doubt in many of the Southern parts of Nigeria and the Gold Coast, people travelling in the forests have often thought that there was far too much moisture, not only coming from above and below, but also in the air around them. However, this should not blind us to the fact that further up country this greater humidity of the air of the forest is spread over the adjacent lands, and thus makes possible the growth of agricultural crops, such as cocoa, Cola, yams, and cacao-yams, which would not otherwise be possible. This greater humidity also tends to induce local minor rainstorms, which in their turn benefit the adjacent agricultural land. This greater humidity of the air also tends to prevent the excessive drying in the dry season of the land situated very near, and taken in conjunction with the other factors, such as the regulating of the temperature and the rainfall, makes it possible to put in crops earlier and almost ensures their growing successfully.

10. The forests prevent the spread of insect and fungoid pests. So often we read that the crops in South Africa or the Argentine have been destroyed by locusts, and on the Gold Coast we read that various pests are destroying cocoa-trees in large numbers. Here, again, a forest or a belt of forests with large numbers of different species of trees interpose a living barrier of green leaf food or woody tissue which these pests may attack, owing to the diversity of the species of trees. Most pests only find a few trees on which they can thrive or reproduce themselves; thus on reaching the forest the scourge tends to lessen, or even die out. Even in the worst case of large hordes of locusts, it is cheaper to allow them into a forest, perhaps sacrificing it, rather than they should spread further and further over agricultural lands.

Having shown that it is necessary in a new and comparatively unsettled country to preserve a certain proportion of the forests, it remains to be considered what proportion is desirable and necessary 
to fulfil the conditions outlined before and give free play to all the beneficial effects of the forests.

Taking the proportion of permanent forest to other land in the more civilized countries, we get the following ratios :-

\begin{tabular}{|c|c|c|c|c|c|}
\hline Finland & . & .. & .. & .. & $\begin{array}{l}\text { Forest per cent. } \\
\ldots \quad \mathbf{8 0}\end{array}$ \\
\hline Russia in & Europe & & .. & . & $\ldots 42$ \\
\hline Austria & $\ldots$ & .. & .. & .. & $\mathbf{3 3}$ \\
\hline Hungary & .. & .. & .. & .. & 29 \\
\hline Germany & $\ldots$ & .. & . & .. & 26 \\
\hline France & .. & .. & . & .. & 16 \\
\hline Sweden & .. & $\ldots$ & . & .. & 42 \\
\hline Switzerlan & ad & . & . & .. & 19 \\
\hline Norway & . & $\ldots$ & .. & .. & 25 \\
\hline U.S.A. & .. & . & - & .. & $\ldots$ \\
\hline India & .. & .. & . & .. & 38 \\
\hline
\end{tabular}

Special note should be made of the fact that in all these countries the agricultural development has gone hand in hand with the preservation of the forest, and especially with no detriment to the development of agriculture in any direction in which it seemed desirable. Russia has, for instance, enormous exports of timber and enormous exports of wheat. Austria-Hungary had before the war considerable exports of hardwood timber, such as oak, as well as grain, both wheat and other kinds. Judging by the experience gained in Germany with its hundred and seventy years of forestry practice, a proportion of 25 to 33 per cent. of the land area of any country can reasonably be retained under forest, or afforested if bare. Such a proportion allows sufficient timber trees to be grown to cover the large quantities of wood used in industrial development and also a considerable surplus for export to other countries.

Turning specifically to the West African Colonies, it would mean, out of a total land area of 4,500 square miles, that in the Gambia, for instance, an area of between 1,100 and 1,500 square miles should be permanently set aside as Forest Reserves or Forest Reserve Afforestation Areas. In the latter case, when all were planted up they would gradually become forests.

In Sierra Leone, with a total land area of 34,000 square miles, the area would vary from 8,500 to 11,000 square miles.

In the Gold Coast, out of a total land area of 80,000 square miles, the permanent forest area would vary between 20,000 and 26,000 square miles.

In the Southern Provinces of Nigeria, with a total area of 79,000 square miles, the permanent forest area would reach between 19,000 and 26,000 square miles. 
In the Northern Provinces of Nigeria, out of a total area of 250,000 square miles, the permanent forest area, including the afforestation areas, would reach between 62,000 and 83,000 square miles.

Large though these forest or afforestation areas appear to be, it can, however, be shown that most of them do not at all trench on existing farm-land. First of all, in Nigeria, taking the protective forests, comprising all those lands or forests situated in most inaccessible places on mountain ranges and hill-sides and the sources of streams, they cannot be said to be desirable localities for extending farming operations. Typical instances of this kind of land are seen in the Boji Hills (Ogoja province), and on the rocky hills near the Cross River in the Afikpo district (Owerri province). In Sierra Leone the peninsular mountain forests and the hills near Kennema are similar typical examples of this type of land or forest.

At the other extreme we have the dry-zone or desert formation, with its sandy soil or bare rock outcrops. In either region, in order to make agriculture possible and permanently profitable, afforestation areas are most necessary. Near the sea, especially in Nigeria and to some extent in Sierra Leone, there are the mangrove forests standing on land which is never used for agricultural purposes. In Nigeria alone these comprise several thousand square miles of land. Again, in Nigeria there are the freshwater swamp forests, either near rivers or in other localities. Although such lands produce quite a profitable amount of timber from many excellent species of trees, no farms have ever been made in such areas.

In other parts of the country, often comparatively level, there are variations in the strata and soil formation, such as that of the laterite formation. Over wide areas most of these lateritic soils are nearly useless for permanent agricultural crops, so at any rate it would certainly pay better in the long run if it were permanently covered with forest. In a similar manner all forests found growing on or near rock outcrops or otherwise stony formations, such as old gravel beds formed by rivers, would be treated in the same way. One or two agricultural crops may be raised on such land, but all the soil is soon washed away in the rainy season each year, so that little is left after a short time except boulders and stones. Many typical instances of this kind of formation are found in the Ibadan and Oyo districts of the Oyo province. In other parts of the country, where practically all the land is covered with some sort of forest (either high forest, secondary growth or scrub), the same proportion as before, viz. 25 to 33 per cent., should be set aside in convenient blocks, well distributed over the area, as permanent forests (so-called Forest Reserves).

Strange as it may sound, there is comparatively little, at the most an area estimated at 7,000 square miles, of real high forest left in the Southern Provinces of Nigeria. As is well known, the natives have 
a special name for this type of forest; amongst the Efiks it is called Ekai, the Yorubas term it Igbo, and the Benin people Egbo. Considering the size of these last remnants of the real high forest, agriculture cannot justly claim the right to clear and farm even this area when so much (estimated at 28,000 square miles), apart from the area. already mentioned, has been cleared during the last fourteen years. In the above estimate, areas even of 500 square miles for roadways and railways, 1,000 square miles for town, village and factory sites, and 2,500 square miles for inland waterways were allowed for when computing the whole area of forest land.

At the present time in Nigeria, with the exception of certain specified trees, and less so in the Gold Coast, Sierra Leone and the Gambia, there is nothing to hinder a native from cutting down any forest he pleases for making a temporary farm. In fact, the difference between farming as practised in civilized countries and in these tropical West African Colonies is that the former partakes of a permanent cultivation of the same land every year, whereas the latter is shifting cultivation of a different piece of land almost every year. At the most, the Yoruba returns to the land in five or seven years, and the native of Benin after ten or twelve years.

Another point which bears on this question is really the comparatively small amount of land which a native actually farms every year. For instance, an energetic Yoruba farmer will make 2,000 yam heaps a year, which, allowing for the distance of 6 feet between each heap, amounts to $1 \cdot 6$ acres per year. This also includes the help which he may receive from his family.

Out of a total population of $8,000,000$, at the most $2,000,000$ are actually men who make farms. It follows, then, that some $2,560,000$ acres, or 4,000 square miles, are cleared and planted each year. Now, allowing sufficient land for the native to be able to return to the original piece cleared after seven years, the total amount of land necessary for the existing farming population would be 28,000 square miles, or rather more than a third of the total area of the country. Even after allowing 19,000 or 26,000 square miles of forest in the country, there would still remain nearly a third, or 25,000 square miles, for the future development of agriculture and the natural increase of the population. It should be especially noted that it is under a system of shifting cultivation that this 28,000 square miles is required. No doubt under permanent cultivation less would be necessary. Quite apart, however, from this consideration, owing to the greater heat, moisture and humidity in the Tropics generally, and in the Southern Provinces of Nigeria particularly, agricultural crops grow much more rapidly and are much more prolific than in the more temperate zones, even without manures. Yet in another way there is not such an enormous demand on the amount of land required per unit of popu- 
lation, in that over an area of fully 30,000 square miles it is possible to raise two crops a year on the same land, and over roughly an area of 10,000 square miles of the country it is possible to raise three crops per year (in each case under a rotation of crops). In this manner less land is required per person than, in a temperate climate in order to grow food either for local consumption or for export.

So far we have dealt with shifting cultivation. However, in most civilized countries, sooner or later a system of permanent cultivation is started instead of shifting farms. In England this was begun at a time in which the population was less dense to the square mile than it is now in the Southern Provinces of Nigeria (average 101 persons per square mile). In Germany the density of population is 323 persons per square mile, yet they had (before the war) 25 per cent. of the land area of their country covered with permanent forests. If it were possible to start permanent cultivation with a rotation of crops in England when the population was less dense than in the Southern Provinces of Nigeria, it should be feasible in Nigeria now. Again, if it is found possible for Germany to retain 25 per cent. of the land area under permanent forest crops, with a density of population three times greater than that of Nigeria, at the same time maintaining a prosperous system of permanent agricultural cultivation, it should also be much easier to have a similar proportion of permanent agricultural cultivation in the Southern Provinces of Nigeria; at the same time, taking into consideration the more favourable climatic factors, it should be possible not only to grow sufficient foodstuffs for local use, but also to grow sufficient to develop into a large export trade for ground nuts, maize and beans, besides cocoa and rubber. 


\section{CHAPTER XIV}

\section{BIBLIOGRAPHY OF WEST AFRICAN FORESTS}

\section{Historical.}

ONE of the first books was Forestry in West Africa, by Sir Alfred Maloney, a former Governor of Lagos, which was published in 1887. This is a most interesting and readable book, and, for the time it was written, gives a very good account of many of the forest trees. It is also much to $\mathrm{Sir}$ A. Maloney's credit that teak, Tectona grandis, was introduced into Nigeria at that time.

In The Journal of an Expedition to Explore the Course and Termination of the Niger, by Richard and John Lander, only very vague descriptions of the forests are given, and it is therefore not of much value from the Forestry point of view, though it is a most entertaining description of the people and their doings at that time.

\section{Botanical.}

From 1868 onwards, Flora of Tropical Africa appeared; so far eight volumes have been published. This work was planned by the late Sir William J. Hooker and edited first of all by Daniel Oliver, and subsequently by Sir W. T. Thistleton-Dyer, K.C.M.G., C.I.E., and now by Lieut.-Colonel D. Prain, the Director of the Royal Botanic Gardens, Kew. It is, of course, very scientific, accurate and botanical, but has very dry descriptions of many of the African trees and plants and no illustrations are contained in these octavo volumes. What also makes it harder to use this Flora is the fact that since 1868 many new plants have been named, and some of the names of the old plants have been altered. A most useful chapter on Elementary Botany is contained at the beginning of Vol. I. This is to some extent also a glossary of botanical terms, but of course it cannot take the place of A Qlossary of Botanic Terms, by D. G. Jackson, 1905.

In many ways a much more useful book to the forester is Engler's Monographien der Pflanzenfamilien, of which eight volumes have appeared :

I. Moraceæ, excluding Ficus.

II. Melastomaceæ.

III. Combretaceæ Combretum.

IV. Combretaceæ, excluding Combretum. 


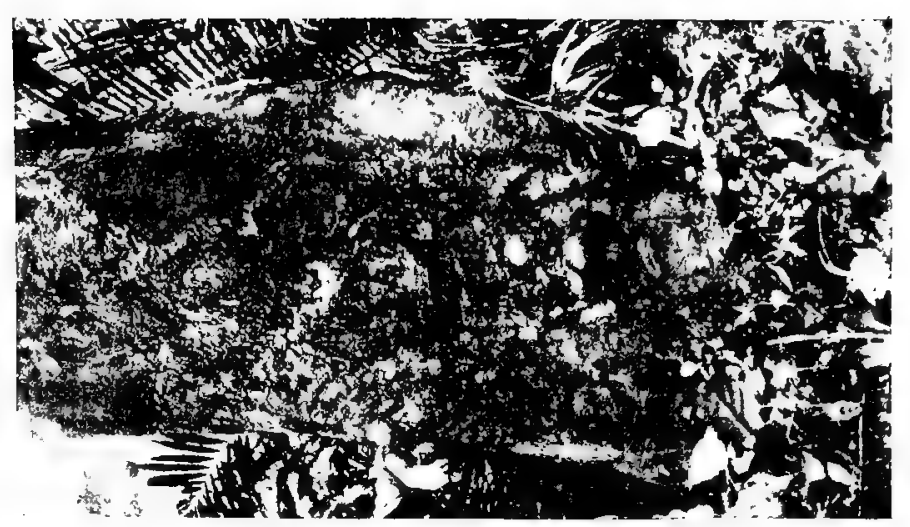

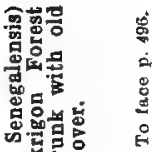

क्षे

용

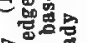

喿哭皆

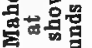

1 옴을

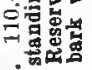

迎
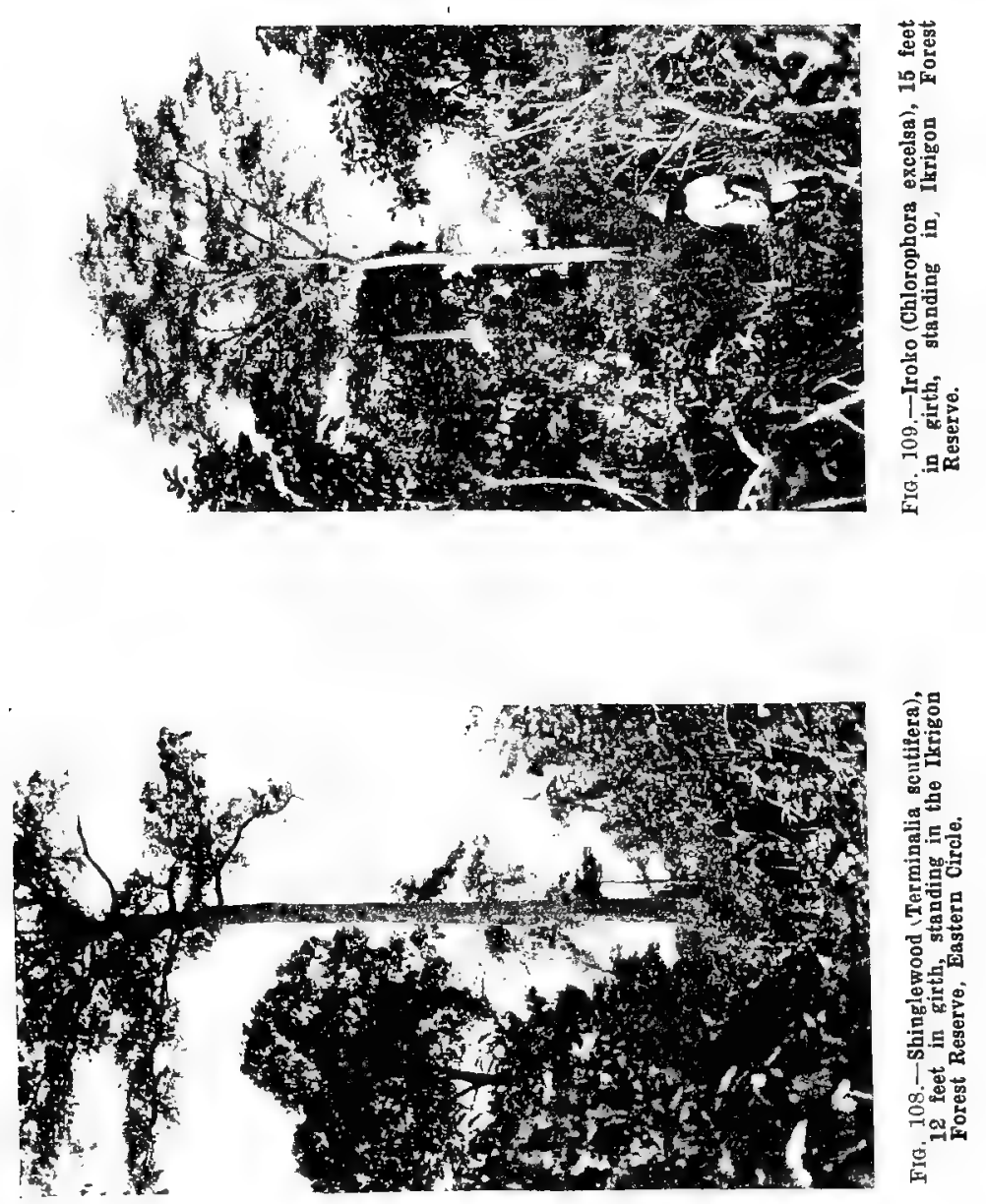

V. Sterculiaceæ.

VI. Anonaceæ.

VII. Strophanthus.

VIII. Sapotaceæ.

The full-page black-and-white drawings of the various plants are very valuable, and as they are all done on the same system, comparison both with the plants and with other books is not very difficult. The expense of these volumes is not excessive, considering the very large number of illustrations and the authority of the text. It is a pity that this series has for the time being come to an end.

In Engler's Pflanzenfamilien, of course, a very complete account of all plants is given, and the additions to it made almost monthly make it quite possible to find out the latest-named additions to the plant-world. The only disadvantage to these volumes is their number, size, and lack of illustrations.

In a similar, though in a less complete way The Kew Bulletin gives the latest list of plants identified at Kew, amongst which are usually some from Nigeria, and occasionally special bulletins appear on the plants from Nigeria-as, for instance, Bulletin of, Miscellaneous Information, Additional Series No. 9; The Useful Plants of Nigeria, Part I, 1908, Part II, Additional Series No. 10, 1912, Part III.

The Bulletin of the Imperial Institute, edited by Sir W. Dunstan, which appears quarterly, always contains the most recent information with regard to tropical products, including those of the forest. In recent years, too, much more has appeared on the subject of the timber, gum and oil-seed resources of Nigeria.

Die Bluitenpflanzen Afrikas, by Franz Thonner, 1908, arranged as it is in the form of a key, is most useful in identifying many of the plants and trees. The black-and-white illustrations add immensely to its value. Additions and corrections to this have also been made in Die Blütenpflanzen Afrikas, 1913. The last edition is in English, and entitled The Flowering Plants of Africa.

Among more recent books is a Catalogue of Plants collected by Mr. and Mrs. Talbot in the Oban district, South Nigeria, identified by A. B. Rendle, M.A., D.Sc., F.R.S., and others, and brought out by the British Museum in 1913. In this book the flora of Oban is specially dealt with, and clearly shows the difference between it and the rest of the flora and silva of Nigeria. Although this is mainly a description of newly discovered plants, the black-and-white illustrations by Mrs. Talbot show most accurately their salient features.

Notes on Nigerian Trees and Plants, by E. W. Foster, late Senior Conservator of Forests, contains accurate descriptions of the most useful trees, and the native names from the Yoruba country will be most useful to anyone working timber in that part of Nigeria. 


\section{WEST AFRICAN FORESTS AND FORESTRY}

The Agricultural and Forest Products of British West Africa, by G. C. Dudgeon, Director-General of Agriculture in Egypt, 1911, gives a short description of the main forest and agricultural products of the country, which is more useful to the trader than the forester or timber merchant. The illustrations showing the making of palm oil and other country products are very interesting, but Fig. 21, p. 112, supposed to be of an Iroko tree, is in reality that of Terminalia superba.

For reference purposes Dr. Adolf Engler's Syllabus der Pflanzenfamilien, 1904, which takes special account of the medicinal and useful plants, is most valuable.

For a proper introduction to Botany, Strasburger's Text Book of Botany is hard to beat.

Kulturgewächse der Deutschen Kolonien, by R. Sadebeck, 1899, gives a very good account of most of the useful West African forest products; the very clear illustrations add immensely to its value, although the book is now somewhat out of date.

\section{TImbers.}

In The Timbers of Commerce and their Identification, by Herbert Stone, F.I.S., F.R.C.I., 1904, a few of the West African timber trees are mentioned, but only very cursorily, with but few illustrations.

In Timber, by J. R. Baterden, A.M.I.C., a few of the West African timber trees are described, and a few photographs show how the timber is worked. Their inclusion amongst the South African timbers does not exactly enhance their value or give a true view of their place in the economy of the timber trade.

Wood, by G. S. Boulger, gives an excellent system for classifying woods by using all their various characteristics, such as taste, smell, hardness, structure of the timber, and the various pith rays and other peculiarities. A very complete list of all the various timbers used in commerce is given, together with the various synonyms of each, and the botanical names of each so far as they are known. The uses of the timber and the supplies of each country are given, and in this way it is a most important book of reference for any Forest Officer.

\section{Formstry Generally.}

In Sylviculture in the Tropics, by A. F. Broun, Director of Woods and Forests, Soudan, 1912, some references are made to West African trees. Some very typical photographs of forest vegetation in various parts of the Tropics are very useful, and demonstrate several forest theories far better than pages of words.

A Dictionary of the World's Commercial Products, by J. A. Slater, B.A., LL.B., 1907, is very useful for looking up the lesser known forest products. The descriptions have to be used with discrimina- 
tion, as some of them are rather cursory and no authorities for botanical names are given.

Gold Coast Report of Forests, by Mr. H. N. Thompson, Chief Conservator of Forests, South Nigeria, 1910, is the authoritative work on the Forestry problems of the Gold Coast. Full descriptions of the chief forests are given, together with the important plants and trees found in each. The laws of South Nigeria as modified to suit Gold Coast conditions are also quoted. Forest policy as suitable for this country is given; the different types of forest and their relation to the climatic formations are also mentioned at length. A suitable establishment carrying out these suggestions is laid down. The black-and-white drawings which illustrate this book, especially those of mahogany, are invaluable to either the Forestry student or the timber merchant.

The Oil Palm and its Varieties, by J. H. J. Farquhar, Conservator of Forests, Nigeria, is an interesting and useful preliminary monograph on that most valuable tree. It gives a summary of all the information of the Forest Department on that subject up to that date.

List of Trees, Shrubs and Climbers of the Gold Coast, Ashantee, and North Territories, T. F. Chipp, B.Sc., F.L.S. ; Der Tropenwirt, by Dr. S. Loskin, Hinstorff'sche Verlagsbuchhandlung, Wismar i. U., 1913 ; The Principal Forest Trees, by H. N. Whitford, Ph.D., Bulletin No. 10, Manila Bureau of Printing, 1911, are three useful books.

The Kew Bulletin and the Journal of the Imperial Institute always contain most valuable notes on the botanical and technical qualities of the various African trees and plants.

The Indian Forester, which appears monthly, is a most necessary periodical for every Forest Office or Timber Camp, containing as it does not only original articles on sylvicultural and other forest problems, but also much information on the uses of timbers, similar kinds of which are found here, and thus gives one an indication in what direction to exploit new timbers.

In the Guiana Forest, by Jas. Rodway, is a very readable book on the tropical forest scenery found in Demarara. It is, of course, written in very popular style, but gives one a very good introduction to the tropical forest, showing both by beautiful descriptions and good illustrations what one should observe in these forests. Much tropical scenery is very similar, and therefore, though this book deals with British Guiana, much of it is applicable to West African forests.

Forestry, by Dr. Adam Schwappach, gives a short, concise account of what is included under the term Forestry in Europe. One obtains a clear view of the divisions under which this subject is treated.

The Trees, Shrubs, Herbs and Climbers of Sierra Leone, by C. E. Lane Poole, Government of Sierra Leone, is the most important 


\section{WEST AFRICAN FORESTS AND FORESTRY}

collection of notes yet issued on this subject. It should prove of greatest use to Forest Officers, and to all others interested in the forests and afforestation.

Much useful information has been obtained from the annual Reports on the administration of the Forest Department from the years 1906 to 1913 , more especially from that of 1906 , which practically summarized the results of the Department's work up to that date. Data on Togo are contained in the report of the afforestation of Togo with teak and other African timber trees. This was the result of a long tour in that country made by the author in 1911 . From Sierra Leone much valuable knowledge was acquired as a result of a five months' tour made in 1908-9, and this was embodied in a report which appeared in 1909. Very useful information is contained in the reports by the Conservator of Forests there, which have appeared since. A most extensive account of the forest trees and plants, including the Oil Palm, is given in Les Végétaux utiles de l'Afrique tropicale française, by $\mathrm{M}$. Chevalier, Parts I and II, 1909,1910 (A. Challamel), chiefly in connection with the Irory Coast.

In the Notizblatt of the Berlin Botanical Station are some useful notes on Die Nutz Holzer der Kamerun, 1909. Also in the pamphlets Die Nutz Holzer Togos, Parts I and II. In this manner it is possible to make a comparative study of the timber trees found in the different parts of West Africa. The addition of the native names in most cases is also very valuable. 


\section{INDEX}

Aba, (Tschandjo), 127

Ababele (Appolonian), 96

Abache (Benin), 392

Abadan (Yoruba), 251

Abafe (Yoruba), 298

Abakallki District, 472, 473

Abange (Jaunde), 442

Abare (Yoruba), 340

Abari (Appolonian), 108

Abba, or Abbo Rubber (Lagos), 251

Abbis (Mendi), 441

Abe (Franti), 93 ; A. flts or A. fufu'(Gold Coast), 466 ; A. Obene, 466

Abeletia (A ppolonian), 93.

A beokuta Province, 152, 154, $158,160,236,240,243,246$, $247,249,251,252,259,260$, $262,263,266,269,270,275$, $277,279,280,282,284,286$, 300, $303,306,309,310,313$, 317, 322, 325, 329, 330, 333, $335,336,339,340,342,343$, $\mathbf{3 4 5}, \mathbf{3 4 7}, \mathbf{3 4 8}, \mathbf{3 5 0}, \mathbf{3 5 3}, \mathbf{3 6 2}$, $366,370,371,374,381,383$, $389,391,305,400,401,409$

Abere (Yoruba), 269

Abi or Yar River, 82

Abilu (Trgchandjo), 145

Ablari (Fanti), 107

Abo (Attie), 86, 262, 366 ; (Xoruba), 334; (Eflk), 390 ; A. Asha (Tbaden), 337; A. Idofun (Yoruba), 269; A. jaga (Yoruba), $344 ;$ A. Lakosha (Yoruba), 265; A. oganwo (Yoruba)

Aboboē (Atakpam

Abolo (Benia) 343

Abonnemma (Owerri Province), 477

Abono (Mbonoi), 83

Aborkpor (Benin), 385

Aborpor (Benin), 230

Abragba, 168

Abubube (Gold Cosst), 466

Abue (Egbado, Yoruba), 267

Abugie (Mendi) 57

Abura (Yoruba), 230

Aburese baka (Agni), 89

Aburuhi (Fanti), 88

Abuwe (Yoruba), 326

Acacia, 19, 204, 212, 232, 234 299

Abida, 199 ; (var. saccharata), 191, 208,220

Arabica, 132, 148, 202, 208, 219

Ataxacantha, 301

Benin Rope, 301

Caffra, 220

Campylacantha, 191, 199, 208,

Catechu, 98, 122, 125, 131

de Gabon (Colons), 8

Farnesiana, 300, 418

Forests, 197

macrosthacys, 220

pennata, 299

Senegalengis, 199, 208

Seyal, 198, 199, 208, 220
Acacia-continued. Sieberiana, 98, 191, 199, 201, $202,208,219,220,299$

Suma, 131

Thorny, 220

Whitethorn, 208

Acalypha, 193

Acantha montana, 113, 197

Acanthaceæ, Gold Coast, 113 Nigeria, 194, 197, 401 ?

Acrocephalus polytrichus, 195

Acwang (Bare), 425

Adabi (Yoruba), 400

Adadaś (Ewe), 144

Adadawa (Wassaw), 96

Adani (AkWa), 393

Adansonia digitata, 53, 105, 116, $118,138,190,210,223,347$,

Adder's tongue, 196

Adema or Baba (Ewe), 132

Adenium Honghel, 199

Adenocarpus Mannii, 430

Ade-po (Gold Coast), 466

Adere (Lagos), 367; (Yoruba), 374

Adiatum lunuatum, 196; A. Schweinfurthii, 196

Adi-be (Gold Coast), 466

Adido (Ewe), 138

Adina microcephala, 145, 192 , $214,225,231,232,233$; A. macrophylla, 441

Adja or Adza (Ewe), 137; (Ibo), 228 ; (Ibo, Asaba), 292; Adja tree, 445

Adjonde (Ebrie), 83

Adom (Jaunde), 442

Adowe (Appolonien), 94; A. and Dupain (Aghant-1),

Adua or Aduwa (Hausa), 198, 210

Adube (Fanti), 93

Adudze (Ewe), 135 .

Adugbin (Ibandan, Yoruba), 281 reshe, 225

Adyanyapeso (Tschandjo), 135

Adykúkola (Tschandjo), 129

Adzadze (Ewe), 137

Asgle Barterl, 312

Folanthus, 195

Aeyedi (Quitta), 94

Afano (Twi), 101

Afara (Yoruba), 179, 230, 263, 371

Afe (Yoruba), 233, 262

Affi (Íbadan and Oyo), 248

Affram (Twi), 96; A. River, 98 Afiramomum, 128

Afikpo District, $466,472,473$, 403

Afoforo (Egba) or Abo-fero (Yorubs), 249

Afoma (Mistletoe-like parasite), 170 ; (Yoruba), 246

Aforwa

Africa, British East, 189 ; Forest, Central, 189 ; Forest escape, 175 ; Africa, 293

African (West) Allspice, 374

Apricot (Colons), 88

Barwood, 178

501

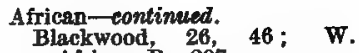
African B., 297

Brazil nuts, 368

Bread fruit, 123, 256

Cabbage Tree, 62; Big leaf C.T., 409

Catechu, 300

Coffee, 63

Copaiba Balsam Tree or Copaivi, 205, 221, 307

Ebony, 192, 214

"Elemi Tree," 221, 315

Elm, 248, 248

Greenheart, $48,153,260$. Light G., 279, 286, 287, $384,416,419$

Indigo, 221

Kapok, 345

Kino, 206

Lignumvita, 446

Lilac, 222

(Wegt) Locust Bean, 207, 282, 283

Mahogany, 20, 120, 135, 149, $175,205,222$; Togo Plan tations of M., 149; Nigeria. 175

(West) Mahogany, 211, 422,

(29, $55,363,462$

Maple, 35

Mistletoe, 259

Myrm, 198, 211

Oak, 26, 27, $32,42,51,54$ $67,70,75,77,86,179,200$ $253,255,342,356,358$, 403

Padowk, 273, 274

Palm, 236

Pearwood, 28, 29, 57, 67, 68, 375

Pepper, 219

Rosewood, 31, 84, 221, 273, 299

Rubber tree, 58, 68, 395

Satinwood, 371; Dry Zone Satinwood, 309, 311

Star apple, 58, 69, 381

Strychnos Tree, 389

Teak (English name), 86, 253, 256 ; small-fruited, 256

(West) Timbers, 293

(West) Timbers, 293

Tragacantha, 5

Tilip tree, 400 , 46

Violetwood, 26, 46 $101,177,328$ : West Africen W., 178, 293, 328, 445, 446 Whitewood, 418

Wisteria, 302

Wood-oll nut, 163, 332, 333 418

Yellow wood, 259

Afrormosia elata, 271, 352 ; A. laxiffora, 66, 73, 97, 110 $158,191,201,202,221$, 230,251 ; A. 8p., 219

Afzelia, 19, 117, 124, 125, 132 , 290,450 ; Ćalabar A., 291 ; Forest A., 291 


\section{WEST AFRICAN FORESTS AND FORESTRY}

Afzelia-continued.

Africans (Rhodegian Mahogany), 17, 26, 47, 97, 117, $118,120,121,159$, 179, 190 ' $191,202,205,220,229,271$, $290,291,292,418,422,430$ 445,446

bella, 291

bracteata, 47, 67, 292

Brownei, 97

Cuanzensig, 290, 291

fastigata, 97

(Kontah), 32

microcarpa, 82, 84

Nov. 8p., 291

pachyloba, 291, 416, 419

red-arilled, 290

sp., 47, 290

Zeñkeri, 430, 417

Aga (Yorubs), 233 of Agbawo, 252

Agan Aparo (Yoruba), 408

Aganokwi (Benin), 17, 375, 378 ; A. No. I, 376

Agave rigida, 117 ; A. Sisalana, 128

Agba, 159 ; A. of the Benis, 229 ; (Ikale, Benin), 304 353 ; (West Side), $\mathbf{3 6 1}$, 393

Agbana (Ewe), 129

Agbara (Ikale), 278

Agbarin (Yoruba), 299

Agbede, 298

Agberibede (Yoruba), 232 ; Agberigeddi, 277

Agboin (Yoruba), 229, 279

Agbon (Benin), 244

Agedegbo (Benin), 260, 263

Agege (Yorubs), 396 ; Yoruba Country, 39

Agelpa obliqua, 96, 196

Agerantum conzoides, 194

Aggan Egbo (Egba), 383

Aghaghe (Yorubs), 267

Aghako (Y oruba), 262

Agiekpogo (Benin), 325

Agmiere (Ebrie), 83

Agnon (A be), 83

Ago (Quitta, Krepi, Accra), 93

Agoma (Benin), 381

Agome Mts., 1.48

Agriculturai Chemistry, by Johnson and Cameron, 483

Agricultural college, E. and W. Scotland, 48

Agricultural land fixed by the older civilized countries, 485

Agricultural Society of England, Royal, 483

Agu (Togo), 477 ; A. Plantation. 469 ; A. Valley, 125

Aguana (Benin), 400

Aguaya (Ebrie), 86

Agui (Ebrie), 8 s

Agumua (Tsehandjo), 132

Agutesi (Krepl), 105

Aguwa, 198

Ahedua (Twi) 97

Ahoada District, 173, 255, 472

Ahon or Ahun (Yoruba), 231, 390

Ai-da (Yoruba, cf. Kalango daji and Bandan Mayu, 220

Alko (Yorubs), 235

Aini (Egba), 394

Ainyere (Appolonian), 100

Ainyesan (Berin), 230

Aiomiti (Kirikir), 141

Ain (Krepi) 94

Aiveygbo (Egbado, Yoruba), 335

Alye (Ondo), 230; (Yoruba), 267

Aiyeni (Egbado, Benin), 267 Aiyo (Egba), 249 ; (Yoruba).

Aja-igi or Ajs-iji (Yoruba), 229, 286

Ajama (Krepi), 95 ; (West Coast), 05
Ajasso Reserve, 160

jia (Yoruba), 278 ; Asaba), 281

(To Akwankusuma (Fanti), 85

Akwantanuro (Fanti), 101

Akwarri (Ibo, Asaba), 39

Akwekwe (Benin), 31

Ala (Ewe), 127

Ajumkobi (ABhanti),

Ajurlo (Krepi), 103 Ishin, 340

Akak (Timani), 46

Akaka (Jaunde), 442

Akala (Yoruba), 382

Akapano (Benin), 407

Alkara (Atakpame), 141

Alkassa (Warri Province), 410 Akata (Twi, Denkira), 105 ;

Akbo (Ibo, Agaba), 345

Akboro (Benin), 419

Ake or Akhe (Mbonol), 83 : (Atakpame), 146 ; (Benin), 392

Akede (Abe), 83

Akee (Tree), 61, 69, 76; $A$. Apple, 222, 341; Bush A.,

khuro (seed, Benin), 298

Aki (Asante), 137

Akika or Aka, 338, 340

Akiko or Agliko (Atakpame), 136

Akilla Timber Workg, 160

Akinale ('Tschandjo), 144

Akinrankiri (Benin), 257

Akion (Ebrie), 83

Akiti (Ibo Owerri), 336

Akiye or Akwiye (seeds), 220

Akkihien (Benin), 295

Akkun (Yoruba), 339, 340

Aklo (Anecho), 133

Ako (Benin) 260, 263 ; (Yoruba) $179,229,236,270,277,315$, $330,366,375,489$; A. bolobolo (Yoruba) 344 A. gbogbonshe, $264 ; A$. Idofun (Yorubs), 269 ; A.(Y), 233, 395

Akodiombi or Zakueblembi (Attie), 88

Akodo (Mbonol), 85

Akoima (Agnt), 88

Akoko (Benin), 350 ; (Yoruba), 401

Akokotsua (Fanti), 88

Akomu (Yoruba), 231, 266

Akondog (Jaunde), 442

Akoriko (Yoruba), 23

Akoribe (Indenie), 88

Akosica (Abe), 88

Akoso (Benin), 372

Akotompo (Fanti), 84

Akpaboyo Rosd, 469

Akpakpa (Ibo), 229

Akpakossa (Benin), 406

Akpakpla (Anago), 139

Akpaku (Ibo, Asaba), 328

Akpanagya (Benin), 272 ; Akpan Etuldiwi (EAk), 274

Akpanya (Efik), 277, 278

Akpe (Ibo), 231

Akplê or Loloẽ (Ewe), 138

Akpo, 413

Akpoklo or Bofuti (Ewe), 198

Akposso, 131

Akronkron (Accra), 105

Aku (Atakpame), 136 ; Akus, 61

Akuana (Agni), 85

Akukan (Ouitta) (Krepi), 103

Akukobagn (Ewe), 146

Akumasse (Fanti), 86, 87

Akume (Benin), 273, 311

Akun (Yorubs), 231

Akuosi, Ambt (Fanti), 85

Akure Province, 322

"Akushi " (native bagin), 212

Akughunmajadin (Iksle), 285

Akwabohorl (Fanti), 100

Alrwabu (Mbonol) 85

Akwafeye District, 415, 416, 410 : A. River, 151, 162

Alsbeta Province, 275

Alade (Irale), 285

Ali (Timani), 46 A. Tree, 421
Alabata (Átakpame), 131

labenum, 87

Alafe (Ewe), 134

Alsfia Landolphioides, 395

Alale (Hausa), 222, 228, 229

Alambo, 219, 221

Alangiacea (Cameroong), 438

Alangium hegonifolium, 438

Alapari (Yoruba), 312

Alasko, 263

Alati (Quitta, Krepi), 93

Alayafu, 195

Albert Lake, 189 , 73, 125, 172. $293,294,295$

Albruana, 9

Amara, 148

Angolensis, 08, 131

Boji, 290

Brownil, 48, 78, 98, 163, 175 .

$178,229,293,294,296$

Cergalpinia, 123

Chevalieri, 191, 199, 208

fastigata, $48,73,84,98,131$ $229,293,294,296$

ferruginea, 84

Iebbek, 29, 175

rhombifolia, 84, 295

sp. $73,293,294,295,296,418$ wipulata, 148 ; A. Wel-
witchil, 429

Alchornea cordata, 197, 203. 204 ; A. cordifolia, 136 . 434 ; A. tloribunda, 434 ;

Alembole (Tschandjo), 139

Alensmeku (Atakpame), 138

Alepo (Yoruba), 325

Aleurites Moluccana, 421

Aligna (Benin), 79; A. (or Adya), 229, 282, 200, 291,

Alikongeba (Yoruba), 419

Aliliba or aliliba, 215, 224, 230

Alinyan (Benin), 301

Alismatacem (Nigeria), 195

Allahbanunu (Agni), 88

Alanblackis forlbunda, 55, 107. 363,461 ; A. parviflore

Allerle (Benin), 396

Alligator apple, 71,262

Allophyllus Africana, 76, 137

Almeldina, 277

Almond Tree, $122 ; A$. wood (Coula edulis), 33 ; Indian

Alobla (Kpedyi), 134

Alode (Benin), 413

Aloe Barteri, 128, 195 ; 4.

Alofin (Jebu), 230

Alongua (Bondoukou), 89

Alsodeia, sp., 55, 108

Alstonia Congensis, 26, 58, 88. $111,119,143,231,390,419$, 440

Alu (Ewe) 135

Alukon raba (Yoruba), 230

Alum bark, 61

Amaké (Iwe), 146

Amaranthaces (Nigeria), 195

Amaranthus caudatus, 195 ; A. viridis, 195

Amaryllidaces (Togo), 128 ; (Nigeris)

Ameliki (Timani), 62

Amellaky (or Egbessye of $S$. Leone) (Benin), 401

Ameme (Benin), 252
Amerere (Agni), 85, 88 
America (8.), 185 ; A. exotics, 175 ; A." "whitewood," 260 Amhio (Boridoukou), 87

Amizi Agni, 84

Ammannia Senegalenais, 192

Amorphophallus Barteri, 185 ; A. dracontioides, 196

Amoyin (Egba) 289

Ampelidex (Nigeria), 193, 197.

Ampelocissus, 193

Amphiblemma polyneuron, 438

Amu-atí (Ewe), $144 ; A$. Ne (New Calabar), 361

Amuan (Attie), 85

Ana River (Togo), 117

Anacardiacex (S. Leone), 52 ; (Liberia), 75; (Ivory Cosst), 86; (Gold Coast), 103 ; (Togo), 136 ; (Nigeria), 191, $196,198,212,222,338,459$; (Cameroons), 434

Anacardium occidentale, 136, 222,338 ; A. sp., 340

Anaküe (Mbonoi), 84

Anamolum (Tschandjo), 130

Anamomila or Anamomilla (Benin), 226, 228, 412

Ananas, 127

Anane (Axim), 107

Anaphe Moloneyi (Wild silkworm), 206 ; A. sp., 207,

Anasphrenium, 191

Anchi (Fanti), 101

Anchomanes Dalzielii, 196

Ancistrophyllum, 70; A. sp., 93

Andira inermis, 134

Andoni River, 151

Andropogon apricus, 201 ; A. Gayensis, 201 ; $A$. sorghum,

Andropogonea, 196, 199

Andropogoneæ, 196, 199 . A. sinicum, 195

Anglo-French saw-mills, 159

Anglocalyx ramifiorus, 29

Angowma, 422

Angular pod, 284

Anikantuhu (Yoruba), $\mathbf{3 1 5}$

Anikiba (Benin), 407

Anisophyllea laurina, 54

Ankent (Timani) 41

Ankump (Timani), 41

Annanoa bracteata, 51

Annatto (orange dye), 364

Anogeissus, 56 ; A. leiocarpus, $108,120,123,140,167,179$, 192, 212, 223, 232, 234, 373, 489 ; A. 8p., 88

Anona, 342 ; A. afzelii, 263 ; A. Mannii, 263 ; A. muricata, 71 ; A. palustris, 71, 95, 262 A. painstris, 71, 95, 190, 201, 202, 219, 262 ; A. sp., 130

Anonacem (S. Leone), 43 ; (Liberia) 71 ; (Ivory Cosst), (Togo), 129 ; (Nigeria), 190; $196,219,259,457$

Anopris ealanis, 108

Anselifa, 201 ; A. Congoensis, 105

Ansophyllea laurina (monkey apple), 33

Ant Trees (Musimba), 487

Anthericum, 195

Anthocleista Kerstingi, 142 ; A. magnifica, 110 ; $\frac{\mathrm{A}}{\text {. }}$ $224 ; A$. parvifiors, 58 , 224 ; A. sp., 110 ; A. Vogelii, 197, 224

Antholyza Zenkeri, 425

Anthostema Senegalense, 51

Antiaris, 70, 249 ; A. Africana, 95,129 ; A. 8 p., 95, 250 ; A. toxiaria, $83,129,231$,
250,426
Antidesma anbryanthum, 103 ; A. lacinatum, 51, 103, 434 : A. ${ }^{\text {Bp. }}$ 336 ; A. venosum, District, 392 ; A. River, Anyan (Eflk), 229

Anyeran (Benin), 158, 271, 352

Anyesan (Benin), 271

Anyl (Anago), 140

Anyo, 391

Anyolo (Timani), 60

Apa (Rhodesian Mahogany) 120, 159; (African Oak, 292; A. oro (Yoruba'), 389, 292 ; A. oro (Yoruba), 380,

Apado (Yoruba), 230, 449 ; (Abeolcuta), 281

Apagban (Yoruba), 269

Apakka (Anago), 132

Apapa (near Lagos), 481; A. Saw mill, 159, 160

Apapo (Yoruba), 302

Apara (Yoruba), 178, 231, 303

Apassa, 159 ; (Eflk), 229, 379

pata, 336, 343, 379

Ape (Attie), 87

Apepe (Yoruba), 231, 273

Aphania, 10

Aphanocalyx 8p., 84

Aplko (Yoruba), 344

Apobo (Jekri, Ijor), 326

Apocynacex (S. Ieone), 58 ; (Liberia), 78 ; Ivory Coast, 88 ; (Gold Coast), 110 ; (Togo), 142 ; (Nigeria), 192, 197 , $190,224,390,394,459$.

(Cameroons), 440

Apodytes Beninensis, 104

Apokpo (Anecho), 138 Appapayi or Wausauwah (Twi),

Apple tree compared with Fagara, 134

Appolonia, 95 ; Appolonians, 109 Apukur (Mbonoi), 88

A purro (Twi), 101

Aqua egbua (Agni), 88

Ara (Yoruba), 231, 273

Arab, 217

Araba (Yoraba), 231, 345, 346

Arabmetu (Adionkron), 84

Arac Palm, 244

Arachi (Ibo, Asaba), 275, 292

Arachis hypogea, 192

Aragbaihi (Benin), 401

Arajon, 445, 446

Arakpa (Benin), 275

Irallaces (S. Teone), 56 (Togo), 140 ; (Nigeria), 192 213, 224, 375 ; (Cameroons).

Aramoho (Benin), 400

Aranhe (Mhonoi), 85

Ararabi (Hausa), 221

Arasa (Yoruba), 337

Arasha (Ondo), 935

Areca catechu, 177

Arenga saccharifera, 177

Arere (Appolonian), 93 ; A. Tree, 153, 178; (Yoruba). $230,351,352$

Argemone Mexicana, 193

Argentine, 491

Aridan (Yoruba), 231, 284 ; A. Abatta, 28

Aril, yellow, 291

Aristida, 196, 202

Aristolochia alba, 185

Aristolochiaces (Nigeria), 195

Arobs (Mbonoi) 84

Aro Boro (Yoruba), 303

Arold, 197

Aroidem (Nigeria), 195

Arojoku (Yoruba), 400

Aroto (Onitsha Province), 297

Aroro (Benin), 335; (Yoruba), 336
Arquane (Mbonoi), 88

Arrow-poison climber, 192

Artabotrys sp., 264

Artocarpus incisa, 122, 148,

Arugbo, 412

Arundo donax, 201

Asa bogilie (Agni), 86 ; A. Gidi, 338

Asaba District, 189, 266, 353, $391,392,393,395$

Asama (Mbonoi), 85

Asana (Yoruba), 288, 330

Asclepladacen (S. Leone), 59 : (Gold Cosst), 112 :' (Nigeria), 192, 199

Asclepias lineolata, 192

Ase (Jaunde), 442

Asemignirl (Mbonol), 84

Ash (European), 316

Asha (Yoruba), 385; (Oudo), 335; (Ibadon), 337 ; A omode (Yornb8), 331 ; A. ragha (Yoruba), $\mathbf{3 3 5}$

Ashanti, 95: A. natives, 105 : Ashanti Report (Gold Coast and Northern Territory) by Mr. H. N. Thompson. by Mr. H. N. Thompson, Ashasha of the Yorubas, 231,

Ashuwole (Yoruba), 278

Asis, 185

Asihue (Atakpame), 131

Askale (Ikale), 304

Asofeyeje (Yoruba), 393

Asogedaka (Atakpame), 136

$A-909-\theta-J u b, 470$

Asokoru Appolinian, 102

Asologun (musical instrument), wood of Alstonia, 391

Asoma (Franti), 102

Asparagus Pauli-Gullelmi (Tree), 42,195

Aspldosperma Quebracho, 123. 124,148

Aspilla, 194

Asre (Yoruba, Egbado), $\mathbf{3 0 4}$

Asses bread, 435

Assi (Benin), 335

Assithato (Agni), 85

Assinie River and Town, 81 82

Assivi (Benin), 335

Assomah (Twi), 102

Assoro (Twi), 109

Assun (Bentn), 407

Astragalus gummifer, 54

Astrochlæna, 194

Asuaindokun (Aowin), 107

Asukole (Ikale), 304

Asunwon (Yoruba) 270

Aswen (Benin), 288

Asytasia Coromandeliana, 197

Ata (Anago), 134; (Yoruba) $232,233,309 ; A$. frifridi (Ibo, Agabs), 395

Atake (Ibo, Asaba), 303 ; Ata kapuresossi (T's chandjo). 130

Atakpame, 117, 122, 123, 131,

Atakpati (Atakpame), 135

Atakpla (Atakpame), 132

Atswa (Aghanti), 103

Atawah or Altawah (Twi), 97

Atidje (Atakpame), 135

Atikuze (Ewe), 131

Atillis (Hausa), 22

Atisio (EwO), 136

Atite (Ewe), 133

Atiyi (Ewe), 134

Atolale (Mboni), 8

Atont (THmani)

Atore (Fflk) 325

Atori (Oban, Ekol), 323 ; Yoruba), 324

Atropa Belladonna, 488

Atsan (Attie), 83 


\section{WEST AFRICAN FORESTS AND FORESTRY}

Atta (Eflk), 260, 363 Attagbo (Yorubs), 301 ; (Benin), 910

Attagura, 218

Attan (Benin), 408

Attenli (Aowin),

Atwen (Monol, 83

Atwon (Aons), 83

Au River (Togo), 117

Abrya Gabunsis, 308

Augor (Benin), 179, 235, 236

Augwameatee (Aowin), 97

Auro (Yoraba), 312

Ause (Yoruba), 265

Austria-Hungary, 492

A sstrian Markets, 325, 326

Autopoi (Tbo, Aksba), 392

Auwolo (Akposso), 132, 138

Avenya (Ewe) 147

Avicennia Africana, 60, 113, 144, 234,397 ; (allied to $A$. 234, 397; (alled to A. tosa, 440

Avogola or Awogolu (Ewe),

Awa (Attie) 87

Awabima (Twi), 106

A wasse (Abe), 87

Awaw District, 394 ; A. (Yoruba), 297 ; (Benin), 297

A we (Yoruba), 331, 337

Awenu (Yoruba) 287

Awesu (Jekri), 228

Awessu (Jekri), 402

Awewe (Yoruba), 342

Awewi (Lagos, Yoruba), 288

Awigbi (Benin), 358

Awin (Ib.), 288

Awipu (Benin), 299

Awka Plantation, 167

Awoa (Yoruba), 266

Awolo (Atakpame), 136

A wong (Jaunde) 442

Awow (Benin), 297

Awowo, 465

A wraw (Egbado), 347

Awshun, 170

Awun (Yorubs), 231, 390

Axim Forests, 17

Aya, 196 . Aya Aya, 196

Ayagdo (Yoruba), 400

Aye (Yoruba), 256

Ayeye (Yoruba), 408

A yibukpo (Eflk), 292

Ayin (Yoruba), 179, 232, 271, 373,489

Ayinre (YorubB) 178, 294, 295 Ayinre Ayinre (Yoruba) 296 ; A bonabona (Yoruba), 228, 294 ; A. eta (Egba, Yoruba), 293, 295; A. ogo, 293, 295; Ayinretts (Yoruba), 296

Ayo (Yoruba), 370

Ayobo-Osuke Road, 297

Azimommon (Benin), 339

Azodo (Abe), 87

Ba-fini, 233 ; Ba-jini, syn. Jinajina (Bok. and Zanf.), 219 ; Ba-reshe, 225 ; Ba-ruwang, By. Ranfare (Katagum), syn. Rai dore, 220

Baba (Ewe), 182 ), 18

"Babool," Indian, 208

Baboon Kola, 54

Babu (Yoruba), 266

Baccaurea Bonneti, 86

Bada, 193

Badagri, Trading Station, 151

Badagry, 465; Badagry District, 264

Bagarumar makka (Sok.), 210

Bagarwa (Hausa), 208, 219

Bagi (Mendi), 56

Bago, River, 48

Baka-biringui (Abe), 80
Bakahehessi (Agni), 85

Bakana (Port), 152

Bakasa (Attie), 88

Bakau (Fanti), 83

Bakbabol (Mendi), 48

Bakbwi, or Bpakpei (Mendi),

Baldesu (Atakpame), 134

Bakin makarfo, 220

Bakossi Road, 417; B. Forest,

B]̄kú (Trchandjo), 183

Bakum (Timani), 55

Bakundu Natives, 417

Balg (Afem), 136

Balakenta (Timani), 48

Balang (musical instrument),

Balanites Egyptica, 198, 210, 453

Balanophorace» (Nigeria), 197

Balata (rubber), 70, 252

Bale (Yoruba), 31

Baledia or Welengele (Tschandjo), 130

Balong natives, 378, 417

Balsam Copaiba Tree, 97, 154, 205, 231, 307; B. apple, $B$ of Tolu, 316 ; B. Tree, 221

Balsamodendron Africanum, 198, 211 B B. pedunculatum, 188

Balsam 6dendron myrrha, 221

Balua (Attie), 89 ; Balua (Rosewood), 31

Balui (Mendi) 41

Bambi (Mendi), 41

Bamboos, 90 ; B. palm, 195, 216. 218 ; B. sp., 93, 117, 122 ,

Bambus, 199

Bambuto Mts., 487

Bamenda District, 415

Bana (Attie), 83

Bananas, wild, 128,147

Bandana River, 8

Bandonge (Duala), 440

Bang (Duala), 425

Banuke or Nje (Duala), 427

Brobab, 53, 105, 116, 118, 190, $207,209,223,347,435$

aphia, 430; B. Barombiensis, 430 ; B. nitida (Camwood), $31,73,84,99,133,197,204$, $232,287,288$; B. polygalacere, $48,232,288$; $\mathrm{B}$. pubescens, $73,197,221$. purescens,' 73 , 198

Bar nagoda (Hauga), 221

Barā (Tschandjo) 145

Barabutu (Hausa), 218

Barambo (Gobir), 210 Barbaji syn. Tsibra or Tsura
(Sok.) 225

Bariba or Biribi (Abo), 85

Barijuko, 189

Bark Bugs, 436 ; Bark exported, 444; Bark fibre, 128, 142

Baro, 189

Baro Kano Line, 159

Barteria aromatice, 437; B. fistulog8 437

Barth, Dr., 198, 206, 207

Barwood or Nigerian Camwood, $31,34,35,158,229,273,417$

Basamu (Sok. and Zanf.), 221

Basel Mission Timber Works, 443

Bassa-basaa (Benln), 232

Bagcam, 428

Bassarl' (Togo), 117, 124 ; B. Savannah, 140, 143, 468

Batabue (Agni), 87

Batanga District, 420

Batwi (Mendi), 4

Bauchi (Highiands), 188, 100, 200,204

Baugbaningbamu (Tschandjo),
Banhinfa, 30, 169; B. Dry Zone, 298 ; B. Krughil, 148 ; B. reticulats, 97,117 , $133,191,201,207,252$, 298; B. rufescens, 191, 201 , 298

Bauji (E. Hausa), syn. Fara Raya, 219

Baulan Bolo (Degema, Calabar), 363

Bauren 1adama; Bauren rafi, (Hausa), 218

Bauri (Hausa), 129

Baushe (Hausa), 192, 212, 222

Baut I. Timanl, 47

Bawie (Hausa), 198, 216, 218

Baya (Twi Kowin), 113

Bayama (Kontagora), syn. Gwazkiya, 220

Baywood, 20 , 211 ; Banzano (Kano and Zaria), 221

Bead Head, 222; B. Tree, 331

Beari (Mendi), 57

Bebeti (Moyen Cavally), 89

Beckindanko (Hausa), 111, 393

eckwith, Mr. $\mathbf{H}$. (depericarping process), 477

Beech, 325: B. compared with Gum Copal, 36

Beef-T'ree, Australian, 174

Reeswax, 226, 444

Befun people, 467

Begnania (rostrats), 197

Belbolei (Mendi), 53

Bek (Timani), 49

Belengbe (Kratschi), 139

Belgian Congo, 423, 424

Belvi (Mendi), 43

Bembe (Bambara), 87

Bembedo (Yoruba), 270

Bembu (Mangu), 13

Ben (seeds), 453

Bēnature (Mangu) 136

Bende, 19 ; B. noso (Tschandjo). 130

Bendiguri (Mendi), 47

Bendwi or Bunduei (Mendi), 48

enin, 153, 178, 236, 238, 240 $243,245,246,247,249,250$, $251,252,253,254,256,257$, $258,260,263,264,269,271$, 273 , 276, 278, 279, 282, 284, $288,289,291,297,306,310$, $\mathbf{3 1 7}, \mathbf{3 2 4}, \mathbf{3 2 7}, \mathbf{3 2 9}, \mathbf{3 3 0}, \mathbf{3 3 3}$ $342,343,347,348,350,367$ $376,381,390,393$ : $B$ arboIetum, 177, 178, 243; $\mathbf{B}$. cane or rattan, 240 ; B. City 166, 175, 304; B Frosts, $19,168,292$; $B$. langugge, 185 ; B. market, 313 ; B. natives and people, 163 , $164,243,246,249,260,264$. 268, 278, 287, 298, 301; $\mathbf{B}$ (North), 154, 158 ; $B$ nut, 258; 1 . Pear

Benitl (Agome), 131

Bentpod, 290, 307

Benué kegion, 212, 215; $B$. Ruver, 188, 189, 203, 204, 207

Beri (Mendi), 48

Berlinia, 19, 298

Berlinia acuminata, 47, 84, 99 $119,133,191,230,281,282$ $290,418,429,449$; $B$ auriculata, 68, $90,280,289$ 420 ; B. Hendelotians, 47 . 99, 182, 197, 204; B. Keratingil, 117, 118, 123, 133 ; B. sp. 416 ; B. sp. 133 ; B. sp. 416 ; B. 8p. B. tormentosa, 138; B. of the Waterside, 292

Berrya ammomilla, 176, 421

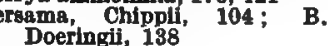


Bersama Paullinioides, 53 Bertiera glabrata, 61 Bessi, 44; B. (Ashanti), 106 : B. K pessei, 44

Betel nut palm, 177 Beteng (Aowin), 93 Betu oil or tree, $210, \mathbf{4 5 3}, \mathbf{4 5 4}$ Beurre de Karité, 90

Bewa or Mano River, 69

Bewe-Bauban (Mendi), 52

Bibiabe (Attie), 86

BIBLTOGR PHY OF W Forests, 406-500

Ayricultural and Forest Products of British West Africa by G. C. Dudreon, DirectorGeneral of Agriculture in Egypt, 498

Bulletin (Kero), 497-499

Bulletin of Miscellaneous Information, 497

Bulletin of the Imperial Imsti tute, ed. by Sir W. Dunstan 497

Catalogue of Plants collected by $\mathrm{Mr}$. and Mrs. Talbot in the Oban Distriet, South Nigeris, 497

Der Tropenwirt, by Dr. S. Ioskin, 499

Dictionary of the World's Commercial Products, by J.A. Slater, B.A., LL.B.

Die Blutenpflanzen Afrikas, by Franz Thonner, 497 Forestry, by 'Dr. Adam
Schwappach, 499

Forestry in West Africa, by $\mathrm{Bi}$ Alfred Maloney, 496

Glossary of Botanic Terms, by D. G. Jackson, 496

Gold Coast Report of Forests by H. N. Thompson, Chief Congervator of Foresta, Sonth Nigeria, 499

In the Guiana Forest, by Jas. Rodway, 499

Journal of an Expedition to Explore the Course and Termination of the Niger. 496

Journal of the Imperial Institute, 499

Kulturgevadchse int Deutschen Kolonien, by $\mathbf{R}$. Sadebeck,

Les végétaux utiles de l'Afrique tropicale franpaise, by $\mathbf{M}$. Chevalier, 500

List of Trees, Shrubs and Climbers of the Gold Coast Ashantee and Northern Territories, by T. F. Chipp, B.Se., F.L.S., 499

Monographien der Pfanzen-

familien, 8 vols. by Dr. Adolf Engler, 496-497

I. Moraces, excluding Ficus.

II. Melastomaceæ.

III. Combretace Combretum.

IV. Combretacer, excluding Combretum

V. Sterculiaces.

vi. Anonacez.

VII. Strophanthus

VIII. Sapotacem.

Notes on Nigerian Trees and Plants, by E. W. Foster, 497

Notizblatt of the Berlin Botonical Station, containing notes on "Die Nutz Holzer der Kamerun," 500

Pamphlets on Die Nutz Holzer Togos, 500

Sullabus der Pflanzenfamilien. by $\mathrm{Dr}$. Adolf Engler, 498
Bibliography or Whet ATRICAN Fon

Sylvioulture in the Tropies, by A. F. Broun, Director of Woods and Forests, Soudan, 498

Text Book of Botany, by Strasburger, 498

The Indian Forester, 499

The Oil Palm and its Varieties,

by J. H. J. Farquhar, Conservator of Forests, (Nigeris), 499

The Principal Forest Trees, by H. W. Whitford, Ph.D., 490

The Timbers of Commerce and

their Identification, by Herbert Stone, T.I.S., F.R.C.I., 498

The Trees, Shrubs, Herbs and Climbers of $\mathbf{S}$. Leone, by C. E. Lane Poole, 499

The Oreful Plants of Nigeria 497

Timber, by J. R. Baterden, A.M.I.C., 498

Wood, by G. S. Boulger, 498

Bignoniaces (S. Leone) 60 ; (Liberia), 79; (Ivory Coast), 89 ; (Gold Coast), 113 ; (Togo), 144 ; (Nigeria), 192 ; (Cameroons), 441

Bijaje (Frausa), 218

Bllinge (Yoruba), 290, 292 445 ; Benin Bslinga, 292 $417,418,422,445,446$

Bimbi District, 42

Bimbwa, 445, 446

Bingeria Africana, 86

Biophytum sensitivum, 193

Biota trees, 420

Biplndi District, 426, 427, 428, $429,430,431,434,438,439$

440,441
Bishiyapl, or Bishiyoyi generic (Hausa), 218

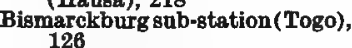

Bisababoko (Attie), 87

Bigsimi (Mendi), 50

Bitter Bark, 415; B. Kola, 55, 77 ; B. Leaf, 409; Bitter tomato, 194

Biunwe (Twi) 07

Bixa orellana, 122, 365

Biracea or Bixinex (Nigeria) $190,196,365$

Black Tumbler, 47, 73

Blackwater Plant, 270

Blackwood, 26, 46; B. African W. 297; B. Benin N., 297 ; B' Indian, 386 Yoruba Blackwood, 298

Blepharis, 194

Blighia sapida, $61,69,76,87$, $104,137,106,222,229,341$ 342 ; B. sp., 342,343

"Blínd" wood or Kapok, 345

Blita Resthouse (Togo), 117

Blood Plum of Sierra Leone, 136

Bloodwood, 221

Blue dye, 407

Bo, 39 ; B. (Balong), 428

Boa (Bakundu) 428

Boanda (Buea district), 434, 436

Bobai (Duala), 429

Bobang (Balong), 425

Bobania Duala, 428

Bobbyboya Water (Timani), 57

Bobby water, or Benin Mahogany, 78

Bobe ba ndiko (Bakundu), 433

Bobolo (Malimba), 430

Bodekadun (Yoruba), 395

Bodgel (Mendi), 47

Bcombe (Bakundu), 426

Bofelei (Mendi), 50

Bofu (Fanti), 84
Bogi or Gbojei (Mendf), 52, 60

Bogo zage (Zanfau), 220

Boglie (Agmi), 83

Boi (Mendi), 50 , 367

Boisima (Agni), 89

Boji, 311; B. Albizzia, 290 . B. Hills, 18, 154, 290, 311, 385,493

Boka or Boko (Bakundu),433,496

Bokata (Bakunda), 428

Bokeku (Duala), 426

Bokombo (Bakundu), 426

Bokome (Bakundu, Bafo), 438

Bokondo (Duala), 427

Boko-pupa (Yoruba), 344

Bokuk (Balong), 440; B. ba mhale (Duala), 440 ; $B$. (Etam), 432

Bolcnkulende (Bakossi), 426

Bokumia (Bakundu), 426

Bola (Bakundu), 440

Bolo (Ijaw and Brass), 230

Bolobolo, 345 ; B. fibre, 345

Bolondo (Duala), 428

Bolugila (Mangu), 138

Bomba (Duala), 440

Bombacacer (Cameroons), 435 ; (Gold Coast), 105 ; (Ivory Coast), 87 ; (Liberla), 76 ; (Nigeria), 223, 346 ; (Bje

Bombax, 231, 445, 446; B. brevicuspe, $105 ;$ B. Buonopozense, $53,76,87,105,138$ $190,196,209,223,345,435$; B. Bp., 105, 346

Bombay Blackwood, 176

Bombay cotton seed, 480

Bomoku (Agni), 85

Bon (Attie), 85

Bonabona (Yoruba), 178

Bongani (Mendi), 53

Bongele or Bopum ba nj (Duala), 435

Bongongi (Bakundu), 428 . (Duala), 428 ; '(Sanagá River), 428

Bongossi (Duala), 415, 436, 445,446

Bonjabi (Bakundu), 438

Bonni (Yoruba), 300

Bonny River, 151

Bōnugu (Mísahöhe), 140

Bonwula or Woula (Duala), 426

Bonyurome (Mbonoi), 86

Bonza (Bambara), 8

Booni (Mendi), 54

Boottia Abysaintca, 195

Bopalo or Bololo (Baktundu), 427,432

Bopanda (Bafo) or Bopende (Bakundu), 427

Bope (Bafo), 431 ; (Duala), 427 Bopek (Balong), 431

Bopolo polo (Duala), 440, 442

Borassus Afthiopium, 70, 93, 233; B., var. \& thioplum. $195,216,218,243$; $B$. or Bottle Palm), 30, 41, 70, or Bottle Palm), 39, 41, 70,
$83,98,117,122,127,195,450$ Borbor, 74

Borepore (Agni), 86

Borer attacks on Anogeissus, 374; on Dalbergia, 175 ; on Diospyros, 385; on any (Ieading Shoot Borer) 167, 175 ; on Terminalia, 56

Borgu Province, 300, 453

Bornu, 190, 198, 206, 207, 209 214,215

Boro (Yoruba), 302

Borraginacen (sometimes Borsginem) (Sierra Leone) 50 : (Gold Coast), 112; (Togo), 143 ; (Nigeria), 192, 215, 224, 396 ; Cameroons, 440 


\section{WEST AFRICAN FORESTS AND FORESTRY}

Borri-borri (Yoruba), 287

Bosambai (Jaunde) Bosambe (Bakundu), 427,

Bosav (Bakundu), or 820 (Duala), 432

Boscia, 190, 198 ; B. Senegalensis, 198

Bosenge (Duala), 426

Bosipi (Duala), 42

Bosole (Bondoukou), 84

Bossi ( $T$ wi), 101

Boswellia Dakrielif, 191, 210, $221 ;$ B. Klaineana, 100 ; B. odorata, 191, 22

Botapia (Attie), 87

Bottle gourd, 193 ; Bottle palm, 39

Botuba (Bafo), 432

Boundary Tree, 245

Bowasa (Duala) 442

Bowiwasi (Fanti) 97

Bowiwnus (T'wi) or

Bowstring Hemp, 127, 128

Boxwood, 58, 79, 176, 394 compared with Cratmva religiosa, 130 ; False B., 391

Boye (Mendi), 44

Brachystegia, 47 ; $B$. cynometroldes, 416,$430 ; \mathrm{B}$. spic:ormis, 68, 119, 229, 277,449

Brakrauku (Asante), 141

Brass District, 240, 405, 406 ; B. language, 185 ; $B$; natives, 358 ; $B$. Port, 151 B. River, $15 i$

Brazil nut, 368,450

Bread fruit, 122, 138, 218

Bridelia atrovirides, 103, 335 ; B. ferruginea, 51, 103, 193, 202 ; B. macrocarpa, 434 ; B. micrantha, 51, 102, 335 B. scleroneurs, 193; B. speciosa, 86 ; $B$. Btenocarpa, 335, 417, 438 ; $\mathbf{B}$. Zenkeri, 335

Brimstone, 31, 32, 60, 69 ; Bush B. 61,$79 ; \mathbf{B}$. Wood, 405

Bristol Port prepared to try Palm kernels, 480, 481

British West African Colonies and Protectorate, 17

Bromabima (Axim), 107

Bromeliacem (Togo), 127

Bubbuoi (Mendi), 59

Bubol (Mendi), 58

Buchholxia macrophylla, 84

Budañ (Tschandjo), 132

Budyonù (Tschandjo) 130

Buea District, 425, 426, 427, 430 $431,433,434,435,436,437$,

Buesse (Mbanol), 87

Buettneria, 353

Buffalo Horn, 222

Bugama Port, 150

Butni (Mendi), 46

Buittigirn (Mendi), 61

Buje nla (Yoruba), 407

Bujl dudu (Yoruba), 407

Balbostylis, 196 ; 'B. barbata 93 ; B. laniceps, 93

Bullet-wood tree, 186

Bulokossa (Benin), 406

Bumbi (Mendi), 46

Bunbola Mountains, 25

Bundu dance, 51 ; Bundu devils, 51

Bundut or Bundw (Mendi), 46, 60

Bunga (Timani), 45

Bungi (Mendi), 57

Buni (Mendi) '54

Bunja (Duala), 440

Bur-grass, 190

Bureh Mill, 35 ; B. River, 25 ; B. Town, 25, 36, 46, 56

Burkea, 302; B. Africana, 132, 191, 207, 220
Burma, 162, 168, 171

Burnatia eneandra, 195

Burogono (Mendi), 47

Burokossa (Benin), 406

Buronona (New Calabar), 364

Buro Naro (Mbonol), 88

Burseracex (Slerra Leone), 49 ; (Liberia), 74 ; (Ivory Coast), (Nigeria), 101, 198, 221, 314; (Cameroons), 432

Bush Máple, $351,353,417$; $B$ Oak, 420, 425 ; B. Pawpaw, 75 ; B. Teak, 417; B. Town, 56

Bussea Occidentalis, 99

Butter tree, 77, 107, 361

Butyrsopermum Parkii 109 117, 119, 141, 179, 192, 202, 214, 224, 231, 358, 379, 439,455

Buxus sempervirens, 176

Bwele ba Mbongo (Duala), 441

Bwombe (Bakwirl), 42

wiba ba mbale (Duala), 431 ; Bwiba ba njon (Duala), 443

Bwiwa (Bakwiri), 431

Byrsocarpus coccineus, 191

Cabbage Palm, 58 ; C. Tree of the Weat Indies, 134, 224

Cacao, 420, 421; C. bean, 163 : C. yams, 421,491

Casalpinia arborea, 148 ; $C$. Bonducella, 197, 303; C. coriaria, 148 ; C. regia, 148 . C. rostrata, 148 ; C. sappan. 1ว4, 148

Crasal ज̆nise (Nigeria), 268

Caindah Wood, 131

Calabar, 152, 153, 154, 157, $177,235,236,237,239,240$, $243,249,250,251,252,256$. $257,259,264,271,273,275$ $276,279,284,288,289,207$. $303,306,310,312,313,315$ $324,327,333,940,343,349$, $350,371,376,382,387,390$, 395, 396, 411; C. Arboretum and Botanical Gardens, 166, 168, 174, 179. 410,468 ; C. Beans, 80 , 298, C. 'Forest land, 17, 49,154 ; C. Market, 368 ; C. River, 18, 151, 152, 154 Calabash nutmeg, 43, 72, 265 Calamus Barteri, 94; C. deeratus, 94,240 ; C. sp., 41

Callichilia subsessilis, 58

Caloncoba Gilgiana, 139

Calonyction speciosum, 197, 203

Calpocalyx, 99; C. Dinklagei, 430

“Cam," 287, 288

Cam Biver, 415

Cambridge University Department of Agriculture, 488

Cameroons, 17, 878, 387, chap. $x$ 415-446 ; C. exports, 444 . C. Mountains, 415, 416, 420, 436 : C. (South), $425 ; C$. Timber exports, 445,446

Campanulacese (Nleeria), 194

Camps of Timber Firms, 187

Camwood, 31, 34, 35, 48, 84, $73,80,98,158,178,221$, $226,229,273,287,288,416$, $417,418,419$; Benin C., Targe-fruited Camwood 275 Splneless truited C. 273

Canarinm, 422 ; C. Auriculatum, 482; C. Mansfeldli. 317,432 ; C. occldentalis, 82,85 ; C. Schweinfurthil. $29,49,67,74,82,221,229$, $315,416,417,425,432$; c. sp., 317
Canary Isles, 20, 177

Candle nut, 421

Canoe-makfng (Nigeria), 158 ; Oguta C., 159; C. Tree, 356; Twelve puncheon C., 159

Canta Bark, 258

Canthium discolor, $61 ; \quad C$. glabriforum, 408,441

Capparidaces (Ivory Coagt). 84; (Togo), 130; C. Vanguerioldes, 197 ; (Nigeria) $190,196,198,213,219,266$ Capparie, 190, 198; C. Thonningil, 266 ; C. viminea, 196 Caralluma Dalzielli, 199

Carapa cake, 458 ; C. Gayensis, 35 ; C. Guianengis, 102 ; Drocera, 49, 74, 119, 135. procera, 49, 74, 119, 135 ,
$317,419,433,458 ;$ C 817, $419,433,458 ; C$

Cardiospermum Halieacabum. I91

Carissa edulis, 192, 395

Carludovico palmata, 127

Carpodinus Barteri (sy $n$. Clitandra Barteri), 392 ; C. fulva, 393 ; C. hirsuta, 111, 197, 309

Carpolobia alba, 50; C. lutea $50,288,332$

Carriers, daties and treatment (Nigeria), 186

Caryophyllace (Nigeria), 193

Casada, 421

Casearia 8p., 230

Caghew nuts, 123, 222, 339

Cassada, 125

Casarava, 204, 471

Casgia, 269, 270; C. Alata, 99 C. Arereh, 201, 206 : C bicapsularis, 99 ; C. dwarf mimosoldes, 191, 202 ; C. fistula, 99, 164, 270 ; C florida, 123, 124, 148 ; C. Goratensis, 201, 221; 220 ; C. Lophirn, 99 ; C. obovata, 109 ; C. occidentalis, 99, 164, 220, 270 . C. podocarpa, 73,270 ; $C$ ' Giamia, 163, 176, 489; C. Sieberlana, 46, 90, 133, 206 . 269 ; C. Tora, 99, 270

Cassytha Guineensis, 195

Castor-oil Shrub, 193

Casuarina, 125, 420, 421; C. equisitlfolia, $122,148,173$; C. sp. 183

Catechu, 98; Burmese rariety. 98

Cauri (Mbonol), 88

Cavally Port, 81, 82 ; C. River. 81,82

Cawthorne RIver, 151

Ceara Rubber, 117; C. R Plantation, 118, 128, 125 , 149

Ceceru (Agnl), 83

Cedar, 101, 416 ; Cigar-box Cedar tree, 122, 173, 420 . Dry lone C., 211, 323 ? Cedar-llke Lsuro, 250 ; C. Mahogany hard, 26. 28 323 ; Red C., 29, 32, 50, 67, 74, 75; Brented Mahogany Cedar, 317,318 ; White Cedar, 418, 419

Cedrat (Colons), 86

Cedrela, 154, 420 ; C. odorata, $122,128,148,173,183$. 420 : C. Toona, 173

Celba, 445, 446, C nentandra 120,122 , 128, 125, 138

Celastracere (Gold Coast), 104 ; (Nigeria), 191. 940

Celosia argentea, 105 
Celtis, hard, 246; C. integri- (Cloth 8hrub, 391 folia, 83, 128, 193, 216, 217 C. Prantili, 128; C. soft, 247 ; C. Bolenostigma, 246, 248 ; C. 8p., 247, 388

Cephalostigma Perrottettii, 194 Cerambix (Borer), 386

Ceratotheca sesamoides, 194

Ceredia, 466

Cestos River, 71

Ceylon, 420 ; C. satinwood compared with Fucalyptus, 174

Chad, Lake, 465

Chailletia floribunda, 332; C. toxiaria, 50

Chang District (Cameroons) 415,489

Charcoal exported from Gambia, 20 ; C. making from Lophira procera, $77 ;$ C Charia indiensis, 86

Che (Fó) 134

Chediya (Hrusa), 193, 199, 216, 218

Chedscho Valley, 125

Chen (Ibo) 229

Cherchen (Twi), 95

Chane d'Afrique (Colons), 86

Cherry, 79

Chestnut (False), 347

Chevalier, Mons. Auguste, 81 ; Books by, $81,198,484$

Chewstick, 55, 56, 77, 120,167

$179,194,212,223,225,234$ $359,360,409$

"Chevi" fat, 462 ; C. seed, 462

Chichiwa (Hausn), 219

Chicue (Attie), 86

Chiriri, 213, 223, 224

Chlebo (Fo), 134

Chloris, 196

Chlorophora excelan, 19, 26, 32 $42,67,70,82,83,95,117,128$, $158,168,171,204,215,219$, $228,253,416,417,418,419$, $422,425,445,446$

Chlorophytum, 19

Chocolate cream (from Shea Butter), 153 ; C. Gaboon, 454

Choka (Attie), 88

Choraschora, 446

Chrinika (A takpame), 131

Chrysobalamus ellipticus, 72 , 84,96 ; C. icaco, 72, 233 : C. sp., 269,459

Chrysophyllam, 57, 232. Africanum, 69, 110, 381 , $382,419,438,456$; ${ }^{\mathrm{C}}$. $\begin{array}{lll}382,419,438,456 ; & \text { C. } \\ \text { Albidum, } 110,382 ; & \text { C. }\end{array}$ ellipticus, 57 ; C. Kainato 381 ; C. macrophyllum 438 ; C. obovatum, 141 . C. pruniforme, 57 ; C. sp. $57,78,381$

Chuiansa (Appolonian), 103

Cissampelos Owariensis, 259 : C. Pareira, 193, 259

Cissus, 193

Cistanthera sp., 343

Citron de la mer, 202

Citrullus vulgaris, 193, 242, 452, 470

Citrus auratium, 74

Claoxylon Barteri, 337 ; C. Prensgii, 434

Clausena Amsata, 312

Cleidon Grbunienm, 10

Cleistopholis, near C. patens, $43,84,130$

Clerodendron, 113, 193, 441 ; C. scandens, 399 ; C. splendens, $400^{\circ}$ C. Thompsonit, 399; C. Thonningil, 399 ; C. volubulu, 399

Clitandra cirrhosa, 303 ; C. elastien, 111, 393 ; C. Togoland, 393 ; C. viscitlua, 393
Clove, 224

Clynogyne, syn. Donax cuspu-

tata, 246; C. filipes, 195 ; C. flexuosa, 128

Cnestis, 196 ; C. ferruginea, 96

Cochlospermaces (Gold Coast) 107

Cochlospermum tinctorium, 107, 190,201

Cockburn Major, 177

Cockchafer Bugs, 436

Coco Fibre, 127 ; C. nuts, 63 122, 226 ; C. nut Palm, (Touloncouna de palmiste) 90:C. yams, 255

Cocon, 421, 444, 476, 487, 491 c. Industry (Gold Coast) 92 ; (Togo), 126 ; C. Plum 72 ; C. seeds, 63 ; C. Tree 436

Cocos nucifera, 94, 218

Colocaryon oxycarpum, 84

Cofiea Liberica, 79

Coffee, 80 ; C. scions, 80 ; seed, 80 ; C. trees, 80

Cola, 232, 351, 354, 355, 356, $396,487,491$

acuminnta, $54,77,106,354$

Afzelia, 106, 138, 354

altissima, 436

astrophora, 138

Augustifolia, 54

Bitter, 359, 462

caricifolia, 106, 138

canliflora, 354

common, 354

cordifolia, 87, 106

digitata, 77

False, 359

Laurel-leaved, 354

Iaurifolia, 106, 138, 196, 204, 354,355

leonensis, 54

mahogany, 354

marsupium, 436

mirabilis, 87

Cola nut, 71, 77, 90, 115, 116, 163

Colaproteiformis, 87

Simiarum, 54

sp., 354, 355, 436

gublobata, 106

suleata, 436

supflana, 138

vera, $87,107,124,126,148$

verticulata, 107

Colonguli (Mendi), 54

Combretacex (Sierra Ieone), 56 (Ivory Coast), 88 ; (Gold Coast), 108 ; (Togo), 139 (Nigeria), 192, 197, 199, 203, 212, 223, 224, 369 : (Cameroons), $438,445,446$

Combretum Afzelia, 108

cineres, 438

constrictum, 197, 209

futinosum, $213,223,373$

reitonophyllum, 22

glutinosum, 213, 223, 373

Hartmannianum, 213, 223, 373

herbaceum, 201

Kerstingii, 140, 223, 224

Lawsonianum, 372

leonense, 213,223

micranthum, 373

mucronatum, 373.

paucinervium, 373

racemosum, 197

Sokodense, 139

sp., 108, 192, 201, 21

sp. near C. altum, 199, 204

verticillatum, 223

viridifiora, 88

zenkeri, 108, 373

Combwood, 35

Commelinacex (Nigeria), 195 . 197,425
Commelyna, 195 ; C. nuditiora, 195 ; C. umbéllata, 195

Commiphore Kerstingil, 191, 211

Communal Rubber Plantations, 179

Compartments," 169

Compositw (Gold Cosst), 114 ; (Togo), 147 ; (Nigerla), 194, 225, 409; (Cameroons), 441

Conapharingia, 79,$233 ; C$. Cragsa, 59, 88, 142; C. durissima, 391 ; C. longifolia, 59 ; C. pachysiphon, 85,391

Confectioner's Gum, 300

Congo, 476; C. Cie Congo du Belge Line, 480 ; Belgian C., 423, 424; French and Belgian C., 189 ; French or Gaboon C., 422, 423 ; C. River, 423, 424 ; Upper C.. 423,424

Congo-Congo (Gabonais), 83

Coniferous trees, 162 ; Conifer, 177

Convolvulaces (Gold Coast) 112 ; (Nigeria), 194, 197 ;

(Cameroons), 440

Convolvulus (Moon), 203

Coondi (Timani), 48

Copaiba Balsam Tree, 205

Copaifera Demensii, 176, 417, 421,428 ; C. Guibourtiana (Gum Copal), 35, 36, 37, 46 ; C. officinalis, 176 ;

Copaifera of the Boji Hills, 198 . of. Copaifera, 298

Copal 44

Copenhagen Market, 325

Copra exported (Nigeria), 226

Coral flower, 301 ; C. Tree, 221

Corchorus, 190 ; C. acutangulus, 344 ; C. olitorious, 344

Cordia Abysginica, 192, 215 224 ; C. (acorn-like fruited), 396 C (Drumwood) 396: C. Gharat 143. C. Trvingia, C. Gharar, 143; C. Irvingia, 112, 396, 440; C. milheni, 230, 396 C. C. sp., 59, 230

396 ; C. Yombomba, 4
rdyla Africana, 133, 197

Coreopsis, 194

Corkwood, 42, 70, 83; C. Tree, $95,252,418,410,488$

Corynanthe Johimbe, 408 ; C. paniculata, 61,407

Corypha elata, 177

Cosomon (Bambara), 86

Costus ofer, 195

Costus afer, 195 53, 76, 117, 153 $160,177,190,204,278,345$, 346, 445, 446

Coula edulis (Almond wood), 33, $43,71,83,95,258,417,426$, 457

Counterwood (Afzella Africana), 47: Counter-top Mahogany 157

Cowhage, 203

Crab-oll Tree, 318; Crabwood, 19, 74, 317

Cratava, Adansonil, 180, 213, 219,266 ; C. religioss, 130

Craterispermum laurinum, 61

Cratopteris Thalictroides, 196

Cream of Tartar, 53

Creepers, 172

Creole, 44, 45, 52 ; C. Damson, 53

Crinum yuccæflorum, 195

Cross River, 151, 152, 153, 156, $157,159,170,179,185,273$, $378,415,418,456,493$; C. R. nut, 376

Crossopteryx Africana or Kotschyana, 61, 145, 192, 214. 225,408

Crotalaria, 191 
Croton pendullftorus, 61 ; C. Danko (Hausa), 11 pyrifolius, 434

Cryptoleptis nigritana, 192

Cryptosepalum tetraphyllum, 47 C. prophetarum, 194

Cucurbita Pepo, 193

Cucurbitaces '(Nigeria), 193, 190,452

Culcagis scandens, 195

Cupania akeesia, 348

Curculigo Gallabatensis, 195

Cussonia, 210 ; C. Barteri, 140 C. Djalonensis, 56 ;

Custard apple (wild), 262

Cutch Tree, 98

Cuviera acutiflora, 197

Cyanastracea (Nigeria), 245

Cyanastrum cordifolium, 245

Cyanothyrsus ogea, 97, 278

Cyanotis, 195

Cycad appearance of Palm, 243

Cycinium camporum, 400

Cylicodiscus, 280, 286 ; C. Gabo nensis, 48, 97 (compared with Piptadenia Africana, 99), $229,295,416,419,431$

Cymbopogon diplandrus, 201 C. gigantum, 201 ; C. C. Ruprechtii, 201; C.' Sennariensis, 199

Cynometra, 117, 120, 231; C. Afzelii, 98, 121, 132, '285. 449 ; C. cryptosepalum, 84 ; C. Mannii, $98,285,429,449$; C. megalophylla, 132,148 C. mitragyne, 19,$36 ; \mathrm{C}$ multynge, 429 ; C. sp., 98 132 ; C. Vogelii, 45, 84, 197 203 ; C. Waterside, 285

Cyperaces (Gold Coast), 93 ; (Nigeria), 196

Cyperus esculentus, 196 ; C. Fenzelianus, 196 ; C. rotundus, 196

Cypress, 420; C. (Bald), 175 C. (Deciduous), 175; C. (swamp), 175

Cyrtosperma Senegalense, 197

Dabadogun (Benin), 267

Dabino (Hausa), 217

Dabudabu (Agni), 87

Dadafunde (Atakpame), 145

Dadie (Asante), 138

Dafara, $19 J$

Dagbongbore (Tschandjo), 138

Dagera (Hansa), 223

Dahomah (Twi), 07

Dahomey, 189

Dakwora (Hausa), 208

Dalbergia, 297 ; D. (False), 270 ; D. Hostilis, 298 : D. Latifolia, 175; D. Melanoxylon, 118, 134; D. RoseWood, 48 ; D. 297

Dali (Hausa), 211; (Kano and Katsima), 221

Dalo, 213, 223

Dalu (Kans and Kataima), 221

Dalziel, Dr. J. M., on "Botanical Features of Nigeria," 188-205: "Some trees of Hausaland," 205-219; "Nigerian trees," 218-225, 244

Dambarra Vllage, 66,69

Damerghu, 207

Dandana, 194

Daniellia, 231 ; D. Caudeta 278,431 ; D. Fosteri, 278 ; D. oblonga, 84, 278; D. ogea (Blue Bessie), 32, 83, $35,68,74,97,230,278$; D. Punchil, 278 ; 0 . sp. 74,424 ; D. Thuriferer, 74,424
205,
Dan marike (Hausa), 221
Danowa (Hausa), 231

sarikin itatuwa (Bok and Katsima), 221

Dantwi (Atakpame), 135

Danya (Hausa), 188, 212, 222

Dargara, 190

Dashi (Havea), 198, 211

Date, 200 ; Date, desert, 210 . Date palms, 124, 125, 217 ; wild date palm, 240

\section{Datura Metel, 194}

Daudawa (Hausa), 207

Dawa (تlausa), 196, 204

Dawo (Hausa), 220, 231

Debundscha (Gameroons), 416

Degema, 364; D. Arboretum, D. District, 405 ; D. Port, 152 : D. Town, 179, 314

Deinbollis Indiensis, 87 ; $\mathbf{D}$. insignio, 104, 233; $D$. primata, 843; D. pycnophylla, 434

Deleb palm, 41, 200, 216, 217, 218

Denbehawi (Mendi), 54

Dendo (Attie), 83

Dengma (Mangu), 130

Dennett, Mr. R. E., Quotation from Paper on "British Trade in Nigeria," 480,481 Dennettia sp., 260, 263; D. tripetala, 260

Denya (Twi), 97

Depapäte (Tschandjo), 132

Derri Stuhlmannii, 133

Desmodium Eriosema, 191

Desplatzia Dewewrei, 434

Detarium, Guineensis, 119, 120, 132, 229; D. microcarpum; 132,430 ; D. Senegalense, $29,69,73,97,123,132,148$ $191,201,202,206,221,306$; D. sp., 97

Dialium, Dinklagei, 73,84 . D. Englerii, 73; D. Guineense, 84, 99, 133, 107, 289, 418,$424 ; G$. Sengalense, $47,48,73 ;$ D. 8 p. 48 ; D. Standiti, 417,430 ; D. Zenkeri, 430

Diancangue (Attie), 83

Diangue (agni) 83

Dibanga (Jaunde), 442

Dibobonga (Duala), 434

Dicadi, 195

Dichapetalacea (S. Leone), 60 ; Nigeria, 332

Dichrostachys nutans, 99, 131 , 191, 201 ; D. platycarpa,

Engleri, 74

Digitaria, 196

Digiten (Brass), 228

Digo (Angeg) 140

Dika bread, 74 ; D. butter, 74 ; D. chocolate, 74 ; D. fat, 454 ; D. kernels, 454 ; Dika nuts, 68, 74, 100, 179, 312,454 ; Benin D. nuts, 313

Dlkbere (Tschandjo), 195

Diki (Hausa), 128

Dilifu (Trehandjo), 135

Dilleniaces (Lberia), 77

Dillenia indica, 421

Dingi (Mendi), 56

Dinjongo (Bakundu), 440

Dinya (Kano), 215, 224

Diocles reflexa, 298

Dioecious trees, 52

Dloscores prehengilis, 195 ; D. sp., 471

Dlosoreacere (Nigeria), 105

Diospyros aggregats, 489

atropurpurea, $230,383,384$, 385, 439

Barteri, 385, 459
Diospyros aggregata-continued.

Blpendensis, 385, 439

crassiflora, 230, 385,459

Dendo, 230, 386, 439, 450

Gligiana, 416, 439

incarnata, 439

Kamerunensis, 385, 415, 439

Mamiacensis, 438

Megaphylla, 430

Mespeliformis, $110,118,123$. $125,141,169,178,185,192$, $214,224,230,383,438$

Mombuttensis, 110, 142, 280, 383

Mombuttensis, syn. sinensis, 383

Multinervis, 384, 385

Nsambensis, 489

Sanra, 88

Species, 57, 118, 383, 385, 416, 417,445

Suaveolens, 386, 420, 439

Tricolar, 142

Vercosa, 385

Xanthoxyplamys, 110, 387

Dipeadi occidentale, 198

Dipterocarpacea (Togo), 139

Diringhi (Ibo), 228

Discoglypremna caloneura, 103

Dissotis, 194

Distemonanthus Benthianum, $100,133,301,430$; D. sp., 430

Dita (Detarium Senegalense), 29 , $48,69,73,120$

Dituture (Tschandjo), 135

Djave Nut, 420, 444

Djengu (Bakwirl), 428

Djo Atbi (Mbonoi), 87

Diombe (Bakwiri), 438

Diuna (Bondoukou), 84

Djuna (Bondoukou),

Do (Trepo), 84

Dodo (Yoruba), 391

Dodongen viseosa, 76 , or Dadori (Hausa), 223

Dodoya, 195

Dogo (Bondoukou), 85

Doka (Ashanti), 98; (Apollo nian), 93 ; (Aowin), 93, 200 :(Hausa), 220, 232

Dolichandrone lutea, 11

Dombeya Buettneri, 356

Dona (A be), 85

Donax, Cusputata, 246

Dongle on Jeti (Ewe), 141

Dorose Populu (Plapo), 89

Dorowa or Darawa (Hausa), 207 220,230

Doti (Ewe), 133

Doumane, 90

Dracena, 22 ; D. arborea, 94 ; D. Cylindrics, 245; D. Mannil, 42, 94 ; D. Perrottettil, 83, 246 ; D. sp., 245 , 246 ; D. Surculosa, 70,94 245

Dragon's blood, 70, 245

Drogeraces (Nigerla), 103

Drosera indica, 193

Dachang Station, 420, 425, 426 , I86, 436, 441

Duakobin or Duabayi (General West Cosst) 87

Duala District, 428,436

Dubiddi (Ashanti), 98

Dubiri Kegingo (Appolomen) 86

Dubon or Dubinl (Twl, Wassaw, Fanti), 101

Duboscia macrocarpa, 87

Dubu (Brass), 281

Dudu (A ppolonian), 108

Dudüreda (Tschandjo), 129

Duika, 361, 378, 408, 422 : D. Chop fruit, 360 ; D. Maxwell 8,250 ; Red-headed $D$. 250 ; Yellow-backed D., 250 
Dukki (Hausa), 216 ; or Dunki, Edem (Calabar), 363 ; (Eflk), 323 | Ekmana (Fanti), 97 syn. Zuwo (Kano Zaria, etc.), or Dinkin, 218

Duko, Durgo, or Duroko (Bondoukou), 86

Dukuma Dugura" (Agni), 86

Dum palm, 94, 200, 216, 217, 218,244

Duma, 193 ; D. namé, 356

Dumoria Heckeli, 378; D. Heckeli (Baca or Abaku), 456

Dumya (Sok), 224

Dunkwah Reserve, 160

Dunstan, Prof. Wyndham $R$. (Opinion on feeding cattle),

Dupwi II (Mendi), 48

Duru Forest, 201

Durumi (Hausa), 193, 199, 216

Dushe (Kana), 220

Dussa (Hausa), 208 ; D. (East Hausa), 220

Duvui (Mendi), 41

Dworom (Asante), 128

Dychoriste Perrottettii, 194

Dyewood industry (Nigeria), 159 Dyewoods, 444

Dzobellobe (Ewe), 127

Dzogbenyabo (Ewe), 128

Eba (Benin), 159, 356 ; E. District, 394

Ebakwe (Benin), 284

Ebar (Brass, Ibo), 230 ; (Brass, North Calabar), 406

Ebattan (Benin), 364

Ebba (Benin), 356

Ebbe (Mendi), 45, 159

Ebbo (Benin), 308

Ebbome (Oban, pkoi), 279

Ebe (Jaunde), 442

Ebegogogbo (Benin), 343

Eben (Efik), 233, 314; (Jekri), 404 ; E.-etridon (EAlk), 229 E. giku, 404

Ebenacex (S. Leone), 57 ; (Ivory Coast), 88 ; (Gold coast) 110 ; (Togo), 141; (Ni(Cameria), 192, 214,

Ebenote (Benin), 390

Fbewaki (Benin), 259

Ebo (Ewe), 129; (Yoruba), 230

Fbon (Duala), 443

Ebonga evodi (Duala), 485; $\mathbf{E}$. manyongo (Duala), 440

Ebony, 57, 110, 124, 226, 415 $417,420,445$; Benin Ebony, 383, 385, 386, 387 ; Black E., 416 ; Brown E.' Cameroon Ebony, 385 : Cross River E., 386 ; E. nut, 385; E."Plantátions (Togo), 149 ; (Nigeria), 164, $169,178,186,226$; Walk ing-stick E., 383; ' Yoruba E., 383

Eborodumuen (Agni), 87

Fbruke (Attie) 87

Ebubri etu (EAlk), 386

Ebumen (Benin), 337

Ebunja (Bakundu), 442

buttemetta Gardens, 168, 170 269 ; D. Sawmill, 159

Ecastaphyllum Brownei, 100

Eché, or Alãfe (Ewe), 134

Echirua (Agni), 8

Eclipts Alba, 194

Econ grass, 176, 179

Edat, 158; (Ekoi), 231, 405 ; (EÁ) , 266, 405

Edde (Mbonoi), 88

Eddo Binoyoba (Benin), 265

Ede (Quitta, Krepi), 93 ; (Yoruba), 300, 397 ; E. Plantation, 17

Eden (Eflk), 228

Edeng (Calabar), 363

Edible nut, 258

Edna (Appolonian), 84

Edum (Bafo), 431

Edun (Benin), 359

Fdundu (Balong), 428

Efam (EAlk), 229

Bffnobrodidwa (Tw), 101

tffmokonkonti (Ashanti) 101

Eflari (Gfik), 233 ; (Benin), 360

Efik, 159, 185, 494

Eflndofindo (Bafo), 439

Giohlø (Ewe), 130

Eflori or Efrie (EAk, Kwa), 359

Efomu (Agu), 84 firiyo, 228; E. moniba (Eflk),

Efuen (Agni), 84

Gfu Iya (Yoruba), 317

Efunmundon (Appolonian, Aorin)

(Agni), 89

gba (Ewe), 136; (Iba, Owerri) 363,368 ; (Yoruba), 234:

Agbe, 163

Egbesi (Yoruba), 401

Egbi (Ibadan), 271

gbo (Atakpame), 142 ; (Benin), 494

Egeun (Aowin), 95

Eggi or Ekka (Tbo, Asaba), 319 ; (Yoruba), 285, 449

ggg-shaped fruit tree (Ocotes cf.), 266

Eggun (Yoruba), 345, 346

Eghogho (Benin), 337

Goyn lukan (Benin), 369 ; $\mathbf{E}$. nebbi, $369 ;$ E. nikwi, $\mathbf{3 6 9}$; E. nufwa (Benin), 179, 371

Egu (Atakpame), 142

Egui (Agni), 83

Eguni (A.ppolonian), 95

Egun oran (Yoruba), 266

gusi bara (Yoruba), 242, 452, 470

Egwa oriakuku or oviakuku, 399

Egyptian Mimosa, 219

Ehan (Bakoko), 483

Ehemba (Jaunde), 442

Ehranbagogo (Benin), 259

Ehranezi (Benin), 364

Ehranpata, or Isanpata (Benin). 336

Ehrenyegbo (Yoruba), 385

Ehretia cymosa, 112, 143, 396

Ehrodo (Benin), 368

Ghrurumesi (Benin), 297

Ehukei (Appolonian), 107 248

Ehye or Incense Tree, 100

Eijan (Appolonian), 105

Gjan (Jaunde) 442

Ejuong (Jaunde), 436

Thai (EAlk), 494

Ekambamba (Bakunku), 442

Ekanesie adie (Yoruba), 843

Eke, deka (Atakpame), 144; E. oyimbo (Toruba), 331

Fkebergia, 50 ; E. Senegalensis, 135

Mkat District, 236 ; E. Port, 152 Hai (Yoruba), 229

Prika Aja (Yoruba), 339

Ekimi or Ekhimi (Benin), 220 279 ; (Mbonol), 85

Ekiti District, 405

Gliyawa (Benin), 290

Ekkana (Yoruba), 266

Fkki (Yoruba), 356

Ekkiowa (Benin), 411

Ekko okpan, 347

Ekku (Ibadan), 332333

Ekkun (Yoruba), 285

Fkns (Agni), 86

Eknalokpoe (ETe), 136

Ekoah (Jaunde) 44

Ekof Platas, 339

Ekok (Oban, Fkoi), 282

Ekol (Bakrosia), 426

Fkolo (Bakundu), 426

Ekom (Ibo, Owert), 368

Ekomba (Bago), 426

Ekombo (Bakossi), 426

Ekonge (Bakwir), 435

Ekopa (Agni), 85

Grosuba, Zenna,Kerenya (Agni), 87

Ekpe (Krepi), 93

Elrpagol (Benin), 230, 281; (Yoruba), 448

Elkpagoize (Benin), 282, 290

Ekpin (Yoruba), 252

Eku or Ekui (Aowin), 105 ; (Twi), 105 ; (Torubs), 229

Ekuba (Appollonian), 105

Ekube (Agni), 83

Ekugbi (Yoruba), 317

Ekugbo (Yornba), 317

Ekuie (Abe), 86

Ekuri Ebu (Ibo, Owerri), 390

Ekuro (Fanti), 84

Ekusa or Ikujo (Benin), $\mathbf{3 6 0}$

Ekusamba (Fanti), 89

Ekusawa (Fanti), 113

Ekuso (Yoruba) (Ikale), 361

la (Yoruba), 257 ; or Elu, 303, 356

Elais, var. Albescens, 466

Angulosa, 466

Ceredia, 466

Communis, 466

Communis forma dura, 466

Guineensis, var. Lisombe, 243

Guineengie, 26, 37, 39, 68, 70, $93,122,127,197,204,218$, $228,241,262,420,425,464$, 466

Guineensis, var. Thompsonii, 242

Idolatrica, 466

Intermedia, 46

Macrocarpa, 466

Nigericum, 110, 138

Orientale, $53,169,190,209$, $223,345,346$

Phifera, 406

Repandra, 466

Rostrata, 466

sp., 243

Elmophorbia drupifera, 103

Eleba (Jekri), 358

Elegbe Oju (Yoruba), 410

Elekikobi (Yoruba), 239

Flekua (Agni), 86

Elemi gum, 314

Elephant hunting, 66 ; $\mathbf{E}$. $\underset{395}{\text { gugar cane, } 375 ;} \mathbf{E}$. poison,

Elika-aja (Yornba), 231

Elili (Ibo, Owerri), 356

Elk's horn fern, 197

Eloby, 424

Flo Uta (Ibo, Owerri), 271

Elui (Agni), 83

Elund (Balong), 428

Emang (Dakosii), 425 ; E.

District, 481 58

Embi-Siembi (Agni), 8

Eme-ela (Yorubs), 246

Emi-emi (Yorubs), 231, 370 ; $\mathbf{E}$. gbegeri (Yoruba, Ibadon), 323 ; Emi ghegiri (Yoruba), 77 ; gbigi, 230, 232; E. ori, 178

Emido (Yoruba), 229, 251, 334, 375,880

Emil, Emril, or Emiri (General Gold Coest), 108

Emmaha (Benin), 236

Emosobegan (Yoruba), 297

Emuinguin (Fanti), 86 
Ena (Atakpame), 131

Enantia chlorantha, 84, 259, 417,427 ; E. polycarpa, 259

Finde (Agni), 88

Endiar or N'diar (Wolof), 84

Endodesmia calophylloides, 437 Endwi (Mendi) 54

Engele or Ongele (Balong), 435

Enjenju (Bskundu), 442

Enjog (Jaunde), 442

Enonge (Bakundu), 440

Entada (Abyssinica), 99, 131, 299 ; $\mathrm{E}$. 8candens, 60, 131, $163,298,299$; $\mathbf{E}$. Soudanica, $99,191,199,201,209,221$, 299

Entandrophragma, 228, 320, 327, $332,364,422,442,445$; $T$; candellei, $177,416,417$, 432 ; E. cylindricum, 102, 324,325 ; E. ferrugines, 86, 102 ; macrophylla, 82, 432 ; E. Tufa, 86; E. F. Bp., 420 ; E. utilis, 102, $323,325,326,416,432$

Entie (Ágni), 84

Enwiwan (Benin), 347

Enyena (Ashanti, Fanti, and Wassaw), 105

Enyenewu, enyenewi (Yoruba), 298

Enyenga (Appolonian), 105

Enyin Mbukpo (Eflk), 232

Enymi (Benin), 282

Enyo (Aowin), 105

Epa ile (Yoruba), 303

Epe, Colony of Lagos, 340

Epindepinde (Bakundu, Duala),

Epiphytes, 195, 199, 216

Epiphytic foliage, 193 ; E.

orchids and ferns

Epuepue (Bakwiri), 428

Epweperu, 348

Eranobapotineddo (Benin), 271

Eremospatha macroearpa, 163, 240 ; T. sp., 163, 240

Freruku (Calabar), 363

Friagbo (Yoruba), 331

Eriagbo (Yoruba), 331

Fimado (Ib.), 332 ; (Benin), 451 Erin (Yoruba), 394

Erinji (Ijor), 276

Eriocolum, 104; E. Kerstingii, 137

Eriodendron, 231, 434; E. anfractuosum, 26, 53, 76, 105,346 ; E. Nigericum 119 ' 138 ' $\mathrm{E}$. orientale, 53 , $169,190,209$, 223, 345, 346

Brogbo (Benin), 240

Frohun of the Ikales, 232

Gru (Yoruba), 233, 260

Trüi (Agni), 85

Eruju (YorubB), 263

Erumacie, 282; (Yorubs), 297

Erun (Yoruba), 229 ; E. obo 2), 275

Erunde orWunga (Bakundu), 428

Erunnor Obi (Yorubs), 449

Erunnor Obo (Yoruba), 449

Erurunuesi (Benin), 297

Eruwa Road 8tation, 169, 171

Erythrina, 231 ; E. excelsa, 430 ; E. Senegalengis, $45,73,100$, $117,191,221,283,801$

Erythrophloum Guineense, (Baseybark), 35, 39, 48, 85, $98,117,120.125,182,197$. $220,229,275,277,429$, 449 ; E. Ivorlensis, 85 ; E. micranthum, 229, 276, 429,449 ; E. Bp., 45, 134, 275 , 429; E. 8 . near
Frythroxylacese (Cameroons),481 Frythroxylon Mannii, 431 Fsakagaka (Bakwiri), 428

Esang (Bakogsi), 428; (Jannde) 442 ; Esango (Bakosil), 428 Fsanigbakhehe (Benin), 301

Esanke or Esangue (Attle), 86

Escravos River, 151
Eselebulka (Bakoko), 443

Eaeme (Mbonoi), 84

Esenge (Bakundu), 433, 434

Bseri (Lflk), 298; E. Bean or Calabar Bean, 450

Eserine or Calsbarine, 450

Esisi (Yoruba), 336

Egiskwi (Benin), 400

Esive (Mbonoi), 88

Eso, 163, 232, 301; Eso or

Esok (Bakuduba), 350

Eson (Bakundu), 442

Gsore ( Fanti), 86

Essago (Benin), 268

Esseah or Tssia (General West Coast), 108

Essenim (ERk), 400

Esseresu opirimú (Asante), 132

Esseri (Appolonian), 106

Essobelia (Tachandjo), 144

Essunsun (Benin), 336

Essunwoi, 410

Esu (origin of " $\mathrm{JuJu}$," the

Fovil), 355

Esura (Yorub8), 344

Esuro (Attie), 84

Etare (Oban, Ekol), 277

Etehetem Sawmills, 159, 364

Ethiopian pepper (Colons), 84

Etiap (Oban, Ekoi), 390

Etini (Yoruba), 384

Etjannake (Akposso), 142

Eto (Benin), 412

Etori (Ekoi), 228

Etotum (Duala), 443

Etsa (Krepi), 98

Etu or Etue (Bakossi), 432

Etuflak or Ituflak (Eflk), 410

Etúi (Agni), 86

Etutu (Bakundu), 441

Eucalyptus, 123, 124, 175 ; E. amygdalina, 174, 410; $\mathrm{E}$. citrifolia, 123, dora, $148,174,410$; E. marginata, 148; E. robusta, 148 ; E. rudis, 410 ; E. 8p,; E. tessitaris, $\mathbf{4 1 0}$

Euchresia (Fantí), 94

Eugenia callophylloides, 56 ; E. caryophyllata, $224 ; \mathrm{E}$. coronata, 192 ; E. Guinensis 109 ; E. owariensis $109,192,213,224,232$, 374,375

Eulophias, 19

Euphorbia Abyssinica, 222 ; E. A9gyptica, 198 ; E. Barter, 199'; E.' pilulifera, 193;

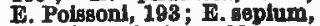
$109 . \mathrm{E}$, unisplna, 198

Euphorbiacese (8. Ioone), 50; (Ilberia), 75 ; (Ivory Coast), 86; (Gold Coast), 102 ; (Togo), 135; (Nigeria), 198; $197,109,215,222,332,447$, 452 ; (Cameroons), 483

Eumen (Misahöhe), 188

Evi (Qultta), 106

Evialegbi (Benin), 258

Eviromilla (Benin), 243

Evolvalus alsinoides, 194

Ewal of the Benis, 231

Ewanenimi (Benin), 245

Ewasi (Aowin), 106

Ewáti (Anecho), 141

Ewayon (wrapping-lesves for
Ewayron (Yoruba), 412

Ewe ofo (Yoruba), 356

Ewelisomũ (Tachandjo), 141

Ewoha (Benin), 355

Ewnon (Bakodo), 443

Fwon (Yoruba), 301 ; E. pala (Ikale), 281

Ewruo or Ewuru (Yoruba), 409

Excoecaria, 103 ; E. sp., 336

Exin (Agni), 84

Eye (Fanti), 93

Eyhrodo (Benin), 307

Eyo (Yor uba), 344

Ezzi (Benin), 268

Fae or Fai (Mendi), 45

Tragara Altisgima, 431; T.

Macrophylia, 85 ; I. Rederi.

431 ; F. Xanthoxyloldes, 134

Fagbajoi (Mendi), 52

Fai Beans, 447

Faia (Aowin), 111

Fako Mountain, 416 ; F. District, 426,440

Falaba, 39

Falcon's Claw, 208

False Boxwood, 391 ; $\mathrm{F}$. Chestnut, 347; T. Cola, 359 ; F. Dalbergia, 270 ; $F$. Iroko, 419 ; F. Nutmeg, Rubber Tree, 79 ; F.'Shes Butter, 370 '; 'F.' Shes Butter Nut, 376

Fan Palm, 39, 41, 70, 94, 117, $216,218,244,450$

Fara dolea (Hausa), 200, 206. 220 ; F. Kaya (Havsa), 208 , 219 F. Kaya, syn. Banji (E. Haussa), 220

Farichin shafu (Hanga), 208 ; F. shafo or Kumbar shafo, 220

Farin Makarfo (Hausa), 207 F. sansami, sym. Shunin Biri Zanfara halshen $\mathbf{8 a}$ 220,221

Farnesian Acacia, 300

Farquhar, Mr., discovered new gp., Tarquharia, 302, 470 . on yield of Oll Palm, 484

Trarquharia elliptics, 391

Faru (Hausa), 212 ; F., syn. Tudi (Zanfara), 22

Fasa daga, 220 ; F. K wari, 196, 221,232

Fate fate (HauBa), 225

Faurea speciosa, 129, 257

Fawcett, Thomas, L.M.R.,A.S.E. on feeding cattle, 488

Fe (Attle), 84, 86

Fegblo (Ewe), 140

Fela (Bambara), 88

Fentla (Dowin), 100

Feretia canthioldes, 192, 202

Fevel (Mendi), 60

Rlver, 419, 487

Ficoldem (Nineria), 194

Flous, 70, 94, 193, 202, 215, 216 F. Asperata, 249, 252 ; Asperifolia, 05; F. Bembicicarpa, 129 ; F. Brachipus, 129 ; F. Capensis, 216, 218 , 219,426 ; F. Courania, 426 ; T. Djurensis, 129 ; F. 128 tics, 122, 123, 124, 126 , F. Ertobotryoldes, 95; F. Eriobotryoldes, 95 ; F. Glumosa, 216, 219 ; $\mathrm{F}$. Gnaphalocarpa, 216, 218 F. Gollath, 88; T. Grandicarpa, $12 \theta$; F. Guineensis, 83 ; $F$. Indea, 251; $\mathrm{F}$. 
Ficns-continued.

Kawuir, 216, 219 ; F. Lutea 129 ; F. Ottonimfolia, 95 T. Platyphytes, 42, 122 ; Fis, 252 Fhylla, 94, 216, 218 , 426 ; F. Rokko, 129 F. Schimperia, 426 ; F. Selechteri, 148; F. Sokodensis, 129 ; F. species, $42,71,83,94,204,218,219$, 251, 252 , $\mathrm{F}$, Syringifolis 199, 216, 218 ; F. Tesselate, 129, 216, 218; F. Tesselate, 129 ; Thonningli, 199 , 216, 218, 251 ; F. Togoensis, 129 ; F. Tollifolia, 129 ; $F$ Triangulus, 95, 251 ; chondex, 129 ; F. Vogelii, 42, 122, 197, 216, 219, 228, 251,418 ; F. Whytei, 71

Fidda gartai, 199

Fiditi (Oyo Province), 266

Fiffätí (Avecho), 146

Fyfei (Ewe), 146

Fig (common), 251 ; F. large Ii. Darrow-leaved, $219 ; \mathrm{F}$ small, 218

Tig species (Antiarus), 70

Tilasko, 199

Filices (Nigeria), 196

Fillseopilis discophora, 431

fimbristylis, 196

Findefinde (Bakwiri), 439

Finger root, 4

Finland Market, 325

Binzan (Bambars), 87

Firbandu (Mendi), 48

Firemood Plantation, 175, 178

FirmianaBarteri, 138, 163,301,350

Fish poison, 302

Fita (Hausa), 128 . F. Flabescens, 366

Flacourtiaces (Sierra Leone), 55; (Liberia), 78; (Ivory Coast), 88; (Gold Coast), 108; (Togo), 139; (Nigeria), 223,236

Flagellaris indica, 127

Thagellariacem (Togo), 127

Fleabane (Ash-coloured), 410

Flintwood, 114

Floscopa, 195

Fluggea microcarpa, 51, 193

Fô (Ewe), 143

Fofol (Mendi), 42

Foonian (Mbonoi), 83

Frojiti (A

Fola (Tschandjo), 128

Fola (Trchandjo,keidi), 48

Fonde (Attie), 84

Fontwans, 420

Forcados Port, 156, 157, 382 ; F. River, 151; F. Btar apple, 382

Foresta, Afzelia, 291; F. Calabar Evergreen, 154 ; F.; Canopied deciduous, 19 ; $\mathrm{F}$ : Control, Gold Coast, 92 ; F. control, lack of, and results, 92; F., Department formed (1910), guarantéed Iroko timber, 173 ; Nigerian, 228 ; $\mathbf{F}$; Evergreen, 18, 19, 152; Evergreen Fringing, 203 ; F. Exports, Sierra Leone, F., 64: Liberia, 80 ; Ivory Coast, 90; Gold Coast, 115 ; NLgeria, 226 ; Freshwater Swamp Forests, 19, 154; Fringing or i Hill, 154 ; $F$. in relation to
Forests-continued. Agrisulture, The, chap. xiii, $485-495$; F. Fand fized in the older civilized countries, 485; F. Law (Nigerian), 162 ; $F$, Locust, 45, 73 ; F. Mixed, 121, 350; $152,150,169 ; \mathrm{F}$. Mixed intermediate, $18 ;$ F. New, 491 ; Officers in Nigeria (European), 184; Rank, Training, Appointments, Salary, etc., 186; Chief Conservators, Senior Congervators, Conservators, ete., 187 ; F. Open decidaous, 19 ; $F$. Orchard, 99 ; F. Peninsular, 39; F Penine 100. Per Leone), Permanent forests, Austria, Finland, France, Germany, Hungary, India, Norway, Russia, Sweden, Switzerland, U.S.A., 492 ; F. Rain, 151, 154, 189 ; F.' Reserves, 91; F. Sapeli, 326 ; F. Savannah, 196, 197, 200 (True, Treeless, Bush, Tree, Sclerophyllus Formation), 18, 19, 93; Nigeria (Tree, Bush, Open Orchard, Treeless), 188; South-West African, 189 ; Bush, 201 ; evergreen, 196; F. South Benin, 325, 326 ; F. State Communal, Municipal, or Private, various countries, 91, 92

Forestry, Arboretum Calabar 342 ; F. Conference at Berlin on Togo Afforestation, 119; F. Progress in Gold Coast, Nigeria, Sier ra
Leone, Gambia, 188

Forked Palm, 244

Frake (Agni), 88

Fram (Bonduku), 88

Framine (Agni), 88

Frankincense Tree, 191, 210, 221

Freetown, 25, 35, 60, 62

Tref (Fanti), 105

French Beans compared to Locust Beans, 153

French Ivory Coast, position of, 17

Frimu (Tschandjo), 135

Fruntum (Ashanti), 111

Fu (Attie), 86

Fufu" mortars, 358

Frilani, 198

Fulo or Folo (Trchandjo), 138

Funfun (Yoruba), 321, 332

Funtumia, 124, 180, 434; F. Africana $58,79,89,111$, $79,89,111,122,123,125$, $126,143,180,228,391,395$, 440 , 459 ; F. species, 79

Furniture Woods, 107

Furu (Tschandjo), 128

Futu (Kirikiti), 133

Gabarua (Hausa), 231

Gabaruwa (Hausa), 218 Gaboon, 29, 293; G. Chocolate, 454 ; G. Nut, 258, 457

Gabun, 144

Gaertuera paniculata, 61

Garamagati (Ewe), 133

Galium Asparine, 431

Gall-bug, 124

Gallery Forests, 130, 138

Gamafada (Hausa), 206, 220 ${ }_{220}^{\text {G. tada hada fuda (Sok.), }}$
Gambia, 17, 20-22, 211, 494; G. Forest Exporta, 24 ; $G$. Forest Trees, 23; G; Mahogany, 135 ; "Gambia" 252

Game Preservation Ordinance, 302

Gamji (Hausa), 216 ; or GanjI (Kano), 218

Ganbe (Yoruba), 344

Gangame (Hausa), 218

Ganta, 194

Gantan Rura, 194

Garcinin conrauana, 233, 359, 360,462 ; G. punctata, G. Kola, 55, 69, 77, 360 G. Mannil, 360 ; G. Ovalifolla, 204 ; $G$. polyant hia, 55,88 ; G. species, 77, 239 . G., var, nov. brevipedi-

Gardeyi (Hausa), 220

Gardenia Abeokuta, 146 ; G erubescens, 192, 201; $G$. medicinalis, 146; G. Sokotensis, 199 ; G. species, physophylla, 61 ; $G$ tenuifolia, 113, 146; $G$. tenu folia 192, 201 : $G$, Thum bergia, 146; G. viscidissima,

Garicha (Zanfara), 218

Garlic, 199

Gassaya, 190

Gatisima (Mbonoi), 84

Gauden kura, 192

Gawasa (Hansa), 199, 213, 219, 231,232

Gawo (Hausa), 208, 220

Gazari or Gizeri (Hadeija), 218

Gbassei (Mendi), 44

Gbetschigbetschi (Atakpame), 144

Gbingbin (Yoruba), 23

Gbingbindo (Yoruba), 272

Gbogbonshe (Yoruba), 263

Gboite (Mendi), 43

Gbolei (Mendi)' 51

Gedar (Hausa), 220; Gedar

$$
\text { kurumi, } 233
$$

Gedu (Benin) 228

Geduloha (Benin), 322

Gemeracex (Nigeria), 197

Genferrebiesó (Mangu), 146

Gera, 204

Geraniacer (NIgerla), 193

German Markets,Sapeli wood,157

Gero, 199

Gesa, 199

Gezs, 204, 223

Ghido (Yoruba), 259

Giant Pod, 290

Gibofoyol (Mendi), 50

Gibowali (Mendi), 61

Gibowull (Mendi), 61

Gidjlko (Kratachi), 143

Gieselis pharnaceoides, 194

Giginys, 195, 200, 216, 218, 233

Gilli-gilli Forest, 160

Gimwi (Mendi), 45

Ginger, 90

Gingerbread palm, 216, 218 ; G. plum, 44, 72, 199, 213, 910

Glwini (Yoruba), 391

Giyaiys (Hausa), 192, 214 ; or Giyeya, 225

Gjira (Kratachi), 141

Gladiolus, 105 ; G. quartinianus, 195

Glortoss superba, 195

Glossonema nublcum, 199

Glycerine in pericarpoll, 480

Glyphres Grewioides, 53, 105 , 343 


\section{WEST AFRICAN FORESTS AND FORESTRY}

Gnibi (Attie), 87

Gnidia, 195

Goga jiki, 223

Gogwi (Mendi), 45

Gola Forest, $50,66-60$

Gold Coast, chapter VI, 91-115 ; Description of, $81-02$; Forest Bxports, 115 ; Forest land, 17, 69, 492, Iist of Indigenons, Trees and Rubber vines, 93-114

Golli (Mendi), 62

Gombei (Mendi), 42

Gomphis, 190 ; G. Congesta, G4; G. Glabrians, 359 ; Offinium, 359

Gongola or Gwongola gwangwala (Nupe), 218

Goñgovi (K pedy), 149

Gongui (Mendi) 43

Gonguonkiur (Mbonoi), 88

Gonistan Mountain, 416

Gonwé (Mendi), 42

Gonwi (Mendi), 42

Goo (Bali), 429

Gora (Hausa), 218

Gorgo (Hausa), 225

Goriba, 218, 244; G. (Hansa),

$195,200,216$

"Gorli" seeds, 462, 463

Goro, 223

Goron biri or G. ruwa (Hausa), 210,221

Gasgrpium Peruvianum, 76

Gotti (Fó), 140

Government of Forest Reserves Central and Federal, 165

Govwi (Mendi), 42

Gramineæ (Gold Coast), 93 ; (Togo), 127 ; (Nigeria), 196, 199,218

Grand Basa, 70 ; G. Forests of $72,73,74,76,82 ; G$.

Grand 81,82

Grass in Treeless Savannah, 19

Grazing Reserves, Nigeria, 163

"Greenheart," 52, 75, 280

Grewia, 190 ; G. Carpinifolia 105,344 ; G. Gigantiflora 137 ; G. Mollis, 190, 201 ; G. Tetragastris, 344; G Villosa, 137

Grepriopis discophora, 435 ; $G$. Globosa, 435

Griffonia palescens Coronkocut locally, 33

Ground nuts, 63

Grumilea vanoga, 89

Guaicum offieinale, 175

Guangua (Attie), 84

Guarea, 50 : G, Africana, 75 G. Glomerata, 416, 433; Guarea sp. near Leptotrichs, 50,228 ; $G$. species, 329,$416 ;$ G. (Satin Mahogany) description, 28,67 101, 328; G. Thompso

Guava, 78 ; $\mathbf{G}$. Mistletoe found on, 43

Gudjápüpü or Gudzawnwu (Ewe), 131

Gueguirotta baka (Agni), 84

Guele (Bondoukou), 83

Guere (Neyau), 87

Guesu (Bete), 87

Guisu (Be) 87

Guiera Senegalensis, 198, 199

Guima Djuma (Bondoukou), 83

Guinea Corn 196, 204: G Pepper, 219 ; G. (Spanish), 424 . G. (Upper) 17

Gum, 278, 298 ; G. African, 176 . 417 ; G. Arabic, 88, 204,
Gum-continued. $226,234,444$; G. Copal, $35,46,63,64,68,74,90$, 97, 152, 164, 226, 234, 424 ; 39 ; G. Resin, 211 ; $G$. True Benin Copal, 298

Gumsh, 39 ; G. River, 35

Gumgui (Mendi), 48

Gummel, 189

Gumnl (Mendi), 45 ; or Gumui,

Gumwi (Mendi), 45

Gung (Grunchi), 105

Gurara River, 211

Gurji, 199 Gurjlya (Hausa), 190, 209 ;
Gurjiya or Guriya, 223

Guru (Hauba), 106

Gurzundali (Katagum), 221

Gughiocho (Kratechi), 134

Guttapercha, 78, 80, 109, 226, 439 ; G. Tree, 218

Guttiferes (Sierra Leone), 54; (Llberta), 77 ; (Ivory Coast), 87 ; (Gold Coast), 107 ; (Togo), 139 ; (Nigeria), 164, $359,416,447$; (Cameroons)

waboa (Hausa), 213 ; (Sok., Kats, and Zanf) 224

Gwandar daji (Hausa), 190, 219, 233

Gwanja kusa (Hausa), 219

Gwaska (Hausa) or Itchen gwaska (Hausa), 220, 229

Gwe (Grunchi), 108

Gymnosporia Senegalensis, 191, 202,340

Gynandropsis pentaphylla, 190

Haake (Berlin Firm), deperlcarping process, 477

Habenarias, 185

Hablancue (Attie), 86

Hadanyar rafl or Kadanyar kurumi (Hausa), 225

Hemanthus rupestris, 19

Hrematostaphis Barteri, 86, 136, 192,222

Hague (Agni), 85

Haguguwa (Kano and Banchi),

Haho-Baloê District Plantations, 117, 119: Afforestation area, 120,121

Haho Rlver, I1

Haiefai (Abe), 85

Hainde (Agni), 86

Hainfain (Attie), 80

Haipi (Bondoukou), 86 ; (Agni),

Hakue (Attie), 85

Halu (Adionkron), 87

Hamburg Market, 157, 325, 326. 345,378

Hamon, 68

Ian Sawmill, 159

Hana Gobard (Zanfara), 221

Hanaball (Oban, Ekol), 280

Hane (Ebrie), 84

Hanfaru (Agui), 84

Hankufa, 190

Hannoa Klaineans, 85,100 , 232 ; $\begin{aligned} & \text { H. Undulsta, } 134 \text {, } \\ & 191,210,213,221,283,813 \text {, }\end{aligned}$ (5)

Hano (Hausa), 221

Hanwego (Bondoulrou), 85

Hapo (Ebrle), 87

Happerrie (Mbonol), 87

Harburg (near Hamburg, Germany), 480

Hardwood, 360, 413, 417; Bls

H., 410 ; Yellow H. 417

"Harmattan," 181

Harmon, 54

Harms, 205, 211
Haronga Madagascariensis, $\mathbf{5 5}$, 107,362 ; H. Paniculate,

Harrisonia Abysainia, 100

Fasskarlia Didymostemon, 52, $75,86,103$

Hate (Attie), 8

Hausa, 163, 185, 198, 205, 206. 350 ; H. Salts, 335

Hansaland, 188, 189, 190, 196. $200,205,207,211,216,217$

Hazel-nut compared with Heisteria parifolia, 257

Heeria Insignis, 13

Feinokohun (Mendi), 59

Heinsia gagminiflora, 61

Heisteria parvifolia, 257, 456 ; H. species, 258

Helel (Mendi), 47

Heleilahin (Mendi), 57

Helichrygum foetldum, 442

Heliotropum, 192

Fellebolei (Mendi), 47

Hendje, Hengné (Agni), 85 ; H., soft-wooded, 485

Hendui' (Mendi), 54

Henna, 192

Heptapleura Manni, 375

Heritiera, 54 ; Н. species, 351. 418 ; H. Utilis, 77, 106

Hete bake (Mbonoi), 85

Hetere (Bondoukon), 84

Heteropterys A tricans, 102

Hevea, 434: $\mathbf{H}$. Braxiliensis, $123,180,420$

Hewe (Mendi), 48

Hexabolus grandifiorns, 43, 96. 263,427 ; H. Morepetalus. 130 ; H.' Dalicifolius, 427 H. Senegalensis, 196

\section{Hibiscus, 201}

Fibiscos Fisculentus, 344 ; H Grewiloides, 344 ; H. Quinquilobns, 344 ; H. Bpecies, 190 : H. THiacens, 105

Fides and skins exported Togo, 150

Hiern, 214

"High Forest," 241

Hiol or Mbia (Bakoko), 428

Hippocrates, 191

Ho Sub-station (Togo), 126

Hobo hapl (Abe), 86

Hofa (Abe), 87

Hog Gum, 863: H. Plum of the Creoles, 52, 108, 222, 282, 338,419

Hogogo (Atakpame), 134

Hoke (Mendi), 41

Holarrhena Africana, 59 ; $\mathbf{H}$ Ovate, 59 ; H. Wulfs bergii, $112,142,233,395$

Holland, Mr., The Uaeful Plante of Nigeria, 278

Homalium Africanum, 88 ; $\mathbf{H}$. of. Africanum, 366 ; $\mathbf{H}$ Molle, $55 ;$ H. species, 55

Honey ezported, 444

Honum (Tw), 110

Hooker, Sir Wm. J., 400

Horns exported, 444

Horse Chestnut Tree, 129 ; H. Radish Tree, 44, 219

House post, 413

Hugonia scuminsta, 100 ; H. octhocosum 100 ; H. Planchont, 100 ; H. Playeepals, 100

Hul (Mendi), 43

Hull Port for Congo Kernels, 480 ; H. Prlce of Cake, 482

Humiriacen (Sferra Ieone), 49 (Ivory Coast), 85; (Nigeria), 808

Fumpe (Ebrle), 86

Humus, 70, 267

Hupfeld, Dr. (depericarping

Hupreld,
process),
Hure (Plapo), 87 


\section{INDEX}

Huti (Fó), 138

Huwi Djenjei (Mendi), 68 Hydrocharitace (Nigeria), 195 Hydrolea, 194 ; H. Guineensis, 194

Hydrophyllace $\circledast$ (Nigeria), 194

Flodendron Gabunense, 428

Hymenocardia acida, 52, 103, 135,202 ; H. Chevalieri. 103; H. Hendelotii, 52; H. Lyrata, 52 ; H. Ulmoides, 136

Hymenodictyon Bracteatum, 407 ; H. Kurria, 145

Hypericines (Nigeria), 190

Hyphæne 244, 459 ; H. Coriocex, 127 ; H. Thebaica, 195 216,218 ; H. Togoensis, 12

Hyrax (squirrel-like animal), 467

Iakuni (Quitta) 108

Ibadan, 159, 174, 175, 185, 240 $241,247,249,251,252,263$ $269,275,285,288,289,294$, 299 , 301, 305, 307, 813, 322, $323,331,336,339,342,349$, $354,362,367,370,383,389$, $391,393,396,401,409,418$ $475,489,490,493$; I Forests, 244 ; Ibsdon-JebuOde Road, 170 ; I. Plantations, 176, 178, 179; I.

Ibadudu (Benin), 368 ; (Jebu, Yoruba), 368

Tbagho (Yoruba), 314, 315

Ibbegoga (Benin), 317

Ibbu (Benin), 391

Ibegogo (Benin), 229

Ibeshe, 367

Ibi, 188

Iblbio Province, 185

Ibitoto (Bembi), 340

Ibo-Akitipa (Yoruba), 392 I.-tabong (Yoruba), 392 I. Ilecki (Yoruba), 392

Ibo (Benin), 393 ; I. (Yoruba), 892

Tbo country, 158, 253 ; I. language, 185 ; I. markets, 284 Ibos, 474

Ibugidi or Ibogidi (Yoruba), 392 Icacinacese (Sierra Leone), 53 (Ivory Coast) $87-$ (Gold Ida Plantation, 167

Idagbon (Ondo), 230

Idah (Yoruba), 270

Idanre district 390

Idi, Idi Odan (Yoruba), 372

Idigbo (Yoruba), 369

Idjawli (Akposso), 143

Idjnake (Bakundu), 442

Idofun (Yoruba), 407

Iedí (Krepi), 96

Ifainaki (Egba), 230

Ifassoa (Bakwiri), 433

Ife, 159

Ifetn, 337

Ifon Owe-Akure Road, 318 ; Ifon Province, 275, 402, 412, 468,473

Ifondo or Wofondo (Bakwirj), 426

Ifwan (Eflk), 229

Igata (Yoruba), 268

Igba (Yoruba, tree), 283

Igbagon Stream, 488

Igberi (Yoruba), 260

Igbeshe, 367

Igbin (Brass), 290

Igbin (Benin), 245, 391 ; (Yoruba), 265; (Lagos), 313, 407,494

Igbofla (Tbiblo), 361 Igedudu (Benin), (Yoruba), 385

Igi Ira (Lagos), 407

Igigum (Egba),

Igili (Mendi), 51
Igmikkia fruit (Benin), 284

igoda (Benin), 363

lgogo (Benin), 257, 331

IgOso, 351

Igun (Yoruba), 302

Ihagobo (Benin)

Thege (Benin), 256

Ihi ( $\mathrm{HkOi}), 229$; (Ibo, Owerri), 276

ja oke (Yoruba), 396

jaiye, old town site, 167

lje (Benin), 256

Ijebo (Yoruba), 228

bbo (Yoruba, Jebu, Ashuwole), 323

Ijebu-Ode District, 278

Tjeni (fruit, Benin), 256

Ijeni Udeg bu (West Side), $\mathbf{3 6 1}$

Ijor, 185

jorg or "Waterboys," 155, 168 $185,187,238$

Ikaka (Bakundu), 442

Ikakama Udia Ebian (Efk, Ibibio), 361

Ikale Village, 354

Ikmn (Benin), 240

Ikagsa (Benin), 379

Ikate (Yoruba), 233

Ikbo (a Benin game), 379

Ikereoha (Benin), 257

Ikhemeni tree (Benin), 284

Ikhimi (Benin), 401

Ikoha (Benin Province), 403

Ikoi (Oban), 368

. Ikom, 168;' I. District, 239, 472 Ikomba (Bare), 426

Ikoto, 244

Ikpa ukoro (Yoruba), 241 ; I. wud n (Benin), 29

Tkpan (Bflk) 452

Ikpanya ( $\mathrm{BGK}), 277,278$

Trpoba Boad, 447

Ikrigon Reserve, $160,168,171$, $172,173,178,372$

Tlku, Seeds (Yoruba), 285, 368

Ikwabobo (Benin), 325

Ikwapbo (Yoruba), 315

Ikwapo (Benin), 228

Ikwepokin (Benin), 283

Ikwian (Benin), 393

Ilaka (Benin), 410

Tlakosin (Yoruba), 265

Ilaro Reserve, $160,166,167$ $170,173,322,343,347$

Tlass Omodo (Yoruba), 344

Ile (Ibo), 231 ; (Bonny and New Calabar), 334

Desha District, 302, 354, 395

Ilobe (Nigeria), 487

Ilorin, Balsam, 44, 307

Ilspoba Road, 447

Ilugbro, 359

Tlugun, 159

Illusbi (Asaba District), 395

Ilysanthes, 194

Imo, Railway, 384 ; Imo River, 152,287

Imonon (New Calabar), 368

Imonor (Ibo), 228

Imperial Institute, Teak samples sent to, 171 ; Report ples sent is

Imperial Institute Bulletins, 20

Incense Tree or Ehye, 100, 229, 314, 315

Indaikihen (Mendi), 48

India, 145, 174, 338 ; I. Almond, 176 ; I. Blackwood or Rosewood, 175; I. Value of Bombay Blackwood, 176 ; I. Rose Chestnut or Ironwood, 178 ; I. Walnut, 175

Indigo, 303 ; I. (Big leaved), 46, 192'; Yoruba Indigo, 303

384, 385 ; Indigofera, 181 ; I. Africana, 430; I. Arrecta, 129; I. Hirsuts, 303 ; I. Secundiflora, 221; I. 'Stenophally, 30 s
Indoabaja (Mangu), 140

Ingidido (Hauga), 190, 213, 219

Inkum, 168

Ynnuwar Bauna (Hausa), 214

Inol 368 ; I. nut 368 ; or Inoye (Effk), 368, 416, 451 ; Inoi (Ekoi), 368

“ Inselburge," 18

Insofaniowoche (Mangu), 130

Insuakoto (Mangu), 143

Insuopangi (Mangu), 130

Intya (Dyakossi), 145)

Intya Joko (Yoruba), 372

Inya (New Calabar), 282

Inyere (Ekol), 228

Inyi (mo), 229; (Ibo, Onitsha Owerri), 275

Inyin Tree, 234

Ipa (Yoruba), 337

Ipahan (Yoruba), 358

Ipapo (Yoruba), 302

Ipawhaw (Yoruba), 232, 358

Ipetu, 337

Ipka market, 473

Ipomæa, 194 ; I. bona-nox, 203

I. involvucrata, 440

Ira Odan (Yoruba), 335

Iragbo Amuje (Yoruba), 257, 393

Iralgbo (Yoruba), 393

Iranje (Yoruba), 337

Ireh Ako, 395; ; I. (False) Tree, 395,440 ; Ireh-ibeji, 395 ; I. Rubber (F'untumia elas tica) Plantations, Nigeria. 180 ; Togo, 149

Irena-kekere (Yoruba), 396

Irere (Yaruba), 330

Irddacen (Nigeria), 105 ; (Camoroons), 425

Iringi (Ibo), 22

Iroko, 19 ; suggestion by $\mathrm{Dr}$. Unwin, 42, 67, 117, 119 $120,124,125,126$; I (chlorophora excelsa) Plantations (Nigeria), 154, 158, $159,162,164,168,171,172$, $215,228,249,252,254,418$, 498 ; Plantations (Togo), 149,153

Tronpost 27: Uses of, 28 Sierra Leone, cut locally, 33,54

Ironwood, 174, 176 ; Dwarf Ironwood, 323, 379, 417

Irosun (Yoruba), 232, 287

Iru (Yoruba), 282, 401

Irugba (Yoruba), 230 ; (fruit), 283

Irugbo Abatta (Yoruba), 282

Irvingia, 85: I. Barteri, 68 , $74,100,179,230,312,313$ $417,418,422,423,445,446$, 454 ; Irvingia Gabunensis, 419, 432; I. Smithil, 191; I. $\mathrm{sp}, 100,313$

Isain (Attie), 86

Isanhianme (Benin), 385

Isbe (Yoruba), 299

Iseko (Yoruba), 330

Isha fere (Yoruba), I. gere (Yoruba), I. kekere, 395

Ishan (Benin), 358

Ishan, 229; I. gege (Yoruba), 343 ; I, jeje (Yoruba), 343, I. oks (Yoruba), 341, 342

Ishighiya (Zanfara), 220

Ishoka, 299

Isienwe (Benin), 354

Jginko (Yorubs), 342 375

Islit of the Akus, 61

Isill Dalzielii, 205,220 ; I. doka $191,200,205,220,280$; I. sp., 234

Isolona pleurocarpa, 427 


\section{WEST AFRICAN FORESTS AND FORESTRY}

Isga oku (Yoruba), 262 ; (Ikale), 246,247 ; I. gangan (Egba) 246 ; Ita-ita (Yoruba), 247 Itaku márket, 300

Itakum (Yoruba), 337 ; I. mountain, 18; I. okere (Yoruba), 344

Itebe (roofing canes), 164

Iteruku (Eflk), 279

Itiuyang (Oban, Ekoi), 386

Ito (Yoruba), 284, 367

Itobo (Tbibio), 368

Itue (Benin), 362 Itunkpe Creek (trib, of Kwa

Ivialegbi (Benin), 457

Ivioha (Benin), 385

Ivory, 80; Exported (Togo). 150-144); Ivory Coast, 66, 69, chap. v, 81-90, 157 Forest exports, 90; Iist of trees, $83-89$; 1 . coast mahogany, 81 ; method of feling, 81

Iwe (Yoruba), 401

Iwu (Yoruba), 19

Ixora radiata, 197, 204

Iya (Eflk), 285 ; (Yoruba), 231. 307

Iyawy (Red Cedar), 32

Iyeye (Yoruba), 232, 388

Iyoha (Berin), 265

Iyokheze (Benin), 407

Izaquente Portugats (Colons.)

Izenagan (Benin), 256

Izeni or Iyockan (Benin), 363

Jackson, D. G., 496

Tagbouei (Mendi), 51

Jagiri, 800

Jahdanko (Acora), 111

Jalei (Mendi), 46

Jama (Ashanti), 111

Jamostima (Mendi),

Th (11) 211 , J. Yaro or Jitache, 222
dari (East Hausa), syn. Gorpo, 225

Jashnll (Mendi), 61

Jasmin, 61

Jatropha curcas, 193

Jaunde District, 429, 433

Jawei (Mendi), 50

Jawul (Hansa) 291

Jebere of the Ondos, 280

Jebu or Jebu-ode, $152,153,154$ $159,303,342,349,354,357$, 361,378

Jekri Country, 308, 398, 474; Jekris, The, 163, 236, 238

Jendi (Togo), 118, 125, 469

Jerusalem Thorn, 221

Tetf (Ewe), 141

Jibda kagse, 193

Jimshi (Sok) 220

Jina Jina (Soik, and Zant.), 219

Jirga (Sol and Kato.), syn. Tsatsagi (Sok., Zaria, Kano, etc.), 220

Jiri (Hausa), 215, 225 ; J. dan parikin itatura (Sok, and Kato.). 225

Johann Albrechts \#öhe. 425, $42 h, 427,428,42 A, 480,431$, $432,433,484,435,438430$, 440,441

Johimbe, 407

Tohimbin alkaloid, 408

Tohn Obev, 25

John Obev, 25 138

Jojan (Kabure), 138

Joloso (Duala), 433

Tom (Ossldinge), 440

Ton (Bail), 441

Tondo (Bakmiri) 428

Ju (Akposso), 138
" Ju-ju," 164, 243, 246, 286,

Jujube Tree, 222

Juma (Wassaw), 95

Jumbowilli, 46

ustocoa, 194

Kaba, 218, 244

Kabeova, 193

Kabu or Ebba Kerncls, 460

Kadanya (Hausa), 214, 281 ; K. or Kadai, 224

adanyar kurumi, 225 ; K. raf (Hausa), 214, 232, 233

Kadaura (Hausa), 191, 205, 220 : (Kano, Zaria), 221

Káde (Hausa), 141

Raderabolo (Tachandjo), 138

Kaduna R.., 189

Kæmpferia Ethiopica, 195

$\mathrm{Ka}$ fafogo (Hausa), 222

Kafahinel (Mendi), 61

Kafe or Kaffi (Mend1), 50, 57 : Kafel (Mendi), 60

Kafro (Grunchi), 105

"Kafu," 457

Kagnari Hountaing, 25, 39, 58

Kaidaji (Hausa), 209, 220 ; or Kardaj1, 220

Kaiguigo (Bondoukou), 86

Kaikai (Hausa), 219

Kaikumba (Mendi), 55

Kainya (Hausa), 230

Kaiwa (Haitsa), 214, 224

Ka Jafgo (Hausa), 215

Kaju (Yoruba), 339

Kakaleka (Bondoukou), 88

Kakana (Agni), 89

Kakanla (Kratschi), 140

Kakatown, 70

Ka KI ganin bula (Zantara), 221

Kakoba (creeper), 163

Kakoro (Fant I), 86

Kaku or Red Ironwood Tree, 107

Kakunt (Timanl), 49

Kala (Trehandjo), 196

Kalangasghi Btation (Togo), 126

Kalangon dafi, 220

Kam (Tjmani), 48

Kamaa River (Togo), 121, 124

Kamatete (Ibo Owerrl), 407

Kambala, 422, 423

Kamban (Fantj), 103

Kambui Hills, 25, 39, 160

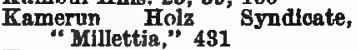

Kameruns. 189, 211

Kamfua (Bagu), 135

Kamori Aguire (Agni), 87

Kanahia consimilis, 112

Kanakan (Yoruha), 246

Kanda Bark, 250

Kandarl (Hausa), 192, 212, 223

Kangahan, 25

Kanja (Bakwiri and Bakundu), 440

Kanjanancule (manmu), 134

Kaniu (B ausa), 222

$K$ ankan (Yorvba), 407

Kankandika (Yoruba), 966

Kanna (A Rante), 140 Kano. 189, 190, 198, 201, 207,

Kanran (Yoruba), 178, 280, 384

Kant (Timanl), 55

Kanti (Mendi), 55

Kenton (Fant1), 85

Kanumfart (Haira) 204

Kanwo (Hausa), 229

Kanya, (Havea), 214, 224

Kao (Hausa), 182

Kapok or C. Pentandra (Cerman Botanists), Friodeniron (Kew Botanists), 122; $\bar{K}$. flbre. $53.90,105,120,128$ $124,125,126.150,209,226$, 345,346 : $\mathbf{K}$. plantations (Tono), 149

Kapro (Grunchi), 94
Kapus (Timani), 43

Karangia, 199

Karan masalachl, 199

Karene District, 46

Karfa (Bambara), 83

Kargo (Hausa), 207

Karina District, $\mathbf{3 1}$; K. Forest, 46

Kariya, 199; Karlye gatari. 220,221

Karjara (Kano), 220

Karki (Sok., Kato,, and Zanf.), 220

Kasfya, 214 ; $\mathbf{K}$. (Sok., Kats., and Zanf.), 225

Kasht Kashi (Kontagora Kols.), 220

Kaskawam, 190 ; $\boldsymbol{K}$. cannabinus, 190

Kassekui (Mbonoi), 86

Kassewe Hills, 25, 36, 39, 46

Katai (Timani), 46

Katambiri (Hauga), 225

Katanga treeless area, 423

Katank (Timan1), 54

Kati (A be), 88 ; K. (Atakpame),

Katsari (Hausa), 209, 220

Katsina, 207; K. (Allah), 210 ; K. (River), 188

Katumbulia (Trchandjo), 141

Kau belia or abalia (Tschandjo), 146 ; $\mathrm{K}$. keure (Tschandjo), 146.

Kauchi, 193

Kauri Gum, 37

Kanriri, 193

Kaülsa (Indenle), 87

Kauwl (Mendi), 58

Kawo (Hausa), 190, 191, 205, 220

Kawogel (Mendi), 59

Kawurl (Bausa), 216, 219

ayar rakumi or Karo (Kano, Sok., and Kats.), 220

Kayo (Bondoukou), 86

Kebarre (Kratachi), 132

Kedă (Trehandjo), 129

Kedeles or Kodolet (Tischandjo), 133

Kedempo (A takpame), 141

Kedemponasl (K ratachi), 135

Keditla (Tschandjo), 132

Kedjetjelo (Tachandjo), 146

Kelwgo (Bondoukou), 86

Keka (Kratsehi), 137

Kekēñ (Tschandjo), 132

Kekpill (Kratschi), 133

Kelung (Timani), 45

Kelantori (Kratschi), 134

Kelengmau (Tschandjo), 134

Keleyn (K ratsch). 133

Kelipotill (Kratachi), 138

Kelle (Kratachi) 188

Kencle (Mbonol), 85

Kenjang (Kratnchi), 132

Kennema, 54, 59, 160, 493

Kent, 25

Kerang, 198

Kere (Yormba), 270

Kerstine, Dr. (P1ptadenia Keratingil experiments), 128

Keruwown (Trehandjo), 138

Kesang (Tschandjo), 139

Kesrede, 466

Kessing (Tschandjo), 133

Kete-Kratschi 8tation (Togo), $118,124,126,148$

Kettbubaka (Aowin), 100

Ketschliantscha (Kratschi), 181

Ketum (Timenl), 60

Ketyelenea (Tschandjo), 146

Kewe (Mendi). 43

K'fut (Timani), 54

Khava, 50, 121, 228, 323, 330 , 393,425 : $\mathrm{K}$, anthoteks, $100,318,320$; $K$. caudeta, 101 . $T$, $417,420,493$; K. grandi- 
folia, 318 ; K. grandis, 75, Kombo seeds, 458 $81,101,318,319,320,322$ $\mathbf{K}$. Ivoriensis, $66,81,82,86$ $101,318,319,320,321,324$ $\mathrm{K}$. Klainii or Klaineana, 119 $120,121,126,135,416,433$; $\mathbf{K}$. punchii, 81, 100, 101, 318, 17, $20,81,101,117,118$ $120,121,123,124,125,126$, $134,177,190,191,203,211$ $222,229,318,321,433 ; \mathrm{K}$. sp., 101, 183, 318, 319, 320 $321,322,424$

Kiangue (Mbonol), 88

Kicksia Africana, 143 ; elastica, 440

Kombolo or Combolo (Duala), 429

Komdi (Timani), 55

Komigbulei (Mendi), 53

Komoe Tiver, 82

Komir (Tschandjo), 138

Kondi (Mendi), 51

ongkong or Kongkonga (Tsehandjo), 135, 14

Kongo (Tschandjo), 142

Kongofura (Tschandjo), 142

Kongoli (Mendi), 62

Kongolu (Tsehandjo), 140

Kongowura (Kotokoli), 139

Konkwa (Bali), 437

Kidgeling (Tschandjo), 136

Kidney-tree Cotton, 76

Kigelia, 60 ; K. acutifolia, 441 ; 225 ; K. Africana, 145, 400 ; K., var. Bornuensis, 215, K25 ; Kar. pinnata, 113, 145,

Fili (Mendi), 41

Kimba (Hausa), 219, 233

Kiachia, 19

King of the Timber, 318

Kingrange (Hausg),

Kinguei (Mendi) 53

Kinkonswon (Mbonoi), 84

Kino (Timani), 50

Kingelu ('Tschandjo), 136

Kiria (Hausa), 131

Kiriandutschi (Tschandjo), 132

Kiriza (Hansa), 207, 220, 233

Kishia (General West Coast),

Kita (Timani), 48

Kinkuesin (Attie), 84

Kiumba (Bondoukou), 89

K'Kuperb (Timani), 45

Klaineodoxa Gabunensis, 230, 432 ; K. Grandifolia, 432

Klo (Ewe), 133

Klokpakpa (Ewe), 131 ; (Kratschi), 132

Klongbau (Timani), 134

Kobei (Mendi), 54

Kobi (Bambara) 85

Kobwi (Mendi), 46

Kochoa (Kratschi), 139

Kodago, 218, 244

Kode lia (Tschandjo), 140

Kofe (Mendi), 55

Kofei (Mendi), 58

Koghia bera (Fantl), 88

Koinad uon District, 58

Kojagei (Mendt) 56

Kokank (Lophira Procera) cut locally, Sierrs Leone, 33

Kolkara (Hansa), 220

Kokjya (Hausa), 215 ; or Kokiyar biri' (Kontagora), 224

Koko Port, 151, 156, 157 ; $\mathrm{K}$ Town, 305

Kokochiko (Hausa), 223

Kokojá (Losso) 128

Kokomezur (Mbonoi), 89

Kokoro or Golloklo (Tschandjo), 133

KokotI (Wassaw, Fanti), 108

Kokotai (Fanti), 87

Kokotswi (Twi), 101

Kokpara (Atakpame), 130

Kokue (Attie), 88

Kokuwa (Sok. and West.), 221

Kola (Tree), 54; Baboon K. 54 ; K. Bark, 145; Bitter Teone), 63, 106. See also Cola

Kola nuts, 54, 63, 69, 80, 106, 150,223

Kolei (Mendi), 48

Koligi (Leopardwood), 35

Kologalei (Mendi), 55
Kontagora, 189, 190, 200, 210 (see Afzelia African) 32,47

Kontsha District, 415

Köpu (Kratechi), 132

Koran tablets made from Crossopteryx Kotschyana. 145

Koriga stream, 200

Koronko (Timani), 45 ; (and

Kotia (Yendi), 137

Koto Dyakossi, 142

Kotokie (Indenia), 87

Kotopapa (Krepi), 98

Kotopuan (Attie), 84

Kotschli, 214, 215

Kotublassu (FO), 139

Kouanda (Attie), 87

Kowi or Kuwi (Mendi), 49

Kpa (Eflk), 352; K. (Ewe), 127

Kpaini (Mendi), 43

Kpalio (Anago), 127

K pakpa (FO), 132

K Pal (Timani), 46

K'Palen (Timani), 58

Kpánena (Kratschi), 131

paoloe (Mendi), 51

7 pendei (Mendi), 47

K pendeideli (Mendi), 47

Kpessei (Mendi), 44

$\mathbf{K}$ petellahen (Mendi), $\mathbf{6 9}$

K poe (Ewe), 139

K poye (Sierra Leone), 457

Kreangú (Asanté), 141

Frekete (Bambara), 88

Krendja Haigne (Acmi), 85

Kroo Coast, 98

Krúbete (Asanté), 135

Krutū (Tschandjo), 139

Kuangua (Agni), 84 ; $\mathbf{K}$. iniama (Ägai), 85

Kuanguan (Amni); 84

Kuatiecuale (Ami), 86

Kube (Akwapim), 93

Küie (Attie), 84

Kuge (Bakossi), 440

Kugrnu (Tschandjo), 134

Kuka (Hausa), 138, 190, 210, 228

Kukorn (Timani), 45

Kukuki, 190, 210, 223

Kukumarugbo (Yoruba), 332

Kuli pia (Bondoukon), 85

Kulil (Timani), 51

Kumba District, 416,420

Kumchi (Sok, and Zanf.), 222

Kuntunkun (Twi), 105

Kuntunkuni (Denkira), 105

Kupaussto (Kabure, Tschandjo), 131

Kuppe Mountains, 415, 417, 420

Kurdi (Hausa), 220

Kure (Agni), 84

Kuriya (Sok. and Zanf.), 223

Kurna (Hausa), 198, 213

Kuman nasara, 191, 219 ; (East Hausa, Kontagora), 22

Kursua (Appolonian), 107

Kuru (Brass), 357; (Tbo,

Owerri), 357
Kusia (Twi), 113 Mendi), 45

Krubua (Twi), 10

Kuakie-kuakie (Agni), 88

Kupkup (Timani), 62
Kuwi or Kowi (Mendi), 49

Kuwul (Timani), 44

K wa (River), 152, 469

Kwaboho (Ashanti), 100

Kwabohri (Twi), 100

K waiebo River, 151, 152

Kwakwa or K wakwar (Hausa), 218

Kwalo nut, 218, 244

Kwandaruja, 220

Kwankanni, 192

Kwantama (Wassaw, General West Coast), 111

Kwantanura (Ashanti), 101

Kwari (Hausa), 224

Kyllingia, 196

Kyukyu or bird, 315

Labiatae (Nigeria), 194, 400

Labuje goriys (largest nuts), 283

Laburnum compared to Casais fistula, 99

Lagenaria, 159 ; L. vulgaris, 193

Lagos, 151, 156, 157, 169, 170 $174,176,185,189,243,264$, $339,358,368,395,410,464$; L. Public Works, 160 ; L. Sawmills, 159 ; Lt Be-

Lagostramia (L. fos Regine), 174 Laguncularia racemosa, 56 , $108,374,397$; L. 8p., 397

La. Hou, 81, 82

Lakole (Yoruba), 849

Lakoshe (Yoruba), 265

Lakoiln (Yoruba), 264, 265

Lakuta (Yoruba), 303

Lalong grass, 56

Lancashire County experiments, 483

LAsodo (Trchandjo), 140

Landolphia, 208, 302 ; Landophia (large frulted), $\mathbf{3 0 2}$; L. bracteate, 100, 392 ; L. Dawei, 440 ; I. Droogmansiana, 111 ; L. ferruginea, 110 ; I. florida, 111 , 192, 392 ; L. Hendelotil, 58 ; L. fenge, 79 ; L. 58 ; L. owariensis, 68,79 . 111, 197, 392 ; L. owariensis jenge, 58 ; L. owariensis, var. rubiginosa, $\mathbf{3 9 2}$; L. Petersiana, 392 ; $\mathbf{L}$.' gcandens, 111, 392; L. Sengalensis, 111, 392; $\mathbf{L}$. Thompsoni, 111, 392

Lane Poole (specles trees, Sierra Leone), 41

Lângẫa (Kratschi), 146

Lannea acidissima, 86, 136 ; $L$.

Iantana camara, 112 ; $I$. salvitolia, 193

Lasiodiscus, 104

Lasiosyhon Glaneus, 437 ; $L$. Kraussii, 195

Latex, 58, 95, 109, 111, 250, 252, $254,266,292,392$

Invaces (Gold Coast), 96 ; Cameroons), 427 ; (Nigeria), 195,266

Lauro (Cedar-like), 250, 346

Lawonong (Jaunde), 442

Lawsonia albs, 192

Laye, Igu (Yoruba), 302

Lecaniodiscus cupanioides, 53 . 104,340

Lecythidaces (Gold Coast), 108 ; (Nigeria), 367

Lees, 105; I. Gufneensis, 197

Leguminose, (Sierra Leone), 44 ; (Gold Coast), 96 ; (Liberia), 72: (Ivory Coast), 84; 269, 276, 277, 301, 305, 447 ; (Togo), 130 
Leicester Peak, 25

Lemon trees, 124

Lentibulacea (Nigeria), 194

Leopardstown (Calabar), 312

Leopardwood, Description of, 35

Iepidoturus occidentalis, 433

Leptadenia lancifolia, 199

Leptaulos daphnoides, 53, 87

Leptoderris, 287

Lia nuwasaure (Tschandjo), 142

Liane, liana (fibre), 72,131

Liasá (A takpame), 129

Liberia, position of, 17 ; L., chapter iv, 68-80 ; L.' able trees, $66-69 ;$ i . Trees and Aubber Vines, 70-79: L. Forest Exports, 80

Liberian coffee, 79

Lifui (Ewe), 144

Light African Greenheart, 278

Lignum Vitro, 175

Lili River, 11

Liliacez (Sierra Leone), 42 ; (Liberia), 70 ; (Ivory Coast), 83 ; (Gold Coast), 94; 199,245

Lllualamombe (Bakwiri), 433

Lime trees, 124

Limonia, 221 ; L. Preussii, 134 ; L. Warnecke, 134

Linaces (Sierra Leone), 49 ; (Ivory Coast), 85 ; (Gold 481 1 ), 100; (Cameroon

Lindackeria dentata, 107, 437 tica, 142

Lipiti or Dsati (Ewe), 132

Lippia Ukambensis, 193

Liptonychia, 54

Lisombe Palm, 243

Lissochilus arenarius, 195

Liver Sausage tree, 145

Liverpool Markets, 157, 252, $255,259,264,268,272,277$, $\mathbf{2 7 9}, 280,282,287,293, \mathbf{3 0 5}$, 348 , 354, 358, 361, 378, 390, $403,404,405,456,460,461$, 480

Liwoma (Bakwirl), 434

Lloyd, Frank J., Analysis of Kernel Cake, 481

Lo (Abe) 85 ; 481 (Attie), 85 ; Lo (Attie), 87 ; (Ewe), 134

Lobog (Jaunde), 442

Locust, 491 ; I. bean, 45, 73 ; Tree, 97, 120, 126, 153, 207 ; L. wood, 131

Loganiacers (Sierra Leone), 58 ; (Ivory Coast), 88; (Gold Coast), 110 ; (Togo), 142; 224,$389 ;$ (Cameroons), 440

Logo (E'we), 129

Logoasagu (Ewe), 128

Ioho (Abe), 83

Loko, 21

Lokoba (Attie), 86

Lokobua (Attie), 86

Lokoja, 188, 189, 202, 206

Lom (Bakolko), 430,435

Loma Mountains, 25, 58, 160

Lomburu (Bondoukou), 87

Lome Experimental Gardens, 122 ; Railway, 119, 121; Taxation,

Lonchocarpus, 35,46 ; L. Barteri, $72 ; L$. cyanescens, 46 99, 197, 219, 221, 303 L. laxifiora, 72, 191, 201, 220, 221; L. sericeus, 46, $72,85,99,183,302$; L. Bp. 303 ; I. zenkeri, $72,231,428$

London markets, 157 ; (Erith), 430

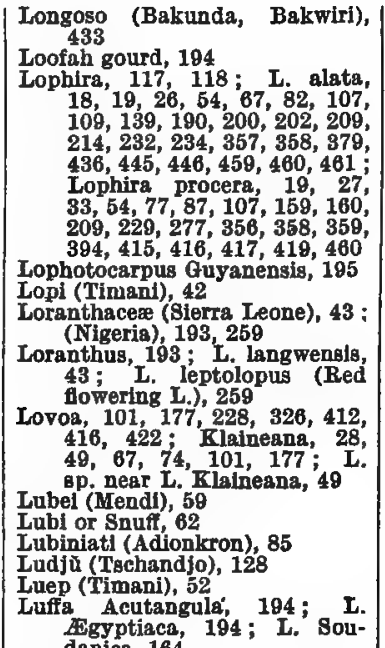
danica, 164

Lumber exports (Gold Coast), 11

Lycopodaceze (Nigeria), 410

Lycopodium phyllamaria, 410

Lymexylon, 326

Lythracex (Nigeria), 192

Maba (Benin), 388 ; M. Mannil, 57,388 ; M. Warnecki, 142

Mabanga (Duala), 441

Mabump (TImani), 47

Macaranga, 337; M. Bartert, 52, 102 ; $M$. heterophylla, 52, 102 ; M. Hendelotif, 86 M. Monandra, 52, 102 ; M. Rosea, 433; M. Row landii, 102 ; M. sp., 433

Mackay or Sea bean, 69, 72, 298 I I elongatum, Mannii, 428; M. MaeroMannil, 428 ; M. Macro$46,85,98,288,289,449$ : M. Preussti, 428; $\mathbf{M}$. reticu-

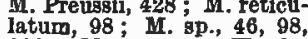
232 ; $M$. sp. near Hendelotij, 47 ; M. Stipulaces 98,289 ; $M$. Zeniker1, 428

Madachi (Hausa), 190, 211, 229 ; M. or Madavachi (Sok.), 222

Madobia (Hausa), 206, 221, 231

Mæsa lanceolata, 438

Mesobotrya caullflora, $103 ; M$ sp., 52; M. stapflana, 86 ;

Magari sarser, 103

Magariyar kura, 198, 22

Magarua or Bagarua (Hausa), 191

Magbevi (Mendi), 50

Magoro (Hausa), 222

Maho River, 39

Mahogany, 50, 67, 75, 77, 119 . $120,228,323,328,392,334$, $363,364,405,413,416,420$, $421,422,424,445,446$

African, $20,120,135,140,175$, 205,222

African, West, 211, 422, 423

Bark Tree, Brass, 308

Bastard, 315

Bean, 205

Benin, 57, 78, 157, 266, 268,

Cedar, 26, 28, 328, 329, 330 ; Hard Cedar
Cherry, 376
Mahogany-continued.

Close-grained, 328

Dita, 73

Dry Zone, 177, 229

Duika, 423

False, 324

False Hill, 348

Gaboon, 29, 315, 816, 317, $320,419,422,424$

Hard, 306,419 ; Hard capsuled, 323

Heavy, 102, 151, 157, 418, 420

Khaya, 423, 325; A. Khaya Senegalensis, 17,$20 ; 21$; Khaya Klainii, 140

Kontah, 26, 67, 205

Lagos, 157, 162, 164, 167

Light, 415, 417

Long-capsuled, 177, 178, 415,

Mountain, 35, 46, 68, 72

Niger, 320

Nuts, 267,269

Oban, 378

Pink, 304, 315

Plantations (Togo) (Khaya Klainii)

Reserves, 107

Rhodesian or Kontah, 26, 67,205

Sapeli or Heavy, 102, 151, $157,418,420$

Satin, 28, 50, 75 $318,329,416$,

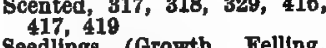

Seedilings (Growth, Felling, Rafting), 187

Spanish, 175

Substitute, 57

Timber, 226

Uhi, 319

Unscented, 416

White or Galvon, 29, 320 . White-barked, 320

Malze, 204, 471

Laje (Hausa), 190, 191, 205; (Sok.), 221

Majigh, 221

Majiriya (Kano), 221

Mak (River), 419

Makarfo (Hausa), 202, 205, 221,233

Makasar adwa, 194

Makua (Mbonoi), 86

Makube (Ashanti), 93 ; (Fanti),

83,93
Malacantha sp. nov., 382 ; M. Warneckeana, 141

Malankwi (Appolonian), 93

Malel (Mendi), 45

Mallotus oppositifolius, 197

Malmo (Hausa), 213, 224, 232

Malphigence (Gold Coast), 102

Malvaceæ (Liberia), 76 ; (Gold Cont) 105: (Togo), 137 ; Nigeria, 190; 344; (Cameroons), 485

47

Mambol (Mendi), 51

Mambul (Mendi), 47

Mamie Kini, 88

Mamte, 418

Mammes sapota, 55 ; M. sp., 230

ammee (Timani), 55

Mammy or Mammee Apple (Ochrocarpus Africanus), 29, 83, 55; Mammy supporter,

M5 Lonu Lohocarpus, 303 ; M. Reserve, 160, 166, 170, 172 , $173,176,178,170,180,246$ 264, 278, 303, 312, 847, 373, 392, 405, 407

Manchester (prepared to take kernels), 481

Manengube Mountains, 415 , 417 
Mangifera, 75; M. Africana, $52 ; \mathrm{M}$. Indica, $222 ; \mathrm{M}$. 8p. 75

Mango, 75, 196, 222 ; M. вp., 75 . M Tree, 75

Mangrove, 19, 438 ; M. Bark, 226 ; Red M., 234, 368, 396, 451 ; White M., 108, 234, $374,397,440 ;$ white Button M., 374; White Nut M., 257

Manorove Forests, 20, 33, 56 , 78 ; M. Swamps, 18, 151, 154

Mangu natives, 130 ; M. station (Togo), 126

Manihot dicotama, 122, 123, 148 : M. Glazlooil, 122, 126 ; $M$; heptaphylla, 123, 124, 148 ; M. Pianhyensis, 123, 124,
148 ; M. utilissima, 47

Manja $R ., 418,419$

Mannia Africana, 85 Manniophyton Africa

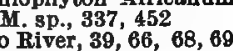

Mano River,

Mansu, 102

Manya River, 418

Manyu River, 418

Maradi, 210

Marantaces (Nigeria), 246; $\mathbf{M}$. (Togo), 128

Maremper, 25

Mareya spicata, 52

Marga (Hausa), 206

Margarine made from Palm Kernel Oil, 480; from Shea Butter Nuta, 153

Marike (Hausa), 92, 212, 223, 232 Marine sapplied with timber, 187 Markhamia Intea, 144, 441; M. tomentosa, 144, 401

Maro, 39

Marna, 190

Masche (Hausa), 132

Mat (Timani), 48

Match-box Bean, 298

Maticke (Ho), 146

Mauritius Hemp, 128

Mawelu (Bakwiri), 441

Mbafo, 432

Mbagboldede (Mendi), 54

Mbako (Bakwiri), 441

Mbana Oyop (Old Calabar), 466

Mbang (Attie), 84, 445, 446

Mbang (Attie), 84, 445,

Mbaraknn (Oban, Ekoi), 290

Mbarakun (Oban, 5

Mbauwi (Mendi),
Mbawe (Abe), 84

Mbomdi (Mendi), 46, 47

Mbomo-kuku (Eflk), 288 ; $M$.rku (Efrie) 232

Mbonda pondo (Balimdn), 442

Mbosse (Agni), 86

Mbosse (Agni), 86 (Attie), 88

M'boy (Mendi), 62

Mbrahu (Abe), 89

Mbu District and River, 417, $418,419,487$

Mbuandæ (Mendi), 62

Mclver, Messrs., Lagos Sawmill, 159

Mdayen (Mendi), 55

Measurements of planted trees (Olokemji Reserve), 183

Mebeli (Mendi), 55; M. dell, 48 ; $M$. or Mbeligni, 45 ,

Megabana (Trillesii), 103

Mekhi (Attie), 83

Melastomaceæ (Cameroons), 438 M. (Ivory Coast) $88 ; \mathrm{M}$. (Nigeria), 375: M. (Siertr Leone), 56

Melia Azedarach, 123, 135, 148, 191, 222, 331

Meliaceæ (Cameroons), 432, 442 , 445, 446 ; M. (Gold Coast),
M. (Lberia), 74 ; M. (N1geria), 191, 196, 211, 222 317,331 ; $\mathbf{M}$. (Sierra Leone), 49 ; M. (Togo) 135

Melianthaces (Gold Coast), 104 (Togo) 137

Memchin (Á ppolonian), 97

Meme (Dlstrict), 415; M. (River) 418,418

Memecylon macrodendron, 438 M. polyanthemos, 88 ; $M$ cf. $M$. spathulandra, $56 ; M$ sp. (near Barten), 375

Mendi or Mendis, 26, 28, 35 , 40 ; M. (Sierra Leone), 26

"Meni " oll, 358, 359, 459

Menispermacese (Nigeria), 193 259 ; $M$. (Sierra Leone), 43 Merremia, 194 ; M. umbellata. 197

Megua Ferrua, 176

Metchi (Attie), 83

Mfam (Ekoi), 228

Mfu River, 419, 487

Moua (Abe), 83

Michelia Champaca, 177

Microdesmis puberula, 52, 103, 336,419 ; M. sp., 230, 336, 452

Mijin kade (Hausa), 209

Mieishia (Appolonien) (Aowin), 94.

Milk-weed, 198

Miller Bros, Messrs., Koko Town Sawmill, 159

rillet (Bull-rush), 199, 204

rillettis attite, 133 ; $M$, of. drastica, 48 ; ir, LanePoolel, 48 ; M. pallens, 48 ;
M. rhodantha, 48 ; $M$. servicens, 203 ; M. 8p., 85 , 428 ; $\mathbf{M}$. $\mathrm{sp}$, near $\mathbf{M}$. gangana, 48, 197, 203, 417, 418 ; M. Thonningli, 99 , 283

Mimbo (Palm Wine), 425

Iimifia District, 430,431

Mímosa asperata, 191, 209; $\mathbf{M}$. Dinklagel, 48, 73

Mimosex (Nigeria) 301

Mímusops, 57, 78, 110, 197 ; M. djave, $57,110,179,229$, $370,376,378,416,419,420$, $438,445,446,455$; M. Egyptian, 210 ; M. elengi. $167 ; M$, Kergtingil, 141 . M. lacera, 67, 78, 141, 159, M. lacera, 67, 78, 141, 159, 378,456 ; $M$. multinervis, $186,228,375,456$; M. 8 . $28,29,57,438$

Minfiriya ( $\operatorname{ano}$ ), 221

Misahohe (Togo), 119, 125, 126, 142

(African), 259 ; M. (parasite), 170, 246

Mitragyne, 62 ; M. Africana, $145,192,202,214,225$, 406 ; M. inermis, 145 ; $M$. macrophylla, $89,113,145$, species, 146

Mixed Plantations, 124

Mo River, 415, 418

Mobo (District), 420, 425, 433, 438: Mobo River, 417 . M. Foto Mountains, 415,417 Mobonran (1jaw), 229

Mcus, $198^{\circ} \mathrm{M}$. Angolensis, 219 Mogbara (Yoruba), 278 ; M. (Ikale and Yoruba), 288

Mohammedan rosaries, 128 ; M. Teachers' use of Vitex, 60

Moigbwamy (Mendi), 43

Mo-Kamaa, Afforestation area, 120

Mokamu (Bakwiri), 430

Moko River, 415, 419
Mokongo or Momangi (Bakundu and Bakwiri), 425

Mowa (Bak wiri), 428

Molemóle (Tschandjo), 130

Mollugo, 194

Moloney, 290

Momangi, 445, 446

Momordica balsamina, 194

Mon (Attie), 84

Mondetu (Tschandjo), 138

Mondoa (Bekundu), 442

Monechms, 194

Monga (Balong), 435

Moniera, 194

Monkey Apple (Ansophylia laurins), 33,$55 ; M$. bread, 53, 223, 347; M. cola, 106, 210 , 355; M. Guava, 215, 384

Bonkwa Rock, 418

Monocotylendonons orders (Nigeria), 195, 197, 199

Monodora hrevipes, 96, 265, 457 ; $M$. myristica, 43, $72,84,427,457$; $M$. myristica, var. grandifolia, $264,265,457$

Monotes Keratingi, 139

Monrovis, 70, 73, 78

Moo River, 51

Moor Plantation, 241

Moraces (Cameroons), 425 - M. (Gold Coast), 94 ; M. (Ivory Cosst), 83; M. (Liberia), 70 ; M. (Nigeria), 193, 197, 199, 215, 218; M. (Sierra Leone), 42 ; M. (Togo), 128

Morelia (Senegalensis), 62, 192 , 214

Morinda Cltrifolla (The Brimstone), Sierra Leone, cut locally, $31,32,60,68,89$, $123,146,197,204,441$; $M$.' 123, 146, 61 . 'Ekiti Morinda, 405 : M. longiflora, 405 ; M. Juclda, 405 ; M. quadrangularis, 61 ; M. sp., 79,405

Moringa pterygosperma, 44, 219 ,

Moringaces (Nigeria), 219, 453

M. (Sierra Ieone), 44

Morto (River) , 39, 66, 68, 69

Morus Mesozygla, 83; M. sp., 250

Mosajc-work and Inlaying, 146

Mosangul (Attie), 87

Mosenge (Bakwiri), 433

Motandra Guineensis, 395

Mountain Ash, 811

Mousandua (Fanti), 94

Moyamba, 36

Moyida (Yoruba) 365

Mozambique, 211

Mpang (Bakoko and Basa), 443

Mpanjo (EAk), 277, 278

Mpot, 168

Mpuri (Oban, Ekol), 266

Mucuna pruriensis, 203 ; M. sp Prevssii, 299; M. urens, 299

Muea (Buea District), 436

Muell, 215

Muenge (Duala) 428

Mukonja, 418 ; M. (Duala), 498. 445

54

Mundulfa suberosa (Bentu), 303

Mungo River, 415, 419, 436

Mungongo (Duala), 435

Munon (Efk), 368

Muruchi, 216

Musa textilis, 128

Musace: (Toro), 128

Muganga, 358:" M. Smithi, 42. $70,83,95,129,159,233$, $252,418,410,420,426,485$ 488

Musk Tree, 411 
Muskat Nut, 72

Mussenda, 197, 203; M. erythrophylla, 407; M. Igertiana, 407 ; M. tenuiflora, 407

Mussake, 420

Myole Polie (Abe), 83

Myrianthus arboreus, 42, 83, 95 , $129,256,426$; $M$. serrstus, $129,256,426 ;$ M. serrstus,
$42,71,83$, g5, 129, 197, $42,71,83,95$,

Myristicacex (Uameroons), 427 ; (Gold Cosst), 96 ; (Ivory Coast), 84 ; (Liberia), 72 ; (Nigeria), 266 ; (Sierr Leone), 44 ; (Togo), 130

Myrh, 221

Myrsinaceæ (Cameroons), 438

Myrtaces (Gold Coast) 108 ; (Ivory Coest), 88 ; (Ĺiberia), 78: (Nigeria), 192, 197, 213, 78 ; (Nigeria), 192, 197, 213, $224,374,410$; (Sie
Leone), 56 ; (Togo), 140

$\mathrm{Na}$ (Attie), 86

Nagudi (Atakpame), 136

Nainvi (Bondoukou), 85

Nali (Mendi), 58

Namifin gwabsa, 210, 221 ; $N$. Kade (Hausa), 190, 232

Naparli (Mangu), 132

Napoleons Imperialis, 367 ; I. Owarlensig, 367 ; $N$. specklefruited, 367; N. Vogelii, $108,197,367$; N. Whit: fleldi, 367

Naprampogo (Dyakossi), 142

Narenga (Dagotnba), 143

Nassarawa, 200 ; N. Province, 300

Nassarli or Nabuli (Dyakossi),

Native Court Plantation, 180

Nayile (Konkomba), 136

Nbob (Moyen Cavally), 86

Ndambabuli (Mendi), 48

Ndat (Eik), 231

Ndau (Appolonian, Aowin), 93

Ndawi or Ndawei (Mendi), 43, 44 ; N. (Badgi), 44

Ndebere (Attie), 89

Ndeh, 19,168 ; N. people, 467

Ndeiwei (Mendi), 52

Ndian District, 415 ; N. River, 110

Ndonge (Bakwiri), 436

Ndototo (Bakwiri), 435

Ndukwun (Appolonian), 98

Negro Pepper, 219, 260 ; (N.P. gmall-flowering, 262

Negro Republic, 66

Nelsonia Campestrls, 184

Nephrodium Asplenium, 196

Nesuwa (Benin), 344

Nettle-tree, 218

Newbouldia lavis, $60,79,113$, $144,192,225$; N.L. com pared with Markhamia tomentoss, 144

New Calabar language, 185 : N.C. River, 151

News, Mr. F. D., Analysis, 482

Newtonia, 280 ; N. Insignis, 49 99 ; near' Newtonia, 290 : 99 ; near Newtonia

New Zealand Kauri Gum, 37

Ngitsa (Fontem or Bangwa), 427

Ngnanake (Abe), 86

Ngodua (Fanti), 107

Ngolo ngoloti (Abe), 86

N'golodulol (Mendi), 54

Trosame (Bakogi)

Ngua (Abe), 87; N. Abo (Attie), 87

Nguangua (Mendi), 52

Nguepe (Attie), 86

Nguni (Kabure), 134

Nguobi or Kusibiri (Attle), 88

Nhueí (Mendi), 53
Niagalei (Mendi), 55

Niam Fat, 358, 469

Niamidua (Twi), 11

Nianga (Agni), 83 ; N. Magui (English), 83 ; (Indenie), 83

Niankuma or Niangama (Fantl, Ashanti, Aowin, Appolonien) 95

Niger Delta, $152,185,189$; $N$. Estuary, 151; N. River, N. Province, 300

Nigeria, chapter viil ; Afforestation, 166-182; Amount of forest land, 17 ; Bugh Savannah, 201-202; Evergreen Fringing Belts, 203205 ; Forest Department. 184-188; Forest Exports 226 ; Imports of Timber. 226 ; Imports of Timber, 227 ; Indigenous Trees, Trees, 218-225; Mahogany or Tímber Industry, 155 160; Measurements of planted trees in Olokemaji Reserve, 183; Park Savannah, 202-203; Permanent Forests, 160-166; Review of the Botanical Features, 188-200; Rivers, Ports, and Forests, 151-154 Schedule of Protected Trees, 228-234; some trees or 67; Southern Provinces, chrpter ix, 493, 494, 495; Tree Bavannah or Sarannah Foregt, 200-201

\section{Nigerian Swamps, 19}

Nihau (Benin), 350

Ni-Kaftei (Mendi), 53

Nikko or Niko Nuts, 267, 268,

Nikll (Mendi), 52

Nimeribaka (Appolonian), 111

Nimmini Mountains, 25, 39, 58, 160

Nimwau Peso (Trchandjo), 137

Ningei (Mendi), 42

Ningo (Bambara), 87

Ntondobi (Bondoukou), 86

Nja (Efik), 272

Njabi, 445; N. (Duala), 438

Njahewe (Mendi), 43

Njakpe (Anlo), 145

Njakpokpo (Anecho), 145

jangsang (Duala), 433

Njasum (Ekoi), 229

Njelei (Mendi) 61

Njokmbore (Bakundu), 442

Njokubwele (Bakundu), 432

Njomboguli (Mendi), 49

Njondji (Bakwiri), 426; $N$. Bwele (Duala), 433

Njorgora (Oban, Ekoi), 336

Njove or Njole (Rio del Rey), 437

Nkiebe (Mbonol), 83

Nidissi River, 276

Nkohen (Ekol), 229

Nom (Bak08si), 438 ; 109 (Fanti). 109

Nkue (Attie) 87

Nkula (Gaboon), 258

Nla Ali Hills, 418

Noami River, 238

Nobe, 199

Non gwankJ, 219

Tormal type of Fringing Forests, 117

Notonima (Ashantl), 108

Nea-sana (Eflk), 451,452 ; Nas-sana kernels, 452

Nagb (Bain)

Nian (Ekoi), 228 ; (Oban, Ekoi), 253

Noukakara (Oban, Ekol), 338

Ntaba (Bambara), 87
AND * FORESTRY

Ntagne (Attie), 88

Ntini Nyok (Kwa), 361

Ntong (Fongtem and Bangwa), 425

Ntung (Fantl and Ashanti), 93

Nuatja, 117 ; N. Agricultural School, 122 ; N. Railway, 119

Nukoi (Mendi), 69

Nun River, 151,174

Nunu (fruit of Danys), 222

Nupé Canoes, 215

Nuso or Aru (Atakpame), 130

Nutmeg, 421, 427; N. African, 264, 457; N. Calabar, 457 ; N. Calabash, 265 ; N. yellow flowering, 265,457

Notasunutsau (Anago), 138

Nuwo (Ekol), 231

Nuxia Mannil, 440

Nya (Eflk), 288

Nyakpekpe (Ewe), 145

Nyam (Efk), 376

Nyama (Mangu), 183

Nyankon, Yankom or Yankun (General West Coast), 106

Nyimo (Atakpame), 146

Nyimu (Mangu), 134

Nyd-nu-Robin (General West Coast), 105

Nrmphrea, 193

Nympheaces (Nigeria), 193

Nyomdobai (Mendi), 53

Nyumbuyambel (Mendi), 62

Oaho (Benin), 37, 413

Oak (Bush O.), 416 ; 0 . (Dry Zone), 379, 394, 422,423 o. 'Tree (Yoruba), 258

Obadan-nik od (Benin), 251,407

Obagle Forest, 160, 166, 339, 407

Obala (Atakpame), 130

Oban Hills, 17, 152; O. Hill Forests, 19, 164, 159 ; 0 . natives, $378 ; 0$. Reserve, $160,168,362,375,392$. $399,450,456,497$

Obang (Bafo), 425

Obba on the Fill (Ondo Province), 400

Obbo (Akposso), 140

Obeche or Obechi, 153, 159, 230. 351

Obl (Yoruba), 321 ; 0. Abata,

Obiache (Benin), 159, 228, 402 , 404, 405

Obidu (Yoruba), $\mathbf{8 5 5}$

Obiedum or Obiedun (Yorubs), 355

Obiletu (Eflk), 230

Obiliteto (Eflk), 386

Obo (Oban, Ekoi) 818

Oboba or Obobo (Yoruba). (51

Obobonikwi (Benin), 228, 928

Obobonufwa (Bentn), 328, 329

Obokha (Benin), 346

Obon (Oban, Ekol), 318

Obong (Efik), 233

Obuba (New Calabar), 281

Obuban (Benin), 899

Obubra Forest, 19, 177, 239 $273,274,307,350,472$

Obudu District, 356, 365, 407. 472

Obuko (Yoruba), 312

Oburuburu (Yorubs), 349

Ochna Afzeli, $139 ; 0$. multiflora, 233,$356 ; 0$. 3 . 64, 856 (new gp.), 190 chnacen (Sierra Leone), 54 (Llberia) 77 ; (Ivory Coast) (Lloeria, 107 87; (Gold Const), 107 ; (Togo), 189; (Nigeria), 190, roons), 436 
Ochrocarpus Africanus, 29, 33, | Oginyi (Benin), 275 $55,88,159,363,462$

Ochthocosmus Africanum, 40

Ocimum, 195 ; 0 . Americanum. $195 ; 0$. viride, 400

Ocinotis gracilis, 396

Ocotea, of. 266

Octodon, 192

Octoknema affinis, 84

Octoknemacem (Ivory Coast), 84

Odahuma (Wassaw), 97

Odala (Ibo), 228

Odan (Yoruba), 309 Ode District, $308,354,357,361$,

Odenya (Wassaw), 97

Odgebu (West side), 362

Odilki, 445, 446

Odina acida 76 ; O. Barteri, 212 , 222 ; 0. sp., 52, 104,

Odji (Agaba), 253 ; (Brags), 233,359 ; (Ibo), 228, 253

Odjiwawa (Ibo), 231

Odo (Jekri), 368

Odoko (Yoruba), 232

Odonomo-kyu-kyu (Benin), 229

Odonumon (Eflr) 397

Odoum or Odum (Appolonian), 83 ; (Asante), 128 ; (Haus8),

215; (ITi), 95

Odu (Yoruba), 308

Odubin (Ashanti), 101

Odudu (Ondo), 230

Oduduku (Atakpame), 138

Odupon (Fanti), 101

Odyendes Grbumensis, 432

Ecological Division of Forest6 (after Warming), 18

Ofarm (Ashanti), 98

Ofemm (Bembi) 390

Offenma (Ashanti), 103

Offonkwari (Ibo, Asaba), 392

Offram (Twi, Fanti), 109

Ofiun (Lagos), 247

Ofka (Timani), 42

Ofriyio (Eflk), 253

Ofu or Ohonton (Franti), 95

Ofun (Yorube), 234

Ofuntum (Appolonian), 89

Ofwho (Quitts, K repl) 105

Ogaba (Benjn), 288, 289, 449

Ogabeszi (Benin), 289

Ogabezzi (Benin), 285

Ogabi, 365

Ogan or Ogun River, 152, 169. $170,174,252,272,276$, 322, 334

Ogan or Okan (Yoruba), 373 ; O. oga (Yornba), 298; pupa (Yorubs), 230, 372, 373,383

Ogangan (Benin), 335, 336

Oganwo (Yoruba), 177; or Ogangwo, 229, 319, 321; Oganwo or Oganwu (Bentn), $177,318,319$

Ogba Forest, 160 ; O. Flantations, 166, 176, 177; 0 . Province, 271; O. River,

Ogbamaton (Benin), 336

Ogbia (Yoruba), 360

Ogbogo nut, 463

Ogbun (Lagos), 397

Ogea (Yoruba), 278

Ogeddin (Benin), 243

Ogedin, 466

Ogege (Benin), 328

Ogege (Benin), 328

Ogi (Calabar District), 399

Ogiahimi (Benin), 400

Ogidu (Yoruba), 348

Ogiedi (Benin), 243

Ogigedu (Benin), 321

Ogihu (Benin), 245

O Gikan (Benin) 328

Orikiomi (Benin), 285

Oginni or Inyi (Yoruba), 449

Kombo seed, 458
Ogiovala (Benin), 330

Ogiovu (Benin), 249

go (Akposso), 140 ; (Yoruba), 295 ; O. Province, Nigeria, 252

Ogodo Dry Zone Forest, 39

Ogohen (Benin), 159, 252

Ogohomeh or Oyohomeh (Benin), 365

Ogoja, 19, 287, 239, 240, 243, $244,247,249,251,252,255$, $257,258,259,262,263,266$, $270,273,275,277,278,279$, $281,283,284,289,291,294$, $297,298,299,301,303,305$, $306,309,312,317,322,324$, $337,340,343,344,345,346$, $350,354,355,357,358,362$ $363,365,369,379,381,382$, $383,390,396,397,400,401$, $402,404,405,406,407,408$, 413

Ograw (Yoruba), 252

grugru Province, 322; 0 . (Yoruba), 349 Ogu (Anago), $138 ; 0$. District,

Ogudugbu (Yoruba), 390

Ogugu (Yoruba), 232, 349, 389

Oguja (Yoruba), 278

Oguk (Oban, Ekoi), 390

Ogungun (Yoruba), 349

Ogunghileh, 159

Ogurohe (Yoruba), 299

Oguru (Brass), 266

Ogwangu (Benin), 321

Ogwega (Benin), 306

Ogwi Tree (Benin), 312

Oha (River), 203

Ohau (Benin), 251

Ohehe (Benin), 301

Ohia (Benin), 246, 247, 388

Ohianamemme (Benin), 246

Ohiomo of the Benis, 230

Ohiorme (Benin), 233, 289

Ofe (Yoruba), 311

Oil and Colours Journal, 482

Oil Bean tree, 45, 73, 97, 178 , 380,416 ; Beans, 68, 308, 804

Ofl Beans, seeds and nuts, chap. $x i, 447-463$; Analysis of-

Ben ofl seed cake, 453

Betu oil, 454

Carapa Guineensis, 458

"Chevi " seeds, 462

Citrullus vulgaris, 453

Dumoria Heckeli, 456

"Gorli" "seeds, 463

Inoy nut, 450

Irvingia Barteri, 454

Lophira alata, 459-460

Lophira procera, 460-461

Meal after extraction of oil, 448,450

Mimusops Djave, 456

Moringa pterygosperma, 453

Toa-gans kernels, 452

Oll after extraction of meal 448

Oil from South Nigeria Beeds, 448

Shea butter, 455

Oil Ben tree, 453

Oil Investigations by the Imperial Institute, 448,463

Oil Nuts, 69, 163, 165

Oil, Seed and Feeding Cakes, by the Imperial Institute, 484

Ojamba (Ashanti), 95

Ojia (Yoruba), 230

Oju Agdigbo (Yoruba), 343

Okagbo (Yoruba), 348

Okahimi (Benin), 388

Okakan, 163
Okan (Benin), 229, 286

Okankan, 240

Okare (Yoruba), 337

Okarora ossa (Undo), 361

Oke-Igbo (Ilesha District), 395

Okenuhen District, 240

Okha (Benin), 231, 345, 346

Okherll (geed) (Benin), 179, 230, 312

Okika (Yoruba), 339

Okikopom (Ibibio), $\mathbf{3 5 7}$

Okilolo (Ijor), 232

Okisibisi (Fanti), 114

Okitsiwanfu (Fanti), 94

Okkwan (Benin), 277

Okkwen (Benin), 332; 0. nebo (Benin), 333

Oko (Ibo, Owerri), 266 : (Yorubs), 409; 0 . Ishin

Okoko (Benin), 348, 349

Okokotaka (Asante), 139

Okokwi (Benin), 400

Okokwo (Benin), 349

Okoni (Kratschi), 143

Okor (Benin), 310

Okot or Okut (Oban, Ekoi,

$$
\mathbf{K w a )}, \mathbf{3 5 7}, \mathbf{3 6 3}
$$

Okoume, 422

Okporoporo (Akure), 349

Okra or Achro (fruit), $\mathbf{3 4 4}$

Okrika Port, 152

Oktobun District, 463

Okume d'Ivoíre (Colons), 85

Okurime, 446

Okumu Forest, 160

Okun (Yoruba), 240

Okunmankra (F'anti), 101

Olcurif (Ashanti), 100

Okuta (Yoruba, Benin), 413

Oknturupu (Yorubs), 332

Okwaba (Benin), 412

Olwan (Yoruba), 449

Okwawa hill system, 112

Okwe (Benin), 335, 452

Okwekwe (Benin), 299, 400

Okwen (Benin), 231; O. seni (Benin), 393; 0 . seva (Benin)' 332

Okwo River, 282,488

Okwoga Plantation, 167

Olacacere (Sierra Leone), 43 (Lberia), 71 ; (Ivory Cosst), 83 ; (Gold Coast), 95 ; (Togo), 129 ; (Nigeria), 191, 257 , 456 ; (Cameroons), 426

Olax, 43; O. subscorpoides, 95

Oldenlandia, 192; O. Grandi202

Oldfleldia Africana, 26, 51, 67, $75,86,342 ; 0$. (imported as Teak), 75

Oleaces (Ivory Coast), 88 ; (Gold Coast), 110; (Togo), Olein, 48

Oleporo Iyop (Calabar), 466

Oli (Atakpame), 136

Olibracha (Egba, Yoruba), 283

Olikiba (Benin), 407

Olim, 445

Olina, 446

Oliver, Daniel, 496

Ollo (Akposso), 127
Olodu (Yorube), 244

Olodu (Yoruba), 244 ba), 301

Ologun She-ghe (Yoruba), 301 Reserves, etc.) (oke =hill, meji=two), 19, 123, 160, $166,168,169,170,171,174$, $175,177,179,185,245,246$. $175,177,178,185,245,246$ $256,260,264,266,270,278$, $302,306,307,310,312,331$ $334, \mathbf{8 5 9}, \mathbf{3 6 5}, 367, \mathbf{3 7 0}, 371$,
$372,374,375,382,387,395$, $306,464,490$

Olong, 445,446

Olosan (Yoruba), 229 
Oluwa (Benin), 244

Omah (Benin), 396

Omar (Yoruba), 348

Ombega, 422

Ome (Benin) 372

Omo (Yoruba), 230, 306

Omocham (Benin), 266

Omoin (Egba), 246

Omomeran (Benin), 336

Omon (Yoruba), 396

Omphalocarpum, 78 ; 0 . elatum, 456; O. Pierreanum, 439 ; 0 .' procerum, 379 ; O. Radlkoferi, 439 ; 0 . 8p., 109

Omnnu or Onumu (Benln), 258 , s14; O. kynkyu (Bentn),

Omunu (Yoruba), 348

Ona River, 152

Onamagugun, onomagungur. orimagugu, or oriwenl (Yoruba), 409

Onanisankianmon (Benin), 391

Oncoba dentata, 108, 366; 0 . echinata, 108, 462; 0 . 366 ; 0 . spinose, 139, 196, 204 ; 223,366

Ondo (Ćircle, Forest, Province, and Reserve), 19, 152, 154, $160,170,180,235,236,240$, 247. 249, 250, 251, 252, 256, $257,258,259,260,263,266$, $268,269,271,273,275,277$, $278,279,282,284,286,287$, $291,301,302,305,308,310$, $312,313,317,318,321,324$, $325,327,329,330,336,340$, $342,346,351,355,356,362$, $365,369,379,381,382,383$, $390,396,397,400,401,402$, $404,405,406,407,408$

Odutu (Trehandjo), 13

Onegozi (Benin), 344

Ongokea Kamerunensis, 416 , 417,$426 ; 0$. Klaineana, 83 Ongina (Twi), 105

Oni River, 152, 160

Onihokhs (tree in flower) (Benln), 848

Ontikokha (Benin), 346

Onion, 19

Onitsha Province, 153, 154, 173 , $174,244,251,252,255,270$, $275,276,279,284,297,301$, $303,305,308,309,349,353$, $358,398,400,401,409,472$, 473

Onitsha-olona District, 353

Onomokyukyu (Benin), 228, 323

Onuru (Tbo, Owerri), 290

Onyaneba (Atakname), 136

Onye (Benin), 334

Onyemo (Benin), 332

Onvena (Fanti), 105

Onyenu (Benin), 339

Onyina (Fanti), 105

Oohoo (Benin), 386

Opaga (Bentn), 178

Opagra (Benin), 303

Opagra (Benen),

Opahan (Benin), 413

Opaina (Fanti), 111 (Twi, Akwaplm), 97

Opapro (Twi, Akwapim)

Opati (Atakpame), 140 246 ; 0

Ifu No. I (Yoruba), 243:

o. Igbo (Benin), 245; 0 . trumto (Yorubo), 248

Opele, 247, 248 : (Yoruba), 388

open Deniduouq Forest, 18

Onen Decidunua Forest, 18

Open Orchard Forest, 18 ; (Yoruba), 228, 369, 402, 404; O.-ira (Yornba), 231, 349; 405

Openera (Yomba), 4n5

Opilja celtidifolia, 191
Ophloglossum vulgatum, 196 Opobo (Nigeria), 481; O. Port, Opochala (Ibo Niger), 303

Opon (Yoruba), 231

Oporipor (Benin), 348

Opoto (Yoruba), 251

Opputtu (Benin), 250

Ora-Igbo (Yoruba), 34

Orange (Colabash), 312 ; 0 . (common), 74, 124

Orban-igba (Yoruba), 383

Orchards (Togo), 124

Orchid, 195, 264

Orchidaces (Nigeria), 195, 246

Ordeal bark, 275, 276 ; 0 . tree, 98

Oregbon I (Yoruba), 250

Orella, 445, 446

Ori (Bentn), 297 ; O. (Oban Ekoi), 235 ; O. (Yoruba) 398 ; O-eta (Yoruba), 809 O.-nla (Yoruba), 398

Orla (Benin), 266; O. Plantations, 168

Oriakuku (Benin), 390

Oriri Ogiktomi (Benin), 398

Orisi (Igbado, Yoruba), 313

Oriweni (Benin), 389

Oriwu (Benin), 409

Orli (Anago), 143

Ormocarpum bibracteatum, 191

Ormosia laxiflora, 99, 117, 123 $133,232,234,270,297,308$,

Oro (Brags) 233,252 ; 249: (Yoruba), 179, 230, 231, 312, 343 ; O.-Igbo,

Oroba (Mbonoi), 86

Orodo (Benin), 291 ; (Brass) 349 ; O. or Orodu (Yoruba), 347

Orogbo or Oragbo (Yoruba), 358

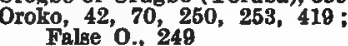

Orokpo (Anago), 132

Orokwa (Benin), $\mathbf{3 6 7}$

Oron Port, 152

Oropa of the Yortibas, 232

Orora (Yoruba), 400

Orrimogungun (Benin), 389

Orro (Yorubs), 322

Orsorsor (Benin), 372

Orupe (Yoruba), 336

ruru (Benin), 414; (Yoruba), 400

Oruwo (Yoruba), 405

Oryza silvestris, 199

Osan (Yoruba), 232; O. odo (Yoruba), 383

Osangbalumo or Osum Agbalum (Yoruba), 981, 882; 0 . Edan (Yoruba), 381; Osbeckia, 194

Ose (Yoruba), 347

Oshen or Oshun RIver, 152, 357 Oshere (Yoruba), 366

Osho (II.), 286

Oshopoto Dudn (Yoruba), 344

Oshoshi (Tbo, Owerri), 290

Oghnn Reserve, 160,839

Oshung (Yoruba), 392

Oshusl (Tbo, Owerri), 364

Osta, 307

Osisiru (Ashanti), 113

Ositwa (Benin), 288

Osas (Ondo), 361

Osse River, 154, 166, 288, 241, 378, 398

Osghohs (Tbo, Asabn), 284

Ossidinge Dlstrict, 425, 482, 435

Ossiomo River, 156, 298

Oseizza Factory, 278

Ossusu (Yoruba), 288

Ostryoderris impressa, 277, 297, 894, 429

Osu (Benin), 394
Osuabise (Akwapim), 102

Osualong (seed) (Benin), 400

Osukaregigi (Benin), 400

Osun (Yoruba), 178, 229, 273 ;

o. dudu (Yoruba), 273 ; O. pupa (Yoruba), 273

Otanta (Ibo, Asaba), 392

Ote (Twi), 86; 0. Oti or Etsu (Accra, Ashanti, Fanti), 96

Otendui (Fanti), 110

Oti Steppe, 131; Valley (Togo), 118

Otien (Benin), 381

Otopol (Ibo, Agaba), 892

Otta farfridi (Ibo, Asaba), 392

Ottelia lancifolia, 195

ottoa (Benin Province), 392

Otugba (Akposso), 139

Otun (Oban, Ekol), 363

Otungue (Jaunde) 442

Otutu (Jebu), 347; 0 , of the Yorubas, 230

Otwa (Benin), 287

Oubangula Klainet, 436

Oukot (Efik), 296

Oukoumea Klaineana, 422, 424, $425,445,446$

Ouratea monticola, 437

Ovalla (Benin), 330

Ovia River, 272, 321

Oviaruza (Benin), 335

Ovieglkwe (Benin), 851

Ovinni (Benin), 276

Ovioza (Benin), 331

Ova (Benin), 250

Owala Beans, 447; O. (Gabonais), 85 ; 0 . oli, 429

Owama (Ashanti), 102

Owango, 445, 446

Owawa (Wassaw), 100

Owawe or Owowe (Benln), 365

Owe (Benin), 288

Owehe (Benin), 412

Owena Reserve, 160; 0 . River, $152,154,156,321$

Owerri, 158, 178, 236, 240, 247, $249,251,252,257,259,268$, $279,281,282,284,286,287$. $288,291,294,301,303,304$, $308,313,317,322,327,338$, 342, 346, 349, 354, 355, 356, 857, 958, 361, 362, 363, 368, 371, 376, $\mathbf{3 8 1}, \mathbf{3 9 0}, \mathbf{3 9 6}, \mathbf{3 9 7}$, $398,400,401,405,447,450$, $466,472,473,493$

Owessu (Brass), 228

Owewe (Benin), 294 ; 0. lagebon (Benin), 285: 0 : nolemare (Benin), 294, 295 Owi (Benin), 411

Owun (Yoruba), 948

Opussu, 158

Oxyanthus speciosus, 62, 441; O. tublfiorus, 114; 0 . anilocularts. 62, 197

Ox-eye Bean, 298

Oxystelma Bornmense, 199

Oxystimma Mannil, 428

Oxytenanthera Abyssinica, 127 , 196,218

Oran River, 302

Oyen (Benin), 384, 397

Oylfe (Yorubs) $\mathbf{3 1 7}$

Oyo, $19,152,158,154,262,266$, $273,283,284,298,299,300$, $901,325,947,355,372,373$, 374, 375, 379, 383, 392, 395, $398,452,493 ; 0$. Iseyin Rond, 170, 322

Oyon Rlver, 399

Ozaba, 307

Oxla (Benin), 230; O. Beans,

Pachvlobus edulli, 293, 314, 315, 432 : $P$. var., 432; $P$. Tenkeri, 4.32

Pachypodanthium, 84; $\quad$ P. staudtil, 44 
Pachystela Cinereum, 383; P.|Palm-continued. Parkdi, 141

Padauk or Padouk, 31 ; $P$. African, 273 ; $\mathbf{P}$. Ediblefruited, 272; P. Indian, 178

Paddlewood, 263, 417

Padiivin (Difale), 129

Pakie-pakie (Agni), 88

Palambanja (Dusia), 443

Paletuvier rouge (Colons), 88

Pallme Station (Togo), 119

Palisota hirsuts, 425; $\mathbf{P}$. thyrsiflors, 197

Palisgya Cordata, 336

Palm Arac, 244; P. Belt (according to Millbourne), cording to Run Palm or 465; Black Run Palm or Palmyra, 244; $\mathbf{P}$ : Bottie or Toddy, 244, $459 ; \underset{479 ;}{\mathbf{P}}$ Coconut, 218, 237, 244, 421 ; P. Date, 124, 125, 210, 217, 240, 459 ; Swampy Date, 239 ; Wild Date, 240 ; P. Deleb, 41, 200, 216, 217 2is : $P, 204,200,216$, 218 ; P. Dam, 94, 200, 216 , Everlasting Life or King Palm, 241, 242, 466 ; $P$ Fan, 244, 459 : P. Forked, $244 ; P$. Fruit Industry 92 ; P.F.I. Cultivation, 21, $22,26,41$; P.F.I. Lberia 68, 70, 'P' Frokerg, 235; P. Kernels, 63, 90, 150, 226 444, 479 ; P.K. Cake. 226 P.K. Oil, 226 ; P.K. Shells $226: P$. Iisomhe or Softchelled. 243. 466, 467; $P$ Methnd of Fxtraction, 38 ; P. Oil export, 35 ; (Gambia), 2i ; (Fold Const), 115; (Ivory Cnast), 99 : (Sierta Leone). 63, 64; (Liberia) 80 ; (Nigeria), 226 : P.O. Plantations (Toqo). 116, 117 118, 149 : P.O. Nnrserjes. $121,123,124,125,126,153$, 197, 218, 228, 235, 237, 240 $241,242,418,420,425,444$ 447, 464: P.O. Fmalt, 243 ; (Sacred Oll Palm). 243, 244. A21: P.O. White, 4A6: The oil Palm and Palm Industry, chapter xil, 464484

1. Ffathetic Agnect, 464

2. Botanical Descrintion of Tree, Froit, etc., 465

3. The firnwing of the Oil Palm. 467

4. Fruit--Rearing Ace, 468

5. Oil Palm Plantations and

6. Destruction of Oil Palms, 479

7. Native Method of Making Oil and Kernel Inspection, 473

8. Amount of Produce rised eaten. and growing, 476

9. Furonean Machinery for extraction (Pericarning), 477

10. Furonean nnt-cracking, 477

11. Furnmegn naas of the nil, Kernels, Palm Wine, etc. 479

12. Value of Oil and Kernels, $4 \times 0$

13. Import, Ports in Fingland and T.S.A. for Oll and And O.S.A.

14. The Crushing of Palm Kempla in Africa and Fincland, 480

15. Palm-Kernel Produce, Analvais, etc... 481

16 and 77. Value ne PalmKernol Oil and Cake, 482

Palmine, Cape,
17. Uses of Palm-Kernel Cake, 482

18. Results of Feeding Experiments with Palm-Kernel Cake, 482

19. Manurinl Value of Kernel Cake, 484

20. West African Shlpping in Relation to Farm Produce 48

21. Blbliography of the Oll Palm, 484

Palm, Paímyra, or Black Ru 244 ; P. Plagsawa, 235 ; $\mathbf{P}$. Roofing, 239; P. Rózal 237 ; P. Sacred, 243 . 244, 466 : P. Swamp, 425 . $\mathbf{P}$ ' Tombo, 234, 236, 237, 244. 464; $\mathbf{P}$. Vegetable Ivory, 421 ; $P$. West African 241: P. Wine Tree (Raphia Vinifera), 38, 179, 216, 218, $236,244,425,464,470$

Palma (Sierra Ieone) (Liberia), 70 ; (Ivory Coast), 83 ; (Gold Coast), 93 : (Togo), 127 ; (Nigeria), 195, $216,218,235,447,459$; Pal (Cameroons), 425

Palmwood, 445, 446

Palmyra," 216, 218, 244

Pambel (Mendi). 41

Panama hat fibre, 124 : Palms, 124

Pancratim trianthum, 19

Pandacea (Ivory Cosgt), 85

Pandanacee (Slerra Leone), 41 ; (Liberja), 74 ; (Ivory Coast), 83 ; (Gold Const), 93:

Pandanus Candelabrum, 41, 74, 83, 308: P. Tibre, 234: $\mathbf{P}$. Kerstingli, 127 ; $\mathbf{P}$. snecles 93: P. enecies near CandeJabrum, 41 ; $\mathbf{P}$. Togoensis, 127

Pandoro (Yoruba). 400

Pancalan (TBchandjo). 130

Pangbaingu (Tschandjo), 137

Pangl (Mangn), 131

Panruma Hills, 25

Panlcum atagninmm, 199

Panyero (Trchandto), 143 ; PanJernbida, 143
pac (Fwe), 132

Papac (Fiwe), 132
Papala (Ynruba), 323

Papao (Aghanti), or

Papan (Asante), 132

Papaveracen (Nigerfa), 193

Panilionacea (Nigaria), 301

Para, 123 ; P. Rubber, 126, 180, 420

Para Dakne (Attie), 8 r

aradanlella, 169 : P. Olivert, 19. 190. 191. 202, 203. 205, 220, 231. 307: P. (T nqewood) 98, 117, 119, 123, J33. 191.202: P. Thurifera, 33, 44, 97, 117, 132

Paradedi (At.tíe), 87

Paran (Yoruha), 297

Paranara (Trachandjo). 139

Parasolier (Cnlona), 8:

Parinarium, 19.67, 22, 233, 418 ; P. Chrvannhvllum, 428 ; $192,201,213,219,269$ : P. excelgum, 83, 44, 60, 72, $2 A R: P$. Gabnnenne, $2 A 9$. 459 ; P. Intermedia, 14R: $P$. Kerstinol, $180 ; \quad P$ ' macronhollum. 44, 72, 192, 199. 213. 219, 232: P. mobnla, 96, 932: P. nnlyan269 : P. Robustum, 84, 96,
267,268 ; $\mathbf{P}$, species, 266 ; P. species (Red Mahogany) 267 ; (small), 428 ; (White Oak), 72, $96:$ : ' (Wite datum, 130, 197, 204; $\mathbf{P}$ tenuifolium, 84

Parkia Africana, 45, 117, 123 131 ; $P$. Agbcensis, 85; P. biglobosa, 45, 132, 230 , 231,$282 ; \mathbf{P}$. flicicoides, 45, $79,97,120,126,131,191$ $202,207,220,230$, 231, 283': P.' species, 45 ; $\mathbf{P}$ Zenkeri, 420

Parkinsonia aculeata, 198, 221

Parrots, need carriers, 251, 252

Partridge wood, 134

Pasau (Trchandjo), 145

Patabua (Bondoukon), 83

Patakli (Atakpame), 128

Patapara (Agni), 84

Pato (Tschandjo) 131

Pattern Wood, 390, 419

Patti Forest, 202

Pau (Twi), 111

Paulal (Mendi), 26, 51, 67

Paullinia pinnata, 104, 191

Pausynistalia Lane-Poolei, 61 ; P. Bpecies, 230, 405

Pauwili, 67

Pavetta Baconia, 61, 146, 407 P. Barteri, 192 ; P. Crassipes, 146

Pavonia schimneriana. 495

Pawi Kpaoloe (Mendi), 51

Pe (Abe) 88

Peach (blossom compared with Stereospermmm Kunthia. mam), 145, 401 ; P. (Sierr Leone), 62.79, 214

Pear, native (Oban), 314, 315 ; $P$. Tree, 445, 446; $P$. Wood, 416, 419

Pebulal (Mendi), 62

Pechi (Attie), 89

Pedaliaces (Nlgerla). 194

Pegblagei (MendI), 6

Pekire (Losso). 130

Peltoforam, 46, 49 ; P. spectes, 97

Penpisetum. 196 : P. pedicelatum, 201 ; P.typhoideam. 109,204

Pentaclethra Macrophylla, 45 68, 79, 85, 96, 119, J68 $178,231,303,380,416,417$

Pentadesma, 77 ; P. Brty rarex, 55, 69.' 107, 232, 361 362. 963. 437,461: $\mathbf{P}$ Grandifolin, R6j ; P. Ker. atingli, 118, 123, 139: $P$ Leucanthe, 88: $\mathbf{P}$. Nieri$\tan { }^{3}, 362: P$ minecjes, 360

Perequn (Yoruba), 245

Perene (Kobnre), 129

Permilaria tomentosa, 199

Perl (Timnnj). 52

Peristrophe bicalymlata. 194

ermanent cultivatior. Fncland, Termany. South Provinces, Nigerin, 495

Permita for Tree-cutting (Togo) 119

Persian Tillac, 222, 331

Pesin (Attie), R9

Peso (Tschandjo), 127

Petwon, 17f

Pencedanim araliamanm, var. fraxinifniliam. 140

Penkwp (Twi). 101

Prandi (Mendi), 46

Pfandiv station (Togo), 118 . 119

Plul (Mendi), 49 ; P. II (Mendi).

Phlalndiscus specjes, 341, 34\% 455: $P$. Unljneatrs, 53 . 104 ; P. Zambesiacus, 434 
Phonix Dactylifera, 148, 217, $4 a y$; 1 . Kecunata, $\forall 4,1 \% 7$, $23 y, 420$; r. suecies, 418 ; r. spuosa, 127,240

Phrynium, 4 sis

Phucophyuum mirabile, 430

Phylantaus Niscoldeus, $5 z, 135$ 434 ; 5 ; sloripundus, 193 2424; 5. Keticulatus, 103

Phyliocosmus Amcanus, 85 ; r. sessullorus, $4 x 1$

Physalis, 1y4

Yhysic nut, 193

Fhysostigma venosum, 298, 450 tramplan (t'antl), of

rianro (Agni), 87

riassava uore, 38; Cameroons, 425; bixported, Dlerra Leone, 63; Gold Loast, y3; Ivory Coast, yu ; Liberia,
$6 \&, 10$, 80 ; Nigeria, 234 , 230, "2uy ; '́logo, 150

Piche Anoko (Atte),

ricralima tilliotil, $8 \forall ; P$. Kloineana, 346

Pierreodendron Grandifolium, $43 \%$

Pigeons, meed carriers, 251, 252 Hya (Wassaw), (H'antı), 107 Heapple, 127

Yink vahogany, 304

Hinus Mercusil, 175

Pio (Duala), 455

Piper Umbeilatum, 197

Piperacea (Nigerra), 197

Piperomia reutcias 197

Piptadenia Airicana, 45, 68, 73, $75,97,119,131,197,229$ $279,286,245,417,414,428$ r. compared with Airican Greenheart, 48 ; 4 . Chevalieri, 85 ; $\%$; Kerstingi, $123,131,295 ; Y$. spectes $46 ; Y$. Winkleri, 428

Pitchong (Ossidinge), 4:27

Pithecolobium Aitimejimum, 97 290,450 ; 5. Dutcis, 122 . 148

Placodiscus Psendostipularis, 87

Plantains as Charms, 258

Plantations (Nigeria), 180-184 (1og0), 121

Planting schemes (Togo), 121

Fiatycerium Athiopicum, 179

Platysepalum, 428

Platythyrsa, 396

Plectronia Glabriflora, 441 ; $P$. Vanguerioides, 146

Pleiocarpa Tricarpella, 50

Heioceras Afzelii, 59 ; $\boldsymbol{P}$. Bar teri, 396

Plekkogo (Benin), 323

Plenisceras Barteri, 197

Plum Abeokuta, 366; P. Blood 'P. Common, 52, 269; $\boldsymbol{P}$ Hog, Jamaica, Spanish, or Yellow, 52, 103, 225, 232, 338 ; 'P. Mirabel, 338 ; $\mathbf{P}$. Niger, 366

Poana-toana, 445, 446

Poga Conofora, 437; P. Oleosa $229,368,416,437,450$

Poinciana drepanophylla, 148 ; $\boldsymbol{H}$. Regia, 123, 125, 148

Polu-Dyenye (Mangu), 184

Polyadoa Eillotli, 58; P. Um. bellata, 112, 232, 394, 424, 490

Polyalthia Olverii, 71

Polycarpaea, 193

Polygala arenaria, 191,$332 ; \mathbf{P}$. butyraces, 197, 462; $\mathbf{P}$. Clarkeana, 197

Polygalacem (Sierra Leone), 50 . (Togo), 135 ; (Nigeria), 191, $197,332,462$

Polysphæria Macrostyla, 204
Polystachys Odorata (Mistletoeuke rarasite), 170,$246 ; \boldsymbol{r}$. species, 246

Polystemonanthus Dinklagel, 74 Ponamagoi (wendi), ou

Pondel (Mendi), $6 \%$

rongol-nei, Yongot-hini (Mendi), 58

Ponhon (Yorubs), 358

Ponpola or Yonponia (Ibandan, Yoruba), 346

Pontya kxeelsa, y3

Foor man's candle, 50

Poose (bakuncu), 435

Poplar, 77

Poposi (Mbonoi), (Ebrie), 86

Fopowia Manni, 146, ¿68; $P$. Whyteil, 71

Porcupine, $\$ 17$

Forepore (Abe), 87

Yoroporo (Yoruba), 353

Yorpnyxanthus 'Kenkeri, 85

Fort Harcourt, $15 \%$

Yotato, sweet, 204 Yotedon (Appolonian, Asbantl,
I'anti, Wasaw), y8

Potepote (Kratschi), 130

royndus (f'anti), dy

HTin, Lt.-Col. D. Director of the Royal Botanic Gardens, Kew, 440

Pranpran ('r'snti), 84

rrekese (kwe), 131

Yremna Hispida, 60 ; P. Zenkeri, 143

Prevostea Africana, 112; $P$. Heudelotii, 112

Pride of India, $2 \% 2$

Propri (T'imani), 53 $202,207,240,233$, 30j

Protea, 191 ; พ. Bismarchi, 129 Proteaces ('́ogo), 124; (Nigeria), 191, 207

Protenceous 'Trees, 55

Frotected Trees of Nigeris, List of Classes with Koyalties, of

Preudocedrela, 50, 75, 117, 119, 422; 1 . Cylindrics, 101 : P. Kotsehyil, 101, 117, 123, P. Kotsehyil, 101, 117, 123,
$185,177,191,202,211,222$, $230,232,345 ; \quad$. 28,$101 ;$ P. species near P. Utilis, 50 ; $\mathbf{Y}$. Utilis, 101

Pseudooinchona Átricana, 89

Pseudospondias Microcarpa, 104, $136,339,434$

Psidium Guajava, 78, 109

Psilanthus Ebracteolus, 61

Psorospermum, 107; $\mathbf{P}$. Senegalense, 190, 201, 202

Pteleopsis, 109; P. Kerstingil, 140

Pterocarpus, 273, 445, 446; $P$. Hrinaceus, $20,30,46,98$, $206,221,231,234,273$; P Lisculentus, 46, 85, 98, 139 , $197,210,220,238,272$; . Indicus, 178 ; P. Osum, 229 274, 275, 811 ; $P$. Satalinoldes, 417; $P$. Soyauri oldes, 417 ; 7 . Soyauxi, $158,275,417,418,424,425$ Camwood), 273, 311, 416 , $419,424,445$

Pterogopodium, 304 ; P. species, 417,430

Pteroloblum, 305

Pterygota, 358: P. Cordifolis $87 ;$. Kainerunensis, 436 ; P. Bchumannians, 138

Pteryyota Wawampe'e ( $\Lambda$ shant),

Public Works Department, South Nigeria, 45, 186, 187

Pulley Wood, 280

Pullum (Timani), 53
Pumplin, 193

Puni (hrepi), 111

Funkwa ( W agsaw), 101

Pupalia lappacea, 196

Pusum (Lamatessi), 14

Puttuputtu (Yoruba), 332, 333

Pwekupwekn (Benin), 's13

Pycnanthus Dinklagel, 72 ; $\mathbf{P}$.

Kombo, 34, 44, 72, 84, 96,

$130,231,266,418,419,427$. 457

Pycreus, 190

Lymmertia ealmensis, 75, $101 ; \mathbf{P}$. Uccidentalis, 86

Pyrenacantha species nov., 340

Quelipe Kelipe (Bondoukou), 88 Guinme Plantations, 420

vulsqualis Indioa, zU3

Rafters exported (Nigeria), 226 Kahaina (tlausa), $1 \cup 2,210,2+25$ Kailway suppued with cumber. $18 \%$

Rainfall distributors, 486

Rake, 196

Raken giwa (Hausa), 221, 224

Rama, igo

Hamaniya, 190

Kamaiya, 190 (Ficus elastica) plantations (Togo). 149

Ramog River, 151

Bandia Candata, 62, 407 ; $\mathbf{R}$. Cladanthra, 407, 44: ; $K$. Genipotiore, 6t, 113 ; near R. Macrantha, 62, 407 ; K. Maoulats, 79, 114, 407 ; R. Malleitlora, 6\%, 2225, 407? H. Nilotica, 144, $22 b ; \mathbf{R}$. Uctomera, 407 ; $\mathbf{b}$. Sp. near K. cendata; 62,407

Ranger (Nigeria), 185, 186

Raphia near $\mathbf{K}$. Gartnerl, 41 . H. Hookerl, 93, 235, 239, 464 ; R. Rufin, 235, 239 464; $\mathbf{R}$ Vinifera (see palm wine tree), 38, 41, 68, $216,218,234,235,236,425$, 464

Ratian, 41, 93; R. Benin.

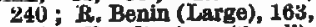
240 . Benin (Small), 163 ; $\mathbf{B}$. Substitute, 241

Rauwolfa Cumminsil, $110 ; \mathbf{R}$. Macrophyla, 440; $\mathbf{R}$. ap., 197 ; $\mathbf{R}$. Vomitoria, 69, 78, $89,112,393,440$; $R$. Welwitschii, 197, 224

Rawaya, 190

Rawsonia spinosa, 108

Rawuya, 102, 215; (Sok.), 225

Red-arlled Afzelia, 290

Bed Cedar (Euphorbiaces sp.). Descrip., 24; cut locally. $32,34,61,54$

Red: Cotton Tree, 58, 76 ; R. Flowering silk C. Tree, 209, 223

Red Dve-wood, 188

Red Ironwood or Ironpost, 26, $27,64,67,77,107,152,154$, $160,169,209,276,356,358$. $370,880,384,415,416,417$, $418,410,420,459$

Red Mangrove, 397

Red Osk (Lophira procera) cut locally, Slerra Loone, $\mathbf{3 3}$. 277, 350, 410 ; Red' Oak (Berlinis aurlevita) 68, (Bor an Red Oak (Sterculia cordiPolia), 54
Red Pine, 68

Bed Reain, 200

Red Water Tree, 40

lledwood (Colons), 84, 159, 424, $425,428,445,446$ 
Rendle, Dr. A. B., M.A., D.Sc., S'.B.S., 497

Rere (Yoruba), 330

Keserve, Definition of, 160,161 ; objects of $\mathrm{k} .16 \%$

Rhamnacer (Gold Coast), 104 ; ('logo), 137 ; (Nigeria), 198, $213,2 \% 2,34$

Rhaptopetalum, Sieghemi, 87

Rhizophora, 139, 254, 368, 451 K. (Liberia), 78, 234, 438 ; R. Mangle, 78, 139, 234, 438 ; R. Mucronata, 139 ; R. 'Racemosa (Mangrove) (Sierra Leone), cut locally, $33,56,88$

Rhizophoracex (Sierra Leone), 55 ; (Liberla), 78 ; (Ivory Coast), 88; (Gold Coast), 108 ; (Togo), 139 ; (Nigeria), 197, 368, 447 ; (Cameroons), 437

Rhodesia, 17

Bhodesian Mahogany (Afzelia Africana), 17, 120, 149

Bhynchosia, 191

Rice, 199, 421, 499

Ricinis communis, 193

Ricinodendron, 278, 314; $\mathbf{B}$. Africanum, 50, 86, 102, 119, $136,163,231,332,333,417$, $418,433,451$; $R$. Hendelotil, 50,75 ; R. Ricin. Rautenii, 332, 333, 334, 451 ; R. sp., 338

Ridi, $19 d$

Rikio (Abe), 86

Rimi (Hausa), 190, 209, 231 $\mathbf{R}$ (Kano), 223; $\mathbf{R}$. or Rini (Sok.), 223

Ringa (Timani), 54

Rio del Rey, 415, 430, 432, 440, 441,442

Risga, 195

Ritchies 8D, 196

Riverine Natives, 187

Rock Elm (Chlorophora excelsa) 26 ; (African Oak or Teak, Description), 29, 253

Roco (Dahomey), 128

Roey or Counter-top Mahogany, 157

Rogeria adenophylla, 194

Rokell River, 36, 39

Ronier (Colons), 83

Ronietta, 46

Roofing paim, 238

Roof Pole (Benin), 363

Rope Tree, 350

Rosaces (Sierra Leone), 44 ; (Liberia), 72; (Ivory 96 ; (Togo), 130 ; (Nigeria), $192,197,199,213,219,266$; (Cameroons), 428

Rosewood (Dalbergia sp. and Pterocarpus erinaceus), 20 , 46 ; Rosewood (Senegal), 98, 206

"Rotation," 162

Rottbollia exaltato, 201

Rough-barked Canarium, 317

Rough-skinned Plum (Slerra Leone), cut locally, 33, 44 ; R. (Liberia), 72

Rubber, 58, 68, 71, 234, 421 444, 487; African R., 68, 228; Balata R., 252; Brown Cluster or Brown Medium R., 392, 393 ; $\mathbf{R}$. Corrugated-fruited R., 392 ; 12. Exports (Liberia), 79 ; R. Exports (Nigeria), 226 ; R. Exports (Ivory Coast), R. Exports (Ivory Coast), Leone), $63 ; \mathbf{R}$. Exports (Togo), 150 ; False R., 79, 395 ; Flake or Paste $\mathbf{R}$.,
392 ; Gambia R., 252; Lagos or Silk R., 111, 440 .

Male Rubber Tree, 395 . Mauve-flowered Vine $\mathbf{R}$. 392; Oban R., 393 ; Ormamental R. 396 ; Para R. 111; Pear-shape fruited R., 393 : Planting $\mathbf{R}$. (Sierra Leone), 36 , 39 ; Rambong R., 125, 149 ; Raw $K$. exported (Gold Coast), 115 ; Red Kano $\mathrm{R}$. 216 ; 'Root' $\mathbf{R} ., 111,392$; Savánnah B., 440 ;'Spurious R., 111; True Rub ber Tree, 79; Rubber Vine

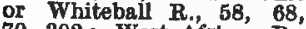
79, 392; West African $\mathbf{R}$. 395 ; Whiteball R., I11

Rubiaces (Sierra Leone), 60 ; (Liberia), 79 ; (Ivory Coast), 89 ; (Gold Coast), 113; (Togo), 145; (Nigeria), 192 197, 199, 214, 225, 401: (Cameroons), 441

\section{Ruka, 200}

Rumfu or Runhu (Hausa), 221

Rura (Hausa), 213, 218

Russegeri, 11

Rnssian Market, 325, 326

Russian Steppes, Afforestation, 486

Rutaces (Slerra Leone), 49 : (Liberla), 74 ; (Ivory Cosst) 85 ; (Gold Coast), 100; (Togo), 134, 300 ; (Nigeria) 186,221 , 309 ; (Cameroons)

Ruwenzort, 189

\section{Sa (Fס), 132}

Sabarra, 198, 199

Sabicea calycina, 408

Sabicu, 264, 310

Sabine, 213

Baccharum officinarum, 196 ; S. spontaneum, 201

Saccoglottis Gabunensis, 49, 85, $158,231,238,405,415$

Sackwi or Mbauwi (Mendi) 53

Sacred Lake, 101 ; S. Oil Palm, $243,244,466$

Sadan mayu (Hausa), 220

Saga Bean, 480

Sagbel (Mendi), 55

Sago (Bendoukou), 87 ; Palm, 177

Saingla (Ásante), 132

Sakuni (Krepi), 109

Salacia debilis, 104

Salicacea (Nigeria), 193, 218

Salix, 193, 218

Sama, 356

Samanta (Tivi), 97

Samantawa (Fanti), 97

Samarin danga, 21

Samba Sankamba (Bondoukon),

Samia (Hausa), 132

San (Attie), 84

Sanaga River, 436

Sanbúgo (Mangu), 138

Sandalwood, white scented, 129

Sandpaper Tree

Sanga-sanga (Ijor), 229 ; S.-S (New Calabar), 279 ; S.-S. (Sok. and West), 220

Sangongo (Barnbara), 88

Sannaba (Mbonoi), 86

Sansami, 215 ; $\mathrm{S}$. or Sagami syn. Jiri dan sarikin itatuwa (Sok. and Kats.), 225

Sansane Station (Togo), 126

Sancevieria, 94 ; S. Cylindrica. 128 ; S. Gmineensis, 127

"Sant" pods, 208
Santiriopsis, 100 ; S. Klaineana, 229

Sanza, Asun, Minika, Seka (Ágni), 88

Sapele-scented Wood (Entandrophragma utilis), 10\%; s. or Sapeli, 151, 157, 323, 5⿻5 Sapho (Yoruba), 389

Sapindaces (Cameroons), 434 ; S. (Gold Coast), lut; is. (Ivory Coost), 87 ; s. (Liberia), 76 ; S. (Sierra Sapium Leone, 53 ; S. (Togo), 137 Kerstingii, 136 ; S. Mánatanum, 136, 494

Sapoba, 320

Sapotacex (Gold Corst), 109 ; (Liberia), 78 ; (Nigeria), $192,197,214,224,875,447$, 455 ; (Sierra Leone), 57 ; (Togo), 141

Sappan, 123

sarcocephalus, 415 ; S, esculentus, 62, 7y, 89, 113, 158, $214,228,402,404$; S. euesculentus, 401 ; S. Pobeguini, 89 ; '201, 202, 214, 224; s. gambucinus, 146, 404, 416, 441 ; S. sp., 231, 405, 410

Sasabani, 210 ; $S$. (Hadeija), 221

Sasanemaga (Ashanti), 113

Sassandra (Port), 64, 81, 82 ; S. (River), 81, 82

Sasswood, 39, 45, 97, 120, 121, $123,125,152,229,275$; Sasswood Plantations (Erythrophlosum Guineense) (10go), 149

Sassybark, 35, 275

Satin wood, $30,49,66,67,73$, $74,88,119,164,174,251$, $309,310,370,412,419,445$, 446 ; S. (African), 271, 309, 311 ; S. (Dry Kone African), 309 ; S. (Dwarf), 311 ; $\$$. (Spiny), 74 ; 8 . (soft), 352 ; S. ('Irue Benin), 310; S. (yellow), 230,271

Sansage-tree, 113, 215, 225, 400 Sausanyebui' (Mangu), 137

Bcale Insects, 250

Scandent Paim, 93

Schio (River), 117 ; S. (Valle of), 116

Schizoglossum, 192

Schmidelia Africana, 53, 191 Schrebera Golungensis, 110, 230, $247,248,388$

Schwenkia Americana, 194

Scitaminex (Nigeria), 195, 197

Scoparia duleis, 194

Scorodophlcen' Zenkerli, 429

scotland, feeding experiments, 483

Scottelia conaces, $88 ; \mathrm{S}$ (Kamerunen), 88, 232 ; \$ Mimflensis, 437

Berewpine, 41, 74, 93, 234, 308 Scrophulariacex (Cameroons) 441 ; $\mathrm{S}$. (Nigeria), 194, 400

Scuridaca longepedunculata, 135 . 191,201

Sea Pean (Mackay) 69, 79

Secretariat and Timber supply conditions (Nigeria), 187

Seglie (Mangu), 133

Segna (Attie), 85

Selaginella Vogelif, 441

Senan (Attie)

Sendar (Yoruba), 329

Senegal, o6

Senegambia, 58, 135

Senna (Senegal), 199

Sesamum, 194 ; S. Indicum, 194 


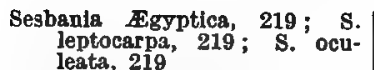

Sesedo (Yoruba), 262

Sesssęu (Atakpame), 145

Shagamu District, 395

Shaki, 153

Shakka (Brass), 231, 345, 346

Shange (Yoruba). 312

Shapo Obibere (广்oruba), 256

Shapon Market, 200

Sharan lobbl (Sok.), ef. Alambo, 221

Shasha (River), 152

Shayo (Yoruba), 303

Shea Butter, in; S.B. Tree, $109,117,118,126,141$, $153,169,179,192,202,209$, $214,224,226,231,323,379$, $380,439,444,455:$ False Shea Butter, 370, 376

Shea Butter Nuts, exports (Nigeria), 204, 226, 378, 456 ; (Bierra Ieone), 63 ; (Togo), 150

Shes Nnt Cake, 460

Shedua or Abonsandua (Ashantl), 94 ; S. (Twi), 94

Shedun (Yoruba), 238, 270, 307, 308

Shemusholoshi, 294 ; S. (Jebu), 295

Shepolo-hun (Yoruba), 340

Sherbro, 37

Shero (Dagomba), 145

Shifting cultivation (Gambia, Gold Coast, Nigerfa, Sierra Leone, etc.), 485

Shinglewood Tree, $119,179,371$, 416,419

Shirinya, 216

Shisinya, syn. Shiriya (Sok.), 219

Shunin-biri (Hausa), 220, 221. Sin. Farin sangamt (Sok. and Kats.)

Siamese Cassia, 176

Sibugane (Basa), 443

Sida $190:$ S. carplnifolia, 344 ; Sida, 190 . Soruba), 329
8. (Yola, 344 ; deroxylon Avimeril, 57, 329 ;
S. longistylum, 57, 78

Sidu (Yoruba), 328

Gie (Yoruba), 299

Sierra Leone, 17, 25, 65, 66, 72, $73,160,287,492,493,494$

Sierra Ieone, ohap. Hil, 25-65; I. The Forests, 25; II: Nintes on Timber Trees, 26 ; III. Trees ent for local use, duce, 35 : V. V. The Forest Denartment, 39 ; VI. Indigenous Forest Trees. 41; Appendlx I, II. Forest III. Timber Imnorts, 65

Sierra Teone (Monntains), 206

Sizo (Yornba) 375

Silk Cotton Tree. 105. 116, 190 $209,223,230,435$

Silkworm. 216

Siluko River, 238: S. Road, $25 R$; 8. Sub-district (Benin), 282

Simarubacer (Gold Cosst), 100 ; S. (Ivory Coast), 85 ; $\mathrm{S}$. $191,198,210,312,313,458$ 154, : 8 . (Tnzo) 134

Sime or semei (Mendi), 42

Simua (Attip), 84

Gino Rasin. 73,79

Sino Kim (Town), 70

síal Hemn. 124

Skiwaka (Hanga), 225

Smeathmannia lrevigata, 78 ; R. pubeqcens, 108, 365 8. an. 77

Smilax Kraussiana, 195
So (Abe), 83

Soap Tree, 62

Sobos (Tribe), 238

Sofo (Attie), 80

Soft-shelled Palm, 243

"Softwood," 42

Sogoto, 213

Sokodé-Bassarl coast forests, 142 ; S. Dtstrict, 117,173 S. Plantations, $118,123,124$ $207,210,211,215,216$,

Solanacex (Nigerla), 194, 225

Solanum, 194 ; S. incanum, 194 ; S. Melongena, 194; 8. Bp., 225

Somabari (Oban, Ekol), 331

Sombreiro River, 151

Soppo, 445, 446

Sopubia, 19

Sorghum, 199, 204 ; S. vulgare, 196 ; S. vulgare, var. Baccharantum, 198, 190

Sorindeia juglandifolia, $53 ; \mathbf{B}$. trimers, 434

Sorono (Asante), 131

Sorowa (Agni), 86

Sosong (Bakossi), 428, 441

Sotibia (Fanti), 85

Soudan or Soudan Zone, 189 $190,191,198,200,203,208$,

Soumbaras, 90

Sounoum (Fanti), 87

Sour Gourd, 223 ; S. Sop, 71

Soyauxia sp., 365

Spanish IElder compared with Melia Azedarach, 135; $\mathbf{S}$. Mahogany, 175 ; S. Plum, 22

Spathodea, 233 ; S. campanulata, $60,89,113,144,197,204$. 400,441

Spermacoce, 192

Sphenoclea Zeylantca, 194

Spice Tree, 43 ; Mountain S.T. 43

Spiny Tree, 413

Spondias dulcls, 124 ; 8. Iutea. $52,76,87,103,136,196$, 222, 232, 339, 419; compared to Pseudospondias mlcrocarpa, 104 ; S. sp. $198,212,222,231,239$

Sponges, 163 ; from vines and lianes. 234

Spruce fills Reserve (c. Paciflc Railway), 480

Ssăre (Tschandjo), 128, 129

serre (Kratschi), 128

Ssisslku (Trehandjo), 139

Ssissina (Tschandjo), 140

Sso abalu (Trchandjo), 133

Ssomin (Trachandjo), 141

Ssosi (Tsehandjo), 130

Ssossosi (Techandjo) 181

Ssua (TschandJo), 140 ; 8 . dau (Tschandfo), 140

Ssuto (Trchand jo), 131

St. Barbara (R.), 151, 154 ; st. Bartholomew (R)., 151; 3t John's River, 74 ;'st. Paul's River, 70, 73

Stachyothyrsins Standitil, 43

Stag-beetle attacks on Fun. tumia elastica, 440

Star Apple, 57 110: Africen 8.A., 57, 381 ; edible S.A., 381: Forcados S.A., 382. 381 Forcados 8.A " 382 S.A., 381: "White S.A., $\mathbf{8 8 2}$ Stauditis Kamerunensis, 427 ; 8. stipitata, 427

Stearin, 480

Stemonocoleus mlcranthus, 481

Stenanthera hamata, 44 ; 8 . laniate, 84 , 190
Sterculia, 87, 106, 138, 233

acuminata, syn. cola acuminata, 436

Barteri, 106, 232

cinerae, 849

cordata, 232

cordifolia, 54, 106, 117, 119, $169,348,349,435$

grandifolia, 43Б

oblonga, $76,87,138,232,435$; 3. near oblonga, 349

rhinopetala, 347, 436

sp., 76, 348

tomentosa, 106

tragacantha, 54, 348, 435

Stereuliaces, 29; 8. (Gold Coast), 106 ; (S. (Ivory Coast), 87; S (Liberia), 76; 223,347 ; S. (Sierra Leone), 64,68 ; S. (Cameroons), 435 ; s. (Togo), 138

Stereospermum acuminatigsimum, 400 ; S. Kunthiamum, 144, 182, 201, 215, 225,400 ; 's. leonense, 60

“ Stinkwood " Tree, 108

Stool Wood, 390

Strephonema A poloniensis, 109

Streptocarpus nobilis, 197

Strlga, 194; S. Senegalensis, 194

Strombosia ' plaucescens, 426 ; S. grandifolis, 426 ; $s$. Pustulata, 83

Strombosiopsis tetandra, 426

Strophanthus hispidus, 192, 395 ; S. Preusgli 395 ; S. Barmentosus, 192

Strychnog alnifolfa, $192 ; \mathbf{s}$. Buettnert, 142 ; S. densiflora, 889 ; S. emarginata, 110 ; S. gnetifolia, 440 ; $\mathrm{S}$. laxa, 142 ; 5 . pubescens, 142 ; S. Aplnoss, 202, 214 ; S. triclisioides, 192

Stylochiton Dalzielii, 196

Subanda (Tschand jo), 133

Suein (Appollonian) 107

Sugar Cane, 196, 199, 421 ; 8 . Loaf Mountains, $55 ; 8$. Palm, 177 ; 8. Plantations, $116 ; 8$. Plum, 84, 51

Sukai I, S. II (Mendi), 57

Sundew, 193

Supom, 102

Surrey price of cake, 482

Susuwuru, 37 Palm, 239; s. (Freghwater), 118; planting, 175 ; S. rice, 53

Swartzia Madagascariensis, 188, 191,219

Sweden Market, 324

Swietenia bljuga, $148 ; 8$ chloroxylon, 174 ; S. macrophylla, 421

Swizele-stick, 59, 78, 393

Sword Bean, 298

Sycopetalum Tarquense, 107

Syctopetalacese (Gold Coast) 107: 8. (Ivory Coast), 87 ; \$. (Cameroons), 436

Symphonla alobulifera, 88, 363

Syzgtum Gulneense, 140

Taba nl ka samu (Hausa) (cf. Kurnan nasara), 219

Tabako (Duaka), 443

Tabol (Atakpeme, 180

Tacca involucrata, 105; $T$. pinnatifda, 128

Taccacem (Togo), 128 ; (Nigeria), 195

Tacerlbe (Mhonol), 84

Tada (Dnala), 428

Trecazea (Barteri), 192

Tafashla (Hausa), 214, 225

Tagalel, 207 


\section{INDEX}

Tagbadja River (Togo), 117 Tagbekove Village, 116 Tahl of the Soudan, 208

Takanda, 196, 199 ; or Takandar giwa (Kats., Sok., and Zanf,), 221 ; Takandar giwa (Hausa) 210, 213

Takwadue (Twi, Wasgew), 104

Tala (Ibo and Brass), 231, 238, 405 : (New Calabar), 40

Talakd or Talakin Yarubawa 221 ; syn. Namijn gwabsa (Kontagora), etc., 221

Talisiopsis oliviformis, 138

Tallow Tree, 69, 77, 107, 361, 461

Tamarind, $99,202,206,207$, 221,306 ; velvet T., 289

Tamarindus indica, 98, 132, 191, $199,206,221,228,232$

Tamarese (Asante), 132

Tamau (Tschandjo), 139

Tambelei (Mendi), 41

Tamenasi (Atakpame), 133

Tanda (Duala), 438

Tangerine, 12

Tanua (English), 86

Tannin, 56, 108, 208

Tano Forest and River, 82

Taramniya, 213, 223

Taro (Tachandjo), 127

Tartar 'Tree, 349

Tata (Duala), 433

Tatairo (Moyen Cavally), 86

Tau (Tschandjo), 133

Taupwi (Young Trees, Mendi), 41

Taura (Hausa), 202, 206, 221

Tanwi (Mendi), 41

Tawatsa (Hausa), 209; T. or Tawatsa, 221

Taxodium distichnm, 17

Tehiat Kottse (Attie), 88

Tchiko (Attie), 86

Teak, 42, 70, 120, 121, 122, 124 $126,169,170,171,500$ Brown Teak, 416 ; Burm T, 162, 168; Bush Teak, 417; T. plantations (Tec(Togo), 149

Tebo (Attie), 85

Tectona orandis, 120, 122, 126 , $148,183,420$

Tegai (Mendi), 45

Tei-tei (Ijor, Brass), 356

Teko District (Buea), 428

Teli (Bambara), 85

Tema (Timani), 42

Tendeba (A pollonian), 110 ; (Aowa), 110

Tenuba, Tanuba (Mbonoi), 86

Tephrosia, 191 ; T. Ansellif, 302 ; $\mathrm{T}$. Vogelii, 302

Teredo borer, 157 ; T. Worm, 357 Terle (Mendi), 57

169 $202,230,416,445,446 ; T$. Altissima, 88; T. Avicennioides, 223, 372; T. Baumannii, 140, 212, 223 T B Brownit, 372 ; T. catalpa, 122, 148; T. catappa, 176 122, 148 ; T. Tictyoneura, 140 ; T. Dry zone, 372 ; T. Elliotili, 212, 228 ; T. Ivoriensis, 88 - T macropters, 100 $140,102,202,212,223$ T. Orange-barked, 370 -T. scutifera, 56, 369, 370, 371 . $416,419.108$ 416, 212 ; 223 . 369 , 370, 371, $192,212,223,369,36,109$ 421; T. Superba, 56, 109, 119, 140, 179, 183, 230, 438, $19,109,117,140,233,371$ T. Yellow, 369

Termites, 31, 70, 73, 249, 257 . $268,280,311,388,408$

Tetere (Mbonoi), 89
Tetracera mrocarpa, 77 ; T. $\mid$ Tolabu (Atakpame), 137 Dinklagei, 77 ; T. pota- Tolongo (Duala), 437 toria, 77 ; T. sp., 77 pota- Toluifera Pereiræe, 177, 421

Tetrapleura, 220, 231 ; T. Toman or Tonas (Hausa) 211 F5ekese, 97 ; Thonningii, Tombo Palm, 41 ; (General West Coast), 98, 23

Tonga (Bondoukrou), 83 Toon, 173

Theobroma cacao, 420,436

Thespesia populuea, 105,137

Thistleton-D per a a, 105, 137 Torto2s, 26 ; (Timani), 51 K.C.M.G., C.I.W., 496 T., $\quad \begin{aligned} & \text { Totengei (Mendi), } 61 \\ & \text { Toto (Yorubs), } 46\end{aligned}$

Toto (Yorubs), 246

Touloucouna oil, 317

Toye (Mendi), 51

Trachylobium sp., 431

Tragacanth, 54

Tragla Manniana, 396

Trakuan (Attie), 84

ria, Report on Gold Coast, and Norther Territory, 91, 101 ; Brough from shaki district 177; Opinion as to Albizzia sp Oping

Thonningia sanguinea, 197 Thorn Apple, 194

Thunbergia (Blue, Benin), 401 ; T. Vogeliana, 401

Thuye occidentalis, 177

Thymelæaces (Nigeria), 195 ; (Cameroons), 487

Tiamatiama (Agni), 86 ; (Appolonian), 86, 101 : ${ }_{T}$ (Aowin), 101

Tiame-tiame (Appolonian), 101

Tigalo (Tschandjo), 141

Tigu Schirafinsa (Mangu), 134

Tigwi (Mendi), 51

Tijoi (Mendi), 52

Tika (Appolonian), 08

Tiko Plain, 416

Tiliacer (Sierra Leone), 53 (Ivory Coast), 87; (Gold Coast), 105: (Togo), 137 ; (Nigeria), 190, 343; (Cameroons), 43

Tim (Tsehandjo), 133

Timand or Tunani, 26, 40

ba or Timba nundi (Duala) 433

Timber, 40, 165, 498; Condltions of working in Liberia, 69 ; T. dogs, 155; T exports (Cameroons), 444; (Sierra Leone), 64; T. T. Imports (Sierra Leone), comparative statement, 65 ; T. Industry (Nigeria Law), 155-166; Nigerian Local Tres Yield, Temperate Zone, 161 : T. Yield Tropics, 161

Timbnctoo, 198

Tingbatau or Patandeu (Tschandjo), 136

\section{Tinya, 193}

Tisal (Togo export), 150

Tisemu (Tschandjo), 129

Titiro (Egbado), 346

Tiupe (Attie), 84

Tochitschíne (Atakpame), 14

Toddalia sp., 312

Toddy, 70

Togba (Atakpame), 145

Togbeli (Mendi), 48

Togo $17,173,189,306,469$ 500 ; $T$., chap. vit, 116-150 Introduction, 116; Forest between or at the Stations, 116-119; Forest depart District plantations, 122127. Indigenous trees, 127127 ; Indigenous trees, 127147; List of Introduced sug of Plantations, 149 Forest Exports, 150

Togo, Tour by Dr. A. H. Unwin, 116-150

Tol-tsi (Tbo), 233

Tokel (Mendi), 43 reculia Africana, 83, 123, 233, 256,426 ; T. mollis, 426 ; T. 8p., 256

Trema afinis, 42, 94, 249, 425 : T. Afrlcana, $42,94,248$, 249,425 ; T. Guineensis, 197 ; T. 8p., 420, 421

Trevor, 'Mr. E. W. J. (Pericarping machlnes), 477

Trianthema monogyna, 194 . 86 T. Candollel, 86 ; $T$ cedrata, $86 ; T$. emetica, $135,191,211,222$; T. Hendelotii, 50, 75, 102, 232, 330 ; T. Prieuriana, 135, 106, 331, $T$; T. retusa, 102 ; $T$. rubesilus, 433 . T. Bp., 50, 102, 330; T sp. near T. Prieuriana, 5039.

Trichodesma Africanum, 192

Trichoxypha, 104; T. Bipindensis, 434

Triclisis macrophylla, 43

Trinkomali Wood, 176, 421

Triplochiton, 19, 76, 119, 370 : Compared with Myrianthus Abroreus, 257; $\boldsymbol{T}$. JohnBonii, 106, 139, 230, 251 253: T. Nigericum, 18 , $117,139,159,178,183,230$, 351, 352 ; T. nov. Bp.'

Tritonis, 195

Triumfetta cordifolla, 344 ; T Rhomboidea, 344 ; T.' sp. $105,191,344$

Triwa (Agni), 83

Trochomeris, 194

Tsada, 191, 202

Tsadar Lamarudu, 222 ; T. masar (Hausa), 222, 232

Tramiya (Hausa), 199, 206 T, or Tramia (Hansa), 229 232 ; Tsamiyar or "Tsamiya," 207, 221

Techabola buanda or Tschabo labunda (Trehandjo), 130

Trchaloware (Tschandjo), 134

Trchamanu (Trchandjo), 133

Trchapea (Trchandjo), 140

Tschato (Tschandjo), 132

Trchengunga (Asante), 130

Tschingbelika (Tschandjo), 138

Tschuou (Tschandjo), 136

Tscisill (Tschandjo) 139

Tsetse or Echéché (Dwe), 140

Taiberl Kinkini, 198

Tsibra or Tsura (Sols.), 225

Tso (Ewe), 130 ; Tes (Ewe), 132

Tsung Oil (Chinese Wood 'Oil), 451,452

Tte (Attie), 84

Tuanyel (Mendi), 49

Tudi (Zanfara), 222

Tui (Mend), 41

Tuinynelli (Mendi), 57
Tripoll senna, 198 


\section{WEST AFRICAN FORESTS AND FORESTRY}

Tukuruwa Palm, 195, 216, 218 Tulip (Tree), 60, 144, 405; African T.

Tulipier de Gabon (Colons), 89

Tuloi (Mendi), 54

Tumbalaka (Atakpame), 130

Tumuku, 194

Tuna, Tunas, or Tunam (Hausa), 222,230

Tunfall (Timani), 60

Tunka (Mendi), 41

Tunkia, Chief of, 66

Tuntumi (Timani), 57

Tura (Tschandjo), 129

Tumdogo (Bondoukou), 84

Turracenthus Zenkeri, 433

Turra Heterophylla, 331 ; T. sp., 50; T. Vogelii, 331

Tursuje (Fansa) 220

Turtle-backs, 189

Turubi, 195

Tusima or Tingma (Trchandjo), 147

Twani (Appolonian), 103

Twe (Neyau), 89

Tyanka or Hogogo (Atalpame), 134

Tyentyem (Mtangu), 128

Tyenyélo or Pasau (Tschandjo) 145

Tyètébu (Nangu), 136

Tylostemon crassifolius, 427 ; T. Mannii, 96

Trambi (Mendi), 47

Ua magungtna (Hausa), 135

Uapaca Benguelensis, 86 ; U. Bingervillensis, 86 ; ;. 215, 231, 334; U. Heudeloti (Sugar ; Plum, Red Cedar) cut locally in sierr Cedar) cut locally in sierra

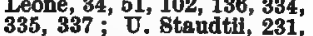
416, 434 ; U. Togoensis, 51

Ubabikpan (Benin), 893

Ubake (Benin), 393

Ubanakwi (Benin), 392

Ubara (Fflk), 287

Ubellu genus, 412 ; U. (nuts), 452

Ubelluname, Ubellunowe(Benin),

Ubuen (EAk), 406

Ubgo (Benin), 392

Uboto (Benin), 392

Uche (Akposio), 134

Udeni (Ibo), 230

Udeni (Ibo, Owerri), 278

Udi Plantation, 167

Udia Ebiong (Efk), 232

Udin (Benin), 241; U. (Benin) 466

Uganda, 211

Ugbamiogou (Benin), 392 ; or Ubamiogon (Benln), 392, 395

Ugbehen (Benin), 303

Ugbodokossa (Benin), 406

Ugenia Owariens1s, 19

Ughahan (Benin), $\mathbf{3 0 9}, 310$

Ugheberi (Benin), 358

Ugibisaro (Benin), 267

Ugo, 258

Ugumu, 892

Uhi Forest, 160, 298

Uhie (Ibo), 229

Ukan (Yornba), 240

Ukana (Efik), 231

Ukape (Benta), 407

Ukhu (Benin), 390

Ukloba (Akpoeso), 128

Ukpa (Eftk), 275

Ukpa (Fflk), 229 ; Uхpa-Kara

Ukpagea (Benin), 303

Ukpaigwi or Okpaigwi (Benin), 414
Clkpami (Akposso), 132

Ukpassa (Efik), 379

Ukpi nikwi of the Benis, 232 , 342 ; U. Nufwa (Benin), 341, 343 ;mall Ukpi (Yoruba), 343 ; U. Wen-

Ukpol (Oban, Ełkoi), 266

Ukposa (Benin), 265

Ukukon (Benin), 239, 240

Ukum (Efik), 231, 345

Ukung (FAk), 229

Ulazo (Benin), 37

Ulmacese, 42; (Irory Cloast). 83: (Gold Coast), 94: (Togo), 128 ; (Nigería), 193; 197, 218, 246 ; (Cameroons) 425

Uloko, U, odigpe, U. nushinog-

Umaja or Umazza (Benin), 263

mbelliferea (Togo), 160 ; (Nigeris), 375

Umberium (Timani), 43, 71, 268 Umbrella tree, 95, 233, 262, 420, $426,485,488$

Ume (Benin), 158, 178, 273, 275

Umowenek (Efk), 220

Uncaria Africana, 197, 203

Undu District, 426

Ungari (Timani), 53

Ungive (Mendi), 53

Ungu (Ibo, Owerri), 277

Ungu (Ibo), 229

Ungungmekkan (Benin), 983

Unie (Benin), 260

United States protection in Liberia, 66

Uno (Eflk), 233

Unscented Mahogany, Entandrophragmacylind'icum,210

Unwin, Dr. A. H., suggestion as to name Iroko, 42; Trip to Togo, 116, 150 : discovery of Thaya in

Unyenghen (Benin), 264

Uoll (Akposso), 143

Upakeka (Benlin), 285, 440

Upeks (Benin) 273

Upper Cross River, 817

Upper Niger, 58

Uputtu of the Benis, 280

Ureben (Benin), 273

Ureno lobata, 190, 845

Urere, 05, 257

Urgines, 195; U. Indica, 195 ; U. Nigg

Urophyllum hirtellum, 113

Urostigma, 193, 216

Urticacese (Gold Coant), 95 : (Nigeria), 257

Uruaro (Benin), 246

Uruba su (Bete), 89

Urueben (Benin), 31

Uruhe (Benin), 272, 367

Uruiju Arogu (Yoruba), 268

Uruk (Efk), 356

Ururata (Benin), 349

U.S.A., Southern States, Decldnous Cypress, native of, 175

Usi (Benin), $\mathbf{8 4 7}$

Uso or Dinka, 861

Usshin (Benin), 297

Uta (Ikale), 246

Utan-tan (Benin), 340

Utriculavia, 194

Uutl (Ewe), 188

Uvaria Afrell, 44, 71, 263 ; U. Buspenil, 263, 417, 427; Dinklagei 71 . U carpa, 44: U' Microtricha, 427: U.' Seabrida, 71: U27: 44

Uwanwanis (Benln), 209 Uwar Yara (Kano and Kata-
gum), 216, 218
Uwen (Efik), 230; Uweny-
riotau or Ưm (Benin), $\mathbf{3 4 3}$

Uwonwen (Benin), 337

Uwowe Lugu (Benin), 293 ; U. Labafun (Benin), 293

Uyat (Eflk), 293

Vandakie (Attie), 85

Vanguerla nigrescens, 62 ; $\mathbf{V}$. chrysocarps, 197; $\mathbf{V}$. euonymoides, 204

Vai (Bali), 425

Velvet Tamarind, 47, 289

Verbenacea (Slerra Lecone), 59 ; (Ivory Cosst), 89 ; (Gold Coast), 112; (Togo), 143 ; (Nigeria), 193, 197, 215; 224, 397": (Cameroons), 440

Vernonia, 35, 194; V. amyg. dalina, $194,225,409$; $\mathbf{v}$. cinerea, 410 ; V. conferta, $62,114,409$, 442; V. Irondosa, 442 ; $\mathbf{V}$. nigritana, 194, 409 ; $\nabla$. Senegalensis, 147 ; V. sp., 225

Vetch, 302

Vetweria zizanoides, 201

Vi (Abe), 86

Victoria District, 416, 420, 425, $428,431,433,441,442$; V. Botanical Gardens, 176 ; V. Falls, 17

Vigna, 191; V. gineusis, 192, 204

Vincentella ampresas, 110

Violacese (Sierra Ieone), 55 ; (fold Coast), 108

Violetwood, Description of (Sierra Ieone), 20 ; Atrican

Visinia leonensis, 55 Vitaces (Gold Coast), 105 ;
(Nigeria), 223

Vitex, $232 ; \mathbf{V}$. angolensis, 197 ; V. Biplndensis, 441; V'. camporum, 143 ; V. cien: kowskii, 59, 148, 144, 193, $202,215,224,398$; V. cuneata, $112,143,441$, diversifolia, 193, 224, 399 : V. doniana, 59 ; $\mathbf{V}$. fosteri, 399 ; V. Erandifolis, 50 , 898 ; V. megaphylla, 112 ; oxycuspis, 60

Vitis, 193 ; V. pallide 108 . V. quadranoulari, 109 ,

Voacenga $107,204,341$; $Y$. obtusa. 59, 197, 204, 224; V. Thonnersil, 59

Voandzeia subterranea, 192

Volta River, 98, 118

Volto Valley, 124

Wa, 198, 216, 219

Wa-Wa (Appolonien), W. (Indenla)

Wacuminate 480

Wadda Tree, 197, 224

Waghebe (Ewe), 142

Wala (Bondoukou), 89

Walehe (Abe), 84 ),

Walnut, 164, 228, 295, 416 , 410 : African W., 293

W., East Indian, 20, 208

Waitheria Americana, 190

Walwel (Mendi), 46

Waogbum (Trchendio), 187

Ware Borf Ware (Agni), 87

Warie (Agni), 84

arr Port, 151: W. (Province) $152,156,235,236,239,251$, $252,257,263,276,277,279$. $286,288,308,813,317,840$. $356,361,362,371,381,393$,

$397,404,405,406,408$ 

Water I.ily, 193 ; W. Melon, 193, | Woods (exported Ivory Coast)

Water Kola, 210

Waterside cynometra, 285

Waterside Ekpagoize, 290

Water Tree, 77

Wawa (Appolonian) (Indenie), 87; Wawa or Wawwaw (Twi), 106

Wawæ (Mendi), 61

Wawapupus (Twi), 106

We (Trepo), 87

Weatherboard Wood, 402

Weihea Africana, 197 ; W. BD., cf. Africana, 368 ; W. Bp.,

Weke (Bakundu), 431

Welu (Tachandjo) 132

Were (Yoruba), 302

Western Africa, Logs exported from, $67 ;$ Conditions of

Wetl (Atakpame), 137

Wheat, 199

Whismore, description of, 34

White Ants, 29, 286, 401

White-ball Rubber, 79

White Cedar (see Pyenanthus Kombo), 34, 44, 77, 266

White Mahogany, 49, 67, 100

White Oak (Parinarium sp.), 32, 52: Ostryoderris impressn, 277,297

Whitewood, 75, 417; W. (American), 260, 313

Wild Custard Apple, 95, 100, 262

Wild Date Paim, 94, 240, 418

Wild Fig. 42

wild Indigo (Yoruba), 219, 221

Wild Mango, 100, 312, 417, 419, 431

Wild Plum, 72 ; W. Rice, 199

Willow, 218

Wine Palm, 70

Wismao (Sierra Leone), 68

Witkoran (Timani), 49

Wo (Ewe), 127, 13i

Wokaka or Wokuka (Bakwiri), 426,449

Wokeku (Bakwiri), 426

Wokotelimon (Abe), 87

Womba (Bakwiri), 440

Wondo (Bakwiri), 437

Wongo (Bekundi) 431

Wonjangagange (Bgkwiri), 433 . or Wonjasanga (Bakundu) or 433

Wonjanja (Bakwiri), 438

Wood Oil Nut, 417

Wood, vart for cabinet making, etc., 90

Woongo (Bakwiri), 431

Worolongo (Bakwiri), 437

Wotenge (Bakwiri), 426

Woto or Atrati (Ewe), 139

Wotobe Ewotobe (Mbonoi), 87

Wu (Ewe), 138

Wueti (Ewe), 141

Wulfram (Fanti), 98

Wulule (Bakwiri), 441

Wuyan damo (Hausa), 223

Wych Elm, 335, 336

Wyfongo (Bakwiri), 441

Xeropetalum Dombeya, 436

Ximenia Americana, 129,191, 202

Xylia Evansii, 45, 75, 97, 232, 307,449

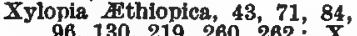
sp. Dinklagei, $43,71, \bar{X}$ gp. near $X$. Elliotii, 43; $\mathrm{X}$. Eminii, 130 - X. Parviflora, $13,43,84,96,130$ $196,204,262,427$; X Striata, 96

Xysmalobium, 192 ; $\mathbf{X}$. granitiolum, 59

Ya (Hausa), 219

Yabasil District, 436

Yabonji, 35

Yafo (K pedyi), 130

Yam, 195, 204-265, 3044, 71 491 ; $Y$. as charms, 255 as food, 186 ; Yam stiek,

Yandahun Village, 66

Yankran (Fanti), 95

Yar or Abi River, 82

Yaru (Yoruba), 259

Yawi (Mendi), 54

Ya-ya or Yar-yar (General West Сониt) 113

Yavabé (Mangu), 134

Yellow Aril, 291; Y-backed -Duika, 250 ' Y.-flowering nutmeg, 265, 457; $\mathbf{Y}$. Y. wood, 71, 76, 427 ; Hard yellow wood, $388,404,417$

\section{Yenagoa, 477}

Yere (Yoruba), 334

Yerepe (Yoruba), 299

Yevo-Gboma (Atakpame), 137

Yewa River, 151

Yeye (Yoruba), 334 inrin-Ylinrin of Ijaws and
Ikales, 230 Y. crushing, 132; Yame
Yokharanku (Dagomba), 142,

Yokomi (Mendi), 53

Yola, 207 ; Y. mosque, 217

York, 46

Yoruba, 158, 163, 164, 185, 212 $243,253,255,270,284,298$ 349,373 ; Yoruba Market 313 ; Yorubas, The, 170 , 246, 247, 250, 252, 260, 267, $338,349,359,389,394$

Yoruba Blackwood, 298; Y Blue Dye, 308 : Y. Charcoai Wood, $305: \mathbf{Y}$. Chewstick 373; $\mathbf{Y}$. Coffinwood, 335 ; $\mathbf{Y}$. Ébony, 384 ; Y. Indigo Y. Ebony, 384 ; Y. Indigo, 335, 384 ; Y. Soft Cane, 246

Yotea or Yo, 141

Yowi or Togba (Atakpame), 145

Yrewo (Ewe), 134

Yukugo (Bondoukoit), 83

Yumba (Mangu), 137

Zacoba (AgnI) (Attie), 86

Záklu (Misahöe), 132

Zamarke (Hausa), 219

Zamingulla, 422, 423

Zanha golungensis, 137

Zanthoxylum, 309, 310, 419 ; Z. macrophyllum. 30,67 , 74 ; Z. parvifolium, 85 ; Z. rubescens, 49 ; $Z$, Senegalengis, 30,100,196, 204 $221,232,300,310$; Z. sp. $49,74,311$

Zaria, 185, 189, 190, 200, 206, $207,216,488$

Zech, Graf (late Governor of Togo), 120

Zeronga (Bambara), 89

Zimingela, 445, 446

Zinder, 198, 210, 211

Zindi (Kantagum, Kanuri), 223

Zlyyphus Jujubs, 137, 198, 213, 222,343 ; $z$. mucronata, $104,137,198,222,343$; Z. Spina-Christi, 104, 198, 213,222

Zogalagandi, 219 ; Z., Bagarumar makka (Sok). 219

Zone Guintênne of Chevalier, 189

Zone Sahélienne, 189 ; BY Chevalier, 198

Zungerv. 189, 241

Zuwo, 216

Zygophyllacex ('Togo), 134 
Printed in Great Britain by

OWWIN BROTHREs, LTMTED

WOKNNG AND LONDON 





